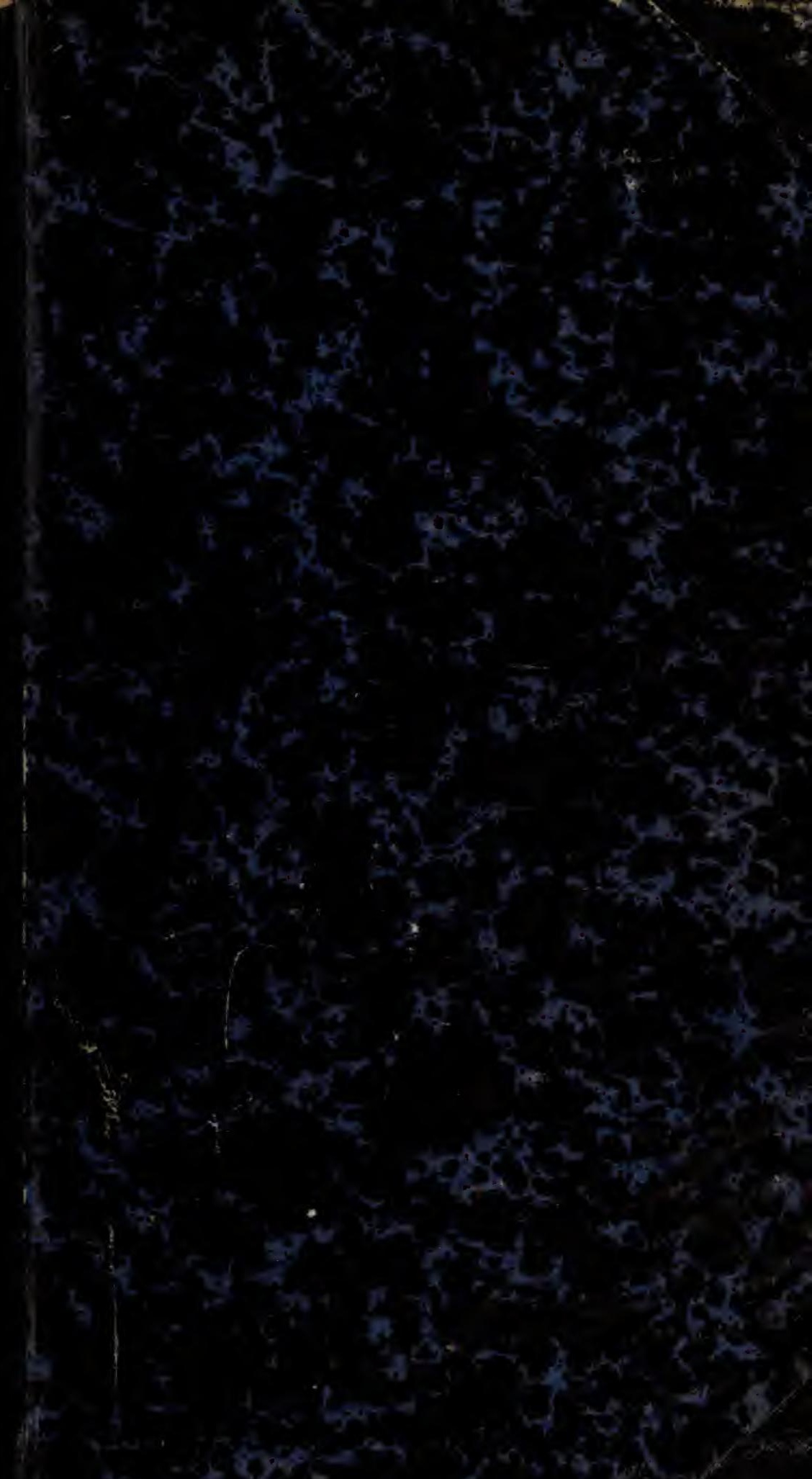




\section{A A}

\section{The Patient Angler.}

BY GUY II. AYERY.

For the Democrat and Chronicle.

$\therefore$ The true angler must lay in great store of yatieuce and you will often see him sitting for honrs without so much as a bite, whereby he loses nothing but his $\operatorname{tin} \theta$, for whlch the honest angler careth not a fig."

An angler sat by an old saw mill

And angled away in the flowing rill,

Dreaming of fish that traditions say,

Deep in those waters nest and lay;

Pickerel, perch, eel and bull pout,

And Legend whispered, a speckled trout,

This last named fish must be taken on spoc,

No man ever saw his heud or nock,

One man had soes the end of his tail

Going down stream like an express manl,

This tail may be true but thin is

Ending up with a dubious Fin-is:

but to our tals; as we said before,

The patient Angler sat by the shore,

The tools of his trade around him las

Hackles, red, speckled dun and gray,

Flies artiflial of every hue,

gillers and moths and grasshoppers too,

And rare old Walt $\sim$ n's angler complete,

The fisherman's Bible lay at his feet;

As thus hesat and angled away,

I gently spoke to this fisherman gray, -

"Hallool my friend, how goes the fight

"With the finny tribes; had'st 'ere a bite?

"Not set"'hir sighed and whispereatow,

"I'vo oniy been here a day or so."

Time rolled on and I passed that way,

There sat the angler old and gray,

The hornet had built a nest in his hat,

His ears were the home of the sporting gnat, Aud yellow jackets were coming $t$, rest

Within the folds of his peacefulvest :

A family (stlect) of mus-quit-t $-\theta$ s

Had taken the a tic over his nose,

Earwi.s, horsefiles and boetles brown

Were si crting around his snowy crown.

But there lie sat by the old saw mill

Happy, contented and patient still:

As thve he sat and angled away,

I gently spoke to thls tisherman gray.

"Helloo! my friend, how goes the fight

'. Wi:h the finny tribes; hads't 'ore a bite?

"Ni. tyet," he sighed and whispered low,

"I've only been here a weèz or so."
TUESDAY, FEBRUARY $24,1880$.

\section{BX THE STREATI}

\section{The Sunday Magazine.}

Sweet tangled banks, whare ox-eyed dalses grov And searlet poppies gleam;

6weet ohanging llghts, that ever come and go Upon the quiet stream!

Once more I see the flash of splendid wings, As dragon flies flit by:

Once more for mo the small sedge-warbler sings Beneath a sapphire sky.

Unce more I feel the simple, fresh content I found in stream and soil

When golden summers slowly came and went. And mine was all their spoil.

I fnd amid the honeysuckle flowérs And shy forget-me-nut.

old boylsh memories of lonely hours Passed in this sllent spot.

Oh, God of nature, hnw thy kindness keops Some changeless things on esirth!

And he who roams far ofr, and toils and weeps. Comes homo to loarn their worth.

Cay vistons vawish, worldly schemes may fail, Hope proves an idie dream,

But attll the blossoms flourish, red and pale, Beslde my native stream. 


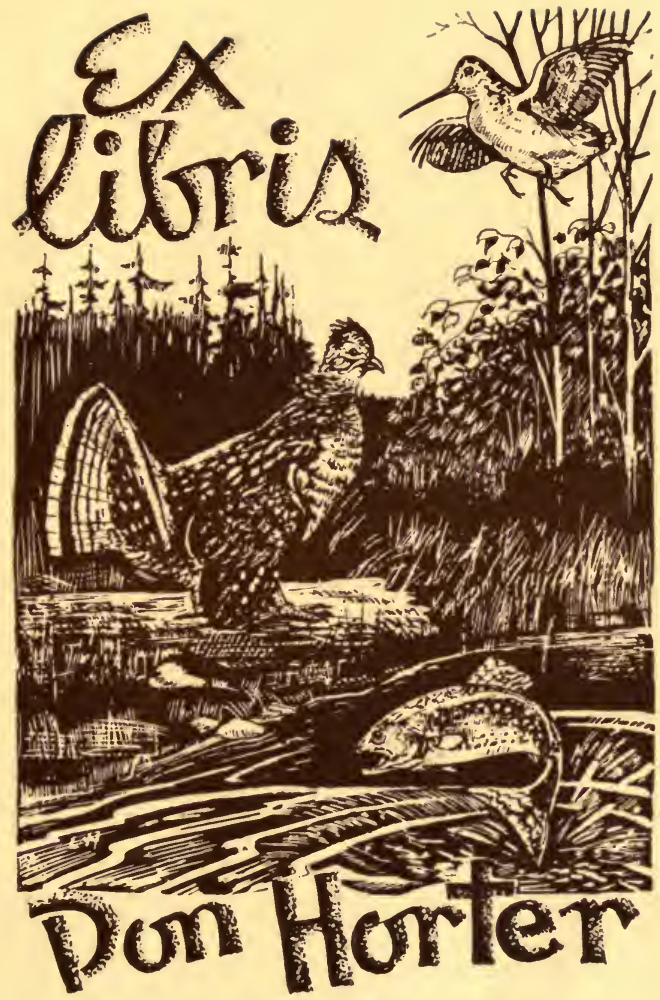


Digitized by the Internet Archive in 2007 with funding from Microsoft Corporation 


AMERICAN ANGLER'S BOOK. Pir often wished that Sha A tandeme tonke to lidege a t. Diver atny gardeni 



$$
\text { A. S. Omantwits }
$$




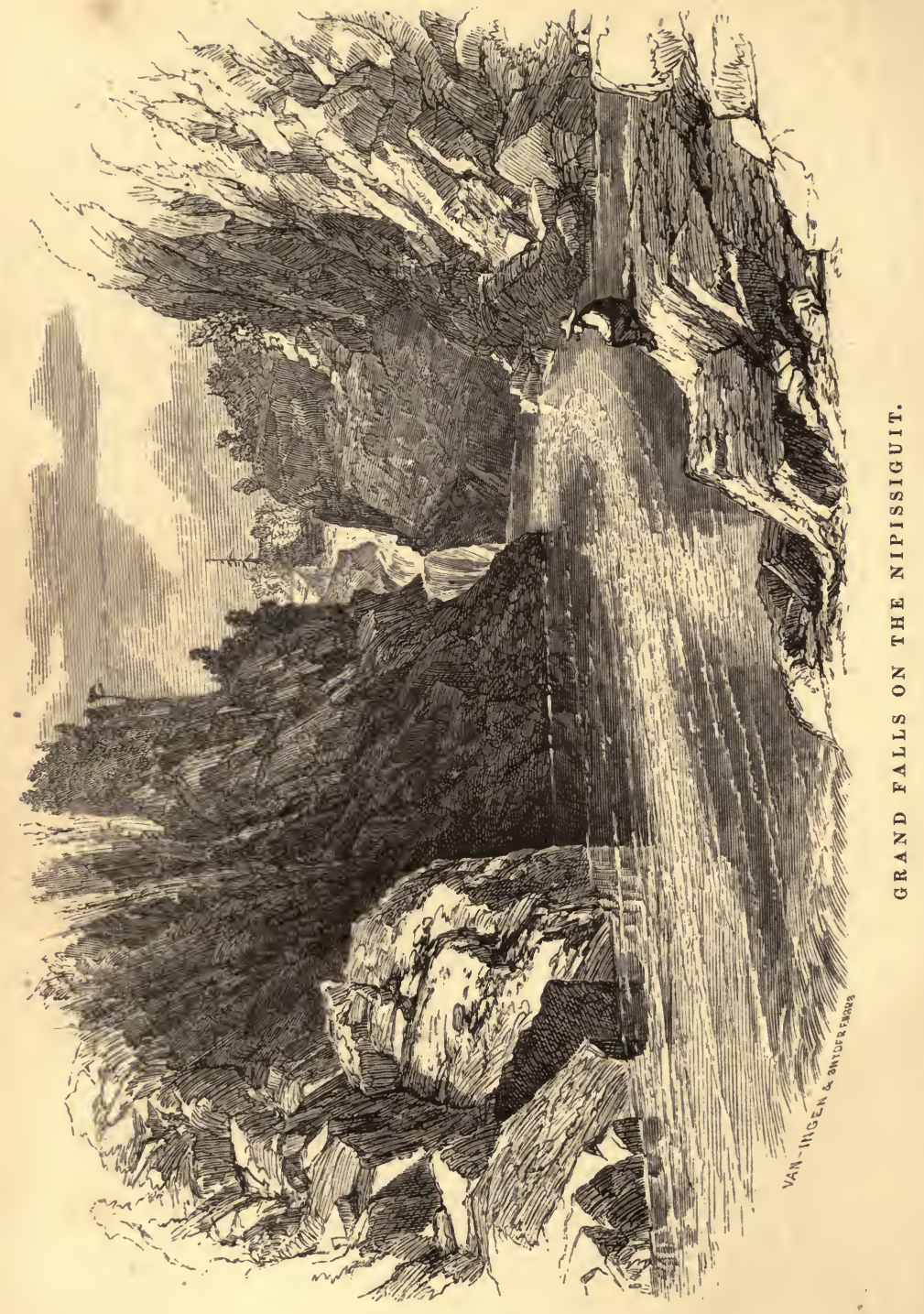




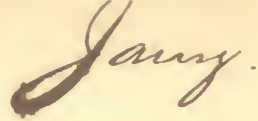

\section{AMERICAN ANGLER'S BO0K:}

- EMBRACING

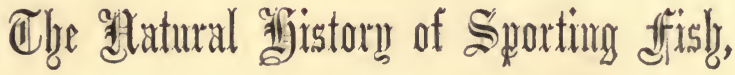

AND

\section{THE ART OF TAKING THEM.}

WITH IXSTRUCTIONS IN

FLY - FISHING, FLY-MAKING, AND ROD-NAKING;

AND

DIRECTIONS FOR FISH-BREEDING.

TO WHICH IS APPENDED,

\section{DIES PISCATORIE:}

DESCRIBING NOTED FISHING-PLACES, AND THE PLEASURE OF SOLITARY FLY-FISHING.

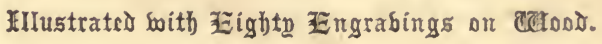

By THAD. NORRIS.

PHILADELPHIA :

PUBLISHED BY E. H. BUTLER \& CO., IONDON: SAMPSON LOW, SON \& CO. 
Entered, according to Act of Congress, in the year 1864, by

E. H. BUTLER \& 00 .

in the Clerk's Office of the District Court of the United States, in and for the Eastern District of Pennsylvania.

MEARS \& DUSENBERY, STEREOTXPERS \& ELECTROTYPERS.

ASHMEAD, YRINTER. 
T H E

FOLLOWING PAGES ARE DEDICATED

To.

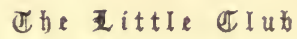

OP

"HOUSELESS A NGLERS;"

AND To

"ALL THAT ARE LOVERS OF VIRTUE, AND DARE TIRUST IN PROVIDENCE; AND BE QUIET, AND GO A-ANGLING." 



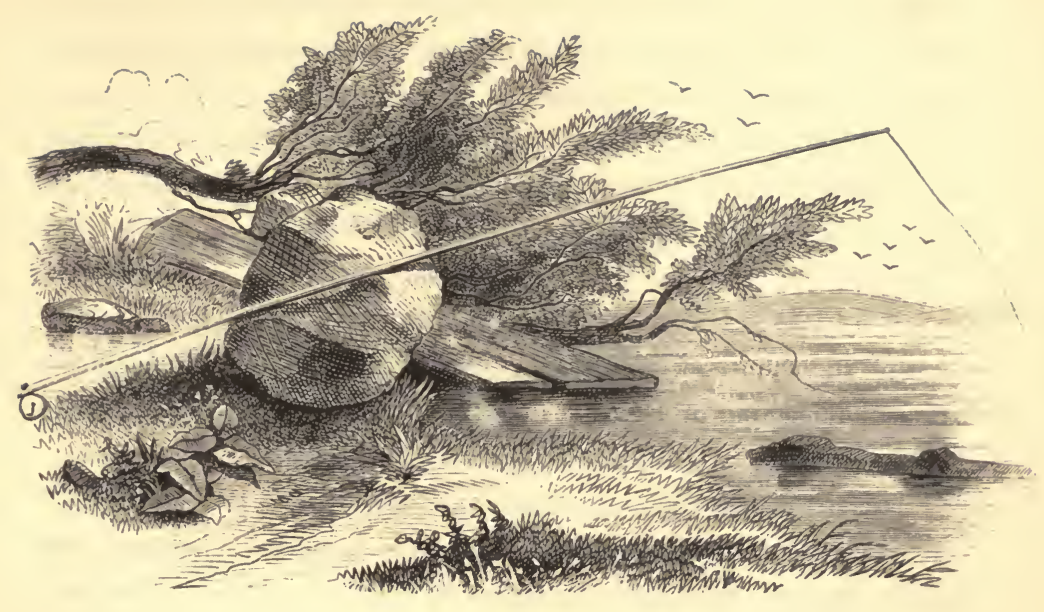

\section{TO THE REA DER.}

IN offering this book for the perusal of those who may feel sufficiently interested in the subject to read works on Angling, I deem it an act of courtesy to say a few words in explanation of the motives which prompted me to commence, and then drew me on in the prosecution of a work involving, as it has proved, no small amount of time and labor.

Every true lover of angling knows that the pleasure it brings with it, does not end with the day's sport; that besides being "a calmer of unquiet thoughts," for the time, it impresses happy memories on the mind; and he looks back to many a day, and many a scene, as an oasis by the wayside in the rough journey of life; and like Dogberry's friend Verges, "he will be talking" when he finds an interested hearer, and may be tempted, as the author of these pages has been, to write of it.

Notwithstanding the many books on angling by British authors, but few American works on the subject have yet been offered to the 
reading public; and this in the face of the fact that we are an angling people, and that our thousands of brooks, creeks, rivers, lakes, bays, and inlets abound in game-fish.

The best informed of those who have written on American fishes, have omitted many important species, and treated slightingly of others which are worthy of a more extended notice. Since the publication of Dr. Bethune's "Walton," and subsequently Frank Forester's "Fish and Fishing," sporting-fish have decreased in some parts of the country where they were once abundant. In the mean while, the opening of new lines of travel has brought within reach of the angler many teeming waters that were then almost inaccessible.

With a view of filling up the blank left by my predecessors, of correcting some erroneous ideas that have been imparted, not only concerning fish, but the adaptation of English rules and theories, without qualification, to our waters; and with the object of making the angler self-reliant, and to encourage him as much as possible to make the best of such resources as may be within his reach, especially as regards his tackle, I have devoted many spare hours to the following pages; in writing which, to use the words of Isaac Walton, "I have made a recreation of a recreation ;" and as reminiscences of my boyhood or maturer years have come back to me, and the mood was on me, I have at times indulged my sense of the ludicrous or the ridiculous; and, again adopting the words of Walton in his address to his readers, "I have in several places mixed not any scurrility, but some innocent harmless mirth, of which, if thou be a severe sourcomplexioned man, then I here disallow thee to be a competent judge, for divines say there are offences given and offences not given, but offences taken." But I am sanguine enough to hope that my simple narrations or allusions to such incidents will touch a chord of sympathy in the breasts of good-natured readers "who love to be quiet and go a-angling."

I had collected most of the matter contained in this book-much of it as the reader finds it, but a greater portion in rough noteswhen the present unhappy rebellion broke out. I then thought it doubtful whether the following pages would ever be printed, but 
some of my angling friends, one or two of whom had read parts of my manuscript, urged me to publish, and overcame my scruples as to my short-comings as a writer, for I profess to be only an angler. One of these, who regards the author and his project perhaps in too favorable a light, addressed me a letter on the subject. I conceive it to be so strong an argument in favor of angling, and so much more to the point than I could express it myself, that I insert it here.

My Dear Friend : Several times you have told me that you entertained the idea of writing a treatise on angling. Let me beg of you not to suffer this "good intention" to be turned into a paving-stone for that locality into which all unfulfilled good intentions are dumped for cobble.

I feel great confidence that if you can impart to beginners but a share of the practical knowledge and insight of the gentle craft which you have obtained by years of patient, observant, and appreciative practice, or can imbue them with a part of that genuine love for the sport which has grown into and with you, then you will be doing the youth of our country a real service.

Perhaps few people claiming to be civilized have greater need than we Americans to be taught the necessity of innocent out-door recreations, for the healthy development of mind, body, and spirit. To the struggle for wealth, and place, and fame, we devote such unremitting ardor, that we are too apt to overlook the simple and innocent joys which a kind Father has so bountifully placed within our easy reach; by neglecting which, we miss the natural means for renewing the spring of life, and keeping fresh and green in our memories the happy days of boyhood.

I have ever felt grateful that as a boy I imbibed a love for angling, for in my maturer years it continues to afford me a keener enjoyment than any other recreation. Nothing has survived to me of my boyish days which has the peculiar abandon and charm of boyish joy like this. At each returning season, when the warm breath of spring flushes the maples with the ruddy glow of budding leaves, what can equal the angler's delight, as, rigged out in sober woollen suit and hob-nailed wading shoes, with creel o'er his shoulder and pliant rod in his grasp, he is permitted to revisit the bright familiar stream (scene of his former triumphs), to listen to the music of its flow, and to try once more if his right hand has lost its cunning, or his flies their attraction.

Though I have always loved angling, I think if I had known you earlier I should have loved it even better. I realize how much I have learned 
from you in the few years we have fished together, and I look back with a kind of regret that I did not have the benefit of your kindly teaching earlier. Many a one who has the true love of angling in him, comes so far short of the enjoyment he could have, for want of willing and faithful teaching at the commencenent, from those whose experience and skill are above his own. Some anglers do not think enough of their duties to their juniors in this respect. I reckon among the chiefest of your qualities as an angler, the sincere sympathy you have always manifested towards any novice who showed that he had a love for the art, and your willingness to teach to such what you knew. Why not manifest this on a more expanded field, and speak through a book to all who are seeking knowledge upon angling, and are disposed to avail themselves of your experience?

There is one department of the school for anglers in which I think you are qualified to speak ex cathedra. I mean the mechanical; if you will undertake to teach what you know upon this branch, you can enable an angler, who has any aptitude for mechanism and a reasonable facility of manipulation, to manufacture for himself, his own rod, flies, and tackle, of a quality for service and effectiveness, which will not suffer in comparison with those to be procured in any good tackle-store in the country. No one has a better right than I to bear this testimony to your handicraft, for my favorite fly-rod and book of flies are the product of your skill.

We have a good many fishermen in this country, and too few anglers; we are apt to value more a glut than a quiet day's sport, where skill and painstaking will reward us with a moderate sufficiency. Catching fish is not necessarily angling, any more than daubing canvas with paint is painting. If you write, you could not help giving aid to the attainment of a truer and juster perception of the delights and uses of angling; and aid your reader, if he has a sympathetic soul, in the attainment of that "sweet content" which can be drawn from all the accessories of the art, and the beauties of nature amid which it is practised.

I say, therefore, write. The labor will not only pleasantly recall many scenes of your piscatorial experience, and memories of the choice spirits with whom you have taken your diversion, but will make you to be remembered with gratitude by those to whom your labor of love will bring an innocent pleasure.

Truly your friend and fellow-angler,

J.

Most of the engravings of fish in this book are from nature. The warine species, found in the chapter on salt-water fishing, are reduced 
copies of those found in Dr. Holbrook's work. The vignettes are the production of the pencil of a good brother of the angle, an amateur, drawn mostly for his own amusement and occasionally for mine, as the subjects have been presented to his appreciative eye during the last ten or twelve years. Many of them are his earlier sketches. $\mathrm{He}$ has expressed an unwillingness that I should reproduce them, after finding that I was in earnest in doing so in this work; but $I$ have, in most cases, so intimately associated them with the subjects or topics to which they serve as vignettes, that I cannot oblige him by relinquishing my purpose.

Most of the tackle and diagrams, and a few of the fish, were drawn by the writer; I confess with some labor, for they are purely mechanical productions.

All of the drawings on wood, with the exception of the plate of hooks and Salmon-flies by Mr. Wilhelm, are by D. Gordon Yates, of this city, and were cut by himself or under his supervision.

I have received so many useful hints from Dr. Bethune's notes to his edition of Walton, and from English works on angling during the last fifteen or twenty years, that $I$ am at a loss to whom to accredit any particular item of information; having so entirely appropriated such knowledge, and stored and mingled it with whatever necessity and some aptness of my own has taught me, as to consider all alike my own property.

Tackle-making I have learned as a pleasant recreation. My tacties and rules are based ox my own experience and upon that of brethren of the rod with whom I have angled. So also is my knowledge of fishing-grounds.

Anglers are all more or less conceited, or, to say the least, selfopinioned, and I may at times have given directions or laid down rules contrary to the views or practice of the reader, or may not have expressed myself as plainly as I endeavored to do; but

"What is writ is writ;

Would it were worthier."

And I only ask the same indulgence of opinion I am willing to extend to those who hold opposite notions. 
To the living, with whom I have enjoyed long days of unalloyed pleasure in boyhood, by the dear old mill-pond, and in manhood by the mountain stream, on the sylvan lake, or within sound of "the warning off the lee shore, speaking in breakers," I send these pages as a reminder of the past. In reference to those who are no more on earth, I quote as applicable those simply beautiful lines of Walton, and say that my allusion to some of the incidents herein contained, " is, or rather was, a picture of my own disposition, especially in such days as I have laid aside business, and gone a-fishing with honest Nat and R. Roe; but they are gone, and with them most of my pleasant hours, even as a shadow that passeth away and returneth not." . 


\section{O N T E N T S.}

Address to the Reader

\section{CH A P TER I.}

ANGLING.

Its harmonizing influences.-Recollections of Angling in boyhood, its after influence on manhood.-Its social tendency.-What and Who is an Angler?-Different kinds of Anglers.-The Snob Angler.The Greedy Angler.-The Spick-and-Span Angler.-The Roughand-Ready Angler.-The Literary Angler.-The Shad-roe Fisherman.-The English Admiral, an Angler.-The True Angler

\section{H A P T E R II.}

\section{GENERAL REMARKS ON FISH.}

Definition.-Origin and order in creation.-Natural mode of propagation.-Habits as regards maternity.-Migration.-Vitality.-External organs.-Internal organization.-Ichthyology . . . 39

\section{CHAPTER III.}

TACKLE IN GENERAL.

Hooks. - Sinkers. - Swivels. - Gut. - Leaders.—Snoods.-Lines.Reels.-Rods.-Bow Dipsys 


\section{CH A P T E R I V.}

\section{THE PERCH FAMILY-PERCID A.}

General Remarks on the Percidæ. - Great number of American genera and species.-Paucity of European species.-Distinguishing marks.-Their abundance and variety in the Valley of the Mississippi.-Migratory habits.-The Rockfish or Striped Bass, Labrax lineatus. Rockfish Tackle. Rock-fishing on the lower Rappahannock.-The White Perch, Labrax pallidus. Perch-fishing.-The White Bass of the Lakes, Labrax albidus. White Bass taken with the artificial fly.-Fresh water Bass of the South and West, Grystes salmoides. Bass-fishing. Bass Fly-fishing.-Black Bass of the Lakes, Grystes nigricans. Trolling for Black Bass with spoon, and with artificial flies.-The Striped Bass of the Ohio, Perca chrysops.-The Short Striped Bass.-Oswego Bass.-The Crappie or Sac-a-lai, Pomoxis hexicanthus.--The Yellow Barred Perch, Perca flavescens.-The Sunfish or Sunny, Pomotis vulgaris.Bream, Ichthylis rubricunda. Bream-fishing on Bayou La Branch.The Pike Perch or Ohio Salmon, Lucioperca Americana.-The Buffalo Perch, Ablodon grunniens

\section{H A P T E R V.}

\section{THE PIKE FAMILY-ESOCID}

Remarks on the Pike Family.-Mascalonge pictured by Cuvier.European species.-American species.-The Garfish; manner of taking it.-Dr. Bethune's remarks on Pikes.-Their introduction into England.-Pliny's Pike.-Gesner's Pike.-The Great Lake Pickerel, Esox lucioides. Trolling from a boat for Pickerel.-The Mascalonge, Esox estor. Angling for Mascalonge.-The Pond Pike, Esox reticulatus. Pike-fishing. Trolling for Pike with the gorge-hook. Pike-fishing in Eastern Virginia.-The Great Blue Pike.-The Little Pike of Long Island.-The Streaked Pike of the Ohio. Story told about a Pike taken in the Kanawha .

\section{H A P T R V I.}

\section{THE CARP FAMILY-CYPRINID无.}

Remarks on the Cyprinidæ.-The Sucker, Catostomus communs.Buffalo Fish, Catostomus babulus. Buffalo Fish as an article of 
diet.-'The Chub or Fallfish, Leucosomus nothus. Errors of American writers in regard to the size of the Chub. Chub an annoyance to fly-fishers. Chub-fishing on the Brandywine. Umbrella invented by a Chub Fisherman.-Roach, and Roach-fishing

\section{CH A P T R VII.}

\section{THE HERRING FAMILY-CLUPEIDAE.}

Remarks on the Herring Family, from the "Iconographic Encyelopædia." Their abundance in the waters of the United States. Great numbers of them taken in the Potomac. Herring-fishing with the artificial fly.-The Shad, Alosa prostatilis. Its delicacy and value as food. Migratory habits. Shad taken with the minnow. Shad-roe as bait

\section{H A P T E V I II.}

\section{CATFISH AND EELS.}

Cattish, Siluride. Extract from Iconographic Encyclopædia. Catfish of the Atlantic States and Western waters.-Eels. Observations on the Petromyzontida (Lamprey Eels), on the Muranida (Common Eels), and on the Gymnotida (Electric Eels).-The Common Eel, Anguilla vulgaris. Fishing for Eels. Migratory habits. Young Eels as bait. Eels not hermaphrodites

\section{CH A P T E R I X.}

\section{THE SALMON FAMILY.-SALMONID屟.}

Remarks on the Salmonidæ.-The Brook Trout. Scientific description. Habits and manner of breeding. Growth. Difference in size between Trout of still waters and those of brisk streams. Effect of light and shade, and bright or dark water, on the color of Trout. Errors as regards new species. Food of the Trout. Its greediness. Its geographical range. Former abundance and causes of decrease. Size of Trout in the regions of Lake Superior and State of Maine. Size in the preserved waters of England, and size the angler is restricted to in rented waters.-The Salmon. Former abundance in the rivers of New York and the Eastern States. Great numbers in California, Oregon, and British Possessions. 
Decline of the Salmon-fisheries in British Provinces. Scientific description. Natural process of propagation. Their growth. Parr, Smolt, and Grilse. Mature Salmon. Size of Salmon. Instinct. Restocking depleted rivers, and introducing Salmon into new waters. Their migration from sea to fresh rivers, and gradual preparation for their change of habitat. Salmon-leaps. Food of Salmon at sea.The Canadian Trout, or Sea Trout, Salmo Canadensis. Error in referring it to the species Salmo trutta of Europe; their dissimilarity. Its affinity to Salmo fontinalis (Brook Trout). Sea-Trout fishing in the Tabbisintac. Mr. Perley's and Dr. Adamson's account of Sea-Trout fishing. Their abundance in the rivers falling into the Gulf of St. Lawrence, and annoyance to Salmon-fishers.-The Schoodic 'Trout, or Dwarf Salmon of the St. Croix, Salmo Gloveri. Account of three summers' fishing in the Schoodic Lakes.-The Great Lake Trout, Salmo namaycush. Manner of taking them.The Lesser Lake Trout, Salmo Adirondakus. Trolling for Lake Trout.--Back's Grayling, Thymallus signifer. Dr. Richardson's remarks on the Grayling.-The Smelt, Osmerus viridiscens. Their great numbers along the northern part of our coast. Smelt in the Schuylkill. Quantity sent south from Boston. Smelt used as a fertilizer.--The Capelin, Mallotus villosus.-The Whitefish, Coregonus albus.-TTrout Bait-fishing .

\section{H A P T E R.}

\section{SALT-WATER FISH AND FISHING.}

Introductory Remarks.-The Sheepshead.-The Weakfish, or SaltWater Trout.-The Barb, or Kingfish.-The Spot, Pigfish, or Goody.-The Croaker.-The Redfish of the Gulf of Mexico.-The Bluefish, or Snapping Mackerel.-The Spanish Mackerel.-The Pompano (Southern).-The Drumfish.--The Flounder.-The SeaBass.-The Blackfish.-The Mullet.-The Tom Cod, or Frostfish.-

The Porgy . . . . . . . . . . . 27

\section{CH A P T E R XI.}

TROUT FLY-FISHING.-OUTFIT AND TACKLE.

Wading-Jacket.-Trousers.-Boots.-Creel or Basket.-Landing-Net.

-Rods.-Reels._Lines.-Leaders.-Flies.-The Whip . . 305 
CH A P T E R XII.

TROUT FLY-FISHING.-THE STREAM.

Casting the Fly.-Theory of strict imitation.-Striking and killing a Fish.-Likely places, how to fish them . . . . . . . 327

\section{CHAPTER XIII.}

\section{SALMON-FISHING.}

Tackle used in Salmon-Fishing.-Rods.-Reels.-Reel-lines.-Casting-lines.-Salmon-fies._Materials required for Salmon-flies for American rivers.-Salmon-flies for the rivers of New Brunswick and Canada.-Theory and practice of Salmon-fishing.-Salmonfishing compared with Trout-fishing.-Casting the fly.-The straightforward cast, casting over the left shoulder, casting in difficult places, explained by diagrams.-Casting in an unfavorable wind.Striking.-Playing a Salmon.-What a Salmon will do or may do.Gaffing.-Camping on the river--Camp equipage.-Protection against mosquitoes, black-flies, and midges.-Clothing, \&c.-Cooking utensils.-Stores.-Cooking Salmon on the river.-To boil a Salmon.-To broil a Salmon.-Cold Salmon.-Soused Salmon.To bake or steam a Grilse under the coals and ashes.-Kippered Salmon.-Smoked Salmon.-Law and Custom on the river . . 345

\section{CHAPTER XIV.}

\section{SALMON-RIVERS OF THE BRITISH PROVINCES.}

Salmon-rivers of Lower Canada.-Salmon-rivers emptying' into or tributary to rivers flowing into the Gulf of St. Lawrence.-Salmonrivers of New Brunswick.-Mirimichi.-Ristigouche.-Metapediac. -Cascapediacs.-Bonaventure.-Tittigouche.-Nipissiguit

\section{H A P TER X V.}

REPAIRS, KNOTS, LOOPS, AND RECEIPTS.

Repairs.-To wax silk, thread, or twine.-Tying on hooks and making. loops, illustrated.-Splicing a line and splicing a rod, illustrated.Knots.-The angler's single and double knot, and knot used in 
tying on drop-flies, illustrated.-A gang of hooks, illustrated.Receipts._For making wax.-For dyeing gut._For dyeing feathers and dubbing

\section{CHAPTER X VI.}

FLY-MAKING.

Implements.-Hand-Vice, Spring-Pliers, \&c.-Book for holding materials.-Materials._Hooks._Gut.-Tinsel_-Dubbing.-Hackles.Wings. -To tie a plain Hackle.-To tie a Palmer.-To make a fly with wings

\section{CH A P TER X VII.}

\section{ROD-MAKING.}

Woods used in making rods._-Wood and Malacca cane for fly-rods.Materials used by amateur rod-makers.-To make a fly-rod of three pieces.-To make a tip.-To stain a rod.-Oiling and varnishing.Wrapping splices and putting on rings.-To make a "rent and glued," or quarter-sectioned tip.-Draw-plate and V tool illustrated and explained.-Manner of splitting cane and joining the pieces of a quarter-sectioned tip described by diagram.-Making middle pieces and tips without splices.-Manner of making a fly-rod to be adjusted to light or heavy fishing.-Ferule-making

\section{CHAPTER XVIII.}

\section{FISH-BREEDING.}

Causes of the decrease of Salmon and Trout.-Remarks on fish-ponds and the manner of stocking them.-Artificial Fish-Breeding-with illustrations, showing the manner of expressing the ova and milt, the arrangement of hatching-troughs, and the growth of the fish ; from "A Complete Treatise on Artificial Fish-Breeding," by W. H. Fry, Esq., with some remarks of the author of this work.-The Aquarium-its appropriate size and form, and manner of stocking it with fish and introducing suitable aquatic plants 


\section{DIES PISCATORIÆ.}

The "Houseless Anglers"

Page 489

The Noonday Roast . . . . . . . . . . . 497

First Nooning-Trout-fishing in Hamilton County, New York . 503

Second Nooning-Trout-fishing in New Hampshire . . . . 513

Third Nooning-Trout-fishing in the regions of Lake Superior . 531

Fourth Nooning-Trout-fishing in the Adirondacks . . . 547

Fly-Fishing Alone . . . . . . . . . . . 567

'The Angler's Sabbath . . . . . . . . . 589

Conclustón . . . . . . . . . . . . . . . . . . . . 599 



\section{LIST OF ILLUSTRATIONS.}

FRONTISPIECE-VIEW OF THE GRAND FALLS ON THE NIPISSI-

guit, From a Photograph by Russel, of St. John, N. B.

RIVER SCENE .

MALACOPTERYGII AND ACANTHOPTERYGII-POSITION OF FINS

IN THE TWO ORDERS . . . . . . $\quad$. 57

POSITION OF TEETH AND GILL-COVERS . . 58

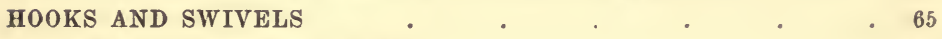

ROCKFISH, OR STRIPED BASS . . . . . 81

UNCLE ROLLY .

WHITE PERCH.-GRAY PERCH . . . . . 90

FRESH-WATER BASS OF THE SOUTH AND WEST • • . . 99

BLACK BASS OF THE NORTHERN LAKES . . . . 103

CRAPPIE, OR SAC-À-LAI _ . . . . . . 111

YELLOW-BARRED PERCH . . . . . . . 114

SUNFISH, OR SUNNY . . . . . . . . 115

FISHING FOR SUNNIES . . . . . . . 117

GREAT NORTHERN LAKE PICKEREL + . . . . 131

CANADIAN BOATMAN $\quad$. $\quad$. $\quad . \quad . \quad . \quad 134$

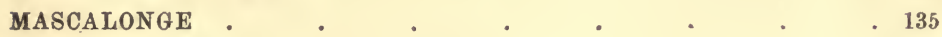

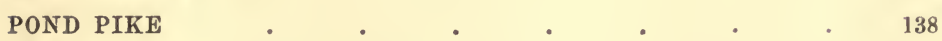

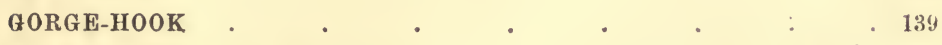

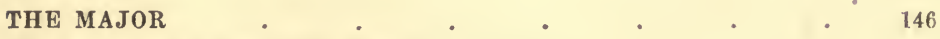

THE HOSTLER TELLING A FISH STORY . . . . 150

THE CHUB-FISHER'S IMPROVED UMBRELLA . . . 160

GIRL FISHING FOR ROACH . . . . . 162

(xxi) 


\section{BROOK TROUT}

SALMON

GROWTH OF THE YOUNG SALMON

SALMON-FRY.-PINK AND SMOLT .

GUIDE

GREAT LAKE TROUT

LESSER LAKE TROUT

GANG OF HOOKS, BAITED

258

SMELT

CHILDREN ON A TROUT STREAM . . . . . . 274

SHEEPSHEAD

WEAK-FISH

BARB OR KINGFISH

SPOT, PIGFISH, OR GOODY

CROAKER

REDFISH OF THE GULF OF MEXICO

BLUEFISH OR SNAPPING MACKEREL

SPANISH MACKEREL .

POMPANO.-CREVALLE

BOAT

302

TROUT-FLIES

LANDING-NETS FOR FLY-FISHING

HEAD OF A TROUT

THE OLD SPRING BY THE ROADSIDE

REEL FOR SALMON-FISHING

SALMON-FLIES

RIGHT AND LEFT-SHOULDERED, AND DIFFICULT CASTING

BARK-PEELER'S HORSE AND STABLE

CANOEMAN

TYING ON HOOKS AND LOOPS

SPLICING LINE AND ROD

KNOTS .

GANG

SETTLER'S CABIN 
ROD-MAKING-V TOOL AND DRAẈ-PLATE

PA E : MAKING QUARTER-SECTIONED TIPS

MALACCA CANE.

450

451

FISH-BREEDING-HATCHING TROUGHS

468

EXPRESSING THE SPAWN $\quad$ P $\quad$. $\quad$. $\quad 469$

OVA AND YOUNG SALMON . . . . . 477

SCIENTIFIC ANGLING . . . . . . 482

SAW-MILL ON TROUT STREAM . . . . . 494

AFTER THE ROAST . . . . . . 500

“THEE MUSN'T GO THROUGH THAT RYE!" . . . 510

A THIEF'S PORTRAIT . $\quad$. $\quad$. $\quad$. . . 528

UNCLE LOT .

BLACKSMITH'S BOY . . . . . . $\quad$. 552

DISCUSSING THE DRAFT . . . . . . 554

OFF FOR A DEER DRIVE . . . . . . . 556

WATCHING FOR DEER . . . . . . 564

STONE THROWER . $\quad$. $\quad$. $\quad$ - . . . 576

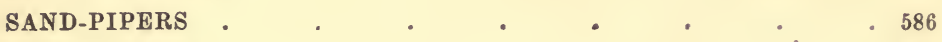

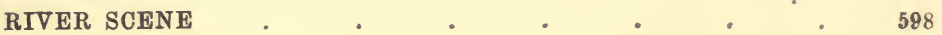



CHA P TER I.

A N G L I N G. 
"Quiverina fears, heart-tearing cares, Anxious sighs, untimely tears,

Fly, fly to courts,

Fly to fond worldlings' sports,

Where strained Sardonic smiles are glosing still, And grief is forced to laugh against her will;

Where mirth's but mummery,

And sorrows only real be.

"Fly from our country pastimes, fly, Sad troops of human misery :-

Come, serene looks,

Clear as the crystal brooks, Or the pure azured heaven that smiles to see The rich attendance on our poverty;

Peace, and a secure mind,

Which all men seek, we only find."

WaLton. 


\section{CH A PTER I.}

\section{ANGLING.}

Its harmonizing influences.-Recollections of Angling in boyhood, its after influence on manhood.-Its social tendency.-What and Who is an Angler ?-Different kinds of Anglers.-The Snob Angler.-The Greedy Angler.-The Spiek-and-Span Angler.-The Rough-and-Ready Angler. - The Literary Angler.-The Shad-roe Fisherman.-The English Admiral, an Angler.-The True Angler.

IT is not my intention to offer any remarks on the antiquity of Angling, or say much in its defence. Dame Juliana Berners, Isaac Walton, and more recent authors, have discoursed learnedly on its origin, and defended it wisely and valiantly from the aspersions and ridicule of those who cannot appreciate its quiet joys, and who know not the solace and peace it brings to the harassed mind, or how it begets and fosters contentment and a love of nature.

I ask any caviller to read Dr. Bethune's Bibliographical Preface to his edition of Walton; and then Father Izaak's address to the readers of his discourse, "but especially to THE HONEST ANGLER," and accompany him in spirit, as Bethune does, by the quiet Lea, or Cotton by the bright rippling Dove; and if he be not convinced of the blessed influences of the "gentle art," or if his heart is not warmed, or no recollections of his boyish days come back to him, I give him up without a harsh word, but with a feeling of regret, that a lifetime should be spent without attaining so much of quiet happiness that might have been so easily 
possessed, and quoting a few sad words from Whittier's Maud-Muller, I only say "it might have been."

Many anglers, such as Sir Humphrey Davy and Sir Joshua Reynolds, besides some of my own acquaintance, have sought its cheering influences in advanced life. I know of one whose early manhood and maturer years were spent on the boisterous deep, and who, though now past eighty, is still an ardent, but quiet angler; and when no better sport can be found, he will even fish through the ice in winter for Roach. No doubt his days have been lengthened out, and the burden of life lightened, by his love of angling.

But how sweetly memories of the past come to one who has appreciated and enjoyed it from his boyhood, whose almost first penny, after he wore jacket and trowsers, bought his first fish-hook; whose first fishing-line was twisted by mother or sister; whose float was the cork of a physic vial, and whose sinkers were cut from the sheet-lead of an old teachest! Thus rigged, with what glad anticipations of sport, many a boy has started on some bright Saturday morning, his gourd, or old cow's horn of red worms in one pocket, and a jack-knife in the other, to cut his alder-pole with, and wandered "free and far" by still pool and swift waters, dinnerless-except perhaps a slight meal at a cherry tree, or a handful of berries that grew along his path-and come home at night weary and footsore, but exulting in his string of chubs, minnows, and sunnies, the largest as broad as his three fingers! He almost falls asleep under his Saturday night scrubbing, but in the morning, does ample justice to his "catch," which is turned out of the pan, crisp and brown, and matted together like a pan-cake.

In my school days, a boy might have been envied, but not loved for proficiency in his studies; but he was most courted, who knew the best fishing-holes; who had plenty of powder 
and shot; the best squirrel dog, and the use of his father's long flintlock gun. And I confess, as I write these lines with my spectacles on, that I have still a strong drawing towards this type of a boy, whether I meet him in my lonely rambles, or whether he dwells only in my memory.

Sometimes the recollection of our boyish sports comes back to us after manhood, and one who has been "addicted" to fishing relapses into his old "ailment;" then angling becomes a pleasant kind of disease, and one's friends are apt to become inoculated with the virus, for it is contagious. Or men are informally introduced to each other on the stream, by a good-humored salutation, or an inquiry of "What luck?" or a display of the catch, or the offer of a segar, or the flask, or a new fly; and with such introduction have become fast friends, from that áffinity which draws all true anglers together.

But let me ask what is an angler, and who is a true angler? One who fishes with nets is not, neither is he who spears, snares, or dastardly uses the crazy bait to get fish, or who catches them on set lines; nor is he who is boisterous, noisy, or quarrelsome; nor are those who profess to practise the higher branches of the art, and affect contempt for their more humble brethren, who have not attained to their proficiency, imbued with the feeling that should possess the true angler.

Nor is he who brings his ice-chest from town, and fishes, all day with worm or fly, that he may return to the city and boastingly distribute his soaked and tasteless trout among his friends, and brag of the numbers he has basketed, from fingerlings upwards.

Anglers may be divided into almost as many genera and species as the fish they catch, and engage in the sport from as many impulses. Let me give, "en passant," a sketch of a few of the many. I have met with. 
There is the Fussy Angler, a great bore; of course you will shun him. The "Snob" Angler, who speaks confidently and knowingly on a slight capital of skill or experience. The Greedy, Pushing Angler, who rushes ahead and half fishes the water, leaving those who follow, in doubt as to whether he has fished a pool or rift carefully, or slurred it over in his haste to reach some well-known place down the stream before his companions. The company of these, the quiet, careful angler will avoid.

We also meet sometimes with the "Spick-and-Span" Angler, who has a highly varnished rod, and a superabundance of useless tackle; his outfit is of the most elaborate kind as regards its finish. He is a dapper "well got up" angler in all his appointments, and fishes much in-doors over his claret and poteen, when he has a good listener. He frequently displays bad taste in his tackle, intended for fly-fishing, by having a thirty dollar multiplying reel, filled with one of Conroy's very best relaid sea-grass lines; strong enough to hold a dolphin. If you meet him on the teeming waters of northern New York, the evening's display of his catch, depends much on the rough skill of his guide.

The Rough-and-Ready Angler, the opposite of the aforenamed, disdains all "tomfoolery," and carries his tackle in an old shot-bag, and his flies in a tangled mass.

We have also the Literary Angler, who reads Walton and admires him hugely; he has been inoculated with the sentiment only; the five-mile walk up the creek, where it has not been fished much, is very fatiguing to him; he "did not know he must wade the stream;" and does not until he slips in, and then he has some trouble at night to get his boots off. He is provided with a stout bass rod, good strong leaders of salmon-gut, and a stock of Conroy's "journal flies," and 
wonders if he had not better put on a shot just above his stretcher-fly.

The Pretentious Angler, to use a favorite expression of the lamented Dickey Riker, once Recorder of the city of New York, is one "that prevails to a great extent in this community." This gentleman has many of the qualities attributed by Fisher, of the "Angler's Souvenir," to Sir Humphrey Davy. If he has attained the higher branches of the art, he affects to despise all sport which he considers less scientific; if a salmon fisher, he calls trout "vermin ;" if he is a trout fly-fisher, he professes contempt for bait fishing. We have talked with true anglers who were even disposed to censure the eminent Divine, who has so ably, and with such labor of love, edited our American edition of Walton, for affectation, in saying of the red worm, "our hands have long since been washed of the dirty things." The servant should not be above his master, and certainly "Iz. Wa.," whose disciple the Doctor professed to be, considered it no indignity to use them, nor was he disgusted with his "horn of gentles." But the Doctor was certainly right in deprecating the use of ground bait in reference to trout, when the angler can with a little faith and less greed soon learn the use of the fly.

The Shad-roe Fisherman.-The habitat of this genus (and they are rarely found elsewhere) is Philadelphia. There are many persons of the aforesaid city, who fish only when this bait can be had, and an idea seems to possess them that fish will bite at no other. This fraternity could have been found some years back, singly or in pairs, or little coteries of three or four, on any sun-shiny day from Easter to Whitsuntide, heaving their heavy dipsies and horsehair snoods from the ends of the piers, or from canal-boats laid up in ordinary-the old floating bridge at Gray's Ferry was a favorite resort for 
them. Sometimes the party was convivial, and provided with a junk bottle of what they believed to be old rye.

Before the gas-works had destroyed the fishing in the Schuylkill, I frequently observed a solitary individual of this species, wending his way to the river on Sunday mornings, with a long reed-pole on his shoulder, and in his hand a tin kettle of shad-roe; and his "prog," consisting of hard-boiled eggs and crackers and cheese, tied up in a cotton bandana handkerchief. Towards nightfall "he might have been seen" (as James the novelist says of the horseman), trudging homeward with a string of Pan Rock and White Perch, or "Catties" and Eels, his trowsers and coat sleeves well plastered with his unctuous bait, suggesting the idea of what, in vulgar parlance, might be called "a very nasty man."

But let us not turn up our scientific noses at this humble brother; nor let the home missionary or tract distributor rate him too severely, if he should meet with him in his Sunday walks; for who can tell what a quiet day of consolation it has been to him; he has found relief from the toils and cares of the week, and perhaps from the ceaseless tongue of his shrewish "old woman." If his sport has been good, he follows it up the next day, and keeps "blue Monday."

We have seen some very respectable gentlemen in our day engaged in fishing with shad-roe at Fairmount Dam. The bar even had its representative, in one of our first criminal court lawyers. He did not "dress the character" with as much discrimination as when he lectured on Shakspeare, for he always wore his blue coat with gilt buttons: he did not appear to be a successful angler. "Per contra" to this was a wealthy retired merchant, who used to astonish us with his knack of keeping this difficult bait on his hooks, and his skill in hooking little White Perch. Many a troller has seen him sitting bolt upright in the bow of his boat on a cool morning 
in May, with his overcoat buttoned up to his chin, his jolly spouse in the stern, and his servant amidship, baiting the hooks and taking off the lady's fish. The son also was an adept as well as the sire. Woe to the perch fisher, with his bait of little silvery eels, if these occupied the lower part of the swim, for the fish were all arrested by the stray ova that floated off from the "gobs" of shad-roe.

As we love contrasts, let us here make a slight allusion to that sensible "old English gentleman," the Admiral, who surveyed the north-west coast of America, to see, if in the contingency of the Yankees adhering to their claim of "ffifty. four forty," the country above Vancouver's Island was worth contending for. He was an ardent angler, and it is reported, that on leaving his ship he provided stores for a week, which comprised of course not a few drinkables, as well as salmon rods and other tackle, and started in his boats to explore the rivers and tributaries, which, so goes the story, were so crammed in many places with salmon, that they could be captured with a boat-hook; and still with all the variety of salmon flies and the piscatory skill of the admiral and his officers, not a fish could be induced to rise at the fly. He returned to his ship disheartened and disgusted, averring that the country was not worth contending for; that the Yankees might have it and be —- ; but it would be indecorous to record the admiral's mild expletive.

The True Angler is thoroughly imbued with the spirit of gentle old Izaak. He has no affectation, and when a fly-cast is not to be had, can find amusement in catching Sunfish or Roach, and does not despise the sport of any humbler brother of the angle. With him, fishing is a recreation, and a "calmer of unquiet thoughts." He never quarrels with his luck, knowing that satiety dulls one's appreciation of sport as much as want of success, but is ever content when he has 
done his best, and looks hopefully forward to a more propitious day. Whether from boat or rocky shore, or along the sedgy bank of the creek, or the stony margin of the mountain brook, he deems it an achievement to take fish when they are difficult to catch, and his satisfaction is in proportion. If he is lazy, or a superannuated angler, he can even endure a few days' trolling on an inland lake, and smokes his cigar, chats with the boatman, and takes an occasional "nip," as he is rowed along the wooded shore and amongst the beautiful islands.

A true angler is generally a modest man; unobtrusively communicative when he can impart a new idea; and is ever ready to let a pretentious tyro have his say, and good. naturedly (as if merely suggesting how it should be done) repairs his tackle, or gets him out of a scrape. He is moderately provided with all tackle and "fixins" necessary to the fishing he is in pursuit of. Is quietly self-reliant and equal to almost any emergency, from splicing his rod or tying his own flies, to trudging ten miles across a rough country with his luggage on his back. His enjoyment consists not only in the taking of fish: he draws much pleasure from the soothing influence and delightful accompaniments of the art.

With happy memories of the past summer, he joins together the three pieces of his fly-rod at home, when the scenes of the last season's sport are wrapped in snow and ice, and renews the glad feelings of long summer days. With what interest he notes the swelling of the buds on the maples, or the advent of the blue-bird and robin, and looks forward to the day when he is to try another cast! and, when it comes at last; with what pleasing anticipations he packs up his "traps," and leaves his business cares and the noisy city behind, and after a few hours' or few days' travel in the cars, 
and a few miles in a rough wagon, or a vigorous tramp over rugged hills or along the road that leads up the banks of the river, he arrives at his quarters! $\mathrm{He}$ is now in the region of fresh butter and mealy potatoes-there are always good potatoes in a mountainous trout country. How pleasingly rough everything looks after leaving the prim city! How pure and wholesome the air! How beautiful the clumps of sugar-maples and the veteran hemlocks jutting out over the stream; the laurel; the ivy; the moss-covered rocks; the lengthening shadows of evening! How musical the old familiar tinkling of the cow-bell and the cry of the whip-poorwill! How sweetly he is lulled to sleep as he hears

"The waters leap and gush

O'er channelled rock, and broken bush!"

Next morning, after a hearty breakfast of mashed potatoes, ham and eggs, and butter from the cream of the cow that browses in the woods, he is off, three miles up the creek, a cigar or his pipe in his mouth, his creel at his side, and his rod over his shoulder, chatting with his chum as he goes; free, joyous, happy; at peace with his Maker, with himself, and all mankind; he should be grateful for this much, even if he catches no fish. How exhilarating the music of the stream! how invigorating its waters, causing a consciousness of manly vigor, as he wades sturdily with the strong current and casts his flies before him! When his zeal abates, and a few of the speckled lie in the bottom of his creel, he is not less interested in the wild flowers on the bank, or the scathed old hemlock on the cliff above, with its hawk's nest, the lady of the house likely inside, and the male proprietor perched high ahove on its dead top, and he breaks forth lustily-the scene suggesting the song-

'The bee's on its wing, and the hawk on its nest, And the river runs merrily by." 
When noon comes on, and the trout rise lazily or merely nip, he halts "sub tegmine fagi," or under the shadow of the dark sugar-maple to build a fire and roast trout for his dinner, and wiles away three hours or so. He dines sumptuously, straightens and dries his leader and the gut of his dropper, and repairs all breakage. He smokes leisurely, or even takes a nap on the green sward or velvety moss, and resumes his sport when the sun has declined enough to shade at least one side of the stream, and pleasantly anticipates the late evening cast on the still waters far down the creek. God be with you, gentle angler, if actuated with the feeling of our old master! whether you are a top fisher or a bottom fisher; whether your bait be gentles, brandling, grub, or red worm; crab, shrimp, or minnow; caddis, grasshopper, or the feathery counterfeit of the ephemera. May your thoughts be always peaceful, and your heart filled with gratitude to Him who made the country and the rivers; and "may the east wind never blow when you go a fishing!" 


$$
\begin{aligned}
& \text { CII A PTER II. } \\
& \text { GENERAL REMARKS ON FISH. }
\end{aligned}
$$


"IN the beginning was the Word, and the Word was with God, and the word was God. * * * All things were made by him; and without him was not any thing made that was made." 
CH A P'TER II.

GENERAL REMARKS ON FISH.

Definition.-Origin and order in creation.-Natural mode of propagation.Habits as regards maternity.-Migration.-Vitality.-External organs.-Internal organization.-Ichthyology.

A FisH, according to the definition of naturalists, is a vertebrate animal with red blood, breathing through water by means of branchiæ, generally called gills. The term fish is frequently applied by unscientific persons, to animals not of the ichthyic class, as in the case of the Whale, which is a true mammal, but resembling the fish in many respects, although its tail is placed horizontally instead of in an upright position. Crustacea and Molluses (Crabs, Lobsters, Oysters, Clams, and Muscles), are also erroneously called "shell-fish."

In the records of Creation, as shown by Paleontologists, the remains of the earliest fishes appear in the upper Silurian system. immediately beneath the Old Red Sandstone. They were the first vertebrate animals, and were cotemporaneous with the earliest terrestrial vegetation. These fish were all of one order, and are termed Placoids by Professor Agassiz. They had internal cartilaginous frames, and an external armature of plates, spines, and shagreen points. This order has representatives at the present day, in the Sharks and Dog. fish of our salt-water bays and inlets. Some of the ancient Sharks had a moutb terminal at the snout, and not underneath as our man-eater, and instead of sharp incisors, the 
interior of the mouth and throat was thickly studded with hard, crushing teeth.

Next to the Placoidal order, and before they had diminished in number, came the Ganoids, whose covering consisted of a nearly continuous armor of hard bone with an enamelled surface. One of the few representatives of this order, known to us, is the "Lepidnsteus" (the Gar-fish of the South and West), whose coat of mail appears to be made of diamondshaped pieces closely joined with sutures between. Hugh Miller says, "with the Old Red Sandstone, the Ganoids were ushered upon the scene in amazing abundance, and for untold ages, comprising mayhap, millions of years; the entire Ichthyic class consisted, so far as is yet known, of but these two orders (Placoids and Ganoids). During the time of the Old Red Sandstone, of the Carboniferous, of the Permean, of the Triassic, and of the Oolitic systems, all fishes apparently as numerous as they now are, were comprised in the Ganoidal and Placoidal orders. At length during the ages of the Chalk, the Cycloids and Ctenoids were ushered in, and gradually developed in Creation until the human period, in which time they seem to have reached their culminating point, and now many times exceed in number all other fishes."

The "Ctenoids," here mentioned by Miller, as the third in order of Creation, is one of the four orders erected by Agassiz, and comprise all of those fishes, the free edges of whose scales are serrated or pectinated like the teeth of a comb. To this order belong the whole family of Perch, and other families which have sharp spinous dorsal fins. Amongst the Cycloids, are contained all those whose scales have smooth continuous margins; these are generally or entirely softfinned fish, as the salmon, shad, herring, carp, chub, \&c.

In describing the fishes of the earlier periods, Hugh Miller 
continues in his earnest manner: "The dynasty of the Ganoids was at one time co-extensive with every river, lake, and sea; and endured during the unreckoned eons, which extended from the time of the lower Old Red Sandstone until those of the Chalk. I may here mention, that as there are orders of plants, such as the Rosacæ, and the grasses, that scarce preceded man in their appearance; so there are families of fishes that seem to belong peculiarly to the human period. * * * * The delicate Salmonidæ and Pleuronectidæ families to which the Salmon and Turbot belong, were ushered into being as early as the times of the Chalk; but the Gadidæ or Cod Family did not precede man by at least any time appreciable to the geologist." We might follow Miller further in his remarks, and might show the reptilean and ichthyic characteristics in the same animal; a fish apparently approaching the reptile, and the reptile the fish.

We do not intend here to go into a lengthy or scientific description of the roe as, it exists in the female; its ejection and impregnation by the milt of the male; its progress in incubation, and the production and growth of the young; but refer the reader to our article on Pisciculture, for all essential information on so interesting a subject.

All observing anglers know that the roe is contained in two sacks; this, as well as the milt of the male, is gradually formed and developed as the fish arrives at the age of puberty, and the same rule of formation, and growth of the roe or milt, is repeated in the same individual after it recuperates from the exhausting effects of spawning.

Fish of the genus Salmo, which includes our Brook Trout, are amongst the few that spawn in autumn. The ova of these require water highly aerated, much oxygen being needed in the incubation. These select the gentle current of the streams, but if this is not accessible, as is the case in 
sluggish trout rivers and lakelets, they find some pool with gravelly bottom where a cool spring enters. They generally spawn in pairs or communities. After preparing the bed, by displacing the gravel with their noses, and excavating an oblong furrow of a few inches in depth, the female deposits her spawn in the trench, and the male ejects his milt over it, when fecundation ensues and the gravel is replaced. Another furrow is then made; the spawn and milt cast; the ova covered over as before; and the process repeated until the roe and milt are exhausted.

The time required for hatching out the spawn, is various with the different orders and families. In the same genera, or even in the same species, the time may vary. Much depends on climate and the temperature of the water; the warmer streams hatching out the eggs before those of a lower temperature. The spawn of the Trout, which is deposited from the middle of September to the first of November, produces the young from the first of December to the first of March, and in artificial ponds, if protected from the cold winds, the young fish are produced sooner, and grow faster than in streams of the forest. I have seen young Trout taken below an artificial pond, near Philadelphia, two inches long, in the latter part of April.

Fish that spawn in still water generally deposit their ova on plants, which give out sufficient oxygen to promote fecundation.

It is seldom that the young of any fish are taken by the angler during the first summer, as they avoid the waters where he finds his sport, and seek smaller streams, and shallower water, to escape the larger predatory fish; the fact of their being of the same species as the destroyer, is no protection to the small fry.

It is unnecessary to go into an account of the mode of pro- 
luction of viviparous fish, the Shark, for instance, and others that produce their young alive, as they are of little interest to the angler, as far as sport is concerned.

Naturalists who confine themselves closely to in-door studies, sometimes adopt general rules and construct theories, to which observers of less scientific knowledge, but with more frequent opportunities for observation, find many exceptions.

One would conclude from the writings of ichthyologists, that fish always desert their ova after fecundation, and, with slight precaution against enemies or accident, leave them to their fate; never caring for, or protecting their ova. It is true that many families, including the Salmonida, are recklessly improvident of their fecundated spawn; male Trout have been found with their stomachs full of the roe of their asso. ciates on the same spawning-bed. But to the rule which indoor naturalists suppose to be general, there are many exceptions; some of them interesting cases of provident care in the protection of the impregnated spawn, and even of maternal solicitude for their young. We might instance that of the little Sunfish, which spawns in the month of June, around the gravelly shores of mill-ponds, removing the pebbles and twigs to the margin of its bed, which is frequently two or three feet in diameter, piling them up a few inches as a rampart to its fortress, driving off all intruders, and keeping watch and ward until the young are hatched. The little Red Fin, which spawns in communities, is frequently observed by the trout fisher constructing its mound of pebbles with skill and care. Scores or hundreds of them may be seen working together assiduously, piling up alternate layers of gravel and impregnated spawn, until the top of the heap is sometimes twelve or fifteen inches high, and its base three or four feet in diameter, leaving it a mass teeming with embryo life. The common Catfish of our mill-ponds and ditches may fro. 
quently be seen with her family around her, protecting and seeking feeding grounds for her dusky progeny. The Stickleback builds a nest, mounts guard, and pugnaciously warns off" all intruders of like, or even larger size.

All fish, in spawning, instinctively seek water containing more or less atmospheric air; Carp, and other Cyprinidæe requiring less for the vivification of their eggs than other fresh-water species.

Griffith, in his Animal Kingdom, says some of the Pelagian geuera spawn amongst floating grass and sea-weed, and says that broad bands of fish-spawn have been seen south of the equator, producing mile-long patches of unruffled surface. I doubt whether this can be so; if true, such instances are rare exceptions to the general rule of spawning on the bottom.

The family of Gaddidx, which includes Codfish, it is supposed spawn in deep water, though this cannot be at any considerable distance beneath the surface, as the solar light, which is necessary to the hatching of the ova, does not penetrate many fathoms.

The knowledge attainable respecting the haunts, habits and breeding of Pelagian fish is necessarily limited.

Oviparous animals are the most prolific, and of these, fish excel all others. A full-grown Carp is said to produce from one hundred thousand to two hundred thousand eggs, a Perch thirty thousand, a Pike from thirty to eighty thousand, and a Codfish a half a million. It is said that a single pair of Herrings, if allowed to reproduce undisturbed and multiply for twenty years, would not only supply the whole world with abundance of food, but would becorne inconveniently numerous. The average number of ova in a Salmon is stated at twelve thousand; if it were possible that all these eggs produced fish, and they arrived at maturity, there would be twelve thousand Salmon, or six thousand pairs, whose produce, at the same 
rate, would be seventy-two millions. At an average of ten pounds, these fish, of the third generation, would weigh seven hundred and twenty million pounds, or enough to load three hundred and twenty-two ships, of a thousand tons each.

Some fish produce large ova, covered with horny shells. Sorne few, including the true shark, are viviparous, producing their young alive; the eggs, of course, being fecundated in the abdomen; but with all fish which contribute to the sport of the angler, the female casts her roe, which is impregnated by the milt of the male being cast over it.

There are no hermaphrodites amongst fish, as has been supposed by some ichthyologists, who cite the Lamprey as one. It has been satisfactorily ascertained, that amongst all the vertebrates, on land or in the water, there are no such exceptions.

There are immutable laws in God's providence, which compel the migration of fish as well as of birds. Some species are anadromous, as the Salmon, Sea Trout, Smelt, Shad, and River Herring; these change their habitation annually from the sea to fresh rivers, which they ascend for the purpose of spawning; most of them with wonderfu] instinct returning, if there be no obstructions, to their native streams, and in their course supply us with food, when in their greatest physical perfection. After propagation, in meagre, lank condition, they seek the sea again, where, from the abundance and great nutritive quality of their food, they recuperate and grow rapidly. The young fry that go seaward diminutive in size, return the following spring or summer adult fish, perfect in their powers of reproduction.

Some of the species common to the long rivers and great lakes of our interior, also change their abodes, traversing perhaps as great an extent of water as the Shad and Salmon, though not for the purpose of spawning. 
That law of nature, though, which impels the migration of some genera to distant waters of the ocean is most wonderful. Many Herring and Codfish come to us from the Arctic seas, the former are the surplus production of that great storehouse thrown off, never to return; furnishing in their distant journey, food to the barbarians of the coast, and wealth and occupation to vast numbers of civilized men; and their yearly advent is looked for, and depended upon, with as much confidence as the return of summer.

The Scombridæ, embracing the different species of Mackerel, come to our latitudes from the south; their natal shores and waters unknown; they come all of them adult fish, furnishing food and employment to thousands, as well as a great maritime school for seamen; it is most likely that most of these also never return to the regions from which they migrated.

Many fish which are bred in the Gulf of Mexico, and the bays and inlets of our southern coast, arrive in our waters mature fish, and are found all summer in our markets. Amongst these are the splendid Spanish Mackerel, the Sheepshead, Croaker, Barb, Spot, and Mullet. These we may reasonably set down as the surplus production of the waters where they breed, and probably never return from their long northern journey. They are not known to us before the age of puberty, while their young are found in great shoals in the shallows of the Gulf of Mexico and our southern bays.

The Sheepshead, in the New Orleans and Mobile markets, are most of them pan-fish, from a half-pound to a pound and a half in weight, while they are seldom found in this latitude below four or five pounds. From any point of the southern coast which approaches the Gulf Stream, fish, by coming up with its current, would be sensible of little or no change of temperature. One cause of the migration of southern fish 
may be attributed to the sea-weed which comes northward with the Gulf Stream; floating on its surface, and amongst, and in it, are found small Crustacea, minute Mollusca, gelatinous animals, and the small fry, which many species follow to feed upon.

It was supposed at one time that Shad and Herring, which enter our rivers for the purpose of spawning, migrated from the south, where it was thought they hibernated. Such supposition was based upon the fact that these fish are found at an earlier period of the season in the bays and rivers of a more southern latitude on our coast. But it is now thought, with much greater show of reason, that they enter those waters earlier only because the season for spawning there, precedes that of our more northern rivers, and that these fish, as well as Salmon, do not wander any considerable distance from the mouths of rivers and bays from which they migrated the preceding summer or autumn.

We should not omit, in these general remarks, to mention the peculiar powers given to some fish of existing for a time out of their natural element, and retaining their vitality when animation is apparently suspended; and also the wonderful vitality of the impregnated spawn.

It is well known by many of our city anglers, that the little Roach, which is taken in winter, and thrown upon the ice or snow, even if it is entirely frozen, will become quite lively if placed in hydrant water of ordinary temperature; this is also said to be the case with the Trout, which, if transported in winter when frozen, will swim about, if placed in spring water. It is said, however, that fish once frozen, lose their sight; the delicate organization of the eye being destroyed by its liquids having been congealed; if this be a fact, it may prevent their breeding, on being transferred to other waters, in such condition. 
When the temperature of the air is below sixty-five, it is very easy to wrap a Roach or Chub of six inches long, in a wet handkerchief, and bring it home alive. White Perch, Labrax pallidus, taken towards sundown in cool weather, if placed carefully in a basket, will live more than an hour, and be as lively in a few minutes in a tub of hydrant water as in the river.

A friend assured me that once, when a boy, during a drizzling rain, he got up into a cherry tree, and in order to keep hi : string of Catfish, which he had lately caught, from the depredations of some hogs beneath, he took them up also, while he got his fill of cherries, and that he forgot his fish in his hurried departure, but found on going back for them the same afternoon, that they were nearly all alive, and evinced it by flapping their tails. Here was an instance of fish living out of water with a switch thrust through one of their gills.

It is stated on good authority, that in Germany, Carp are even kept in a basket or net in a damp cellar, through winter, with the snout protruding through wet moss, and fed with crumbs of bread, and fattened after the manner of cramming poultry.

In China, the spawn of fish is a regular article of traffic, and is exported from one part of the country to another, after being impregnated with the milt.

It is an established fact, that on draining Carp ponds in Germany, to cultivate the soil, which had been flooded and made a fish-pond of, for the purpose of enriching it, that the spawn of the Carp, left after drawing off the water, does not lose its vitality, though exposed for two or three years to the heat of summer and frost of winter; and that, when the field is again converted into a pond, there is no necessity for restocking it with Carp, but the ova remaining beneath the 
surface of the ground produces a stock of Carp; thus keeping up an alternation of crops-fish and vegetables.

The ability of a fish to return to its vitality out of water, depends in a great degree on keeping the delicate tissue of its gills wet. For this reason, a few of them have a peculiar construction in the head, in which water is retained after leaving a river or lake; the gills being kept wet by percolation from this reservoir. Such fish sometimes have also the power of using the lower fins as feet or legs, and are enabled, by these two singular gifts of nature, to pass over land from one body of water to another. Incredible as it may appear, it is even said, that in India, there is a species of fish that by an extraordinary use of its fins can climb trees. A friend, who is curious on such subjects, has handed me the following account of those that travel over land; it was clipped from one of our daily papers.

"Sir Emmerson Tennant's account of fishes walking across the country, has excited much astonishment and no little incredulity in England. The following passage from the Penang Gazette, is singularly corroborative of that gentleman's statement:-

" A correspondent in Province Wellesley informs us that while passing along during a shower of rain, the wide sandy plain which bounds the sea-coast in the neighborhood of Panaga, he witnessed a singular overland migration of Ikan Puyu (a fish much resembling the Tench in size, form, and color), from a chain of fresh-water lagoons lying immediately within the sea-beach, toward the second chain of lagoons, about a hundred yards distant inland. The fish were in groups of from three to seven, and were pursuing their way in a direct line towards a second chain of lagoons, at the rate of nearly a mile an hour. When disturbed they turned round and endeavored to make their way back to the lagoon they had left, and 
would very soon have reached it, had they not been secured by the Malays who accompanied our correspondent, and whe looked upon the migration as an ordinary occurrence at this season of the year. Upwards of twenty were thus taken during a walk of about half a mile, and no doubt many more could have been obtained had the Malays been allowed a little delay. The ground these fish were traversing was nearly level, and only scantily clothed with grass and creeping salolaceous plants, which offered very slight obstruction to their progress. This singular habit will account for the rapidity with which the paddy fields in Province Wellesley become stocked with fish when they are flooded by the rains. The lagoons from which they come contain water throughout the year, while those toward which they are going are mere hollows, filled by the.late rains.'"

Although digestion in fish is rapid, they are capable of living longer without food than land vertebrates, and apparently suffer little from an abstinence of many days. Fish of quick growth digest food rapidly. It is said that a Pike will digest a fish of one-fourth its length in forty minutes. If this be so, it sufficiently accounts for the circumstance of this and other predatory species being found so often without food in their stomachs, and little or nothing in their intestines.

It is yet a mystery, how Shad fatten and increase in flavor after their appearance in fresh water; no food ever having been detected in their stomachs after leaving salt water. The same emptiness of stomach is also common to the Salmon when taken in fresh water: this peculiarity appears to prevail with anadromous fish.

The several species of the genus Coregonus (Whitefish) of our northern lakes, are also said to be found generally with empty stomachs. There is a theory adopted by many, that such fish as the last mentioned, as well as the Shad, live 
on the animalculæ retained in the passage of the water through their gills.

Shad caught in the salt water of the Chesapeake Bay and brought to this city, have been found with small fish in their stomachs, but they were of species known only in salt water. All fish are more or less omnivorous. I have opened Rockfish, which are known to be predatory in their habits, and found the tender shoots and stalks of aquatic grasses in the throat and pouch.

The fish which furnish sport to the angler, have generally eight fins; two pectorals, two ventrals, one anal, two dorsals, and one caudal.

The pectorals, as the term implies, are the breast fins, and project from the humeral bones; they are homologous to the arms in man, or the fore legs of quadrupeds. The ventrals, named from being attached to the belly, in most spine-rayed fish, are immediately or nearly under the pectorals; in softfinned fish, about midway between the head and tail. The anal is immediately behind the vent; the dorsals on the back; and the caudal, which is generally called the tail, is the hindmost fin. This last fin is the chief motor; it is used as an oar in sculling, and acts also as a rudder: the dorsals and anal preserve the equilibrium, or, in nautical phrase, keep the fish on an "even keel." The ventrals are used principally in rising, and the pectorals in backing, and keeping the fish stationary; when they are used alternately, and not simultaneously, as any other pair of fins.

The eye of the fish has no lids, as land animals have, but a very thin transparent membrane drawn over it, which does not give it the power of excluding the light; hence the eyes are always open, whether awake or asleep-if a fish can be said to sleep. By the prominence of its eyes it is able to direct its sight, somewhat backward and downward, as well 
as forward and upward. The iris is capable of no contraction or expansion, and in order to avoid an objectionable degree of light, it seeks greater depths, or the shady banks of the stream. As the fish may be said to have no neck, its head being set immovably on its shoulders and spine, it is necessary to change the position of its whole body, in order to obtain much variety in the direction of its vision.

The nostrils are situated between the eyes and the snout; they are double, and not constructed in such manner as to allow the water to pass through them in breathing, that function being performed entirely by the gills. Notwithstanding this, smell appears to be the most acute of all the senses in fish, and one which contributes much to procuring their food.

The gill-covers, in the generality of fish, are divided into four parts: the preopercle, the opercle, or gill-cover proper, the subopercle, and the interopercle. The opercles are intended as a protection to the delicate organization of the gills and branchiostegous rays, and open and close as the water passes through them.

That brilliant substance which imparts a metallic lustre of so many hues to fish, is secreted in the dermis or skin, beneath the scales; the scales themselves are transparent, and are formed of a horny substance, though, in some families, the outer covering is of a bony substance, and frequently covered with an enamel. The "lateral line," is a series of perforated scales, which extend in most fish from the gillcover to the root of the tail.

The gills consist of series of leaflets, suspended to certain arches, termed "Os hyodes;" each leaflet is covered with a tissue of innumerable blood-vessels. The water which enters the mouth escapes through the gills posteriorly, and the air contained in the water acts on the blood, which is constantly impelled through the gills from the heart. The venous blood, 
after being changed into arterial, by its contact with the air in its passage through the gills, passes into the arterial trunk, situated under the spine, and is dispersed by diminishing blood-vessels, through the body, whence it returns by the veins to the heart.

As Fish breathe through the intervention of water alone, and restore to their blood its arterial qualities, by means of the oxygen which is suspended in the water, their blood is naturally cold, often below the temperature of the water they inhabit. Immediately under the back bone is the air-bladder, divided into two lobes or parts, which, by expansion or compression, enables the fish to change its specific gravity, and maintain any desired elevation in the water. In connection with the gills, the air-bladder is homologous to the lungs in land animals.

There is no outward ear in fishes; internally there is a sack representing the vestibule, filled with gelatinous fluid. By frequent experiments, Mr. Ronalds, the author of "The Fly-Fisher's Entymology," ascertained that trout are not disturbed by frequent and heavy discharges of firearms, if the flash of the gun is concealed, and justly holds in derision, the notion, that fish are frightened by persons talking on a stream. They are more easily startled by the sudden jar of a heavy tramp on an overhanging bank, or a thump on the bottom of a boat; the vibration from either of these causes, acting on the nerves generally, rather than on the ear of the fish. There are instances recorded, however, where fish have been called by the ringing of a bell, or a familiar voice.

There are no organs of voice in fish; though some,-as the Weakfish, Croaker, Catfish, and Drurn, make a croaking noise when taken from the water, but these sounds are entirely ventral.

The sense of taste is necessarily deficient, or wholly want- 
ing; the tongues of some species are nothing more than hard cartilage, in others the tongue is armed with teeth. None have the salivary glands to lubricate the parts with the moisture necessary to the sensation of taste.

The sense of feeling is confined almost entirely to the nose; most fish being covered with scales, which are of a horny or bony substance, with as little sensation as a man's finger-nails. In some, as the southern Garfish, the scales are enamelled, and it is said, resist a bullet if not fired point blank. The Catfish, and also the Barb (a species of Umbrina) have barbels or cirri, by which they appear to detect the nature of substances and whether they be food or not. These organs of touch, as they may be termed, are provided by nature to assist them in their nocturnal search, or groping in deep water for food.

Yarrell, in his work on the Fishes of Great Britain, says: "There are external openings to each nostril, surrounded by several orifices, which allow the escape of a mucous secretion. These apertures are larger and more numerous about the heads of fishes generally, than over the other parts; the viscous secretion defending the skin from the action of the water. Whether the fish inhabits stream or lake, the current of the water in one instance, or progression through it in the other, carries this defensive secretion backwards, and liffuses it over the whole body. In fishes with small scales, this secretion is in proportion more abundant."

The latter part of the above quotation sufficiently explains the presence of a large supply of this mucous secretion on Trout and Catfish, and the increased quantity of slime on Eels.

Teeth, with which fish are generally well supplied, are not not only serviceable in seizing their prey, but by their peculiar position and form assist them in swallowing it. Teeth are found in many genera on the maxillaries, intermaxillaries, palatine, vomer, and tongue; sometimes also on 
the arches of the gills, as in the Pike; but only on the pharyngeal bone of the Chub-apparently backing the assertion of the little boy, who said it had "swallowed its teeth."

Teeth are of some importance to the naturalist, in deter-. mining genera and species. The observing angler will know from them, the habits of fish, whether they are predatory; or live on vegetable substances, or by crushing molluses and crustacea.

Fish shed their teeth, the new coming up beneath the old and displacing them, or the new tooth appears at the side, pushing out the old one and occupying its place.

The fish being so different in its structure and internal organization from land vertebrates, and inhabiting a cold, dense element, must necessarily differ also in its emotional nature. It is coldly obtuse in its sexual emotions, and in its cares or joys of maternity; no feeling of friendship attaches it to a higher being, as with the dog. With blunted sense of hearing and voiceless, no call of mate attracts it, or draws forth response, as in the bird. And in the dense medium through which it looks, no object delights its lidless eye. Reproducing its species, or migrating in obedience to a law of its nature, it appears with many families, as if condemned to roam the wastes of ocean, or lie torpidly in silent depths, until storm or hunger or enemy incites it to activity.

Yet this class of animals, so cold, so dull in its sensations; is one of the most beautiful and wonderful of the Almighty's creations-nothing exceeds it in its symmetrical proportions; no form so well adapted for motion through the element it inhabits; no organs of motion so well contrived for imparting rapid and easy progress as its fins; no burnished or molten silver, or gold, more brilliant than the varied reflections of its sides; no armor so light, or so well adapted to its wearer, as its lustrous scales. It will always 
remain an object of interest to man, from its beauty, the strangeness of its habits, the mystery of its haunts, and its trackless wanderings.

ICHTHYOLOGY.-To the angler, this is the most interesting of the natural sciences. It received little attention until the time of Linnæus. Afterwards Cuvier, by a more natural and judicious classification, divided the Ichthyic class into Orders, Families, Genera, and Species, which has been adopted in the main, by all ichthyologists who have succeeded him.

Of the four orders established by Professor Agassiz, already mentioned in reference to palæontology; the two last, Ctenoids and Cycloids only, come properly within the scope of the angler's ichthyology.

The Ctenoids are those whose scales are pectinated on the edges; these comprise all the Acanthoptherygii, which em. brace the Perch family; and a few of the Malacopterygii. The Cycloids have scales with a continuous margin, and include most of the Malacopterygii, or at least those with which the angler has to do.

The term "Acanthopterygii" is derived from the Greek words, acantha, a thorn, and pterrugion, a little feather. "Malacopterygii" has its origin in the Greek word malacos soft. The wood-cut on the next page is introduced to elucidate the difference between these two divisions, and to explain at the same time the position of the different fins, and their scientific names.

The upper figure represents the outline of a Trout, one of the Malacopterygii ; the lower, that of our White Perch, one of the Acanthopterygii. The first fin on the back of either figure is the first dorsal; the second back fin is the second dorsal; the fins just behind the gill-covers are the pectorals; the ventral fins in the Malacopterygii are about midway on 
the belly; in the Acanthopterygii, they are just below the pectorals, or very near them; the anal fin in both is just behind the anus or vent; the caudal, the hindmost fin. is commonly called the tail.

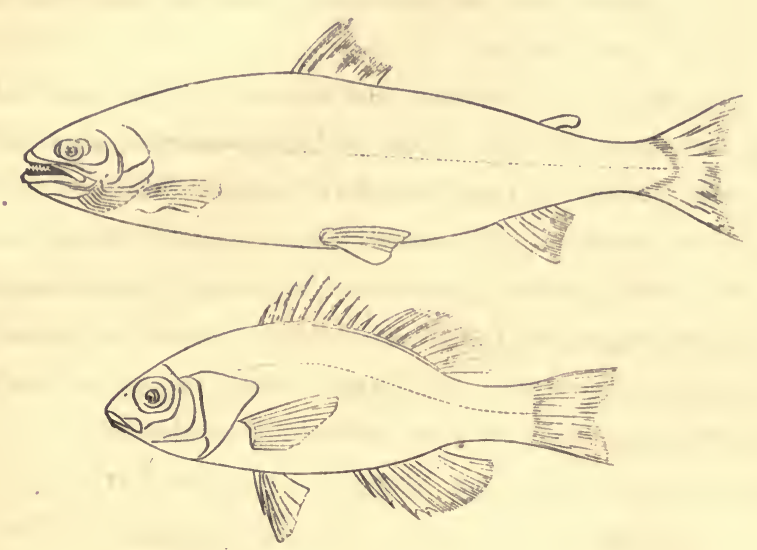

Of fish that come under the notice of the angler, the Malacopterygii embrace those that are called "abdominal," from having the rentral-fins on the belly. The Acanthopterygii include the "thoracic," which have the ventrals near the throat. Some families of the former division have only one dorsal fin, others two, and some even three, as the Codfish. The Acanthopterygii have either one or two dorsals; if only one, the anterior rays are spinous, and the posterior soft and flexible; if they have two dorsals, the first is composed of sharp spines, and the second of rays, or one or two spines followed by soft rays: this division has also one or more spines on the pectorals and on the anal fin. With the exception of the Salmoridx and Esocidx, nearly all of the gamefish the angler meets with, belong to the Acanthopterygii. The Acanthopterygii belong to the order of Ctenoids, and the Malacopterygii mostly to the Cycloids. 
The reader will observe the peculiar shape of the second dorsal of the first figure; it is one of the characteristic marks of the Salmonidx. No other family the angler meets with, has it except the Saluridx (Catfish). This fin is adipose, generally opaque, and without rays-being nothing more than a flexible cartilage.

The first figure of the annexed wood-cut represents a front view of the open mouth of one of the species of the Salmon family, and shows the position of the teeth. Those along the centre of the roof of the mouth above 1, are on the vomer; those on the sides above 2 , are on the palate; those around 3 are the pharyngeal teeth; those on the edge of the upper jaw, are the upper or super maxillaries; and, those on the edge of the lower jaw, the lower or inferior maxillaries.
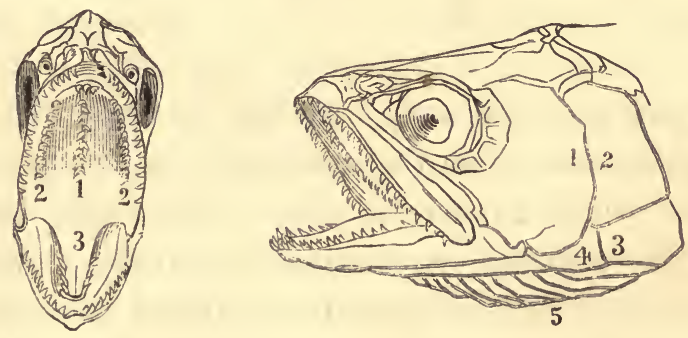

The second figure of the same plate shows the anatomical structure of the head, including a side view of the teeth. 1 is the preopercle or fore gill-cover; 2, the opercle or gillcover proper; 3, the subopercle or under gill-cover; 4 , the interopercle or intermediate gill-cover; and 5, the branchiostegous rays, or, as they are more generally termed, the branchial rays.

By reference to the foregoing wood-cuts, and reading with some care, scientific descriptions of fish, an angler may be able to describe any species, which may be unknown to him, 
with sufficient accuracy, for the naturalist to refer it to its family, genus, and species.

Any description of a fish, is of course rendered more intelligible by an accompanying sketch, even if it is rudely done. And if the angler will describe, as accurately as he can, the general outline and form; the proportions of the length of the head to that of its body (exclusive of the tail); its breadth, as compared with its length; its color, markings, and the course of the lateral line; the gill-cover and fore gillcover, whether either or both have scales, and on which they are largest-mentioning also, if the gill-cover has spines on its posterior margin; the number of branchial rays, fin rays, and spines, also the color of the fins; the dental arrangement, and then the general local names: he may contribute much that will be interesting to others, while it will be a source of satisfaction to himself.

Linnæus received his description of American fishes from Dr. Grordon, of South Carolina. Bloch, and Schoef (who was a surgeon in the British army, during the American Revolution), as well as Catesby, contributed, though meagrely, to our ichthyology. The descriptions of the latter were mostly of the fish of the Caribbean Sea, and our Southern coast. In 1820, Rafinesque, a French naturalist, published at Lexington, Kentucky, an account of the fishes of the Ohio and its tributaries. His nomenclature, as well as his mode of description and classification, differs from that of Cuvier; his descriptions, generally, are not minute, but some of them are interesting. His work is not illustrated by drawings. Bose gave Lacepede descriptions of some species found in our waters. In 1814, Dr. Mitchil, of New York, entered with some zeal into the work; and, in periodicals, described more species than had been before noticed.

In 1836, Dr. Richardson produced his "Fauna Boreali." 
which includes some of our Northern genera. Dr. Storer, in 1839, published an able report of the fishes of Massachusetts. De Witt Clinton, Mr. Wood, of Philadelphia, Redfield and Haldeman, also contributed to this branch of natural science. It was reserved, however, for Dr. De Kay to give the first elaborate description of American fish, which he did by authority of the state of New York in 1842; his work is illustrated by engravings that are badly colored, and some of them are incorrectly drawn. He enumerates thirty-two families, one hundred and fifty-six genera, and four hundred and forty species. His description includes the Lacustrine genera, as well as those of the coast of New York. Amongst the latter are many that are emigrants from Southern waters, which fact he fails to note. Dr. Holbrook, of Charleston, has recently published an interesting work on the fishes of South Carolina, which is of much interest to the angler, as it contains an account of the habits, as well as scientific descriptions of many game-fish, common to this latitude and the Western States. His work is beautifully illustrated with colored engravings. Girard, Gill, and Professor Spencer F. Baird, of the Smithsonian Institute, have recently made valuable additions to American ichthyology.

In closing these observations on the natural history of fish, it is proper to remark, that they are those of a mere angler, who aspires to no place amongst the learned doctors, and who has picked up such information, as he has imparted to the general reader, from the books of the Academy of Natural Sciences, and from his own observations noted here and there, as any fish that takes a bait has interested him. He presents what is here written with the hope of inciting other anglers to a study of the fishes that afford so much pleasure in the taking of them. 
C A A P T E R III.

TACKLE IN GENERAL. 
"LEx me tell you, Scholar, that Diogenes walked on a day, with a friend, ts see a country fair ; where he saw ribbons, and looking-glasses, and nut-crackers, and fiddles, and hobby-horses, and many other gimcracks; and having observed them, and all the other finnimbruns that make a complete sountry fair; he said to his friend, "Lord, how many things are there in this world of which Diogenes hath no need!"

Walton. 


\section{CH A P T ER III.}

\section{TACKLE IN GENERAL.}

Hooks.--Sinkers._Swivels.—Gut._Leaders.-Snood8.-Lines.-Reels._Rods.-Bow Dipsys.

In these observations it would be well to have some settled plan or order in which Tackle should be mentioned; I have, therefore, thought it better to commence at the bottom and go upwards.

Hooks.- - Of the various kind of hooks sold in this country, the Kirby is mostly used. The point of this hook is not in the same plane with the shank, but is bent to one side, and is there-fore less apt to draw from the mouth of the fish without hooking, than the Limerick. There are several varieties of the Kirby; those made with short shanks and of stout wire (some of which have flattened heads), are most appropriate for fishing with dead bait, or where the fish are large, or their mouths hard.

The long-shanked Kirby is to be preferred for live-bait fishing, or where much nicety is required in putting on a worm, brandling, or grasshopper : they are made of fine wire, and the barb not so rank as the Limerick. These are sometimes called "Weak Trout Hooks" by tackle venders.

Limerick hooks, although preferred by many on account 
of their superior temper, are better adapted to tying flies on, than for bait-hooks.

The O'Shaughnessy differs materially from the common Limerick, in the shape of the bend, and in the direction of its point, which sets out at a slight angle from the shank; it is much surer of hooking than the old Limerick, and is preferred by all anglers who tie their own flies. Salmon hooks of this shape, some of which are hammered after being bent, are highly esteemed by Salmon fishers. Trout hooks of the O'Shaughnessy shape, are sometimes made of very fine wire, lightness being a desideratum in artificial fies, particularly in droppers.

The Limerick hook, as its name implies, as well as the O'Shaughnessy, which bears the name of its original maker, were made first in Limerick, Ireland. They have since been imitated and made at a much lower price in England, where most of the hooks known by these names are now manufactured; they are not as well tempered, though, as the Irish hooks.

The "Sneck bend" is much used by fly-fishers in Scotland, though I have failed to discover its merits. The peculiarity of this hook consists in its bend, which assumes more the

- form of the three sides of a square than a continuous curve. I have never heard or read of any plausible reason for its shape.

The "Virginia hook," it is said, was first made by a blacksmith named Rivere, in the lower part of Virginia, and at one time was held in much esteem by bait fishermen, on account of its strength and supposed adaptability to fish of all sizes. Its peculiarity consists in its shape and the tapering of the steel from the top of the shank to the bend. I have reason for doubts as to the person and place of its invention. 

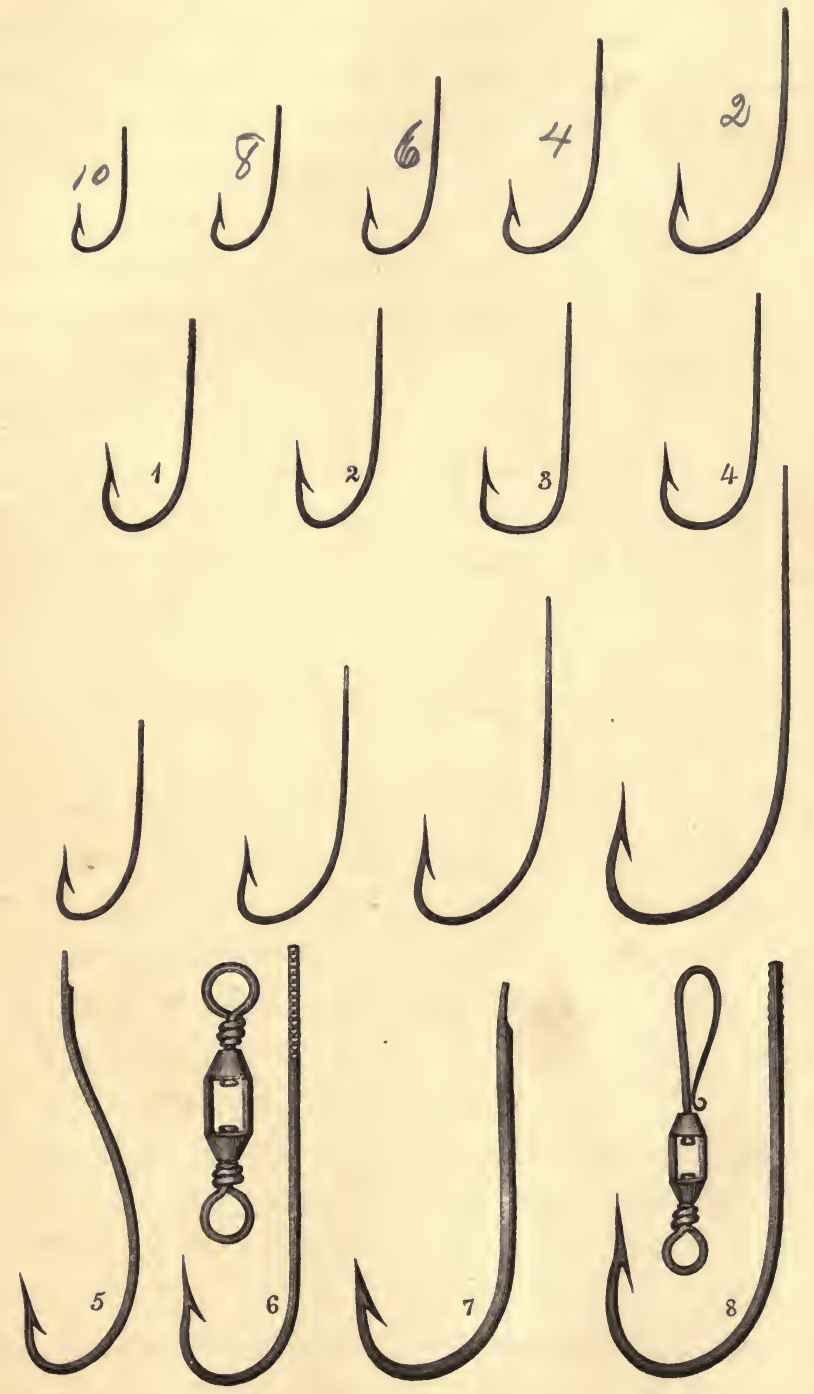

5 

as I have found them common at Mackinaw amongst the old habitans, at an early period of my fishing experience.

It is said, that Prince Rupert first taught the art of tempering hooks, to a fish-hook maker of London by the name of Kirby, who transmitted the art to his descendants, and his name to the hook now so commonly used. Sir Humphrey Davy and other English anglers in later years, have succeeded in making hooks which did them good service.

There are other hooks kept by the tackle stores which we think it unnecessary to describe here; as, double-hooks, eelhooks, snap-hooks, sockdolagers, \&c., most of which are not worth the notice of the angler.

On the plate of hooks on the opposite page, * the top row represents the O'Shaughnessy. Commencing on the right, the first size is No. 2, and then $4,6,8$, and 10 , in succession towards the left.

In the second row, No. 1 is a short-shanked Kirby; No. 2 the old style Limerick; No. 3 a Sneck bend; No. 4 an Aber. deen.

The third is a row of Salmon hooks, the sizes according to the standard adopted by the author of "The Book of the Salmon;" the largest is No. 4, the next No. 6, the next No. 8 , and the smallest No. 10. There are intermediate sizes, as well as three sizes larger than No. 4, viz.: $3,2,1$; but they are seldom, if ever, used on this side of the Atlantic. Nos. 7 and 8 being the principal sizes.

Of the lower row, 5 is a "Shanghai," 6 a long-shanked Kirby, 7 a Virginia hook, and 8 a stout short-shanked Kirby.

The two remaining figures are Swivels; the one to the

* I am under obligations to Mr. John Krider (Gun and Tackle Store, corner of Second and Walnut Streets, Philadelphia), for this handsome woodcut of Hooks, which he had prepared expressly for this book. 
right is a "hook" Swivel, and that on the left a "box" Swivel.

SiNkERs.-In bottom or bait fishing, sinkers of various sizes and shapes are used; the weight proportioned to the tide or current. Those in general use are split shot. The slidingsinker is oblong with a hole running longitudinally through the centre. The advantage of this is, that the bait may drift off with the tide while the sinker is comparatively at rest. The swivel sinker is a combination of sinker and swivel, which allows the snood and bait to revolve; it is seldom used.

In bottom fishing or trolling deep, where the bottom is rocky, the sinker is apt to be caught foul. To provide against loss of leader and hooks, in such cases, it is better to have the sinker attached, where the leader joins the line, by a piece of weak gut or thread; so that the angler, if he is obliged to pull away at the risk of losing some of his bottom tackle, may only lose his sinker.

Swivels are necessary when the bait is required to spin or revolve. The box-swivel is used by looping the leader or bottom through one ring and the line through the other. When it is necessary to disengage the bait and snood from the leader, as in trolling for Pike, the hook-swivel is convenient, and in many cases indispensable. All bottom fishers and trollers should be well supplied with , hese useful little articles; steel swivels should be used for fresh-water, and brass swivels for salt-water fishing.

FLOATs are made of cork, hollow wood, or quills, of a great variety of shapes and sizes. The quill is preferred for Roach, Chub, and other fish that bite delicately. The size of the float should always be regulated by the weight of the sinker; the shape is a matter of fancy. I have whittled shapely floats out of the bark of a pine tree.

Gut Leaders, Snoovs, Traces, \&c.-Silk-worm gut, which 
forms so important a part of the angler's outfit, is the substance of the worm in an immature state, and is made by steeping the insect in vinegar or some other acid, a short time before it is ready to commence spinning its cocoon, stretching it to the required length, and securing the ends until the strand is dry. It is then divested of any extraneous substance by rubbing. It is imported from China, Spain, and Italy, in hanks of a hundred strands, and sold by all the tackle stores, the price varying according to its size, length, and roundness. A scientific friend informed me once, that he had produced the veritable article, by stretching out the worms after steeping them in vinegar, and securing the heads and tails in notches made in each end of a shingle.

Gut is considered a superfluity by most rustic anglers. Though not always essential, in fine angling it is indispensable. Its strength is astonishing, as every angler knows from experience. It is almost transparent in water, when dyed of a neutral tint. This color is to be preferred to any other, a receipt for dyeing which will be found in another part of this book.

LEADERS.-Although double gut and twisted gut leaders are recommended, I have found the single, when stout, round, and of the best quality, to answer every demand made on it by the strength of the fish. Single gut is certainly neater, and when it is borne in mind that the spring of the rod, and the judicious use of the reel, contribute so much to lessen the strain on line and leader, one must reasonably conclude, that gut which will bear a strain of five pounds would secure a fish of any size he may be lucky enough to hook.

For fly-fishing, the gut lengths of a leader should always be joined by a neat knot; the double knot is preferable. The leaders sold at the tackle stores, generally have the ends of the gut secured with silk lashings, which are liable to fray 
out, and being usually of some bright tint, deceive the fish into rising at one of these frayed lashings for a fly, and indispose them to take the cheat you intended for them.

On a subsequent page, the reader will find directions for making leaders and tying gut, with descriptions of the knots used by anglers and tackle makers.

Leaders, bottoms, and snoods, are made also of horsehair and sometimes of "gimp" (the article of which the coarse strings of violins are made). The latter is used for Pike, Bass, Sheepshead, Bluefish, or where gut is liable to be frayed by coming in contact with sharp rocks, or to be bitten off by the fish.

Anglers who have not the skill or patience to tie on their own hooks, purchase them already snooded at the tackle stores. A more economical and convenient way for one who can tie them himself, is to cut up a gut length into pieces of two or three inches-short refuse pieces will answer as welland forming a short loop, seize it on to the shank of the hook.

In leaders for fly-fishing, the gut nearest the line should be stout, each length diminishing in size to the finest that can be procured, where it is tied to the stretcher fly.

LINES are made of flax or plaited silk for bottom-fishing; flax is preferred when it is necessary to make a long cast, as in Bass or Pike-fishing, as it runs more freely through the rings or guides, and the end of the tip.

Plaited silk is to be used invariably for trolling from a boat, as it does not kink in passing through the water, as a twisted line is apt to do.

The best lines for fly-fishing are made of silk and hair; they taper gradually from the end which you attach to the axle of the reel, to the end which joins the leader. I would here remark, that in fly-fishing, the usual clumsy loop, or a 
knot in the end of a reel-line should be dispensed with, by seizing on a length of stout gut to the end of the line, to remain there permanently; the leader should be attached to this piece of gut with a neat knot. By this contrivance, you avoid the contingency of having fish rise at the loop, as they will at a bit of frayed silk, as mentioned on the preceding page.

A bait or trolling line should have a gut-loop seized on the end, which loop is fastened to the leader by a similar loop in its end, as described in our article on tackle-making.

Oiled-silk plaited lines are frequently used for trolling, but more generally for Salmon-fishing.

REELS.-Many innovations have been made on the old English Reel by American anglers and mechanics; some of these, it is contended, are not improvements.

The balance-handle, patent-check, and jewelled bearings of the modern multiplier, are certainly desiderata in reels used for Bass, and are now considered indispensable by crack fishers; but the simple reel with a click, and without the balance-handle, is to be preferred for fly-fishing; it is less liable than the multiplier to get out of order, and the line is not so apt to be caught by the handle or crank. An improvement in English Salmon-reels has been lately introduced, which precludes the possibility of the latter contingency : it is the insertion of a short handle or pin in a disk, revolving parallel to, and against the outer plate; this improvement is applicable only to simple reels for fly-fishing. The reader will find a wood-cut of one, in a subsequent article on Tackle for Salmon-fishing.

Some anglers prefer the multiplier even for fly-fishing, on account of its enabling them to shorten line faster, if a trout on being hooked should run towards them. This seldom happens in wading a brook or creek; but in deep, still waters, 
where the angler fishes from a boat, and large trout endanger his tackle, such a necessity sometimes arises.

Whether it be a multiplier or simple reel, in fly-fishing for Trout, it should be small; for a greater length than twenty yards of line is seldom if ever required.

By the aid of the balance-handle (an American inven: tion which helps to keep up the momentum when the bait is cast), reels have been made to run with so little friction, that the motion imparted by a whirl of the crank, with the hand, causes the spool to revolve for two minutes. The bearings of the more costly reels are made of jewels. I know of one made by an amateur mechanic, without the jewels, which will run for a minute and a half. Reels of this kind are used mostly by Bass-fishers, who make long casts, when it is desirable that the line should run out as freely as possible.

In all reels a short. axle is to be preferred, as it enables one to wind up the line quicker and more compactly on the spool.

A well-made reel does not jar or clatter, but while the journals fit nicely, they run easily in their bearings, and the inner plates of the spool revolve without friction in the outer.

RoDs.-Although rods are still imported from England, and those made by her celebrated tackle-makers are thought by many to possess some qualities not found in American rods, the latter as a general rule are equal to the English, and in many respects better adapted to the requirements of our anglers; the metallic tip and guides being preferred by all (in any but fly-rods) to the English mode of having rings for the line to pass through, and the usual wire loop at the tip. In bass, pike, and trolling rods, they are now considered indispensable, as the line passes through with less friction, and in casting, the line is less apt to get foul. 
There is a diversity of opinion as to the weight and length of rods for various kinds of fishing; it is much a matter of fancy.

The woods in general use are ash for the butt, hickory for the second and third joints, and lance, iron-wood, or bamboo for the tips; of course they should be well seasoned.

The best materials for a fly-rod, are ash for the butt, ironwood for the middle joint, and bamboo for the tip.

Fly-rods in three pieces are to be preferred, as they require fewer ferules, and distribute the spring of the rod more equally through its whole length. It is better for those who have patience and knack, to join the tip to the middle piece with a neat splice, wrapped with coarse, well-waxed silk, making only one ferule necessary.

The angler whose park of artillery consists of one piece of ordnance, should possess himself of a general rod with a hollow butt, in which he may keep his tips of various lengths and sizes; this rod with its variety of pieces, may be put together for trolling, for bait-fishing, and should occasion call for it, may even be used as a fly-rod, although it is a kind of a makeshift. A general rod, if made in pieces of two feet, can be conveniently carried in a travelling trunk; in joints of this length the ferules should be short, fit well, and without the usual wooden sockets. By dispensing with the latter and having the ferules short, the elasticity of the rod is less impaired.

I shall give my notions of the rods appropriate for different kinds of fishing, as I describe each fish and the manner of angling for it; and advise that the best rod should be bought for any or each kind of fishing; though, let me here say, the most expensive is not always the most suitable.

The Bow Dipsy.-A friend has lately shown me a Chinese contrivance, which was brought over many years since by an 
old East India merchant; it may have caused the introduction of the "bow-dipsy" in Philadelphia. This is a piece of whalebone bent at right angles, each side or arm being fifteen to eighteen inches in length, with a snood attached to the ends. It is lowered to the bottom by means of a hand-line, and a conical leaden sinker fastened ten or twelve inches beneath the angle. It is well adapted for taking small fish in any rapid tideway (especially White Perch), where they collect in schools and bite rapidly. It is braced by lateral pieces of cord, which cause the whalebone to give and resume its position as the fish takes the bait-making it almost sure to hook him. I have heard of forty dozen White Perch being taken in the Delaware by three fishermen, in the last two hours of an ebb-tide, with this strange-looking contrivance.

The tackle used exclusively in fly-fishing, I will mention under its appropriate head, in a subsequent article.

There is a great deal of superfluous tackle pictured and described in English books on angling. There is the clearing ring, the angler's friend (a curved blade sharpened on the inner edge), baiting-needle, disgorger, paternoster, kill-devil, a plummet to get the depth of water, \&cc., \&c., which would better grace the window of a tackle shop, or a museum of useless tackle, than an angler's wallet. It is amusing and even wonderful, what an amount of such stuff an ardent, green angler, with a flush pocket, can collect. As he grows older in the art, of course he throws it away, or imposes it as a present on some one no less verdant than he was himself a few summers before, exclaiming with that ancient philosopher: "Lord, how many things there are in this world of which Diogenes hath no need!" 
C H A P TER IV.

THE PERCH FAMILY 
"As inward love breeds outward talk, The hound some praise, and some the hawk:

Some better pleased with private sport,

Use tennis, some a mistress court:

But these delights I neither wish, Nor envy, while I freely fish.

"Who hunts, doth oft in danger ride;

Who hawks, lures oft both far and wide; Who uses games, shall often prove

A loser; but who falls in love, Is fettered in fond Cupid's snare;

My angle breeds me no such care.

"Of recreation there is none

So free as fishing is alone:

All other pastimes do no less

Than mind and hody both possess:

My hand alone my work can do,

So I can fish and study too."

W.ALToN. 


\section{H A P T E R I V.}

THE PERCH FAMILY-PERCID必.

General Remarks on the Percide. Great number of American genera and species.-Paucity of European Species.-Distinguishing marks.Their abundance and variety in the Valley of the Mississippi.-Migratory habits.

The Rockfish or Striped Bass. Labrax Lineatus, - Rockfish Tackle.Rockfishing on the lower Rappahannock.

The White Perch. Labrax pallidus.-Perch Fishing.

The White Bass of the Lakes. Labrax albidus.-White Bass taken with the artificial fly.

Fresh Water Bass of the South and West. Grystes salmoides.-Bass Fishing.-Bass Fly Fishing.

Black Bass of the Lakes. Grystes nigricans.-Trolling for Black Bass with spoon, and with artificial flies.

The Striped Bass of the Ohio. Perca chrysops.

The Short Striped Bass.

Oswego Bass.

The Crappie or SaC-A-Lai. Pomoxis hexicanthus.

The Yellow Barred Perch. Perca flavescens.

The Sunfish or Sunny. Pomotis vulgaris.

BREAM. Ichthylis rubricunda.-Bream Fishing on Bayou La Branch.

The Pike Perch or Ohio Salmon. Lucioperca Americana.

The Buffalo Perch. Ablodon grunniens.

DE KAY, whose work on ichthyology was published in 1846, says, there were more than sixty genera and six hundred species of Percidæ known at that time. How many new 
species have been added to the number since, it would be difficult to say.

It is somewhat remarkable, that in British works on angling, we find only one species of this family described; it is a barred Yellow Perch, resembling our Perca flavescens. Cuvier describes comparatively few as being found in Europe; while here the Percidæ include as many fresh-water species of game-fish, as all the other families combined. And our anglers of the Atlantic States are not generally aware of the great variety found in the Southern and Western States, and the sport they afford to the fishers there.

The distinguishing marks of the Percidæ are, edges of gillcover or fore gill-cover, and sometimes both, denticulated or pectinated like the teeth of a comb, or armed with spines. Both jaws, the vomer and palatine, armed with teeth. First rays of the dorsal, or entire first dorsal (if there be two), armed with sharp points; the first ray of the anal-fin being always spinous; and the ventrals with one or more spines. The free edges of the scales are pectinated, and the ventralfins under the pectorals. From this latter peculiarity, the ventral-fins being in close proximity to the throat, earlier ichthyologists termed them Thoracic fishes. The sharp spines of the fins have caused the Percidæ to be placed amongst the Acanthopterygii. According to Professor Agassiz's classification in reference to paleontology, they belong to the Ctenoids-the third order of fishes in creation.

The Yellow-barred Perch, although the type of the family, is its least worthy representative. The splendid Rockfish, and the Southern Bass belong to other genera. The latter, which is found in all the Southern and Western States, furnishes great sport to the angler. It is taken with minnow, shrimp, spoon-bait, bob, and artificial flies. If by any dis- 
pensation of Providence the Percoids should become extinct, there would hardly be sport left to the anglers, who fish the numerous creeks, rivers, and lakes where they now abound.

I have alluded on another page, to the replenishing of the lakelets, found so abundantly scattered along the margin of the Mississippi, through its alluvial bottom lands, by the occasional overflow of that river. This phenomenon is strongly presented to the notice of observing anglers in the neighborhood of St. Louis, and one is apt to wonder where the great numbers and varieties of the Perch family come from, to stock these sluggish waters. In thinking over the matter I have fallen back on my favorite theory, the instinctive migration of surplus production, as applicable to fresh-water fishes, as well as to salt water or pelagian genera.

If the reader will take the trouble to look at a good map, he will see that the states north and west of the confluence of the Mississippi and Ohio, are threaded for thousands of miles by rivers of gentle flow, and dotted with innumerable lakelets, which, to a great extent, are the feeders and sources of the Mississippi. These are the breeding places of Bass, Crappie, and other Percoids; most of them spawn early in the spring, soon after the ice has left the lakelets; and as most fresh-water species instinctively run down stream after spawning, it is easily conjectured how large schools of these fish are hurried along by freshets, and deposited in the ponds that are fed by the overflow of the great river.

After a rise in the Mississippi, the lakes and ponds that skirt its course, above the mouth of the Ohio, and down through the regions of cotton and sugar, are filled with fish of this family.

In the ponds which have been replenished in this way in the neighborhood of St. Louis, their numbers decrease very little the first summer; the second season they spawn and 
breed, as in their native waters, but if the ponds are not refreshed by an overflow of the river every two or three years, the waters lose the chemical condition necessary to the reproduction of fish, from a continued infusion of decayed vegetable matter, and the lakes become barren, until another overflow of the mighty river comes rushing through, clearing them of foul, and filling them with fresh water; and restocking them at the same time with fish, and most numerously with Percoids.

Below its junction with the Ohio, the Mississippi has made in the course of time, many a "cut off," forcing its way in times of flood, across the neck of a peninsula or a bend, in seeking a more direct course, and leaving considerable bodies of water, of a horse-shoe shape, as the old channel closes. These are fed by the annual or occasional overflow of the river, and their waters refreshed and restocked with fish, as just described. Bruin Lake, opposite Grand Gulf, Mississippi, is a water of this kind, and is said to contain Bass (or as they are there called Trout) of immense size. I have been told by an angler, that he has taken there, in a day's fishing, thirty of these fish, whose aggregate length was sixty feet. 



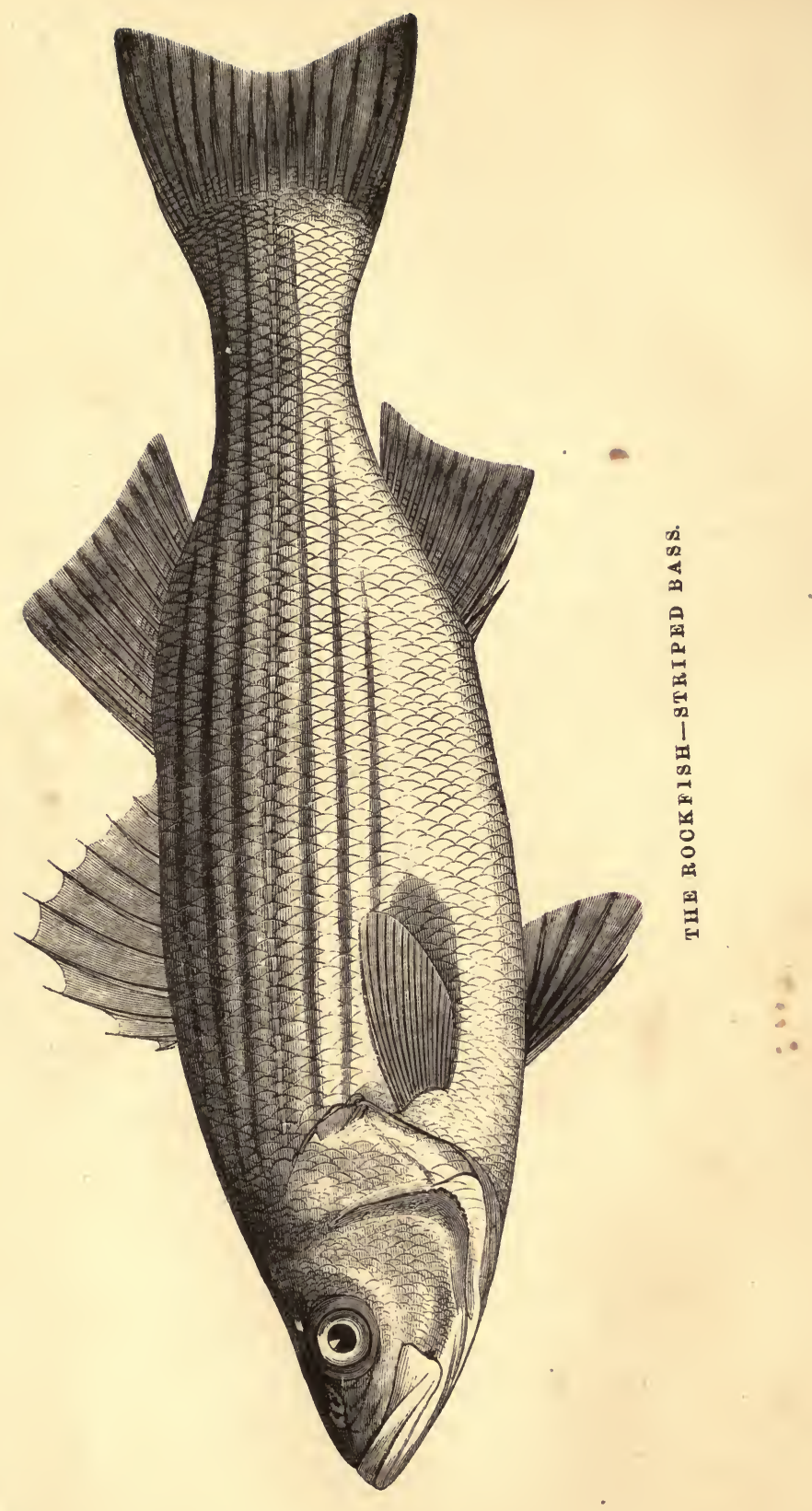




\section{THE ROCKFISH, OR STRIPED BASS.}

\section{Labrax Lineatus: CUvier.}

The following description is taken from a fish of stout proportions, weighing four pounds; its length nineteen inches, exclusive of its caudal, breadth five inches.

Form elliptical, compressed; length of head compared with body, as $5 \frac{1}{2}$ to 19 ; tail slightly forked; head opercle and preopercle scaly; two flat spines on the posterior margin of the opercle, with a membrane between and extending beyond them-the lower spine the longer. The eye is about onethird of the distance between the tip of the snout and posterior angle of opercle; irides light yellow. Teeth on the maxillaries and palatines, also on the sides of the tongue, which is soft, and on the arehes of the gills; the lower jaw is the longer.

Color; bluish green on the back, shading gradually lighter to the lateral line, which commences above the superior spine of the opercle, curves slightly upwards for a short distance, and is thence straight to the centre of the caudal; belly white. There are eight dusky stripes, the four above the lateral line extending to the tail. The lower margin of the preopercle and the chin are roseate white; caudal and dorsals dusky lead color; pectorals roseate at the roots and greenish yellow on the rays; ventrals roseate white in front, shading to a light lead color posteriorly. Scales on the roots of the caudal fin. 
The first dorsal has nine stout spines; the second one spine and twelve soft rays; pectorals seventeen rays; caudal six. teen; ventrals one spine and five rays; anal three spines and eleven rays.

Rockfish are not plentiful in the Gulf of Mexico, but are abundant along the whole coast, from Georgia to the Gulf of St. Lawrence, and are found in larger numbers from the Chesapeake Bay to Nantucket, than in any other part of their geographical range. They have been known to reach the weight of ninety pounds, and have been taken with rod and line as high as forty or fifty, - though one of six or eight pounds affords the angler sport enough. As far as game qualities are concerned, it is the finest fish the American angler meets with, south of the regions of the Salmon.

In the Chesapeake and Delaware bays, they leave the salt water as soon as the ice disappears from the rivers, and have been taken in the Schuylkill, at Fairmount dam, as early as the 20th of March, by trolling with a minnow, or roach, or a small pickled eel, kept from the previous season. The first Rock-fishing of the season, on the Potomac, is at the Falls above Georgetown, where great numbers, and large ones, are sometimes killed; and there is no doubt that they can be taken in this latitude, as early as April or May, on any river communicating with salt water, where the tide is obstructed by a dam or impassable fall. At Newport and Narragansett Bay, they are caught from June to November, by baiting with a small species of herring called Manhaden. Along the sedgy creeks and inlets, from Cape Henlopen to Sandy Hook, they are taken with soft crabs and shrimps, during the months of August and September. Large Rockfish are frequently caught in nets, when they are following a school of herrings on the fishing grounds, where they cause 
much annoyance to the fishermen by tearing their nets, and allowing the shad and herring to escape.

An erroneous opinion prevails, that Rockfish ascend fresh rivers above the head of tide to spawn; but food is their only object. They generally spawn in tidal creeks and rivers, where smaller streams of fresh water enter. When they are taken in the Delaware and Hudson above tide, they are generally of large size, and are caught mostly on set lines and in fish-traps.

Rock-Fishing.-The first dash of a Rockfish is terrific to a novice. Thirty yards are frequently spun off the reel before a large fish can be checked. At the Falls of the Potomac, or in the rapids of the Susquehanna, his play is not less vigorous than a Salmon's; his runs are much longer, and he frequently escapes by chafing or cutting the line or leader against the sharp edges of rocks, being assisted in his desperate struggles by the strong current. Still, though sturdy, he is a fair fighter, and where there are no such obstructions, a gentle hand, a taut line, and a steady pull secures him.

You must not be too anxious when playing him, to get a first sight of your prize, or be too familiar by bringing him close to the boat or shore, until he is well tired out. When he gives in at last, and lies exhausted on his broad side, you may, in absence of a gaff or landing-net, put your thumb in his open mouth, and your fingers under his chin, and lift him in-being careful at the same time of the sharp flat spine on his gill-cover.

Rods of various lengths are used in angling for Rockfish. In bottom-fishing in a tideway, one of twelve feet with a stiff tip is necessary. When using a float, one of greater length and more pliability affords better sport; but in casting a minnow over a bold, rocky stream, which is the 
ne plus ultra of Bass fishing, a stout salmon-rod, or a bamboo, or a native reed pole of eighteen feet, fitted with reel and rings, is more appropriate.

In all cases a good multiplying reel should be used, with a hundred yards of well-laid hemp line, which should pass through metallic guides, and a metallic tip at the top of the rod. The crack Bass fishers of New York are so fastidious, as even to have the tip (the end-piece through which the line passes) jewelled, in order to lessen the friction as the line runs out, when casting.

Many anglers do not feel secure unless the leader be of double gut, which is entirely unnecessary, unless there are sharp rocks on the bottom; for a single strand of the best and stoutest gut, when wet, will bear nearly as much strain, as an ordinary hemp line. Stout-wired Kirby hooks, long or short shanks, from No. 1 to 00 , are preferable; they are much more certain of hooking than the Limerick.

The weight of the sinker should be proportioned to the depth of the water or force of the tide. In bottom-fishing, an oblong sliding sinker may be advantageously used. In trolling or casting over rapids, a bullet, from the size of a buckshot to a half ounce, is best; then, also, one or more swivels should be looped on, to insure the spinning of the ninnow.

The usual mode of using the minnow, when trolling, is to "bridle" it, which is done in several ways. The easiest is, to put the hook in at the mouth, out through the gill, and then, after taking a half hitch around the head, to pass it through the side of the back; so that the bend of the hook may set upwards, with the point towards the head of the bait.

Another and a better plan, is to have a small hook (size 2) on the snood, about three inches above the larger; the smaller hook is passed through the under, and out through the upper 
lip of the minnow; and the larger hook, as just described, through the back. To increase the spinning or twirling of the bait in its passage through the water, it is better to put on the minnow slightly bent, which is done by passing the larger hook through the back nearer to the tail than you would when you intend the minnow to swim straight, and then doubling it a little.

In baiting with shrimps, which are good in some waters, and at certain seasons, a float should be used, if the tide is not too strong; this bait should not touch the bottom, as Rockfish are not in the habit of looking for them there; it should also be kept in motion by occasional short jerks or twitches of the rod. Soft crabs are always found on the bottom by the fish, when feeding on them, and, of course, in using crab-bait, you should fish near the bottom, whether it be with or without a float. I have sometimes found Rockfish so well on the feed, as to take a slice or oblong piece of fish-bait, readily striking at it, if it is white and well put on; for, like other fish, they have not the delicate sense of taste, that anglers give them credit for.

The pearl minnow, or a tuft of raw cotton, or a white rag tied on a hook, will frequently take small Rockfish, where a strong tide sweeps under a bridge, or around the corner of a pier. The fish wait in the eddies on the lee side of the timbers of the bridge, or angles of the pier, for minnows or shrimp; and seize any small object having the appearance of life. There is no doubt that at such times, a light colored fly, particularly the white moth, would be taken greedily, though a white rag answers the purpose as well. Half flood is the best time of tide for such fishing. The pearl minnow should we drawn against the current, a few inches below the surface, and near the edge of the eddy; the angler being careful to keep out of sight and not to cast his shadow over the swim. 
At the Rancocas bridge, a few miles above Philadelphia, some years ago, a party of three anglers, on a day in the latter part of June, took fifteen dozen Rockfish, from ten to fourteen inches long, with the pearl minnow.

In strong tideways, or deep water, the last half of the ebb, and the first half hour of the flood tide is generally considered the best time for taking this fish. In the shallow bays and sounds extending along our coast, there are thoroughfares between the low grassy islands, which are almost dry at low water. Here crabs are found in great numbers, and the Rockfish come in with the flood tide in search of them. In such places, the last half of the flood and high water are the proper times. The most famous place along the coast for catching these fish, is Narragansett Bay. I have heard stories of the Bass fishing there, that it is not prudent to repeat.

The American Angler's Guide, by J. J. Brown, Esq., of New York, has an excellent article on Striped Bass fishing in the waters around New York.

Frank Forester, in speaking of this fish, says, "The fly will take them brilliantly, and at the end of three hundred yards of line, a twelve-pound Bass will be found quite sufficient, to keep even the most skilful angler's hands, as full as he can possibly desire." The author in question must have delighted in "magnificent distances"; for a line of three hundred yards, with a Bass at the end of it, would certainly be "playing at long taw," and is suggestive of "shooting with a long bow." Most anglers will kill a Bass of any size, and not give him fifty yards of line. Frank Forester's idea of trolling for Rockfish, as some anglers fish for Pike, with a leaded gorge hook, from the shore, even if successful, would be dull sport compared with the usual mode of taking them. It would moreover be degrading to the bold Rockfish, to place him in the same category with a sneaking Pike. 
Flies are not the natural food of this fish, though they may be of the Southern Bass or the Black Bass of the great lakes; still it is not an uncommon thing to take Rockfish with a large gaudy artificial fly, at the Falls of the Potomac; though a hook wrapped with a piece of yellow, or sometimes with red flannel, will answer the purpose. This fish follows and seizes the fly under rather than on the surface, and does not start from the bottom with a spring, as the Trout or Salmon.

Rock fish below twelve inches, are not good, the flesh appearing to be wilted and immature, bearing the same relation to that of a four-pounder, as veal does to beef. When of two or three pounds, they should be split and broiled, they are then very good; above this size, they are generally boiled. They are better though, cut into steaks, - that is, in transverse slices-and broiled, and seryed with melted butter and parsley. The flesh of overgrown Rockfish is said to be coarse, and is not esteemed.

Most tidewater anglers have pleasant reminiscences of this fish, but no recollection of Bass fishing comes back to me with greater pleasure, than my first essay amongst the "big ones." It was many years ago, in the month of June, when on a visit to a relative-an ardent though not a scientific angler-who lived on the banks of the broad Rappahannock, near its mouth. On the morning after my arrival, my host improvised a bout with the Rockfish; and I saw from my chamber window, a negro boy, with no othèr implement than a four-pronged stick, capture as many soft crabs as sufficed for bait and breakfast. Our canoes were staked out some distance from the margin of the sandy beach, which made it necessary to be carried to them. This task was speedily ancomplished by a sturdy little negro; who with trousers rolled up on his sable drumsticks, dumped the whole cargo-bait, rods and four anglers-into two "dug 
outs." We were soon staked down on the flats, a half mile from the shore, where the water was six feet deep. Our object was, to place the boats in such a position, as to fish into the "galls," or bare places, where there was no grass; these were of various sizes, from three rods square to half an acre.

The rods, reels and scientific tackle of the city anglers, excited the wonder, and no doubt the silent contempt of the native fishermen; who were rigged, one with a hand-line, and the other with a stout cedar pole, with a line attached to it, that might have held a Shark. My host, a staunch Democrat and anti-bank man, dubbed my rod, which was not over stout and fifteen feet long, "The Nick Biddle pole," and assured me it was all well enough for White Perch, but would not hold a Rockfish, such as he could bring with a strong pull, and a "whop," right into the canoe.

It was my good fortune to hook the first fish, a fine fellow of six pounds. There was much laughter, of course; Uncle Rolly declared I would never get him in. "See how your pole bends! Why he's way off in the middle of the gall already! Why don't you pull him in?" The old man was here interrupted by the disappearance of his pine-bark float, and in less time than it takes to tell it, he had his fish flapping in the bottom of the canoe. "There!" said he, "I can catch ten to your one. I tell you, your Nick Biddle pole will never do here!" By this time I had my fish pretty well in hand, and after a dash or two more, Jordan, the negro boy, put a wide crab-net under him, and lifted him in. The next fish Uncle Rolly hooked broke his hold; so did a good many more, and large ones too; while every fish struck by the dandy pole, was killed artistically, though the old man thought with much unnecessary ceremony. At the ebb of the tide science had told. We had a good time of it, and the owner of the "Biddle pole" felt great confidence in his fine tackle, and 
much quiet satisfaction in his first success with it; while Uncle Rolly laughed at his tactics. We went home and ate the stewed head and shoulders of a large Rockfish and soft crabs for dinner. Next day we tried our luck again with equal success; and before leaving for home one of the town anglers killed a Rockfish of twenty-five pounds, which Uncle Rolly would certainly have lost.

Besides the fishing in this part of the Old Dominion, I have vivid recollections of the hat, hair, and hospitality of

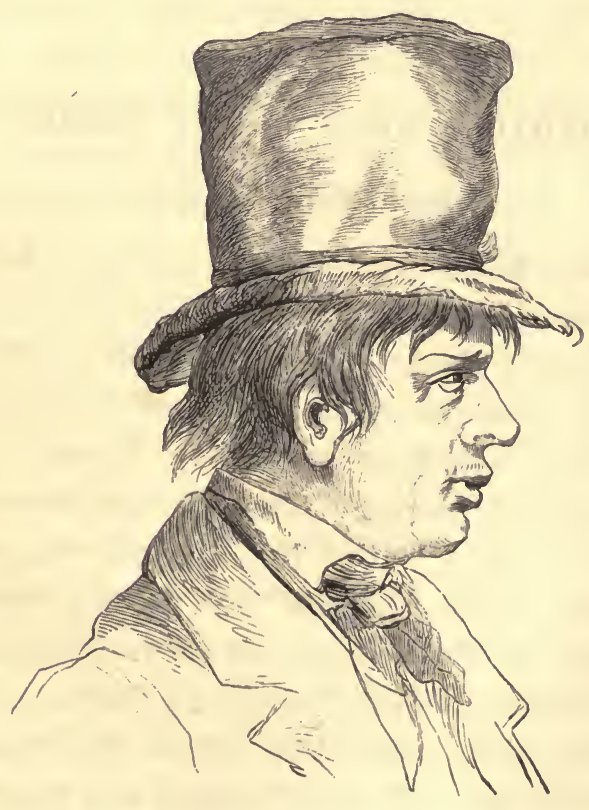

"Uscle Rolly." 


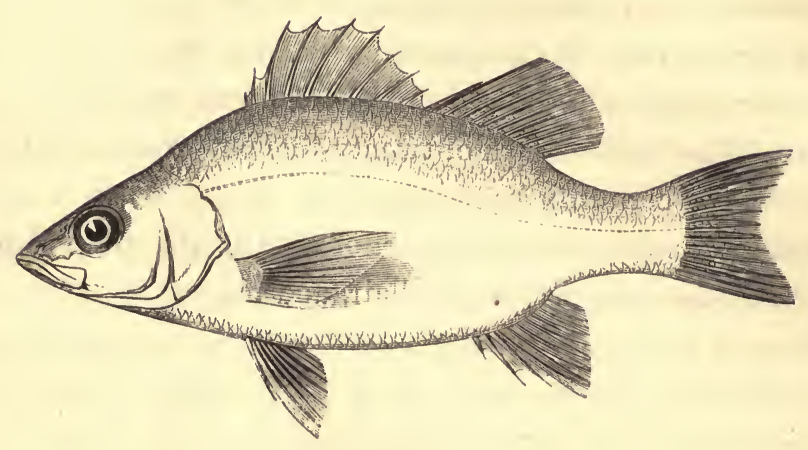

WHITE PERCH. GRAY PERCH.

Labrax pallidus : De $\mathrm{K}_{\mathrm{AY}}$.

Color-back, bluish gray; sides, silvery gray; belly, white ; body compressed, elliptical ; breadth, one-third of its length ; head not quite a third; eye one-third distant from snout; opercle and preopercle scaly, a single flat spine on the opercle, with a membrane extending beyond; preopercle serrated on lower margin. Branchial, and fin rays. B 6; D $9,1,12 ;$ C 16; P 14; V 15; A 3, 10. Compared with Labrax rufus of De Kay, this fish is of a more lustrous silvery hue; its fins longer and more transparent; the rays more delicate; spines longer and sharper, some of the dorsal spines with a sabre-like curve. The facial line is more depressed, eye full, mouth larger, and bearing all the marks of a game predatory fish. It is seldom found north of the Delaware.

De Kay's specific appellation "Pallidus" denotes the color, and marks the difference between this and his Labrax rufus, or Ruddy Bass. I believe as he did, that the two are distinct 
species. Holbrook, quoting Gmelin, calls it Labrax Americanus, and falls into the same error as Cuvier and Storer, making no specific difference between the two.

Labrax rufus is a northern fish, seldom if ever found south of New York. Its habits differ from those of Pallidus, being found mostly on flat clayey and muddy bottoms, and in shallows, and in some of the fresh-water ponds of the New England states and New York. It has not the game qualities of Pallidus.

The White Perch is a congener of the magnificent Rockfish, and is frequently found feeding in the same place and in his company. Its average length is eight or nine inches; it is not often more than twelve, though in rare instances it is found fourteen inches long.

This beautiful, free-biting little fish, which affords so much sport, and, which is found in all the fresh and brackish tide-waters, from Cape Hatteras to Sandy Hook, does not receive that favorable notice from writers on ichthyology and angling which it merits. De Kay, in speaking of it, after describing the Ruddy Bass, says: "Like the preceding species, it inhabits salt and brackish waters; but as far as my observations have extended, it is invariably a small fish, and rarely brought to market for food. The Little White Bass, or White Perch, may be readily distinguished from the other, by its light color, small size, and very compressed body."

I am disposed to object to its being called a salt-water fish. Its most natural habitat is fresh tidal-rivers. It is frequently found far above the terminus of the tide, and they are even more abundant in fresh than in brackish waters, at the season of the year when they are sought for by anglers. This fish when found in salt-water creeks, is darker in color, but there is no specific difference.

The rernark above quoted, that it is "rarely brought to 
market for food," is an error so glaring, as to cause one to suppose, that the explorations of the naturalist in question, could not have extended south of New York. The same author also says or implies, that its average size does not exceed six or seven inches; by which he also evinced his slight knowledge of this fish. Frank Forester, in his book on angling, after a slight notice, dismisses it, as "not sufficiently important to merit more particular notice." The latter gentleman missed much, by not becoming acquainted with our little friend Pallidus. In season, the White Perch is the pan fish (and there is none better) of the Philadelphia, Baltimore, Washington, Norfolk, and Richmond markets. And as for sport; should it be said that a man or boy has no sport, or is not an angler, because he does not use reel or gut? Did not Billy Jones, the chair-maker, down town, go a Perch-fishing four or five times every summer; shutting up his shop for the day, and taking his wife, children, and apprentices in his sailboat down the river-or in a furniture car down the "Neck;" and with his brandling-worms in an old coffee-pot, and his minnow-net and frying-pan, and store of bread and butter and bottled ale, make a day of it? Did not "our Johnny" shoulder his reed-pole every Saturday morning, when there was a run of Perch at Fairmount dam; and return at night with a string of them as long as his leg, and his trousers smeared with shad-roe? Is not Uncle Jima respectable colored gentleman-who lives in a quiet nook by the Curratoma, down in Old Virginia, always sure of a mess of them? And Old Davy, whose shanty is on the high bluff, by the mouth of the Sassafras, does he not "count on 'em ?" And still the learned De Kay, and the eloquent Frank Forester speak disparagingly or hardly notice this game little fish, so intimately associated with the early, and happy 
recollections of every angler, of the waters that find their way into the Chesapeake and Delaware.

White Perch hybernate in the deep salt water of our bays, and ascend the fresh tide-rivers soon after the ice and snowwater have run off. They feed greedily on the spawn of other fish, particularly that of the shad; on insects, grubs, minnows, and on the migratory schools of young eels, which are found in the months of April and May, in great numbers, at any rapid or dam obstructing the upward flow of the tide. Perch usually spawn in May, and then resort to deeper waters to recuperate, and all summer long, are found by the angler, ever swimming around the deep sunken pier, or the timbers of the rickety old bridge, snapping at shrimp, or chasing the minnows on the flood-tide high up amongst the water-lilies; and never refusing a bait, if of the right sort, and properly presented.

The first Perch-fishing of the season, is always at the terminus of a tideway, as just mentioned. Through the summer, they are taken on the ebb-tide in deep water, on sandy or rocky bottoms or muscle-beds, or around stone piles or sunken hulks; and on the flood-tide, along the margins of rivers, or creeks, where the long grasses or waterlilies afford a home for the minnows.

In brackish water, shrimps are decidedly the best bait; in deep holes, in fresh tide rivers, brandling-worms; on the floodtide, along the margin of the grass or water-lilies, minnows are good, or a wedge-shaped fish-bait is greedily taken, if the Perch are well on the feed. This last should be cut with the skin adhering, which makes the bait so tough, that six or eight fish may be taken before renewing it. For early fishing, young eels, spawned the preceding autumn, which are beautifully transparent and not larger than a darning-needle, are the most attractive. These, as I have just said, are to be had where the tide is impeded by dam or rapid. Here 
the Perch and Rockfish devour immense numbers of them, and it is only at such places that these fish look for them. The vitality of these little animals is wonderful; and if the hook is passed through them below the vitals, which are easily seen, they remain alive for some time. Two or three eels are put on each hook. This bait is found in small pools left by the ebb of the tide, and can be easily secured with a small net of sea-grass skirting.

The first catch of Perch, with Philadelphia anglers, is, or was, below the dam at Fairmount waterworks; beginning in April with young eels, and occasionally small minnows for bait. Early in the season, the most likely places are where the rapid subsides into deep, still water; in May they are found more in the rapids and nearer the fall of the dam.

The tackle which affords the best sport is a common native reed pole, of twelve or thirteen feet, not thicker at the butt than the thumb, and tapering to a fine point, which can be rendered still finer and stronger by splicing on a tip of lance or iron-wood. The same rod may also be used with a reel, by putting on rings, and a metallic tip at the end for the line to pass through.

A fine line of flax or silk should be used, with a gut leader of three or four feet, with two hooks, one at the end, and one eighteen inches or two feet above. The best hooks when baiting with little eels, are those termed "weak trout" hooks. They are long in the shank, which facilitates baiting and taking off the fish; the wire is also delicate, mutilating the bait less than a coarser hook, and being more elastic, or at least more flexible, lets go its hold more easily when caught on the bottom. If in pulling it away, the hook should straighten to any extent, it may be easily restored to its shape, by pressing the bend together between the fore teeth. With delicate handling, these hooks are strong enough to : ccure a three-pound Rockfish, if he should take your bait. 
The sinker, conical or round, should be in size from a buckshot to a half ounce bullet. Its weight must depend on the depth and force of the current; it should be attached by a weak piece of gut or thread at the junction of the leader with the line; so that in case of its being caught between the rocks, you may lose only the bullet, and not your leader and hooks.

When fishing in slack water, especially by the edge of the water-lilies or grass, it is advisable to use a float; the Perch, . like other predatory fish, seldom taking a bait on the bottom, unless it is in motion. The distance between the hooks and the float should not be more than two-thirds or three-fourths the depth of the water.

Where the tide sweeps around the end of a pier, or the piles of a bridge, Perch frequently are found in the eddies on the edge of the current, waiting for minnows or shrimp; then a short line (without a reel) is preferable. In such places they can at times be taken with a pearl minnow. In a tideway or lively water, always fish down stream, to prevent the current bringing your line home to you, and so as to allow it to lift the sinker and leader from the bottom, and veer it about in such way, that the bait will appear attractive. In fishing from a boat, anchor just far enough above the desired place to. fish into it, occasionally trying either side. If you are in the right place, and the fish are on the feed, there is no necessity for striking, if the line is kept taut, for they generally hook themselves at the first pass they make at the bait.

If the angler is not greedy for a large catch, and the fish are found near the surface, and on the shallow rapids, as they sometimes are on a warm day in May, a stout fly-rod and light tackle might be used, baiting with a single eel, and without using a sinker, casting and drawing as with a heavy fly. Of course it takes longer to secure a fish by such means, but the sport is heightened. 
Perch-fishing in the month of May, in brisk water, where the run of fish is from nine to twelve inches, is not a whit inferior to bait-fishing for Trout. I prefer the former, because Perch, by such appliances as I have described, are taken in a sportsmanlike manner, and Trout (which should be taken only with a fly) are not. Sometimes in deep holes at the head of tide-water, when fishing with a minnow, the broadsided Shad will take the bait; or a three-pound Rockfish will come into your swim; then. if you have no reel, or your hand be not gentle, and if you do not grasp your rod by its extreme butt, and give him the whole spring of your fragile reed, you are a ruined angler; and you may not forgive yourself for a week, for lack of skill or precaution.

Many anglers object to a reed rod, on account, as they say, of a feeling of insecurity in its use. But for Perch-fishing, its lightness, and graceful bend, when a fish is on, commend it; and the very objection that is urged increases the sport to one who is fond of fishing fine.

The Perch is decidedly a pan-fish; and when rolled in grated cracker, or coarse corn meal, and moderately browned, is better fried than broiled. To a man of wholesome, unpampered appetite, it is hard to serve up a better dinner than fried Perch, with good bread and butter, and a little claret; or what is still better, though more homely, a bottle of Philadelphia ale. Large White Perch are sometimes boiled, and served up with egg sauce.

A piquant dish may be made as follows :-Cut off the heads and tails, and fry the fish enough to lay them open, and take out the backbone and ribs, dividing each fish into two slices; then put them in the pan again, and brown them in coarse corn meal; pouring over them, when nearly done, a little Worcestershire sauce, or walnut catsup, and serve them up with drawn butter and an additional quantity of either sauce or catsup. 


\section{THE WHITE BASS OF THE LAKES.}

Labrax albidus: DE KAY.

De Kay says: "This fish is bluish white above the lateral line, a few narrow dusky parallel streaks above and beneath this line; sides and belly white; pupils black; irides white intermixed with a little brown; dorsal, caudal, and anal fins brownish, tinged with blue; pectoral fins whitish, tinged with olive green; ventrals light transparent blue, tipped with white. Length $5 \cdot 10$, depth $3 \cdot 0$. Fins, dorsal $9,1,13$; pectorals 17 ; ventrals 1,5 ; anal 3,12 ; caudal 17 . This is a very common fish in Lake Erie, and is known at Buffalo under the name of White Bass."

In the year 1844, I made an appointment with a fine old gentleman of the medical profession, known and loved by all Philadelphians, who had taken up an idea that I was something of an angler, to meet him at Mackinaw, on my return from a western tour. We were to have gone to Sault St. Marie, where he had renewed his early love for angling, by taking some of the large Trout in the rapids, the previous summer, with an outfit which I had furnished him. Much to my regret I received a letter from him, when I reached Mackinaw, telling me that his presence at home was indispensable, and requesting me to call at Detroit and spend a few days with his son, then a lieutenant in the U. S. Engineer Department, who had charge of the construction of a fort there. I stopped, and we spent two long days angling 
in Detroit River. Our success was varied. On the afternoon of the first day, near sundown, we took twenty-five White Bass, with the artificial fly, in a creek on the Canada side opposite the town. They were all of a size-eight of them weighing just seven pounds. The fly was a rough affair of my own make, the wings being of the end of a peacock's tail feather. We afterwards learned that we had been fishing in preserved waters; the Canadian fishermen, who supplied the Detroit market, had caught the fish with a net in the river, and had turned them loose in the back-water of the creek and placed some brush across, so as to have them ready when there was a demand for them.

I have passed Detroit since, and tried to identify the place; I think the railroad depot at Sandwich, on the Canadian side, is near it; the creek has been drained off, or has become a mere ditch or uninhabited water, and the lieutenant, in the course of promotion, has become a great general. I wonder if, arnidst the arduous duties of the present, he ever thinks of that quiet afternoon? 


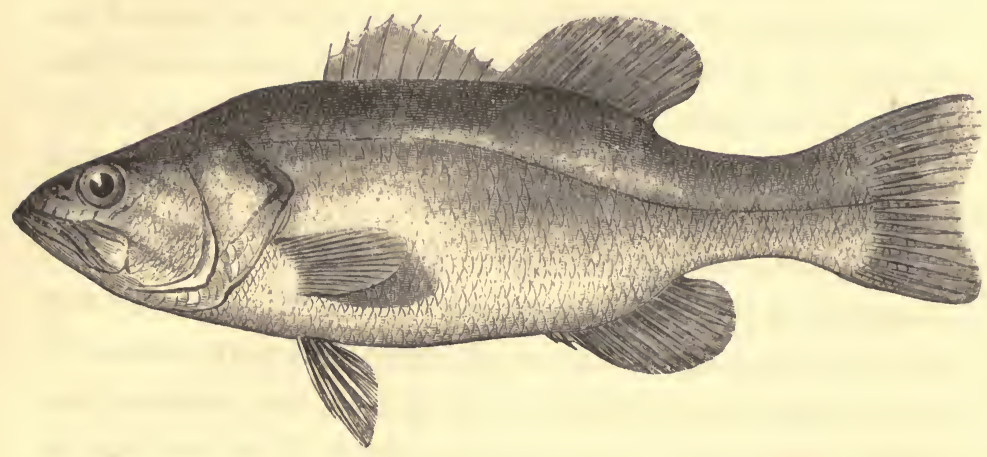

FRESH-WATER BASS OF THE SOUTH AND WEST.

Grystes salmoides: Cuvier.

This fish is known under various names, through the wide extent of its habitat. In the neighborhood of Richmond, it is called the James River Chub, sometimes Bass. In its more southerly range, it goes by the names of Trout, Black Trout, and Brown Trout, and is seldom called Bass, except in the Northwestern States. Although it is called "Trout," at the South, there is no family or generic affinity between it and our northern Trout.

The following is an abridgment of Holbrook's description, connected with a few observations of the writer. Head and body, dusky olive above, sometimes with a yellowish tint, lighter on the sides. Belly white; opercles light green or greenish yellow; first dorsal fin, nine spines and eighteen soft rays ; pectorals, fifteen; ventrals, one spine and five rays; anal, three spines and twelve rays; caudal, nineteen rays. Body elongated oval, straight on the belly. Eye large. Mouth very large, lower jaw longer. The vomer has brush- 
like teeth in front. Teeth on the palatines and pharyngeal bones. Tongue smooth, without teeth in front.

They are found in the James River, in the lagoons of the Dismal Swamp, in the Roanoke, and in every fresh-water stream of any size in the Southern Atlantic States; in the streams and lakes of Florida, and in all the rivers which flow from the north into the Gulf of Mexico along its whole extent. All the creeks and bayous are stocked with them; so are the lakes formed in the old bed of the Mississippi, wherever the river has made a cut-off, though they are seldom or ever taken in the river itself-the fish of most families only using it as a high road or thoroughfare from one lake to another. They are also found in the Cheat, Holston, Green, Kentucky, Alabama, Cumberland, Tennessee, and Ohio, and in their tributaries, to their very sources in the highlands and mountains. They are not so plentiful in the streams or their tributaries that fall into the Mississippi on the western side; but the long still lakes of the alluvial bottom lands on the east side, from the Ohio to Rock River, are stocked with this and other percoids by the occasional overflow of the Mississippi.

The rivers of Missouri, Kansas, Nebraska, and the streams and clear lakes of Iowa, Wisconsin, and Minnesota $a_{b}$ also supply them, with a little variety in form and color.

This fish is taken generally by still fishing, with a live minnow, and it is only of late years in the Southern States, that anglers have used the spoon, which is found to be very destructive. An accomplished angler of the "Houseless," gave me a glowing description of a party who started from Columbia, South Carolina, to fish the Edisto River, in the month of May 1860; they used the spoon bait, trolling near the bank under the overhanging branches, each angler occupying a boat paddled by his servant. They collected at night on 
board of the flat-boat which accompanied them down the river, with stores, cooking utensils, and bedding. They fished fifty or sixty miles of the river, and had a glorious time of it, taking Bass weighing as high as eight pounds.

In the states bordering on the Gulf of Mexico, this fish is taken with the minnow, shrimp, and bob; the latter is an artificial bait, made of gaudy feathers and tinsel (on two or three hooks); it is as large as a humming bird. It is said that the tip end of a buck's tail answers the same purpose in Florida. The bob is used from a boat, with a long rod and a short line; the boat is paddled silently along, at a convenient distance from the shore, while the angler is dapping his bob along in likely places near the bank; or, if he "paddles his own canoe," the end of a long reed with a short line projects beyond the bow of the boat, the bob just touching the water. When the fish seizes it, which is always with a bold rush and a spring, a short and decisive tussle ensues, in which the fish is taken by the angler or the rod is carried away by the fish.

- I have taken this Bass in the vicinity of St. Louis, on a moonshiny night, by skittering a light spoon over the surface of the water, while standing on the shore. In the South, a minnow or shrimp is considered the best bait, and a float of suitable size is used on such occasions.

The anglers of New, Orleans who have summer residences on the Gulf coast between the latter eity and Mobile, formerly enjoyed Bass-fishing to its full extent; many of them were ardent and skilful anglers.

I have often thought that this fish would take a large artificial fly well, and give grcat sport, on a stout trout rod, and corresponding tackle. My belief has lately been verified by an account given me of an English or Scotch angler, who spent last summer at the town of Rock Island, Illinois. He 
waded Rock River and fished for Bass as for Trout or Salmon, and killed a great many, some of which were of very large size. I hope he did not take the chills and fever home with him, to disturb his pleasant reminiscences of his sport.

The rod used is generally a springy weapon of fourteen feet for bait-fishing, and a lighter one with the bob. A good reel, and stout line and gut are required; the hook from No. 1 to 00 ; the latter size is preferable, as the Bass has a large mouth.

This fish is unsurpassed in flavor by any of the Perch family. The smaller are broiled or fried, the larger should be boiled and served up with egg sauce. 


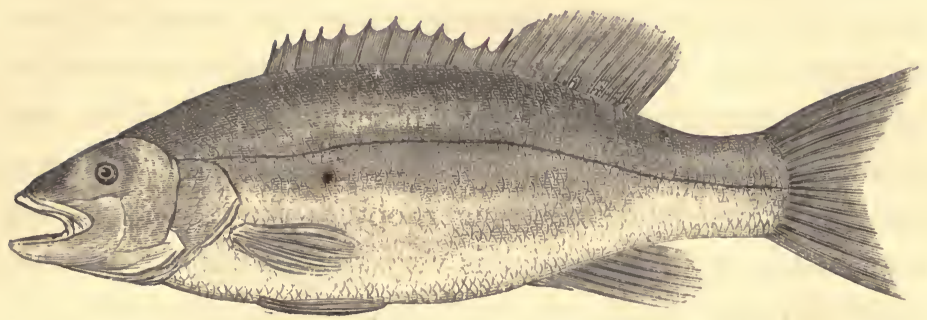

\section{BLACK BASS OF THE NORTHERN LAKES.}

\section{Grystes nigricans: Agassiz.}

The color of this fish (which appears to vary with locality, or the season) is generally dark olive-green on the back, shading gradually into a brownish yellow on the sides; belly, opaque white. Body compressed, oval; back arched; belly less curved than the superior outline; breadth as two to seven. Lateral line concurrent with back. Head small, little less than one-fourth the length of the body; preopercle covered with small scales, scales larger on opercle. The eye is on a line between the snout and posterior angle of opercle, one-third distant from the snout, and is about five-eighths of an inch in diameter; the irides are dark brown above, and pale yellow below. Nostrils small, double. Tongue toothless; both jaws with small brushlike teeth, small patches of the same on each side of the pharynx, as well as on the branchial arches. Branchial rays seven. The first dorsal fin has ten sharp spines, the anterior ray being short; the second dorsal is 
covered at its base with scales, and has fifteen rays, preceded by an obtuse spine of half their length; this fin is arched, and rounded posteriorly. The pectorals beginning immediately beneath the point of the opercle are yellow, nearly obovate in shape, and have eighteen rays. Ventrals commencing slightly posteriorly, have five branched rays. The anal terminating beneath the posterior point of the second dorsal, has two sharp, and one longer obtuse spine, and twelve branched rays. The caudal is very slightly forked, and has eighteen rays.

The specimen which the wood-cut at the head of this article represents, and from which my description was taken, was caught early in September near Rouse's Point, on Lake Champlain. I have been particular in my description, and find it differs from that of Agassiz and De Kay; from the former, in the color, spines, and fin rays. The difference of color I attribute to the season of the year, or some local cause.

I regret that my sketch, which is accurate as regards proportions, does not do justice to the original in other respects. The specimen was fourteen and a half inches long, and about two pounds in weight; one of four pounds taken on the same day, measured only eighteen inches.

There is some difference between this fish and his Southern congener; he is much stouter, and not as symmetrical in his proportions; his habits and manner of taking the bait are much the same, but his haunts-from the difference in the waters which he inhabits-are necessarily unlike the lurkingplaces of the Southern Bass. The Black Bass of the Lakes loves the rocky shores of the islands, the sand-bars, and reefs. He takes a live minnow in still-fishing, which is by far a more sportsmanlike mode of capturing him than trolling with the spoon,* though the latter is the method most in

* Buel's patent is most generally used. 
vogue. He is also trolled for with large gaudy flies-sold at the tackle stores expressly for the purpose-from four to six of them being attached by single lengths of gut to a long salmon casting-line. But the neatest way of taking these fish is practised by a veteran angler, who spends part of his summers in Trout-fishing on Manitoulin Island; to vary his amusement he takes Black Bass from the shore, with a stout trout-rod. They rise so readily at the artificial $\mathrm{fly}$, that it is almost unsportsmanlike to kill them in any other way. In trolling for these fish, a stout rod of ten feet and a good multiplying reel, containing from fifty to a hundred yards of plaited silk line, are required; a pair of swivels are necessary when using the spoon, but may be dispensed with if trolling with flies.

Written directions for trolling from a boat are hardly necessary, as the boatman, who is generally acquainted with the feeding-grounds, rows over the most likely places. When a Bass is struck, the boatman should cease rowing, and as the fish is generally securely hooked if trolling with the spoon, there is little chance of his escape, except from undue excitement, or unskilful handling on the part of the angler. In trolling with a gang of flies, it is best to have a landing-net about eighteen inches in diameter.

With all the game qualities of the Black Bass, his capture by trolling with spoon or flies does not afford the pleasure that taking fish from the shore does; there is no skill required in finding the game, for that is done by the boatman; striking is not necessary, as the fish hooks himself, and as for killing him, you must take him, to get him off the hook. So, in going out with a boatman who knows the waters, it necessarily follows that the merest bungler is as apt to have as good a catch as an expert angler. It is exciting certainly, when trolling with flies, to have two or three plucky fish on at the same time, fighting hard, and 
leaping above the water; but like all trolling from a boat, one has little else to do than wind up his line. How different from putting on a brace of light hackles, and going at sundown to try "a comfortable conclusion" with a Trout that refused your fly at midday!

Before the introduction of the spoon, the best fish were taken with the minnow, by still-fishing, from a boat anchured in some favorable place, a long rod without a reel being used, or a shorter one with the reel, and a good-sized float. This we consider far preferable to trolling with that deadly and unsportsmanlike implement, the spoon, as a fish will always give more sport, and has a better opportunity of displaying his pluck when he commences the fight at close quarters, and increases the distance by bold dashes and desperate leaps, obliging the angler to give and take line, and deal promptly and coolly with his adversary; while in trolling, you strike him at a long distance, and though he veers from side to side, leaps high, and fights hard, there is much of a dead pull in winding in so long a line, while it strains your rod, and is distressing to the works of a good reel.

Black Bass were once abundant in Lake George, but the steady demand for them at the watering-places has almost depopulated that beautiful water, and those that remain are mostly small fish, taken by deep still-fishing with a drop-line. They are still plentiful at the northern end of Lake Champlain. Alburg Springs is a favorite place for an angler's sojourn. They are found in abundance at many places on the shores of Lake Ontario, at Cape Vincent, and Alexandria Bay, opposite the Thousand Islands; also in the Niagara and Detroit Rivers, and in Lake Erie. Squaw Island, near Sandusky City, Ohio, is a noted place for them. They are found likewise in Lake St. Clair and Lake Huron.

The usual route for anglers of the Atlantic cities who visit 
the Thousand Isles, is by the New York Central Railroad to Rome, thence to Cape Vincent, and early next morning by steamboat to Alexandria Bay; where Rowe Brothers have quarters that would have delighted Father Izaak himself, and where boats and oarsmen can always be procured. Anglers from all the towns of New York on the Central Railroad come in large numbers to this place, and have immense sport amongst the Bass, Pickerel, and Mascalonge.

Like the other fish of this genus, the Bass is esteemed for the excellence of its flesh, though I think it is somewhat overrated.

This fish differs from the Oswego Bass, to which it bears so close a resemblance, in having a smaller head, and its belly less protuberant, though the position of the fins, their shape, and number of spines and rays, are almost identical. It spawns in the spring on the breaking up of the ice, when many of the largest fish are speared on their spawning-beds.

An officer of the United States Engineer Department, who had charge of the construction of a fort or lighthouse on Lake St. Clair, some twenty years ago, informed me that on several occasions he took scores of Black Bass by trolling with a hand-line from a boat; the average size was four pounds; he showed me the artificial bait he used, which was a large Limerick hook about an inch and a quarter across the bend, with a white feather whipped to the back of it. 


\section{THE STRIPED BASS OF THE OHIO.}

\section{Perca chrysops: RAFINESQUE.}

I adopt the scientific name given by the naturalist above quoted, with a condensation of his description.

Body oblong, silvery, with five parallel longitudinal stripes on each side, two of which reach the tail. Lateral line diagonal, but straight. Head brown above. Mouth large. First dorsal fin eight spines; second, one spine and fourteen rays; pectorals, sixteen rays; ventrals, one spine and five soft rays; anal, one spine and fourteen rays; branchiostegous rays, six. The tail is forked, roseate, tipped with brown.

Though this fish is longer in its proportions, it may be the same species as the Striped Bass found at the mouths of the fresh-water bayous and rivers that fall into Lakes Ponchartrain and Borgne, and along the Gulf coast; the latter being modified by a change of its habitat, becoming deeper and more compressed. This species was called "Rockfish" by the early settlers of Kentucky, who supposed it to be identical with the Rockfish of the Atlantic States. It differs, however, in the number of stripes on its sides; the Rockfish has eight and this only five; the other has two spines on the opercle, and this only one; there is also a difference in the number of spines and rays of the fins.

This fish has been taken in the Mississippi above its junction with the Missouri, weighing as much as six pounds though that size is extremely rare. I have never taken it above a pound. The largest are taken with a live minnow, and no doubt afford excellent sport. 


\section{THE SHORT STRIPED BASS.}

I regret that I have no engraving or ichthyological account of this pretty fish, but if the reader will imagine our White Perch with stripes on its sides resembling those of the Rockfish, though not so many of them, he will have this Bass in his mind's eye.

There is also a variety called the "Broken Striped Bass," which I have no doubt is of the same species; for we frequently find individual cases in which the stripes on the Rockfish are not continuous, but irregular and broken.

The Short Striped Bass of both of these varieties are found frequently in great abundance in Lakes Ponchartrain and Borgne, and along the Gulf coast, where fresh-water bayous and rivers come in. They are most abundant in Lake Ponchartrain when the Mississippi is high, and discharges some of its water by crevasses or smaller channels into that lake. I have taken fifteen pounds of them before breakfast, off the pier of the New Orleans and Ponchartrain Railroad. With a neat rod, a float, and small hooks, they afford fine sport. The best baits are shrimp, the head and legs taken off, and the hooks baited with only the white meat of the body. They are not inferior to the White Perch of this latitude, and resemble them much in flavor and firmness of flesh.

The creoles of Louisiana sometimes call these fish "Pattisa ;" this name, however, is applied by them indiscriminately to any small pan-fish. They are taken from seven to twelve inches in length, and sometimes longer; though nine inches is a good average size. 


\section{OSWEGO BASS.}

This fish resembles the Black Bass so closely, that few anglers have any appreciation of the difference. It is taken on the same feeding-ground, and in the same way; it leaps from the water when struck, though perhaps not as often as the latter, and is almost as game; its flesh is said to be inferior to that of the Black Bass.

The only difference perceptible to the angler, is the greater bulk of this fish in proportion to its length, a greater protuberance of belly, and larger head.

I counted nine spines and fifteen rays on the dorsal fin, the pectorals had sixteen, anal thirteen, preceded by two short obtuse spines detached from each other. The specimen I examined weighed three pounds, was sixteen inches long thirteen in girth, and five and a half broad. There is certainly a specific difference between the two, though naturalists, as far as I have been able to ascertain, have failed to notice a fact which is apparent to anglers. 


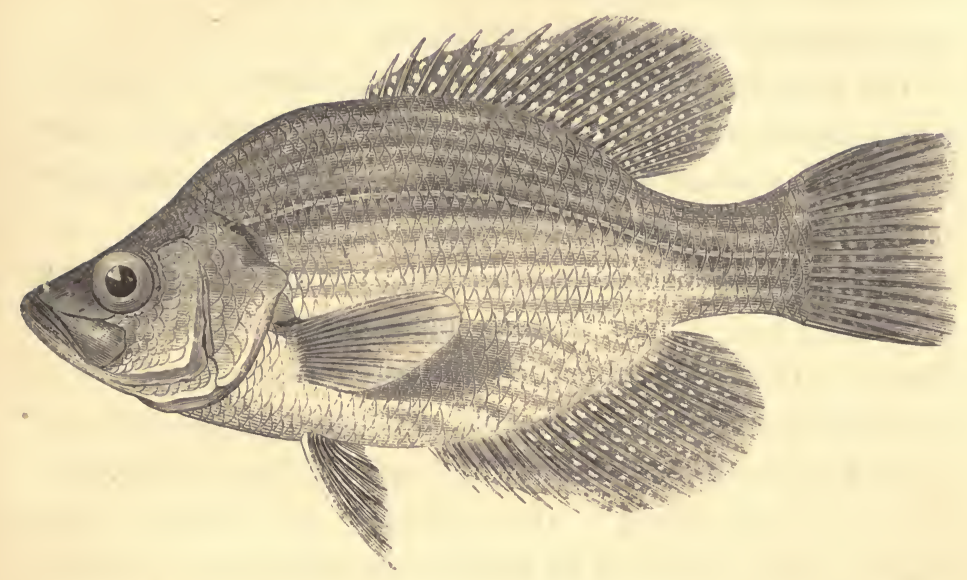

\section{CRAPPIE, SAC-A-LAI, OR CHINKAPIN PERCH.}

Pomoxis hexicainthus: Cuvinr.

Form-body oval, much compressed; breadth compared with length as 3 to 7 . Lateral line concurrent with the back. Head small, facial line much depressed; small scales on preopercle, but larger on the opercle, which is without a spine; nostrils small and double; a few denticulations at the lower posterior angle of opercle; branchial rays seven ; dorsal fiu seven spines and sixteen soft rays; pectorals twelve; ventrals one spine and five rays; anal large, with six spines and eighteen rays; caudal eighteen rays.

There are five indistinct dark lines above the lateral line in the fish of Louisiana, but wanting in those of Illinois; I have found dark transverse markings on the latter. The back is yellowish blue; sides silvery; belly white, tinged with yellow. The pectorals carnate nearest the humerai bone, with a light shade of orange at the tips; ventrals pink, tipped with 
black; dorsal, anal, and caudal, with dark irregular transverse markings. Teeth on vomer, tongue, and palatines acute, they are small, and recurved on maxillaries.

The specific name, Hexicanthus, is significant; its anal fin being armed with six spines, which number of anal spines exceeds that of any other percoid,-at least as far as the writer has observed.

This graceful fish is known by the creoles of Louisiana as the "Sac-à-Lai," where it is also sometimes called "Chinkapin Perch." In the neighborhood of St. Louis, Mo., it was called originally "Crappie," by the old French habitans, and still bears that name. It is known in some of the north-western lakes as "Grass Bass." It is found in the Atlantic States south of Cape Hatteras, in the bayous in the vicinity of New Orleans, and all the creeks, lakes, and ponds, fed by the overflow of the Mississippi, from Louisiana to Minnesota. It abounds particularly in the lakelets of what is termed the "American Bottom," extending along the Illinois side, opposite St. Louis.

The lakes, as they are called (though they are more properly ponds), along the alluvial banks of the Mississippi, become very low after a succession of dry seasons, and the fish cease to breed in them; this, with excessive fishing with nets and hooks, almost depopulates those waters; but when a good rise in the river overflows the bottom lands, the ponds are swept of the foul water and replenished with fresh; and, at the same time, restocked with fish. Then it appears almost miraculous where the vast numbers of Crappies, Bass, Perch, and other fish come from, and there is no other way of accounting for this fact, than by supposing that all the lakelets and streams of Wisconsin and Minnesota to the north, have thrown off their surplus production, which they appear to have garnered up. 
As soon, then, as the water becomes clear in the lakes and ponds, there-is a great turnout amongst the fishermen of $\mathrm{S}_{\mathrm{t}}$. Lonis. But to have good sport with the Crappies, one should get on the right side of Squire Cogswell ur of Uncle George Matlack's boys, who think it a small matter to hitch up their team, and stowing in tent, ice-box, minnow-kettle, frying-pan, and provender for men and horses, are ready at almost any time for a start to Long Lake; or thirty miles away to Mur. dock's Lake, for Bass and Crappies.

Crappies are frequently taken in company with Bass. They love to lie in the brushwood, and about the bushy tops of trees that have fallen in the water; a sultry showery day is most favorable for them.

A live minnow, hooked below the back fin, is the best bait; a substitute for which may be found in a wedge-shaped piece of fish, with the smaller end pendent from the hook; in fishing with the latter, the bait should be kept in motion. Worms are objectionable, as they attract the smaller fish, while they are not fancied by Crappies. Shrimp are generally used by the New Orleans anglers.

Whatever be the depth of the water, the float (which is generally used) should not be more than three or four feet above the hook. As the mouth of the Crappie is large, a Kirby hook, No. 1 or 0 , is to be preferred. The dangerous vicinity of brushwood makes the use of the reel objectionable; for then it is necessary to secure them as soon as possible after being hooked.

Holbrook states the extreme length of this fish to be twelve inches. I have seen it, in the vicinity of St. Louis, as long as fifteen, and in one instance, seventeen inches. 


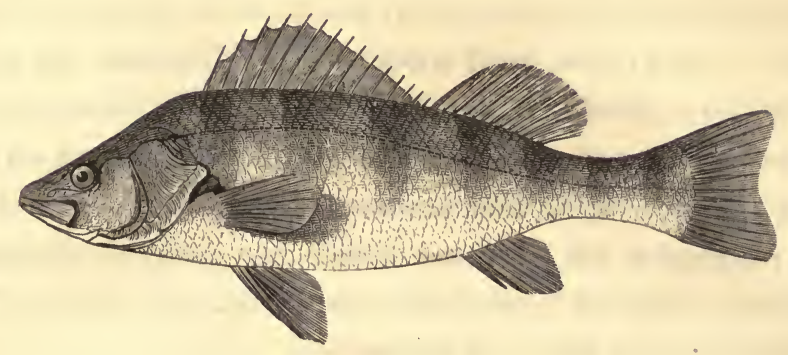

\section{YELLOW BARRED PERCH.}

Perca flavescens : Cuvier.

Back yellowish green; sides yellow, with six or seven dark vertical bands; body compressed, elongated; back slightly arched and tapering towards the tail, it is quite slim between the second dorsal and caudal fin; the anal and pectoral fins are of a yellowish red, or bright orange; the first dorsal has twelve or thirteen spinous rays; the second, two spinous and fourteen soft rays; ventrals, one spine and five soft rays; anal, two spines and eight soft rays; caudal, slightly concave, with seventeen rays. There are some beautiful tints about this fish.

Yellow-barred Perch are found in most of the large northern lakes, and with some other species which they closely resemble, as far south as Carolina, inhabiting tidal waters or lakes indiscriminately. They are easily taken with minnows and worms. In trolling the lakes for Black Bass, the angler is frequently annoyed by the great numbers of these Perch, and holds them in small esteem when in search of nobler prey 


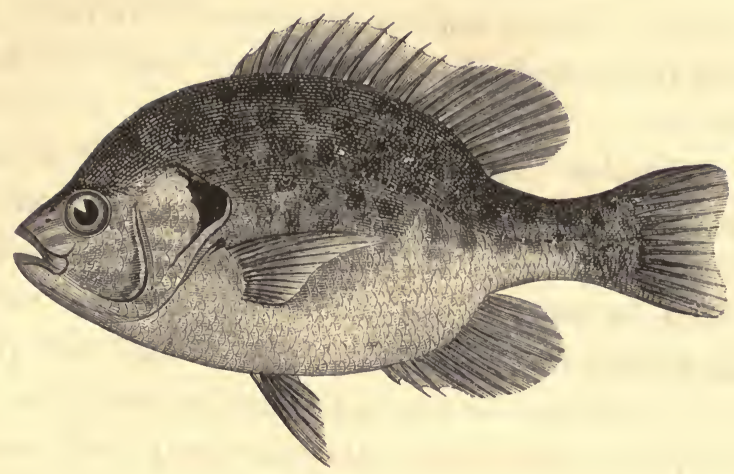

SUNFISH.

Pomotis vulgaris: Cuvier.

There are several species of Pomotis, and even fish of other genera known as "Sunfish." A diminutive species of the genus Centrachus is constantly called by that name. I have taken a synopsis of a description of the true Sunfish (Pomotis vulgaris), from Holbrook, one of the most exact ichthyologists of our day.

Body ovoidal in form, convex above and below, but straight on the belly; color of body brown, with a greenish tint above, with pale blue, waving, horizontal lines on the preopercle and opercle. Opercular appendix dark, with a bright red blotch on its posterior margin. The dorsal fin has ten spines and eleven rays; pectorals, thirteen rays; ventrals, one spine, and five rays; anal, three spines and ten rays; caudal, seventeen rays. Mouth small, rather protractile, and armed with small thickly-set teeth. Extreme length eight inches.

This beautiful little fish, associated in the minds of all anglers with the first rudiments of a piscatorial education, is known in the Middle and Southern States as the Sunfish of 
"Sunny." Yankee boys call them "Punkin Seeds," or by the more euphonic though appropriate name of "Kivers;" probably from their appropriate shape for the cover of a tea-cup or pickle jar.

It is a bootless task to describe the manner of taking Sunnies; any incipient angler of twelve summers would beat Theophilus South or Sir Humphrey Davy at catching them.

It would be hard to tell the amount of early Saturday morning digging for earth-worms; or how much bark-peeling of old logs for grubs; or how much anxious search for wasps' nests, they have occasioned. Or how many long sunshiny Saturdays have been spent in search of them; or, when alternating swimming with fishing, and starkly skirting the edge of the mill-pond, how often the youthful "sans culotte" has dropped his bait before their noses, beside the old stump or big rock, and "whopped them out."

Many an angler will remember the untiring patience with which, in boyhood, he has displayed his worm-covered hook before a half score of these pretty fish, and seen the larger (dux gregis) separate himself from the rest and come towards the bait, sail majestically around, backing and filling, eager, though doubtful of the cheat, and glaring on it with his big permanent eye, and, at last, just as the little angler gives up the game, and is despairingly drawing it away, with a bold rush, the Sunny seizes the barbed hook, and in a trice he is bouncing on the grass, and a hand is on him that relaxes not its grasp till the cruel switch is thrust through his gill.

Sunfish are extremely predatory in their habits, and the tyrannical little fellow of our aquarium, whom we have dubbed "Captain Walker," is dearer to us, because he is a representative of those we were accustomed to fish for in our schoolboy days.

In preparing their bed for spawning, a pair of Sunfish will 
clear a place a foot or two in diameter, piling up the gravel, chips, and twigs on the margin; at such times they refuse a bait, remove anything offensive as soon as it drops in, and pugnaciously drive off all intruders.

A neat line, small float and hooks, number six to ten, are appropriate tackle.

I have a valued friend, who, although long since passed the meridian of life, will still roll up his trousers, and angle for this attractive little fish, with all the ardor of his youthful days.

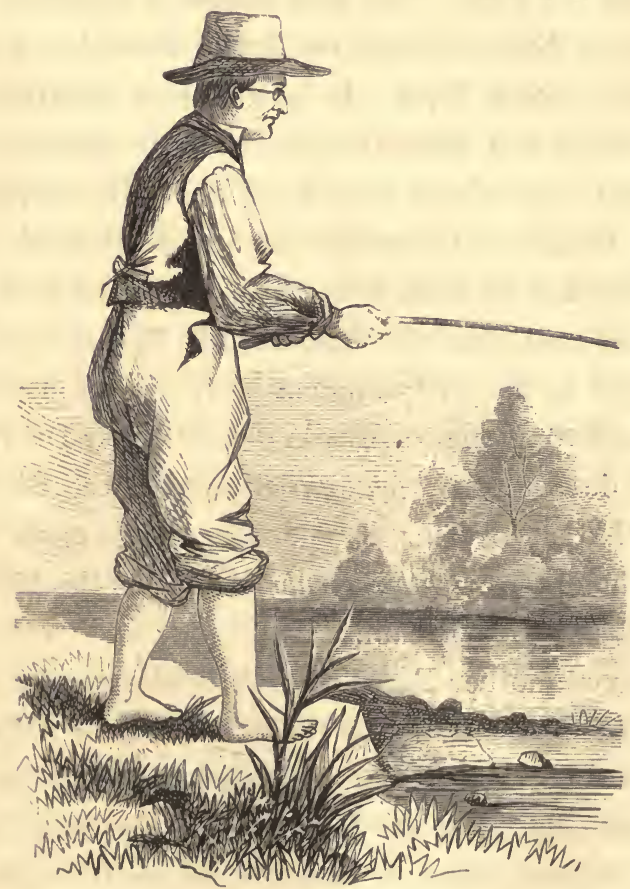




\section{BREAM.}

In the Southern States this fish is called "Bream," from some fancied likeness to the European fish of that name, which it resembles only in its outline. The true Bream belongs to the peaceable family of Cyprinidæ, and our rapacious little friend to the Percidæ. The first attains a weight of five or six pounds, in England, and the latter is seldom taken over eight or nine inches long. It is found in nearly all of the Atlantic States, and generally in the small streams and lakelets through the whole length of the Mississippi valley, decreasing in size as its range extends northward. It is an excellent pan fish, its flesh being firm, crisp, and well flavored. I have been told that the Red-Bellied Bream is taken of a pound weight in the still waters of North and South Carolina.

There are two species of Bream described by Dr. Holbrook. The one he describes as "Ichthylis incisor," is the Blue Bream, or Copper-Nosed Bream; it seldom. exceeds eight inches in length. The other, "Ichthylis rubricunda," is the Red-Bellied Perch, or Red-Tailed Bream.

There is yet another Percoid, with brilliant sides and dark green mottled back, known as the Goggle-Eye, or War-Mouth Perch. Its shape is different from either of the first named, carrying its oval form no farther than the anal fin, where it falls off suddenly, and is thence very small to the caudal. I have never seen a description of it in any work on ichthyology. These three species are frequently called Sunfish, or Sun Perch, and are taken in the same company. 
Bream are taken with shrimp, minnows, crawfish, red worms, or a wedge-shaped fish-bait. They should be fished for with a slight reed rod, short line, and a No. 3 Kirby hook; the bait from fifteen to twenty-four inches below the float, whatever be the depth of the water. They haunt the mouths of small branches that put into creeks, ponds, or bayous, and are found around old stumps and logs, and love to lie beneath the scum or drift of sluggish waters.

In fishing the bayous in the South, the angler frequently pushes aside the light drift with the end of his rod, and drops his bait into an opening not larger than the crown of his hat, and in a short time has captured a hatful of them. They are the delight of all juveniles; a little urchin of ten years frequently catching a string of them as long as himself, and when Bass are not on the feed, they are the dernier ressort of the more ambitious angler.

I have taken all three of these species in Bayou La Branch, about thirty miles north of New Orleans, on the Jackson Railroad, going and returning the same day. With a pleasant companion, a bottle of claret, ice, and cold fowl, the day would pass pleasantly enough. In the month of April the blackberry bushes that grew along the banks of the bayou were laden with fruit, and when we could not reach them from the pirogue, we were sometimes tempted to go ashore for them, at the risk of meeting an alligator in its journey from the bayou to its nest in the canebrake. It was a dismal water, with long weepers of gray moss drooping from the trees; and when a solitary fisherman paddled his canoe over the dark, waveless bayou, his form in the distance would suggest the idea of Old Charon. It certainly was a river of "sticks," if not of Acheron.

Will I ever wet my seagrass line in Bayou La Branch again? I think not. 


\section{PIKE PERCH. OHIO SALMON.}

Lucioperca Americana: Cuvier.

Of the many misnomers given to fish, that of "Salmon," as applied to this, is the most inappropriate. It has as few of the characteristics of the true Salmon as the Southern Bass has of the Trout. Still we are not disposed to find fault with rustic anglers because, in the absence of scientific knowledge, they have given what seemed to them the most fitting name for it.

Anglers who look into books on ichthyology are at a loss to know why this fish, with its elongated body and general appearance so unlike the Perch, should have been placed in the family Percidæ. The scientific name "Lucioperca" (Pike Perch), adopted by Cuvier, indicates its affinity to the Pike as well as the Perch. Recent ichthyologists, however, amongst whom is Mr. Theodore Gill, are in favor of placing it in a sub-family, "Percinæ."

Having no specimen at hand, we copy from Mr. Gill's "Synopsis of the sub-family Percinæ," and his description of this genus :-

"Body slender, elongate, fusiform, covered with scales arranged in oblique rows. Head semiconical, quite broad, with cheeks and opercles generally covered with. scales; isolated patches of scales on the sides of the posterior part of the head; rest of the head covered with naked skin. Preopercle serrated. Opercle armed with from one to five spines. 
Dorsal fins two, the first supported by from twelve to fourteen spines. This genus is peculiar to fresh-water streams, rivers, and lakes of North America."

There are several species of this genus found in Europe, where it is known as the Sandre.

I have seen this fish as far south as Memphis, Tennessee. It is common, though not numerous, in all the tributaries of the Ohio and Mississippi. It is taken in Lake Champlain, where it is called Pike, in contradistinction to the Pickerel found there. It is remarkable that the Susquehanna and Juniata are the only rivers on the eastern slope of the Alleghanies where it is found; but it is not as abundant as it once was. There also, as west of the mountains, it is called "Salmon."

Its flesh, which is perfectly white, is highly esteemed by the residents along the Ohio River. It is said that it does not bite freely at a bait. When fished for, a live minnow is generally used; a float and large hook are required in stillfishing. It is sometimes taken in trolling with the spoon in Lake Champlain. It is taken in the Alleghany from one to four pounds in weight, by trolling with a minnow at the foct of the rapids. 


\section{BUFFALO PERCH. WHITE PERCH OF THE OHIO.}

\section{Abloden grunniens : RAFINESQUE.}

Although this fish is known by the above common names, it is not a species of Percidæ, but belongs to an entirely different family, that of Scienidæ. It is the only Scienoid found in our rivers, and is confined to those on the western side of the Alleghanies, which flow into the Gulf of Mexico. I have placed it amongst the species of this family, only because it has the common name of Perch.

Rafinesque's description of this fish, which was published nearly half a century ago, is quite interesting. I quote from his work on the fishes of the Ohio:-

"Entirely silvery, upper lip longer, lateral line curved upwards at the base, bent in the middle and straight posteriorly, tail lunate, first dorsal fin with nine rays, the first very short, the second with thirty-five rays, the first spiny and short.

"The vulgar names of this fish, are White Perch, Buffalo Perch, Grunting Perch, Bubbling Fish, Bubbler, and Muscle Eater. It is one of the largest and best found in the Ohio, reaching sometimes to the length of three feet, and the weight of thirty pounds, and affording a delicate food. . It is also one of the most common, being found all over the Ohio, and even the Monongahela, and Allegheny, as also in the Mississippi, Tennessee, Cumberland, Kentucky, Wabash, Miami, and all the large tributary streams, where it is permanent, since it is found in all seasons except in winter. In Pittsburgh it appears again in February. It feeds on many species of 
fishes; suckers, catfishes, sunfishes, \&c., but principally on the muscles, or various species of the bivalve genus Unio, so common in the Ohio, whose thick shells it is enabled to crush by means of its large throat teeth. The structure of those teeth is very singular and peculiar; they are placed like paving-stones on the flat bone of the lower throat in great numbers, and of different sizes; the largest, which are as big as a man's nails, are always in the centre; they are inverted in faint alveoles, but not at all connected with the bone: their shape is circular and flattened, the inside always hollow with a round hole beneath: in the young fishes they are rather convex, and evidently radiated and mamillar, while in the old fishes they become smooth, truncate, and shining white. These teeth and their bone are common in many museums, where they are erroneously called teeth of the Buffalo-fish, or of a Catfish. I was deceived so far by this mistake, and by the repeated assertions of several persons, as to ascribe those teeth to the Buffalo-fish, which I have since found to be a real catostomus; this error I now correct with pleasure.

"A remarkable peculiarity of this fish consists in the strange grunting noise which it produces, and from which I have derived its specific name. It is intermediate between the dumb grunt of a hog and the single croaking noise of the bull frog; that grunt is only repeated at intervals and not in quick succession.

"This fish is either taken in the seine or with the hook and line; it bites easily, and affords fine sport to the fishermen; it spawns in the spring, and lays a great quantity of eggs."

The fish here described, though quite common in the Ohio River, my own observation leads me to suppose is comparatively scarce in the Mississippi, above its junction with the former river. 
At the time of the Sauve Crevasse, in the Mississipp 1 above New Orleans, about fifteen years since, it found its way into Lake Ponchartrain, and thence into Lake Borgne, and the brackish and salt waters along the Gulf coast, where it is now permanent. It is very prolific and has improved in its flavor and appearance, having an increased silvery brightness, is more elongated.in form, and of more graceful proportions. These changes are no doubt owing to the greater abundance of moluses and crustacea found in its new habitat. It has the true characteristics of the Scienoids, which are molusceating fishes, indigenous to shoal salt water. It is not very unlike the Croaker in shape; it makes a similar noise, and is sometimes taken in company with that fish. The pharyngal bones, with their peculiar crushing teeth, closely resembles those of the Drum.fish.

When young this is one of the most beautiful of the Acanthopterri. I have never seen it larger than five pounds in the New Orleans market,-there it is generally of a good size for the pan. In the Ohio it attains four or five times that size, ten or twelve pounds not being uncommon. This is no doubt the fish referred to in the "American Angler's Guide," (page 220), in these words:- "OF THE CATFisH.-This is the common fish of the western waters, and is taken by western sportsmen by squid and fly-trolling, and affords capital amusement. They take their name from the noise they make, similar to the purring of a cat."

I have never heard them called "Catfish" along the Ohio or Mississippi,- that name being applied only to the bigmouthed fish, known all over the South and West by that appellation; they do not take a squid or fly. Mr. Brown has doubtless been imposed upon, by some person addicted to telling "fish stories." 
C H A P T E R V.

THE PIKE FAMILY. 
"GREEN air thy waters-green as bottle glass They lay stretched thar;

Fine Muscalongy and Oswego Bass

Are ketched thar;

Wonst the red Injuns thar took their delights,

Fisht, fit and bled;

Now the inhabitants is mostly whites

With nary red."

From " A Node to Lake Ontario," found in the

" $K$ N Pepper Papers,"-quoted from memory. 


\section{UHA P TER V.}

\section{THE PIKE FAMILY-ESOCID开.}

Remarks on the Pike Family. Mascalonge pictured by Cuvier.-European species.-American species.-The Garfish; manner of taking it.-Dr. Bethune's remarks on Pikes.-Their introduction into England._Pliny's Pike.-Gesner's Pike.

The Great Lake Pickerel. Esox lucioides.-Trolling from a boat for Pickerel.

The Mascalonge. Esox estor.-Angling for Mascalonge.

The Pond Pike, Esox reticulatus.-Pike-fishing.-Trolling for Pike with the gorge-hook.-Pike-fishing in Eastern Virginia.

The Great Blue Pike.

The Litthe Pike of Long Island.

The Streaked Pike of the 0hio.-Story told about a Pike taken in the Kanawha.

IN Cuvier and Valenciennes' great work, the only fish of this family I find pictured is our Mascalonge, Esox estor. The figure is incorrectly colored, and in its markings resembles the Great Northern Pickerel, Esox lucioides, rather than the fish it is intended to represent. There are but few species of Pikes found in Europe. Esox lucius, which is common both to England and the Continent, is a handsome fish and grows to a large size.

I think it quite likely that there are American species of this family which have not yet been described. De Kay, Richardson, and Holbrook, jointly, do not mention more than six or seven. Besides the Mascalonge and Great Northern 
Pickerel, I am impressed with the idea that there are two other species in Lake Ontario. The large fish called the "Blue Pike" or "Black Pike," found in Pennsylvania and Virginia, west of the Alleghanies, which equals the Mascalonge in size, and another species found in the Ohio and its tributaries, I have never seen properly described or pictured.

Frank Forester, in his remarks on the Esocidæ, assigns the Great Garfish of the Southern and Western States to this family, calling it "Esox osseus." There can be no generic affinity between the two. The Gar (Lepidosteus), as I have remarked on a preceding page, is one of the few representatives of the ancient order of Ganoids remaining at the present; while the Pikes, according to Hugh Miller, were not ushered into existence until perhaps millions of years after. Even if they had been cotemporaneous in Creation, the two orders, being so entirely different, would not admit of such classification.

In the waters along the Gulf of Mexico, Gars are frequently an annoyance to the fisherman; they appear sometimes in numbers, scaring away other fish, taking off one's bait, and often cutting the line with their sharp teeth, while there is hardly a possibility of hooking them in their hard bony jaws. I have tried frequently to secure one, but was never successful. A friend has since told me of a way of taking them, in which he says the negroes are more fortunate; he describes it thus:-A noose is made by passing a string through a fish of suitable size, say of seven or eight inches, lengthwise, which can be done with a long baling-needle, and then through a loop at the other end of the string, where it is tied to the tip of a long pole or stout reed. The fish is adjusted so as to form the base of a triangle, the slip-knot being at the upper angle, nearest the pole. This triangular snare is then displayed on the surface of the water, and dabbled up and 
down to attract the notice of the Gar, which soon appears, and as it seizes the fish crosswise (which is its custom) it runs its long upper jaw or rather its bill into the noose, when the string is tightened by lifting the pole, and the Gar drawn ashore. I have heard it said that the Alligator Gar has been taken as long as eight feet.

Dr. Bethune in his notes to his edition of Walton, says: "The name Esox is first used by Pliny, who describes a great fish in the Rhine, which attained the size of a thousand pounds (!!!), was caught with a hook attached to a chain (catenato hamo), and drawn out by oxen (boum jugis)." Of its introduction into England he remarks: "The Pike is said to have been brought into England about the time of the Reformation, according to a distich erroneously quoted by Walton, when speaking of the Carp, from Baker's Chronicles (p. 317, ed. 1665), where it is,

\section{'Turkeys, Carps, Hoppes, Piccarel, and Beer, Came into England all in one year ;'}

i. e., the fifteenth year of Henry VIII. This is, however, all error. Pike or Pickerel were the subject of legal regulations in the time of Edward I. Turkeys were brought from A merica about 1521. Hops were introduced about 1524."

The Doctor says that Pliny, in his description of the thousand pounder, wrote only from hearsay. In alluding to Gesner's Pike, he quotes Bloch, the ichthyologist, who says: "This Pike was fifteen feet long, and weighed three hundred and fifty pounds. His skeleton was for a long time preserved at Manheim."

Pickering, in his Piscatorial Reminiscences, speaks of a Pike killed (caught) in Loch Spey that weighed one hundred and forty-six pounds. Of another of twenty-eight pounds, in 
which the cook found a black ribband and keys. Quoting Dodsley's Register, 1765, he says: "In emptying a pool which had not been fished for ages, at Lilleshall Lime Works near New Port, an enormous Pike was found, weighing one hundred and seventy pounds."

It is said that Pikes will eat all the smaller fish in a confined pond, and then the larger will devour the smaller, until at last only the largest remains, a solitary proprietor of the domain.

After being so amiable as to quote the foregoing "fish stories," without openly expressing a doubt as to the truth of them, it would hardly be fair in the reader to doubt the story of a large Pike on a subsequent page, which was told to me by the hostler of a hotel in Wheeling, twenty years ago.

The term "Pickerel" is applied to all fish of this genus, with the exception of the Mascalonge, by the people of New York and the Eastern States. In the Middle States they are called "Pike," and in Virginia and further South they go by the name of "Jackfish." 
$+7 e^{2}$ 


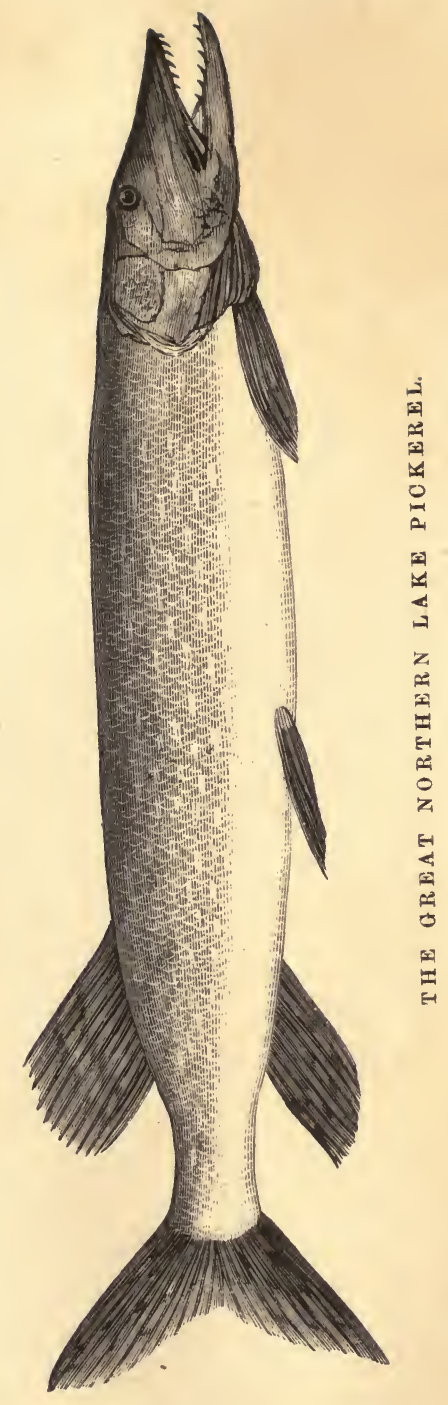




\section{GREAT' LAKE PICKEREL.}

Esox lucioides.

The body of this fish presents the characteristics of all the Pike Family, carrying the breadth of body well aft, even to the anal fin; its section is almost rectangular. Length of head compared with body as seven and a half to twenty-eight; breadth one-seventh; back one-twelfth.

Color, dark bluish-green above, with a lighter tinge of the same on the sides. Belly white. The markings are white, irregularly shaped on the back, but rectangular on the sides, and twice or thrice as long as they are wide.

The head is long, depressed between the eyes, with a slight upward curve of the snout. The under jaw has also an upward curve, and projects beyond the snout; it is armed on each side with seven long sharp teeth projecting forward, but with the points curved somewhat back. The teeth of the upper jaw are shorter and inverted. The palatine teeth are gradually larger towards the vomer. The vomer, pharynx, and branchial arches have teeth which are shorter, but not less keen.

The eye has its posterior margin nearly half way between the snout and angle of opercle, and is slightly below the facial line; its diameter is about one-tenth the length of the head.

The specimen I examined exhibited a deficiency in the number of fin-rays as compared with Frank Forester's de- 
scription. There are fourteen branchial rays. The dorsal fin, which is one-eighth the length of the body, has eighteen rays; pectorals fifteen; ventrals (midway between snout and end of the caudal), fifteen rays; anal (slightly posterior to the dorsal), fifteen. The caudal is bilobed, rather than forked; it has eighteen rays reaching the posterior margin, and two or three stout rudimentary rays above and below them; the upper lobe of the caudal is the longer.

For want of a better artist, I was induced five or six years since, when on a visit to the Thousand Isles, to try my hand for the first time on this fish; and with the aid of an inch measure-for it is a purely mechanical production-made as correct a drawing as I could. The figure at the head of this article is a reduced copy of it. As I had never seen the peculiar markings of this fish correctly drawn, I took some pains to do so. My description is from one taken at the same time.

This fish is known about the Thousand Isles as the Marsh Pickerel, and is found more generally in the coves and on the flats than in the deep water. The "Channel Pickerel," which I suppose to be another species, is a more symmetrical fish, with less fulness of body between the dorsal fin and the tail. It has a yellow instead of a leaden tinge. The markings are three times as numerous and about one-third the size, though of the same shape as those of the Marsh Pickerel; it is found generally in deep water. 'There is a third variety, which is shorter in the body than either of these, but the color and markings the same as the Marsh Pickerel; some of them, though, are the shape of the letter L, with the lower limb elongated. It is called the "Short Pickerel."

The larger species (the Marsh Pickerel) grows to the weight of twenty-five pounds; it is even said that it has been taken as high as thirty-eight. It is common in the St. Lawrence and Lake Ontario, and all of their connecting waters, 
and in Lake Champlain. It has been introduced into Lake George within the last seven or eight years.

Pickerel are taken almost entirely by trolling with some artificial spinning bait; of these the murderous implement called the spoon is in general use. A stout trolling-rod of ten feet, a multiplying-reel with a hundred yards of plaited-silk line, and the spinning bait, attached by one or two swivels, completes the troller's outfit. A gaff is sometimes used; but as the fish, when he is drawn up to the boat, has generally two or three hooks in his jaws, it is not required.

Alexandria Bay, near the Thousand Isles of the St. Lawrence, is a favorite resort for those who fish for Pickerel. In trolling for them, when the angler takes his seat in the boat, he generally finds his oarsman supplied with one or two stout cedar poles, which by your permission he will rig out on one or both sides, like studding-sail booms. Trailing from each of these poles, there will be thirty or forty yards of strong hemp line, with a spoon attached by a swivel; and while he looks after them, he leaves you to the enjoyment of your jointed rod, your multiplying-reel, and your pipe, in the stern. When a fish is hooked the boatman slacks his speed, keeping easy way to prevent the lines on the other rods from becoming entangled, or the spoons from sinking to the bottom. If the fish be on the line attached to the native rod, you throw the point forward, grasp the line, and pull in the victim hand over hand. As he nears the boat, he will perhaps raise his head out of the water and rattle the spoon (in the oarsman's vernacular, "ring the bell"). By the time you get him alongside he is generally docile; when you put your hand over and grasp him by the nape of the neck, bring him on board, disengage the hooks, give him a few taps on the head with a stick kept in the boat for that purpose, and the drama is played out. When you strike a fish with your 
own rod, if you request it, the boatman will cease rowing, draw his lines in, and let you fight your adversary in your own way, which after all is not much of a fight, and after a steady strain on your rod and reel, he is drawn in and knocked on the head, as just described.

The number and weight of Pickerel taken in a day's fishing in this way is considerable; though I cannot see that the wear and tear of fine tackle expended on them is justified by trolling for them, with any other than that used by the natives. But to one to whom angling is really "the contemplative man's recreation," the fairy boat, the clear deep water, and the beauty of the Thousand Isles, are suggestive of the far-off times, when the Indian in his bark canoe, the early explorer, the devout Jesuit missionary, and hardy voyageurs passed over the great inland seas and their connecting waters; and strange legends, traditions, and history almost forgotten come up before him.

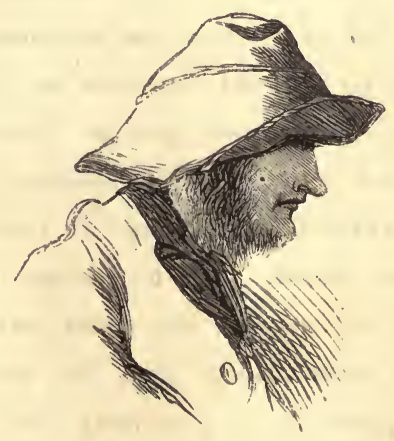




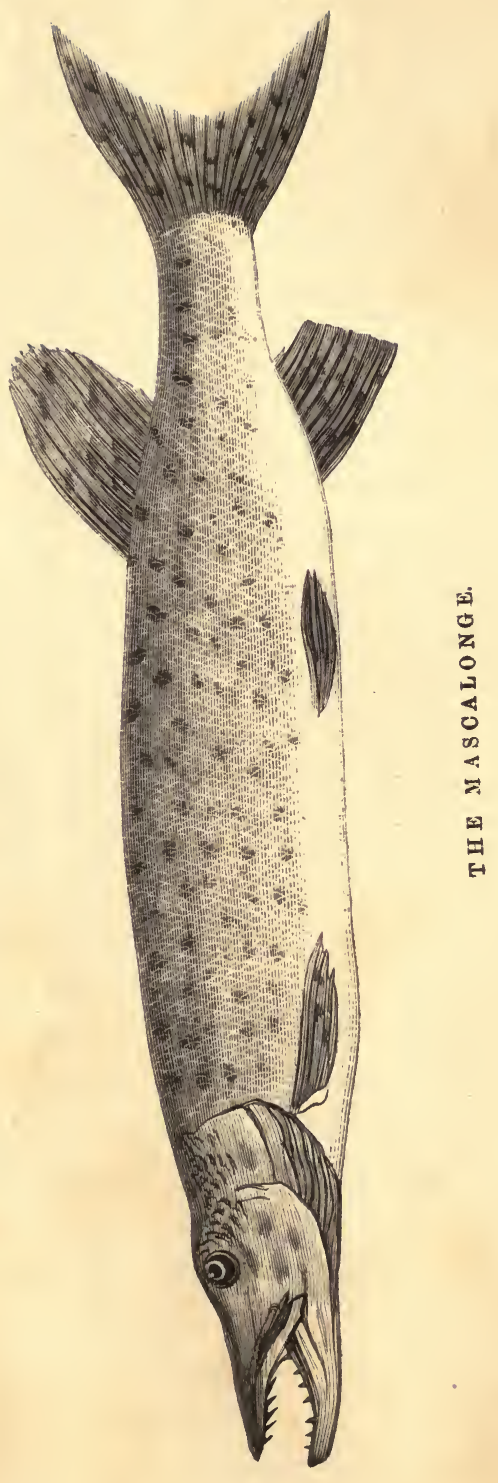




\section{MASCALONGE.}

Esox estor: Cuvier.

Body elliptical, elongated; section oval, not quadrangular as in the Pickerel. Color green, with a tint of steel blue on the back, shading lighter and into a bluish pearl color on the sides; the body is covered with round or oval spots of much darker color. Belly white; the whole body has a pearly lustre. Head not quite one-fourth of its length, and very slender, causing it to appear much longer in proportion to length of body than it really is; the skull depressed between the eyes, and the profile concave between the eyes and snout; upper part of preopercle and opercle covered with small deep green brilliant scales, those on opercle are the larger. Eyes large, near the top of the head, and midway between snout and angle of opercle. Irides light yellow. Cheeks and gillcovers resembling gray pearl, with four or five clouded spots on preopercle, and one or two on opercle. Upper jaw broad, verging to a point; under jaw terminated with an upward curve. Branchial rays seventeen, the series extending high up against the opercle. The arrangement of teeth similar, but not quite the same as in the Pickerel. Fins all covered with dark spots half the size of those on the body. I counted in my specimen seventeen rays in the pectoral fins, which are pinnate in shape, and situated beneath the extremity of the gill-cover. Ventrals slightly posterior to its mid-length, with twelve rays. Anal seventeen. Dorsal two-thirds length 
from the snout, twenty-two rays. The caudal, which is deeply lunate, has twenty-eight rays; the six in the centre are branched.

The specimen from which Frank Forester's drawing was taken must have been unusually stout; a fish of eighteen pounds should measure over three feet, instead of two and a half. My representation is a drawing of a smaller specimen; like the picture of the Great Northern Pickerel, it is an attempt of my own, which, though rude, is mathematically correct in its proportions.

The Mascalonge differs materially from the Pickerel described on a preceding page; the head is extremely small, a section of the body presenting almost an oval; the mouth is smaller, not opening so far back; the color of its body much more silvery, the spots being dark instead of white, also of different shape, and much larger than in the Pickerel. The tail of the Pickerel is bilobed; while that of the Mascalonge is deeply lunate.

It is said that this fish is found in the Wisconsin and Upper Mississippi, about the Falls of St. Anthony. It is generally sought for in the upper waters of the St. Lawrence, and the smaller lakes on the Canada side, by anglers from the Eastern cities. From all accounts they were never numerous; the angler who captures four or five of fair size in a day's fishing at Alexandria Bay, is considered in luck. Rice Lake, farther west on the Canada side, is said to afford them in some abundance, though twelve or fifteen of six or seven pounds weight is reported to be a good day's fishing even there.

This fish is said to attain a weight of sixty or seventy pounds, but generally it does not exceed the size of the Blue Pike taken in the rivers and small lakes of Western Pennsylvania. Its size varies from three to thirty pounds; a few have been taken as high as forty; one or two instances only 
are spoken of where the weight was as much as seventy pounds.

Angling for Mascalonge is the same as for Pickerel, the spoon being almost universally used. They are active, and have more pluck than the large Pickerel; though any angler who holds a stout trolling-rod, with a good multiplyingreel and a hundred yards of good line, if he is cool and waits assiduously on his enemy, is sure of him. I had rather trust to a good grip on the nape of the neck, than to a gaff-hook in getting one into the boat.

I know of old anglers who have experienced better things, who make long excursions in pursuit of Mascalonge, who will sit on a cushioned seat with a cushioned back in the stern of a boat, and suffer themselves to be pulled about all day, with a trolling-rod extended from each side. I never could appreciate this inactive mode of taking fish, which is little better than cockney punt-fishing, and does not require one-tenth the skill. If spoon-fishing had been practised in Maelzel's day, and that ingenious man had been an angler, no doubt he would have constructed an automaton Pickerel-fisher. 


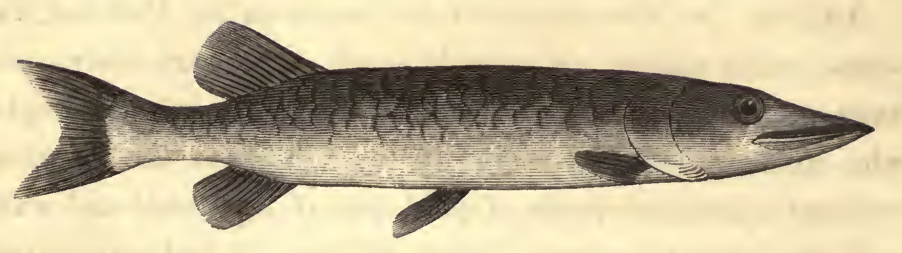

THE POND PIKE, OR COMMON PIKE.

The smaller species of Pikes are confined almost exclusively to the streams on the eastern slope of the Alleghanies. There is much resemblance in their general appearance. I give the wood-cut at the head of this article, as a general representative of the whole.

The Pond Pike is not often taken above five pounds, its average being less than a pound and a half. They are seldom if ever captured by trolling with a spoon; I suppose, for the reason that they are not fished for in that way. The live bait is used in still-fishing, when the Pike generally takes it near the bank, where he is in the habit of looking for small fish. In fishing a pond, where there are water. lilies, grass, or other aquatic vegetation, it is generally from a boat, with a long light rod, the bait a. minnow, frog's leg, a piece of the Pike's belly, or a strip of pork.

The Pike of England is larger than our common Pond Pike, and doubtless more worthy of the elaborate tackle and scientific angling used in its capture. And, although there is a prevalent indisposition amongst our anglers to learn any. thing out of a book, there are still a few who have profited by the lessons taught in English books, and use the leaded gorge-hook, with much advantage over the usual manner of 
fishing for them here. The tackle and the mode of taking them, described with so much minuteness by Hofland and Salter, are seldom resorted to in this country. Our anglers having so many fish amongst the Perch and Salmon families, and salt-water species, affording an infinite deal more sport, the Pike of our ponds are considered fish of secondary or third-rate importance.

When fishing a pond from a boat, the snood should have two hooks, the smaller about two inches above the larger; the end of the bait or head of the minnow being held by the upper, while the lower hook is passed through it midway. When the Pike takes the bait he should be allowed to run a short distance; the line should then be tightened and the angler strike, and get the fish into the boat as soon as possible, never allowing him any slack line.

Trolling for Pike with a Gorge-Hook.-Where there are deep holes close in by the bank, trolling with the gorgehook is far more successful than any other mode. A good bass rod of twelve feet, with metallic guides and tip, and an easy-running reel with forty yards of plaited-silk line, are then required: a tin bait-box, carried at one's side like a powder-flask, is best to hold the minnows used for bait; they should have bran, coarse meal, or saw-dust put in with them, to prevent their rubbing or bruising. A piece of gimp of twelve inches is attached by a box-swivel to the line, and a hook-swivel is fastened at the other end of the gimp, for the purpose of taking off or putting on the bait after it is placed on the

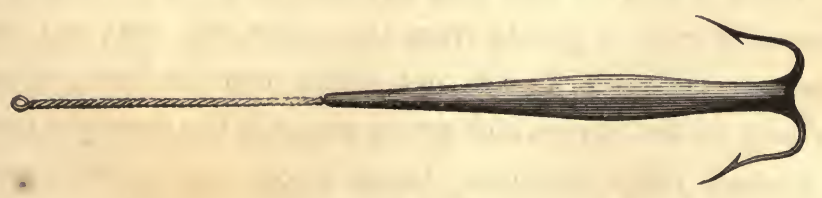


The disgorging-hook and baiting-needle are considered superfluous by American trollers, a forked stick being used to disengage the bait when it is far down the fish's throat.

In putting on the minnow for a bait, the twisted wire to which the leaded hook is fastened is put-small end foremost of course-into the mouth of the bait, and worked along the backbone until it comes out at the tail, when it is drawn entirely through, the lead lying in the belly of the minnow. The tail and back fins are then nipped off with a knife, or with the thumb and finger-nails, and the minnow bent slightly near the tail to insure its spinning or twirling, and attached to the gimp by the hook-swivel. In trolling, the minnow is drawn through the water tail foremost. If you cast much among weeds and grass, it is necessary to tie the tail of the bait to the wire of the gorge-hook, with a few turns of coarse thread; it is perhaps better in all cases. English anglers are sometimes so nice as even to sew up the mouth of the minnow.

With a line of convenient length, not longer than the rod, approach the bank carefully, casting close in shore, dropping the bait in softly, and by successive short pulls, raising and lowering the point of your rod, draw it towards you. You will notice that as you lower the point of the rod, the bait shoots forward and downward with a spiral motion, assisted in its twirling by the easy turning of the swivels and its having been bent, and that it spins or twirls in the same way as it is drawn towards you. When you have drawn in the bait sufficiently near you by these short pulls, raise it gently from the water, and cast and draw as before. If your bait is not taken near the bank, extend your cast up and down, and across towards the opposite bank, and towards the water-lilies, brush-wood, and under-bushes, and around and about old stumps, being careful not to be caught by roots or brush. 
As the length of the cast is increased, draw a proportionate length of line from the reel, holding part of it in a coil in your left hand, and letting it go as you cast; the impetus acquired by the leaded bait will not only take the coil held in your hand, but an additional quantity from the reel, if it runs freely. The extra length of line is recovered by winding up; or gathering at each raising, and lowering of the point of the rod, a foot or two at a time, with the left hand, holding it in coils ready for the next cast. It is said that English Pike-fishers are able to east thirty yards or more, when they cannot approach a desirable spot.

It is well to draw the bait well home between each cast, as a Pike will occasionally follow it for some distance, when he is not hungry, as a cat does a mouse, and seize it only when he finds that it is about to escape, as you draw it from the water. When your bait is arrested, or you feel a tug, lower the point of the rod, and give the fish as much line as he wants; he will take it to his haunt, or some place near at hand, and swallow, or, as the English anglers say, "pouch it;" for the Pike seizes his prey crosswise in his long jaws, and taking it to his haunt, turns it and swallows it head foremost. As this requires some moments or perhaps minutes, the angler is kept in hopeful suspense, and in the meanwhile his line should remain perfectly slack: but as soon as the fish has pouched the bait, the hook pricking the sides of his stomach, causes him uneasiness and he starts off; then give him a yard or so to run, and winding up the slack strike sharply, for in nine cases out of ten he is hooked beyond all peradventure of escape. If he is a fish of moderate size, reel him in and lift him ashore, or catching hold of the gimp trace, throw him out. If he is large and requires line, give it grudgingly, and keep him away from all places that would endanger your tackle, or enable him to get your line foul; if you do so, there is 
little chance of losing him, for he pulls as steady as a Conestoga wagon-horse, and knows few of the wiles of the Trout or Bass.

If, after seizing your bait and making his first run, he appears long in pouching it, you may feel him gently, by winding up the slack slowly and bearing on him slightly. If he is still there, he will resist or signify his dissent by a shake or another tug, when the line must be again slacked, and more time given him.

On certain kinds of days a Pike will seize the bait, make his first run and then drop or only chew it, as if he was overfed or indifferent. Then it is better to use hooks, as described for pond-fishing on a preceding page, putting the smaller through the lips of the minnow, and the larger through the back, just behind the dorsal fin, and fish as there directed.

Much depends on the day in Pike-fishing, some persons say even on the quarter the moon may be in. On a cloudy day, if not too warm, I have found them to take a bait from sunrise to ten o'clock, or from four in the afternoon until dark, though sometimes they are on the feed all day.

The Pike spawns in this latitude in the latter part of February, or early in March, or directly after the ice is gone, and soon recovers condition. He may be taken by snapfishing at almost any season after spawning. Trolling with the gorge-hook is not successful until later in the seasonfrom August until November is considered the best time, or even later if the weather is warm. They may be taken all winter in open weather by trolling, and numbers of them are caught by fishing through holes cut in the ice.

'Trolling from the bank is the most sportsmanlike way of taking the Pike; and, as will be observed, is very different from trolling or rather trailing the bait from a boat, as it is rowed along. Still, after one has taken the magnificent 
Striped and Fresh-water Bass, Trout, Weakfish, Barb, and Redfish through the summer, at the end of a long line, he is apt to think trolling for Pike stupid sport, notwithstanding the importance attached to it by English anglers. There is one recommendation to it, however; it is apt to fill the creel, in parts of the country where diminutive streams and ponds furnish no other than small or worthless fish.

It is scarcely necessary to say to a sagacious angler, that the larger the run of Pike, the larger the bait to be used, and as a consequence the larger the hook. When the fish are small-from three-quarters to a pound and a quarter-a minnow the size of one's little finger is large enough; if they run two pounds and upward, a roach or chub of four or five inches is better. A pike of four pounds will readily take a roach of six inches.

Pike-fishing is enjoyed much by the anglers of Virginia, between tidewater and Blue Ridge, in the fall of the year. The usual method is to bait one or more holes for Carp, as they are called there (though truly Suckers). A half-peck or so of coarse corn meal is made into a stiff dough, and thrown in at intervals of two or three days, for a week or so, to attract the Carp, which are fished for before breakfast, and late in the afternoon. This food also draws the minnows, and the small fry of course attract the "Jackfish," as the Virginians call the Pike.

Early on some frosty morning, then, the angler of the Old Dominion may be seen wending his way to a baited hole, preceded by a negro boy, with four or half a dozen pine poles on his shoulder, and a chunk of corn bread in his hand, the use of which I will mention anon. When he gets to the baited hole, he proceeds deliberately to bait his Carp-hooks with earth-worms, and drops them quietly in, some distance out from the shore. Then with a small hook and line he 
catches his minnows, baits his Jack-hooks (which are suspended to the ends of stout lines two feet or so below large corks), and ranges them in a line close to the bank, where the Pike are most likely to lie in ambush for the minnows, as Captain Walker used to wait in the chaparral for the "Greasers," down on the Rio Grande.

After he sets his poles he then "sets himself," on a stump, or log, or on a bench made for that purpose, and for the use of all anglers who fish that hole, and waits patiently for a bite. When there is a tremulous motion of his Carp-corks, the angler shows a disposition to rise, as if to discuss an "abstract question;" but if a school of minnows skip suddenly along the surface, mention of the John Brown raid could not arouse him so thoroughly_Jack are about! his middle cork sails away and disappears; he gives him a little time, then pulls with all his might, and the fish is landed. He places the toe of his boot under the abdominal fins, and sends Johannis Esox some ten paces farther inland, and leaves him flouncing and rustling in the dry leaves. Then baiting his hook again, he "sets his pole," and takes his seat on the bench to wait for another bite.

If there are no signs of Jack, after awhile he crumbles up a little piece of the corn bread his black adjutor has brought along, strews it over the water to attract the minnows, and sits down again, perhaps rising occasionally to land a Carpbut look out! the minnows skip again! there, the cork nearest the alders! jerk-he has missed him-he pulled too soon. Perhaps he "cusses" a little, but baits his hook again, resets his pole, and once more takes his seat on the bench. If the Jack bite well, he resigns the capture of the less noble game-the Suckers-to his henchman, who has been standing all the time with his hands in his pockets, rubbing one foot over the other to keep them warm, and shivering as a negro 
boy always will on a frosty morning, whether he is cold or not. As the day advances, he wiles the minnows with the crumbs of. corn bread, and the minnows attract the Jackfish. At last, after more or less sport, he strings his fish on a dogwood switch, hands them to Cæsar, goes home, takes a honey dram, or, if he has taken the temperance pledge lately, compromises on a mug of persimmon beer, which he calls "36.30," and sits down to breakfast; and such a breakfast as is seldom found outside of the Old Dominion.

On such excursions, when I have been with "the Major," minnows would be scarce, and the Jackfish would keep their hiding-places; then with my trolling-rod and gorge-hook, I have forced from him acknowledgment of the superiority of science over native aptness. But he always viewed trolling in the light of some new-fangled "Northern heresy;" and when I have attempted to drill him in my tactics, he would make a few casts and return to his big cork lines; and still adheres to their use with as much pertinacity as he does to the "political teachings of Thomas Jefferson," or the doctrine of State Rights.

I would not imply from the foregoing, that the anglers of the Old Dominion are solitary or unsocial in their sports; on the contrary they are gregarious, and consequently convivial. A fishing-party, if stationary, sometimes lasts all day, and is apt to draw an occasional passer-by; when a game of "sevenup" or a tune on a fiddle is interluded. "The Major" says, a cockfight sometimes varies the amusements of the day; and that he has even known a quarter race to come off in an adjoining lane, by way of finale to the day's sport.

[Since penning the foregoing sketch of an old friend, the besom of war has swept over the broad fields along the upper Rappahannock, where he lived; crops have been destroyed, 
farm stock driven off, servants scattered, and many a hospitable home, that was open to all comers, has been desolated. I prefer not altering what I have written, for I love to think of that part of the country and its people as they were, and indulge the hope that when our Union is restored, I shall again behold "the Major" as I last saw him after returning from Jack-fishing-warming himself before his big log-fire.]

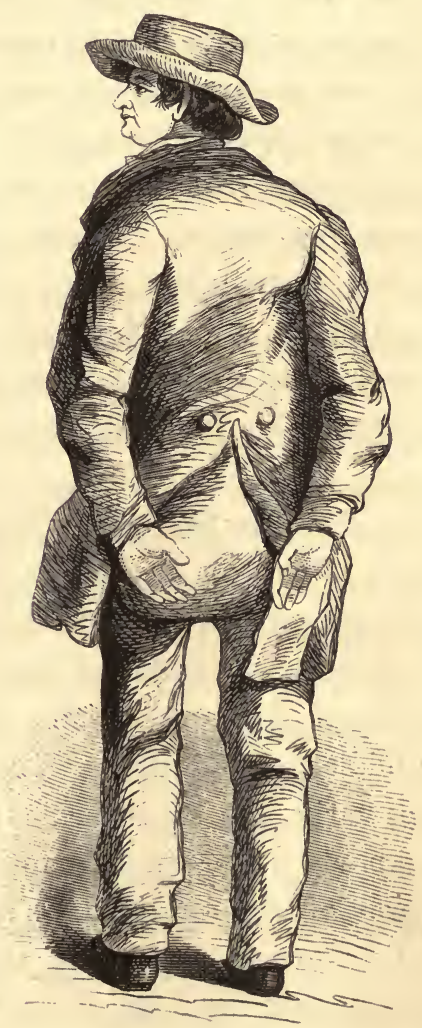




\section{GREAT BLUE PIKE.}

This fish has a broad short snout, which is very different from the ducklike bill of the Pond Pike; its head resembling what one might imagine the produce of the bulldog and greyhound would be. It has a formidable array of broad lancet-looking teeth. I have the head of a specimen, sent from Meadville, Pennsylvania, in a jar of alcohol, which measures twenty-five inches in circumference; after large slices of it being cut off, to get it into the jar.

Mr. Wilson, who keeps the gun and fishing-tackle store in Chestnut Street below Fifth, Philadelphia, has the dried head of a Pike of the same species in his window, with its two rows of teeth all complete; it is worth examining.

This fish is found in the lakelets and in the streams that are tributary to the Ohio, in the south-western part of New York, Pennsylvania, and North-western Virginia. A friend tells me it takes a live bait nine or ten inches long, and pulls like a Shetland pony. It has been taken weighing as much as eighty pounds in Connaught Lake in Bradford County, Pennsylvania.

\section{THE LITTLE POND PIKE OF LONG ISLAND. •}

In olden times on Long Island there was a small Pike which bothered the fly-fisher a great deal, rising at the fly and insisting on being caught. Frank Forester describes it at length in his book as Esox fasciatus. 


\section{THE STREAKED PIKE OF THE OHIO.}

Esox vittatus : RafinesQue.

Of the Pikes found in the Ohio, Rafinesque says :- "There are several species of Pikes in the Ohio, Mississippi, Wabash, Kentucky, \&c. I have not yet been able to observe them thoroughly. I have, however, procured correct accounts, and figures of two species; but there are more. They appear to belong to a peculiar subgenus distinguished by a long dorsal fin, a forked tail, and the abdominal fins anterior, being removed from the vent. It may be called Picorellus. The French settlers of the Wabash and Missouri call them Piconeau, and the American settlers Pikes or Pickerels. They are permanent but rare fishes, retiring however in deep waters in winter. They prefer the large streams, are very voracious, and grow to a large size. They prey on all the other fishes except the Garfishes, \&c. They are easily taken with the hook, and afford a very good food, having a delicate flesh.

"Streaked Pike. Esox vittatus. Brochet raye.

"White, with two blackish longitudinal streaks on each side, back brownish; jaws nearly equal, very obtuse, eyes large and behind the mouth; dorsal fins longitudinal between the abdominal and anal fins; tail forked.

"This fish is rare in the Ohio, (although it has been seen at Pittsburgh), but more common in the Wabash and Upper 
Mississippi. It is called Piconeau or Picaneau by the Canadians and Missourians. It reaches the length of from three to five feet. The pectoral and abdominal fins are trapezoidal, the anal and dorsal longitudinal, with many rays and nearly equal. It is sometimes called Jack or Jackfish. Lateral line straight."

I saw an account, and an engraving of a fish of this species in some scientific journal a few years since, at the Academy of Natural Sciences, Philadelphia, and fully intended to have referred to it in this work; but on looking for it recentlyhaving forgotten the title of the periodical-much to my regret I was unable to find it, even with the assistance of the librarian.

I have been told by Kentucky anglers that this Pike takes a Chub or a Sucker a foot long, and prefers a bait of that size to a smaller one; and that in setting night-lines for it, the usual way is to go in a boat to pools which it frequents, and tie the line to the limb of a tree, extending over the water. When the fish takes the bait, the branch giving, allows him to run a little with his prey, and when he is securely hooked, it also acts as a rod, yielding, though still holding him.

Miraculous stories are told of the size of a Pike found in the Kanawha and other tributaries of the Ohio, below Wheeling, Virginia, which must be of the species referred to above. If these accounts are to be credited, it is the largest Pike. ever taken with hook and line-excepting, always, Pliny's and old Gesner's.

One of the stories alluded to, I heard many years ago, when detained at Wheeling, Virginia, waiting for the Cincinnati packet. It was from the hostler of the hotel opposite the steamboat landing. He told me that the proprietor, who was then on a fishing excursion to the Kanawha, on a former trip 
had taken a Pike which reached clear across the dining-table after its head and tail were cut off; and that it was necessary to have a tin boiler made expressly to cook it. He did not say how much wood was consumed in boiling it; probably something less than a cord. From his "dare-devil" air, and the leer in his eye I had a faint impression that he was quizzing me. But he affirmed positively as to the length of the fish, as he sat in his shirt-sleeves, with his thumbs under his suspenders, and a very long native segar in his mouth.

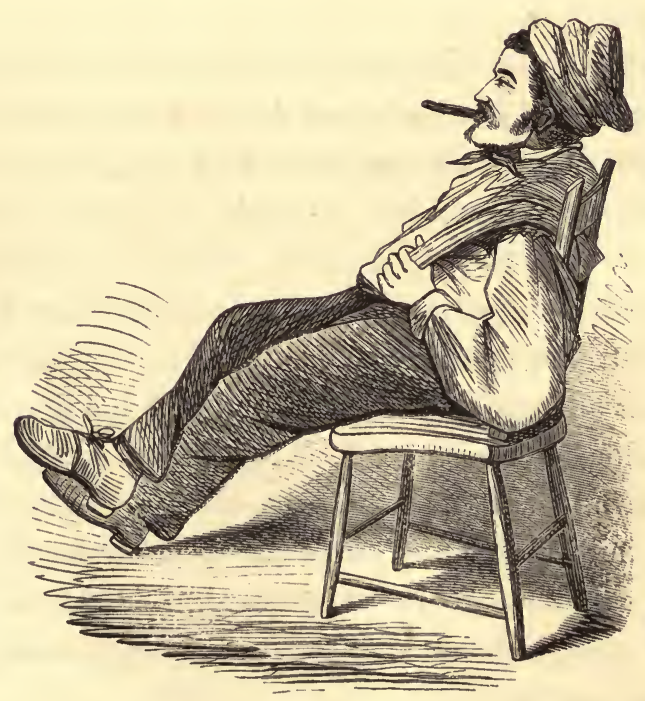


CHA P T R VI.

THE CARP FAMILY. 
"LET me live harmlessly, and near the brink Of Trent or Avou, have a dwelling-place;

Where I may see my quill or cork down sink

With eager bite of Perch, or Bleak, or Dace,

And on the world and my Creator think;

Whilst some men strive ill-gotten goods to embrace,

And others spend their time in base excess

of wine, or worse, in war and wantonness.

"Let them that list, these pastimes still pursue, And on such pleasing fancies feed their fill, So I the fields and meadows green may view, And daily by fresh rivers walk at will, Among the daisies and the violets blue, Red hyacinth, and yellow daffodil,

Purple narcissus like the morning rays,

Pale gander-grass, and azure culverkeys."

Jo. DAvors, Ese. 


\section{CHA P TER VI.}

\section{THE CARP FAMILY-CYPRINID必.}

\section{REMARKS ON THE CYPRINIDE.}

The Sucker. Catostomus communis.

Buffalo Fish. Catostomus babulus.-Buffalo Fish as an article of diet. T'he Chub or Faldfish. Leucosomus nothus.-Errors of American writers in regard to the size of the Chub.-Chub an annoyance to fly-fishers.-Chub-fishing on the Brandywine.-Umbrella invented by a Chub Fisherman.

ROACH, and Roach-fishing.

THIS family furnishes but few species that may be called game fish. The more ambitious angler who has access to Trout-streams or waters where Bass and Pike are found, seldom fishes for them in this country. As food they are not esteemed, and in warm weather are scarcely edible.

There are pleasing associations, however, connected with some of the fish of this family. To many an angler they have furnished the means of a rudimentary knowledge of the gentle art, while the pursuit of them along the streams that flow through green meadows, has likely fostered a love of quiet pastoral scenery; and if, in after years, he reads the lines attributed by Walton to "Jo Davers, Esq.," quoted on the preceding leaf, he will more thoroughly appreciate the character of our simple-hearted, though strong-headed Father 
Izaak, as in his fancy he hears him discourse with his pupil, under a honeysuckle hedge during a shower.

The characteristics of this family are: the mouth slightly cleft; weak jaws, most frequently without teeth; margin of the jaws formed by the intermaxillaries. Pharyngeals strongly toothed; lips fleshy. Branchial rays few. Body scaly. One dorsal fin. Belly not compressed; never serrated. Intestinal canal short. The least carnivorous or predatory of all fishes. There are nearly thirty genera, and over two hundred species.

\section{THE SUCKER.}

\section{Catostomus communis: $\mathrm{DE} \mathrm{K}_{\mathbf{A Y}}$.}

There are several species of the genus Catostomus known by this common name; they appear to be ubiquitous in the streams of the Northern, Middle, and Western States, are less numerous in the Southern, and are seldom found in those states that border on the Gulf of Mexico.

The Sucker cannot be called a sporting fish, yet the diffculty of taking it with hook and line, and the nicety required in fishing for it, makes the taking of it a matter of interest to those who like to accomplish something difficult in angling. As an article of food it is only esteemed when other fish are scarce.

When fly-fishing in the month of June, I have frequently found then to collect in large numbers in some gentle current to spawn; then Trout are apt to lie at the lower end of the school to catch the ova as it drifts down stream. At such places the angler is sure of a good catch of Trout, which will rise readily at the fly although they may be gorged with the spawn of the Suckers. 
In Eastern Virginia the Sucker is called "Carp," and they are fished for in the same manner as the Carp in England; this mode of angling having no doubt been handed down by the early settlers. A hole in the creek, river, or mill-pond is baited every evening for a week or ten days with coarse corn-meal dough, and is then fished early in the morning and late in the afternoon; the season of the year, April, October, and November.

In still water a float is used, and a small hook with an earth-worm put on so as to let it crawl on the bottom; it is sucked in by the fish; the motion of the cork is slight, the angler striking as it moves off, or as it is drawn gently under.

\section{BUFFALO FISH.}

\section{Catostomus babulos: Rafinesque.}

In mentioning the specific characteristics of this fish, Rafinesque says: "Diameter one-fifth of the total length; olivacious brown, pale beneath, fins blackish, pectoral fins brown and short; head sloping, snout rounded, cheeks whitish; lateral straight, dorsal fin narrow, with twenty-eight equal rays, anal trapezoidal with twelve rays." "It is called everywhere Buffalo Fish, and 'Piconeau' by the French settlers of Louisiana. It is commonly taken with a dart at night when asleep, or in the seine; it does not bite readily at the hook. It feeds on smaller fishes and shells, * and often goes in shoals."

This is a true Sucker, though his proportions are very unlike the elongated friend of our youthful days. Its shape

* An error. None of the Catostomi feed on molluses; their weak jaws and peculiar mouth render it impossible. 
resembles what a huge Perch might be, if inflated; for its body is not only very deep, but thick and full, and is puffed up to the very tail; a fish of thirty inches, weighing almost as many pounds. It is seldom taken with a hook and line, and is of little interest to the angler. I notice it here, only because it is never seen by the angler.of the Atlantic States, though it is common to all the waters that connect with the Ohio and Mississippi. Its flesh is gross and unpalatable.

At St. Louis I have seen a dray-load of these unwieldy, misshapen fish, brought on board of a steamboat bound for New Orleans. Although kept in ice, they would get rather stale by the time the boat reached the cotton and sugar regions. Billy Clark, an assistant clerk on one of these boats, who was somewhat of a wag, would write them down at the head of the bill of fare "Mississippi Salmon à la tartare," but quietly remarked, he would as soon eat a piece of the Ohio Fat Boy. Some of the natives though, who came aboard, apparently from inland, on our passage down, seemed to relish them hugely. I remember one of these, a short, pot-bellied, baldheaded little man, with low-quartered shoes, short trousers, and a brown linen jacket, an outline of whose figure closely resembled the fish in question. There used to be some fast eating on western steamboats in those days. I have seen all the courses from "soup," down to "almonds and raisins," done in twenty minutes: but when this piscivorous little gentleman sat down to boiled Buffalo, it was astonishing to a man accustomed to slow eating. The mention of this fish brings up other ludicrous reminiscences; but

"Farewell! a word that must be, and hath beenA sound which makes us linger-yet, farewell!"’

The Sunny South-farewell, great Babulus, and all the minor Catostomi. 


\section{THE CHUB, OR FALLFISH.}

\section{Leucosomus nothus.}

There are several species of the genus Leucosomus found in the Eastern and Middle States. I therefore omit a description of any one species as a representative of the fish called "Chub."

The Chub is a persecuted individual in a Trout-stream; one whose name is cast out as a reproach amongst fly-fishers, whose head is knocked off, or he is thrown ashore on a sunshiny day to linger and die on the pebbly beach, like ar Ishmaelite in the sands of the great Sahara. Every man's hand is against him.

Dr. Bethune, in a note to his edition of Walton, says: "The Chub in this country is the scorn and vexation of the angler, and, except when large, is by no means the shy fish that Walton and other English writers describe him to be; on the contrary, he is a bold biter, more ready than welcome at any bait offered him." Mr. Brown, in the "American Angler's Guide," says, "Their length is not usually over ten inches ;" and Frank Forester writes, "The American Chub never exceeds ten inches."

The writers last quoted could not have fished many of the tributaries of the Delaware and Susquehanna, or they never would have recorded so gross an error. The Upper Delaware, the Beaverkill, Schuylkill, West Canada Creek, and many other streams, abound in large Chub, and any urchin who wets his clumsy line, with a white grub at the end of it, knows better. Immediately below Frank Forester's remark just quoted, I find (in a copy of his book in my possession) the following note by the president of our little club: "A 
mistake-I have taken them twenty-two inches long and weighing three pounds; common in the Schuylkill, eighteen inches."

Dr. Bethune is unnecessarily disparaging in his remarks on this fish. In many sections of the country it furnishes excellent sport, especially in those streams where Trout have been fished out, or have disappeared from other causes; it takes a grasshopper at midwater or on the surface, and on a warm day rises freely at the fly, and shows much pluck when hooked. But when fly-fishing for Trout, in some streams they are so numerous as to be deservedly considered a nuisance; for it is a severe trial of the angler's patience, when he hooks a good Trout in a rift, and as he gets him into still water and has almost drowned him, to have a big Chub with his fresh vigor seize the other fly, and be held tight by his leathery mouth, while the chances for the escape of the Trout are augmented. Then again they will be jumping at your flies, frequently getting the start of a shy Trout, or, after being hooked, swim deep and strong, and encourage the vain hope that it is a stout, steady-pulling Trout; but one glance at the back fin or his forked tail as he gives in, dispels the illusion. They prefer a fly with a big red body, and in such streams those who fish for Trout should avoid a dubbing of that color.

Some years back I was one of a party on the Beaverkill, when an incipient fly-fisher hooked a large Chub, and played it some minutes, supposing it to be a Trout; on landing it, he looked at a veteran native angler, as if to solicit his approval, but "Uncle Peter," turning over the Chub with the toe of his boot, remarked in his quiet way, "why, he's as big as a lamb." There was a laugh, and of course the angler was chagrined, when he was told the Chub was never basketed there. 
A friend who is a veteran Chub-fisher, and who stands up for his favorite, writes thus in his defence; I insert his remarks, word for word:-

"I suggest that the mistake of Frank Forester arises from the fact of a fish with a clumsy, horny head, which is washy and worthless, and rarely attains a greater length than ten inches, is frequently found in Trout-streams, and is called 'Chub.' But the fish in question, which is known in Chester county and in many other parts of the state as 'the Fallish,' probably from his being in the best condition and most readily taken in the autumn months, is a shapely, cleanly fish, with a white, silvery belly, and when well grown is shy and requires careful and quiet fishing. The sides and heads of those above twelve inches are often colored with a pink tinge."

From the above it will be seen that the Chub is much esteemed in many streams for the sport he affords in bottomfishing. The best season of the year is September; a grasshopper or grub-worm, or a small cube of tough cheese, is a good bait; the bottom-tackle should be neat, as he bites delicately; a long, light cane rod, a small float, and a No. 1 Kirby hook, are appropriate tackle.

Some anglers now residents of the "Quaker City," who came from an adjoining county, as our friend just quoted, are expert Chub-fishers. I am acquainted with a retired merchant, a neat, dapper old gentleman, who fishes the Brandywine, and has all kinds of contrivances pertaining to catching them. To be appreciated, he should be seen with his tin bait-box strapped before him, his portable stool, and his improvement for holding his umbrella without the use of his hands; the latter invention is a long pocket, two inches wide and twelve inches deep, down the back of his coat, into which he slips the staff of his umbrella, and waits patiently 
for a bite, regardless of April showers or July's scorching sun. When the mild Indian summer is over, he greases his long reed pole with linseed oil, and lays it carefully away; viewing it now and then with the same satisfaction that Gloster did his "bruised arms hung up for monuments." I have suggested to him the use of the artificial fly, but he believes not in things ethereal, or things ephemeral, but has more "confidence in the flesh," viz. red worms and white grubs. Long may he live to fish for Chub, chewing "the cud of sweet and bitter fancy," as well as his Bologna sausage at noon, while he contemplates the beauties of nature by the peaceful Brandywine.

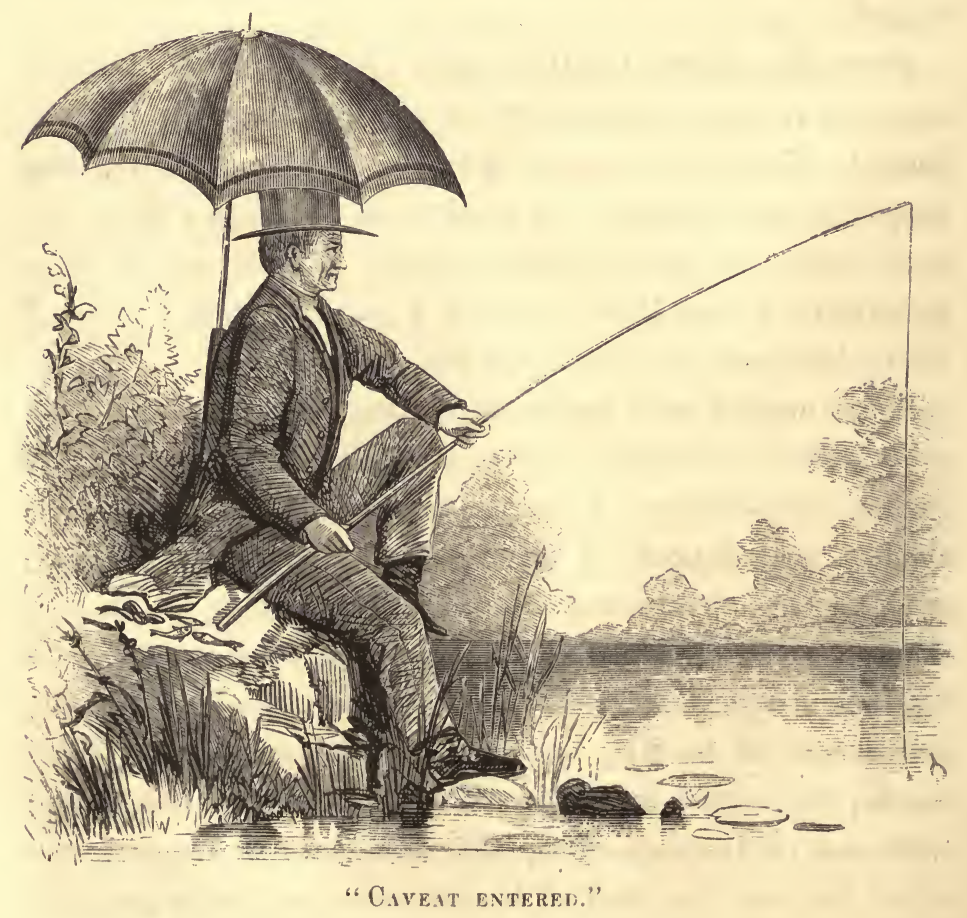




\section{THE ROACH.}

Of course no angler will fish for Roach when better sport can be had; but as they are only in season when all other fish refuse a bait, and thus act as a palliative to one who suffers from "Anglo-Mania," they deserve some notice.

On any warm day from October to April, the angler may unite recreation with exercise, by taking his walking cane rod in his hand, and with a lump of tough dough or a few small wood-worms, have an hour's sport with these pretty little fish. If he has some juvenile friend with him, the pleasure is enhanced. I have taken scores of them during the winter, from seven to nine inches in length, at Gray's Ferry, also in Cooper's Creek, and at Red Bank below the city. They are generally found on the lee side of a pier stretching into a fresh-water creek or river; and sometimes in the dock itself.

When fishing for Roach I have frequently laid them on the snow or ice, when they would become frozen; but on taking them home carefully, and putting them in hydrant water, would have the whole catch swimming about. There is some nicety required in taking Roach artistically, which is not attained by bunglers, and this fact adds to the pleasure of this kind of winter angling.

The rod should be slight and from eight to ten feet long the line of fine silk; bottom of fine gut; hooks No. 12, Kirby, one of which should be seized to the extreme end, and three others to short pieces of gut, diverging at intervals 
of eight inches; float, a neat quill; the sinker should be just heavy enough to sink half or two-thirds of the float; the bottom hook should touch or be near the bottom.

The bait, if paste, should be rolled in small pellets, not larger than a No. 1 shot, between the finger and thumb; it should merely cover the point and barb of the hook. When they bite freely, a small mite of the tough skin of a chicken's leg will obviate the necessity of baiting often. Worms obtained by peeling the bark from rotten logs, are generally used in winter. On a cold day a bite is almost imperceptible to a novice, but a little observation will soon teach him when to strike, which should be done by a quick but slight motion. Roach will not rise at a fly in winter, but I have caught them when casting for Trout on a pond in March. They are soft. and have a muddy taste.

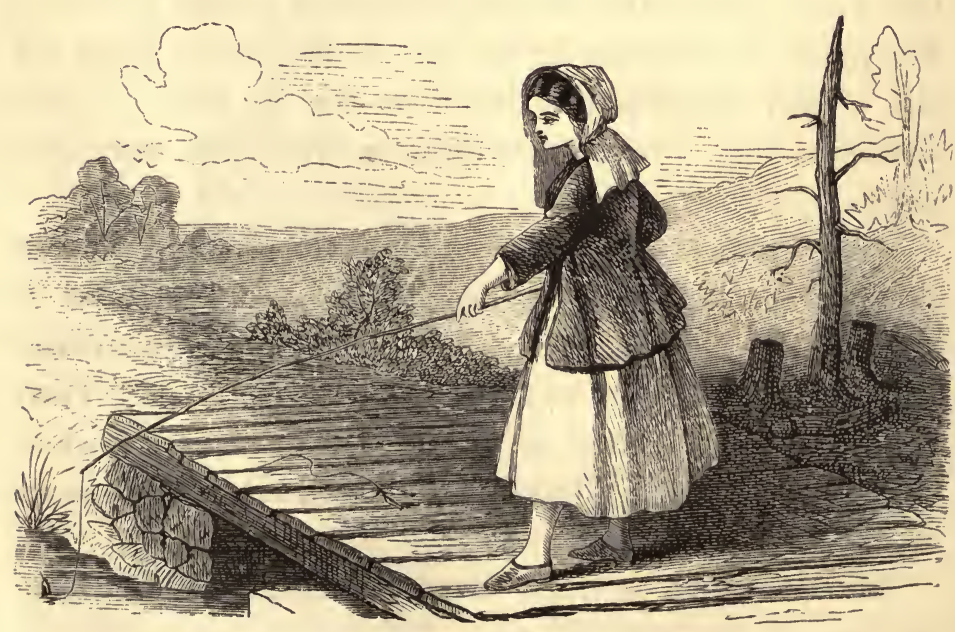




\section{H A P T E R V II.}

THE HERRING FAMILY. 
Quaker Lady (raising the window). I say, man-thee with the wheelvarrow-what does thee ask for shad?

Colored Fishvender. Hay dar! (turning quickly round and touching the rim of his bellcrowned hat) From three fips, marm, to a quarter and a fip, 'cordin' to de size of 'em.- None of your grass-fed shad, marm, but ra'al fat corn-fed fellows._- Sha-a-ad, 0 shad! let go my knife and fork, fresh shad!_-Whih! here dey go !

old Times in Philadelplia. 


\section{CHA P T E R VII.}

\section{THE HERRING FAMILY-CLUPEID正.}

Remarks on the Herring Family, from the "Iconographic Eneyelopædia."-Their abundance in the waters of the United States.-Great numbers of them taken in the Potomac.-Herring-fishing with the artificial fly.

The Shad. Alosa prostatilis.-Its delicacy and value as food.-Migratory habits.--Shad taken with the minnow.-Shad-roe as bait.

Although this family of fishes is of little interest to the angler, as far as sporting qualities are concerned, its import. ance in an economic and commercial point of view is so great, that I am induced to copy at length an interesting article from the "Iconographic Encyclopædia of Science, Literature, and Art," a work which has been translated from the German, and edited by our countryman, Professor Spencer F. Baird, of the Smithsonian Institute, and published by the Messrs. Appleton, of New York.

"Clupeide. The fishes of this family exhibit considerable analogies to the Salmonoids, differing, however, in the absence of an adipose dorsal. Both maxillaries and intermaxillaries are employed in forming the margin of the upper jaw, instead of the usual introduction of the latter alone. The body is well scaled, the scales sometimes very large. Bones of the mouth variously provided with teeth, these occurring sometimes on the pectinated tongue.

"The fishes of this family are among the most useful and indispensable to man. It includes the Anchovy, the Sardine, 
the Sprat, the various Herrings, and the Shad. The Anchovy, Engraulis encrasicholus, is a small fish, a few inches in length, distributed throughout Europe, and especially abundant in various parts of the Mediterranean. It is distinguished, as a genus, by the projecting and pointed upper jaw, and the long anal. The top of the head and back is blue; irides, sides, and belly, silvery white. This fish was well known to the ancient Greeks and Romans, who prepared from it a sauce called garum, held in great favor. They are taken in countless numbers on the coast of Sardinia, 400,000 having been caught at a single haul. The fishing is highly successful by night, when the Anchovies are readily attracted by the glare of fire-pans. In preparing them for purposes of commerce, the head and viscera must be removed; the former being bitter, and for this reason called Encrasicholus by Aristotle. The Anchovies, after being washed clean, are placed with the belly upwards in vessels, a layer of fish alternating with one of salt, until the whole is full. Pressure must be exerted to drive out the oil as much as possible. A hole is left in the top of the vessel, which is then exposed to the sun. After fermentation has commenced, the hole is stopped up, and the vessel removed to a storehouse. The operation is not completed until the following year. The Anchovy is taken from December to May.

"The Clupeidæe, with non-projecting upper jaws, are divided into various genera, as Clupea, Sardinella, Harengula, Pellona, Meletta, Alosa, and others. A distinction was formerly made between a genus Alosa, characterized by an emargination of the upper jaw, and Clupea, with the border of the jaw continuous or entire. This division, however, has been found to be inadequate to the wants of the present system.

"Alosa vulgaris, a European species, is represented in America by one of much finer flavor, the A. sapidissima, or 
common American Shad. This well-known species commences its entrance into our rivers, at periods varying from January to May, according to the latitude. It penetrates all the Atlantic streams, and when unobstructed by dams or other impediments, travels to a considerable distance from the mouth for the purpose of depositing its spawn. They are taken in great numbers, especially in Chesapeake and Delaware Bays, by various means, the most conspicuous of which are large seines and gill-nets. The price varies from five to fifty dollars per hundred, according to the abundance or size. As already remarked, various Herrings occur in immense numbers. Conspicuous among European species, in this respect, is the Sprat, Harengula sprattus; but vastly more so the common Herring, Clupea harengus. The true abode of the immense hordes of Herring is not, even at this day, definitely ascertained, the fish being scarcely known, except in its wanderings. Some naturalists suppose it to come from the high north to deposit its spawn upon the shores of the North Sea; others, again, consider the bottom of the North Sea to be its home, since it is first visible at the Shetland Islands in April. Here myriads of Herrings combine into armies many miles in length, and then pass on to the coasts of Norway, England, Germany, and the Netherlands. From the main army, branches go off in various directions, supplying almost the whole coast of Europe, and possibly extend their migrations even to the northern coast of North America. They have never been seen to return to the north, and their migrations themselves occur neither at perfectly regular intervals nor in the same direction. The density of the columns also varies much in different parts of the army. In some seasons the numbers are countless, in others very limited; at one time the individuals will be fat and large, at another very lean. By the end of August they 
are no longer seen. The Dutch, who, since 1164, have prosecuted the Herring-fishery with the greatest success, sometimes employ whole fleets of boats in the pursuit. At no very remote period, the number of boats annually leaving the Texel, under the protection of vessels of war, amounted to not less than eleven or twelve hundred. This trade was at its highest state of prosperity in the year 1618, at which time the number of boats employed was 3000 , manned by fifty to sixty thousand men. Since that time the trade has passed out of the hands of the Dutch, to a certain extent, and is carried on by many nations of northern Europe. According to Black, the fishermen of Gothenburg alone, in his time, took upwards of 700,000,000 Herrings. More than 130,000 barrels have been exported from Bergen in Norway; the amount consumed in the entire land exceeding double this number. At the present day, the largest quantities are taken on the shores of England. Recent investigations have rendered it probable that the Herring actually does live within a moderate distance of the localities where it is caught, coming in from the deep water for the sake of depositing its spawn.

"A beautiful spectacle is seen when the Herring approach the shores; the rays of the sun are reflected from myriads of silver scales, and above the army may be seen hovering hosts of gulls, terns, and other sea-birds. Behind and alongside are numerous rapacious fish, which, with seals, porpoises, and other marine animals, devour immense numbers. The water is filled with loose scales, rubbed off by their close proximity. On account of their vast numbers, these fish are very easily captured. This is done by means of nets, either on shore or at sea. Every Dutch smack has four smaller boats along with it, to carry fresh fish to the sea-ports, and for other purposes. They use nets of 500 or 600 fathoms in length, made 
of coarse Persian silk, as being stronger than hemp. These are blackened by smoke, in order that the fish may not be frightened by the white thread. The nets are set in the evening, buoyed by empty barrels, and stretched by weights; they thus rest at the surface of the sea. In the morning they are drawn in by means of a windlass. The Herrings are sometimes attracted within reach of the nets by lanterns suspended at various intervals. But a faint idea can be formed of the actual number of these prolific fishes, which exists at one time in the ocean. When we remember, however, that an annual consumption of over two thousand millions in Europe, not to mention the myriads devoured by fishes, birds, and various marine vertebrata, scarcely appears to affect their number, we may obtain an approximate conception of what that number must be to which the sum of those annually destroyed is in such small proportion.

"As the Herrings are so abundant, and the flesh at the same time so excellent, various modes have been adopted to preserve them for a certain length of time. Even at sea many are salted down, and sold in this state. This is called by the French saler en vrac. To keep them longer than is permitted by this method, two other ways are made use of: they are called white-salting and red-salting (saler en blanc and saurer). To white-salt Herring, they are gutted on being caught, and packed in barrels, with a thick brine poured over them. They are there retained, until it is convenient to give them a final packing. After the bustle of the fishing is over, the smacks or busses run in and discharge their cargoes, when the barrels are inspected, and the fish sorted under the inspection of official authorities. They are then repacked with fresh lime and salt, and the particular quality marked on the barrel by the brand of an inspector. The red-salting is effected by allowing fat Herrings to lie for a considerable 
time in the brine, then arranging them on hurdles, and placing them in ovens holding from ten to twelve thousand, for the purpose of being dried and smoked. The invention of pickling, as applied to Herring, has been ascribed to Wilhelm Böekelson, or Beukelson, a fisherman of Viervliet in the province of Zealand (about 1440): he, however, only improved an art known before his time. The Emperor Charles V. eat a herring over his grave, in thankful acknowledgment of his worth, and erected a monument to his honor in 1556 .

"Several species of Herring are caught in vast numbers on the coast and in the Atlantic rivers of the United States. The principal of these is the Clupea elongata, the representative of C. harengus. Besides Alosa sapidissima, or Shad, already mentioned, Alosa tyrannus and A. menhaden are of economical value, the former as an article of food, the latter for manure. Immense numbers are taken and spread on poor lands, to which they impart a fertility not inferior to that produced by guano."

In the United States, Herrings are most abundant in the rivers that flow into the Chesapeake. In Maryland and Virginia they have even been used as manure, as the small species known as "Manhaden" and "Mossbunkers" have been farther north. In Virginia and North Carolina, the custom of visiting the "fishing-shores" annually for a supply of Herrings to salt down, still exists as an "institution," and the inhabitants for many miles back from the rivers that furnish these fish, come every spring and take away immense numbers of them.

One of the greatest hauls with a seine that I ever heard of, was made by a fisherman on the Potomac near Dumfries, Va. With one sweep of his long net he encompassed a school which supplied all applicants. He sold them as long as they 
would bring a price, and then, after furnishing them to the people of the immediate neighborhood without charge, lifted his net and allowed the remainder of the imprisoned fish to esćape.

The Herring will occasionally take a bait, and on a sunshiny day in May, when the wind is from the south, will jump at a piece of red flannel tied to a hook. An old Scotch merchant of New York-a superannuated Trout-fisher-some years back was in the habit of fishing for them with a fly, from the decks of vessels in the East River.

\section{THE SHAD.}

\section{Alosa prcestibilus: DE KAY.}

The Shad is held in greater estimation by the epicure than by the angler. When properly in season, it is considered by many the most delicious fish that can be eaten. Fresh Salmon, or a Spanish Mackerel, or a Pompano may possibly equal it; but who can forget the delicate flavor and juicy sweetness of a fresh Shad, broiled or "planked;" hot from the fire, opened, salted and peppered, and spread lightly with fresh May butter.

- There is one peculiarity of the Shad, which some of its advocates of our city claim for it, which is, that the longer it remains in fresh water up to the time of spawning, the fatter and more juicy it becomes. This is seemingly paradoxical, as the Shad is never found in fresh water with any food in its stomach or intestines. What then does it feed on; or how does it grow fatter as it gets towards its place of spawning? Is the theory, or more properly the hypothesis, that it "lives by suction," correct? That is, that it retains aninialcula and 
microscopic animals contained in the water as it passes through its gills in breathing, and appropriates such food to its sustenance.

It is hardly worth while to go into a description of this fish, or give a portrait of it; for the outline of its form and general appearance is as familiar to us all, as the cut of the coat worn by "one of our oldest and most respectable citizens," to which coat the Shad has given a name-may his tribe decrease not, nor his fatness and flavor diminish with each vernal return of his Shadship!

Yarrell says the Alice Shad, a European species, also improves the higher it ascends the rivers. It is admitted, however, by Englishmen, that the flesh of the Shad he mentions, bears no comparison to ours; nor does it attain more than one-third the size.

Shad ascend all our rivers, from Georgia to Maine, in the spring, for the purpose of spawning, and at one time every tributary of the larger rivers, that had depth enough to float these deep-bodied fish, were annually visited by them, until mill-dams, tanneries, and other obstructions and nuisances prevented their return to their native waters and spawn beds. They entered the various creeks and brooks that feed the Susquehanna, away up amongst the mountains, hundreds of miles from their marine feeding-grounds, where they had spent the winter in attaining that increase in size, which is only exceeded by the almost miraculous growth of the Salmon. It is hardly to be wondered at, that many of the old settlers on the streams in the interior; opposed the introduction of canals and slack-water navigation, when these improvements were at the expense of the annual visits of the Shad, which not only furnished them an article of luxurious diet until the month of June, but gave them a stock of smoked and salt fish for the winter. 
Shad are taken at Savannah in the latter part of January. As the season advances, they enter the rivers successively along the coast towards the north, and are not found in the waters near Boston until about May.

It was supposed at one time that Shad, as I have already remarked, were of southern birth, and that the same great migratory shoal gradually found its way along the coast. It has since been pretty clearly ascertained that this is not the case; and it is now thought, with much show of reason, that they do not wander far from the mouths of the bays and rivers from which they migrated the preceding summer or autumn.

In more than one respect there is a elose analogy between the Shad and Salmon; both are anadromous fishes, changing their habitat annually from salt to fresh water to spawn; both present the same phenomenon of never having any foodin whatever process of digestion-in their stomachs, after reaching fresh water; and both are not only fish of extremely rapid growth in salt water, but present the same peculiarity of proportions, that is, a remarkably small head and deep fleshy body.

Frank Forester's idea that the Shad habitually takes a bait or an artificial fly is an erroneous one; it is not a predatory fish, and it is to be feared that his impression, or hope of its being classed among game fish at some future day, will never be realized; though there may have been rare instances in which it has been taken with a fly, and occasionally with a small silver minnow. I was once fortunate enough to hook three in succession, when fishing for Perch with a bright little minnow below Fairmount Dam, and secured two, the third was lost for want of a landing-net, for the mouth is extremely delicate. They have also been taken, though rarely, with shad-roe. A friend of the writer, a novice in 
angling, some ten or twelve years ago went to Fairmount, and in the course of a morning's fishing caught three with this bait. He has never been fishing since to my knowledge, and I have no doubt, he is thoroughly convinced that they can be taken in the same way at any time, and perhaps even in the water above the dam.

I have had young Shad to leap into my boat in the twilight, pursued, likely, by Rockfish; they were not as long as the blade of a breakfast-knife and not much thicker. One of these I examined carefully; but a slight handling of the silvery delicate thing destroyed the young life, which next season after its return from sea would have made a meal for two or three hungry men.

After spawning, the Shad, in Salmon-fisher's parlance, is a kipper, and has lost nearly half its weight; it then finds its way to the sea, and next season returns with its accustomed size and fatness.

The roe of the Shad is a tempting bait to all fish, and is much used by Philadelphia fishermen; great care is required in attaching it to the hook by means of the slight membrane that envelops it. Each ova as it is washed from the baited hook and floats off down the tide, is greedily swallowed by any fish, small or large, and he is toled along until he finds the "placer," when the "nugget" is swallowed at a gulph, if his mouth is large enough. Then if the fisher strikes at the particular time he hooks his prize; but an inexpert person will lose a half dozen baits for every fish he catches, and will bedaub the but of his rod, hands, and coat sleeves. until he presents anything but the appearance of a well-dressed angler. 
CH A P T R VIII. CATFISH AND EELS. 
"CATS and Eels, and sich as that."

"ONE Sat'day night

De niggas went a huntin',

De dogs dey run de Coon,

De Coon he run de Wolver,

De Wolver run de Stiff-leg,

De Stiff-leg run de Devil,

Dey run him up de hill,

But dey cotch him on de leve!.

"Sat'day night come arter,

De niggas went a-fishin',

Dey call for Billy Carter,

'Case he want to go a-cattin',

Dey filled de jug an' started

For de Pocomoka river,

Chicken-guts wus better bait,

Dey dug a gourd o' wurrims."

From a song of the "Peasantry of the Soutl"-banjo accompaniment omitted. 


\section{CHAPTER VIII.}

\section{CATFISH AND EELS.}

Catrish, Siluridae.-Extract from Ieonographic Encyclopædia.

Catfish of the Atrantic States and Western waters.

Eecs.-Observations on the Petromyzontidce (Lamprey Eels), on the

Murcenida (Common Eels), and on the Gymnotida (Electric Eels).

The Common Eel. Anguilla vulgaris.-Fishing for Eels.-Migratory

habits._-Young Eels as bait.-Eels not hermaphrodites.

CATfish and Eess are so closely associated in the minds of anglers, that I have thought it proper to include them in the same chapter. In treating of them I give a brief but comprehensive article from the Iconographic Encyclopædia on the Siluridæ, as well as an account of the different families of anguilliform fishes known as Eels, from the same work.

"SALURIDA.-Fishes of this family have the skin either naked, and covered with a slimy secretion, or provided with osseous plates of various number and shape. The head is usually depressed, and provided with a variable number of barbels. In most, there is a second and adipose dorsal, sometimes confluent with the caudal. The first rays of the dorsal and pectoral fins are generally enlarged into strong spines; and the pectoral spine is capable of being inflexibly fixed, by peculiar mechanism, in a direction perpendicular to the axis of the body. The edge of the mouth is formed by the inter- 
maxillaries suspended from the sides of the ethmoid, which enters into the outline of the mouth, forming the superior median portion. The suboperculum is absent in the whole family.

"Species of this polymorphous family are found distributed throughout the globe. In Europe, however, there is found but one species, the Silurus glanis, or Sheat Fish. This species, interesting from the fact of its being the largest freshwater fish in Europe, the Sturgeons excepted, is most abund. ant in Central Europe, its existence in England being hypothetical. The weight has been known to exceed $100 \mathrm{lbs}$., in this respect equalling some of the American Siluridx. It differs from the North American species in the absence of a posterior adipose dorsal, in the very small true dorsal, and in the very long anal. Other species of this restricted genus, Silurus, are found in various parts of Asia, and perhaps Africa, but not in America. The American forms are highly varied, those of the northern continent, however, being quite uniform in structure. 'The two most conspicuous fresh-water genera are Pimelodus and Noturus; the former with a distinct adipose dorsal, the latter with this dorsal confluent with the caudal. Numerous species of Pimelodus (Catfish, HornedPout, Bull-Head) occur in the various waters of North America, some of which acquire a large size. One species. from the Mississippi, has been known to weigh over $100 \mathrm{lbs}$. The flesh of many species is highly prized, owing to its sweetness and freedom from bones. The genus Noturus, known provincially as Stone Catfish, embraces but few species, found in the Atlantic streams south of New York, and in those of the Mississippi valley. They will probably be discovered in the eastern rivers (in the Hudson at least), when their ichthyology has been more fully studied. Marine forms 
are met with in Galeichthys, Arius, and Bagrus, the former characterized by the high dorsal and pectorals.

"South America exhibits some Siluroids of especial interest. Conspicuous among these are Arges cyclopum, or Pimelodus cyclopum of Humboldt, and Brontes prenadilla, which inhabit the, highest regions in which fish are known to live. They are found in Quito, at elevations of more than 16,000 feet above the level of the sea, living in the streams running down the sides of Cotopaxi and Tunguragua. The most interesting fact in the history of these fishes is, that they are frequently ejected from the craters of the above-mentioned volcanoes, in immense numbers; the supply being probably derived from the subterranean lakes in the body of the mountains. Our space will not permit us to mention any other members of this interesting family, excepting the $M a$ lapterus electricus, the Silurus electricus of older authors. This species is characterized generically by the absence of the first dorsal, the adipose dorsal alone existing, as also by the possession of an electric apparatus or battery, somewhat intermediate in character between those of Gymnotus and Torpedo, although of much finer texture. The whole body beneath the integuments is enclosed by the apparatus in two layers of great compactness, and at first sight suggesting a deposit of fat. A dense fascia separates the battery from the muscular system. The cells, formed by transverse and longitudinal fibrous partitions, are rhombic in shape, and exceedingly minute. The nerves of the outer organ come from branches of the fifth pair of nerves, the inner organ is supplied by the intercostal nerves. The direction of the current is probably from the head to the tail; the cephalic extremity being positive, and the caudal negative." 


\section{CATFISH OF THE ATLANTIC AND WESTERN WATERS.}

No artist, not even Landseer himself, could give a correct picture of this familiar old friend. A profile does not convey a correct idea, and a perspective view won't do; so I give it up in despair, believing that photography would even fail in its likeness.

It is not necessary to tell the angler that there are many species of Catfish in this latitude. There is the Catfish of our sluices, meadow-ditches, and ponds. The less ugly White Catfish, of rare excellence for the pan, which comes up our rivers in April, stays all summer, and goes back to brackish or salt water in winter. And there is the great "Sockdologer" of the Mississippi and its tributaries, with a mouth large enough for a little boy to get his head into, and a throat big enough to thrust his leg down. Old Jack, a "short-haired brother" of the angle, down in Mississippi, has declared to me he has seen one "as long as a cotton bale." I have, myself, seen one carried through the streets of New Orleans, tied by the gills to a fence rail, with a negro man supporting each end, and the tail of the fish touching the ground. I have heard of them weighing one hundred and twenty pounds; but I forbear, lest the reader should think I exalt this fish above measure. At the cabarets along the levee at New Orleans, I have heard the music of the frying-pan; as steaks of these "whoppers" were cooking, and have seen the laborers eat them with an appetite, but never had the curiosity to taste of them. 
There are two varieties of these monsters in the Ohio and Mississippi: the "Mud Cat," with a broad flat head, and the "Channel Cat." The latter is far more active and stronger than the former.

In my boyhood, I frequently went Catfishing with a rustic angler, whom I shall never forget. After breakfast, one of the servants would appear with a gourdfull of worms, and we would proceed to his favorite pool, and "set our poles," sticking the buts, which were sharpened, into the muddy bank, and resting them on forked sticks. Ponto, an old bobtail pointer, would be one of the party, and appeared to enjoy the sport as much as his master; at the slightest tremor of the cork, he would become restless; when it disappeared he would come to a stand; and when the fish was landed, he would seize it or keep it away from the water with as much assiduity as he would look for a wounded partridge. "Aunt Bett," the cook, one day docked Pont's tail with a cleaver, for some depredation, as he was retreating from the kitchen; and it is said, the neighbors could always tell when "Uncle Tom" hsd been at his favorite fishing-hole, by the impression that Pont's tail left in the mud, as he sat on his hurdies.

As an expedient, on one occasion, when we forgot the gourd of worms, and were waiting while the boy had gone back for it, we shot a squirrel, and a small bait of its entrails appeared perfectly acceptable to our friends of the muddy water.

When the negroes went "a catting" at night, they not unfrequently supplied themselves with chickens' entrails, as well as worms, averring that the former took the largest Catfish.

In regard to the question whether any fish manifest a care for their young after the latter are hatched from the spawn, I am informed by a brother angler-the same who writes in 
defence of the Chub, and on whose statement I can rely with entire confidence- that in his younger days, when going to a large mill-pond to bathe, he was struck with the movements of a Catfish some ten to twelve inches long, which was swimming near the bank, in water about twelve or fifteen inches deep, making circuits round and round a mass of dark specks, which were lying huddled together in a space about a foot in diameter. Upon lying down on the bank and parting the sedge and long grass which overhung the water, he discovered that the dark specks were young Catfish, about one-half to three-fourths of an inch in length, while the maternal anxiety manifested by the parent fish was explained by his observing at a short distance a number of hungry Sunfish, who were hovering round, and with greedy eyes watching their chance to make a dash at the young innocents. Whenever any of the heedless brood would show an inclination to swim away from the flock, the old one would head them off and drive them back to the fold, and protecting them from the maw of the spoilers so long as my friend watched this curious exhibition of an instinct which till then he had supposed all kinds of fish to be wholly devoid of.

It is hardly necessary to describe the tackle and manner of taking the Catfish: either or both must be suited to the water and size of the fish.

The smaller species are favorite pan-fish in the Atlantic States, from Delaware to Georgia. The larger, particularly the White forked-tail Catfish of tide-water, makes an excellent stew. They should not be skinned, nor the heads taken off; but well scraped and washed, then seasoned with onions and other pot-herbs, and smoked bacon-flitch: a little rich milk should be poured in the stew before it is taken off the fire. 


\section{EELS.}

Observations from the "Iconographic Encyclopædia."

"Petromyzontides. This family, the last of the Dermopteri, is also without lateral fins: a continuous median nn is formed by the coalescence of the dorsal, caudal, and anal. Respiration is generally performed by means of fixed gills, the lateral openings to which are seven in number on each side. A single nostril is placed on the top of the head. The principal forms belong to the genera Petromyzon or true Lamprey Eel, and Ammocæes, or Sand Lamprey. The former have a circular mouth provided with numerous teeth, and fringed with ciliæ to assist the animal in attaching itself to the bodies of its prey. The mouth is a true sucker, adhesion being effected by atmospheric pressure. Fishes of various kinds are not unfrequently caught bearing the bloody circular scar produced by the bite of the Lamprey, and quite often the Lamprey itself. The Catfish, or Pimelodus, appears to be especially liable to such attacks. The Lampreys attain to great size, and are highly prized by some nations. The love borne them by the ancient Romans is a matter of classical history, and at the present day they are the favorite food of epicures.

"The Murænidæ or Eels, with the normal structure of the gill apertures, yet have them very small and capable of being completely closed. The body is serpentiform, and although provided with scales, these are scarcely apparent, being embedded in a thick mucous skin. The airbladder is polymorphous, and the intestines without cœca. The Eels, in their different species, are inbabitants of both 
fresh and salt waters; those living in the former belonging generally to the restricted genus Anguilla. Species of Anguilla occur in greater or less number throughout the United States, being, however, very rare in many if not most of the waters of the Mississippi basin. Popular opinion assigns to these species a viviparous reproduction, owing to the apparent absence of individuals containing eggs. The ova are yet, probably, present in a due proportion of the supposed males, escaping observation by their diminutive size. The Eel hardly yields to any other fish in the power of sustaining a deprivation of its proper element for a considerable length of time. To transport these animals over a considerable space, all that is necessary is to pack them in damp grass or some similar substance. They even leave the water spontaneously at night in search of food, or of a body of water better suited to their convenience than the one in which they may happen to be placed. Eels are said to be very susceptible to magnetic or galvanic influence: the simple contact of a knife being sufficient to paralyze them. When a magnet is presented to the dish in which the living animal may happen to be, violent contortions, a painful gasping after breath, and other signs of inconvenience, are reported to be exhibited.

"The Gymnotidæ, highly interesting on account of their electrical properties, are characterized by the anterior position of the anus, the entire absence of dorsal fin, the extent of the anal, and the position of the gill-opening. The best known species, Gymnotus electricus or Electric Eel, is a native of the tropical portions of South America. It attains to a great size, being sometimes over six feet in length, and almost a full load for a strong man to carry. The electric or galvanic apparatus consists of four longitudinal bundles, disposed in two pairs, one larger above, and a smaller below, against the 
base of the anal fin. The fasciculi are divided by longitudinal partitions into hexagonal prisms, and transverse divisions separate these into small cells. The cells are filled with a gelatinous matter, and the whole apparatus is abundantly supplied with nerves from the spinal marrow. In the Torpedo, these nerves come directly from the brain.

"The amount of electricity furnished by the Gymnotus is enormous. Faraday made a calculation in regard to a specimen of ordinary size examined by him, that a single medium discharge was equal to that from a battery of 3500 square inches charged to its maximum. It need not then be a matter of surprise that the Gymnotus is capable of killing a horse by repeated discharges; which it does by applying its whole length along the belly of the animal when in the water. The method of capturing the Gymnotus made use of by the South American Indians, consists in driving a number of horses and other cattle into the muddy pools in which the Electric Eels abound. Roused from their retreats in the mud, the Gymnoti emerge into the water, and gliding in among the animals, give to them violent shocks. A succession of discharges results in weakening the Eels to such a degree, as to make it a matter of little danger or difficulty to capture them. The voltaic pile, formed by the electric apparatus of the Gymnotus, is much like that of the Torpedo; the column being longitudinal, however, in the natural position of the animal, instead of vertical. The anterior or cephalic extremity is positive; the caudal negative; and the animal is capable of discharging any portion of its column. The substance occupying the cells is a dense albuminous liquid, with a small amount of common salt. Each cell is separate and independent, answering to the cell of the galvanic battery. 


\section{THE COMMON EEL.}

Anguilla communis.

I cannot say that Mr. Billy Allen, who kept a tavern at Culpepper Court House, Virginia, many years ago, had a very extensive knowledge of the natural sciences; but he sagely remarked on one occasion, that a Mink was "a great incendiary to a hen-house!" Quoting the aforesaid authority, I might pronounce the Eel a great incendiary to a fishing-line. Knots and slime! how often he has brought the youthful angler to grief!

It is astonishing how many knots a nimble little Eel, of a half yard long, can tie in a boy's line, from the time he is landed, until he is taken off the hook, or until his head is cut off. There are hard knots and bow knots, single knots and double knots, all cemented with the pervading slime. The last resort of the little angler is, to do as Alexander the Great did with the Gordian Knot; and take out his jackknife and cut his line; thus reducing the many knots to one.

Albeit the Eel is a "slippery fellow," there are several facts in its natural history which are interesting. One is, that it spawns in salt or brackish water, and migrates to fresh water; the very reverse of Shad, Herring, and Salmon.

Young Eels are found all along shore in fresh tidewater streams, in this latitude, in April or May, by turning over a stone, when they shoot out and seek another hiding-place for the time; at that season of the year they are not larger than a darning-needle and quite transparent, showing their vital 
organs plainly. They collect at the head of tidewaters in great numbers, endeavoring to surmount falls or rapids, and many perish in the attempt or are devoured by fish. They may be taken, in such places, with a small scoop-net made of sea-grass skirting, or other open fabric, and used with great effect as bait for Perch and small Rockfish.

I have seen no less than a barrel of these silvery, transparent little animals congregated in a pool at low tide, below the western angle of the dam at Fairmount, waiting to renew their efforts to get over the fall at high water; and any little boy will go in and dip up a quart of them for the asking, or for a half dime.

In the fall they descend our rivers and are taken in weirs, traps, and eel-pots in immense numbers; in the Susquehanna a single weir sometimes produces two barrels of Eels in a night. They are speared at night in the upper Delaware; the reflection from the torch giving them a white, glaring appearance.

I used to bob for them from a boat, when a boy. Imagine three or four urchins, barefooted, with trousers rolled up to their knees, and occasionally a cold slimy Eel of larger size than common, gliding over their feet or around their ankles. There was some screaming and laughing on such occasions, which did not accord with the general idea of a fishing-party; and there was also some suraping of dry slime from jackets and trousers next morning.

Eels are speared in winter, on the salt flats along our coast, at low water; the harpooner judges by certain indications what hole to drive his implement into, without seeing them, and draws it out with the impaled Eels writhing and squirming.

These fish are not viviparous or hermaphrodites, as some suppose, but the spawn is impregnated by the male after 
ejection, as is the case with other oviparous fishes. They spawn in salt or brackish water, and the vernal migration to fresh-water streams commences at an early period of their existence. The autumnal journey towards the sea begins in September in this latitude.

It would appear without reflection that it is strange that there are no Eels in the Mississippi and its thousands of miles of tributaries, at least I have never seen one there; but if we look at the immense distance upward and downward, and the time it would occupy, it would seem that instinct or some wise law of Providence annuls the rule which obtains in the tidal streams of the Atlantic States.

Although a prejudice exists against Eels, on account of their reptilian form, they are excellent eating. Sometimes, when taken in a muddy creek or mill-pond, they are purified by putting them in a box with holes bored in it, in a spring branch, when they rid themselves of any strong taste they may have acquired in their former home. 
CH A P T E R I .

THE SALMON FAMILY. 
"ABused mortals, did you know

Where joy, heart's ease, and comforts grow, You'd scorn proud towers,

And seek them in these bowers;

Where winds sometimes our woods perhaps may shake,

But blustering care could never tempest make,

Nor murmurs e'er come nigh us,

Saving of fountains that glide by us.

"Blest silent groves, oh may you be For ever mirth's best mursery !

May pure contents

For ever pitch their tents

Upon these downs, these meads, these rocks, these mountains, And peace still slumber by these purling fountains,

Which we may every year

Meet when we come a-fishing here."

WALTON. 


\section{CH A P T E R IX.}

\section{THE SALMON FAMILY.-SALMONID}

\section{REMARKS ON THE SALMONIDE.}

The Brook Trout.--Scientific description.-Habits and manner of breeding.-Growth.-Difference in size between Trout of still waters and those of brisk streams.-Effect of light and shade, and bright or dark water, on the color of Trout.-Errors as regards new species.-Food of the Trout.-Its greediness.-Its geographical range.-Former abundance and causes of decrease.-Size of Trout in the regions of Lake Superior and State of Maine.-Size in the preserved waters of England, and size the angler is restricted to in rented waters.

The Salmon.-Former abundance in the rivers of New York and the Eastern States.-Great numbers in California, Oregon, and British Possessions.--Decline of the Salmon-fisheries in British Provinces.Scientific description.-Natural process of propagation.-Their growth. -Parr, Smolt and Grilse.-Mature Salmon.-Size of Salmon.-Instinct. -Restocking depleted rivers, and introducing Salmon into new waters. -Their migration from sea to fresh rivers, and gradual preparation for their change of habitat.-Salmon-leaps.-Food of Salmon at sea.

The Canadian Trout, or Sea Trout. Salmo Canadensis.-Error in referring it to the species Salmo trutta of Europe; their dissimilarity.Its affinity to Salmo fontinalis (Brook Trout).-Sea-Trout fishing in the Tabbisintac.-Mr. Perley's and Dr. Adamson's account of Sea-Trout fishing.-Their abundance in the rivers falling into the Gulf of St. Lawrence, and annoyance to Salmon-fishers.

'The Schoodic Trout, or DWarf Salmon of the St. Croix. Salmo Gloveri. -Account of three summers fishing in the Schoodic Lakes.

Tue Great Lake Trout. Salmo namaycush.-Manner of taking them.

The Lesser Lake Trout. Salmo Adirondakus. - Trolling for Lake Trout. Back's Grayling. Thymallus signifer.-Dr. Richardson's remarks on the Grayling. 
The Sмelt. Osmerus viridiscens. - Their great numbers along the northern part of our coast.--Smelt in the Schuylkill.-Quantity sent south from Boston.- Smelt used as a fertilizer.

The Capelin. Mallotus villosus.

The Whiterish. Coregonus albus.

'Trout Batt-Fishing.

THe family of Salmonidæ embraces many genera, of which the genus Salmo furnishes nearly all the species that contribute to the sport of the angler, or that may properly be called game fish.

Of the genus Salmo, the following species are herein described :-

The Brook Trout, or Speckled Trout. Salmo fontinatis.

The Salmon. Salmo salar.

The Canadian Trout. Salmo Canadensis. Known as the Sea Trout.

The Schoodic Trout. Salmo Gloveri. Of the St. Croix River.

The Great Lake Trout. Salmo namaycush.

The Lesser Lake Trout. Salmo Adirondakus.

There are other species than these, described by ichthyologists as being found in the rivers and lakes of that vast extent of country on our north, known as the British Possessions, and in the rivers on the Pacific coast; but as the object of this work is to interest the angler rather than the naturalist, I mention only those that are accessible and furnish sport to the brethren of the rod.

Of the genus Thymallus, to which the Grayling of England belongs, we have only two species, as far as has been ascertained. I only give an account of one, Thymallus signifer, the Standard Bearer, Back's Grayling.

Of the genus Osmerus, we have only one acknowledged species in this country, O. viridiscens, the Smelt.

Of the genus Coregonus, we have ten species described by 
ichthyologists, and perhaps several more of which no description has yet been given. As none of this genus are sporting fish, I have only referred to C. albus, the large Whitefish.

Of the genus Mallotus, we have only one species, M.villosus, the Capelin or Sparling, which is found on our north-east coast.

One of the characteristic marks, by which the most careless observer can distinguish any species of Salmonidæ, is the second dorsal fin, which is always adipose, a mere cartilage, wanting in the usual fin-rays. Any tish that one meets with having it, except a Catfish, may safely be set down as one of the Salmon Family.

The Salmonidæ delight in cold waters, and their geographical range, whether inland or on the sea-coast, seldom extends below the thirty-eighth parallel. Their value as an article of food, and importance in a commercial point of view, «เn hardly be appreciated, unless one enters into an investi. gation of all the statistical information on record. 


\section{BROOK TROUT. SPECKLED TROUT.}

Salmo fontinalis: MıтснгL.

Form elliptical, elongated. Color, olive on the back, shading gradually lighter to the lateral line; sides still lighter, with roseate pearly reflections; belly white and rose-tinted, sometimes shaded with yellow, and occasionally a deep orange. The markings of this fish are beautiful; the sides are covered with yellowish spots of metallic lustre interspersed above and below the lateral line with smaller spots of bright vermilion; the back is vermiculated, that is, marked with dark tracings of irregular form, many of which run into each other. The dorsal fin has five or six lines of dark spots; the pectorals are olive, with the exception of the two anterior rays, which are black and much stouter than the others; the anterior ray of the ventrals and anal is white, the next black, and the remaining rays a deep orange; the caudal is slightly concave, with dusky markings on the upper border of the rays. The head is rather more than one-fifth the length of the body, exclusive of caudal ; breadth one-fourth.

There are ten branchial rays: the first dorsal fin has eleven rays; the second dorsal being adipose is without rays; the pectorals have twelve rays; the ventrals eight; anal nine; caudaì nineteen.

No fish affords as much sport to the angler as the Brook Trout; whether he is fished for by the country urchin, who ties his knotted horsehair-line to his alder-pole, and "snakes 


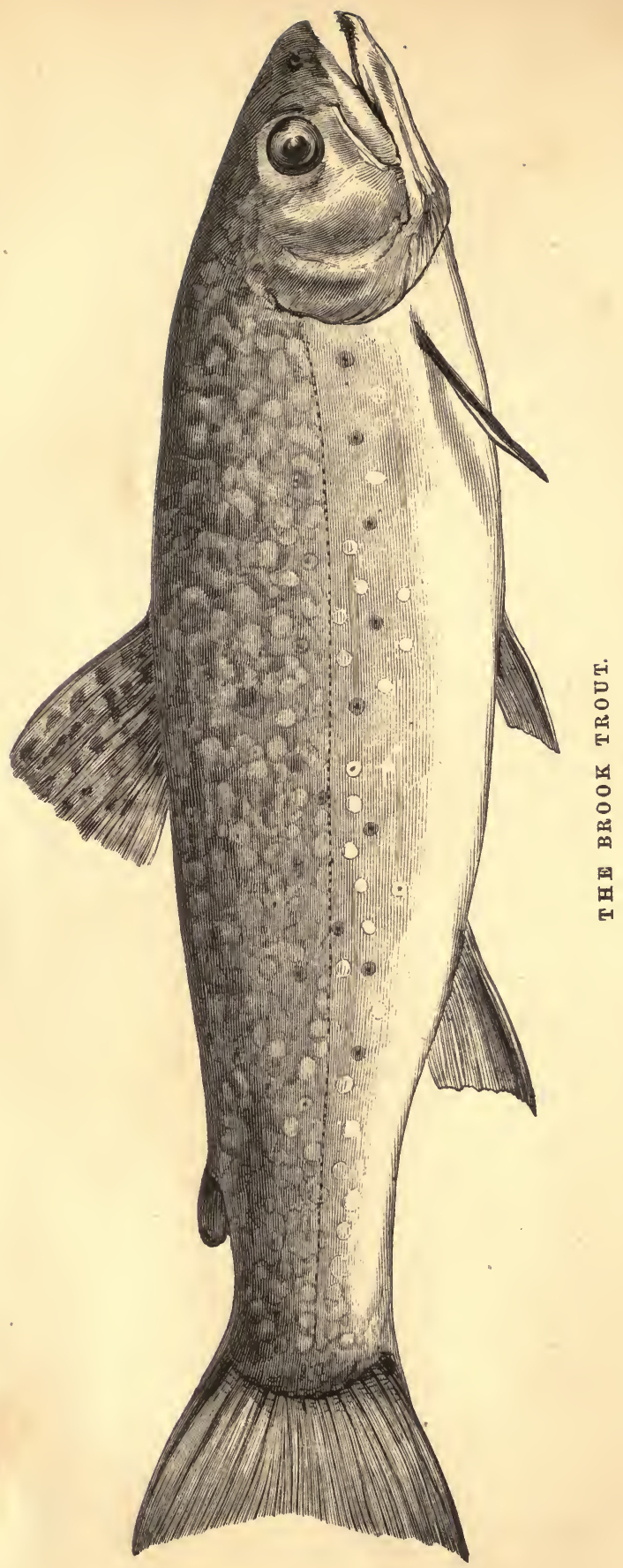


out" the speckled fellows by the caving-bank of the meadow brook, and from under the overhanging branches of the wooded stream; or by the scientific angler, who delivers his flies attached to his nine-foct leader-straight out and lightly -from his well-balanced rod, and kills his fish artistically.

$\mathrm{He}$ is as game as a bantam cock, and with a pliant rod and fine tackle, a twelve-incher gives as much sport as most other fish of four times his size, on a stout rod and coarse tackle. But let us begin with a slight glance at his habits and natural history; his unnatural death we will speak of afterwards; though the angler may think it more natural that the Trout should die by his hands, than in any other way.

Towards the end of August, if you loiter along a Troutstream, and look into a pool with smooth gliding current, where a spring branch enters; or wander along the banks of some clear, cool tributary of the main brook, you may find a dozen Trout congregated-sometimes a half dozen or a single pair-and if not disturbed by a freshet, caught by the angler, or snared by the villanous poacher, with his wire-loop, they will remain there until October or November, when the female will cast her spawn-some say in a furrow, made longitudinally or diagonally in the bed of the stream, by rooting with her nose; others say, more after the manner of broadcast. Whichever it be, the male fish follows immediately, ejecting his milt over it. The parents of the future progeny then, as a usual thing, take their course down stream to some deep pool, and there remain in winter quarters, recovering strength and flesh until the ensuing spring, when they move up stream with every rise of water, always on the lookout for something to eat, and ever eager to take a bait ()r rise at a fly, and reproducing in autumn as before.

After fecundation the ova assumes a somewhat brownish 
transparent hue, each egg showing in its centre a small dark spot, which is the embryo of the future fish. The young fish are hatched out in two or three months, and appear somewhat larger than the little wriggle-tails in a barrel of stale rainwater. They have large prominent eyes and little pot-bellies, ichthyologically termed "umbilical bladders," in which is stored the sustenance left from the egg, and which lasts three or four weeks, or until they commence seeking their own food. By this time they have grown to an inch and a half long; they then seek the shallows and gentle margins of the brook, or smaller rills, and commence feeding on minute aquatic insects and the larva of flies.

It is surprising how small a quantity of running water will sustain a school of young Trout. I have seen a half dozen in a track left by a horse's foot, in a mossy spring branch. Trout have the same dusky patches or finger-marks, that all their congeners have, when young. As far as I have observed, they rarely attain a size beyond four or five inches during the first summer in our mountain streams. They seldom venture into the larger waters until the second summer, when they are the little fingerlings that jump at one's droppers, as he is killing their progenitor on the stretcher-fly.

At our noonings, when we have emptied our creels to select the larger fish for a roast, or a bake under the ashes, I have placed the whole catch in a row, the smallest at one end, increasing in size to the largest at the other end, and endeavored to theorize as to their ages, or separate the yearlings from the two year old, and those of three from those of four years; but have never been able to draw a line separating, with any degree of certainty, the fish of a year from those of two, or those of two from those of three years, and so on to the largest. No general rule as to their growth could be laid down, unless all the fish of one year had been hatched 
out at the same time, and enjoyed the same advantages of feed and range of water, up to the time of being caught. Still, in a brisk stream, I have generally considered a Trout of seven inches as being in its second summer; one of nine or ten in its third summer; a fish of twelve or thirteen in its fourth; and so on.

The Trout found in the deep still waters of the state of New York, though a variety of this species, are a third, or one-half larger at the same age, than the fish of our clear rapid streams; and as the rivers and lakelets there are less fished than the tributaries of the Delaware, Hudson, and Susquehanna, the Trout have a chance of growing older, and consequently larger. From my own observation, the average size of the adult fish in northern New York is at least double that of the fish taken in the streams flowing into the rivers named above.

Some years ago, I had an afternoon's fishing in Hamilton County, when the catch was forty-five pounds. The fish averaged fourteen inches in length, and not less than a pound in weight. A friend on whose word I can rely, tells me he has taken three Trout of two pounds each, at a single cast, in the Raquette River, and repeated it several times in succession; and that he took off his drop-flies, to prevent a surfeit of sport, or too much strain on his light rod.

I have achieved something in the way of taking large Trout in Hamilton County, but after a man has satisfied the sentiment of camping out, and been bitten to his heart's content by mosquitoes and punkies, he prefers sleeping on a good straw bed, and enjoying the comforts of civilization, where although the fish are smaller, the streams are livelier and clearer, and it requires finer tackle and greater skill to take them.

There is a specific difference between our Brook Trout and 
the Common Trout (Salmo fario) of Great Britain. The Brook Trout when taken in its natural habitat (the clear rapid mountain stream), is a more symmetrical fish; its spots more brilliant; its sides of a brighter silvery hue; its flesh of finer flavor, though of lighter color; and its average size much smaller. The Trout of Hamilton and Franklin Counties, New York, are, as a general rule, not inferior in size to the Trout of England; their average is larger than those of the ponds of Long Island, and about equal to those taken below the ponds, where the fish have aceess to salt water.

I cannot agree with Frank Forester, that the Trout of Long Island aré superior to those of our inland brooks and rivers; on the contrary, I think the pond Trout of Long Island much inferior in delicacy and flavor, though I admit, that those which have the run of both fresh and salt water are at least equal to those taken in mountain streams.

Fish inhabiting still, sluggish waters, dams, and lakelets, are of stouter proportions than those of rapid, tumbling streams. The difference is remarked by anglers who have fished the waters of Hamilton County; those of the lakes being deep of body and proportionately short, while those taken in the outlets are longer, and afford more sport when hooked. In some of the ponds of Long Island they are extremely stout; a Trout of twelve inches weighing a pound, which is four ounces more than one of the same length taken in a mountain stream would weigh.

I would here say, from personal knowledge of the fish, that the "Silver Trout" mentioned by Frank Forester as being taken in Green's Creek, on Long Island, is in every respect the same as those of the neighboring ponds. The lighter and more pearly hue is to be attributed entirely to the bright open creek flowing through a meadow, unshaded by trees, and communicating directly with the salt water of the bay. 
All observing anglers have noticed the effect of water and light on the color of Trout; those taken in streams discolored from having their fountains in swamps, or flowing through boggy grounds where hemlock and juniper trees grow, are invariably dark, their spots less brilliant, and their sides and bellies frequently blurred; while those of bright streams flowing through open meadows or cultivated fields, are as remarkable for the deep vermilion of their spots, their light color, and delicate shading. Anglers who have fished the Tobyhanna and Broadhead's Creek, in Pennsylvania, will remember the color of the fish of these two streams; the former is boggy, much shaded, and the water almost the color of brandy; while the latter is clear, open, bright, and rapid. The Trout of the former are almost black, while those of the latter are light of color, and brilliant. I have seen anglers who could identify the Trout belonging to the different streams in the vicinity, when one turned out his catch from the creel.

Mr. Brown, in his "American Angler's Guide," says: "The Silver Trout or Common Trout is found in almost all of our clear, swift-running northern streams, and weighs from one to fifteen pounds. A splendid specimen of this species of Trout is found in Bashe's Kill, Sullivan County, New York." Mr. Brown was imposed on by the person on whose authority he makes this statement, for they are seldorn if ever taken in Sullivan County above the weight of four pounds. Nor does an average catch in that or the adjoining counties exceed four or five ounces; nor is there any species called the "Silver Trout." The Black Trout also, which he describes as "found in muddy, sluggish streams with clay bottoms, in the roughest and wildest part of our country," is also nothing more nor less than our ordinary Brook Trout (Salmo fontinalis), which, as already stated, be- 
comes dark from inhabiting water discolored by vegetable infusion.

Frank Forester's strictures on this disposition to claim a difference of species, on account of local or accidental causes producing a difference in size, condition, or color, are entirely appropriate, and he had good reasons for saying that the "Sea Trout" claimed by Mr. Smith of Massachusetts as a new species, was none other than a well-fed Brook Trout that had access to salt water, where its greater variety and abundance of food produced a brighter hue and deepercolored flesh.

Mr. Brown, after quoting Mr. Smith's observations on the fish just referred to, says: "The last-mentioned species, Lepomis salmonea, is common in our Southern rivers, and with many Southerners goes under the name of Trout Bass, or Brown Bass." Mr. Brown here takes an error of Mr. Smith as a basis, and piles an error of his own, or that of his informer, on top of it, making "confusion worse confounded." Let me assure the reader that the so-called "Southern Trout" is not a Trout, nor has it the least generic affinity to it; it is a fresh-water Bass, Grystes salmoides, and belongs to the Perch family; and let me further say that there are no Trout, or any species of the Salmon family, found south of Virginia.

Food of Trout.-Flies, beetles, bugs, caterpillars, grasshoppers, in fact all manner of insects that are so unlucky as to touch the surface of the water, are arrested by the vigilant Trout; and little stonefish, minnows, and shiners are chased and devoured by them at night, in shoal water. I once opened a Trout of eleven inches, which appeared rather stout, and took from its pouch eight small shiners, which equalled nearly a fourth of its own weight. At another time, in a dark, still water, I took a Trout of twelve inches, which had nearly swallowed a water-lizard of six inches, the head of the 
victim protruding from the mouth of the fish; choked as he was with the lizard, he seized my fly. The little worm hatched from the egg of. the fly (which a few days before, as she dapped on the surface of the water, she deposited at the risk of her life), is devoured with its little house of sand, in which, by the aid of its gluten, it encases itself. Hence the quantity of sand found in a Trout's 'stomach, in the early months of fly-fishing. The grasshopper is a good big mouthful; and sometimes as the angler grasps his prize, to disengage the hook, he feels them crush like rumpled paper, as if wings and legs were cracking beneath his fingers.

In watching the glassy surface of pools in the still of the evening, we see Trout dimpling the water with diverging circles, as they rise and suck in the little midge, or gray gnat, too small to be seen in the distance by the human eye. In every still water, or eddy, or hurrying rift, or under the shelving edges of stones, he searches for larva, diligent in earning his living "by the small;" or from his lair under ledge of rock or overhanging bank, he watches for larger prey as it floats past, seizing it with unerring and lightninglike rapidity.

Concerning the disposition of Trout to rise at a fly after having previously escaped from the angler with a hook fastened in its mouth, I would say that some years ago I took a Trout of ten inches out of a tumbling little hole under some alder-bushes, and to my surprise found what I thought to be a hristle sticking out of its mouth. On pulling hard on it, I drew the stomach of the fish up into its throat, and found the supposed bristle to be a stout piece of silkworm gut, four or five inches long, and a pretty ginger hackle on the end of it. I disengaged it, and on showing it to my fishing companion, he recognised it as his own drop-fly which a fish had broken from his leader, in the hole I 
described to him, three or four days before. He supposed the fish to have been at least twelve inches in length, when he lost his dropper. Only last summer a young fly-fisher of my acquaintance caught a Trout with a hook in his mouth, to which was fastened a gut-leader two feet long, and three good-sized shot on it, and yet the fish rose greedily at his red hackle. On returning to the house and showing the leader, it was claimed by a bait-fisherman, who had lost it the day before.

Brook Trout were once abundant in all the clear, rapid streams on the eastern side of the Alleghanies, from the Arctic regions to the thirty-eighth parallel, and even below it in the mountains of Virginia; in the upper tributaries of the Ohio, as well as in many of the northern streams flowing into the Mississippi; also in the smaller rivers which flow into the great chain of lakes from the north, and in many of those coming in from the south. They are taken frequently along the shores of Lake Superior, and in the more southern lakes, where creeks and brooks of a lower temperature than the lake itself fall in, and in the rapids at the great outlet of Lake Superior, known as Sault Ste. Marie. Most of the beautiful lakelets of New York, Maine, New Hampshire, and the Canadas, abound in Brook Trout of large size.

They are found also in many of the streams that flow eastward and southward from the Rocky Mountains; in the great basin between the latter range of mountains and the Sierra Nevada; and are numerous in the waters of the whole Pacific coast, as far down as the Bay of San Francisco, though perhaps with some distinction in variety, and, it may be, in species also.

In the rivers and brooks of the more settled part of the country, Trout have decreased both in numbers and size. 
This is to be attributed to many causes; to the clearing up of forests, exposing the surface of the ground to the sun, which has dried up the sources of sylvan brooks, or increased their temperature, and consequently that of the larger waters which they feed, rendering them less suitable for Trout, and promoting the introduction and increase of coarser families of fish. Streams which once had few fish besides Trout in them, now abound with Chub and other inferior fish. The saw-mill, with its high dam obstructing the passage of fish, and its sawdust filling the pools below; the tannery, with its leached bark, and the discharge of lime mixed with impure animal matter extracted from the hides, flowing in and poisoning the Trout, have done more to depopulate our waters in a few years, than whole generations of anglers. It is an old story everywhere along our mountain streams, of how abundant Trout once were; and the angler is shocked and disgusted on every visit, with the unfair modes practised by the natives and pot-fishers in exterminating them.

Trout were probably more abundant in our mountain streams at the time of the early settlement of the timber regions by the whites, than they were during the time of occupation by the Indians; for the red man, although he took no more than he could consume at the time, was a destructive fisher; his weirs and traps at the time of their autumnal descent, the spear on the spawning beds, and his snare or loop, were murderous implements; the proximity to good fishing-grounds was always a desideratum in placing his wigwam.

The rivers flowing into Lake Superior, as well as the outlet of that water, the Sault Ste. Marie, contain Brook Trout of large size. A friend who was on a north-west tour, during the summer of 1860 , brought me the profile of a Trout, cut out of brown paper, with the following memoranda 
on it:- "Taken by J. E. Cady, of Sault Ste. Marie, July 30th 1858. Weight six and a quarter pounds, length twenty-four inches, circumference thirteen inches; at the same time took seven Trout from the same pool weighing thirty-one and a quarter pounds; taken in Batchewaunaung River, Canada West." This may appear improbable, but the gentleman who presented it, and the captor, are both truthful men.

I have lately been shown a letter which stated that a party of three anglers went last summer from Chicago by rail and boat, to the town of Green Bay, and there packed their luggage on mules and travelled a distance of forty miles to a stream not over twenty feet wide, within twelve miles of Lake Superior. They fished two pools where there was neither tree nor bush to interfere with their fly-cast, and during their stay of ten days, each of them killed from fifty to a hundred pounds of Trout per day; the fish weighing from two to four pounds each. In the state of Maine, Lake Umbagog and Moosehead Lake have great reputation. The tributaries of the St.' John and Mirimichi have many and large Trout; and from all accounts they fairly swarm in Lake Nipissiguit, at the head of the river of that name, in the British Province of New Brunswick.

Mr. B., an angler of this city, a few years ago, brought home from Maine, where he had been on a fishing excursion, the skin of a Trout, which he has since had stuffed; the weight of the fish exceeded eight pounds.

The following was clipped from the "Saturday Evening Post" last summer, and handed to me by a friend:-

"Enormous Trout.-Mr. George S. Page, of the firm of George S. Page \& Brother, of this city, has shown us a basket of Trout, caught-he says it does not matter where, and he would rather not disclose the precise locality-but which are by far the largest of their kind we have ever seen. In the hasket before us the heaviest fish weighs,eight pounds and 
three-eighths; another weighs eight pounds and a quarter; and another, seven and a quarter pounds. Two others weighed six pounds and a quarter and six pounds; one weighed five and a half, and two five pounds each.

"These fish are all the catch of two gentlemen, Mr. Page and Mr. R. O. Stanley, of Maine, in the early part of the present month. In eight days they caught two hundred and seventy-three pounds, steelyard weight, and the fish caught averaged three and a half pounds each.

"Mr. Page desires us to say that all these fish were caught in fair play, with the fly. Trout-fishermen must look out for their laurels."

If these fish were caught in the St. Croix River or its tributaries in Maine, they may have been the Schoodic Trout, Salmo Gloveri. One who is not accustomed to mark specific differences, may easily have been deceived, though there are some instances of Brook Trout exceeding even the size of the Schoodic Trout.

Sir Humphrey Davy, in his "Salmonia," gives the reader the impression that in strictly preserved streams in England, Trout under two pounds are not basketed, but returned to the water. This is by no means a general rule. Last summer, in looking over an English angler's fly-book with him, he produced his written authority, signed by the steward of some nobleman, I think the Duke of Northumberland, to fish a certain water. The paper specified that the catch of the angler should at any time be subject to the inspection of the gamekeeper, and that he should basket no fish under four inches. 


\section{THE SALMON.}

Salmo salar: Linneus.

This magnificent fish has been the exalted theme of all writers on angling, from the time of Walton to the present. It is said that two or three varieties of the true Salmon are found on the eastern coast of America, while there are several described as distinct species by Dr. Richardson, in his "Fauna Boreali-Americana," existing in the Arctic regions, and as many more mentioned by Dr. George Suckley, U. S. A., in his report upon the fishes of the Pacific coast.

The economic value of the Salmon has been the cause of much legislation in Great Britain and her American colo. nies; and its habits and manner of brèding, together with the growth of its young, and its wonderful increase in size, caused by periodical visits to the sea, have been the subject of much discussion and voluminous essays amongst naturalists and observers.

As abundant as Salmon once were in the waters of the United States, they are now only found in two or three of the rivers of Maine, and these furnish but a small number to netfishers in tide-water: a few years more and they will be known amongst us only by tradition and in books. Salmon once abounded in all of our rivers from Maine to New York, but, if we except a few stray Salmon which have been taken in the Delaware. were never found south of the Hudson, notwithstanding Mr. Thackeray, in his book "The Virginians," makes General Braddock, Washington, and Franklin dine on Shad and Salmon at Lady Warrington's table in lower Vir. ginia. 



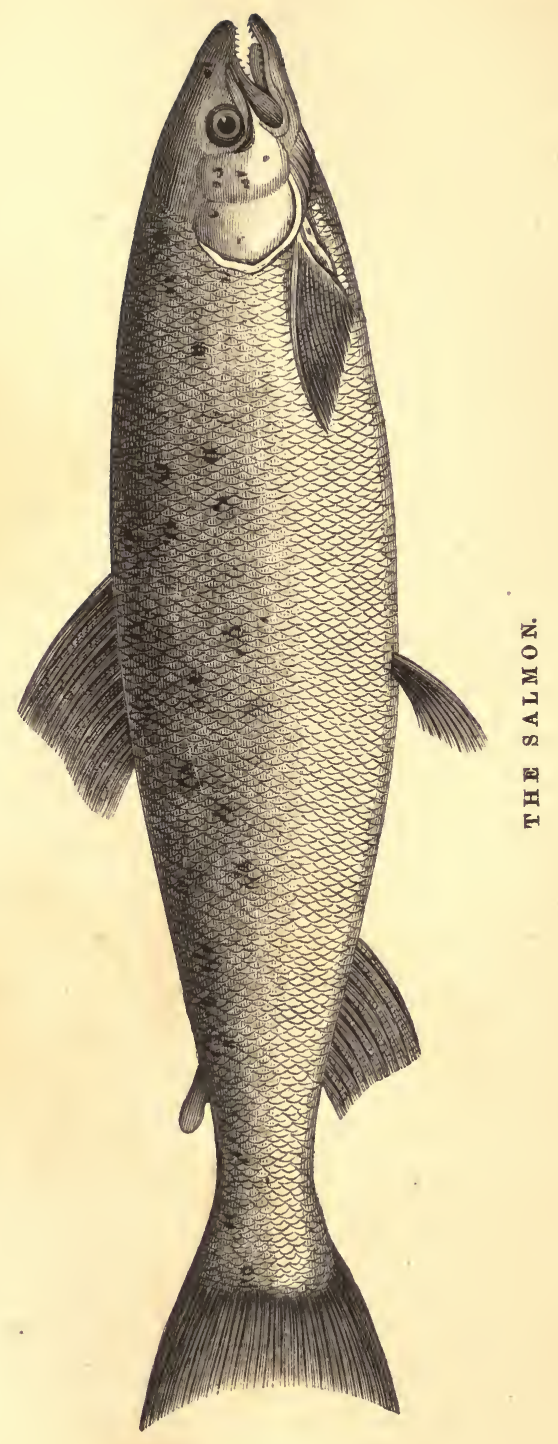


Hendrick Hudson, when he first ascended the river that bears his name, recorded in his journal, "many Salmon, Mullets, and Rays very great;" and when he passed the Highlands remarks: "Great stores of Salmon in the river." They were formerly abundant in all the lakes in the interior of New York, that communicate with Lake Ontario, and were also found in Lake Champlain and the rivers flowing into the St. Lawrence, from the south. Stories have been handed down of the great numbers once taken in the Connecticut, and it is said of old dwellers on its banks, that in their articles of indenture, it was stipulated that the master should not feed his apprentice on Salmon more than three days in the week.

The only fresh Salmon we get now, come from Montreal, and from St. John, New Brunswick: from the latter by steamer to Boston, packed in ice, where they are repacked and sent to cities further south. At Chatham, Bathurst, and several other ports of the British Provinces, there are establishments where they are parboiled after being cut into pieces of suitable size, and packed in hermetically sealed cans, and shipped to Europe and the United States. The smoked and salted Salmon generally come from points further north.

The rivers which flow into the St. Lawrence from the north, below Quebec, and those that empty into the Gulf of St. Lawrence, and into the Atlantic along the coast of Labrador, still furnish rare sport to the angler who will undertake the journey. In the more southern portions of those regions, every means, fair or foul, of taking them is practised, without a thought for the continuance of the species; as if extermination was the present and ultimate object.

The streams of California connecting with the ocean, from the thirty-seventh degree of latitude northward, and the rivers of Oregon and Washington Territory, as well as those 
of the British and Russian possessions, contain them in vast numbers.

Dr. Suckley, in his report on the fishes collected on the Pacific Railroad Survey, says, in that part of it devoted to the Salmonidre of the North-West Coast: "The species of Salmon which is principally used for salting in Puget Sound, is the Skowitz, an autumnal visitor. Of these Messrs. Riley \& Swan, proprietors of the Salmon-packing establishment at the mouth of the Puyallup River, have taken three thousand at one haul of the seine." Fisheries, I am told, have been established on the Eel and Russian Rivers of California, but owing to the lack of practical knowledge in preserving the fish, they have not proved remunerative. It is said, that notwithstanding the great numbers of Salmon in the rivers of our North-West Coast, where they collect in great shoals at the falls, and rub their noses raw in their efforts to get up the rapids, and where a spear thrown at random strikes a fish, that they are never known to take the fly. This may be for the want of the proper kinds of pools that make a flycast; there is no doubt, however, that it will yet be found, that there are casts on some of those rivers where a proper combination of fur and feathers will entice them.

If we believe the tales of explorers-and they seem probable - there are whole tribes of Indians on the Pacific, as well as on the rivers that flow into the Arctic Ocean, from Mackenzie's River eastward, and into Hudson's Bay, who would become extinct but for the periodical appearance of almost incredible numbers of these fish. There is no doubt that they are the chief food, for a great part of the year, of the tribes that dwell on the rivers that debouch into Baffin's Bay, Davis's Strait, and the streams on the coast of Labrador, and that such is also the case to a great extent with the barbaric tribes of northern Asia above the sixtieth parallel, 
and the rude population of the extreme north of Europe; for the geographical range of this prolific fish, so valuable to the human race, extends from the North Pole downwards on all sides of the globe (except in one or two instances where the isothermal line bends unduly northward), to the forty-fifth parallel, and in some cases, as in California and Japan, even below it.

Mr. Richard Nettle, of Montreal, in his comprehensive little work, "The Salmon-Fisheries of the St. Lawrence and its Tributaries," says, in reference to the Salmon-fisheries of the mother country:-

"Man, the destroyer man, commenced a war of extermination, hunted them with nets of all descriptions, with spear, with hook, with leister; poisoned them with lime, spearing them by torchlight, mangling and wounding as many as he killed; and to crown all, denied them a right of way by building dams, and thus destroyed their fisheries.

"I have said that the fish are dogged and sullen. All sportsmen know what I mean. Prevent them from reaching their old haunts-their spawning-beds, and experience proves that it is with difficulty they are enticed back. Good laws, time, and a right of way may induce them to return. . . . . . .

"Before the year 1812, and even in 1815, almost every river in the kingdom swarmed with fish: witness in Scotland the Tweed with its 150,000 Salmon at a rental of $£ 20,000$ per annum, the Tay, a similar river, the Deveron, the Findhorn, the Don, the Spey, and numerous others.

"In Ireland, the Shannon, the Bann, the Lee, the Foyle, the Blackwater, the Lagan, the Moy, with its 70,000 fish in one season. Numerous others also are to be found in the Emerald Isle."

Mr. Perley, in his "Report upon the Fisheries of New Brunswick," Dr. Adamson, in his appendix to his "Salmon. 
Fishing in Canada," and other writers, speak also of the former abundance of Salmon in the Canadas. Mr. Nettle says, "The late Robert Christie, so many years the member for Gaspé, and by whom I have been urged to do battle in behalf of the Salmon-fisheries, has often told me, that while he resided there he never took less than 2000 tierces in the Ristigouche alone.... Bouchet, in speaking of the same river, says 2000 to 3000 are taken..... What would that gentleman say, could he know that the 2000 or 3000 of his day has dwindled down to 200 or 300 at the present time?"

Our own countrymen, in their everlasting search after "that other dollar," after having destroyed their own Salmonfisheries, are now prompting and assisting the illegal fishers of Canada in doing the same, by establishing packing-houses for the exportation of smoked, pickled, and "canned" Salmon. Setting a price on the head of every fish of this species that finds its way up the rivers, after escaping the gill-nets that drift out even beyond the entrance of the bays and estuaries, and the stake-nets that extend beyond the prescribed distance from the shore, by paying the mongrel Indians four or five cents a pound for all the Salmon they spear at night.

It is claimed with some show of justice that the Indians have an hereditary right to the use of the flambeau and spear-it is the only way in which they take Salmon; but this is no reason why they should be permitted to practise it at improper seasons of the year, for the injury they do to the rivers is visited upon themselves as well as the whites, by the gradual extirpation of the fish.

A few years back, and there was scarcely a stream of any size on the coast of New Brunswick, that was not visited annually by large numbers of Salmon, and still are to a limited extent; but the drift-net, the stake-net, the spear, and the high dams-without a sluiceway to help them over. 
are steadily doing their work of destruction, and unless more stringent laws are enacted for the protection of Salmon, or those already passed are more rigidly enforced, the Salmonrivers of the British provinces will, in the course of a few years, become as barren as our own.

Scientific Description.-The following is a description of a fresh-run female Salmon, of sixteen pounds, taken in the Nipissiguit last summer :-

Length to the fork of the caudal fin, thirty-three inches, girth eighteen, breadth seven, caudal when expanded, nine. Form, an elongated ellipse, its greatest breadth in front of the dorsal fin. Color; back, of greenish blue; sides, light silvery gray; belly, white; there are angular but irregular markings, sometimes like the letter $\mathrm{X}$, dispersed along the back and above the lateral line about an inch or two apart; the brilliancy of a fresh-run fish is unsurpassed, its sides gleaming in the sunlight like burnished silver, as it leaps above the water. The head is a dark steel-blue above, shading lighter belqw with pearly reflections, and entirely white beneath; it has two or three dark spots on the opercle.

There is a great difference in the proportions of a male and female Salmon, which is more perceptible as the summer advances; the head of a male fish is nearly one-fourth of its length, exclusive of the caudal, that of a female is not much more than a fifth, while the head of a female Grilse is not more than a sixth. The lateral line is straight, as in all the Salmonoids. There are twelve branchial rays. The pectoral fin, which has thirteen rays, is a pearly gray, with the first ray black; ventrals grayish white, with nine rays; anal roseate white, with nine rays; dorsal dark pearly blue, with twelve rays; the caudal is slightly.lunate, and has eighteen, exclusive of the rudimentary rays.

There is a cartilaginous projection on the tip of the lower 
jaw in the male fish, which closes into a cavity in the snout; it becomes harder and longer, and has more of an inward curve, as the time of spawning approaches: it is supposed by some persons, that it is used by the fish in removing the gravel when preparing the spawning-bed in autumn. The eye is one-third distant between the snout and posterior margin of the opercle. There are sharp but short incurved teeth on the palate, maxillaries, pharynx, and tongue, but none that I could discover on the vomer.

The artificial propagation of Salmon has been resorted to. in Scotland and Ireland, and nurseries for this purpose have been successfully established on rivers which had been depleted of the vast numbers they once produced. As the reader will find a chapter on Pisciculture in a subsequent part of this work, I will make no further mention here of that mode of producing them-or rather of assisting, or stimulating their production; but would remark, that if the waters of Great Britain are ever restored to their former fecundity, or our own restocked, it must be one of the mepans employed.

The Natural Process of Propagation.-To give a lucid description of the manner of generation with the Salmon, it is necessary to advert to one of its specific peculiarities, which is, that it is anadromous. This term is commonly applied to fish which inhabit the sea the greater part of the year, but enter fresh rivers to spawn; a residence of a certain length of time in fresh water being necessary to mature the spawn and milt. Salmon, as a general thing, begin to ascend the rivers on the north-eastern coast of America the latter part of June, and there will be an occasional run of fish from the sea until the middle of September, each school being influenced to some extent in their migration by easterly gales or a rise in the rivers they enter. The first run of Grilse does not occur until a month later, and the 
number taken by the angler at that time, compared with Salmon, is often five to one.

The early emigrants of course are prepared to spawn first; but as a general rule, all the Salmon leave the pools and rapids, and collect for this purpose on the shallows and in the tributaries of the rivers by the middle of October,* and the spawning season, instead of extending over a period of six months, as it does in Scotland, hardly embraces as many weeks, for by the last of November the rivers are generally closed by ice, and the spawning beds sealed against the fecundating influence of the air, and many of them are frozen hard even to the bottom by the middle of December. The probability therefore is, that incubation is arrested for months by the spawn being encased in ice; so, it follows, that a much longer period (perhaps even double the time) is required for the ova to hatch, than is necessary in the temperate waters of Scotland and Ireland. I have never read or heard of any person having tested it in America by experiment, as has been done in Scotland, but it is probable, that spawn deposited in American Salmon rivers late in October or in November, does not produce the young fish until the ensuing month of June or July. But it is not my object now, to show that the general rule for the time of incubation, as laid down by Scotch naturalists and observers, is inapplicable to the northern waters of America, from great disparity of winter temperature; but to give the result of their experimentscarefully conducted through a long series of years-as to the

* In Scotland and Ireland, where the rivers are open all the year, Salmon begin to come into fresh water in January and February, and continue to do so every succeeding month until October. The rivers of British America being ice-bound four or five months in the year, the time of coming and going is limited to about four months. 
laws of nature that govern Salmon, in generating as well as the process of incubation and growth of its young.

Those who take an interest in the subject, will refer with pleasure and profit to the "Book of the Salmon," by a Mr. Graham, who wrote articles on angling for "Bell's Life in London," for many years, and who also, with the soubriquet of "Ephemera," was the author of "A Handbook of Angling." He was assisted in his "Book of the Salmon," by Mr. Andrew Young, of Invershin, Scotland, the manager of the Duke of Sutherland's northern fisheries, who had been an experimenter on Salmon for more than thirty years. Part of the information imparted by Mr. Young was in writing, and much was communicated orally, whenever Mr. Graham visited him for the purpose of angling, and observing the habits of the Salmon. In the following pages, I will endeavor to give the gist of Mr. Graham's remarks, or quote them verbatim as may best suit the purpose.

"Salmon preparing to spawn.-The" male and female Salmon appear together on that part of a shallow in which their bed is to be dug, and they remain moving about upon it for a few days before they begin the process of nidification. No precise period can be fixed for their appearance. Salmon spawning-beds are made by the fish in sandy or gravelly parts of the river, generally high up towards its source, and not unfrequently in rivers and almost rivulets, ${ }^{*}$ tributaries to some large river, of course connected with the sea. Before two Salmon, male and female, commence the formation of their nests, they make efforts to drive away every fish that may

* This was the case last fall in Pabineau and Gordon's Brooks, both small tributaries of the Nipissiguit: the outlet of the latter is over a gravelly shoal, and so small that Salmon eannot ascend through the outlet to the deeper water above, unless with the assistance of a freshet. Yet they were found there in large numbers depositing their spawn. 
come within their vicinity. The spawning-bed, which may be called a continuation of nests, is never fashioned transversely or across the water-current, but straight against it.

"A Salmon-bed is constructed thus: the fish having paired; chosen their ground for bed-making, and being ready to lay in, they drop down the stream a little, and then returning with velocity towards the spot selected, they dart their heads into the gravel, burrowing with their snouts into it. This burrowing action, assisted by the power of the fins, is performed with great force, and the water's current aiding, the upper part or roof of the excavation is removed. The burrowing process is continued until a first nest is dug sufficiently capacious for a first deposition of ova. Then the female enters this first hollowed link of the bed, and deposits therein a portion of her ova. That done, she retires down stream, and the male instantly takes her place, and pouring, by emission, a certain quantity of milt over the deposited ova, impregnates them. After this the fish commence a second excavation, immediately above the first, and in a straight line with it. In making the excavations they relieve one another. When one fish grows tired of its work it drops down the stream until it is refreshed, and, then, with renovated powers, resumes its labors, relieving at the same time its partner. The partner acts in the same spirit, and so their labor progresses by alternate exertion. The second bed completed, the female enters it as she did the first, again depositing a portion of ova, and drops a little down the stream. The male forthwith enters the excavation, and impregnates the ova in it. The ova in the first part of the bed are covered by the sand and gravel dug from the second being carried into it, chiefly by the action of the current. The excavating process just described is continued until the female has no more ova to deposit. The last deposition of ova is covered in by the 
action of the fish and water breaking down some of the gravel bank above and over the nest. Thus is formed a complete spawning bed-not at once, not by a single effort, but piecemeal, and at several intervals of greater or less duration, according to the age and size of the fish, and quantity of ova and milt to be deposited and emitted. A female Salmon in its third year has a larger quantity of ova to deposit than a female Grilse, or young Salmon in its second year; and it may be taken for granted, that the older and larger either fish-male or female-is, the greater quantity of ova to be deposited, and of milt to be emitted. In consequence, the time occupied in deposition chiefly depends upon the size and fecundity of the female fish. The average time is from five to ten days. It would be more correct to say the mean time lies betwixt.

"When the spawning operations-I am describing those of a single pair of Salmon-are terminated, the female fish, with instinctive view to repose and convalescence, falls back into some pool below the spawning-bed just completed, and sown with Salmon-seed. The male frequently follows her example, sometimes from two motives: 1st, to consort with another female, if he have any milt remaining; $2 \mathrm{~d}$, if he have not, for the purpose of recovering from the debilitating effects of spawning. A male Salmon may impregnate the ova of one or more Salmon. A mature male Salmon has milt enough to impregnate the ova of several Grilse, or young Salmon; and he will continue the operation of impregnation as long as the seminal fluid lasts. If, in the first instance, a female choose a mate unable to fecundate all her ova, she will, when his milt is exhausted, go in search of another, and will be a bigamist or polygamist, as long as nature, or (as phrenologists would say) philo-progenitiveness, compels her to be so. The length of a spawning-bed depends upon the quantity of spawn 
to be deposited therein, and also upon the hardness or softness of the gravel which has to be excavated. The harder the gravel-bed, the shorter the spawning-bed, for then the succession of nests will be more compact, and take up less space, whether in length or width.

"A single pair of Salmon may be forced to form distinct beds, in different spots. For instance, they have commenced spawning in a stream two feet in depth more or less, and whilst so engaged, the river falls so low, that they cannot continue to work in the first selected spot, for want of water wherein freely to move. When this happens they will drop lower down, or at any rate retire elsewhere, in search of deeper running water. Other causes may induce them, e. g., floods, to have recourse to the formation of a second bed, in a spot suited for it.

"Thinking as I do the laying and impregnating, covering up and hatching of Salmon-eggs-I use plain words purposely-most interesting points in the history of our Riverking, I will not, if I can, leave anything connected with them untouched. When I do not state facts, I will bring forward deductions, and, as it were, circumstantial evidenee, as convincing to the reasoning mind as fact itself. $\mathrm{We}$ have seen that the bed, or trench, in which Salmon deposit their spawn, is made bit by bit, and no doubt the inquiring reader will ask why? I have, I hope, a ready and satisfactory answer. The ova of the female Salmon are not mature all at the same time. That portion of them next the vent becomes first ripe for deposition, whilst the part in the pectoral regions is immature. In consequence, the ova can be deposited by piecemeal only, ard that is one of the chief reasons why the Salmon-bed consists of a succession of excavations, the first for the reception of the ova next the vent which are already mature; the second for the ova that will 
become next the vent and matured in four-and-twenty hours, perhaps, and so on for several days until all the eggs forming what is called the 'hard roe' are ripe and fit to be laid. On this point the common hen, and other birds, afford an analogy. They deposit their eggs at intervals, as their outward covering or shells harden, that is, as they become mature. The analogy extends no further. Birds' eggs are impregnated before they are deposited; Salmons' eggs are not; birds' eggs naturally require animal heat to vivify them, Salmons' eggs never do. The analogy, therefore, applies only to deposition or laying at intervals.

"Let any one examine the roe of a female Salmon about spawning-time, and the peas, grains, or eggs of that part of it nearest the vent will always be found of larger size, and softer than those situated higher up in the stomach of the fish. They are softer also, and their outward filaments are thinner and more porous, and thus they are fitter for impregnation-for absorbing the milt of the male as it is poured over them. There is another reason why all the ova cannot be deposited at once. It is forced from the fish, or rather the fish forces it from itself by pressure-by forcing itself into the gravel of the nest. No natural pressure would be sufficient to expel the ova at once. When artificial pressure is employed-I mean manual pressure-the mature ova alone come freely away through the vent; the immature ova remain firmly.enclosed within their reticulated tissues or membranes, within, as it were, their net-work fastenings. Although the unripe ova should be expressed, they would be useless for production, for their absorbing pores are still closed against the interpenetration of the milt, and consequently in this state impregnation is impossible. The milt of the male, like the ova of the female fish, becomes mature by degrees. When mature they are very easily exuded, for even holding up the 
fish by the heads will cause limited exudation of milt and ova. The pressure, or weight of the roe above on the roe beneath, is sufficient to produce this partial exudation.

"The facts stated in the preceding paragraph are sufficient not only to account for impregnation taking place at intervals, for the impossibility of its being done tout d'un coup, but also for the improbability of impregnation by intermission or coitus either before or at the time of the deposition of ova. Mr. Young dissipated all doubts upon this point by the following experiments:-He took a female Salmon, exuded by manipulation a portion of her ova, and having simply done so, he buried it beneath the gravel of one part of an artificial spawning-pond. From the same Salmon he exuded another portion of ova, but before he covered it over with the gravel of another portion of his spawning-bed, he impregnated it by pressing milt from the male Salmon, and causing it to come in contact with the last ova deposited. He then covered them in beneath the gravel, and in due time they produced fish. The ova he had covered in without impregnation produced nothing. He repeated the experiment frequently, and always with similar results. He has even taken two female Salmon in the act of spawning. The ova of one he impregnated with milt from a male; the ova of the other he did not impregnate. He covered in each under equal conditions, apart in the same spawning-bed. The ova that he had caused to be impregnated were productive; the other proved perfectly barren. This experiment was repeated, and the result was ever the same.

"It may be asked, how is it that ova and milt are not swept away by the action of the rapid water in which they are deposited-that they are not swept away in the act of deposition, and before they can be covered in beneath the gravel? It would appear that at the critical moment of 
deposition, the specific gravity of the water is less than that of the mature spawn, for the grains of ova fall to the bottom like grains of shot, and the milt sinks as if it were molten lead. However, we must take into account the effect of the force by which ova and milt are expelled downwards by the spawning fish.

"As some of the ova are deposited and impregnated ten or more days sooner than other portions, we must expect to see the incubating process completed by degrees. Such, in fact, is the case. The evolving of the fish foetus is not simultaneous, but gradual, and the infant fry come out from their sandbed by degrees; at intervals of time corresponding with the intervals that took place during the deposition of the ova. We may, therefore, have young fish, from one and the same nest, differing in age from one to ten or fourteen days.

"The length of time necessary for the completion of the incubating process varies according to the localities of rivers, because locality produces different temperatures. The temperature of river-water is also very sensibly affectedheightened or diminished by the mildness or rigor of the season. In the rivers of the north of Scotland Salmon ova are hatched in a period varying in duration from one hundred to one hundred and forty days. In conformity with the habits of oviparous, or egg, or spawn-bearing fish, the parent Salmon having deposited their spawn, impregnated it, and covered it in beneath sand and gravel, take no further heed of it, or the fry it produces, except, perchance, hereafter to feed upon them. Water influenced by atmospheric action is the sole incubating agent. I may here observe that after the ova are covered in they are safe from all casualties, on which point more hereafter.

"It is during the deposition of ova that they are destroyed, and the great destroyers of them are river Trout of every 
species. These Salmon-pests are ever on the watch whilst Salmon are depositing their ova, and are only kept away from the spawning-beds or trenches by fierce attacks and rapid charges made on them by male and female Salmon, both whilst they are preparing to spawn, and are, at least one of them, actually engaged in doing so. However, as long as a spawning Salmon is in its bed, or nest, laying ova or impregnating it, no Trout will venture to come near the excavation. It is only when spawning fish drop down the stream, to gather vigor for the formation of another nest, or link of the bed above that already excavated, and in which uncovered ova are deposited, that Trout dart towards the bed and devour the spawn. The falling down stream for a short time and short distance on the part of Salmon is of twofold necessity : first, to gain renewed strength by temporary cessation from labor; and secondly, to get space enough to 'take a run,' if I may use a jumper's phrase, in order to be able to dart their heads with greater force and effect into the sand and gravel for the formation of a new nest, or link in the bedtrench. The water-ousel is also a sad destroyer of Salmon ova. It watches their emission by the spawning Salmon, then dives into the water, and descending to the bottom, runs along it to the spawning-bed, out of which it extracts a large quantity of spawn, and would steal more did not the procreating fish see it and drive it away. The spawn once fairly covered in, neither Trout, nor water-ousel, nor any other fish or bird can injure it. The supposition that Eels burrow into Salmon-beds and feed upon the spawn beneath, is erroneous.

"It is alleged that alluvial deposits frequently settle upon and cover the beds, thereby destroying the ova-addling them, in fine, by preventing the chemical action necessary for their incubation from reaching them. Such occurrences can very rarely, if ever, take place in the spots Salmon select 
for spawning. Those spots are in running waters, where alluvial or other matter brought down by floods cannot well abide. And here let me remark, that Salmon never deposit their ova in the sand or gravel of still, smooth, or deep waters. They never breed in lochs or lakes. Nor, a very curious fact, will they spawn in new gravel, nor in gravel that has been recently disturbed by natural or artificial causes. For instance, a spate or flood shall sweep away a portion of the gravel of a ford, and, for many years, a favorite spawning locality, and by so doing expose a new stratum of gravel. Not only will Salmon spawn no longer there, but they will not even rest in their journeys in water having a bottom recently disturbed. A period of about two years must elapse before they will frequent a pool or stream from which gravel has been removed, or to which gravel has been added. So that an excellent spawning-bed, or a famous pool, may be annihilated by a furious rush of water.

"Growth of SALmon-Fry.-The ova having been hatched, the embryo Salmon pierces the sandy and gravelly crust of its nest, and almost instanter assumes a shape somewhat like a hairless caterpillar, or fringed larva of about three-quarters of an inch in length, and tapering from head to tail, having a small sac attached to it, near the throat, about the size of, or rather less than, the original ovum, or single pea or spawn. This sac is the remains of the incubated ovum or egg, and still, no doubt, contains vitelline, or matter equivalent, for the sustentation of the infant Salmon. In connection with the sac and incipient fish, several conduits, or veins, are visible. The sac remains attached to the imperfectly formed fish for about a month, and is detached or consumed by degrees. The gradual detachment may be observed in a specimen of twelve days old, for at that age it will be seen that the sac 
has visibly decreased in volume, though it has not as yet. become undetached, or entirely consumed.

"At a month old the fish-foetus has grown in length, and exhibits to the naked eye plain traces of head, eyes, and tail. Still it is barely more than a pale, misshapen, little longitudinal, half-animated substance.

"At two months old the 'fry' measures about one inch and a half, is of nearly perfect piscine formation, having all its fins well defined, and on its coat a slight appearance of transverse bars, commonly and erroneously termed 'parr marks.' In speaking of the young of Salmon I shall invariably use the word 'fry', until they have attained the age of twelve months, when I shall call them 'Smolts.'

"At from three to four months a Salmon-fry measures in length from two to two and a half inches-hardly so much. Its head is round; there are pink spots on the body, and the transverse bars are plainly apparent.

"At six months the young fish measures from three and a quarter to three and a half inches in length, and the pink spots and transverse bars continue to become more and more distinct.

"At eight months the fry is very little longer than it is at six months of age, but it is evidently thicker or more bulky. At nine months, even, the increase of growth does not tally with the increase of age. No doubt its growth is impeded by (I beg the reader to bear in mind that I am speaking generally, and not of exceptions) its attaining the above age in the winter months, when its favorite food, flies, other insects, and larvæ cannot be procured in anything like abundance."

"A Salmon-fry at ten months measures about four inches, and the transverse bars begin to disappear, silvery smolt scales uy degrees taking their place. 
"At eleven months its length is four and a half inches, and the bright silvery scales are now seen descending towards the region of the belly.

"A Salmon-fry at twelve months old is called a "Smolt." "

"It now assumes the migratory coat, that is, the silvery one. The transverse bars have disappeared, and so have the pink spots on the sides. The young fish, a part of the back, belly, and head, is covered with bright silvery scales. At the shoulder a few Trout-like spots are visible. It is now ready at the first fitting opportunity to commence journeying down river to the sea. In order to induce and enable smolts to do so, it is not necessary that rivers should be flooded, but there must be a sufficient volume of water to carry the migrating fish safely over weirs, shallows, and other impediments. They will not migrate at low water."

Although repeating in part what has just been said, to elucidate the subject still further, I give on the next page my own explanation of the subjoined illustration.
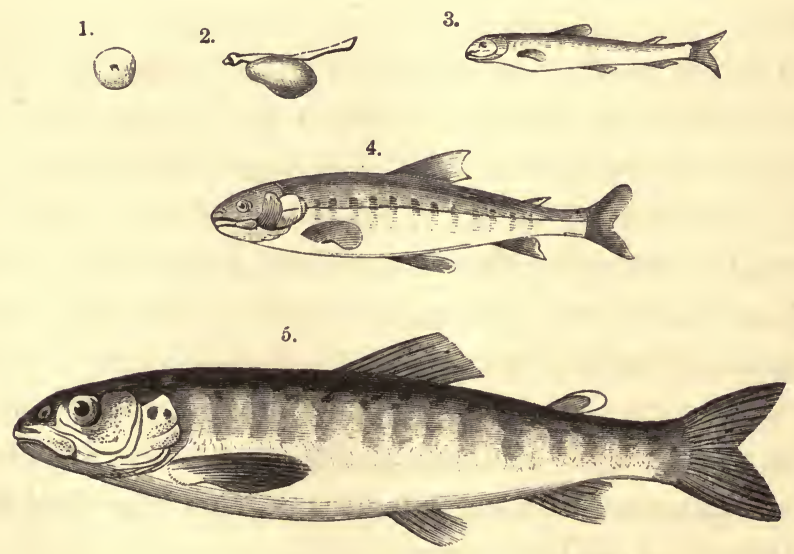
In the foregoing figures, No. 1, represents the impregnated egg ;

2. The young fish on emerging from the egg-with the umbilical bladder, from which it draws its sustenance for the first month, attached-this little sack of nutriment being absorbed in about that time;

3. The young fish after the umbilical bladder has disappeared ;

4. Represents its size when three months old.

5. Represents the size at five or six months old.

Figure 6, on page 227, shows the size at ten or eleven months. It is seldom found larger with the bars or "fingermarks" on it; and has much the appearance of a young Trout. Figure 7, on same page, represents the fish, when a month or two older, after it has assumed the silvery coat, that ushers it into the "Smolt" state; soon after which it takes its course seaward to return in a few months a beautiful Grilse, weighing as many pounds, as it did ounces when it set out on its first journey to the great deep.

The first four figures, on page 224, I have had copied by Mr. Fry's permission, from his work on Fish-Breeding; the remaining figure (No.5), and those on page 227 (Nos. 6 and 7), are fac similes of those in the "Book of the Salmon."

A careful observer will have no hesitation in distinguishing the fry of the Salmon from small Trout. The Salmon-fry have scales which are much more perceptible, and easily detached; they are also more brilliant, and generally with a single row of red spots; the eyes are larger and more prominent.

There is a fact connected with its change of apparel, not mentioned in the "Book of the Salmon," but which Mr. Scrope turns to account in proving that the little fish, known for a long time as the "Parr," and thought to be of another 
speries, is no other than a young Salmon. This he demonstrated conciusively by scraping away the silvery scales of the Smolt for half the length of its body and exhibiting the red spots and bars of the so-called "Parr," still distinctly painted beneath, on the skin. In his "Days and Nights of Salmon Fishing," can be found a beautifully colored engraving of a Smolt, with half of its body denuded of the scales, showing that it had not entirely parted with its beautiful vesture of red spots and bars, but had only concealed it with the silvery coat of its progenitors. The spots and bars which remain beneath the scales, are only obliterated by its first visit to sea-during its transition from the Smolt to the Grilse state.

The usual manner of designating the different stages of growth and changes in the condition of the Salmon is thus:-

As long as it bears the red spots and finger-marks, it is known as "Pink," "Salmon-fry," "Samlet," and is sometimes yet called "Parr." When it puts on the bright coat preparatory to going "to sea for the first time, it is called a "Smolt." After its return, it is a "Grilse." After its second migration, it is a "Salmon," and is ever after so called.

A Salmon just from the sea is called a fresh-run fish, when it generally has parasites, called sea-lice, adhering to different parts of its body and in its gills. After it has been long enough in fresh water to lose its silvery appearance, it is called a "Blackfish." After spawning it is a "Kelt," or "Foul" fish.

Let us turn back, now, to the young fish at the time it became a Smolt. The "Book of the Salmon" says that the greater portion of Smolts descend the rivers of Scotland in April and May, and implies that they continue-though in smaller numbers-to go to sea all summer, and even until autumn. This naturally occurs where the spawning season is 


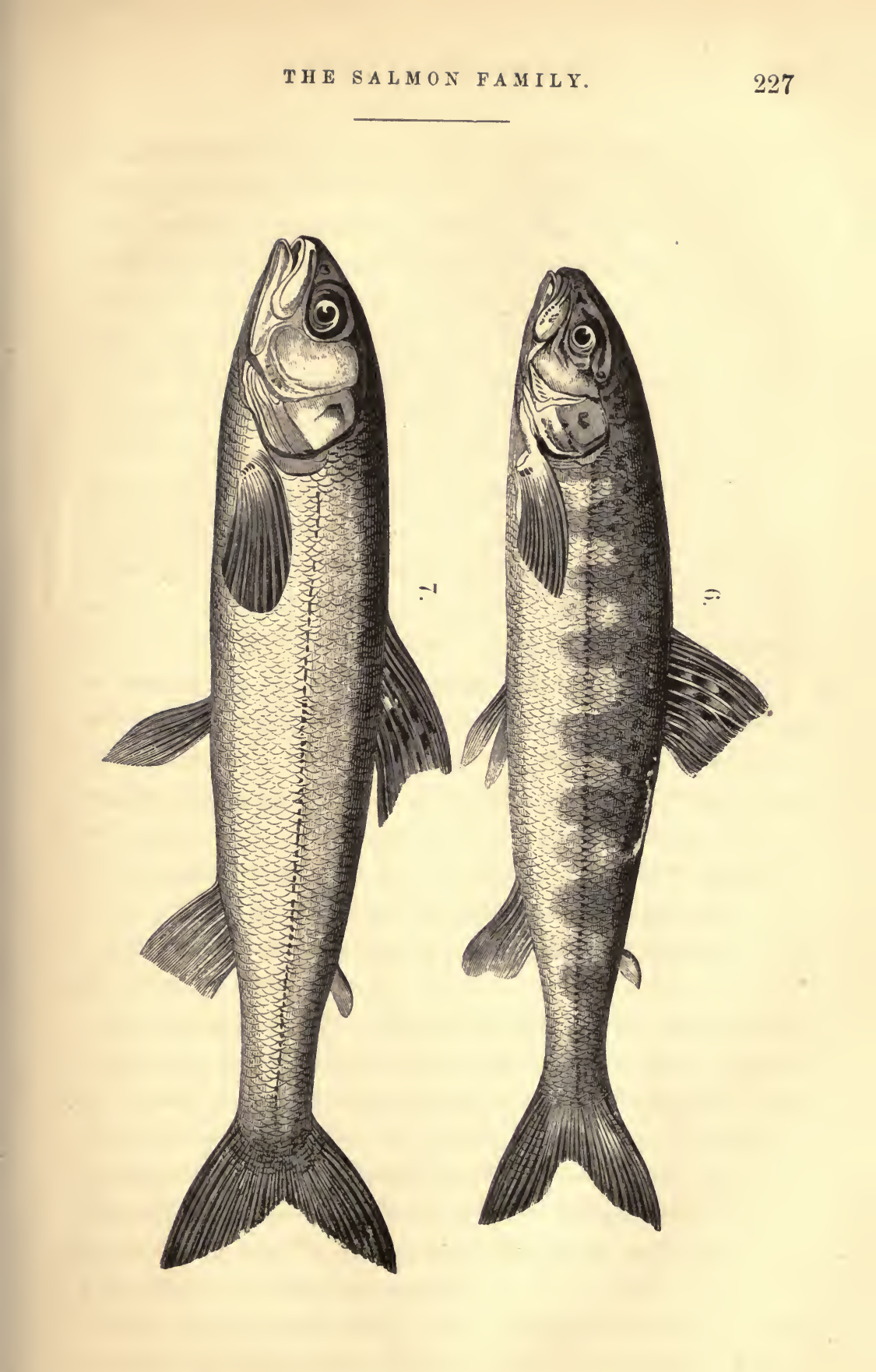



distributed over a space of five or six months; but from information received from the best sources, and from reasonable conclusions drawn from premises already laid down, it is doubtful whether the migration of Smolts-that is, in large numbers-from the rivers of New Brunswick and Canada. commences until late in the summer or early in autumn. I did not take a Smolt during my last summer's fishing in the Nipissiguit, although I caught numbers of the fry with bars and red spots. Nor, in my inquiries, did I meet with any person who had ever seen the young fish in the Smolt state in that river. I therefore concluded, that the bars and spots on the young fish disappeared later in the season, after the angling, which lasts until the middle of September, was over, and that it was not until after that time that they assumed the silvery coat of the Smolt and migrated to sea.

It is also a matter of doubt whether the young fish returns as a Grilse until the following summer. The long time necessarily occupied in incubation in those cold waters, and the length and low temperature of the winter which follows. debarring it from feeding and retarding its growth, it appears. would prevent its attaining the Smolt state until the autumn of the second year, and too late to return as a Grilse before the river was closed by ice.

In opposition to this idea, it may be argued that Grilse, when they do enter the rivers the next summer, after remaining at sea all winter, should be very large. This is not the case, nor does it necessarily follow, if we consider that the extremely cold winter which closes harbors and bays, and frequently fringes the shore for miles out with ice, must, of course, lessen that class of animal life which constitutes the shief food of the Salmon at'sea.

From all accounts there is a disparity in the size of American and European Grilse. It appears from the "Book 
of the Salmon," and other British authority, that in all probability the Smolt that goes to sea not larger than figure 7 on page 227, returns in eight or nine weeks a Grilse of five pounds or more. Some writers mention them of eight or nine pounds, and say that the average is over four pounds. The generality of American Grilse, as far as my experience goes, do not weigh over three pounds. During the whole of last summer's fishing on the Nipissiguit, I killed but two that weighed as much as five.

A Grilse can easily be distinguished from a Salmon, even if both should be of the same size (which is not usual), by its short small head, and the shape of the markings above and along the lateral line, which are more numerous, and are round or oval instead of being angular and shaped like an $\mathrm{X}$, as they frequently are on a Salmon.

From personal observation, and the information obtained from the canoe-men (and certainly they have the means of judging, for they open enough of them), the female Grilse is never found with roe, though the milt occurs in the males; who, no doubt, perform the office of procreation with the female Salmon. Grilse lose flesh and condition in fresh water, as Salmon do, though it may not be to the same extent.

There is nothing in the water that surpasses a Grilse in its symmetrical beauty, its brilliancy, and its agility and pluck. I have had one of four pounds to leap from the water ten times, and higher and further than a Salmon. Woe to the angler who attempts, without giving line, to hold one even of three pounds; he does it at the risk of his casting-line, or his agile opponent tears a piece from its jaw or snout in its desperate efforts to escape, and frequently it is not until after repeated attempts that the canoe-man is able to gaff it. The only safe plan to secure one is with a wide landing-net.

The usual manner of noting the growth of Grilse or Salmon 
in Scotland, it is said, is to mark them when taken in a net, by fastening a small piece of copper or zinc, with a fine copper wire, in the root of the adipose fin, or in the rudimentary rays of some of the other fins, or in other parts of the body where it interferes least with the health and growth of the fish; the piece of copper or zinc has a number stamped on it, which is entered with appropriate memoranda in a book kept for the purpose. The fish, impelled by an unerring instinct, returns year after year, if not prevented by accident, to continue its species in its native river, and many of those thus marked are retaken and the growth ascertained. Sometimes this is repeated, and their subsequent growth from time to time found out. This and other means of collecting facts concerning the natural history of the Salmon, are at the command of large landed proprietors in Great Britain, whose domains frequently include several fine Salmon rivers.

The Mature Salmon.-We now come to the mature fish; no longer the rollicking hobbiedehoy, or frolicsome maiden Grilse, but the bright glorious Salmon in all its strength and beauty. There is nothing fairer; no fish that so flutters the heart, and blanches the cheek, when for the first time a great swell, and perhaps a gleam of molten silver is seen above the surface on the very pitch of the pool, and the tyro finds that he is fast, by a small hook and a hairlike piece of silkwormgut, to something strong and heavy; which goes at first where it pleases, with head against the current, and presently with a mad rush takes its course down stream, and by desperate leaps endeavors to rid itself of the frail tackle, that at last, by the unceasing bearing of the pliant rod, brings it within reach of the deadly gaff.

A Salmon that comes from the sea in July a bright fish of ten pounds, loses its pearly hue and stout proportions as the summer wears away. Its fins, which were white and 
comparatively soft, become blue and of a whalebone consistency, from stemming the rapids, and from its stay in fresh water. By the time the spawning season is over, it has lost nearly half of its weight, and all of its fine flavor. Then with lank body and big head, bedimmed of its lustre and miserable in appearance, it seeks once more its old home in the ocean, where from the abundance and nutritive quality of its food, it regains its lost flesh and adds some four or five additional pounds to its weight, and when it ascends its native stream again, it is likely a fish of fifteen pounds.

"Ephemera" says in his "Book of the Salmon:" "A Salmon weighing, when caught in its descent to the sea, ten pounds, has been taken on its return, after a sojourn of thirty-eight days, on its salt-water feeding-grounds, and when captured it weighed twenty-one and a quarter pounds." This is an instance of wonderfully rapid growth, still it is difficult to estimate from it, the general increase in size. The same author remarks truly, that some Salmon, from being generated by large parents, have an inherent disposition to grow rapidly. Certain rivers also have a larger breed of Salmon, while in others they are small. Much also depends on the quantity and quality of the food they may find on their feedinggrounds, and the length of time they remain there.

We have no account of Salmon having been taken in American waters, as large as the recorded sizes of those which have been captured in Scotland. It is probable, that the North Sea and Atlantic surrounding Great Britain, being warmer, and of more equable temperature than the Atlantic on our north-east coast, are also more favorable to that order of marine animals (as crustacea, \&c.) on which Salmon feed, and as a consequence, fish that spend the winter at sea there grow larger. Salmon have been taken in Scotland weighing over eighty pounds. Mr. Perley, 
in his report upon the fisheries of New Brunswick, says, he has been told of several taken in the Ristigouche that weighed over fifty. The largest I ever heard of in the Nipissiguit, was a fish of forty-two pounds: the canoe-man who speared it, said it had been in the river some time, and would probably have weighed fifty pounds when it came from sea. It was not a very rare thing to take fish of twentyfive and thirty pounds with the rod in the Tweed, the Shin, and other rivers of Scotland some years back, and many are still taken of twenty and twenty-five pounds. On this side of the Atlantic it is as rare to take them with the rod, over fifteen pounds. The largest fish I have ever heard of being taken with a fly in the Nipissiguit, was one killed at the Grand Falls, by Mr. Lilly, of New York; its weight was over thirty-three pounds: ten or twelve pounds, though, is a fair average weight for the angler, on any of the streams of New Brunswick or Canada.

Instinct.-The instinct which induces this fish to seek its native stream for the purpose of spawning, has been frequently turned to account, in stocking rivers having. the natural properties of Salmon-streams, but which before had none in them. The following instances of this kind are mentioned in the "Book of the Salmon."

"Loch Shin, a piece of water about twenty-one miles by fourteen, situate in the heart of the Sutherland mountains, is the immediate feeder of the River Shin, noted for its Salmon fecundity. The loch itself has four feeders, middling-sized rivers, viz.: the Terry, Fiack, Garvie, and Curry, in which, previously to the year 1836, not a Salmon was ever seen, though many were in the habit of entering the loch or lake. In the year mentioned, at the request of his Grace of Sutherland and Mr. Loch, M. P., Salmon were caught in the River Shin, shortly before the spawning season, and conveyed to the four 
rivers above named, amongst which they were distributed in due proportions. Mr. Young was the managing director on the occasion. In the wonted season all the fish spawned, each in its respective river. Now, mark one of the consequences: Salmon at present, and ever since, come regularly to spawn, traversing the lake to do so, in all these heretofore Salmonless rivers. Nay, more, the fish hatched in the Terry, at least those that survive long enough, return to the Terry; and the young of the other three rivers return from the sea to them, each Grilse or Salmon entering never-failingly the stream that gave it birth. What wonderful and unerring instinct! One might think that they would remain in the River Shin, spawn where their ancestors had spawned; but no, they leave their own natal shallows, pass down the lake, through the River Shin, along the kyle of Sunderland, to the sea; and there having become adolescent, they retrace their route, and, after necessary rests on their long voyage, very frequently on the spots of their parents' nativity, they revisit for the first time, the scenes of their birth and infancy. Revisit them-for what? Being nubile, to perform the nuptial rights, which they do where their forefathers begat them, and so they go on increasing and multiplying in colonies heretofore tenantless of Salmon, ever since volcanic action called from the "vasty deep,' the mountains and rivers of northern Caledonia!"

On our coast Salmon begin to leave the deeps and come into the bays and estuaries in May, and prepare for their residence in fresh rivers by spending a few weeks in the brackish water, where they still find food, though of less nutritive quality, such as Shrimp, Capelins, and Smelts. My friend, John Chamberlain, says, he once speared a Salmon at the entrance of Bathurst harbor, in which he found eleven Capelins.

After these fish have thus gradually prepared themselves 
for a residence in fresh water, they ascend the rivers on the first rise, surmounting rapids and leaping falls of less than five or six feet with perfect ease, and resting in the pools above. In the early part of the season they make short stages, sometimes occupying a pool for a day or two. As the season advances, those that enter the river travel faster; it is thought making twenty or thirty miles a day. As a general thing, they have an instinctive liking for the part of the river in which they were ushered into being, should any caprice or law of nature, however, impel them to ascend farther, and an impassable fall prevent their doing so; after fruitless attempts to leap it, they return to the next pool, or deep still water below, and renew their efforts to pass the barrier at every rise in the water. When the time for spawning draws near, they drop down the river to the shallows, or seek some of the smaller tributaries for that purpose.

"Ephemera" properly ridicules the notion that formerly existed, and still does to some extent amongst ignorant people, that the Salmon in surmounting a fall, puts its tail in its mouth, and so bending itself like a bow, with a sudden spring and letting the tail go, throws itself above the obstruction. It is clear to every tbinking mind that in making its leap, the Salmon must have depth of water, to acquire impetus in throwing itself above the fall. The author in question says, he has seen a Grilse leap upward and forward, somewhat obliquely, the length of his fishing-rod, which was seventeen feet long; and that Mr. Young has known Salmon to clear a fall of sixteen feet. Mr. Scrope, who had been a Salmonfisher more than a quarter of a century, states that they jump on an average no higher than six feet.

There is a great difference in the activity and endurance of Salmon; a young fish of eight pounds, which is as small as they are generally taken, sometimes giving more sport thau 
one of fifteen, hooked in the same pool. There is consequently much difference in the time required to kill a fish, but this arises in some instances from the nature of the water, still or rapid, or the weather and the time of day. The first Salmon I ever hooked-one of sixteen pounds-I killed in about ten minutes, without its jumping once, while a nine-pound fish, which contended with me for two hundred yards down a succession of rapids, required three-quarters of an hour. Then, again, I have killed one of ten pounds in three minutes, from its having exhausted itself by continued desperate leaping.

Food of THE SALmon.-The natural food of the young fish, in its native stream, consists no doubt of small insects, the larva of flies, and the flies themselves that deposit their eggs in pools and running water to pass through the process of incubation. I frequently took the fry last summer when fishing for Salmon with an ordinary-sized Salmon-fly. These young fish appeared not to feed in still pools or in the eddies on the margin of the rapid, as the Trout do, but in the smoothly gliding, swift water, where the Salmon are found; they would frequently jump at the knots on my casting-line. Before the British Salmon-streams were protected from improper fishing, and before it was known that the little fish then called the "Parr," was really the young of the Salmon, they were indiscriminately slaughtered by boys and foolish anglers. This was also the case, to a great extent, after they had arrived at the Smolt state, and were descending the rivers on their first migration to sea.

It is supposed, that the feeding-ground of the Salmon at sea, is not very remote from the mouth of the river from which it migrates.

Regarding its food while at sea, Dr. Knox says: "The tint of its flesh, its superior flavor, and its wonderful growth, is 
owing to its feeding on the eggs of various echinodermata and crustacea." Sir Humphrey Davy supposes the Sand Eel to be one of its chief means of subsistence. It is certain, however, that it does not exclude small fish, such as Capelins and Smelt, from its bill of fare.

Every one who has seen the transverse section of a Salmon, has noted the small cavity in which its stomach, intestines, and vital organs are contained; a fish of twelve pounds frequently having the flesh on the belly at least an inch thick. This with the proportionate smallness of its head, is the cause of its giving more edible substance than any other fish of its size.

Concerning the remarkable fact that this fish is seldom found with food in its stomach after its appearance in fresh water, Sir Humphrey Davy, who was a close observer of all that pertains to the Salmon, says: "I have opened ten or twelve, and never found anything in their stomachs but tapeworms bred there, and some yellow fluid; but I believe this is generally owing to their being caught at the time of migration, when they are travelling from the sea upwards, and when they do not willingly load themselves with food. Their digestion seems to be quick, and their habits seem to show, that after having taking a bait on the river, they do not usually offer to take another till the work of digestion is nearly performed; but when they are taken at sea and in the rivers in winter, food, I am told, is sometimes found in their stomachs. The Sea Trout is a much more voracious fish, and like the Land Trout, is not willingly found with an empty stomach."

I have reserved my remarks on "Salmon-fishing" for a separate chapter. 


\section{THE CANADIAN TROUT. SEA TROUT.}

Salmo Canadensis: HaMilton Sмiтн.

With a view of correcting an error which prevails in regard to this fish, I have adopted the specific name above. It is improperly referred by Mr. Perley to Salmo trutta, an European species found in the rivers of Scotland and Ireland, and known there as the Salmon Trout, Sea Trout, or White Trout. As no scientific description of the Canadian Trout has yet been published, I have deemed it a matter of sufficient importance to give an account of its specific characteristics, comparing it with the European fish and the Brook Trout of America.

Griffith, in his "Animal Kingdom" (Vol. X., p. 474), in alluding to a beautifully colored, though not correct drawing, found on a preceding page of the same volume, says: "Our figure of Salmo Canadensis was drawn by Colonel Hamilton Smith from a living specimen taken in Canada; it is beautifully dotted with blood-red in white circular spots." This is all that this naturalist says of it. Mr. Perley, in his letter to Frank Forester (see "Fish and Fishing," page 122), gives none of the specific characteristics of this fish; even his account of its habits and general appearance would not warrant his referring it to the same species as the Sea Trout of Scotland, for he implies when comparing it with the Brook Trout ( $S$. fontinalis), that the Canadian Trout has red spots, which $S$. trutta never has, but on the contrary dark irregular markings, as Yarrell says, "somewhat resembling the letter 
X," which are the shape of those found also on the Salmon. Sir Humphrey Davy and Yarrell make no mention of red spots on the Sea Trout of Scotland, and Irish and Scotch anglers, in whose company I have taken the Canadian fish, say, positively, that the Sea Trout they caught in the "old country" is entirely a different fish, and has no red spots.

Mr. Perley says of the habits of the Canadian, or Sea Trout, as he calls them: "They proceed up the rivers as far as the head of tide in each, but never ascend into purely fresh water."* Here he was no less at fault than in confounding it with the European fish, for it is an established fact, that all the Salmon Family seek water which is highly aerated for the purpose of spawning, and of necessity "ascend into purely fresh water," and that fish of this species will go to the very sources of a river for that purpose, if not prevented by impassable falls or the smallness of the upper waters; frequently occupying the same feeding and spawning grounds with Brook Trout, or, as the Canadians call them, "River Trout." This intimate association is one reason why they are so often confounded with the latter by careless observers; for a residence in fresh water gives them much the appearance of light-colored Brook Trout, and many persons can only distinguish them by laying an individual of each species side by side.

It was thus by imperfect observation, and too readily crediting stories of persons who were ignorant of the habits of this

* Yarrell, in his work on British fishes, says: "Doctor McCulloch states, that the Salmon Trout, or Sea Trout as it is called in Scotland, is now a permanent resident in a fresh-water lake on the island of Lismore, one of the Hebrides, and without the power of leaving or reaching the sea. There it has been known for a long course of years perfectly reconciled to its prison, and propagating without any apparent difficulty." Journal of the Royal Institute, No. xxxiv., page 212." 
fish, that Mr. Perley not only referred it to an entirely different species and misled persons as to its habits, but has communicated the same errors to Frank Forester, who entails them upon his readers.

Taking Mr. Perley's account with Frank Forester's endorsement as true, I arranged my tackle accordingly, and last summer visited the Province of New Brunswick, expecting to take the true Salmo trutta, but after diligent search and inquiry, seeking every source of reliable information, I could not find or hear of its locality. All who had observed fish or had to do with them, averring that there were no Trout in the Provinces but those with red spots, or any fish of the Salmon family in the rivers without red spots, except Salmon, Smelts, and Capelins. I also found that the general average size of this fish when taken in the rivers, was not as large as $\mathrm{Mr}$. Perley's remarks would lead one to suppose, and that his "average from three to five pounds," and his killing "in one morning sixteen Trout weighing eighty pounds," were wonders "few and far between." Such rare sport may occasionally be found in May or early in June, when many of the schools that enter the bays and harbors are composed entirely of fish of large size, but in fresh water I do not think, as a general thing, that the average will reach a pound. I have taken them as small as four ounces.

A Canadian Trout, fresh from the sea, compared with a Brook or River Trout, has larger and more distinct scales; the form is not so much compressed; the markings on the back are lighter, and not so vermiculated in form, but resemble more the broken segments of a circle; it has fewer red spots, which are also less distinct. It is more slender until it reaches two pounds, a fish of seventeen inches (including the caudal), after it has been some time in fresh water, weighing only a pound and three-quarters, while a Brook Trout of the 
same length, in good condition, would weigh three-quarters of a pound more. They become more robust, however, as they increase in weight, a fish of four pounds resembling in its outline the engraving of the Sea Trout in Yarrell's or Frank Forester's book.

In color, when fresh run from sea, this fish is of a light bluish green on the back, light silvery gray on the sides, and brilliant white on the belly; the ventrals and anal fin entirely white; the pectorals brownish blue in front, and the posterior rays roseate white. The tail is quite forked in the young fish, as in all the Salmonidæ, but when fully grown it is slightly lunate. There are recurved teeth on the palate, maxillaries, and tongue, but none on the vomer.

If the number of rays in the fins indicate specific difference, or affinity, the following table will show that this fish is more nearly allied to the Brook Trout than to the Sea Trout of Europe:-

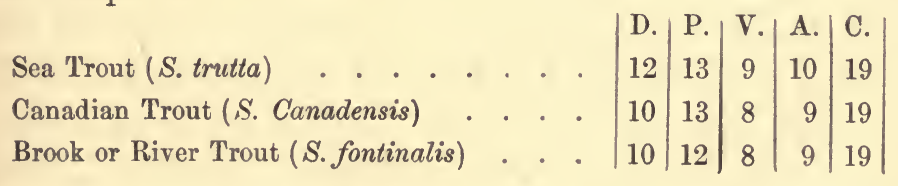

There being only a difference of one ray in the pectorals, which may be accidental.

Although I have taken some trouble to prove that $S$. Canadensis and S. trutta are distinct species, and that the latter does not exist in the waters of the Gulf of St. Lawrence, I have no doubt that it is found in the Arctic Seas, on this side of the Atlantic, as I have examined, at the Academy of Natural Sciences, specimens of the young fish brought by Dr. Hayes, in his last Arctic expedition, from Upernavik, which agree exactly with the description of $S$. trutta given by Yarrell. There were no markings, however, on the back, which might be accounted for from the fact that the specimens 
were quite young, not being over eight or nine inches in length; or the markings might have been obliterated by the alcohol in which they were preserved.

In a recent publication ("Game Fish of the North"), the author, who writes over the name of "Barnwell," says, when speaking of fishing for Canadian Trout on the way from Chatham to Bathurst: "In case you should be too late to, reach Bathurst the same day, or have leisure on your hands, stop at the Half Way House, on the Tabisintac, which has the last syllable accentuated, and fish that-night and next morning for Sea Trout. They are taken from a horse-boat in abundance and of great size."

After reading the above, I concluded, last summer in visiting the Nipissiguit, to take "Barnwell's" advice, but was puzzled as to what he meant by a "horse-boat;" after thinking the matter over, though, I came to the conclusion that the Tabisintac was a river of some size, crossed by means of an old-fashioned horse ferry-boat, from which an angler had nothing to do but cast his flies, and take wheelbarrow-loads of three and four pound Trout. Judge of my surprise, when I found the Tabisintac, at the Half-Way House, a shallow brook crossed by a wooden bridge of a sing!e span; that there was no fishing worth stopping for, unless one would make up his mind to go five or six miles down the brook, where it joined another stream of the same size, which would occupy a whole day, or necessitate one's staying all night at the junction, if he started in the afternoon; and then with a certainty of being stung terribly by mosquitoes, and bled copiously by black flies. I also found that Barnwell's "horseboat" was a large, leaky old "dug-out," made of two huge logs, joined together with wooden pins, and drawn up and down the bed of the brook by a pair of stout horses, the bottom grating over the pebbles, and bumping along over the 
larger stones, doubtless to the astonishment and terror of all the troutlets in the brook.

Notwithstanding my being so completely "sold" by "Barnwell's" brief but glowing description of the fishing and the "horse-boat," I travelled one afternoon in this delightful conveyance three miles down the brook; but as I did not reach the celebrated pool at the confluence of the two streams, and only found one or two places of any depth, my catch, with the exception of one fish of two pounds, was rather small.

Without mooting the question of the late Mr. Perley's proficiency in ichthyology, he was, besides being a genial, warm-hearted gentleman, an ardent sportsman. In proof of the latter qualification, I quote his spirited account of taking this fish :-

"It is to be understood that the whole Gulf of St. Law. rence abounds with White Trout from one to seven pounds in weight. They proceed up the rivers as far as the head of tide in each, but they never ascend into purely fresh water. In the salt water they are caught only with the 'Prince Edward's fly', so called, the body of which is of scarlet with gold tinsel, or of gold tinsel only, with four wings from feathers of the scarlet ibis-the 'curry curry' of South America.

"In the estuaries of rivers where the water is only brackish, they take the Irish lake-fly with gay colors; the scarlet ibis seems the most attractive, however, in all cases. In fresh water the Trout are quite different; they are much longer, very brilliantly colored, with tricolored fins of black, white, and scarlet, and numerous bright spots over the body. When the fish are in good condition, these spots are nearly as large as a silver penny. They rarely exceed three pounds in weight, but are very sporting fish; they take most of the Irish flies, but the red hackle, in all its varieties, is the 
favorite. A brilliant hackle, over a yellow or fiery-brown body, kills everywhere, all the season through.

"The Sea Trout fishing in the bays and harbors of 'Prince Edward's Island,' especially in June, when the fish first rush in from the gulf, is really magnificent; they average from three to five pounds each. I found the best fishing at St. Peter's Bay, on the north side of the island, about twentyeight miles from Charlottestown. I there killed in one morning sixteen Trout, which weighed eighty pounds.

"In the bays and along the coasts of the island, they are taken with the scarlet fly from a boat under easy sail, with a 'mackerel breeze,' and oftentimes a heavy 'ground swell.' The fly skips from wave to wave, at the end of thirty yards of line, and there should be at least seventy yards more on the reel. It is splendid sport! as a strong fish will make sometimes a long run and give a good chase down the wind."

There is also a glowing description of what the author calls "Sea Trout" fishing, in a book by Dr. Adamson of Quebec, "Salmon-Fishing in Canada," which will no doubt interest the reader:-

"In writing of flies for the Canadian rivers, I ought not to omit to state, that in every stream where I have found Salmon, except the Jacques Cartier, the Sea Trout are to be met with in extraordinary abundance, and that they rise freely at any of the usual Salmon flies, provided they are made of a small size, but that the most attractive I know of is a small-sized fly, with a scarlet body, gold twist, red hackle, and stair's wing.

"The avidity with which these fish take, their great size, beautiful shape, and exquisite flavor, must all be experienced before any account of them can be implicitly believed. Sometimes they become a source of annoyance to the nervous and excited fisherman, who, having prepared a seductive fly, 
is about to fish a favorite pool, and sees, at his first throw, five or six of these rush at it furiously-in which case there is no alternative but to change the fly and kill them all offthen you may fish in peace for your Salmon, but not till then. I confess I never found this to be a very great punishment. I am fond of all sorts of fishing, and never could consider it to be any great misfortune to hook and play eight or ten beautiful fish, vying with molten silver in their brightness, and varying from one pound to seven pounds in weight, to say nothing of their flavor when broiled for breakfast, all the time having the conviction on my mind, that as soon as I had done so I should in all probability kill two or three noble Salmon in the same pool.

"The best time for fishing for these beautiful fish is when the tide is flowing, and the best place is that part of the stream where the salt water unites with the fresh; they come up with the tide into the stream, and continue to roam and play about it in immense sculls until the ebb comes on, when they return to salt water; in the mean time, however, they take with much avidity, and afford most excellent sport if fished for with light tackle. They are frequently accompanied in their ascent of the rivers by the more weighty and more cautious Salmon, who is often tempted in such circumstances to take the fly.

"I remember one morning in July, 1849, the yacht Iroquois was lying in the river Moisie, when about six o'clock my friend the major came down from the deck, where he had been performing his ablutions, and calling me a lazy dog because I was still lying in bed engaged with a book, asked me to accompany him on shore, as the tide was making, and assist in getting some fish for breakfast. We started instanter, the captain telling us we had no time to lose, as breakfast was nearly ready. In less than an hour we returned, and 
then we turned out our spoil upon the deck; the baron and captain admired them so much, that they insisted on weighing them before one was committed to the gridiron, and their united weight was found to exceed eighty pounds. Of their exquisite flavor, fresh as they were, and immediately after the wholesome exercise in the invigorating air of the sea and of the mountains, it is only prudent to be silent."

In the month of May there is fine sport to be had in taking these fish in the Nipissiguit at the head of tide, three miles above Bathurst. In my visit to that river I was too late for them, and only took an occasional fresh-run Trout, but not of large size, in the pools above the "Rough Waters." In the "Basin," a mile and a half below the Grand Falls, these fish collect in great numbers, at the mouth of a small brook which trickles in over a beach of gravel; but they are not large here, and, having been some time in fresh water, have lost their brilliancy and resemble Brook Trout, a few of which are also taken at the same place. I have taken thirty pounds here in an hour with a Salmon-fly of ordinary size, and only stopped because they were so easily caught that there was no sport in it. At the "Falls Pool," a hundred yards below the Grand Falls, they are often a nuisance, seizing the fly which in a moment more might have induced a rise from a Salmon. As they are not large there-seldom exceeding a pound and a quarter, and not valued much after they are caught, their frequent intrusion is vexatious. A red-bodied, red-winged fly, wrapped with gold tinsel, is the most captivating, and even when torn by their sharp teeth, as it soon will be, it is still preferable to a new one of plainer colors. I have no doubt that a piece of red flannel tied at the head of the hook would answer the purpose, and better than a well-dressed fly of less glaring hue.

It is a source of regret that I was not early enough in my 
visit to Bathurst to find these fish in brackish water, for there is no questioning the great sport they give when just from sea and of a large size; though I think Dr. Adamson, to use his own expression, does not "draw it mild," when he mentions one of seven pounds as being at all common.

Amongst the most amusing chapters of the amusing book just alluded to, is one (the eighth) devoted to a review of $\mathrm{Mr}$. Lanman's book, discussing his merits as an angler and author.

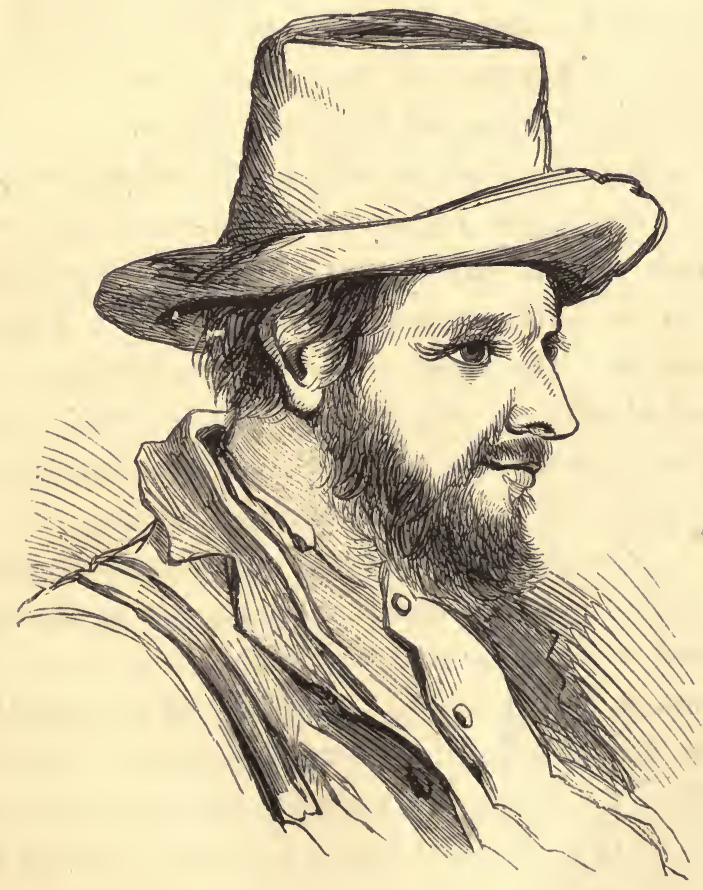


THE SCHOODIC TROUT, OR DWARF SALMON OF THE ST. CROIX.

Salmo Gloveri: GIRARD.

The only scientific account I can find of this fish is given by Girard; it was brought to his notice by Mr. Townsend Glover, of Fishkill Landing, New York, in compliment to whom the specific name of Gloveri was bestowed on it. The characteristics of interest to the angler I have taken from Mr. Girard's description, and give them below.

"The body of the male is subfusiform and rather slender, particularly the caudal region. The female is stouter, with the peduncle of the tail shorter. The eye is very large. The caudal is deeply emarginate posteriorly. The scales well developed. The upper surface of the head and dorsal region are blackish-brown, the sides are silvery white, and the belly yellowish. The region above the lateral is densely spread all over with black, irregular spots, some of which are confluent; a few scattered ones may be seen beneath that line on the middle of the abdomen. Four to six of these spots well defined are always observed on the operculum. A few reddish orange dots individually situated in the middle of a black spot, are occasionally observed along the middle and upper part of the flanks. Whether these dots are peculiar to the female or proper to both sexes, I am not prepared to say, "from want of sufficient information upon that point."

There is much obscurity as to this fish. Some suppose it to be a species produced originally from Salmon which were prevented by some obstacle from making their annual visits 
to the sea, but continuing to breed under such restraint, produced dwarfed fish, and apparently a new species. Others think it a hybrid, the produce of the Salmon and Brook Trout, which is improbable. It is permanent in the St. Croix and in the Schoodic and Grand Lakes, which are the sources of that river. A friend who examined a specimen presented. to the Academy of Natural Sciences, Philadelphia, says it has much the appearance of a Grilse. It had, however, been in spirits some time, and the spots described by Girard were not visible. The number of fin rays are almost identical with those of the Salmon.

An angler of Philadelphia, who enjoys the pleasure of taking the Schoodic Trout with the artificial fly nearly every summer, uses a stout one-handed fly-rod and strong Trouttackle; he describes the sport as being very exciting. Sometimes a brace of them are taken at a cast, pulling hard, and making desperate leaps above the water. He has given me from his journal the following memoranda:-

“June 1856. Three rods, six days, 634 Trout; 872 lbs.

"June 1857. Three rods, six days, 432 fish; 642 lbs.

"June 1858. Two rods, eight days, 510 fish; 725 lbs.

One rod, six hours, 65 fish; 94 lbs.

"Average time of fishing, four and a half hours per day."

He also says that these fish are not found as low down as Calais.

The Schoodic Lakes are reached by means of the steamers which leave Boston for St. John, New Brunswick, twice a week, and stop at Eastport, Maine; from whence there is a daily boat for Calais, and a railroad to within ten miles of the lower fishing-places. At Calais the angler must procure his canoe and stores, and make other preparations for camping out. 


\section{THE GREAT LAKE TROUT.}

\section{Salmo naymacush: RICHARDSON.}

The Naymacush can scarcely be enumerated amongst what are strictly called "sporting fish;" but as it possesses several points of interest to the angler, besides its enormous size, a work of so general a character as this would be incomplete without a notice of this monster Trout. It is purely a freshwater fish, and exceeds in size any species of Salmon known. Its average weight is nearly double that of the true Salmon. In the waters of the United States, it is found in Lakes Superior, Michigan, Huron, and Erie; the Falls of Niagara preventing its passage into Lake Ontario.

Dr. Richardson describes this fish under the above scientific name, giving it the Indian appellation, and says it is found in Winter Lake. I have no doubt it also inhabits Winnipeg; Athabasca, Great Slave, Great Bear, and other lakes which discharge their waters into Hudson's Bay and the Arctic Ocean. With us they are most abundant in Lake Superior, though they are taken in quantities in Lakes Huron, Erie, and Michigan. They are generally caught in gill-nets sunk at the bottom, on set lines, and by fishing with hand-lines in deep water, as well às by trolling at certain seasons of the year. In winter they are taken by spearing through a hole in the ice.

In stopping for a few days at Mackinaw some years ago, I saw a Trout of this species weighing forty pounds. It was 



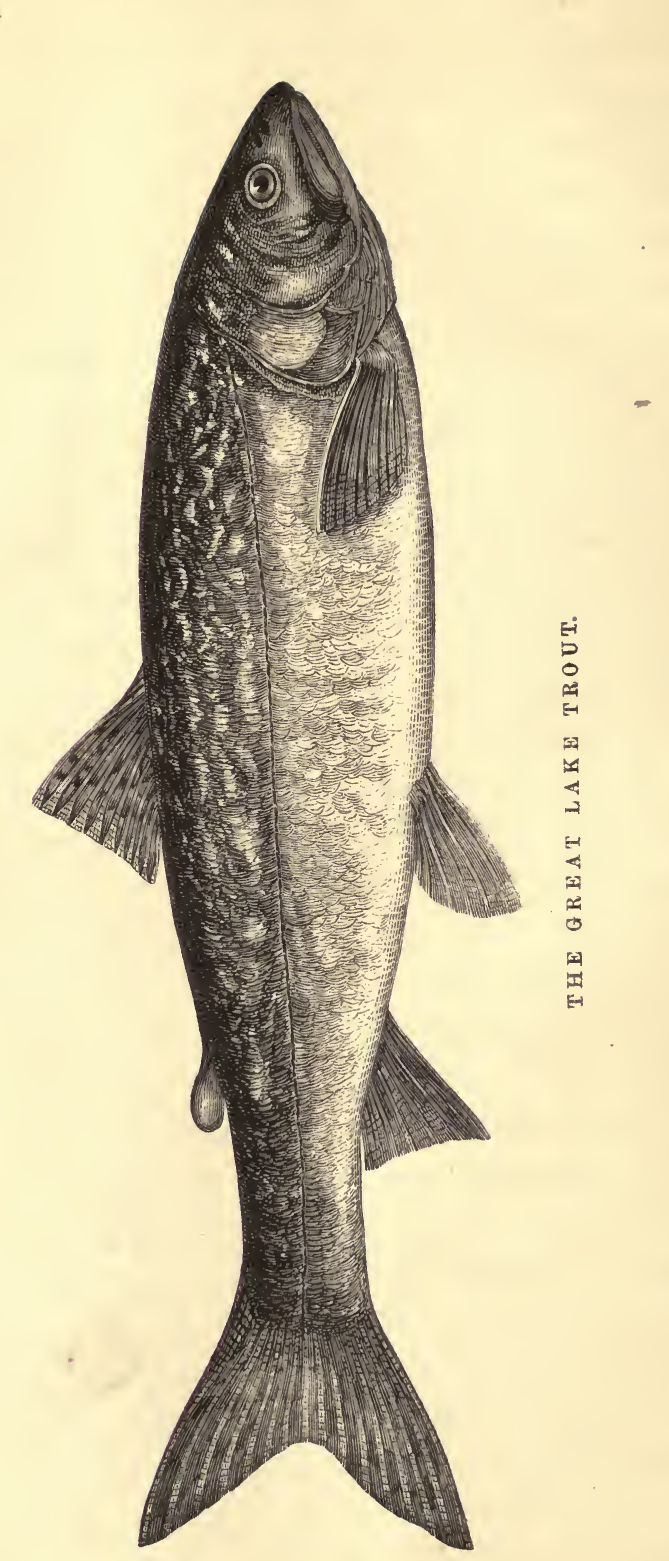


taken on a set line in the straits opposite Bois Blane Island. The fisherman assured me it was not a very unusual size. Its proportions were rather shorter than those indicated by the preceding engraving. It has been taken in Lake Superior weighing as much as a hundred pounds. The flavor of this fish is nothing to boast of. They are seldom eaten when the delicate Whitefish, which inhabits the same waters, is on the table.

It is said that the Naymacush spawns along the shores of the lakes in the month of November. I have never been able to ascertain whether they seek those places where the aerated waters of brooks or rivers flow into the lake, or that they enter the mouths of such streams for that purpose. They are doubtless fish of rapid growth, although there is no reliable means of judging what size they attain in a given time.

In returning from Sault Ste. Marie in July, 1844, in a "Mackinaw boat," such as was then in general use among the voyageurs, I threw a line over, with two stout 00 Kirby hooks at the end of it, baited with a white rag and a piece of my red flannel shirt, and hooked several Trout of this kind near the "Detour," but the hooks in every instance but one were straightened or broken, and the fish lost; the single exception being a small one of about eight pounds, which was evidently a young fish, from the fact of its meat cutting nearly white, when we broiled it.

The degree of skill attained by the Indians, half-breeds, and traders in spearing the Naymacush is wonderful; but it is only by early education, or long practice, that they become adepts in the art. The usual mode is as follows:-

The spearer provides himself with the necessary weapon fastened into the end of a long ash handle, and the leaden counterfeit of a small fish, six or seven inches long, which he 
keeps bright by scraping with a knife, and ties it, evenly balanced, with a string, which passes through a small hole in the back. After making a hole of proper size in the ice for spearing and taking out his captives, he cuts another, through which he lowers the leaden imitation; then covering the larger hole and himself by means of one or more blankets suspended on upright sticks, he is ready for operation, and proceeds to lower and raise the counterfeit fish to lure the great Trout within reach of his spear. As the large hole is darkened by the blankets, the spearer is not seen by the Trout below; as he rises in pursuit of the leaden fish and comes within striking distance, he is impaled by the deadly spear and landed on the ice, where, after a few flaps of his tail, he dies a martyr to his voracity or curiosity.

The wood-cut of this fish I have taken from Mr. E. Cabot's representation, filling in the proportions somewhat between the anal and caudal fins to suit my own notions of its form. 


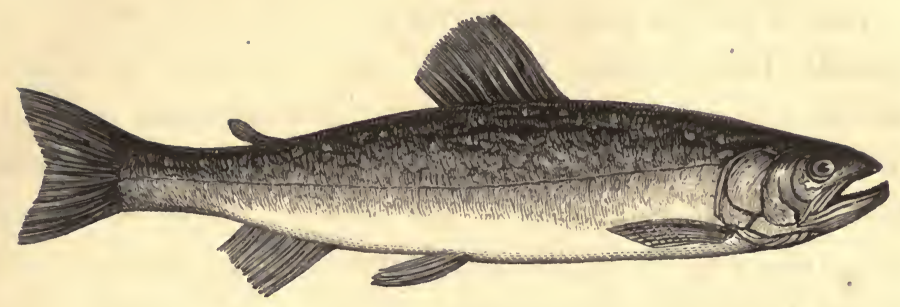

THE LESSER LAKE TROUT.

Salmo Adirondakus: NoвIs.

This, the Lake Trout of Hamilton and Franklin counties, in the state of New York, is found in all the small lakes stretching along at intervals west of the Adirondack Mountains. It differs much in its proportions from the engraving of Salmo confinis, found in De Kay's book, and reproduced by Frank Forester; the latter looks more like the huge misshapen Brook Trout, sometimes taken when trolling in those waters, than any fish found in Lakes Pleasant, Piseco, Indian or Long Lake, or in Tuppers or the Saranac Lakes, further north: still I have no doubt, from what I have heard, that there are other species, or at least varieties of Lake Trout found in those regions, and that De Kay's representation may resemble an overgrown specimen of one of them.

This fish, in form, is oblong; head one-fourth its length; upper jaw slightly longer; no scales on opercles; eye onethird distant from snout. Color: back, bluish green; sides, silvery gray; belly, white; lateral line straight; the body is mottled rather than spotted; branchial rays 12 ; dorsal $1 \cdot 10$; pectorals 13 ; ventral 9 ; anal $2 \cdot 10$; caudal (forked) $3 \cdot 22,3$. There are two rows of teeth on each side of the roof of the 
mouth, a row on the upper and lower maxillaries, and on the tongue, but none on the vomer. The teeth are curved inwards.

This Trout is sometimes taken as high as twenty-five pounds, though such instances are extremely rare, they seldom exceed six, and the general average is not over four pounds. They have one of the habits of large Salmon when hooked, which is sulking at the bottom; but as far as sport goes, they bear about the same relation to the Salmon or the Brook Trout, as a wagon horse does to a full-blooded racer, or a vicious mustang.

They are said to spawn in November, along the shores of the lakes, or the rocky margins of islands. They are found in May and June, or as soon as the ice has disappeared, near the outlets, where they are on the lookout for minnows and shiners, which do not venture into deep water. So in trolling, greater numbers, but smaller Lake Trout, are taken near the outlets; and larger ones, and fewer, in the depths of the lakes.

Deep places in the lakes are marked with buoys, and, after being baited a few days, are fished with hand-lines. In winter, a place thus baited is fished through holes cut in the ice; but this kind of fishing affords poor sport, and, as a general thing, but few fish.

I have never heard of Lake Trout rising as Brook Trout do, though they are sometimes taken when trolling, on a large gaudy fly, attached by a gut length to the line or leader, eight or ten feet above the minnow.

The usual mode of angling for them is by trolling with a "shiner," a small fish resembling a roach or dace. At the end of this article is a wood-cut representing a gang of hooks baited with a minnow. Stout Limerick hooks are generally used; the pair at the tail, as well as those in the middle, should not be smaller than No. 1 ; the lip hook, No. 3 or 4 ; the length of the gang is regulated by the size of the bait. The 
bait is generally put on alive: the lip-hook being passed carefully through the upper and lower lips, effectually closes its mouth; one of the middle hooks is then passed through the back, just beneath the dorsal fin, and one of the tail-hooks through the upper part of the body, near the tail, in such manner as to bend the tail slightly, to insure its spinning, as pictured in the vignette. Two swivels are used: one joining the foot length, on which the gang is tied, to the leader; and another attaching the leader to the line. The rod should be stout, not over eleven feet long, and rigged with metallic guides and end-piece. The reel (a multiplier is best) should contain not less than a hundred yards of plaited silk line. The leader should be of the stoutest single gut, and seven or eight feet long. A single buckshot is used to sink the bait in water of moderate depth, and two or three when it is deep; and should be placed at the junction of the line and leader.

In trolling, it is the custom of the angler to sit on a stool or low chair, with his back to the oarsman; I prefer sitting on the stern seat, facing the bow of the boa ${ }^{+}$, as it is more pleasant, and enables one to see ahead. Forty or fifty yards of line are allowed to run off the reel. The most likely time for the "Laker" to seize the bait, is when the boat makes a turn, as the minnow is then apt to rest on the bottom, and will recover its animation, and swim about; and if there is a fish near, he is likely to seize it, when it starts again, as the boat gathers headway.

There is a constant strain on the line and rod, though the boat may not move fast. But when a fish lays hold, it is known by a backward surge of the rod; when the angler strikes smartly, the headway of the boat is stopped, and the fish reeled up, gaffed, and lifted in. If the fish is large, the boat is backed towards him, or follows; and as he likely has 
more than one hook in his mouth, there is small chance of his escape.

When a large fish sulks or takes the bottom, his capture is a question of time only. I have known an angler, on such occasions, light his segar from that of his friend in another boat, and wait on his victim patiently for a half hour, humoring him in all his runs and sulks, and at last bring him within reach of the gaff. To increase the sport, I have sometimes landed, and killed my fish from the shore.

There is much difference in the condition of "Lakers." I have had fish in the boat not weighing more than threefourths as much as others of the same length, that were fuller fed.

The flesh is of a much paler color than that of the Salmon; the meat of a fish of five pounds being a delicate pink, while that of a three-pound fish is almost white. A fish of four or five pounds is excellent when boiled; it is more remarkable for its delicacy than its richness. I have eaten them planked, but they are not to be compared to Brook Trout, cooked on a stick or under the ashes. I have also had them smoked to bring home, and think, on the whole, they are as good in this way as any other, though inferior, of course, to smoked Salmon.

These fish are found in our markets, as far south as Philadelphia, in the months of October and November.

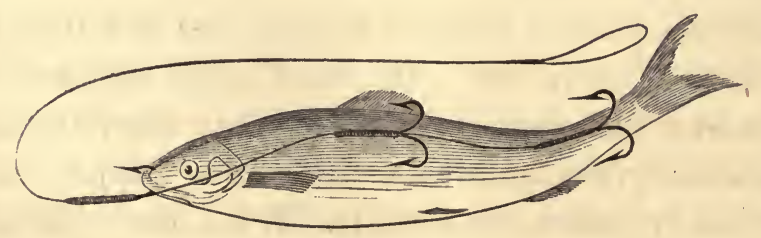




\section{BACK'S GRAYLING. THE STANDARD-BEARER.}

Thymallus signifer: RICHARDSON.

Dr. Richardson, in his "Fauna Boreali-Americana," gives not only a glowing description of the exquisite beauty of this fish, but speaks with all the ardor of a true angler of its game qualities. He describes it thus: "Back dark; sides of a hue intermediate between lavender-purple and bluish-gray; belly black-gray, with several irregular whitish blotches. There are several quadrangular spots of bluish-gray on the anterior part of the body.... The head is hair-brown above; the cheeks and gill-covers the same, combined with purplish tints, and there is a blue mark on each side of the lower jaw. The dorsal fin has a blackish-gray color, with some lighter blotches, and is crossed by rows of beautiful Berlin-blue spots; it is edged with light lake-red. The ventrals are streaked with whitish and reddish lines in the direction of their rays. The body is compressed, with an elliptical profile...... The greatest depth of the body is scarcely onefifth of the total length, caudal included. The head is small, being one-sixth of the total length."

Dr. Richardson further says: "The Esquimaux title (Hewlook-Powak), denoting 'winglike fin,' alludes 'to its magnificent dorsal; it was in reference to the same feature that I bestowed upon it the specific appellation of Signifer, 'The Standard-bearer,' intending also to advert to the rank of my companion, Captain Back, then a midshipman, who took the first specimen we saw with an artificial fly."

It appears from the same account that it is found only in cold, clear waters, and delights in the most rapid part of mountain streams. In this it differs from the European 
Grayling, which loves the gentle current, and is generally found at the tail of a rift or "stream," as English anglers call it. This naturalist, and keen angler-he must have been-also says: "In the autumn of 1820 we obtained many by angling in a rapid of the Winter River, opposite Fort Enterprise. The sport was excellent ; for the Grayling generally springs entirely out of water, when first struck by the hook, and tags strongly at the line, requiring as much dexterity to land it safely, as it would to secure a Trout of six times the size."

My experience in Trout-fishing is that large fish of any species are sluggish in comparison with those of an ordinary size; but I am not inclined to concede the superiority claimed by this author for the Grayling over the Brook Trout. Making all allowance, however, for the ardor of the angler, the "Hewlook-Powak" must have given such sport as the fly-fisher seldom has the happiness to enjoy.

It is often a source of regret to the angler, that the naturalist, in describing new species of game-fish, is indifferent or silent as to the sport they may furnish; and the fisher reads a scientific description as a story that is half told; and is apt to set the ichthyologist down as a humdrum bookman, more interested in specific distinctions than in the pleasure of catching fish. It is a great relief to find such an exception to the general rule in Dr. Richardson.

There is a smaller species of Grayling (Thymallus thymallnides) described by the same writer, which does not grow above eight inches in length; he says they are taken in company with the larger.

The Grayling being a fish in the capture of which the American angler cannot participate, we give no account of the manner of angling for them; but refer the reader who may have interest or curiosity on that score to English authors. 



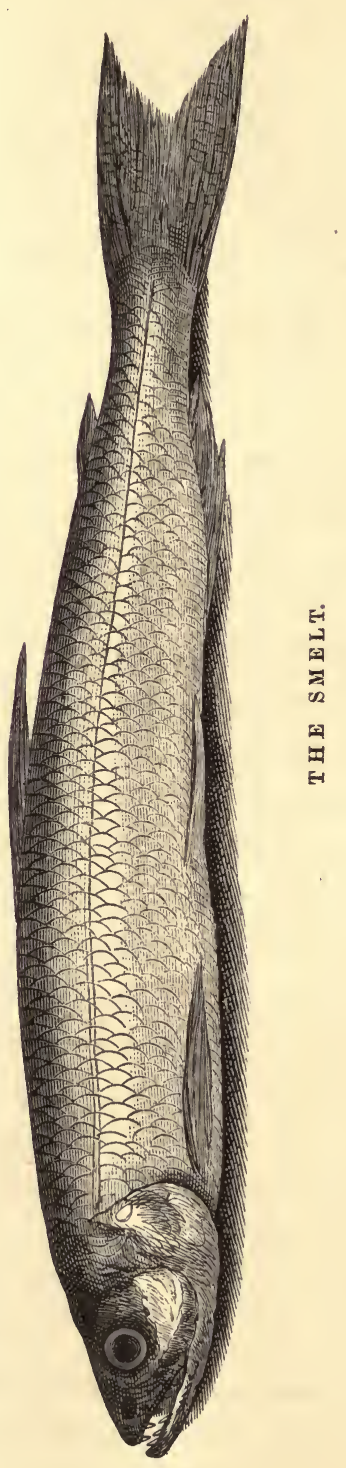




\section{THE SMELT.}

Osmerus viridescens: $\mathrm{D}_{\mathbf{E}} \mathrm{K}_{\mathbf{A Y}} \mathbf{Y}$.

This is the beautiful, symmetrically formed, bright little fish brought from the north, and found in our fish-markets from December till March.

Ichthyologists say there is only one species of Osmerus found in the United States; notwithstanding the small Smelt taken in the Passaic, the Raritan, and of late years, in the Delaware, are claimed by anglers and epicures to be different from those brought from Boston.

On discovering the smaller variety in the Schuylkill, where it had not before been found by ichthyologists, I thought it a matter of sufficient interest to present specimens with some written observations* to the Academy of Natural Sciences.

* At a meeting of the Academy of Natural Sciences at Philadelphia, held March 26th, 1861, on report of the respective committees, the following paper was ordered to be published in the proceedings:-

"Remarks on a species of Osmerus taken in the Schuylkill, below Fairmount Dam, by ThaD. Norris:-Form. Elliptical, elongated; section oral; breadth compared with its length (exclusive of caudal) as 2 to 11 , and head from tip of lower jaw to posterior angle of opercle as 5 to 22 .

"Lower jaw projecting, with an upward curve; scales on all the gill covers, largest on preopercle; five large recurved teeth on the tongue, the largest on the extreme point; two of the same kind on the front of the upper jaw; no teeth on the vomer, but a patch of small ones on the palatine bones and maxillaries.

"Color. Silvery steel above, with light greenish reflections; a distinet streak of bright roseate purple extending immediately above and along 
Afterwards I ascertained from good authority that it is sometimes taken in the Brandywine, at Wilmington, Del., and at Trenton, N. J.

the lateral line; sides silvery; belly brilliantly white. Branchial rays 8 ; D. 11 , C. 20 ; P. 11 ; V. 8, A. 15.-The second dorsal has about twenty minute but distinct cartilaginous rays; tail forked, upper lobe slightly longest.

"The points of difference between this and the O. viridescens are the more southern habitat of the new species, its smaller and more uniform size, and the distinct roseate purple of the streak above the lateral line. O. viridescens (the northern Smelt) attains the length of 12 inches. I have seen the new species here described in quantities at New Brunswick, New Jersey, but never exceeding $6 \frac{1}{2}$ inches exclusive of caudal.

"Storer enumerates 14 rays in the pectorals of 0 . viridescens, but on a recent examination of that species I found only 11, as in the new species, and that the fin rays of both are identical.

"There are several circumstances of interest connected with this little fish. It is the smallest of all the Salmonidæ, except the two genera of Scopulus and Mallotus. It is the only fish of the Salmon family, besides the Brook Trout, found in our waters, and the only species of anadromous salmonidce that visits the Delaware and its tributaries. Whether this fish enters any fresh rivers south of Cape Henlopen, is a matter of conjecture, but I have no doubt, if properly sought for, it may be found very early in the spring, in many streams falling into the Delaware, particularly in rapids or near the falls of a dam which obstructs the upward flow of the tide.

"It appears to visit our waters only for the purpose of spawning, and is found at the falls below Fairinount Dam for a few days in February or early in March. In those I examined a few days since, I found the milt partly discharged from the male and exuding in a semi-fluid state from the vent. Many of the females had cast their spawn, in others it was partially discharged, and the ova were found sticking to the sides of the fish as they lay in a heap.

"I have been told that these fish can be taken occasionally in February along the wharves and in the docks of the Delaware with a cast-net. They are taken with cast and scoop nets at Fairmount Dam. They are common and abundant at New Brunswick, New Jersey, on the Raritan, 
As an article of trade the Smelt is of some importance. It is said that a firm in Boston, who, it appears, monopolizes the trade in this delicate little fish, sells no less than a hundred thousand dollars' worth of them during the season, which commences in October or November and lasts till March. They are taken in large numbers along our coast north of Boston, and are still more abundant along the Gulf of St. Lawrence, where they come up the rivers as far as the head of tide to spawn. In the month of May, just above the head of tide-water, immense schools of them are directed in their course so as to pass through a narrow opening, formed by piling stones in two oblique rows nearly together at the upper ends. As the Smelts rush through in a continuous stream, they are dipped up with scoop-nets. A hundred barrels of them are sometimes taken in a week on the Nipissiguit by a man, assisted by a half-grown boy. There they are used for manure, selling for fifty or sixty cents a barrel at Bathurst. The usual price in the New York market is from ten to fifteen cents a pound.

and it is said also in the Passaic, though during some winters they even there are comparatively scarce.

"It is evident from the size, shape, and arrangement of the teeth, that this fish is extremely predatory, and in that respect more closely allied to the true Salmon than either of the genera of Coregonus or Thymallus.

"In the examination of this fish I have ascertained a fact which is also worthy of note: it is, that the second dorsal or adipose fin (which in this fish is transparent), has about twenty minute cartilaginous rays; they are quite distinct, and the question arises, are there not rays in the adipose fin of all the Salmonida, though it may be covered with thick skin or fat, concealing the rays? The adipose fin was given for use by the Creator, and not as a useless appendage, and without the rays how else could it be contracted or expanded, or moved from one side to the other? It may be said that they are merely cartilaginous, but so are many of the rays, especially near the ends or border of the fins. Dr. Bridges could not discover these rays on examining this fish, as it had been dipped in alcohol, and the fin rendered opaque." 
In England Smelts have been transferred to fresh-water ponds having no communication with the sea, and have continued to thrive and breed abundantly. A like instance is said to have occurred on Long Island.

There is not the least doubt that much sport may be had in angling for Smelts with fine tackle and a light pliant Trout-rod, and that they would -take the fly on a favorable day, for they are caught at the north with hook and line in all the harbors; generally from the wharves by boys, who catch large strings of them during the autumn, and even ip winter, when other fish refuse a bait. This is the case with an inferior fish, the Roach, which is taken in the docks along the Delaware in winter. A Smelt of ten and twelve inches, to which length the northern variety sometimes grows, would be no mean prize, if caught in winter, by those who feel that angling is almost "one of the necessities of life." Small minnows or pieces of fish would, no doubt, be good bait. On examination I have found small shrimp in the stomachs of those brought from Boston. When taken from the water, Smelts have a fragrant smell, resembling that of a fresh cucumber. They are certainly the most delicate fish that is eaten; the roe, which is very large for their size, is peculiarly so.

The best way of cooking them, after having drawn the entrails out by clipping them at the gills and vent with a pair of scissors, is to roll them in coarse corn-meal or grated cracker, and fry them in salad oil, or fresh sweet lard. There should be sufficient lard or oil to keep the fish from the bottom of the pan. When served up, open a Smelt while hot, and spread a little butter on the inside to melt; pepper and salt it, and lay a piece of the fish on a slice of buttered bread, and take a mouthful of each at the same time. 


\section{CAPELIN.}

\section{Mallotus villosus : Cuvier.}

This, with the exception of the genus Scopulus, is the smallest species of Salmonidre found in American waters. Dr. Richardson says it is nearly allied to the Osmerus (Smelt). It is of small size, seldom exceeding six inches in length. They are said to be a delicious little pan-fish, not excelled by the Smelt itself, and that they resemble that. fish in the peculiar smell for which it is noted when taken from the water.

Capelin are found in immense numbers on the coast of Labrador, and in the Gulf of St. Lawrence, where they are used as bait for the Codfish. One sweep of the net at night as they come in shore, is said to secure as many as will serve a fishing-smack for the next day. They are only mentioned here for their value as pertaining to the Cod-fishery of the northern coast. The following notice of the taking of these little fish is from the April number (1861) of Harper's Magazine; the article is entitled "Three Months in Labrador":-

"At early evening, after the labors of the day, the seineboats go in quest of Capelin (bait), carefully searching the little coves and inlets, and creeping along the shores; three men pulling in the usual way, an oarsman in the stern standing up and pushing, while he scans the surface of the water for the ripple of passing schools, and a lookout in the bows, motionless as a figure-head, resting upon his elbows, and peering into the depths before him. Now one gives 
warning, and over goes the seine smoothly and noiselessly, and with a rapid circuit the bait is impounded and quickly hauled on board. One cast is generally sufficient, for the Capelin swarm in millions, swimming so densely that often a dip-net can be filled from a passing school. They keep near the shore to avoid their finny pursuers, and are left floundering upon the rocks by every reflux wave. The Cod often leap clear of the water in their pursuit, and at such times may be taken by the hook almost the instant it touches the water. The Capelin is a delicate fish, about six inches in length, and not unlike a Smelt; his back a dark olive green, sides of changing rainbow hues, and belly silvery white."

Great numbers of these little fish are, no doubt, devoured by Salmon, as they come in from sea and enter the bays and mouths of rivers they ascend. 


\section{THE WHITEFISH.}

Coregonus albus.

There are not less than thirteen distinct species of Coregonus described by ichthyologists. Dr. Richardson, in his Fauna Boreali-Americana, mentions seven: C. albus, the Attihawmeg; C. trlibee, the Tulibee Coregonus; C. artide, Le Sueur's Herring Salmon; C. quadrilateralis, the Round Fish; C. Labradoricus, the Musqua River Coregonus; C. lucidus, the Bear Lake Salmon Herring; C. Hurongus, the Lake Huron Salmon Herring. De Kay describes three species: C. albus (the large Whitefish brought to our markets from the great lakes during the autumn months, and identical with the Attihawmeg of Dr. Richardson); C. Otsego, the Otsego Lake Whitefish (now almost extinct); and C. clupeiformis, the Lake Herring.

On the continent of Europe there is the Laverett (in the lakes of Westmoreland, England); the Gwynaid (in the lakes of Dumfrieshire, Scotland); and the Vendace, and another species, in Ireland.

The Round Fish mentioned by Dr. Richardson is as large as our Whitefish; the remainder, both on this continent and in Europe, do not exceed in size a large Herring, and are mostly known as Lake Herring.

The geographical range of the Whitefish in the United States, extends from the Falls of Niagara through the great lakes up to the head of Lake Superior. They are of larger size in their more northern habitat, the average at the Sault Ste. Marie (the outlet of Lake Superior) being four or five pounds; while those brought to our markets from the more southern lakes do not average two pounds. The largest I 
ever heard of being taken in Lake Superior was one of fifteen pounds; but such instances are rare.

At one time they were exported largely from the great lakes, being salted and barrelled, as Shad are with us. The usual mode of taking them is with gill-nets sunk in deep places in the lakes; but in autumn they come in large schools into shallow water along the lake shores, to spawn, when great numbers of them are taken with the ordinary seine.

Whole tribes of Indians subsist entirely on them in the Arctic regions. I found a considerable portion of the tribe of Chippewas permanently encamped at Sault Ste. Marie about twenty years ago, whose only means of living were the Whitefish found there. To take them, the Indians go, two in a canoe, to the lower part of the rapids; one in the stern, with pole or paddle, keeps the prow steadily heading up the current, while another, with a dip-net, the long handle bent backwards near the bow of the net, stands in the bow of the canoe. The latter, by a sudden dip, apparently pressing the fish towards the bottom, turns the net dexterously, lifts it, and throws the fish into the bottom of the boat, sometimes taking two at once, and never failing to secure his prey.

The flesh of this fish is snowy white, and, though delicate, it has a gelatinous richness which entitles it to all the laudation bestowed on it by epicures. Dr. Richardson says it never cloys, but rather grows in favor with those who eat it, and that one never feels the necessity of bread as an accompaniment. It is said that it is seldom found with food in its stomach, and then only a few small crustacea. Still its conformation shows it to be a fish of rapid growth, and of course a gross feeder. What the food is, that gives it such fatness, or where it is found, has never been ascertained. In the fall of the year, before spawning, it loses all reasonable proportions, looking as if it was deformed. The head, not much larger than a 
Herring's (attached to a body as deep, and thicker than a Shad's), appears to sink into its shoulders; and it becomes so fat at that season, that a very large portion of its substance is lost in frying; or if broiled, it is difficult to keep it from taking fire on the gridiron; though, in the early summer, as I have seen it at Sault Ste. Marie, it is symmetrically formed; but even then it is remarkable for its small head.

From its outward appearance, the Whitefish would hardly be taken for one of the royal family of Salmonidx, its adipose dorsal fin appearing to be the only characteristic in common. Its thin head and small toothless mouth, so different from the powerful jaws and formidable dentition of species belonging to the genus Salmo, shows it to be an inhabitant of the quiet deeps, earning its living peaceably, and not as the great predatory trout of the same waters. Any attempt by Frank Forester, Mr. Brown, and "Barnwell" to make it out a gamefish is ridiculous. I have never heard of its being taken even with hook and line on the bottom, let alone its rising at an artificial fly. Nor do I believe that either of the abovenamed writers has any reliable authority for holding out such an idea.

The following description of its specific character is from a specimen obtained in our fish-market last fall:-B. 8; D. 2, $11 ;$ C. $16 ;$ P. $15 ;$ V. $11 ;$ A. 12 . The roots of the ventrals are immediately beneath the middle of the dorsal; the terminus of the adipose dorsal perpendicular to that of the anal; anterior of adipose dorsal with minute scales. The specimen weighed twenty-eight ounces, was $16 \frac{1}{4}$ inches long, and $4 \frac{1}{2}$ inches broad. 


\section{BAIT-FISHING FOR TROUT.}

The manner of angling for Trout with bait, depends much on the kind of water one fishes, or the bait used. In a rapid stream, a light, pliant cane rod, with a tip somewhat stiff, and without a reel, is to be preferred; a tine line of silk and hair, with a gut bottom of three feet; a weak-trout hook of No. 25 or 26 is better than the short-shanked Kirby; split shot should be used for sinkers, one or more, as the current may require.

With such tackle and in water as above mentioned, let me describe the manner of baiting the hook. Take a whole worm - not mutilated - of medium size, and enter the point of the hook about midway or rather nearer the tail, and passing it along bring it out a half inch or so from the head; the tail will then move as well as the head, showing signs of life; and when it loses its vitality, it is still attractive when drawn against the current. Whether wading or from the bank, cast in at the head of the rift, and let the bait drift along near the bottom, drawing it back occasionally to make it show plainly. When a minnow is used for bait in still water, the hook should be passed through its back; if in rapid water, through the upper and lower lips; or it should be bridled as described in Rock. fishing.

After fishing the main current, try the sides of the rift. On feeling a bite, draw away a little, coaxing the fish to lay hold more vigorously; by his resistance and pulling hard you can ascertain when he is securely hooked; then draw 
him towards the shore and lift him out, or by slipping your hand down the leader, grasp him by the nape of the neck, and stick your thumb under his gill to make your hold more secure.

Allowing your bait to trip along under bushes that overhang the bank, or to float off towards the end of the rift, sawing it backwards and forwards, is an effective way of baitfishing.

When fishing with a grasshopper, the sinker may be dispensed with; and with this bait the still parts of the stream may be fished, where a Trout would be less likely to take a worm than in brisk water.

There are several ways of scouring earthworms; the simplest is to put them in a flannel bag, discarding those that are mutilated, and parts of worms, and allow them to purge themselves for five or six hours. They may be kept a day or two in moderately cool weather; the mouth of the bag should be closed at night to prevent their escape. When fishing, the bag may be pinned or buttoned to the waistband of one's pantaloons, with the mouth of the bag open. Four or five inches of the toe of an old woollen stocking will answer in place of a flannel bag.

In fishing the ponds of Long Island, I have seen a float used by some anglers. There is little need of a landing-net in bait-fishing, for by giving time enough, and a little coaxing, a Trout will hook himself very securely.

Having said thus much on bait-fishing, I leave the subject of fly-fishing for another chapter, assuring the beginner that it is no abstruse science, notwithstanding all the learned essays on the subject, and promising him, that after an honest endeavor to master the rudiments, that he will lose confidence in ground-bait, and resort to it, not for sport, 
but only in time of a freshet to get Trout for his dinner or a roast; and that the only use he will find for his bait-hooks, will be to give away to the little barefoot boys and girls he may meet on the stream, trying to catch a string of Trout for their supper.

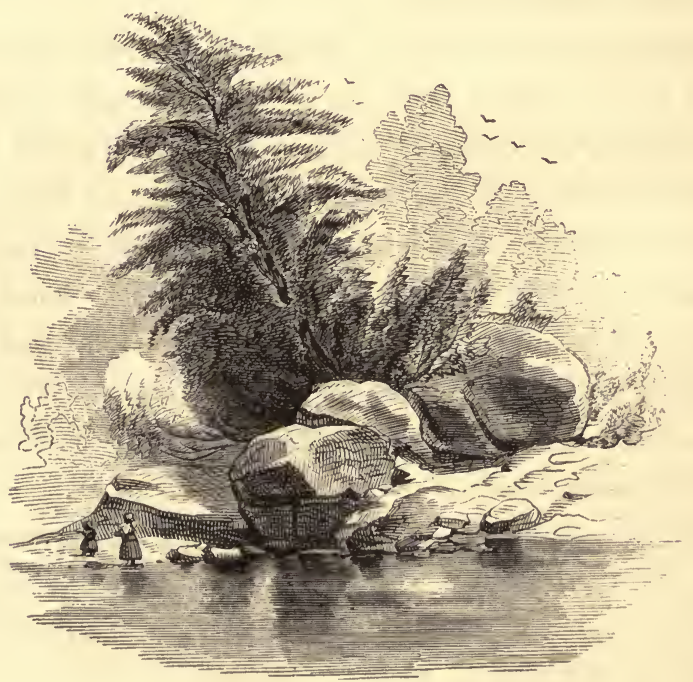




$$
\begin{aligned}
& \text { UH A PTE R } \mathrm{x} . \\
& \text { SALT.WATER FISH AND FISHING. }
\end{aligned}
$$


“Unohavgeable, save to thy wild waves' play, Time writes no wrinkle on thine azure browSuch as creation's dawn beheld, thou rollest now.

"Thou glorious mirror, where the Alnighty's form Glasses itseif in tempests; in all time,-

Calm or convulsed-in breeze, or gale, or storm, Icing the pole, or in the torrid clime

Dark heaving-boundless, endless, and sublime, The image of eternity, the throne of the Invisible."

BYRON. 
CHA PTER X.

SALT-WATER FISH AND FISHING.

INTRODUCTORY REMARKS.

The Sheepshead.

The Weakfish, or Salt-Water Trout.

The Barb, or Kingfish.

The Spot, Pigfish, or Goody.

The Croaker.

The Redfish of the Gulf of Mexico.

The Bluefish, or Syaping Mackerel.

The Spanish Mackerel.

The Pompano (Southern).

The Drumfish.

The Flounder.

'The Sea-Bass.

The Blackfish.

The Mullet.

The Toм Cod, or Frostrish.

The Porgy.

THE topography of our coast shows long stretches of low sandy beach, which beat back the waves of the Atlantic, from Sandy Hook to Cape Florida. Inside of these are intermi. nable sounds, creeks, and quiet bays, abundantly stocked with Bluefish, Weakfish, Blackfish, Rockfish, Sheepshead, Barb, Croakers, Pigfish, Porgies, Sea-Bass, \&c. Here the angler may listen to the waves beating against the ocean side of the barrier, and see the white breakers; and at times may even feel the salt spray which flies over the narrow 
strip of sand, sprinkling his face, as he sits in his boat ana makes havoc amongst the fins.

Along our seaboard there are places of summer resort, where hotels and boarding-houses are kept for the accommodation of those who come to shoot and to fish; the visitors frequently bringing their families to enjoy the bathing and invigorating sea air. To almost any of these let one who is fond of fishing repair between the middle of July and first of September. Let him provide himself with a stout rod, good flax line, large hooks, a felt hat, a red flannel shirt, and a few "store clothes" for Sunday and dress occasions, and he will have fishing to his heart's content-big ones, and plenty of them. If he takes the advice of old fogies, or the man who furnishes his boat and bait, he will fish with a hand-line. If he follows the instinct of the true angler, he will fish with rod and reel, and as a consequence his enjoyment of the sport will be enhanced.

Of all places within easy distance of our city, commend me to Long Beach, where the accommodations are good (barring the butter), mosquitoes few (if the wind is not off land), and the landlord one of the most obliging and appreciative men in the world, as to the requirements of the angler or shooter. And moreover where Sammy Shourds is always on hand. Sammy can find soft crabs when no other man can; besides he knows all the fishing-grounds, and when the tides suit at each; when to go on the flats for Weakfish, when in the Cove for Barb, when in the channel for Sheepshead, when to the flat, sedgy islands for Rockfish, and when to squid for Bluefish. Here, according to the adjudication of the aforesaid Sammy, a friend and myself caught with our rods in three mornings (fishing four hours at each time), over five hundred pounds of Weakfish and Barb, and touched up the Rockfish in the afternoons at the islands. 


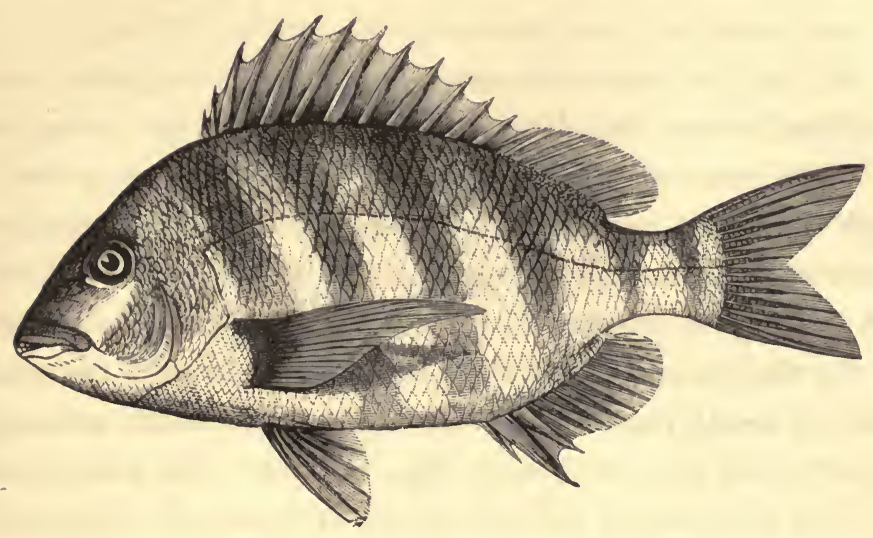

THE SHEEPSHEAD.

Sargis ovis: MiтchIL.

Form: Body compressed; back arched, rising abruptly from the snout; nearly straight on the belly from the lower jaw to the first spine of the anal, thence rounding to the last ray of that fin, where the body is small to the caudal. Color: dark gray on the back; sides silvery; belly white; six or seven dusky bars, reaching from the top of the back nearly to the bottom of the belly. Teeth: four or six incisors in front of both upper and lower jaw, with obtuse crushing conical molars in the roof of the mouth and inside of lower jaw. Fins: there is only one dorsal, which has twelve formidable spines and twelve rays, all of which close, at the will of the fish, in a groove on the back; the anal has three stout spines and eleven rays, which close also (but not entirely) in a groove; the pectorals are very long, and have sixteen rays; ventrals have one spine and five rays; and the caudal. which is forked, has seventeen.

These fish arrive in the bays and inlets on the coast of New 
Jersey as early as the middle of May, and are frequently found in large schools. As a general rule, they bite more freely at a bait as the season advances. They are emigrants from southern waters, and all adults, the average weight being six or seven pounds, though sometimes they are taken even as high as fifteen pounds. According to my theory, which is founded on personal observation, those found in this latitude are the surplus production of more southern waters; for most of the Sheepshead in the Mobile and New Orleans fish-markets are small, from a half to two pounds in weight, and subjects for the gridiron rather than the pot. The restaurants of New Orleans are famous for Sheepshead, where they are broiled whole or split, and served up to a charm; and with a modicum of claret after his gumbo, a moderate eater is apt to get no farther into the bill of fare than "fish."

The food of this fish consists almost entirely of molluses; the soft-shell clam is therefore the usual bait. It is said, by the "longshore" men of New Jersey, that it can even crush a hard clam; this can hardly be doubted, when the immense muscular power of its jaws, and the peculiar arrangement of its incisors and crushing teeth, are considered. The teeth in the throat are similar to those of the Drumfish. The sheeplike teeth in front, from which it has received its name, are well adapted to nipping off the barnacles and shell-fish that adhere to sunken rocks and timbers.

In fishing for Sheepshead, it is a common practice in lower Virginia and other southern waters where they are found, to drive down stout stakes, forming an enclosure; to these different species of molluses will attach themselves in a few months, and attract the Sheepshead. When they have made it a place of resort, the fisher ties bis boat to a single stake on either side, at a convenient distance, and throws his bait towards the pen. 
In fishing with a hand-line, which is the usual mode of taking him, the Sheepshead gives one or two slight premonitory jerks, and then a steady pull, when the fisherman gathers in his line as fast as possible, the fish coming along with a heavy drag. When he approaches the boat, there is a desperate contest; there is much probability of his breaking the hook, or his quick downward lunges are apt to snap the line; then the fisher takes in slack, or lets the line run through his fingers, as the action of the fish dictates, and, when a proper opportunity offers, throws him into the boat, where he flounces until the transfer to a new element deprives him of life.

Along the coast of the Gulf of Mexico, they are frequently taken with rod and line, as they are by New York anglers in the vicinity of that city. A bout rocks and precipitous banks, when there are no obstructions to a fair contest, a stout rod of eleven or twelve feet, a strong hemp line on a good multiplying-reel, gimp snoods, and stout Virginia hooks, are used. His pull is at first strong and steady, but as he comes to the surface, his lunges are quick and desperate; still, by keeping a steady strain on your opponent, and yielding to his downward plunges as he approaches the boat (which is done better with the spring of a rod than with a hand-line), he at last gives in; and when he is lifted aboard, and in your basket, he weighs something.

An accomplished angler of New Orleans, whose hospitality I have partaken of at his summer residence at Pass Christian, on the Gulf coast, says he has taken Sheepshead frequently at the mouth of Wolf River, in company with Black Bass, with a float on his line, and that they lie about the thick branches of trees that have fallen in. From this it would appear that they habitually come into brackish water, in search of crustaceous animals or molluses, which fasten themselves to any stick or branch in the water along the southern 
coast; and that Bass, whose natural habitat is fresh water, meet them here on common feeding-ground.

Mr. Bull, a noted angler of New Orleans, assures me he has taken fourteen Sheepshead, whose average weight was seven pounds, in the course of an afternoon's fishing at the breakwater, not over a mile from the steamboat landing, at the terminus of the Ponchartrain Railroad. The bait he uses are large shrimp, fiddlers, young crabs, and muscles. After the prevalence of strong south-easterly winds, large schools have been known to come in shore along the piers of the abovementioned landing, and numbers of them have been taken for some days, when they suddenly disappear in search of other feeding-grounds.

The excellence of this fish is so universally conceded, that I do not deem it necessary to say a word in praise of it, whether boiled or baked. It is considered by sorne equal to Salmon, but, like "Midshipman Easy," I am disposed to " argue that point." 


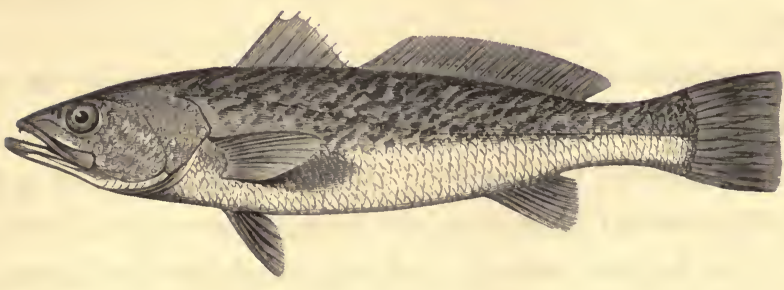

\section{WEAKFISH. SQUETEAQUE. SALT-WATER TROUT.}

Otolithus regalis: Cuvier.

The most striking characteristic of the genus to which this fish belongs, is its doglike teeth. There are four species: Regalis, Thelassinus, Nothus, and Carolinensis, described by Dr. Holbrook as common to the coast of South Carolina; the second and third species were established by that ichthyologist. The first two closely resemble each other in appearance, and the second ( 0 . thalassinus), if taken in the waters of the New Jersey coast-as doubtless it is-may be easily confounded with the first ( $O$. regalis), which figures at the top of this page. Though closely resembling each other, Dr. Holbrook says they differ in their habits; that 0 . thelassinus is found only in the ocean, that it approaches the bays and inlets along the coast, and that it is a larger animal.

Otolithus nothus is described by Dr. H. as entirely white and silvery, and wanting the markings or spots of other species. Otolithus Carolinensis is marked with numerous spots on the upper half of its body, as well as on the dorsal and caudal fins; which doubtless suggested the name of "SaltWater Trout" at the South.

The species of our coast differs from those of the same genus 
found in Europe; the former having canine teeth only in the upper jaw, whilst the latter have them in both upper and lower.

The subject of these remarks-Otolithus regalis-is a fish of great beauty as regards its colors and proportions. The tints are difficult to describe; there is something of a green tint with carnate gleamings above and along the lateral line, pearly or bright metallic reflections about the throat and head, and irregular dusky markings, inclining to the formation of oblique lines, on the back and sides; the belly is white; head sharp and long; mouth large, upper jaw armed with long, sharp, recurved teeth. Form elliptical, slightly compressed; back somewhat arched. Fins; first dorsal, nine spines; second, one, short spine and thirty rays; pectorals, sixteen; ventrals, one spine and five rays; anal, one spine and thirteen rays; the caudal has seventeen rays, and is very slightly convex.

WEAKFISHING.-No salt-water fish of this latitude affords more sport than this big-mouthed denizen of our bays; and it is only the freedom with which he takes the bait, and the great numbers that are caught, that causes Weakfishing to be undervalued. Though he has not the strength and endurance of the Rockfish, his first rush is not less vigorous; and as his mouth is somewhat tender, it is necessary to give a fish of two pounds some line. His first dash is from the boat, and ten yards of line will be run out in a "jiffy;" he fights well and at long range if you allow him line, but bear well on him, as the least slacking of the line gives him a chance to disengage the hook, which he sometimes attempts to do by jumping above the water and shaking his head.

If angling with a float it should not be at more than threefourths the depth of the water. With a large float, and a quarter or half ounce bullet for a sinker, you may allow your 
line to be carried out by the tide some distance from the boat; thus fishing over more ground than when angling at the end of your rod with only a sinker; your chances of a bite are still more increased as your line is reeled in. An excellent plan when the fish are scattered, is to cast as far as you can, and reel your line in slowly, allowing your bait to rest awhile, and then giving two or three turns of your reelcrank, drawing the bait home by degrees. This plan, though, is objectionable if there are weeds or much grass floating about.

TACKLE.-A stout, pliant rod of twelve feet, with a stiffish tip; an easy-running reel, with fifty to a hundred yards of fine flax line, and stout gut leaders; the hooks should be as large as 00 .

BAITs.-Soft crabs beyond all comparison are the most certain; though a white piece of fish-bait,* with the skin adhering to make it stay on the hook, or even the eye of the fish will answer, if they are well on the feed.

Great numbers of these fish are taken with the hand-line by what is called "drifting:" that is, to sail into a school of them in a tideway, and letting the sheet go, allow the boat to drift while you fish over the sides at half depth. If the boat drifts faster than the school, she is put about and the fish found again.

The flesh of the Weakfish is not held in much esteem when other fish are to be had, and soon spoils after being taken, though it is rich and gelatinous if it is eaten soon. They are generally fried or broiled.

* I have had occasion to mention this bait frequently in my remarks on angling for different kinds of fish, and would here say that it is not generally appreciated. Most of our game fish are predatory in their habits, and the first impulse is to seize the bait if it is attractive in its appearance : they do not wait to taste it, as some persons suppose. 

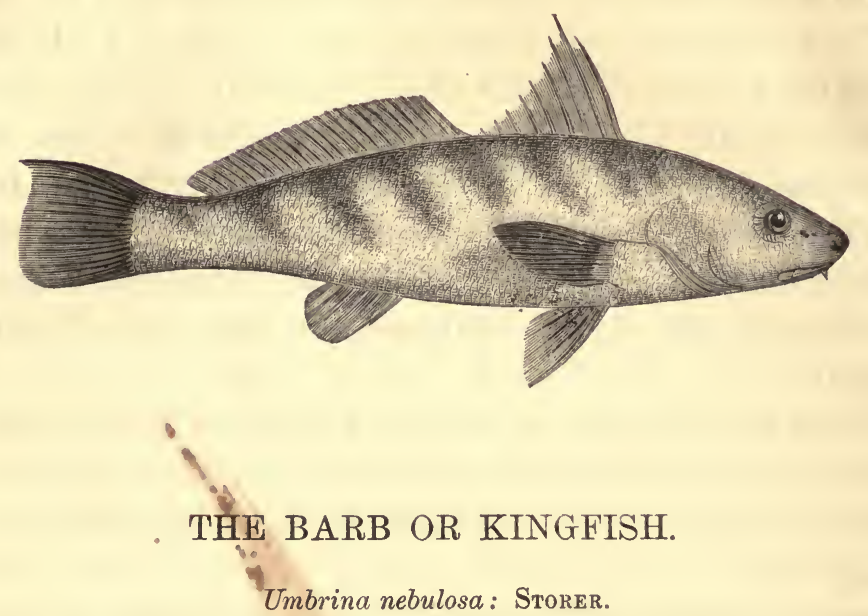

There are two species of Barb or Whiting described by Dr. Holbrook, with various synonyms to each; the specific name of the northern 'species, however, signifying cloudy, adopted by Storer, in his report on the fishes of Massachusetts, will strike the angler as the most appropriate for the animal figured above.

Umbrina littoralis, described by Dr. Holbrook, is peculiar to the waters of the South Carolina coast, and said to be seldom taken with the hook. It is entirely white and silvery, without the clouded markings of the northern species. The fish he describes as Umbrina alburnus, is identical with the animal pictured above; both species are called Whiting at Charleston.

This fish (Umbrina nebulosa) has a body elongated and tapering, the section nearly sub-triangular; back gracefully arched; belly nearly staight; color gray, with purplish reflections. There are six or more oblique bars over the back and sides; belly clouded white; head small; mouth small, and beneath: 
a single wattle or cirrus under the chin, which is no doubt an organ of feeling or touch in procuring its food. Its average weight is a pound, though sometimes taken as high as two pounds. Fins : first dorsal, ten spines, of which the third is much attenuated, terminating in a filament; second dorsal, one weak spine and twenty-five rays; ventrals, one spine and five rays; pectorals, twenty rays; anal, one spine and eight rays; caudal, eighteen rays.

Professor Baird says the young of this fish have been taken at Beesley's Point, near Great Egg Harbor. Their almost total disappearance from our bays for successive summers, and then their sudden reappearance, has led me to the belief that most of them are emigrants from the south. Like most of the Scienoids, they are evidently mollusc-eating fish; for they are always found near muscle-beds. The smallness of the mouth, however, and the absence of crushing teeth and incisors, suggest the belief that they feed entirely on seedling: muscles and clams, and small crustacea. They are found mostly in the coves, and on the sand-bars and flats, where there is little current, and not often in the channels or deep tideways.

BARB Fishing.- In angling for this fish, a good bass rod of twelve feet is best; a light sinker is sufficient, say a bullet of a quarter or half ounce, which should be placed at the bottom of the reel-line, where two snoods, one of twelve and one of twenty-four inches, with No. 1 or 0 Kirby hooks, should be attached. The sinker should touch the bottom, where the fish generally seeks its food. When on the feed, it seizes the bait without nibbling, but frequently there is a premonitory shake, then a vigorous pull, and under goes the tip of the rod; after a stout resistance, your prize is brought to the surface and alongside the boat, but the least slacking of the line, and he is off again, and in the second round is 
almost as game as at first. As he has leathery lips, and the hold is generally strong, he is lifted in with small risk of losing him.

When fishing for Barb, it is well to use a No. 1 hook at the bottom, and loop on one of 00 size to a gut length, eighteen inches or two feet above the sinker, for Weakfish, as the angler sometimes takes both at the same time. Soft crabs or soft-shelled clams are the best bait.

The fish is much lauded by the epicures of New York, where it has sometimes been sold at as high a price per pound as Sheepshead. It is seldom boiled, and is better cooked in the pan or on the gridiron. It has a peculiar sweetness of flesh and a richness of flavor; as all fish that feed on molluscs and crustacea have.

When on a visit to Long Beach in August 1855, a brother angler and myself had great sport with Barb in the cove just below the Hotel. They had not been taken in numbers for some years, and had become comparatively a rare fish, until we met with them. In a few hours on the ebb we took upwards of three hundred weight with two rods, and left off from mere satiety, for the certainty of hooking them as fast as our bait found the bottom ceased to be sport. 


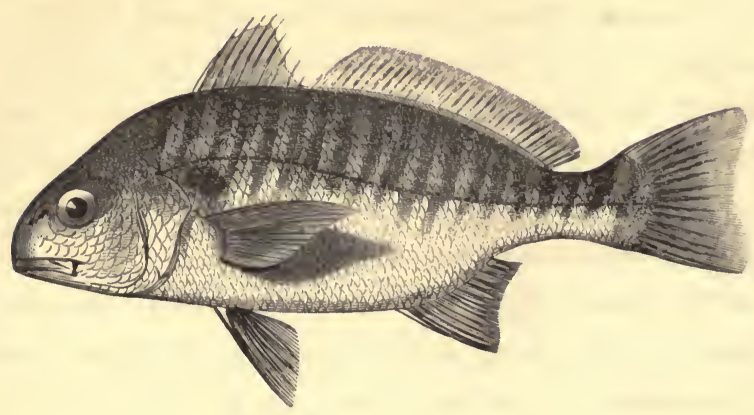

\section{SPOT, PIGFISH, OR GOODY.}

Leiostomus obliquus: CUvier.

Body compressed, oval; back arched anteriorly; belly straight to first ray of the anal fin; head large. Color : back gray, shading to a yellowish-bronze at the lateral line; sides brownish-yellow; belly light yellow. There are twelve or more oblique bars extending from the top of the back to a small distance below the lateral line, which is concurrent with the back. It has a distinct dark-brown spot above the posterior point of the opercle. Fins: first dorsal, ten spines; second dorsal, one short spine and twenty-nine or thirty soft rays; pectorals, eighteen; ventrals, one spine and four branched rays; anal, two spines and twelve rays; caudal, eighteen. The mouth is small; the upper jaw is set with small, obtuse, conical teeth; so also are the pharyngeal bones.

De Kay gives this fish the local name of "Lafayette Fish," from its having first been found in the waters about New York, at the time of General Lafayette's visit to America. Holbrook, in his Ichthyology" of South Carolina, calls it by the common name of Chub, which of course will strike any fresh-water angler as a misnomer. The most common name 
along the New Jersey Coast is "Goody." It is known at Lewes, Delaware, where it sometimes appears in great numbers, as the "Spot," from the mark near the gill-cover. It frequently happens that its annual visits are almost, or totally suspended for a season or two. Like all emigrants from the southern part of our coast, it is more abundant during some summers than others.

From the description received from Southern friends, of the "Pigfish" or "Hogfish," so renowned in the lower waters of the Chesapeake for its flavor, and its grunting or croaking noise when caught, it is doubtless the same.

Few salt-water anglers fish for them as a matter of choice, preferring the larger and less edible fish, for their size, as they give more sport; while the little Goodies frequently linger around and nibble off one's bait, when the Weakfish or Barb cease biting. At such time it is well to be provided with small perch-hooks, which can be substituted for the larger, and tied on, one a foot and the other two feet above the sinker (a half-ounce bullet), and baited with small mites of fish or soft crab, and the float dispensed with. If they are frightened away by the reappearance of larger fish, they will return as soon as the school passes on, and bite as freely as before. In angling for Weakfish, I have often made a profitable operation by thus changing my hooks, catching dozens of these delicious little fellows expressly for the pan. For richness and flavor, no pan-fish surpass them. The hooks should not be larger than No. 2 or 3 Kirby; the long-shanked or what is called "weak-trout hooks" are best. They strike hard, pull vigorously, and bend the rod well, for fish of such small dimensions. They are often taken in company with small Porgies and with the same tackle. They are frequently found in July and August, on the flats between the hotel at Long Beach and Tuckerton, New Jersey. 


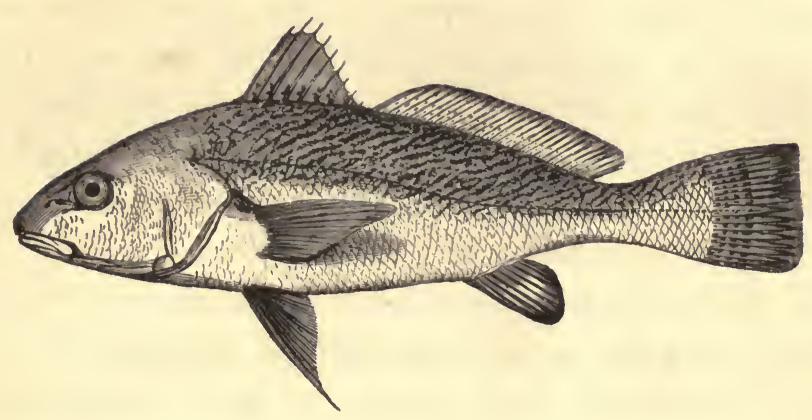

THE CROAKER. GRONIER.

Micropogon undulatus: CUvier.

My acquaintance with this fish commenced twenty-five years ago, in Lake Ponchartrain. I have never seen it north of that water, though Dr. Holbrook says "it is known to inhabit the waters of the United States from Virginia to Lake Ponchartrain, near New Orleans."

Form elliptical, tapering towards the tail; back arched; belly straight. Head large, rather long; minute cirri under the chin. Color, silvery gray on the back and sides, with undulating or irregular lines of dark spots, or rather markings, reaching below the lateral line; belly white. Fins; the first dorsal has ten spines, the second twenty-eight rays; pectorals, fourteen; ventrals, one spine and five rays; anal, two spines and eight rays; caudal, eighteen rays. There are two or three longitudinal rows of spots, or minute blotches, on the dorsal and caudal fins.

Croakers are taken in great quantities in the bays and lakes which connect with the Gulf of Mexico. In Lake Ponchartrain, Lake Borgne, Mobile Bay, at Pascagoula, and Pass Christian, they are found in great abundance. In 
fishing for them, a slight, pliant rod, with a stiffish tip, should be used, with or without a reel (though the reel is preferable, as his giant congener, the Redfish, may take a fancy to your bait), a float or not, as the depth of water, the wind, or current may dictate; hook, No. 2 or 3 Kirby; bait, shrimp, crawfish, or soft crab; the first is preferable, peeling the shell off, and baiting with the white body.

At New Orleans anglers expect them generally from the middle of April to the first of May, and catch them in Lake Ponchartrain until autumn. I have anchored off the lighthouse at the end of the Shell Road a mile from shore, and with a pleasant breeze to soften the heat of the sun, a light fifteen foot cane rod, a pitcher of ice-water, a good segar, and a quiet companion, I have passed a pleasant morning and had fine sport.

The most approved way of cooking Croakers, as adopted by the New Orleans restaurateurs, is to fry them in sweet oil ; the vessel being so large as to float the fish, not allowing them to touch the bottom or sides; cooked thus they are highly and deservedly prized. 


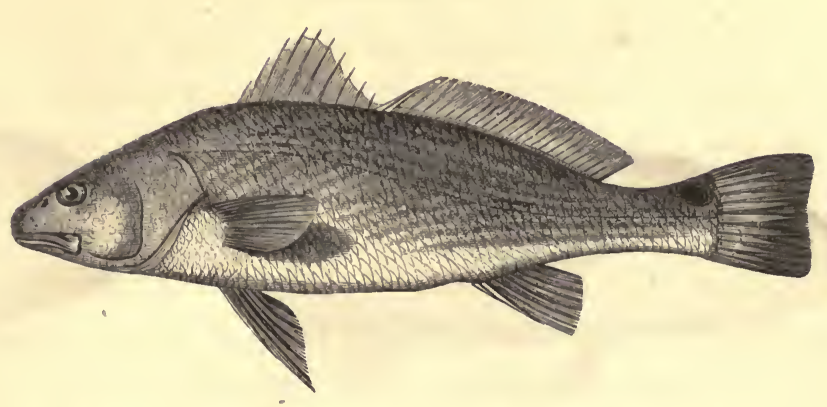

REDFISH OF THE GULF OF MEXICO.

Corvina ocellata.

Holbrook, in his Ichthyology of South Carolina, says, of this fish, "it is of a beautiful silvery color and iridiscent when taken from the water." In the gulf it is invariably red, and retains that color until it is cooked; but, from the above, appears to assume an entirely different tint in the neighborhood of Charleston.

These fish are exceedingly numerous in the waters of the gulf; at Charlotte harbor, they come into shallow water in such numbers that they are easily speared.

Although many persons esteem it a good fish for boiling or baking, or in a "cubrion" or chowder, I have always found its flesh stringy and lacking flavor, and in no way comparable to its little kinsman of frying-pan celebrity, the Croaker. They are angled for with the same tackle, and much in the same way, as for Barb or Weakfish; they generally take the bait near the bottom. As those taken with the hook and line are usually large-sometimes as long as twenty-four and even thirty inches-they afford fine sport. They strike boldly, and run off thirty or forty feet of line at the first dash; as the mouth is fleshy, they are seldom lost when fairly hooked.

A rod of fourteen feet, fifty yards of good silk or hemp line, No. 00 Kirby hook, and a large float, are generally used. 


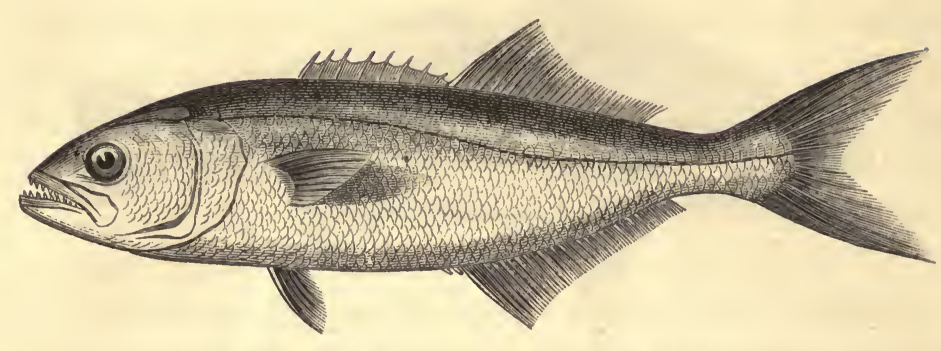

BLUEFISH. SNAPPING MACKEREL. SKIP-JACK. TAILOR.

\section{Temnodon saltator.}

Body oblong, compressed, thicker above, and almost as sharp below as the Shad, though the belly is not as completely carinated. Head large, profile slightly convex; mouth large, lower jaw slightly longer than the upper; both jaws are armed with straight, compressed, lancet-shaped teeth, the upper jaw having also an internal, but less extensive, row; the vomer, palate, and pharyngeal bones have minute brushlike teeth. Branchial rays, seven. Fins: the first dorsal has eight weak spines, which Holbrook says are enclosed in a sheath or groove; this I have failed to observe; the second has twenty-seven rays; pectorals sixteen rays; ventral, one spine and five soft rays; anal, twenty-eight soft rays; the caudal is deeply forked; has twenty rays, and is covered threefourths of its length with minute scales. Color, green on the back, shading gradually to a silvery white on sides and belly.

This fish sometimes reaches the extreme length of three feet, though the average of those taken in our inlets and bays is not over two or three pounds.

Bluefish are found all along the Atlantic coast from Maine to Florida; the smaller fish frequenting the bays and inlets; the larger are found outside, but within soundings. 
This is one of the most active and unyielding fish that swims. To use the words of Nimrod Wildfire, "he can jump higher and come down quicker, dive deeper and stay under longer," than any other salt-water fish of its size. Look at his clean build, and it is accounted for; his narrow waist and depth of hull falling off sharply as it approaches the keel, enabling him to keep well to windward, as if he had his centre-board always down. See his immense propeller behind! No fish of its size is more wicked or wild when hooked. I have sometimes struck a three-pound Bluefish, and thought I had a six-pound Weakfish on, until he commenced jumping, and after giving him considerable play, have at last (with full confidence in my tackle) drawn him in by sheer force, with his pluck not the least abated.

Though the Bluefish is seldom angled for "per se" (as President Tyler used to say), with rod and line, he frequently comes into the swim of the salt-water fisher when he is angling for Weakfish or Barb. Then look out for your snood! one nip with his sharp incisors, and it is cut off "clean as a whistle." On such occasions, brass wire or gimp snoods are your only security.

SQUIDDING FOR BLUEFISH.-The usual mode of taking this fish is by squidding. The squid is generally a white bone with a hook at the end, or a piece of pewter, which is kept bright by scraping it occasionally; the line is of strong hemp or cotton. With a good breeze when crossing a school of these fish, the sport is highly exciting, and great numbers of them are sométimes taken.

The Bluefish is not esteemed as food. It is extremely predatory in its habits, swimming in schools, and causing great havoc amongst Mossbunkers. Barb and Weakfish, even, are not secure against the attacks of the larger ones. 


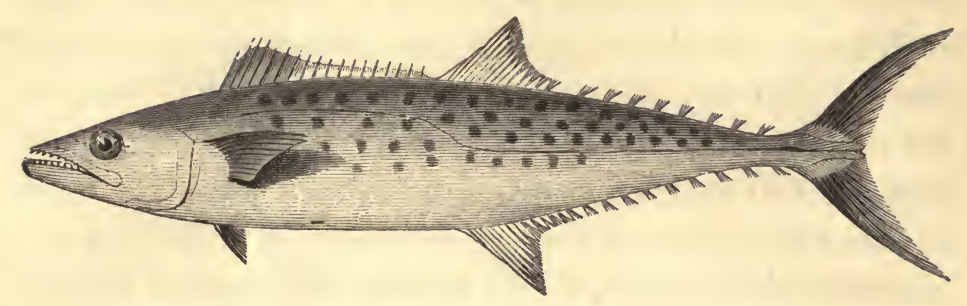

\section{SPANISH MACKEREL. BAY MACKEREL.}

Cybium maculatum: Cevier.

No adequate idea of this graceful and brilliant fish can be conveyed by description. or engraving, to one who has not seen it.

Its body is an elongated ellipse, somewhat compressed; its section oval; head small and long; mouth large; each jaw armed with long pointed, but compressed, teeth, inclining forwards. There are very small teeth on the vomer, palatine, and pharyngeal bones, as well as on the tongue. Color: greenish-blue on the back, shading away into a grayish pearly hue, but slightly roseate along and below the medial line; belly white, like molten silver or mother-of-pearl. It has a series of rows of dark but shining spots extending along the back and sides, from the pectorals almost to the caudal. The first dorsal fin has eighteen short weak spines; the second has one spine and fifteen rays; pectorals, nineteen rays ; ventrals, one spine and five rays; anal, two spines-not sharp—and fifteen rays; caudal, twenty or twenty-two rays. The tail has a carinated projection on each side, extending along the peduncle to the anterior curve of its caudal, which is deeply lunate, or crescent-shaped. 
A Spanish Mackerel which cost me the moderate price of sixty-two and a half cents, on the last day of August three years ago, weighed just four pounds. It was twenty-two inches long exclusive of the caudal, and eleven in girth. I found several small Mossbunkers in its stomach in various stages of decomposition; the tails of those last swallowed had scarcely disappeared down its throat.

This fish attains an extraordinary size on our coast and in the Gulf of Mexico. It is considered one of the greatest delicacies of the fish kind amongst us, equalling even the Shad or Pompano. Yarrell, in his work on British Fishes, says that the Spanish Mackerel taken off the coasts of England and France does not exceed fifteen inches, and is an indifferent fish on the table.

The Spanish Mackerel is truly a pelagian fish, and seldom enters even our salt-water bays for any distance. It is comparatively scarce in this latitude, and is found here only in August and September, but it is more common towards the south. In the Gulf of Mexico it is sometimes taken with the shrimp for bait, at the end of the long piers where steamboats land, in going from Mobile to New Orleans. I have heard southern anglers say that on a pliant native reed pole it furnishes rare sport. If they could be found in any great numbers, and were fished for with fine tackle and all the necessary appliances, they would no doubt afford splendid angling. A Salmon-rod and a good casting-line, with a fly of red and white feathers at the end, would take them without fail.

I have eaten Spanish Mackerel boiled, but it bears no comparison with one of the same when broiled; by the latter mode, the juices which impart so delicious a flavor are retained. It should be split on the back, as the Shad, when broiled; and the dish garnished with bits of fresh lemon when it is served up. 


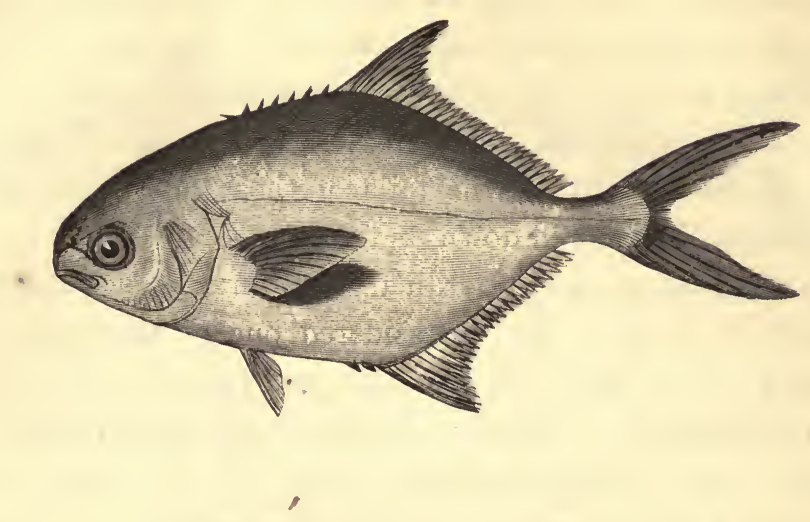

\section{THE POMPANO. CREVALLE。}

Barthrolomoeus pampanus: CUVIER.

This fish has not been described in any previous American work on Angling, and is unknown to the piscine epicure of the north, unless he has had the good luck, in some southern tour, to test its exquisite delicacy and flavor. For these reasons $I$ take pleasure in giving it a place.

The Pompano is a species of the Mackerel family, and no doubt a free-biting fish; though the fact of its feeding at the bottom must make it a fish of less interest to the angler than its congener, the splendid Spanish Mackerel, which lives on the small fry that swim near the surface.

I have often desired, but never had the good fortune, to examine a specimen just taken from the water, as those brought to New Orleans, where I have seen them, had been caught some hours. I have therefore given a reduced copy of Dr. Holbrook's representation of this fish, without his scientific description, believing that the wood-cut will convey a more correct idea of the Pompano to the angler than a scientific account of it. The naturalist just mentioned says: 
"The Crevalle or Cavalli makes its appearance in the waters near Charleston in the mouth of April or May, and remains during the summer or late in October, and even longer if the summer is warm. It feeds on various kinds of molluscous as well as crustaceous animals, and takes the hook greedily when baited with clams, shrimp, \&c., \&c."

This fish sometimes grows to the length of twenty inches, though fifteen is as long as the average.

\section{THE DRUMFISH.}

\section{Pogonias cromis : Cuvier.}

"The prominent characteristics of this "big fish" are the number of cirri under the chin, and a black spot near the base of the pectoral fin. It attains an immense size, frequently a length of four feet, and a weight of seventy pounds. It is sometimes taken in the surf at our Atlantic bathing places, the fisher casting his line in a coil, beyond the breakers, and drawing it in. When a Drum is hooked, there is a stubborn contest, the fisherman gathering in or giving line as the occasion demands, and it is only after an exciting and tiresome combat that the fish is subdued and brought to the beach.

\section{THE FLOUNDER.}

The Flounder can hardly be called a sporting fish; still, when other sport cannot be had, it affords some pastime to one who angles with a stiff tip. Its flesh is close, firm, and of excellent flavor. The large ones are best when broiled. 


\section{THE SEA-BASS AND THE BLACKFISH.}

These are taken mostly with the hand-line, and are only sought for by the angler when fish of gamer qualities are not to be found. The Sea-Bass and Blackfish are both plucky fish. They are good in the pan, being firm of flesh. A rod with a stiff tip is required; they are angled for without a float. A sinker or dipsy suitable to the force of the current is required; the hooks, No. 1 or 0 Kirby, made of stout wire; clams, either soft or hard shell, are used for bait.

\section{THE MULLET}

De Kay mentions four speeies of Mullets: the Striped, the White, the Spotted, and the Rock Mullet. The Striped Mullet found in Lake Ponchartrain is the only species I have ever taken with hook and line. It is a shapely fish, elongated, with the line of the belly more curved than the back. Bluish on the back, silvery sides, with rows of dusky spots extending from the opercles to the tail. It has two dorsal fins, the first with four weak spines. It is found only in salt or brackish water. The fresh-water fish known as the Barred Mullet, which never takes a bait, is a species of the Sucker family.

In the Gulf of Mexico and contiguous waters, Mullets swim in large schools, and are generally taken with a cast-net. Sometimes they appear near the surface of the water, when they will frequently jump at a white rag or cotton wrapped 
around the hook; at such times they would doubtless take a white or light-colored fly.

As an article of food they are not generally esteemed, though the roe, which is very large, is prized by some persons.

\section{THE TOM COD, OR FROSTFISH.}

This fish is very abundant along the New England coast in autumn. After the first frost they become almost torpid in shallow water, and can sometimes be taken with the hand; they have even been thrown ashore with a common rake. They are sometimes taken in deep still holes, by those who persist in using a rod in all kinds of fishing. The tip of the rod should be rather stiff; and one should strike sharp and quickly, as they do not seize the bait with much avidity.

The flesh is very tender and delicate, and resembles that of the Codfish in its flaky whiteness; they are generally fried, but this should be done with care, for if overdone they are dry and unpalatable.

\section{THE PORGY.}

\section{Pagrus agyrops: Covier.}

Body ; compressed, oval, arched above anteriorly. Color ; bluish-green on back, shading lighter on sides; belly, silvery white. Head large; mouth small, with incisors and rounded molars inside. The dorsal fin, which is continuous, has thirteen stout spines and twelve soft rays, which close completely in a groove; the caudal is forked, and has seventeen rays; pectorals, seventeen; ventrals, one spine and five 
branched rays; anal, three spines and twelve rays, closing in a groove, though not so entirely as the dorsal.

This sedate-looking little fish is taken with bottom tackle. The hooks should be small to suit the mouth, as they are great nibblers, and often annoy the angler when fishing for Barb or Weakfish.

The Porgy is an excellent pan-fish, and would be more in favor if it was not so common.

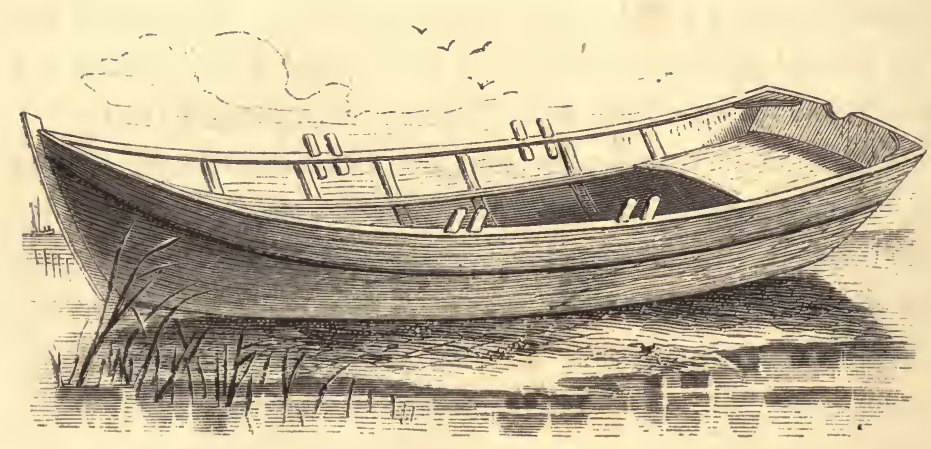


CHAPTER XI.

F L Y - T A C K L E. 
"Sing, sweet thrushes, forth and sing!

Have you met the honey-bee

Circling upon rapid wing

Round the angler's trysting-tree?

Up, sweet thrushes, up and see!

Are there bees at our willow tree?

Birds and bees at the trysting-tree?

"Sing, sweet thrushes, forth and sing!

Are the fountains gushing free?

Is the south wind wandering

Through the angler's trysting-tree?

Up, sweet thrushes, tell to me!

Is there wind up our trysting-tree?

Wind or calm at our trysting-tree?"

STODDART.

\section{"AND the pleasant watercourses}

You could trace them through the valley,

By the rushing in the Spring-time,

By the alders in the Summer,

By the white fog in the Autumn,

By the black line in the Winter."

LONGFELLOW. 

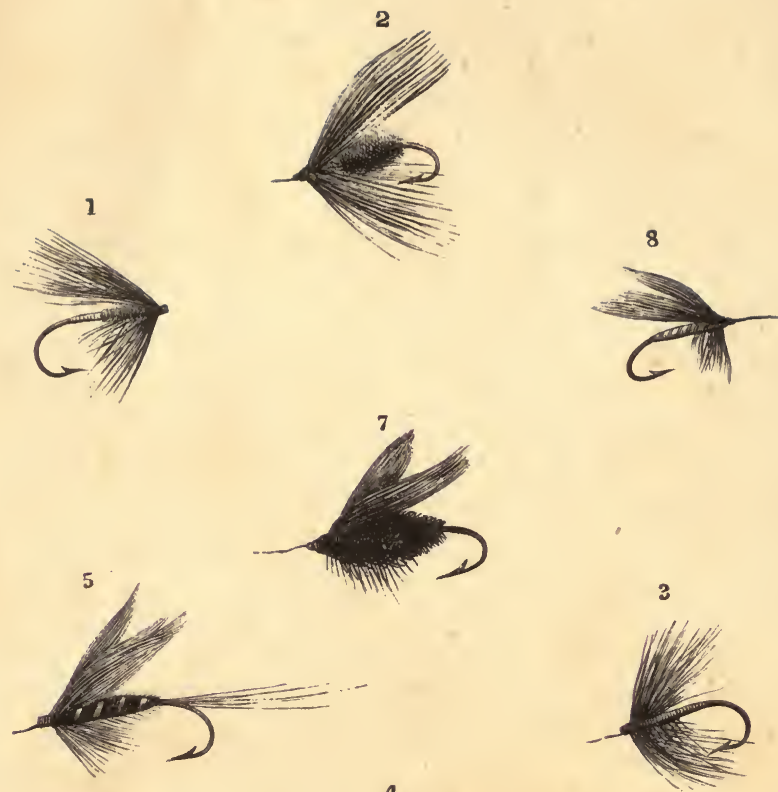

4
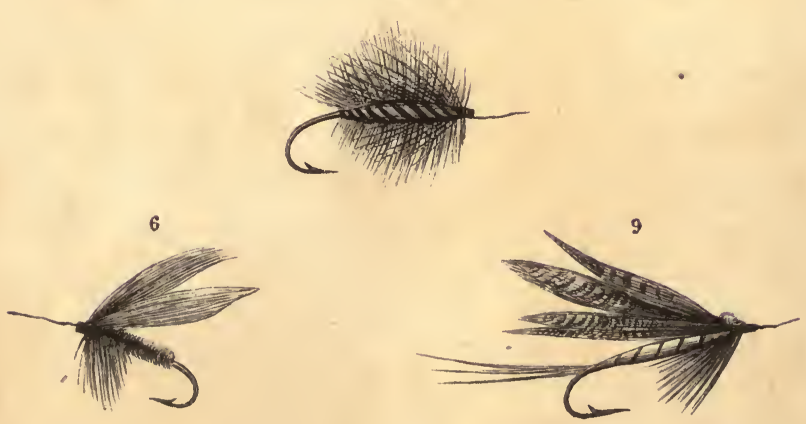

TROUT FLIES.

1. Ginger Hackle.

C. Coachnian.

2. Grouse Hackle.

7. Alder Fly.

3. Dotterel.

8. Yellow Sally.

4. A J'almer.

9. Gray Drake-A May Fly.

5. Red Syinner. 


\section{CHA PTER XI.}

TROUT FLY-FISHING.-OUTFIT AND TACKLE.

Wading-Jacket. - Trousers. - Boots.-Creel or Basket. - Landing-Net.Rods.-Reels._Lines.-Leaders.-Flies.-The Whip.

WADING-JACKET.-This article of dress, though it may not contribute to the angler's success, will, when made with an eye to convenience and comfort, add much to his satisfaction in fishing. It should not reach lower than his hips, and should be sufficiently loose for a top-coat in travelling. It should have pockets on the inside and outside of the skirt, also an inside and outside breast-pocket, the latter sufficiently large to hold a fly-book. In the choice of his dress, the angler should avoid any glaring color, emulating rather the gray mists of the morning, or the "gloamin" itself.

WAdING-Trousers should be of heavy, strong woollen material, to stand the usual wear and tear in wading rough streams.

WADING-Boots.-Avoid, by all means, those abominable long India-rubber boots that come up to the hips; they are cumbersome and slippery, and limit the depth of one's wading. They are certainly water-proof, if they are not cut through by sharp stones; but in the event of a fall, which is likely to occur to the wearer, or wading an inch deeper than the height of his boots, their imperviousness to water becomes an objection, and it is as hard to get the water out as it was for it to get in. I have seen an angler, who insisted on using 
thern, after getting a fall, lie on his back and elevate his heels into the air, forming a humanized letter $\rightarrow$, and the water which ran out of his boots, ran down, or rather up, his back. Do not be persuaded to try a pair of them; if you do, to use the expression of an Irish friend, "you will come to grief;" but go to your bootmaker, and get him to make you a stout pair of double-soled lace-boots, to come above and fit snugly around the ankle; have only one heel-tap, and stud the soles (not too thickly) from toe to heel with soft iron hobnails, such as are used by foundrymen and forgemen to protect the soles of their shoes when treading on hot iron. The soft iron of which these nails are made gives a firm hold on slippery rocks. Stout woollen socks or stockings should invariably be used to wade in; they are softer and feel warmer than cotton when wet.

The CReel or Basket should be of the usual shape, to fit one's side, and of capacity for fourteen pounds of trout; this size is convenient for stowing wading-shoes and trousers in, and a bottle of claret or anything else may be securely rolled in the trousers, when packing up for an excursion.

The "top-tile" should be a drab or light-gray mixed felt hat, with a twisted string, as well as a band (or in place of a band), which is convenient to tuck flies under, when one is changing them, and does not wish to return them wet to his book.

LANIING-NET.-I have tried many nets that were recommended as handy and easily carried, and, after many experiments, at length hit on the following simple expedient, which I will try to describe: When preparing for an excursion, put into your rod-bag, or lash on the outside of it, a piece of rattan the size of your little finger, and about four feet long. On arriving at your quarters, bend it in the middle, and, after slipping the net on, bring the two ends together so as to form 
a handle, as represented in the larger figure of the annexed illustration, and then take a few turns of waxed twine near the bow, and again at the end of the handle, fastening in a leather tab with a button-hole. It is to be suspended by a button sewed on the back of your coat below the collar. It does not annoy or impede your progress, and is ready for use when required; a bow ten or twelve inches in diameter, and a handle six or eight inches in length, is sufficient. Where
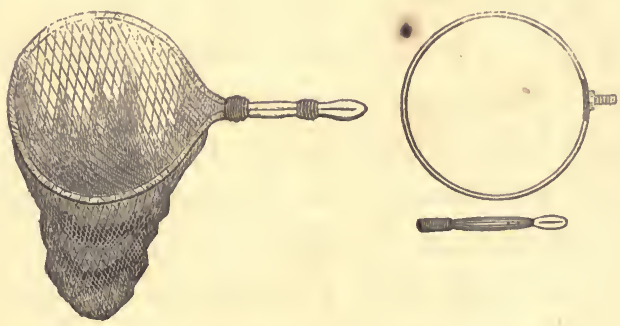

the two surfaces of the rattan come in contact, pare off a thin strip from each, to make them lie together snugly; but do not take off enough to impair the strength of the handle.

A more sightly net can be made as follows [see the tigure to the right]: Bend a piece of rattan thirty inches long into a circle, sticking the two ends into a brass tube, which has a screw on the outer circumference; this screw is fitted into a nut in the end of a ferule fastened on the end of a short handle. The handle can be unscrewed, and the net may be packed in the creel by slightly compressing the bow. It is carried, when fishing, in the same way as the net before described, buttoned to the wading-jacket by a tab.

For fear I may fail to mention it elsewhere, I woúld here impress on the angler the convenience, and, as it frequently turns out, the absolute necessity, of having fine and coarse silk and twine in his pockets, as well as the indispensable lump 
of shoemaker's wax pressed between the folds of a stout piece of leather, for it may be that he will have to splice his line or rod, or repair other damage.

FLY-RoDs.-There is as great a diversity in the size and flow of the waters where Trout are found, as there is in the size of the fish found in them; it is therefore expedient for an angler who fishes all waters, to have two rods for casting the fly. For the rivers and lakes of Maine, the streams of Canada, and wherever Trout are found in large waters, a good stout rod of not less than twelve and a half or thirteen feet is best; it should weigh at least twelve ounces. Though withy, it should have a stiffish tip; the line, leader, and flies required in such waters being larger than the fly-tackle in general use. For the lively tributaries of the Susquehanna, Delaware, and Hudson, the streams of New England, and for brook-fishing generally, where wading is necessary, a rod from seven to nine ounces in weight, and from twelve to twelve feet four inches long, is most suitable. A rod of this size is so light, that incessant casting does not weary one, and the size of the fish does not make a rod of greater power necessary.

Having a preference for such streams as last mentioned, I give my notion of what a rod for such fishing should be, from one made for my own use. Using a scale with minute fractions of an inch and a pair of callipers, I find the diameters at various distances from the lower end of the butt, as follows:-The grasp of the rod, say at eight inches from the lower end, is one inch; at eighteen inches, $\frac{15}{3} \frac{5}{2}$ at twenty-four inches, $\frac{13}{3} \frac{2}{2}$; at four feet (the first ferule), $\frac{11}{3} \frac{1}{2}$; at six feet, $\frac{9}{3 \cdot 2}$; at eight feet (the splice, or upper ferule), $\frac{7}{3 \frac{2}{2}}$; at ten feet (the middle of the tip), $\frac{4}{3 \frac{2}{2}}$; at the extreme tip, $\frac{2}{3 \ddot{\Sigma}}$.

The butt of a fly-rod should be of well-seasoned white ash, the middle joint of ironwood, and the tip of quartered and 
spliced barnboo. The manner of making tips of this kind is explained in an article on "Rod Making," found in a subsequent chapter. The tip would be as efficient, though not so stiff, if twelve or eighteen inches of the stouter part were of the same wood as the middle joint.

The groove which holds the reel should be below the place where the rod is grasped by the hand. I prefer its extending beneath the ferule at the extreme butt; the "balance" of the rod is thus thrown nearer the hand, and its weight "outboard"- to use a nautical phrase-is reduced, and the fatigue of the wrist and forearm in casting is thus lessened, or scarcely felt.

To avoid the difficulty of taking off the reel, which so often occurs from the swelling of the wood, and the consequent tightening of the reel-bands, I have adopted the plan of having no sliding band, but to secure one end of the strip to which the reel is fastened by slipping it under the butt ferule, and binding down the other end with a neat braid or buckskin string, three or four turns being sufficient to hold it tight.

To provide also against a similar inconvenience, I make each joint of my fly-rods without the usual wooden socket at the lower end of the outside ferule, and consequently without any projection of the wood below the end of the male ferule, which fits into it; for the reason that wood will. swell on becoming damp, and the plug-if I may so call it-expanding inside the wooden socket, will stick fast; and the angler is under the necessity of taking his rod home unjointed, or doing sume violence to the ferules.

In fly-rods, the ferules which join the different pieces together are generally unnecessarily long, and interfere with the play and spring of the rod. There is no necessity for having the ferule which joins the middle piece to the butt more than two inches long, and that which joins the middle 
piece to the tip more than one and a half inches. It is better, if the angler has the knack and patience, to join these two pieces by a neat splice about three inches long, which should be closely wrapped with coarse waxed silk. This splice will be all the more secure by rubbing each surface where they are brought in contact, with shoemaker's wax. In the days of stage-coaches, a rod of four pieces was most convenient in travelling, but of late years, when most fishing-grounds can be reached by rail, one of three pieces is easily and safely carried, and is preferred by most anglers, on account of its having fewer ferules. The rings through which the line passes should be as light as possible, gradually lessening in size towards the end of the tip, where they need not be larger than to allow the free passage of the line.

Under the head of "Rod Making," I shall endeavor to impart to the reader whatever knowledge of suitable wood and materials I may have acquired as an amateur rod-maker; being well satisfied that the angler who has leisure. and aptness for mechanism, will derive additional pleasure from fishing with a rod of his own make.

English writers recommend that the last six or eight inches of a fly-tip should be of whalebone. The objection to this is, that when this material is reduced to the requisite size, it becomes soft and inelastic from moisture, and brittle from cold or dryness; in its former condition it is too limp to lift the line from the water with a proper spring. Some authors also recommend hollow butts, on account of their convenience for carrying extra tips; they are now as obsolete as hazel tips and wooden reels.

Such a rod as I have recommended might not stand a long day's fishing without warping, where the average size of Trout are such as Sir Humphrey Davy speaks of taking from his noble friend's preserves in the Coln or Wandle, or such as 
are to be found occasionally in the lakes of the Adirondack Mountains or Maine; but for lightness, spring, and pleasant casting, a rod of this kind is generally preferred to a heavier or stouter rod, and will meet every demand made on its strength by the usual run of Trout found in a stream that requires wading. Few anglers, after having accustomed themselves, though only for a day, to casting with a light, pliant, one-handed rod as here described, are ever satisfied to resume a two-handed rod, or one of greater length and weight.

There are many highly-finished one-handed English flyrods imported and sold by tackle stores, but they are too stiff, besides being heavier by one-third than is necessary, and so clogged with unnecessary mountings, reel-fastenings, ferules, wrappings, and varnish, that the purchaser is apt to abandon them after a few seasons' experience, for a rod of his own designing, or his own make.

The more weight or force applied to the tip of a wellproportioned fly-rod, the more the strain is thrown on the lower part ; exemplifying the principle of Remington's bridge, in which the strain is longitudinal where the timbers are small, and transverse at the abutments.

The color of a rod, if not too light, is of little importance ; it may be stained black or yellow; the latter color should never be produced by strong acids, which are apt to impair the strength of the wood. Dark woods, of course, require no staining. A neutral tint is imparted by one or two coats of common writing-fluid, of bluish tint.

Shellac, which is soluble in alcohol or ether, is generally preferred to copal varnish; it should be applied thin; the glare of the last coat should be removed from a new rod by sprinkling a little segar ashes on a wet rag, rubbing gently, and then wiping it off with clean water. 
A good plan for protecting a rod from moisture, is to give it a thin coat or two of boiled linseed oil, after staining it. The oil should be applied warm, and rubbed well into the grain of the wood. It should dry thoroughly before varnishing.

In a rod for my own use I prefer a tip rea'sonably stiff, and the middle piece somewhat slight below the ferule that joins it to the tip. This is what some anglers call a "top-heavy" rod, which makes casting easier; the tip being stiffish, lifts the line more readily from the water.

ReELs.-A small light reel, which will hold twenty-five yards of line, is best for Trout-fishing. One with a short axle, which brings the plates of the reel close together, is to be preferred; as it winds the line more compactly on the spool. I have a simple click reel of this kind, which is two inches in diameter and only three-quarters of an inch between the plates. John Krider, at the north-east corner of Second and Walnut streets, Philadelphia, generally keeps them on hand, or will have them made to order.

LINES.-A plaited or twisted line of hair and silk, tapering for the last five or six yards, is by all odds the best for 'Trout-fishing.

LEADERS.-A leader should taper gradually from the end where it joins the line, to the end to which the stretcher-fly is attached, and should be two-thirds or three-fourths the length of the rod. I prefer making my own leaders to buying them at the tackle stores. It is very easily done by soaking the gut well, and using the angler's double knot. An illustration of this knot will be found in another chapter.

FLIES.-In giving a list of flies best adapted to American waters, I have done so without reference to the opinions of English writers, considering many of their rules and theories regarding flies inapplicable to our country. The observations 
here jotted down, are rather the result of my own experience, as I have learned them on the stream and from members of our little club the "Houseless Anglers."

Much, perhaps most, of the theoretical knowledge of flies acquired by the reading angler, when he begins, is obtained from the writings of our brethren of the "Fast-anchored Isle." Every fly-fisher can read Chitty, Ronalds, Rene, "Ephemera," and others, with interest and profit. Though I do not pretend to condemn or think lightly of their precepts, drawn from long experience of bright waters and its inmates, yet if followed without modification and proper allowance for climate, season, water, and insect life here as contrasted with England, the beginner is apt to be led into many errors, corrected only by long summers of experience. So he will come at last to the conclusion, that of the many flies described and illustrated in English books, or exhibited on the fly-makers' pattern-cards, a very limited assortment is really necessary, and many totally useless, in making up his book. He will also find, after the lapse of some years, that of the great variety with which he at first stored his book, he has gradually got rid of at least three-fourths of them, as he has of the theory of strict imitation, and the routine system, (that is, an exact imitation of the natural fly, and particular flies for each month), and settles down to the use of a half dozen or so of hackles and a few winged flies; and with such assortment, considers his book stocked beyond any contingency.

An extensive knowledge of flies and their names can hardly be of much practical advantage. Many a rustic adept is ignorant of a book ever having been written on fly-fishing, and knows the few flies he uses only by his own limited vocabulary. One of the most accomplished fly-fishers I ever met with has told me that his first essay was with the scalp 
of a red-headed woodpecker tied to the top of his hook. Notwithstanding all this, there is still a harmonious blending of colors or attractive hues, as well as the neat and graceful tying of a fly, that makes it killing.

With these few preliminary remarks, I shall describe only the flies which I have used successfully, and refer the reader to the English works on angling just mentioned, for a description of the great variety known by so many different names.

Hackles and Palmers. The Red Hackle.-This is what the renowned Mr. Conroy, of Fulton St., New York, calls a "Journal-Fly," which we suppose to mean a fly for general use. It is one of the indispensable hackles. All fly-fishers, from the country bobkin to the most experienced angler, have constant use for it; few make their whip for the first cast of the season without it. It is particularly killing when the water is discolored by a freshet, at which time it is best as a stretcher on a No. 4 hook, and dressed Palmer* fashion. When used as a drop-fly, it should not be dressed on hooks larger than No. 6 or 7. It is a good fly from April to the 1st of September, after which, as Dr. Bethune righteously says, no "true-hearted angler" will wet a line in a Trout-stream. The body of this fly is made of red mohair or the ravellings of red moreen or floss silk; sometimes with yellow floss; or the hurl of the peacock, the tail tipped with gold tinsel. If dressed as a Palmer, the body is wound with gold or silver thread; gold is best. The hackle should be of the darkest natural red, not dyed.

The Soldier Haclele, from its high colors, is attractive on dark waters and deep pools, though not generally as killing as the Red Hackle; hooks, from No. 2 to 6 for stretchers, $†$ and from 6 to 9 for drop-flies. $\dagger$ It is better dressed as a Palmer,

* For an illustration of a Palmer, see figure 4 on plate of Trout-Flies.

$\dagger$ For explanation of "stretcher" and "drop-fly" or "dropper," see article "The Whip," a few pages further on. 
the body of red or crimson mohair, wrapped with gold or silver thread; hackle dyed crimson. It is seldom used as a drop-fly.

The Brown Hackle is scarcely inferior to the Red. I have used it with great satisfaction on the subsiding of a freshet, when the water had become rather bright for the Red Hackle, on the same sized hooks, and especially as a stretcher, from 9 A. M. to 4 P. M. The hackle of most appropriate color for this fly is not easily obtained. I have sometimes found it on the necks of eapons, which are brought to our market picked, with the exception of the neck and head. What is termed a furnace-hackle is frequently used in tying this fly, for a cock with brown hackles on his tail-coverts is seldom found. I invariably dress the body of the Brown Hackle with the darkest copper-colored peacock's hurl, the tail tipped with gold tinsel.

The Ginger Hackle.-The hackle used for this fly is a yellowish or a very pale red; it is frequently taken from the neck of a cock whose tail-coverts are of a tint deep enough for the Red Hackle. The Ginger Hackle is better used as a drop-fly than as a stretcher; the body should be of dubbing of the same color as the hackle, and wrapped with silver thread if it is used for a stretcher. When it is used for a dropper, the body may be of orange or lemon colored floss silk; the latter tint is preferable towards sundown. The hook used should not be larger than No. 7 ; No. 9 or 10 is not too small on still, smooth water. Where the hackle is very pale, this fly will kill as long as you can see it on the water. It is sometimes dressed Palmer fashion, though I do not like it so well as when it is tied simply as a Hackle. I generally tie it-as I do most Hackles-on a Kirby hook, on account of its superior hooking qualities.

Black Hacleles are better for drop-flies. As they are used. 
chiefly on fine water, or on bright days, or at midday, they should be dressed on small hooks, say from 8 to 10 or even 12 (Kirby). I prefer the bodies of copper-colored peacock hurl, though black mohair is generally used. The bodies of this fly are also made of orange and red floss silk; they are sometimes dressed as Palmers, and ribbed with silver or gold thread or tinsel, or with coarse red or orange silk.

A Grizzly Hackle is a good drop-fly on a bright day towards noon; it is best on a body of black floss or mohair. The hackle for this fly is a mixture of black and white-the darker the better. It is obtained mostly from the neck of the cock. It is good on bright water, and more appropriate for a dropper.

A pale yellow mottled, or barred Hackle, with light yellow silk body, is a good evening fly. I sometimes tie it on a No. 10 or 12 Kirby hook. It comes into play with great effect, with the Yellow Sally at sundown, and as late in the evening as Trout will rise.

A White Hackle, with white or very pale yellow body, it is thought by many, will kill later in the evening than any other fly, though I think it not superior to the pale yellow mottled hackle just described.

The Dotterel is one of the flies described by Hofland- "body of yellow silk, legs and wings from the feather of a dotterel." This feather is not known to American anglers; my imitations are made from the light barred feather of the partridge or snipe, and the body of light yellow floss silk. It is easily made, and on small Kirby hooks it is killing on well-shaded waters, especially towards sunset.

The Grouse Hackle has a body of orange floss, or peacock hurl; I prefer the latter. A suitable feather for this fly can be had from the wing-coverts and rump of our common 
prairie fowl ; a cock partridge's feather is still better; a snipe's or woodcock's will do. This is a good fly on clear water, as well as on a full stream; if for the latter, it is better to have the body tipped with gold tinse! It is better used as a drop. fly; the hook should never be larger than No. 6 on full water, and 8 or 10 when it is fine.

A light mottled lead-colored Hackle may be made from the feather that hangs on either side of the rump of an English snipe; it is slightly barred. The body may be made of lead-colored floss, or a pale but distinct yellow; it is a good drop-fly on hooks from No. 6 to 9 . It is almost identical with the Dotterel.

The last seven of the aforementioned Hackles are better without having the bodies tipped with tinsel, and are good ones to induct the beginner in the art of tying his own flies. Most of them should be used exclusively as droppers. The Red, Brown, Soldier, and Ginger Hackles are quite as successful as stretchers. The Red Hackle, I am in the habit of dressing on hooks from No. 3 to 5, made of stout heavy wire, so that it will sink somewhat below the surface of the water; which mode of fishing I have frequently found necessary, especially after a freshet; the Trout in the rifts appearing to take it as bait, carried along by the current beneath the surface, rather than as a fly.

WINGED FLIES.-Of the great variety described in English books on fly-fishing, I place foremost of all, the Great Red Spinner, which Hofland says is made, "body of hog's wool dyed red brown, ribbed with gold twist; tail, two long whisks of red hackle; wings from the feather of a starling's wing; legs, bright amber, stained hackle." This is the Red Spinner found in the tackle stores. As we have no starling with us, I generally make the wings of a brown mottled feather from the wing-covert of the mallard; borly 
of red mohair. If there are Chub in the stream, and they are troublesome, I substitute a dubbing of bright orange, generally of hog's down, to avoid them, for red is very attractive to those pests.

A Brown Spinner is -made by using a brown mallard's feather for wings, brown mohair or hog's wool for body, and a brown hackle for legs. This is considered by many a better fly than the Red Spinner, and is used mostly as a stretcher. The same fly is sometimes made by picking out the hog's wool dubbing under the wings, to represent legs, instead of using a hackle for that purpose.

The March Brown, and Cowdung, I have never taken a fancy to, nor the Stone Fly; they are useless when one has a supply of Spinners in his book.

There are several small flies with light yellow or slate bodies and lead-colored wings, described by Ronalds, which resemble each other closely; they are good for the evening, or on well-shaded waters at midday. These are the Cockwing, Golden Dun Midge, Yellow Dun, Skyblue, Whirling Blue Dun, and Little Pale Blue Dun. None of them should be on hooks larger than No. 7.

The Iron Blue Dun is used with effect at almost any time of day. It is preferable as a drop-fly.

The Grannom has a body of hare's fur; wings of a partridge feather, made full; legs of a pale ginger hackle, and a short tuft of green floss silk at the tail, to represent the bag of eggs which this insect carries at the extremity of its body. In this country, the Grannom is found on the water towards the latter part of June, mostly towards sundown; this imitation of it is a killing fly as a stretcher on a No. 8 hook.

The Jenny Spinner (this is a Hackle).-I have seen this diminutive fly used with great success as a dropper, on the same whip with the Grannom; borly, white floss silk, wound 
with a light dun hackle, or a dirty white hackle will answer in the absence of the former; the head and tail of brown silk; hooks No. 9 or 10 .

The Black Gnat is a small $\mathrm{fly}$, and a pretty good imitation of a gnat; it is best on bright waters after ten o'clock; hooks 8 to 10 .

The Yellow Sally has yellow wings, body, and legs; sometimes it is tied as a hackle. It is a good fly at sundown, and as long as the angler can see where it falls on the water.

The Fern-Fly is attractive, with its bright orange body and lead-colored wings.

The Alder-Fly.-Next to the Red and Brown Spinners, this is the best stretcher-fly on Hofland's list. I have used two of them on fine low water at the same time, with great effect, one for dropper and the other for stretcher. The body of this fly'should be made of copper-colored peacock's hurl, and the wings of a feather from a brown mallard, or brown hen. This fly can be varied by having a black mohair body, picked out near the head to represent the legs, as in the Brown Spinner.

May Flies (the Green and the Gray Drake are the chief representatives), as killing as they may be on English waters, are seldom used successfully in this country.

The Mackerel-Fly is supplanted by the Brown Spinner.

A Fancy Fly, with red or brown hog's wool for body, picked out beneath near the head, for legs; a dark brown mallard or hen's feather, with a few fibres from the feather of the scarlet ibis and green parrot thrown in for wings; a tail of two fibres of a red macaw or ibis feather, and the end of the body tipped with tinsel, is sometimes a good stretcher. I have used it successfully on the rifts of the Beaverkill, in Sullivan County, N. Y.; it also does well on the still waters of the Adirondacks. The hook should be No. 2 or 3 . 
The Scarlet Ibis, as much as it is lauded by some, I have never had much success. with, except for those splendid Canadian fish known as Sea Trout. With a red or bright yellow body ribbed with gold twist, it is very killing in angling for them.

The Governor, though a beautiful fly, I have not tried successfully. It closely resembles the Fern-Fly.

The fly-fisher who keeps a varied assortment should not be without a few small dark Camlet-Flies. The Irish fly-makers excel in these. I have found, however, that small dark Hackles, and the Alder-Fly, when tied on a No. 10 hook, with wings from a dark mottled brown hen, to raise Trout when anything artificial could induce them to come to the surface.

At the Sault Ste. Marie, and on the lakes of Maine, and on some of the rivers about Lake Superior, small Salmon-flies are more killing than Trout-flies; hooks smaller than No. 2 (Trout) are seldom used there.

After having gone into a somewhat lengthy description of the flies I have found to take well, I will refer to a few which I tie for my own fishing, and with slight variation of color and size, I find them ample for all seasons, weather, and water. I do not pretend to say that other flies may not be as killing on the whip of other anglers, but the constant use of these for the last five or six summers, has given me (it may be) a kind of blind faith in them, which has led me to adopt them to the exclusion of nearly all others.

Of winged flies I use only the Brown Hen and the Coachman; of Hackles, only a brown, a black, and a ginger.

There is no variation in the bodies of my Coachmen; they are always of copper-colored peacock's hurl, tipped with tinsel, the legs invariably of red hackle. The wings are of four tints: first, white; second, a light lead color, generally from a tame pigeon; third, a shade of lead color rather darker-a 
gull's feather is very appropriate ; fourth, a decided lead color - say from a blue heron. I tie those intended for droppers on hooks from No. 6 to 10 ; for stretchers, I use Nos. 2, 4, and 6 , and in fishing with them, vary the color of wings and size of hooks according to the weather (bright or cloudy), the water (full or fine), and the time of day. The white wings are best when the water is full and the sky overcast, or late in the afternoon.

The Brown Hen I tie without varying the colors: body of copper-colored peacock's hurl, tipped with gold tinsel; legs of dark brown hackle; wings from a dark brown hen's feather, mottled or speckled with yellow at the outer ends of the fibres. This feather, which I have mentioned so often, is taken mostly from hens known as the "golden pheasant breed," and is not generally appreciated by professional flymakers. On a No. 8 hook for a stretcher, this fly kills splendidly on fine still water, and on a bright day. I generally use with it, a brown or black Hackle on a No. 10 hook, as dropper.

A Ginger Hackle, with a light yellow body, is my favorite evening fly.

Any of these flies are tied to order, and by the angler's own pattern, if he wishes it, by Mr. George, at Philip Wilson's gun and tackle store in Chestnut above Fourth street, or by Mr. Jackson, in Gold below Dock street, or John Worden, at Krider's, corner of Second and Walnut streets, Philadelphia.

THE WHIP.-The leader, with its flies attached, is generally termed the Whip, the neatness and proper arrangement of which is of much importance. The fly at the end is called the Stretcher, Drag-Fly, or Tail-Fly. Those above are the Drop Flies. Sometimes they are termed "Bobbers" or "Droppers."

The stretcher, as a general rule, should be larger than the 
drop-fly; the greater size and weight being at the end of the leader, enables the angler to cast further, and with more precision. And the consequent greater resistance in drawing it over the surface, keeps the leader taut and the dropper more at right angles with it, than if the reverse was the rule.

The distance between the stretcher and drop-fly should be proportioned to the general length of the cast. In fishing where it is more convenient to cast a short line-say of eighteen or twenty feet-the flies should not be more than thirty inches apart. This distance between the flies is more suitable to the beginner; but as practice enables him to throw a longer line, the dropper may be moved further up the leader, until four, or even four and a half, feet may intervene.

The stretcher should be tied to the end of the leader by the common water-knot, which is illustrated on page 409 , and the dropper fastened, as shown by figure 3 , on the same diagram. The pieces of gut on which droppers are dressed, should be stiff, and not more than five or six inches in length. If the angler fishes with two drop-flies (though more than one is seldom used), the upper should be twelve inches or so above the first dropper. The leader should not be more than three-fourths of the length of the rod, i. e., nine feet for a twelve-foot rod. With the beginner it should not exceed six feet, for a short line, if light at the end, is not as easily cast by the novice as a heavy one. A good large-sized hook also will make casting easier, in his first attempt. He should not commence with more than one dropper.

Frank Forester recommends a leader of fifteen feet. This length would make it impossible for the angler to reel up his fish within reach of his landing-net, as the knot which fastens the line to the leader, and those by which the different gutlengths are joined, would catch in the wire loop at the end of the tip, or in the rings, and, as a consequence, the fish could not be brought near enough to put the landing-net under it. 
CH A P T E R XII. FLY-FISHING FOR TROUT. 
: I NEVER wander where the bordering reeds

O'erlook the muddy stream, whose tangling weeds

Perplex the fisher; I, nor choose to bear

The thievish nightly net, nor barbed spear;

Nor drain I ponds, the golden Carp to take,

Nor trowle for Pikes, dispeoplers of the lake.

Around the steel no tortured worm shall twine,

No blood of living insect stains my line;

Let me, less cruel, cast the feathered hook,

With pliant rod, athwart the pebbled brook,

Silent along the mazy margin stray,

And with the fur-wrought fly delude the prey."

QAY. 


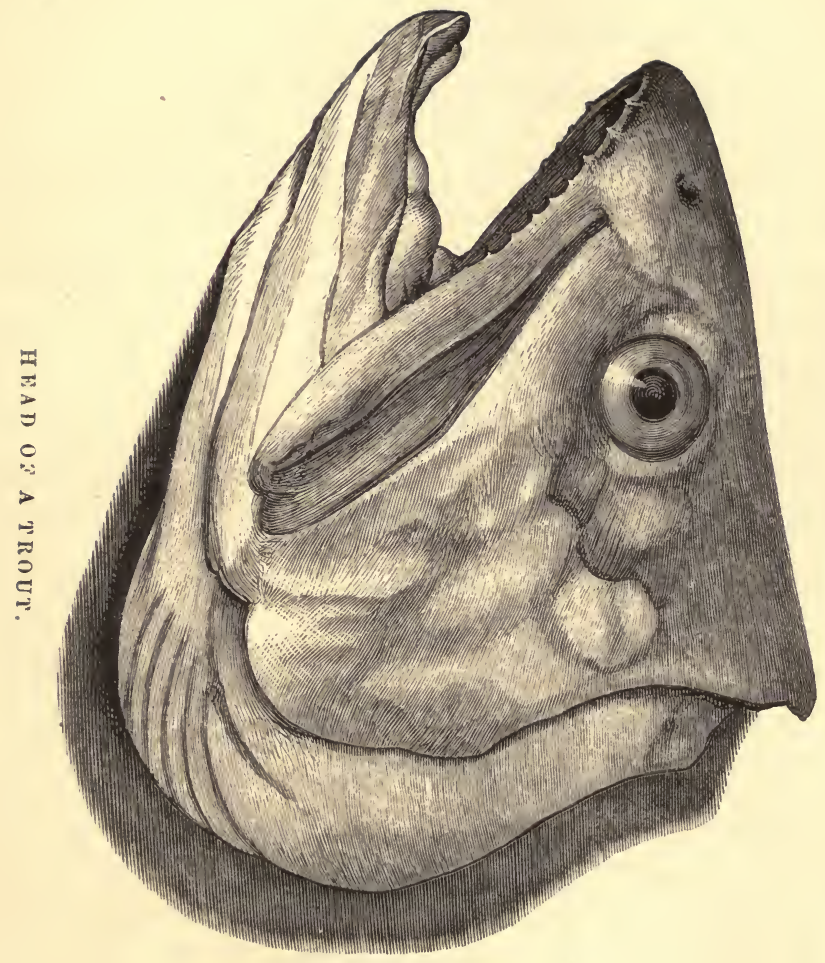





\section{CHAPTER XII.}

TROUT FLY-FISHING.-THE STREAM.

Casting the Fly.-Theory of strict imitation.-Striking and killing a Fish.-Likely places, how to fish them.

Casting the FLY.-So much has been written on this subject, that the learner who consults the authorities, not only finds that "doctors disagree," but that he is bewildered with what may appear to him unnecessary detail; and he is thus impressed with an idea that Fly-Fishing is a science to be attained only with much study and practice. It would therefore be much better to learn the rudiments from some skilful friend on the stream, and afterwards read such authorities as Chitty, "Ephemera," and Ronalds.

As it is likely, however, that some of my readers who may wish to try their hands, may not be able to avail themselves of the practical instruction of friends of experience, or may not have access to English authors on fly-fishing, I will, with some misgivings as to my ability to profit them, describe the usual manner of casting the fly, as practised by our best anglers. Advising the beginner not to be ambitious at first of accomplishing what he may deem a difficult feat, that is, to cast a long line, but rather by patience and diligence to acquire the knack of delivering one of moderate length straight out and lightly; by perseverance he will in due time find "how use doth breed a habit in a man."

On a farorable day the learner, with faith and industry, 
and no preconceived notions of the difficulty of fly-fishing, may find at his nooning that he has made a catch which does not compare unfavorably with that of his more skilful brother. If the contrary be the case, let him not lose heart, as there may have been many circumstances against him: as inexperience of the waters, the arrangement of his whip, landing his fish, \&c., which he has yet to learn, and that it is not his casting which is altogether at fault.

Some writers have objected to the accepted term "whipping," contending that casting the fly is different from whipping with a long staff and lash. I acknowledge that in the main it is. Still the first motions of the arm and rod are not unlike the motions of the arm and whip-staff of a stage-driver. The latter intends that the end of his lash shall reach a certain part of the horse's body, while the angler intends that his flies shall fall on a certain part of the stream; but here the similitude ends. The driver, by a sudden backward motion of the arm, causes the lash to strike the horse with force, and rebound; while the angler avoids the quick backward motion, and allows his flies to fall lightly; and then, not hastily, but by a gentle movement of his rod, draws his flies towar's him or across the water.

But to commence.-Let the beginner draw out as much line as he can conveniently cast. If he uses a twelve foot rod, eighteen feet (that is, from the tip to the stretcher-fly) is enough. Then with a backward motion of his rod, let his line go well out behind him, and before it has time to fall to the ground, by a forward motion of the forearm and wrist, cast his flies to the desired place on the water.

The backward motion of the line is chiefly impartel by the spring of the rod, as the flies are lifted from the water, and if it does not go to its full length behind, it will come down clumsily on the water before the angler, when he casts 
it forward, and short of the place aimed at. The same bad effect is produced by using too much force. The beginner should bear in mind that it is not strength, but an easy sleight, and the spring of the rod, that effects the long and light cast. The arm should be extended slightly, and the motion imparted to the rod by the forearm working as on a pivot at the elbow, and the hand turning as on another pivot at the wrist. The motion of the hand and wrist only is required in a short, straight cast.

. The angler should not cast at random over the water, but each portion of it should be carefully fished, the nearest first. He should always aim at some particular place; he will soon learn to measure the distance with his eye, and exert the exact amount of force to propel his flies to the desired spot. In drawing them over the water, the primary object is to have the drop-fly to skim or dap along on the surface; the stretcher which follows in its wake may be allowed to take care of itself, for, as a general thing, it matters little whether it is on or beneath the surface.

When the flies first fall on the water, they should be allowed to rest a moment, and the slight motion imparted by tightening the line, or in recovering the full grasp of the rod on the instant, should be avoided. If in the current, they should be left for some moments to its will, then guided gently and sometimes with a tremulous motion across or diagonally up against it.

After the learner (and he will always be learning) has acquired the first principles of the art, necessity, ingenuity, and observation will teach him how to cast in difficult places. Our streams and lakes are generally fished, the first by wading, the latter from a boat, and seldom from a high bank. It is therefore less necessary to cast a long line than many suppose, or English writers describe it to be. But our 
rugged forest strěams, overhung by bushes and branches of trees, and other obstructions occurring, make it requisite that the angler should acquire tact and skill, to meet these difficulties.

In casting under branches which hang within a few feet of the water, the motion of the rod and course pursued by the line is necessarily horizontal. For instance, in wading down a stream, if you intend whipping under the branches on the right, a back-handed cast is necessary; the backward preparatory motion of the rod being across the stream to your left, and the cast horizontally from the left to your right. When the branches you wish to cast under are on your left, the course of the line is vice versa, that is, from the right to the left.

The largest Trout love the shade of trees and bushes which overhang the bank, and it is only by the means just described that you can present your flies. It is customary to fish down stream, and there is much difference of opinion as to whether the general rule should be to cast directly down or across the water. In this the angler must be governed much by circumstances, and his own judgment. I prefer the diagonal cast, as presenting the flies in a more natural way, although the drop-fly may appear to play better, and set more at right angles with the leader, when drawing up against the stream.

When the wind is blowing up the stream, it becomes in a good degree necessary to fish across, if possible casting below the desired spot, and allowing the wind to carry the flies to the right place as they fall on the water. If, however, it blows strongly in the direction of the cast, care should be taken when putting on a fresh fly to moisten the gut to which it is attached, if it be a stretcher. Many flies are cracked off by neglecting this precaution.

The advice of English writers to fish up stream, or with the 
wind at one's back, in most cases cannot be followed; for our rough rapid streams in the first instance, and the thicklywooded banks in the other, which make it necessary to wade, ignore both rules. The force of the current in many a good rift would bring the flies back, and, as I have seen with beginners, entangle them in the legs of his pantaloons. It is only in a still pool, or where the current is gentle, that one is able to fish up stream with any degree of precision.

A word or two here about the flies coming down

"Light as falls the flaky snow,"

and that the flies only should touch the surface, or that they should touch it before the leader. The first idea is a very poetical one, and may be carried out in a good degree, if the line is light, the leader fine, and the cast not too long. The second is impracticable with a long line, unless from a bank somewhat elevated above the water. But in a day's fishing on our streams, the miraculous casting or falling of the flies, which some writers speak of, and their skill in this respect, are things we "read about."

My experience is, that the falling of the leader-which is almost transparent when properly dyed-does not frighten the fish, but it is the incautious approach or conspicuous position of the angler. In casting over a piece of water, the flies always precede the leader and line, and, as a matter of course, fall where the fish lie before the line does, as the fisher advances or extends his cast. As the line will swag more or less in a long cast, it must necessarily touch the water.

I would not give the impression from the foregoing that it is not necessary that the flies should fall lightly, for in fishing fine it is important that they should. To accomplish this, as I have already said, no sudden check should be given to the 
flies, but they should be eased off (if I may so express it) as they fall, by the slightest downward bending of the wrist.

There is a great deal of poetry also, as well as fiction, in the stories told about casting a very long line. Experience will teach you to cast no longer line than is necessary, whatever proficiency you may acquire. Still it should be borne in mind, that the higher your position above the water, the more visible you are to the fish, hence the greater the necessity for fishing far off when occupying such a stand. But with such elevation, it is easier to cast a long line. When a person is wading the stream, he is less visible to the fish than if he was on the bank, as the medium through which the line of sight passes is more dense than the atmosphere above, and the rougher the water the more the line of sight between the angler and the fish is disturbed.

Nicer casting is, of course, required on a still pool than on a rift; a careful angler, when he wades such water, will always go in softly, without floundering or splashing, fishing it by inches, scarcely making a ripple, and creating so slight a disturbance, that he will find the fish rising within a few yards of him; then he should cast with not too long a line, and lightly. If he sees a large Trout rising lower down the pool, he does not fish carelessly, or hurry on to get to him, but tries to take those that may lie in the intervening water, and approaches him slowly and imperceptibly, knowing that he will be found there when his time comes. I may add here that in such water a landing-net is indispensable, as it would disturb the pool to wade ashore with every good fish, and that here also you have a better opportunity of using your net and securing your fish, than in a rift.

In casting a long line, or even a short one, particularly on a windy day, it is better to wet it occasionally by holding the leader and flies in your hand, and let it swag in the water; 
the weight of the line thus increased, helps the cast. If it could be accomplished, the great desideratum would be, to keep the line wet and the flies dry. I have seen anglers succeed so well in their efforts to do this by the means just mentioned, and by whipping the moisture from their flies, that the stretcher and dropper would fall so lightly, and remain so long on the surface, that a fish would rise and deliberately take the fly before it sank.

One instance of this kind is fresh in my memory: it occurred at a pool beneath the fall of a dam on the Williwemock, at a low stage of water-none running over. The fish were shy and refused every fly I offered them, when my friend put on a Grannom for a stretcher, and a minute Jenny Spinner for a dropper. His leader was of the finest gut and his flies fresh, and by cracking the moisture from them between each throw, he would lay them so lightly on the glassy surface, that a brace of Trout would take them at almost every cast, and before they sank or were drawn away. He had tied these flies and made his whip especially for his evening cast on this pool, and as the fish would not notice mine, I was obliged to content myself with landing his fish, which in a half hour counted several dozen. Here was an exemplification of the advantage of keeping one's flies dry, and the fallacy of the theory of not allowing the line to fall on the water, for in this instance I noticed that a fourth or a third of it touched the surface at every cast.

It seems to me that there is no more appropriate place than this to say a few words about the "routine" and "strict imitation system," which some English writers advocate so strenuously. The former, that is, certain flies for certain months, or for each month, is now considered an exploded theory by practical anglers who wish to divest fly-fishing of all pedantic humbug; for the fly that is good in April is 
killing in August, and the Red and Brown Hackle, the Coachman, Alder-Fly, and Brown Hen, will kill all summer. For the theory of "strict imitation," there is some show of reason, but I cannot concede that Trout will rise more readily at the artificial fly which most closely resembles the natural one, for the fish's attention is first attracted because of something lifelike falling on the water, or passing over the surface, and he rises at it because he supposes it to be something he is in the habit of feeding upon, or because it resembles an insect or looks like a fly, not that it is any particular insect or fly; for we sometimes see the most glaring cheat, which resembles nothing above the waters or beneath the waters, a piece of red flannel, for instance, or the fin of one of their own species, taken greedily.

The last time I had positive proof of this was some years ago, when I happened to spend a quiet Sabbath in the "Beech Woods" of Pennsylvania, with a cheery Irishman who had made a clearing on the Big Equinunk. Towards noon I missed my creel, and on inquiring what had become of it, was told that the boys had gone a-fishing and taken it with them. In the afternoon they returned with the creel full of Trout, which far exceeded my catch of the day previous. I asked them if they had taken them with wormsno; with the fly-no, they had none; and then I remembered the "dodge" I had practised myself in my early Trout-fishing days. They said they had "skittered" with the belly fin of the Trout. A worm to catch the first fish was the only bait they wanted, all the rest of the Trout were taken by drawing this rude counterfeit over the surface of the water. They did not know-happy little fellows-that their practice was in opposition to the theory of learned professors,-Hofland, Blaine, Shipley, Ronalds, and others. 
Striking ańd Killing a Fish. Striking.-Various directions have been given about striking a fish when it rises at the fly. Some maintain that it is unnecessary, or even wrong, to strike at all, if the line is kept taut. Others say that you should strike as soon as you see the fish or the swirl he makes as he turns to go back. Either is wrong, if adopted as a rule without exceptions.

In most cases when Trout rise freely, and are in earnest, they will hook themselves, for the yielding of a pliant rod, as a fish takes the fly, allows him to bear off his prize; but when he attempts to cast it from his mouth, the spring of the rod fixes the hook in his mouth, as he relaxes his hold. So it frequently happens that the rise is seen and the strain on the rod is felt at the same moment. A fish may even miss the fly, and make another effort to seize it, if not drawn away too hastily. When a fish, therefore, takes the fly vigorously, it is only necessary to keep the line taut. A mere turn of the wrist may be given to fix the hook more firmly in his mouth.

On the contrary, when the water is subsiding after a freshet, ) and the fish have been feeding on worms and insects which have been washed in, they/will frequently tug at your' stretcher, taking it for such food. Then it is necessary to strike sharply. I have sometimes fished all day in this way, allowing the stretcher (generally a red hackle) to sink a little, and trolling as with a bait, and striking when I felt a bite. Again, on warm days, when Trout lie beneath the shade of trees which stretch their branches over deep still pools, they will rise almost without ruffling the surface, or softly arrest the stretcher beneath, as if to ascertain if it is really something to eat; then a slight but quick stroke is necessary to secure the fish before he casts it from his mouth.

Killing a Fish.-Many Trout are lost by the beginner, 
from excitement or a lack of judgment in managing them. It is always the safer plan to handle a fish as if he was slightly hooked, and in fishing a rift, to get him out of the rougli water and towards the margin where it is comparatively still, as soon as possible. For in his efforts to escape, you have the force of the current, as well as his strength and agility, to contend with.

If the water is still, and the fish indisposed to show fight, tow him gently to one side and then to the other, as you reel in the line. If there is a sloping shore without obstructions, and you think he is securely hooked, you may sometimes get a little headway on him, and, by a steady pull, lead him ashore before he overcomes his astomishment at being hooked, or has realized his danger. If in landing a fish in this way, though, you allow him to come in contact with a stone or other impediment, it will arouse all his fears, and in his desperation he may tear loose.

When a fish of unusual size is hooked, and you can do so without disturbing the lower end of the rift or pool, it is safer to lead him down stream, for this increases the difficulty of his breathing, while you are assisted by the current, and the strain on your tackle is diminished.

English writers direct us, after hooking a fish, to keep the rod in a perpendicular position, or the point well back over the shoulder; this is very well if he is securely hooked and swims deep. If he struggles and flounders on the surface, though, the point should be immediately lowered, and the rod held nearly horizontally aeross the stream, giving. him the whole spring of it, thus keeping him under. It is better not to raise his head above the water until he is sornewhat exhausted, or until you are ready to slip the landing-net under him.

If your reel has a moderately stiff click, and the fish is large 
enough to run the line off, he should be allowed to do so, bearing on him with the line unchecked by the slightest pressure of the fingers. As he slacks in his resistance, reel in the line, giving when you must and shortening when you can, "butting him," as some persons call it, or bearing hard, only when he approaches some dangerous place, and leading him away from it. After you have ventured to raise his head above water, give to any strong effort he may make to get beneath, or to his humor to take another run, but bearing on him all the while with a taut line. When you can venture to bring him near, reel in until the end of the leader, where it joins the line, has reached the end of the tip; he is then, if the leader is three-fourths the length of the rod, and the rod pliant, close enough to slip your net under him. This should be done not with a swoop, but gently; seize him with the left hand, sticking your thumb under his gill, and taking the hook out of his mouth put him tail-foremost into the hole of your creel.

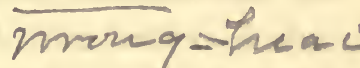

There is much less strain on one's tackle in playing a fish than is generally supposed. In killing a Salmon, if he is properly handled, it does not exceed a pound, and with a Trout, it is not over an ounce or two.

I have known anglers handle fish so well as to make a common practice of slipping the hand gently down the leader, and seizing them behind the gills, sometimes wearing a thread glove to insure a firmer grasp. Few, however, have sufficient skill and coolness for such dangerous practice. A landingnet is almost indispensable when there is no convenient place for leading your prize to the bank, or when wading ashore would disturb the quiet of a pool.

Likely PlaAes, AND HOW TO FISH THEM.-The success of the fly-fisher depends almost as much on what might be called 
an intuitive knowledge of likely places, as his skill in casting, or in killing a fish.

The beginner generally prefers a lively rift, where there is an open cast, for the current takes a good hold on his stretcher, and bears it down stream, while it keeps his leader taut, and his dropper dapping prettily on the surface. But he should remember that in most cases, at such a cast, he is likely to be exposed to the view of the fish, which always lie with their heads up stream. He should therefore approach cautiously, fishing the slack water on each side at the head of the rift, with as long a line as he can well manage. Coming nearer step by step and casting as he advances, he will fish the near, and then the opposite side lower down, drawing his flies lightly across the rough water, and submitting them in some degree to its will. Still approaching he will cast obliquely across, then straight down and over the water where the current abates.

As a general rule the larger fish take precedence, and lie nearer the head of a rift and rise first. If found at the lower end, it will be where the water is deeper and where there are rocks or an overhanging bank. Trout are not often found in a rift or pool with a smooth even floor of rock, or small pebbles, as it affords them no harbor or hiding-places.

Where a large rock projects above the surface in water of sufficient depth, the angler should cast near its edges on both sides, then above where it repels the force of the stream; or he may have a rise in the eddy just below, where the divided current unites again.

A deep bend in the stream where a caving bank overhangs, affords a likely cast, especially where stumps, logs, or drift-wood lie about.

If the stream has a long still reach, one generally fishes from the shallower side, finding his cast opposite where it is 
deeper, casting close to, or under the pendent boughs, or in the shade of the bushes or trees-drawing his flies diagonally or directly across. It is not a bad plan when fish have risen and refused one's flies, in such a pool, to sit patiently down and change them for smaller ones of different colors, and after a little while "try back," that is, fish from the lower to the upper end. Different flies cast from another direction will sometimes induce fish to "reconsider the motion," and adopt your amendment if properly presented.

When the season is well advanced-say July or August, Trout will assemble in pairs or little communities in some suitable place for spawning, and remain there if there is no excessive rise in the stream, until it is time to spawn. This is frequently beneath the overhanging alders; there chuck your flies under, if you cannot present them more civilly, and if you take a good fish, try again, for the rest are likely to be as hungry. If the sun be bright, use the Alder-fly on such occasions, for either dropper or stretcher, or both. The same kind of a shallow side-rift is a likely place carly in June when the Suckers congregate there to spawn, and the Trout are on the lookout a few yards below, to eatch their roe as it is carried down stream by the current.

Immediately below a mill-dam, if there be any depth of water, is invariably a good place; but you should never stand conspicuously above on what is called "the breast" of the dam, or on a high rock; such a position is to be condemned even in a bait-fisher; but get below, and if there is no way of fishing from the sides, go to the tail of the pool, and cast upwards. This, if there be but little water coming over the dam, is the best place to fish from. Trout will not take the fly immediately under the fall or in the foam, but a little below.

In a deep still pool much exposed to the sun, if there is a 
tree or two on the bank with drooping boughs, Trout are apt to collect there, for they love the shade. Here, if the weather is warm, they are not apt to rise with a splash, as I have just remarked, but will suck in your fly with a mere dimpling of the water, or you may have a vague sense of its being arrested beneath the surface. Then strike sharply, but do not be violent, and you have him; try again, there are more there, and good ones.

Never pass a piece of still water of reasonable depth where a fresh spring brook, however diminutive, comes in, particularly in warm weather. I have in my memory such a pool bordered on one side with hair-grass and duck-weed, which I had frequently passed heedlessly by, supposing it to be backwater from the main stream, or left in the old bed of the creek, from the overflow of the spring freshets. But one day, seeing a quiet dimpling of the surface, I waded lazily in, and threw my flies carelessly on the water, when a thirteen-incher laid hold, and was away in the duck-weed before I recovered from my astonishment. After many turns, however, and much contention, the pliant little rod exhausted him. Thus encouraged, I fished the shaded pool its whole length as noiselessly as an otter, and the result was a dozen very handsome Trout. I never passed that pool again without giving it the attention it merited.

Sometimes on the subsiding of a freshet, Trout will surmount a long rapid, and rest in a pool, or the snnooth flow of water above, where it is not a half yard in depth. Fish such water with as long a east as possible, and su as not to throw your shadow over the swim.

A brisk clattering little brook, as it rushes along over rocks and logs, through the woods, washes out many a pretty hole in its sharp turns, and amongst the big stones, where the laurel and alders render casting impossible. The only way 
here is, let the current carry your flies down stream, until the dropper bohs enticingly on the water. Play them on each side of the little rift, drawing them towards you and allowing them to drift off again. If there are fish in the hole they will be jumping at the dropper, or tugging at the stretcher. Three to one they will hook themselves; if they don't, strike gently at each tug or jump, as if you were fishing with a bait, but not drawing your flies entirely from the water. I have taken good fish in the small tributaries of a larger stream in this way, the monarch of the rift always first, and his successors in order, according to size. The head of a mill-dam, where a rapid meets the back-water, is invariably a good place.

I have already said or intimated, that on a bright day Trout will always rise better in the shade. Therefore when a pool is of equal depth across, one side of it may be better in the morning, and the other side in the afternoon. There are many good pools also which are not shaded on either side, or where persons pass frequently; or show themselves to the fish; here they scarcely rise until after sundown. Such places are often fished without success by an angler, and in a very short time one who follows him may have good sport. The largest fish are nearly always taken after the sun is down, or at least off the water.

But of all places commend me in the still of the evening, to the long placid pool, shallow on one side, with deeper water and an abrupt overhanging bank opposite. Where the sun has shone all day, and legions of ephemera sported in its declining rays; the bloom of the rye or clover scenting the air from the adjoining field! Now light a fresh pipe, and put on a pale Ginger Hackle for your tail-fly, and a little white-winged Coachman for your dropper. Then wade in cautiously-move like a shadow-don't make a ripple. 
('ast, slowly, long, light; let your stretcher sink a little. There he has taken the Ginger-lead him around gently to the shallow side as you reel him in, but don't move from your position-let him tug awhile, put your net under him, break his neck, and slip him into your creel. Draw your line through the rings-cast again; another, and another. Keep on until you can see only the ripple made by your fly; or know when it falls, by the slight tremor it imparts through the whole line down to your hand-until the whip-poor-will begins his evening song, and the little water-frog tweets in the grass close by.-Not till then is it time to go home.

- If you have dined on the stream, it may be. that the Trout you roasted were too highly seasoned and you are thirsty; if so, stop at the old spring by the roadside.

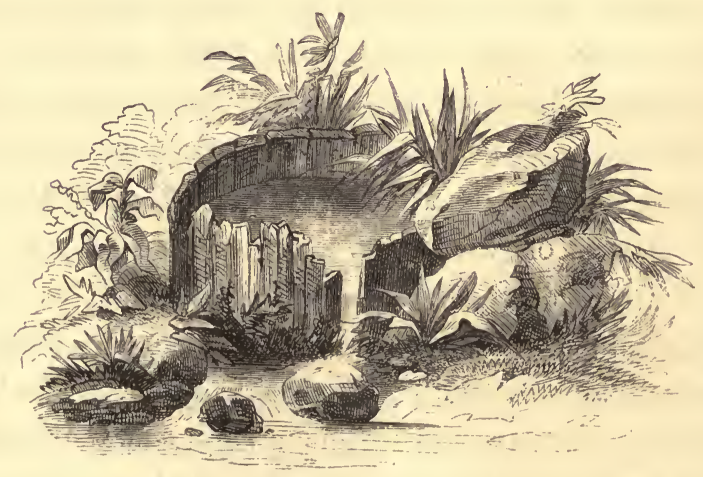


C H A P T E X I I I.

S A L M ON - F I S II I N G. 
"I LOVE to see a man forget His blood is growing cold, And leap, or swim, or gather flowers, Oblivious of his gold,

And mix with children in their sport, Nor think that he is old.

"I love to see a man of care Take pleasure in a toy;

I love to see him row or ride, And tread the grass with joy, Or throw the circling Salmon-fly As lusty as a boy.

"The road of life is hard enough, Bestrewn with slag and thorn;

I would not mock the simplest joy

That made it less forlorn,

But fill its evening path with flowers, As fresh as those of morn." 


\section{CHA PTER XIII.}

\section{SALMON-FISHING.}

Tackle used in Salmon-Fishing. Rods.-Reels-Reel-lines.-Castinglines.-Salmon-flies.-Materials required for Salmon-flies for American rivers.-Salmon-Flies for the rivers of New Brunswick and Canada.Theory and practice of Salmon-fishing.-Salmon-fishing compared with Trout-fishing.-Casting the fly.-The straight-forward cast, casting over the left shoulder, casting in difficult places, explained by diagrams.Casting in an unfavorable wind.-Striking.-Playing a Salmon.-What a Salmon will do or may do.-Gaffing.

Camping on the River. Camp equipage.-Protection against mosquitoes, black-flies, and midges. - Clothing, \&c.-Cooking utensils.Stores. Cooking Salmon on the river.-To boil a Salmon.-To broil a Salmon.-Cold Salmon.--Soused Salmon.-To bake or steam a Grilse under the coals and ashes.-Kippered Salmon.-Smoked Salmon.-Law and Custom on the river.

\section{TACKLE FOR SALMON-FISHING.}

RoDs.-A Salmon-rod should be of the toughest and most springy wood that can be procured. It should taper so truly, that its elasticity, or rather its tendency to bend, will be distributed over its whole length, though in a diminishing ratio -from the point of the tip to the place where it is grasped above the reel. In a rod of true proportions, the greater the power applied or the weight it has to bear, the nearer will the apex of the curve caused by lifting the weight approach 
the butt, and, as a consequence, the more the upper part will be relieved of the strain.

To demonstrate this theorem, let any person who is curious on the subject, place a two or four ounce weight in his tobaccopouch, and suspend it to the end of his line, after passing the line through the rings of a well-proportioned Salmou-rod, and he will find that the tip will bend, while the lower part of the rod will remain comparatively straight. Let him increase the weight to eight ounces, and the curve will be transferred to the next joint below, the tip assuming more the direction of a straight line. Then, by increasing the weight successively to twelve and sixteen ounces, he will find that there is little or no curve in the tip, the additional weight having drawn it nearly or quite straight, and transferred the transverse strain proportionately towards the lower part of the rod, where it is strong.

A rod of sixteen feet, which I deem sufficiently long, need not weigh over two pounds two ounces; and one of seventeen feet should not exceed two pounds six ounces. Of the two, I prefer the smaller, on account of the ease in casting with it, for it is no boy's play to wield a heavy Salmon-rod for hours. The smaller has power enough to kill any Salmon. 'The dimensions of such a rod, if in four pieces of equal lengthmeasuring. the diameter of the inside or "male" ferules as they come in order from the butt outward-should be eleven, eight, and five-sixteenths of an inch, and the diameter of the butt half way between the ferule and lower end, seven-eighths of an inch; the thickest part, where the reel-band is placed, say nine inches above the end, should be an inch and fivesixteenths.

A seventeen-foot rod-supposing the butt and second joint each to be four feet six inches long, and the third joint and tip four feet-should have the two upper ferules the same 
size as the smaller rod, and the lower ferule the sixteenth of an inch larger. The butt should be of the best coarse-grained white ash; the second joint of hickory or ironwood; the third of lance or ironwood; and the tip of the best Malacca cane, rent and glued. The strain on a tip caused by the oftrepeated lifting of a long line from the water, makes it necessary that it should be of material of the closest and hardest fibre; for the weight of the line is not sufficient to throw the strain on the lower portion of the rod, as in killing a fish; but the constant lifting of the line from the water preparatory to casting it, gives the top a downward swag in a week or two, which makes it necessary that the angler should provide himself with one or two extra tips.

The advice of English authors, to have the rod-rings very large, that the line may pass through freely, shows a want of proper consideration; for if there should be a knot or kink in the line, it would be certain to catch in passing through the wire loop at the end of the tip. The large size of the rings, therefore, would not provide for the contingency, while they are awkward and rattle in the wind, augmenting the resistance to the air in casting, and increasing the leverage on the rod when killing a Salmon. In making a couple of Salmon-rods for my own use, I went in direct opposition to this antiquated notion, and put on metallic guides like those on American bass rods, but lighter, and find them far preferable to rings. In fastening on the reel I use but one reel-band, which is stationary; under this I slip one end of the brass plate to which the reel is fastened, and secure the other end with a string, so as to avoid the contingency of the slidingband becoming tight by the expansion of the butt of the rorl from moisture, as already explained in my remarks on Trout. rods. 


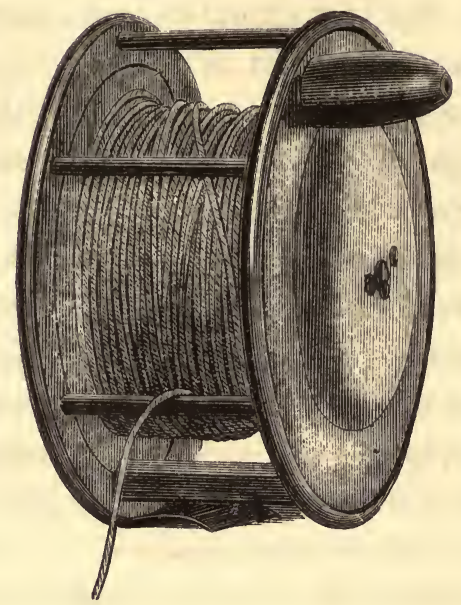

REELS.-A Salmon-reel should be large enough to contain a hundred yards of line without filling the spool so full that it will clog. A simple reel is to be preferred to a multiplier, for several reasons; an important one is that it is less apt to get out of order from the rough usage to which it is sometimes subjected. One with the outer plates about three and three-quarters inches in diameter, and an inch and a half between the plates, is large enough. The click or bearing, which is arranged between one of the inner plates and the small outer plate next to it, should offer resistance enough to require about six ounces to draw the line from the reel. Of course there is an additional friction when the line passes through the rings of the rod and out through the tip; and this is all the bearing that is required or safe to offer in controlling' a Salmon, even when you are butting him to press him from a dangerous place, or towards the gaff as he becomes exhausted. The best Salmon-reels have a smooth conical crank fastened in an outer plate, which revolves against the 
one next to the spool, the object being to prevent the line becoming entangled in the handle, which is apt to occur in one of the ordinary kind. The best reels of this kind I have ever met with, are those made by Farlow, of London. The figure on the opposite page gives a perspective view of one.

REEL-Lines. - Those made of plaited silk, and prepared in linseed-oil, notwithstanding the original cost, are to be preferred to all others. Those of silk and hair are liable to rot when exposed to the dew, if they are left out at night, or when they are wound up wet and allowed to remain so. With care, an oiled silk line will last three or four years. After fishing, as much of it as has been wet should be drawn off the reel, and coiled or wound in such a manner as to dry. When one end of an oiled line becomes soft from casting and passing through the rings of the rod after a summer's fishing, it may be taken off the reel, and the end which has been used wound next to the axle, the stiff fresh end being outwards, next to the casting line. An unoiled plaited-silk line can be bought for half the price of an oiled one, and the angler can prepare it himself by the recipe, found in the note below, which I copy from Chitty.* I found, however, that the last

* " To a quarter of a pint of ' doubled-boiled cold-drawn' linseed-oil, add about one ounce of gold-size. Gently warm and mix them well, being first careful to have the line quite dry. While the mixture is warm, soak it therein until it is fully saturated to its very centre; say for twenty-four hours. Then pass it through a piece of flannel, pressing it sufficiently to take off the superficial coat, which enables that which is in the interior to dry well, and, in time, to get stiff. The line must then be hung up in the air, wind, or sun, out of the reach of moisture, for about a fortnight, till pretty well dry. It must then be redipped to give an outer coat, for which less soaking is necessary: after this, wipe it again, but lightly; wind it on a chair-back or towel-horse, before a hot fire, and there let it remain for two or three hours, which will cause the mixture on it to 'flow' (as 
drying requires three or four times as long as the time he mentions. The gold-size mentioned in the note can be had of those who sell painters' materials; I have bought it of Mr. C. Shrack, in Fourth street above Cherry, Philadelphia.

Casting-Lines should be of treble twisted gut, for the three gut-lengths next to the reel-line; the next two or three lengths should be of double twisted gut, and the remainder of stout single gut, each length finer than the preceding one as it nears the end. Single gut is strong enough to hold any Salmon if properly handled, but the treble and double lengths and then the single length, graduate the line to a proper taper, thus increasing the ease and lightness in throwing the fly. When the water is discolored after a rise in the river, a casting-line of ten feet is long enough. As the water becomes slearer, the length should be gradually increased by adding lengths of single gut at the lower end, until it is nearly or quite as long as the rod. By doing so, one can cast a lighter line, and, of course, the probability of raising a Salmon will be greater than it would be by allowing the heavy reel line to fall or swing near the fish.

SALMON-FLIES.-There is an endless variety in the combinations and colors of the feathers, dubbing, and tinsel, that go to make up the Salmon-flies described in books and sold in tackle stores. Of the latter, many are made by persons who never saw a live Salmon, and are tied more to please the eye of the purchaser, than with any idea that they will entice

japanners term it), and give an even gloss over the whole. It must then be left to dry as before: the length of time, as it depends on the weather and place, observation must determine upon. By this means it becomes impervious to wet and sufficiently stiff, never to clog or entangle-the oil producing the former quality, and the gold-size (which is insoluble in water) the latter; while the commixture prevents the size becoming too hard and stiff." 
the fish. Notwithistanding the minute directions given for tying any particular fly, it must not be inferred that an imitation that lacks some of the tints, will not take fish. The main thing is to have the prevailing colors as near those of the fly described as possible; if there is a slight difference in regard to the feathers that compose the wings or tail, when the exact feather cannot be had, it may still be a killing fly on the same kind of water, and on the same kind of a day, that the original is. Fresh-run Salmon are not over nice, and if the colors are at all suitable to the water, they will lay hold; as to a certain fly being the fly for any water, to the exclusion of all others, it is sheer humbug. The first Salmon I ever killed was on a fly I tied before leaving home, from some idea I had of the water I was to fish, and from a general knowledge of the proper colors for Trout-flies. It was not intended as an imitation of any I had seen or read a description of; and I continued to tie my own flies, and killed Salmon with them all summer, being guided in selecting the colors by the state of the water and the day, omitting the unimportant detail of a tag or feelers, and frequently not putting on a collar when indolent, or pushed for time.

Very few of the flies imported from England and Ireland are suitable for the rivers of New Brunswick, being generally too large and showy for those clear waters. The gaudy Irish flies tied for the Shannon would frighten the Salmon on this side of the Atlantic, while others would not be noticed by them. The profuse variety of beautiful but useless flies imposed on some of our verdant countrymen, with full pockets, by London and Dublin tackle-makers, is astonishing. An accomplished Salmon-fisher of St. John, with whom I had the pleasure of fishing for two weeks last summer, had only two standard flies for the Mirimichi and Nipissiguit; one the "Blue-and-brown," the other the "Silver-gray;"-the 
latter for high water. The Blue-and-brown, by tying with darker-tinted hackles and bodies, as the water clears, he uses almost entirely. He told me he fished the Lakes of Killarney, and the clear rivers of Ireland, with the same flies in his boyhood, and he still adheres to them: his favorite, the Blue-andbrown, has become so famous amongst the anglers of the province, that it has taken his name, the "Nicholson fly."

Flies for American rivers-except when the water is discolored by a freshet-as a general rule, should be of darker and more sober tints than those used in Scotland and Ireland. The feathers to be preferred for wings, are taken from the wing-coverts of the male mallard, the tail of the wild turkey, and the second joint of the wing, and tail of a dark-brown mottled hen, or spruce grouse; the two last are for small flies, and will raise a Salmon on fine water when nothing else will. For full water, or when it is discolored, wood-duck and gray mallard are used, mixed occasionally with a few fibres of red ibis, or a single topping of golden pheasant.

The bodies of those that have dark wings should be of red, brown, and purple dubbing, of different shades, varied occasionally with orange, yellow, and black, and wrapped with hackles of the same colors. Sometimes two hackles of different color, as red and blue, are used. The bodies and hackles of flies for high water should be of light colors to correspond with the wings: of these, pale yellow, pearl color, and light gray are most suitable.

This limited assortrnent of feathers for wings, and hackles and dubbing for bodies, is all that one requires on the rivers of New Brunswick. Add to these, black ostrich and coppercolored peacock hurl, for collars; a dozen or so of golden pheasant breast-feathers for tails; gold and silver tinsel-flat and twisted; tying silk, wax, and a little varnish to put on 
the heads to protect them, and the list of fly-materials for a trip is complete.

Tying Salmon-flies is an art which is easily acquired by those who are at all proficient in making Trout-flies; they hardly require as delicate manipulation. I saw some very rudimentary-looking flies tied by the natives about Bathurst, that were killing at the "Rough Waters" on the Nipissiguit, last summer.

The annexed plate was drawn and engraved on wood, under my direction, by Mr. Wilhelm of this city. It represents four flies; the killing qualities of the first two I tested last summer.

No. 1 represents the Brown Fly. It is a plain little fly, on a No. $9 *$ hook, and intended for low water. Wings of the dark mottled feather of a brown hen, or wild turkey's tail; body of copper-colored peacock hurl (four plumelets twirled and twisted around the wrapping-silk to make it secure), wound with gold thread, and a dark brown or purple hackle, and tipped with gold tinsel; tail a few sprigs of the same feather as the wings; collar of black ostrich hurl.

No. 2 represents the "Nicholson." Hook, No. 8. Wings of brown mallard; body of blood-red seal's fur, wrapped with gold tinsel, and a blue, and a blood-red hackle, and tipped with gold tinsel; tail of mallard, and a few sprigs of golden pheasant breast-feathers; collar, black ostrich hurl. The dubbing and hackle of this fly should be of deeper tint, as the water becomes clearer. The angler, whose name it bears, in tying it gives the tail and wings an upright set, which it retains to the last, giving it a peculiarly gay appear-

* The standard of sizes for hooks here mentioned, correspond with the numbers on the plate of Hooks, page 65. 
ance, as the reader will observe. The figure is an exact drawing of one tied by Mr. N. himself.

The Silver Gray, which Mr. N. ties on hooks No. 6 and 7, is intended for high water, or when it is discolored after a freshet. It has wings of gray mallard and a few sprigs of wood-duck; body of lead or pearl-colored seal's wool mixed with a little yellow, and wound with silver tinsel and a gray or barred hackle; tag and collar of ostrich hurl. It is not represented by either of the four figures, but in form resembles No. 2.

Nos. 3 and 4 are exact copies of Nos. 11 and 12, found in the "Book of the Salmon." I have introduced them here to show what is meant by "feelers," and to explain what a "topping" is. The former are intended to represent the pair of long antennæ found in a natural fly; they are folded backward in the artificial fly, extending above and beyond the wings. The tail and upper portion of the wings of the third figure are "toppings," that is, feathers from the crest of the golden pheasant.

In addition to the flies I have described, there are several tied by John Chamberlain that are in great repute on the Nipissiguit. Amongst them is one which I will describe as the "Chamberlain." In tying it.(commencing at the bend of the hook) the body is first tipped with gold tinsel, the tail is then tied on, and the lower part of the body, say one-fourth of the way up, is wrapped with bright yellow floss, when a blood-red hackle, and purple or maroon-colored floss are fastened in, and the dark floss wrapped on for the remainder of the body, followed by the gold tinsel and the hackle (four turns are enough). Brown mallard or wild-turkey wings are then put on, and it is finished with a collar of black ostrich hurl. The first fly I tied of this kind, was according to 


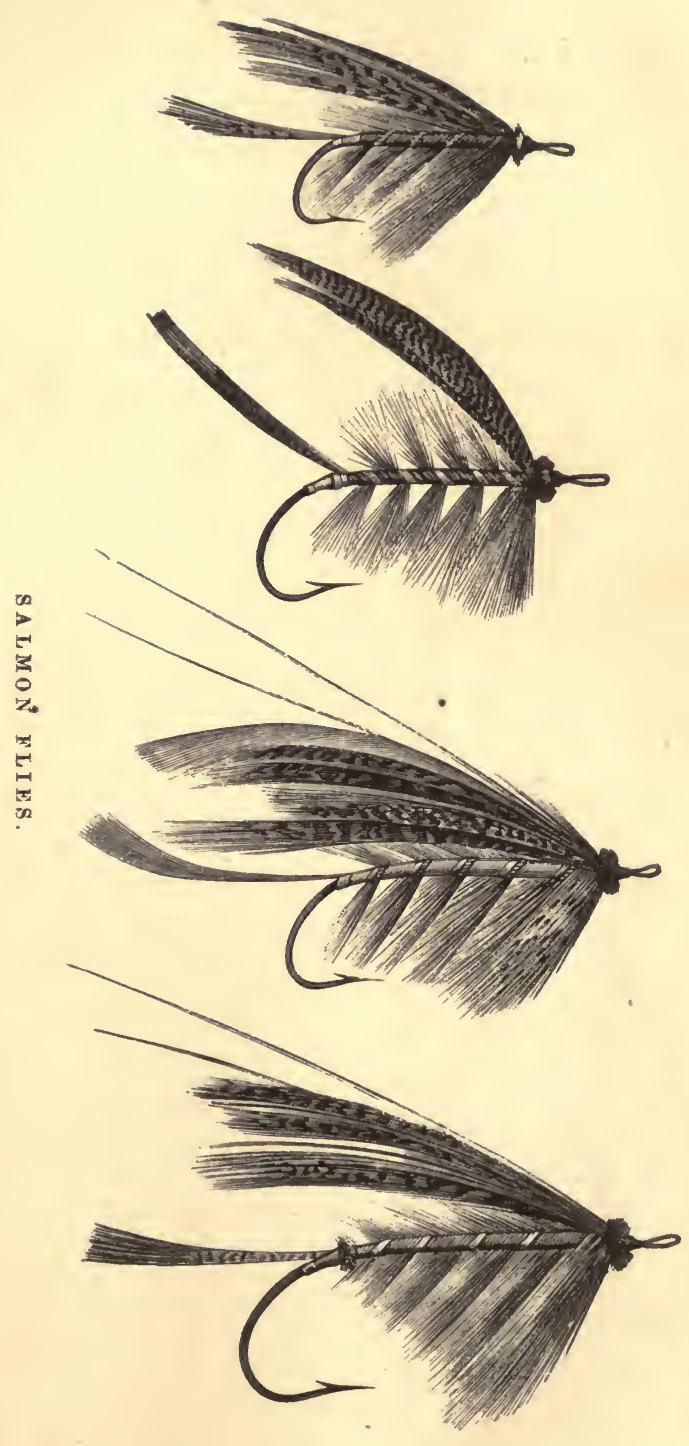



John's directions as he sat by. I have been quite successful with the "Chamberlain."

Dr. Adamson, in "Salmon-fishing in Canada," gives the following list of flies used on the rivers emptying into the St. Lawrence :-

"The Louise is an extremely beautiful fly, having the wings composed of fibres from the golden pheasant's topknot, breast-feather, and tail, with sprigs from the green parrot, blue macaw, and kingfisher; the body is of fiery brown mohair with gold twist; the head of orange mohair; the tail a single feather from the golden pheasant's topknot, reddish. brown hackle, and jay legs.

"The Edwin is a much more simple fly, and often equally efficacious amongst the fins, the wings being composed of the golden pheasant's tail-feather, with a dash of yellow macaw; the body yellow mohair, ribs of black silk, head black mohair, tail golden pheasant topknot, hackle yellow, and scarlet silk tip.

"The Forsyth.-Wings of yellow macaw with a slight dash of mallard wing at each side; yellow mohair body with black ribs; head black, tail golden pheasant topknot, hackle yellow, with light blue silk tip.

"The Stevens.-Wings of golden pheasant breast-feather, with a slight mixture of mallard; body of reddish brickcolored silk gold twist, head black ostrich; tail golden pheasant topknot; hackle red to match the body, tip blue silk.

"The Ross.-Wings of mallard and peacock's hurl; body cinnamon-colored silk gold twist; no head; tail, green parrot, red and black hackles, and black tip.

"The Parson.-This is a beautiful and efficient fly. The wings are mixed, and very similar to those of the Louise, but have a slight mixture of wood-duck in them; the body is 
of very dark claret silk with gold twist; head black ostrich ; tail golden pheasant topknot, hackle dark claret; legs blue, with a tip of yellow and gold.

"The Strachan.-Mixed wing chiefly of golden pheasant tail, yellow macaw, and jay's wing; body of crimson silk with gold twist; head black ostrich; fail golden pheasant; black hackle with jay's wing; legs tip yellow and gold.

"The Langevin.-Wings, body, tail, hackle, legs, tip all yellow; made of the dyed feathers of the white goose; the head of black ostrich, and the twist of black silk."

Casting the Fly.-As bait-fishing or trolling can scarcely be called a sportsmanlike way of killing Salmon, I shall confine my observations to angling for them only with the artificial fly.

In my remarks on Trout-fishing I have alluded to the impossibility of learning how to cast the fly well from written directions alone. One may get the theory ever so well in his head-and good theory too-when he comes to try his hand, however, there are so many things he must remember to do just at the nick of time, and so many contingencies which he did not look for, constantly arising, that he will likely recollect no more of the lessons he has learned from books than some general directions, and will depend rather on his own judgment and native aptness. This is more the case in Salmon-fishing even than in casting the fly for Trout.

I do not mean to convey the idea that the written directions are useless; on the contrary, they are of much service when combined with some practical knowledge of the art. It would, therefore, be well for the beginner to learn all he can from books, and not discard his theory entirely, if not approved of by anglers, whose instruction he may have the benefit of on the river. A little experience will show him that he may combine the teachings of the two, and profit by both. 
Although I had been a Trout fly-fisher for a quarter of a century and had gained, as I thought, much knowledge from Chitty, Scrope, and "Ephemera" (and there is no better authority than the last), I must confess that I received more instruction last summer in a few days from the hints and suggestions of John Chamberlain, an unlettered canoe-man, than I had from books in many years; though still adhering to the teachings of "Ephemera" in opposition to John, on points which were in accordance with my own notions.

I have heard anglers say that Salmon-fishing is only Trout-fishing on a grand scale. There is much truth in the remark, for a person who can cast well for Trout, will soon acquire the knack of throwing the fly for Salmon. But in several important points there is a difference, for Salmon do not often lie in that part of a pool where the angler would look for Trout. He moreover fishes for Salmon with only one fly, and displays it differently - mostly beneath the surface.

I offer these hints not with a view of enlightening Salmonfishers of experience, but with the hope that they may be of some service to beginners who have not access to the authors I have mentioned, or who may not fall into as good hands in their first attempts as I did.

A few words in the first place as to holding the rod.-A right-handed man will naturally grasp it with the right hand above the reel, and with his left hand below at the end of the butt; and will throw from over the right shoulder. The lefthanded man will do the reverse, that is, grasp with his left hand above the reel and cast from the left shoulder. A righthanded man will advance his right foot in casting, and a lefthanded man his left foot. Supposing then that the great majority of men are right-handed, I will shape my hints accordingly.

The first thing is to get out as much line as one intends 
making his first cast with; this is done as in Trout-fishing. To describe it, we will suppose that the angler approaches the stream, the hook clasping one of the bars of the reel (the usual way of carrying it), his. line consequently (or as much as has passed through the rings) the.same length as his rod, or nearly so. He disengages his fly, throws it on the water, and draws a few feet of line off the reel; the line falling in a loop between the reel and the ring next above it. Now by switching his rod to the right or left-his fly dragging the mean time in the water-the slack line which hangs in a loop is pulled through the rings, and out at the end of the tip; lengthening the line, by so much. This is repeated until he has drawn the point of the rod around so far to one side that he is obliged to lift the line from the water and throw it further out, in order to continue the operation. Thus by pulling the line from the reel, and consecutively switching the rod, the required length is obtained. Of course this preliminary operation is not done in the direction in which the fish are supposed to lie.

Now, with a smart spring of the rod, the angler lifts his fly from the water to make the first cast, and directs its course backwards over his right shoulder until he thinks it has nearly reached the distance the line will allow it to go behind him; then with a steady forward motion, succeeded by a switch of the rod, he sends it on its errand across the smoothlygliding water, that it may float or swing over the current and entice the silver-sided Salmon with its sheen and life-like look.

In this plain, straightforward throw, the top of the rod describes nearly an arc in its backward course, and the chord of the same arc in its forward course; in other words, the backward course is a curve, and the forward a straight line. The left figure of the cut on page 62 , gives a bird's-eye 
view of the line the point of the rod describes; the dotted line is the course the fly takes, $\mathrm{O}$ the place where the angler stands, and the large arrow the course of the river.

It is hard to fix the exact time that the particular spring which sends the fly far and straight, is imparted to the rod; it is somewhere about the time it is vertical, or perhaps just before that time, in its forward movement. A person, though, as he acquires the knack of casting, will find it out, though he may not be able to describe it.

As in Trout-fishing, the learner is apt to labor hard in casting, using much more force than is required, until he gets the habit of making the rod perform neatly, what he, by mere physical effort, would do clumsily. Another thing that he has learned in Trout-fishing will also be of service to him; it is that lowering of the point of the rod the least bit, by the mere downward bending of the wrist of his right hand, as the fly reaches its destination, dausing it to fall lightly on the water, instead of striking it with a splash. There is a way of sending the fly straight out, as if aiming at something above the surface, say on a level with one's shoulder, and easing it off in the manner just described, which.is the perfection of casting. It requires much practice to acquire it.

The manner of getting more line out as one successively increases the length of his cast, is by drawing a few feet from the reel before raising his fly from the water, and as the rod is drawn backward, the slack goes out through the wire loop at the end of the tip.

The "fly is generally cast directly or obliquely across the stream, the current, or a proper inclination of the rod, or the two combined, bringing it over the place where the fish lie. After the fly has fallen on the water, it is acted upon by two opposing forces-the tendency of the current to take it down stream, and the raising of the point of the rod to restrain or 
direct it; the result is, that the fly swings across the stream towards the side on which the angler stands, describing in its course the segment of a circle, and sweeping along in front of the fish. By increasing the length of the cast directly or obliquely across, as just described, the radius is lengthened, and the segment enlarged and of course extended down stream, as well as across. In this manner, that portion of the pool within reach of the angler is gradually covered; then, by advancing a step at a time, or by short successive pushes of the canoe, he fishes the whole of it, or as much as can be covered from the side he is on.

The fibres of the feathers of which the fly is composed, are made to contract and exparid as it passes through the water, by the least possible raising and dropping of the point of the rod, in order to show the fly attractively. This, however, cannot be done effectually, if the current is so strong as to press the fibres continually against the body of the fly, not allowing them to open when the top of the rod is lowered.

The general rule laid down by "Ephemera," in his Book of the Salmon, for fishing a pool "upwards in the direction of its source," appears to me entirely wrong. It is impracticable on many American rivers, from the rapidity of the current. He ignores his own rule, however, in a remark on a preceding page of his book, when speaking of the motion to be given to the fly in drawing it through the water. He says, "the Salmon-fly is always to be worked or humored against the current, never with it." How the angler is to humor the fly against the current, when drawing it with the current, I leave him to find out. As to fishing up stream, it may do where the current is slight, but in swift water it should only be when there is no cast but from the lower end of the pool. 
The Left-Shouldered CAst.-It frequently occurs, in fishing down either side of a river, that an abrupt bank rises immediately at the angler's back. If on the right side of the river, such an obstruction makes it necessary to cast from over the left shoulder; for in making the ordinary right-shouldered cast, the high bank would prevent the backward motion of the rod and the backward sweep of the line. In casting from over the left shoulder, it is not necessary, as "Ephemera" directs, to shift one's hands; that is, to grasp the rod above above the reel with the left, and the end of the butt with the right hand, and make an awkward attempt, for the time, to become a left-handed man. A much easier plan is not to shift the hands at all, but, keeping them as they are, to bring the line backward over the left shoulder, and cast from the left side. This way of casting, though it may appear awkward at first, will become quite easy after a little practice, especially to one who is used to whipping over the left shoulder for Trout. The middle figure of the diagram on the next page shows the line described by the top of the rod in the leftshouldered cast; the dotted line represents the course of the $\mathrm{fly} ; \mathrm{O}$ is the stand of the angler.

A greater difficulty than that just described is to be overcome, when one wishes to cast directly across the stream, and a precipitous bank or cliff rises immediately behind his back, and, it may be, also on his left hand. In this case he has first to get his fly out, down stream; the current will assist him somewhat. Then, lifting it with a smart twitch of the rod, he brings it back (but not too far) over the left shoulder, and suddenly facing the desired spot, casts with a short abrupt spring of the rod in that direction. A bird'seye view of the course described by the top of the rod in this throw is represented by the right-hand figure of the cut. The largest arrow points down stream. B is the point from which the fly is pickerl up, and A the direction in which it is cast. 


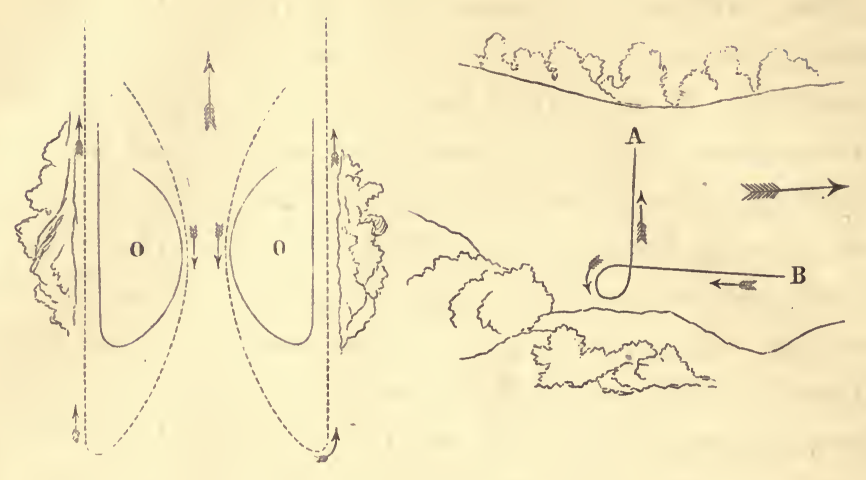

After practising these two casts for some years whenever the emergency required it in Trout-fishing, I was agreeably surprised in reading Chitty's ("Theophilus South's") "FlyFisher's Text-Book," to find them illustrated, and have introduced the above diagram, which is somewhat similar, to show that the same casts can be used in Salmon-fishing.

There are other obstacles and impediments the Salmonfisher meets with, which he will have to bear patiently or overcome as well as he can. Amongst these, there is nothing so annoying as an unfavorable wind. At one time it may blow obstinately in your very teeth, requiring a deal of "elbow. grease" to get the fly out. At another time there is a spanking breeze astern, and if you can get your line out behind you, there are many chances of cracking your fly off. Then there is a side-wind blowing up stream or down stream, requiring a nice calculation as to how much you must allow for leeway, when aiming above or below the spot, as the case may be. At such times, unless the fish are very much disposed to rise, "the game does not pay for the candle," and the fisher had better get into some sheltered nook and light his pipe, instead of thrashing the wind and getting up a feeling of animosity against old Boreas or Ėolus. 
Salmon frequently leap above the water as if in play or to inhale an additional quantity of atmospheric air; at such times they are not disposed to take your fly. But when one is observed to rise at a natural fly-and there are very few of these on a Salmon river-the angler may expect a rise also at his counterfeit.

The length of line that can be cast depends much on the length and spring of the rod; three times its length is the limit that most writers on the subject give as the distance that can be cast with precision and lightness, but with a moderate fair wind, twenty-five yards can be covered with a rod of sixteen feet.

A Salmon-pool is generally different from the water in which Trout are found. Not in the shade of trees overhanging a still pool, where a cooling spring branch trickles in; not in the tossing, troubled head of a rift; nor often in the eddies that whirl in circles at its sides; nor in its backwater. But in the deep smooth rapid, generally occupying but a small portion of the breadth of the river; or close to the rock that juts boldly up from the deep swift water; sometimes on the brink of the pitch, as it leaps over a ledge of rock. Then again where a moderate deep current terminates in a glassy rapid, called a "tongue" or a "sled-run," or just above the rocks on either side which force the current into these fancied shapes. In such places as the last mentioned, Salmon generally rest after the labor of winning their way up the strong rapid.

Although an experienced Salmon-fisher may go to a new river and point out most of the good pools, there are many casts he would overlook until one who has fished the stream before, or an attendant, who is acquainted with the river, points them out to him.

StRikiNG.-There is a great difference of opinion amongst 
Salmon-fishers as to striking a fish, most of them contending that you should strike as soon as you see the fish, or the swell it makes in its attempt to seize the fly; others that it should not be done until the fish has turned to go back. Some maintain (see Scrope's "Days and Nights of Salmonfishing,") that you should feel a tug, or in Scotch parlance "a rug," before you strike. This deliberate way of dealing with a Salmon is advocated by "Ephemera."

The novice in his agitation will be apt to forget any written directions, and strike violently, or too quickly, or not at all. The negative action is the least objectionable of the three; for if the fish is at all eager he will generally hook himself, and the strain on the rod is frequently felt before the angler has time to raise the point of it. So in most cases one can take little credit to himself for hooking the Salmon, for it is rather the act of the fish than his own. The hook may be struck deeper in its hold by a dexterous movement of the wrist, and this is advisable if the fish does not strain the rod sufficiently to do so.

Playing a Salmon.-A person who is accustomed to the use of the reel in playing other large fish, will soon acquire a reasonable degree of self-possession and skill in killing a Salmon. In doing this, three important things are to be observed: one is to keep up the point of the rod so as to bring its whole spring to bear on the fish, and by no means allow him to "straighten" on you (i.e., to get the line and rod in a direct line between you and him). For if you do, and there should be the slightest catch, or undue pressure on the line to prevent its running freely, he will have a dead pull on you, and will be almost certain to break the hold that the hook has in his mouth, or carry away your casting-line. The reel-line itself would hardly be strong enough to hold a large Salmon under such circumstances, particularly if by coming 
towards you, he should get some slack in the line, and then suddenly turn and rush down stream.

By undue pressure, I mean other resistance to the line passing out, than is caused by a moderately stiff click in the reel, or by that slight uniform pressure of the finger on the line, or of the thumb on the reel, which only an angler of experience with perfect self-possession can give.

Some Salmon-fishers use reels without a bearing. of any kind, depending on this acquired delicacy of touch; but the only safe plan is to have one with a click, for the click bears continually and without variation; and this is all the resistance that it is prudent for the angler to offer in playing a Salmon. And it is wonderful how slight this resistance is, when we consider what it accomplishes, for combined with the unceasing bearing of a springy rod, it wearies out and completely exhausts a powerful fish, even when assisted by a strong current. I have stated on a preceding page, that the resistance of the click, with the friction on the line in passing through the rings, does not exceed twelve ounces, and mention the result of the simple experiment here, to show how small a strain there is on the rod and line when a Salmon is properly managed, and to convince the novice how violence lessens the chances of securing his prize.

When a Salmon takes the fly, he generally goes to the bottorn, and on the instant evinces little or perhaps no alarm, pausing for a few moments as if astonished, or rnoving off slowly and generally a little way up stream. During this brief space of time the angler has opportunity to put on that self-possession which he will require before the fight is over. If the fish swims against the current, the point of the rod should be turned in the opposite direction. Presently he may drop down stream, not usually with headlong speed, but gradually, when it is necessary to wind up, 
keeping a taut line on him as he passes down. When he gets below and becomes thoroughly aroused to a sense of his danger, he commences a series of desperate leaps or long runs, or both alternately. If he takes the current, he may run off a third of the line at'a dash; then the point of the rod should be turned to one side, butting him stoutly to get him into the still water on the side of the rapid. If this cannot be done he must be followed down stream, recovering line when you can, and giving it grudgingly when you must, keeping the rod in the mean time as nearly perpendicular as possible, and giving him its whole spring. When he leaps, if he is near you, the point of the rod is raised; if far off the point should be lowered. In either case though, after a leap, if there is any slack line it should be immediately recovered, and the usual tension given.

Whether fishing from the shore or from a canoe, there is not as much danger of losing a Salmon as one might suppose when it goes over a pitch. For, as I have just said, it does not rush headlong over, but drops down tail foremost, or sideways. At such time the rod should be kept well up, to ease the fish over with its spring. After guiding the fish carefully through the safest channel, another tussle should be had at the first favorable place to get it in shore, or out of the current.

In bringing a fish within reach of the gaff, it is not safe to press him harder then, than at any other time of the contest. For by this time the hold of the hook may have nearly worn out. Many a fish is lost by rough usage, or even a little additional force, at such time. I have had the mortification on more than one occasion, of seeing a good fish, after he was fairly conquered, rid himself of the hook by a lazy wollop, or a wave of its broad tail, and sink to the bottom or move slowly away.

Some writers give directions as to what part of the body 
a Salmon should be gaffed in. The first object should be to gaff it somewhere, and even this is not always easy; though it sometimes happens that a fish is brought near shore, or within reach of the gaff, before it is half killed, and in a lull of the contest or in some quiet moment it may be gaffed, when a prolonged contest might lose it.

On American rivers, although one is compelled in many places to cast from a canoe, he should fight his fish from the shore if practicable. It is always necessary to land either on the shore, or on a rock at some convenient place in the river, to bring him within reach of the gaff:

In the foregoing, I have supposed a case-a common oneas to how a Salmon may act, and endeavored to give the uninitiated some idea how the case should be treated; but there is no telling what a Salmon when fully alarmed will do. At one moment he may be jumping, at the next running towards you, towing the slack line as it bags behind him, when it is necessary to run backwards if he comes faster than you can wind up. - Or he may turn his prow down stream, and with his powerful propeller, to which the flanges of the Ericsson screw are as nothing (when compared with the size of the body to be moved), and get headway enough to run out your whole line, if you do not follow fast. And then there is that desperate sawing and jerking of the head when the gentlest hand is required; or, he may dart around a boulder and double towards you, getting a dead pull, or foul the castingline in a drift-log, and snap it like a cobweb; or saw it against the sharp edge of a sunken rock, or go over a high pitch, while you have to run along the rocky bank, or shoot the rapid in a frail canoe; or he may sulk on the bottom, when you have to throw in stones, or the canoe-man poke at him with his setting-pole. But why attempt to describe what a Salmon may or will do? 


\section{CAMPING ON THE RIVER.}

The next thing in importance to the angler, after sport, is his comfort on the river; he would therefore do well to bestow some thought on the subject before leaving home. His tent, his stores, his clothing, protection against mosquitoes, midges, and black flies, \&c., are all matters that require care and foresight.

Camp Equipage. The Tent.-The most convenient size for the accommodation of one person, though it might answer for two, is an eight-foot tent; that is, eight feet long, eight feet wide, and eight feet high, to the ridge-pole. There should be an opening at each end, to create a draft of air through it; it should also be provided with a "fly," which, in addition to being a double roof to the tent, can be stretched over inclined poles, and used as a shelter for the canoe-men, when one's stay is of short duration at a station where there is no bark-shed. To shed the rain well, the roof of the tent should have an inclination of not less than forty degrees; and to have room inside and allow a suitable elevation to the mosquito-bar, which is arranged on one side of it, the walls should be three and a half feet high. The best material for a tent of this kind is American cotton drill, weighing eight ounces to a yard, the goods being thirty-three inches wide.

At most of the fishing-stations on Salmon rivers frequented by anglers, bark sheds have been erected at different times, and, as a matter of mutual interest, they are kept in repair by the canoemen. They are more suitable to sit or eat in, more convenient, with an impromptu table before you, to tie flies in, and even more comfortable to sleep in, with the usual $\log$ fire in front.

Many persons prefer a bed of spruce boughs, and, to protect themselves thoroughly from the moisture of the ground, 
spread over the boughs an India-rubber blanket or a buffalorobe. If one wishes to sleep above the ground, a stretcher can be used. This is simply a piece of heavy linen eanvas, six feet long by two and a half or three feet wide, with a hem of six inches on each side. A pole of suitable size and length is thrust through each hem, and the ends of the poles are supported by forked stakes, a foot or so above the ground, or by stout logs, one at the foot and the other at the head, with notches cut in them. When the camp is moved, the poles are drawn out of the hems, and the stretcher packed with the tent. To support the mosquito-bar, stakes three or four feet long are driven into the ground at each of the four corners of the stretcher; and the bar is suspended by means of rings which slide along a stout cord extending from stake to stake on each side. The bar can be pushed to the head or foot of the bed by this means, when convenience requires it.

As the nights are generally cold, even in summer, in the regions of Salmon, two thick blankets-one to sleep on, and another to cover one's self with-will be required. One will answer if you have a buffalo robe.

Protection against Mosquitoes, Black-Flies, and Midges.-The angler frequently finds these pests of the wilderness so annoying in daytime as to detract seriously from the pleasure of his sport. At night they are intolerable without a "smudge," so long as he sits up, and a good mosquito-bar after he has gone to bed. In daytime, the best protection is a veil for the face, and gauntlets for the hands.

The best material for a veil is a thin cheap stiffened cotton fabric called "tarleton;" it is much lighter than barege, inore open than silk tissue, and cooler than either, as it admits the air freely. It is also more suitable for a mosquito-bar than the article in general use, as the spaces between the threads of this fabric are small enough to exclude even black-flies. 
The veil should be made in the shape of a bag, but open at each end, about fifteen or eighteen inches long, and two or two and a half feet in circumference. A piece of fine gumelastic cord is run in the hem at the top to clasp the body of the hat, while a similar cord in the hem at the bottom secures it around the neck; the rim of the hat keeps it out from the face. The bottom of the veil can be lifted somewhat, and the stem of a pipe stuck in the mouth when one wants to smoke.

Gauntlets can be made by sewing linen cuffs to a pair of easy old kid gloves; a piece of gum-elastic cord run in a hem at the top of the cuff, clasping the arm under the coat-sleeve. Last summer, I found a veil and gauntlets of this description effectually to keep out these unwelcome visitors.

Different lubricating compounds have been recommended as preventives: among these are tar and sweet-oil, coal-oil, creosote and oil, and oil of pennyroyal. The latter is the cleanest, is not offensive, and is most convenient to carry; it should be diluted with sweet-oil, as it is extremely volatile. The Canadians make a "smudge" to drive off the mosquitoes and flies, which is not only movable, but has a pleasant odor, not unlike that of the incense burnt in Catholic churches. It is made by beating strips of dry bark of the white cedar, and binding them into bundles four or five inches in diameter and two or three feet long. One of these bundles will burn for five or six hours, gradually smouldering away, and emitting a pretty stream of blue smoke. It is convenient to place by one's side at mealtime, or when reading or tying flies.

I will not endeavor to anticipate by description, the interest with which the novice will mark the skill and readiness of the man of the woods, in the use of his paddle and pole, his axe and his knife, and the various materials and appliances he so aptly finds in the forest, for making rude tables, benches, stools, beds, baskets, buckets, \&c. 
Clothing, \&c.-One requires strong warm clothing on the river; he should not be without a good jacket to come to the hips, two pairs of heavy woollen pantaloons, two warm flannel shirts, two or three pairs of stout yarn socks ("Shaker" socks are best), a change of such underclothes as he wears in this climate in winter, and two pairs of good lace-boots ; one pair of the latter should be sparsely studded with wrought-iron hob-nails, in case he may wish to wade at times. He should avoid glaring colors in his dress; light-gray is the most suitable.

His wallet should include thread and needles, awl, waxedends, shoemakers' wax, a few hob-nails, coarse and fine twine, a pair of small pliers, a file, a spring-balance to weigh his fish, court-plaster, a box of Seidlitz powders, shellac varnish, prepared glue, and boiled linseed-oil; the last three in vials as large as the end of one's thumb.

Cooking Utensils.-The cooking utensils and table furniture are an iron pot and kettle, a coffee-pot, a folding wire fish-broiler, three or four tin plates and as many tin cups to fit into each other; pewter spoons, pepper-boxes, knives and forks, \&c.

If the angler has in view easy transportation and snug stowage, and would diminish the hard work to which his canoe-men are subjected in poling against a strong current, and in making difficult portages, he will not take barrels or cumbersome trunks into a birch canoe, but pack his provisions, as many of them as he can, in bags, his clothes in carpet or India-rubber wallets, and his camp equipage in bundles.

STORES.-Camping out, to be enjoyed with zest, should be attended with as few home luxuries as a person can well do with; still, some of those that pertain to his table, add greatly to the edibility of the food he gets by rod or gun, when continual feeding on it begins to cloy the appe- 
tite. A moderate assortment of such things might include vinegar, Worcestershire sauce, salad-oil, essence of coffee or "caffeine," solidified milk, a small quantity of desiccated meats and vegetables for soup and pottage, and a box of claret, if it can be carried, for, as I have before remarked, there is no beverage like it with fresh fish.

The stores that go to make the real staff of life are pork, ship-bread, potatoes, onions, beans, salt, pepper, butter, tea, sugar, \&c. It may be asked, Why such a profusion? or it might be said that fresh Salmon is good enough; and so it is; but one becomes satiated with it after a while, and longs for some of the common things he ate at home. The canoemen will not forget their tobacco, and should be sure to have a pound or two of rosin to patch and stop up the cracks in their canoe.

Cooking Salmon.-On the river there is a variety of ways of cooking or preparing Salmon for the table. The following are a few simple receipts :-

To boil Salmon.-Have a sufficient quantity, but not too much water, boiling briskly with a good handful of salt in it. Cut off a piece of fish of suitable size, notch it to the bone, put it into the pot, cover it up close, and give it from ten to twenty minutes, according to its size. Serve it up hot, with some of the liquor left after boiling.

To broil Salmon.-Cut steaks across the fish, or, if lengthwise, let the pieces include some of the fat glutinous portions of the belly; lay them between the folds of the wire fishbroiler; turn it often, and be careful not to overdo them. When served up, the dish should be placed on a flat hot stone, and your plate also, if you prefer; butter the fish well while hot, and season it to your liking.

Cold Salmon.-Put aside part of the fish boiled for dinner, and eat it cold for supper; it is extremely delicate. 
Soused Salmon.-Take a piece of boiled Salmon, and put it in a pan with due proportions of salt, red pepper, vinegar, Worcestershire sauce or walnut catsup, and salad-oil; let it stand five or six hours, and eat it cold; it is very appetizing.

To bake a Grilse.-Scale and wash it outside, but let no water touch the inside. Score or notch it to the bone, season it by rubbing the inside and the gashes with plenty of pepper and salt, wrap it in a single envelope of buttered paper, and then in a half-dozen folds of coarse straw paper; saturate it thoroughly in water, press it slightly between the hands, and then lay it in a bed of hot coals and ashes, and cover it up. A Grilse of three pounds should be left in about twenty minutes, and one of four pounds five or ten minutes longer. In serving it up, take off the paper covering, lay it on a flat hot stone, and butter it while hot. Grilse are generally split and broiled or planked like Shad.

"Kippered Salmon" is excellent, especially for breakfast, when one becomes somewhat satiated with fresh fish. The canoe-men all understand the process of kippering fish. The Salmon is split along the back, and the bone taken out; it is then thoroughly peppered and salted inside and out, and spread out and pressed between two pieces of birch bark laid on the ground; if it is intended for immediate use, from twelve to twenty-four hours is sufficient. It is then spread open by means of flat slats of cedar, hung up by the tail, and dried in the sun and air for a day or two. When one intends taking kippered Salmon home with him, they should be taken out of press, and salted a second time, and exposed to the sun for at least a week or ten days. A dozen Salmon prepared for me in this way by Peter Chamberlain, whilst at the Grand Falls on the Nipissiguit last summer, were packed at Bathurst in a box, with layers of birch bark between them, and were brought home with my luggage in excellent condition. 
When you get home, it is necessary to soak a piece in water from four to twelve hours (according to the length of time it has been kept) before broiling, in order to soften it and get some of the salt out.

When Salmon are smoked, they are first put in a strong pickle of brine for twenty-four hours, or salted and pressed between pieces of bark, as already described, and then stretched with slats, and smoked with chips of "hard wood" (maple, birch, \&c.) in a bark but built for the purpose. It requires a longer time to smoke fish than to kipper them, and unless a person has time to give them at least two weeks in the smokehouse, he had better not attempt to carry them home, if the distance is more than three or four days' journey.

Law and Custom on THE River.-Although there is no law, properly speaking, on a river which is free to all, still there are rules of right and courtesy that obtain, or at least which should be observed, amongst anglers.

A discreet angler will not consent that his party shall consist of more than two, including himself. Two are company for each other; if there are more, a smaller proportion of the fishing falls to each rod, while sociality is not increased. It is the custom to apportion the pools of a station as fairly as possible between the rods; and to make the division more equitable, and to prevent the monotony of one angler fishing the same set of pools every day, they are shifted; that is, the rod that occupied one set on one day will take the other set the next day, and vice versa. The plan of changing the pools at noon on each day is sometimes adopted, so that the new occupant, if he thinks the pools have been fished too persistently by his predecessor, can rest them that afternoon, and have them all the fresher the next morning. Such a course is frequently adopted with great advantage to one who follows an over-industrious and indiscreet angler. 
A proper regard for the rights of his successors, though, will always restrain a considerate, fair fisher in such cases, however ardent a sportsman he may be. I have seen a Salmonfisher continue to whip a pool under a bright glaring sun, long after the fish had shown the least disposition to rise, and even hand the rod to one of his canoe-men, to give it a more thorough thrashing, because his right to the pool would pass to his successor in an hour or two. A specimen of this style of Salmon-fisher I met at the Grand Falls of the Nipissiguit, last summer. A fat, short-winded little Englishman from Manchester, who talked largely of the moor-fowl(?) he had bagged on the Derbyshire hills, and the number of Salmon he had killed in a single afternoon in Scotland. He was careful of his comfort, and generally had his bottle of claret or a well-filled flask with him on the river-side, and took it easily; while one of his canoe-men (an expert) would thrash the water industriously until he hooked a Salmon, and then hand him the rod to kill it; reversing the custom of the Highland laird who hooks his own fish, and hands the rod to his servant. His plea for enjoying the sport by proxy was, that "he could not come the left-shouldered cast" (which was necessary in fishing some fine pools from the right bank of that river), or that he "wanted Francis to limber his new rod." I am not aware of the exact proportion of his catch, the canoeman hooked for him, perhaps half, perhaps three-fourths; he set them all down however in his memorandum-book, as the product of his own skill. His canoe-man afterwards quietly remarked to me, with a broad grin, that the little man would have booked more Salmon, if he had handled them properly after he (the said Francis) had hooked them for him. The companion of this gentleman was just his opposite: a young Scotchman, who, though he had never fished for Salmon 
before, cast a fly admirably, and hooked his own fish, and killed them in a masterly manner.

Very few fishing-stations will "carry" more than two rods, and new comers, finding such water occupied, generally refrain from intruding, and seek other grounds. It frequently happens, though, at some famous place-I would instance the Grand Falls of the Nipissiguit-that the new comers have travelled a long distance, and there is no station beyond. If the stream is free to all, there is no gainsaying their right to stop and fish; but the privilege of dividing the pools is generally conceded to the first occupants, and it would be a breach of courtesy and fair dealing in those who come last, to wet a line without consulting them.

When pools have been over-fished, a mutual agreement to rest them for a day or two, or every alternate day, resulta beneficially to all. Such course is frequently resorted to.

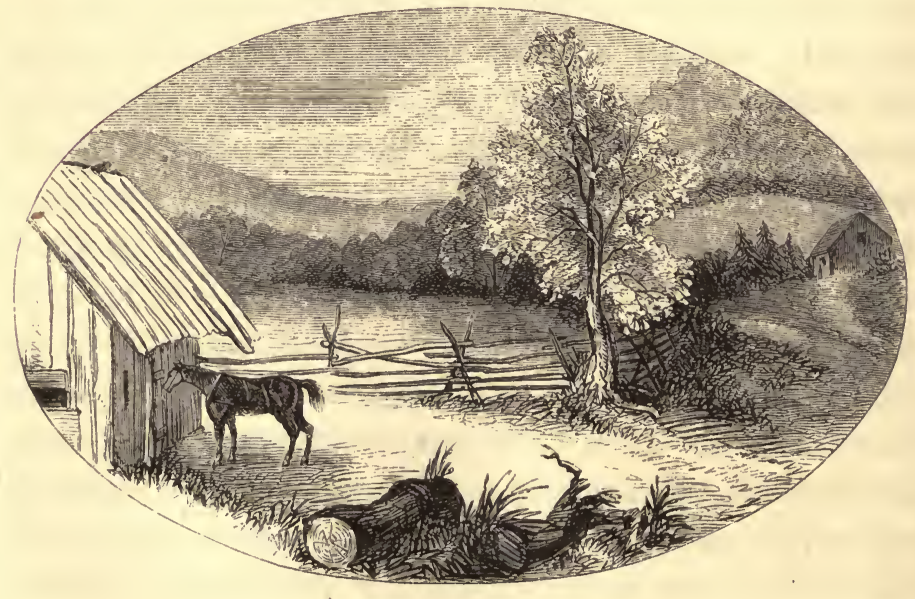


CHAPTER XIV.

SALMON RIVERS OF THE BRITISH PROVINCES. 
${ }^{15}$ Thо pausest not in thine allotted task, 0 darkling River! through the night I hear Thy wavelets rippling on the pebbly beach, I hear thy current stir the rustling sedge That skirts thy bed. Thou intermittest not Thine everlasting journey, drawing on A silvery train from many a woodland spring And mountain brook."

Bryant. 


\section{CHAPTER XIV.}

SALMON-RIVERS OF THE BRITISH PROVINCES.

Salmon-Rivers of Lower Canada. - Salmon-rivers emptying into or tributary to rivers flowing into the Gulf of St. Lawrence.

Salmon-Rivers of New Brunswick.-Mirimichi.-Ristigouche.-Metapediac.-Cascapediacs.-Bonaventure.-Tittigouche.-Nipissiguit.

\section{SALMON-RIVERS IN LOWER CANADA.}

THE following extract from "Salmon-Fishing in Canada," (a book to which I have before had occasion to refer), is so full of 'information as regards the rivers of the provinces, and the laws and rules respecting Salmon-fisheries, that I quote the article at length :-

"The following list includes the principal Salmon-rivers and Sea-Trout streams which discharge into the Saint Lawrence and Saguenay Riv'ers, along the north-east or Labrador coast, between the province boundary eastwards (Blanc Sablon), and the river Jacques Cartier, above Quebec; also those emptying upon the south or eastern shore of the Saint Lawrence, and others flowing easterly into the Bay of Chaleurs.

"In addition there are many other bay, cove, and inlet stations along these extensive coasts, but which are disposable chiefly as sedentary net-fishings for Salmon and Trout.

"The immediate expiry of the lease of that vast territory commonly known as 'The King's Posts,' opens up to the 
public competition numerous valuable coast-fisheries (such as Tadousac, Seven Islands, \&c.), besides many famous Salmonrivers and sea-trout streams, and renders disposable certain commodious building establishments long occupied as furtrading posts, by the Honorable Hudson's Bay Company, at the mouths of the most important of these fine rivers.

"ST. PAUL'S.

“North Shore.

" Discharge into River St. Lawrence.

Esquimaux . . Fine Salmon-river. Formerly yielding 52,500 Salmon each season.

Corkewetpeeche . . Neighboring stream. Contains steady run of Salmon.

Ste. Augustine . . Well supplied with Salmon.

Sheep Bay . . . Considerable size. Good Salmon-fishery station.

Little Meccatina . . Discharges large body of water by several channels. Fine Salmon-river.

Netagamu . . . Large, deep stream. High falls inside. Swarms of Trout. Salmon ascending it only to the falls.

Napeteteepe. . . Empties into spacious bay. Abounds with Salmon.

Etamamu . . . Celebrated for its Salmon-fishery.

Coacoacho . . Discharges into fine basin. Good Salmon-river.

Romaine . . . Large, but shoal stream. Salmon abound. Is remarkable for a rare, beautiful, and flavorous quality of white or silver Trout.

Musquarro . . . Bold, rapid river. Affords fine Salmon-fishing with fly. Good net-fishery station.

Kegasbka . . . Salmon abundant - steep rapids impeding their ascent. Fishery in bay.

Gt. Natashquan . . Famous stream. Salmon of finest kind and numerous.

Agwanish . . Large stream. Good Salmon-fishery location. (N.E. bound of "Lordship of Mingan.")

Pashasheeboo . . Tolerable size. Fair fishery.

Mingan . . Excellent net and fly-fishing for Salmon. Pools always hold a heavy run of large fish.

Manitou . . Branch of the Mingan, equally good and well known.

Saint John . . . Very large stream. Splendid Salmon-fishery.

Magpie . . . Tolerably good fishery for Salmon. Rapid little river.

Saw Bill . . . Considerable stream. Chief net-fishery.

Manitou . . . Large-obstructed by perpendicular fall. At its mouth both Salmon and Trout resort. 


\begin{tabular}{|c|c|c|c|}
\hline Moisie & - & & $\begin{array}{l}\text { Noted for numbers of weighty Salmon. Extensive } \\
\text { and lucrative net-fishery. Fine fly-fishing. }\end{array}$ \\
\hline \multicolumn{3}{|c|}{ Ste. Marguerite (en bas) } & Excellent river for Salmon and Trout. \\
\hline Pentecost & - & . & $\begin{array}{l}\text { Full, swift stream, much frequented by Salmon. } \\
\text { Stationary fisheries at the mouth. }\end{array}$ \\
\hline Trinity $(\mathrm{Ba}$ & & - & $\begin{array}{l}\text { Favorite river. Salmon and Trout fishing, for net } \\
\text { and rod. }\end{array}$ \\
\hline Goodbout & - & . & $\begin{array}{l}\text { Fine Salmon-river, widely known as such. The } \\
\text { net-fishery in its tide-water and adjacent bay is } \\
\text { very productive. }\end{array}$ \\
\hline English & . & - & $\begin{array}{l}\text { Empties into deep cove. Salmon-fishery. Plenty } \\
\text { of Trout. }\end{array}$ \\
\hline Bersimis & $\cdot$ & - & $\begin{array}{l}\text { Immense stream, and has many tributaries. Scenery } \\
\text { interesting. Abounds with large-sized Salmon. } \\
\text { They do not affect the fly except on the waters of } \\
\text { its branches. }\end{array}$ \\
\hline Nipimewec & w'nan & . & $\begin{array}{l}\text { Tributary of Bersimis. Fairy-like stream. Falls } \\
\text { nine miles inside. Exquisite fly-fishing. }\end{array}$ \\
\hline Jeremie & - & - & - Small. Trout only. Fur-trading post, chiefly. \\
\hline Colombier & - & - & . Good Salmon-fishery. \\
\hline Plover & - & - & . Do. \\
\hline Blanche & - & . & . $\quad$ Do. \\
\hline Laval. & - & - & $\begin{array}{l}\text { Picturesque and wild river, alternating with gentle } \\
\text { rapids and deep narrow pools. Besides valuable } \\
\text { net-fishery, it affords abundant Salmon and Trout- } \\
\text { fishing. }\end{array}$ \\
\hline Sault de Co & chon & . & $\begin{array}{l}\text { Steep falls hinder ascent of Salmon. Famous for } \\
\text { Trout-fishing along the estuary border. }\end{array}$ \\
\hline Portneuf & · & • & $\begin{array}{l}\text { Pleasant stream to fish with fly. Up to the first } \\
\text { falls swarms with Trout. For several miles higher } \\
\text { up is frequented by Salmon. Net-fishery station } \\
\text { along the tideway. }\end{array}$ \\
\hline Grand E8co & umain & . & $\begin{array}{l}\text { Once famous for Salmon. Mill-dam bas now an } \\
\text { artificial fishway. Fine net-fishery for Salmon in } \\
\text { bay. }\end{array}$ \\
\hline G. Bergeror & & . & Good Trout-stream. \\
\hline L. Bergeror & & . & $\begin{array}{l}\text { Fair Salmon and Trout river. (Both the Bergeronne } \\
\text { rivers are within few miles of Saguenay and } \\
\text { Tadousac.) }\end{array}$ \\
\hline
\end{tabular}

\section{Discharge into River Saguenay.}

St. Margaret (en haut) . Large tributary of river Saguenay. Fine Salmonfishing for both net and fly. Trout abundant.
L. Saguenay
Considerable stream, affording tolerable rod and good net fishing. Mill-dam inside, not in use.

St. John's (en haut)

Do.

\section{Discharge into River St. Lawrence.}

Black, or Salmon . . Formerly good fishery.

Murray . . Flows down beautiful valley. Yields Salmon.

Du Gouffre . . . . Much deteriorated.

Ste. Anne . . . Pretty river, and latterly has afforded fair Salmonfishing just below the chute. 
Montmorenci

Jacques Cartier

Ouelle

G. Mitis

Matanne

St. Ann

Mount Louis

Magdelaine

Dartmouth

York

St. John's (du Sud)

Grand

G. Pabos

Cataract at mouth. The upper water swarms with (river) Trout.

- Excellent Salmon-stream.

\section{South Cosst.}

- Promises to become again a good Salmon-river. Mill-dam and ffshway.

-Well stocked with Salmon. Mill-dam broken up.

- Large stream. Has dam.

- Fine Salmon-river. Dam and Salmon pass in course of erection.

- Formerly good. Now few Salmon taken. Mill-dam across.

Important stream. More noted of recent seasons for Sea-Trout than Salmon.

- Salmon-river, clear.

First-class stream, flowing into Gaspé basin. Abounds with Salmon.

Do.

Do.

Fine Salmon-fishery. Mill above.

Salmon-fishery. Superior station.

\section{Flow into Bay of Chaleurs.}

G. Bonaventure

Cascapediacs

Nouvelle

Matapediac

Ristigouche

Patapediac

Mistouche .
Large and valuable stream. Many tributaries. Abounding with Salmon.

Both the little and great Cascapediacs yield high numbers of Salmon.

- Good Salmon-fishery in bay.

- Considerable magnitude, and abounds with Salmon.

- Noble river. Has fine tributary streams. Salmon frequent it in large numbers, and of heavy weight. Head of Bay Chaleurs.

- Branch of Ristigouche. Salmon ascend it about forty miles.

- Feeder of Ristigouche. Salmon-river.

"Nearly all the rivers described in the foregoing schedule are tidal streams, and most of them have stationary Salmon and Trout fisheries within the embouchure, and at bays, coves, and inlets on either side. Those upon the north shore of the St. Lawrence descend out of wild, rocky, and mountainous country.

"Most of these streams, with their numerous tributaries, and the large lakes at the head of each branch, present every 
variety of river and lake adapted to the breeding and feeding of fish.

"Where there are mill-dams it is specially so noted. None elsewhere.

"The names of certain rivers at present advertised for sale are printed in italics.

"The true Salmon (Salmo salar), and the Tide Tront (Salmo trutta marina), are herein mentioned.

"The Grand Trunk Railway, now in operation to St. Thomas, will be opened next autumn to River du Loup, 110 miles below Quebec. Passenger steamboats ply between Quebec and the Saguenay.

"Synopsis of the laws and by-laws now in force in Lower Canada, having especial reference to the preservation and regulation of Salmon and Trout fisheries.

(Act 22d Vict. cap. 86.)

Section 4. The Governor in Council to grant special fishing leases and licenses; and make all needful or expedient regulations for management and disposal of fisheries.

“ 5. A general superintendent and local overseers to be appointed, and paid by the Government, for each province.

" 8. The Government may set apart any waters for natural or artificial propagation of Salmon and Trout.

“24. The open season for Salmon-fishery limited betwixt 1st March and 1st August. Fly-surface fishing extended to 1st September. Exception in procuring spawn for scientific purposes.

“ 25. Spawning pools of Salmon protected against all fishing.

“ 26. Nets and fishing apparatus shall not obstruct the main channel or course of any river; and such channel or course shall be at least one-third of the whole breadth of a river.

. 27. Owners of dams must attach fishways thereto.

" 28. All parties concerned in breach of 24th Section become liable to fine or imprisonment.

29. The meshes of Salmon-nets must measure five inches in extension from knot to knct. 
Secrion 31. Trout-fishing illegal between 20th October and 1st February.

“ 33. Netting for Trout in any lake or stream prohibited, except upon the River St. Lawrence.

“ 36. Purchase, sale, or possession, during prohibited seasons, of any Salmon or Trout, made a punishable offence.

\section{Regulations under Order in Council.}

BY-LAW A.-Parties forbidden to occupy Salmon or Sea-Trout fishery stations without lease or license from the Crown.

" B.-The use of nets confined to the brackish waters within the estuary tideway: and forbidden upon the fresh-water streams above confluence of tide.

" C.-All nets, \&c., to be set no less than two hundred yards apart.

" E.-No other fishing whatever allowed over limits covered by exclusive leases or licenses from the Crown, except by express consent of lessees or licentiates.

“ F.-Prohibits capture of Salmon or Sea-Trout by torchlight, and with leister or spear.

“ H.-The receipt, gift, purchase, sale, and possession of speared Salmon or Trout declared illegal.

" J. - No mill rubbish to be drifted awaste in any Salmon or SeaTrout river.

"Appropriate penalties of fine or imprisonment, with forfeiture of materials and fish, are provided by law for the contravention of the several preceding sections and by-laws.

"Also, effective and summary modes of proceeding are laid down for recovery of the same."

The following is an account of ten days' fishing in the Moisie, in the summer of 1858, by J. M. S., Esq., a noted Salmon-fisher of Toronto, Upper Canada. It was originally printed by request for private circulation. The average weight of fish is probably greater than the best river in Scotland would produce at the present day. I still adhere, however, to the opinion I have already expressed, that Salmon in the rivers of Scotland are generally larger than they are on this side of the Atlantic. 
Ten days' Salmon-fishing on the coast of Labrador, in June and July, 1858, by J. M. S.

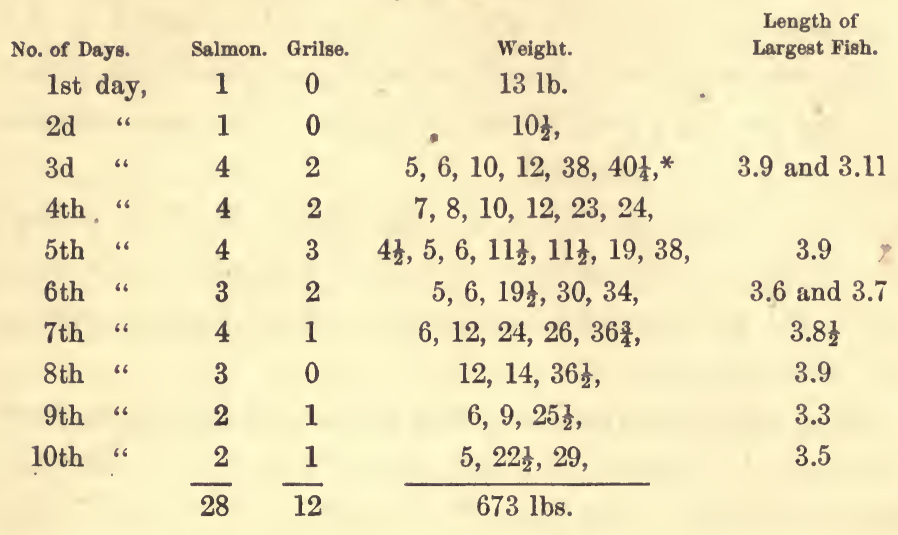

Average weight of Salmon . . $21 \frac{1}{2} \mathrm{lbs}$.

" " "Grilse . . . . $5 \frac{3}{4}$ “

The angler who accomplished this great feat says, in a letter accompanying the above account:-

"The particular river in which I killed my large Salmon last year was the 'Moisie,' a very large stream which empties itself into the St. Lawrence four leagues below Seven Islands, fifteen leagues west of Anticosti, and one hundred and forty leagues below Quebec. It can only be reached by chartering a schooner from Quebec, or by taking passage in the Hudson's Bay Company's boat, which leaves early in May.

"There are a great many excellent rivers on this coast, both above and below the Moisie, such as the Bersimis, Goodbout,Mingan, Romaine, Natashquan, Little Natashquan, Magnoime and others, all of which are full of Salmon; some of which have never been fished with the fly.

"The Moisie has always been considered the best Salmon-

* This is the largest Salmon ever killed on this coast with a rod. 
river on the coast, but it has been so poached and bedevilled with nets, torches, seines, and all sorts of things, that it is comparatively nothing to what it was,- - still I intend to fish it this year, and if any American gentlemen should happen to visit the ground, I shall be very happy to show them where a good cast may be obtained.

"I may as well remark, that although the Moisie is a large river, there is really not room for more than three rods, upon such posts as I have hitherto discovered, without interfering with each other."

Either the Moisie or Mingan is now leased by two or three gentlemen of Boston, who fish it every summer. The last season is said to have been one of rare sport; a great many fish were killed, many of them of unusual size,-two or three over thirty pounds.

Two Salmon-fishers of St. John, N. B., last summer made an excursion to the coast of Labrador. They called in their schooner at Bathurst for boats and to get canoe-men; one of the latter on his return gave a glowing account of the sport which these gentlemen had. A brother of the rod at St. John promised to send me an account of the trip. I regret I am obliged to send this to press before hearing from him.

\section{SALMON-RIVERS OF NEW BRUNSWICK.}

In giving a list of Salmon-rivers in this province, I will only advert to those in which the angler has a hope of sport Those in which the rod-fishing has been destroyed, by net, spear, and high dams I pass over, and refer the reader, who wishes information about Salmon-fisheries as a matter of commercial or statistical importance, to Mr. Perley's report of the British fisheries of New Brunswick. I shall first mention the rivers which have been described to me by others, and 
give an account of the only one I ever fished (the Nipissiguit) at the end of this chapter.

The Mirimichi.-A friend of whom I have asked information concerning this river, gives the following account of it:-

"Dear N.-The Mirimichi has been a fine Salmon-river, but the net and spear have done their work upon it, as upon nearly every other river in New Brunswick. Now it is scarcely worth visiting for its fish, though its wild and beautiful scenery can never fail to attract admiration.

"The first cast as you ascend is ten miles beyond Boiestown, and is called 'Salmon Brook.' I would advise any angler to pass it by, for if I live to be a hundred, I shall never forget the welcome given me by the flies and mosquitoes of that wretched place. I here, for the first time in my life, saw a Grilse. I fished here two days and killed nothing. We then broke up camp and pushed on eight miles to 'Rocky Bend,' the next cast, reaching it in the evening.

"The next morning about half a mile below the camp, I hooked and killed my tirst Salmon, a fresh-run fish of eleven and a half pounds, and I then thought it the most beautiful thing I had ever seen. The next day I killed my first Grilse of three and a half pounds, which is their average weight in this river.

"My next move was up to 'Clear Water,' which is really the first camp that an angler should make after leaving Boiestown. The camping is on the left bank of the river, just above 'Clear Water' brook, and is a beautiful place. This is a little bit of meadow-land, covered with grass and flowers, and the view to the westward, up and across the river, extensive and fine. The hills are five or six hundred feet high, and as the points at the river-bends incline gradually, upon looking up or down stream, one can see three or 
four hills, one beyond the other. I killed a few Grilse here and saw a few Salmon.

"The next camp, and the last, is at 'Burnt Hill,' five and a half miles higher up, and it is certainly the best place upon the river. It is on the left bank just below Burnt Hill brook, upon the hard rock; for the hills here come down to the edge of the stream, and the only objection to it is, that the spring is on the other side, and the frequent passage of the canoe disturbs the fish. There is a good cast not ten feet from the tents, and fine water both above and below. If an angler were fortunate enough to have a rise of water while here, which I had not, he would still have fine sport; but in low water it is time lost, except indeed he be, as I was, a beginner, and then I could give him no better advice than to go to McKay's at Boiestown, and send for William McKiel, and put himself under instructions, to as good a man as ever threw a fly or killed a Salmon.

Wishing that we may yet meet upon the banks of a fine Salmon-river, where the spear and the net are unknown:

"I remain, yours truly, "S."

The Mirimichi is reached by way of St. John, New Brunswick, from whence there is a boat every evening for Fredericton, on the river St. John. Here the angler buys his stores, and takes the stage for Boiestown, where he engages his canoe-men. As will be seen by the foregoing letter, the glory of the Mirimichi as a Salmon-river has departed.

The Ristigouche.-Although this river is still frequented every summer by great numbers of Salmon, it is said to afford no fly-casts on account of its want of rapids and proper pools. My informant, a canoe-man who accompanied a party of anglers one summer, could not tell me how high they 
ascended the river, but its upper waters and tributaries most likely furnish good fly-fishing.

The Matrapediac. - To get to this river, if approached by way of St. John and Bathurst, one must go to Dalhousie, and from there to Campbelltown, where the angler will have to engage such canoe-men as he can find. Most likely half-breed Indians, who are not generally reliable as regards sobriety or honesty, nor are they always good canoe-men. This, it is said, is a fine river for rod-fishing.

The Cascapediacs.-These rivers, both the Little and Great, as well as the Bonaventure, are on the northern shore of the Bay of Chaleurs. To fish them it is necessary to get boats, canoe-men, and stores at Bathurst, and cross the bay in a sailing-craft.

In going from Shediac to Bathurst one crosses a great many rivers, some of them quite small, that not many years ago abounded in Salmon. On some of these there was, no doubt, formerly fine rod-fishing.

At Bathurst, as will be observed by the map, there are three rivers flowing into the little bay which forms the harbor. The most northerly is called the Tittigouche; on the map it is printed Jittingouche. This was a fine little river at one time, but a mill-dam a mile or so above its mouth, now limits the range of Salmon and Sea-Trout to that distance. There is even now fair fishing at the dam, and at one or two pools below it on private property; these casts are two or three miles from Bathurst. The Middle River, which is crossed by a long bridge connecting Bathurst proper with the "Village," as it is called, on the north side, has a few stray Salmon to run up a short distance, but no rodfishing. 
'T'he next river, which enters on the south side of the town, I had the pleasure of fishing last summer, spending six pleasant weeks in doing so; it is the most famous river in the province. I will describe it at length.

The Nipissiguit.*-The usual route in going direct from "the States" to this river, is from Boston to St. John, New Brunswick, by one of the boats of the International line, which leaves every Monday and Thursday, at 8 A. M.; the time occupied in the passage is from twenty-eight to thirtyfour hours. The cars leave St. John every morning, and arrive at Shediac, on the Northumberland Strait, a distance of a hundred and ten miles, to dinner. From thence to Chatham, eighty miles, and from Chatham to Bathurst, fortyfive miles, the only reliable means of conveyance is in an open stage, and even then one may have to take an extra or lie over a day at Chatham. A boat leaves Shediac for Chatham every two weeks, on the arrival of the cars from St. John; and if the day can be ascertained from the St. John papers before leaving home, one may avoid a night on the road. The roads of New Brunswick, however, being kept in repair by the government, are hard and level, and the horses, generally two in a team, much "better to go" than one would suppose from their appearance.

Bathurst is situated at the mouth of the Nipissiguit, at the head of a beautiful little harbor on the Bay of Chaleurs. where Thomas Baldwin, a clever, obliging Irishman, keeps a good hotel, and will give an angler all the assistance and information he requires. Bela Packard, an intelligent Ameri-

* It appears strange that the author of "Salmon-Fishing in Canada," in giving the foregoing list of rivers, including those flowing into the Bay of Chaleurs, should omit the Nipissiguit, although it is fished every summer by anglers from Quebec. Nor does he mention the Tittigouche. 
can who settled there forty years ago, also accommodates anglers; and those who prefer more retired quarters, stop with him. Mr. Packard is a fine, erect, hale old man of seventy, has followed lumbering on most of the rivers of New Brunswick, and being communicative, and, like most Yankees, a little inquisitive, will interest a stranger while he posts him on the geography and history of the province. He is also thoroughly acquainted with the canoe-men, and the requirements of the angler when on the river, and will put him into good hands.

Although most of the pools on the Nipissiguit are fished from the shore, a canoe is indispensable in getting to them, as well as in travelling the river. Those in use are made by the Indians of birch bark. They are preferred on account of their light weight, a great desideratum in making the portages, which occur frequently on this river.

There are many requisites that go to make a good canoe-man. He should have a character for sobriety and honesty; he should be athletic, quick, cool, of unflinching nerve, and good-humored; he should be acquainted with every rapid, pool, and eddy in the river; where the fish are accustomed to lie at different stages of water; and should be a thorough woodsman, as well as a good river-man. The canoe-men of the Nipissiguit possess these amphibious qualities to a great degree. There are whole families-the Chamberlains, the Venos, the Levins, the Buchets, the Youngs, and others-who take to poling and paddling a canoe as young ducks take to water. Many of these have spent every summer from their boyhood in the employ of anglers from England, Ireland, Scotland, the Provinces, and the States, drawn thither by stories of the fishing on the Nipissiguit. Some of these men are also expert anglers, and can give the tyro many useful hints. I shall 
never forget the interest John Chamberlain* evinced in my success, when I told him I had never killed a Salmon: suggesting, by some well-timed hint, or modestly showing, how my casting could be improved, and apologizing (however serviceable his advice) for the intrusion.

All the stores that are really necessary on the river, and many of those that may be called luxuries, including good brandy and fine Scotch ale and whiskey, may be had of Messrs. Ferguson, Rankin \& Co., at Bathurst. Desiccated vegetables and meat, solidified milk, essence of coffee (if the angler wants them), smoking tobacco, and claret, he had better take from home. As to the quantity of provisions required for

* The author of the "Game Fish of the North" makes this uncalled for, and certainly unmerited, mention of the Chamberlain brothers: "The following are good men: John, Peter, and Bruno Chamberlain; John makes a good fly, but is sulky and wilful; Bruno is lazy; Ned Veno and David Buchet, both of whom are excellent and willing."

From a long summer's acquaintance with John, I found him exactly the reverse; he, with his brother Peter, were my canoe-men. They were always willing, respectful, and untiring in their efforts to show me the best fishing, and to promote my comfort by a hundred little acts of kindness and courtesy that appear to be inherent in French Canadians; and I know that my appreciation of these honest fellows is fully endorsed by such men as Messrs. Lilly, Emmet, Nicholson, Cooper, and other accomplished anglers. John attributes the remarks of the author I have quoted to the ill-humor of his friend "Dalton," who, one summer, had Peter and John for his canoe-men, and whom John describes as an irascible little old gentleman, who broke a great many tips, and smashed countless flies against the rocks; who would not be advised, but insisted on having his canoe in the middle of a pool, while fishing it, much to the terror of the Salmon; and "carried on generally" in the most unamiable way.

As for Bruno, there is no better canoe-man; he is one of the toughest, most untiring, and cheerful fellows on the Nipissiguit. I say this with no wish to underrate other canoe-men, but as an act of justice to my friend John and his brother Bruno. 
a trip, it would be well to leave that to Messrs. Ferguson \& Co.'s head man, and be guided in some degree by his canoemen.

Until last summer, the Nipissiguit had been free to all anglers, the first party at a fishing-station claiming the pools as a sort of pre-emptionary right. But with the alleged object of protecting the river from illegal and injurious fishing, it was let on the first of last July-for the season-to Mr. Ferguson, of Bathurst, and the privilege of fishing any of the stations was sub-let to different parties at a price, for a specified time. This was the first time the fishing on any river in New Brunswick had been leased to an individual, and the anglers, who had before resorted to it from St. John and other parts of the province, were loud in their denunciations, at the introduction of any rule that had the semblance of the game laws of the "Old Country," and the consequence was that few of them visited the river. There were persons, however, from Montreal and Quebec-generally British officers who came around by steamer-who rented the privilege of fishing several of the stations of Mr. Ferguson, and the Papineau and Grand Falls were in request. The advantage of paying for the privilege of fishing any station is, that it gives the lessee possession for the time, without the contingency of cavil.

The lowest fishing-station on the Nipissiguit is "Rough Waters," three miles above Bathurst, at the head of the tide. Here there is a succession of splendid pools, extending at short intervals for more than a mile. These, in order as you ascend the river, are the Lower Pool, the Rolls, Miller's Pitch, Willis's Pitch, Buchet's Falls, Proctor's Rock, and others that have no particular name, scattered along amongst them-embracing in all more than a dozen good casts. The earliest fishing of the season is found here, for the first run of Salmon appear to linger about these pools awhile, before making their way 
to the upper part of the river. The land on each side of the "Rough Waters" being owned by different individuals, the leasing of the fishing privilege of the river does not debar any angler from these pools, and every summer they are assiduously fished by people from the town and neighbor. hood, and the angler who camps here frequently finds his morning's cast anticipated by an earlier riser than himself,generally some Canadian stripling fishing for his breakfast or dinner, many of whom cast a fly with astonishing lightness and accuracy, and if their tackle was as good as the city angler's, the latter would stand a poor chance in fishing after them. A few flies though, a few shillings, and a little good humor, properly expended, will buy them off. Mr. N., of St. John, and the writer, last summer bought off a persistent young fellow of this kind, by employing him as camp keeper, at the extravagant price of fifty cents a day; he proved to be an excellent canoeman, and did us good service. But these competitors seldom have a canoe, and cannot get to many of the best pools in high water without, and, as a consequence, they are preserved to the angler who has one. The first Grilse also are taken at the "Rough Waters," and about the middle or 20th of July, they come in such numbers as to give fine sport.

Round Rock, the next station, is about two miles above Rough Waters. It has a half-dozen or so of excellent pools ; the best is that in-shore near the camp, called the "Rockpool." Here within a fly-cast of my tent door I killed my first Salmon,-an epoch in the life of an angler which he marks "with a white stone." I had hoped to be initiated gradually, killing first a Grilse and then a small Salmon, but fortune would have it otherwise, and with a rod and a fly of my own make, I brought to gaff in less than fifteen minutes a splendid fresh-run fish. "Bon poisson!" exclaimed Peter, as 
he tapped the Salmon on the head with a short billet of wood; "Bon poisson!" responded John, holding it up with the hook of the spring balance in its snout, and down went the index to sixteen pounds.

Six weeks later I hooked my last fish of the summer in the same pool, and killed it in the same eddy below. They were both fresh-run from the sea; both females, and both of the same weight. This singular coincidence cast a halo of quiet satisfaction around my recollection of a summer on the beauful Nipissiguit.

Papineau Falls, the next station, some eight or nine miles from Bathurst, is as renowed for the wild beauty of its scenery, as for its splendid Salmon-pools, of which there are three that are in high repute amongst the anglers who visit the river. Many fish are lost here from the rapidity of the water and the difficulty of getting along the precipitous rocky bank. About eighteen or twenty years ago, a packing establishment was opened here, and as many as six hundred barrels of salted fish were put up in one summer, which were taken by spearing and netting the river at this place and above.

Bittahock, two or three miles above, has two pools, where there was formerly good fishing, but they have deteriorated of late years, and there are but few fish taken here now. This place is remarkable for its deep still waters, the fairy-like nooks along its banks, and the singular appearance of the rocks, which seem to have been broken and lifted from horizontal strata, and piled with remarkable accuracy in parallel layers like mason's work.

The next station is Mid Landing. Here the river rushes through a deep narrow gorge, that one might pitch a biscuit across. The canoe-men say, that the depth of the water at the lower end is forty or fifty feet. There is one quiet pool 
below the gorge said to be good at low water, but I did not raise a fish in it. There are also three or four casts above; two of them are in-shore along the margin of the gorge, where I had good sport in stopping over-night, killing two fine Salmon in the afternoon, and two more next morning before breakfast. I afterwards took three Grilse in one of the same pools, when passing it at broad noon.

Chain of Rocks, three miles above, is said to afford good fishing occasionally, though in camping here a night, and fishing the three pools late in the afternoon and early in the morning, I did not hook a fish, having only two faint rises. This is a poor camping ground, much infested with flies, and has no spring near it.

Grand Falls, two and a half miles further on, and twenty miles from Bathurst, is the last fishing-station for Salmon on the river, the height of the falls preventing them from ascending further. In former years this was a favorite resort, when four or five anglers would find good sport for weeks. But, alas! two rods now are as many as the station will well carry, and even then careful fishing and frequent resting of the pools, for a day or two at a time, are required if the water is low. The fishing here commences at least two weeks later than it does at Rough Waters, and it is not until after the 8th or 10th of July that one can be sure of sport.

No description can convey an adequate idea of the rugged sublimity of the scenery here. The wide shallow river, suddenly contracted into a narrow channel, chafes and ioams over boulders and huge fragments of rock in its mad course, and leaping two smaller precipices, comes thundering down the main pitch, thirty feet, into a dark ravine, which in the course of time it has worn through the hard rock. After pursuing its way, and widening its channel through the gorge, to some sixty or seventy yards, it flows with abated current into a wide deep basin a mile and a half below. 
In winter the gorge is filled with frozen slush and ice from above; the falls disappear, and the surface along the ravine, above and below, is one roughened level, while the river flows beneath. The boatmen as they ply the pole and paddle in summer, to force their birch-canoe against the strong current in going to the "Falls Pool," will point out to the angler the trunks of trees barked and chafed by floating ice, nearly to the summit of the cliff's, and masses of snow and ice, ground into hail-like consistency, remain there in the deep shaded dell nearly the whole summer.

The camp, with its two capacious bark sheds, is on the west side of the river, rather more than a hundred rods below the falls. It is from a hundred and twenty to a hundred and fifty feet above the river. Twenty or thirty feet from the camp an icy cold brook, which comes from a spring a hundred yards above, flows through a wet meadow covered with alders, briars, and rank wild grass, and goes rattling down the rocky declivity to the river. Here the canoemen have scooped out the turf, and, damming the rivulet with a few large stones, have made a pretty pool for the use of the camp. I have seen six or eight silvery Salmon laid in it to keep fresh and cool.

This is a favorite camping-ground. Those who travel the river to or from the lumber regions above, make it an object to stop here all night when they make the portage of the falls. The toiling canoe-men, as they pole their bark, laden with the angler and his outfit, against the stubborn stream, look to it as a haven of rest. It is the angler's paradise, and many a pleasant day has been passed here, by jolly brethren of the rod who have travelled far by land, or crossed the broad Atlantic, to fish at the far-famed "Grand Falls." I have pleasant memories of this camp, which I pray may never fail me. The bright rushing river below, and the hill rising 
behind, covered with luxurious raspberries and whortleberries; the songs and stories of the unsophisticated canoe-men; the oozy meadow, with its alders and wild shrubbery, where the robin, the "peabody," the "chitchie-ke-witchie," and whole choirs of other warblers rouse the angler from his early morning slumbers, that he may souse his face in the cold brook, and prepare for his day's sport.

The "Falls Pool" is about a hundred yards below the last pitch of the falls. It is difficult to fish, there being but two casts. One is from the lower end of the pool, where you are compelled to throw up stream, the swift current bringing your fly back, and making it very hard to keep the line taut enough to strike successfully. The other a few yards higher up, by the side of the ledge, is a better stand, but you must keep well back, for the fish will see you unless the water is discolored. This is a perfect mausoleum for flies; how many have been broken against the granite cliff that rises abruptly at the angler's back, it would be hard to say: unless he is proficient in the left-shouldered cast, he can scarcely come away without the loss of three or four. In this pool Mr. L., of New York, has killed his dozen Salmon (not counting Grilse) before breakfast; but those days have'passed long since. The left-hand portion of the frontispiece of the book represents this pool.

The "Camp Pool," opposite the landing, is easily fished. There is a good open cast here, and one who fishes it, frequently has participants in his sport, for there is a fine view of the pool from the camp, and when the water is clear, those above can see all the runs and leaps of the fish, and the stratagem of the angler.

"Rock Pool," two hundred yards or so below the landing, is the glory of the station. The head of the pool on the right-hand side is the best cast at high water. When the 
water falls the opposite side is better. The angler is more certain of a fish in this pool than in any other on the river. I have lit my pipe at the camp-fire at sumrise, and killed a brace of fine Salmon here before I knocked the ashes out.

"Cooper's Point" (named after Captain Cooper, a retired British officer, who in former years came every summer from England to fish at the "Grand Falls") is the next cast below, and a continuation of "Rock Pool." It is fished generally from the shore on the right-hand bank. This is as difficult a place to cast from as the "Falls Pool," and as destructive to flies.

The "Unlucky," so named from the number of fish that have been lost here after hooking them, is still a continuation of the same pool-the lower end of it. It is fished from the same side as Cooper's Point. It is good only when the water is full. There is also a cast at the head of the basin on the left side when there is a freshet on. "Grilse Pool," opposite Gilmore's brook, and another by the bluff, with yellow pines on the left side below the basin, are good Grilse-pools, the water being rather shallow for Salmon in both, unless the river is full.

When the water is clear, Salmon can be seen in the river quite plainly. I have counted twenty from the bluff above Rock Pool, and half that number from the camp, in the pool below; and have seen the angler play his fly above their very noses at such times, without their showing the least disposition to take it.

There is one thing attending a sojourn at this station, which at times impresses the angler with a feeling (though not a sad one) of awe. It is observed mostly when fishing the pools just below the camp. I allude to the intense silence which reigus when the wind comes from any other quarter than the falls. If the birds sing high above in the 
shrubbery and stunted timber, they are not heard by the fisher down in the deep ravine through which the river flows; but a voice of ordinary pitch, a thump on the canoe, or the splash of a Salmon when it falls, after leaping above the water, is heard a long distance off, and the sound is prolonged and reflected from the almost perpendicular rock that walls in the stream on either side. Thus you frequently know when another angler, though he is not visible, has a fish on, and you may frequently receive or give a hint to make less noise, when the culprit is not aware of any lack of caution at the time of offending. It is a realization of the idea of audible silence.

This, as is the case with most Salmon rivers, is infested by poachers. The Indians spear, and the whites net the stream far beyond the limits prescribed by law. A straggling remnant of a tribe occupying a little island in Bathurst Bay, some of whom have skins as white as my own, spear at night and sell their fish at early daylight, or next evening, to the packing establishment at the mouth of the harbor, for four or five cents a pound. As the summer advances they extend their operations high up the river. I found them one night invading our pools at the Grand Falls. A shot from a carbine, though, dropped between the two canoes of the poachers, caused them to leave in a hurry. One fellow was in such trepidation, that he did not even think of dousing his torch, but went paddling down stream, illumining the bare cliffs with the glare of his flambeau.

It is not well for one who visits the Nipissiguit (and it is so with all Salmon-rivers) to be limited as to time. The angler may arrive when there is a continuation of rainy weather, and have to wait some days, perhaps for a week or more, until it falls; or he may get there when a long spell of dry weather has retarded the run of fish from the bay, and 
have to wait for a rise in the river before there is fishing. I have heard an angler, who has since been quite successful, say, that it was not until his third visit to this river, that he killed a Salmon; and was told of a very sure Salmon-fisher, who once spent three weeks at the Grand Falls, waiting for the water to fall, and went home at last without killing a fish. One should therefore have the whole of the month of July, and the greater part of August, before him to be certain of sport. A recommendation to the Nipissiguit as a Salmonriver is, that there are no trees near enough to the pools to obstruct one's cast. As celebrated as this river once was, four or five Salmon a day now, may be considered excellent sport: sometimes the catch will be one or two, or you may have several blank days in succession.

The sources of the Nipissiguit, the Ristigouche, and some of the upper waters of the tributaries of the St. John and Mirimichi are in close proximity, and those who have a fancy for such mode of travelling, may, by means of Indians and birch-canoes, ascend one river, or a branch of it, and portage into another. For instance, the Nipissiguit can be approached from the Mirimichi by way of the Northwest River, one of its tributaries. Or from the St. John (when the water is high enough for steamboats above the Grand Falls of that river), by ascending the Tobique, one of its branches, and making a portage of four miles to Nipissiguit Lake, where, from all accounts, Trout are shockingly abundant. A party of excursionists who made this trip last summer passed a station I was fishing on the Nipissiguit, each occupying a canoe manned by an Indian. The Ristigouche is accessible from the St. John by way of the head-waters of the tributaries of each, and also from the Nipissiguit.

Salmon-fishing in this country (as in Great Britain) is not an inexpensive amusement, unless one is fortunate enough to 
reside near the rivers in which these fish are found. The privilege of fishing some of the rivers of Scotland is let by the proprietors at round sums; two miles of a stream that will carry four rods commanding, I am told, from fifty to a hundred pounds sterling. In this country, the preparations for a trip, travelling expenses, hire of canoe-men, stores, and difference between "greenbacks" and gold, or Canadian cur. rency, amount to "something considerable," and a trip is apt to cost the angler more than double the amount set down by "Barnwell."

Anglers from "the States" uniformly meet with kindness amongst the "Blue-noses;" there is an inbred urbanity amongst those of French descent, however humble their sphere in life, which is always pleasantly remembered. One of the most agreeable days I ever spent, was a quiet Sabbath amongst these primitive people-the families of my canoemen. I have inserted this little vignette, fancying that it bears some resemblance to John Chamberlain; it at least expresses his fashion of wearing his hat.

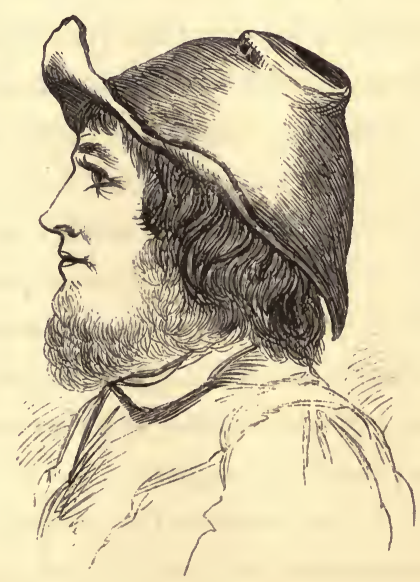




\section{H A P T E R X V. \\ REPAIRS, KNOTS, LOOPS, AND RECEIPTS.}


"LET independence be our boast." 


\section{CHAPTER X V .}

REPAIRS, KNOTS, LOOPS, AND RECEIPTS.

RrPaIRs.-To wax silk, thread, or twine-Tying on hooks and making loops, illustrated.-Splicing a line and splicing a rod, illustrated.

KNors.-The angler's single and double knot, and knot used in tying on drop-flies, illustrated.-A gang of hooks, illustrated.

Recerprs.-For making wax.-For dyeing gut.-For dyeing feathers and dubbing.

To WAX WrapPING-SILK.-The preliminary step in tying on a hook, making an artificial fly, or repairing tackle, is to wax the silk or twine to be used for that purpose. As there is some little knack in this, particularly when the weather is cold, and the wax stiff, it may not be a useless task to describe how it is neatly and effectually done.

Press between a small piece of folded leather a lump of shoemaker's wax, not larger than a pea; then holding one end of the silk between your teeth, and the other at arm's length, pass the wax lightly but quickly over it, at first with short rubs, then as the wax warms by the friction, with a longer and slower motion, drawing it towards the edges of the folded leather, for the last rub or two, to get rid of any unnecessary quantity of wax on the silk. Thread or twine is waxed in the same manner.

In fly-making, a wax, lighter, though less adhesive than shoemaker's, is generally used. A small pellet is rolled between the thumb and forefinger until it is soft, when the 
silk is drawn through, and the superfluous wax wiped off by drawing it between the thumb and finger.

To TIE on a Hook.-Hold the hook in your left hand between the thumb and forefinger, with the shank uppermost, and the head outward or towards your right, then take two or three turns around the bare shank of the hook near the head, and laying the gut-length on the back of the hook or underneath, wrap down closely until the wrapping covers the end of the gut, which in a short-shanked hook will be opposite the point. Figure 1, on the annexed wood-cut, shows

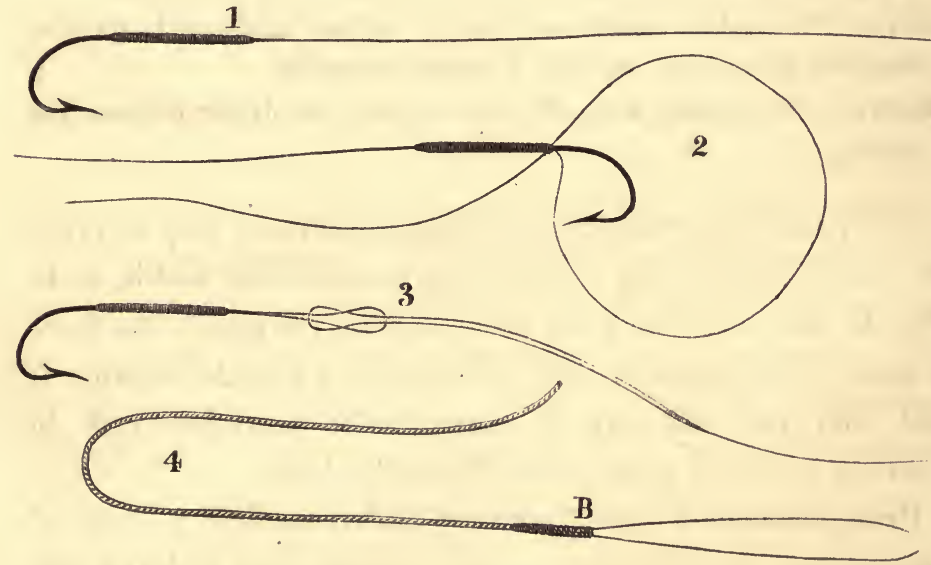

the position of the hook thus far. Then seizing the shank of the hook and reversing it-that is, with the bend outwardslay the silk along the shank with the end towards the wrist of your left hand, as in figure 2, and forming a loop at the bend of the hook, take the lower part of the slack, and continue the wrapping for three or four turns more, and holding it securely, though not too tightly in its place, draw the slack through and cut it off close, thus making what is by some anglers termed the invisible knot. 
Loops.-In tying on hooks for bait-fishing, an excellent plan is to whip the hook to a gut-loop, as shown by the lefthand portion of figure 3. The right-hand portion of the same figure represents a loop on the end of a gut-leader, and shows how a hook may be attached to the leader or taken off; it is convenient in changing one's hooks; the loops draw together closely when the gut becomes soft in the water, and present a neat appearance.

To carry out the same idea of neatness and convenience, a line should also have a gut-loop at the end of it, for the purpose of fastening on or taking off a leader, and to dispense with knots. The loop can be fastened to the line securely and neatly in the following manner:-Taper the end of the line for three quarters of an inch with a sharp knife, and after holding a piece of shoemaker's wax in a candle or gas-light, draw so much of the line through the soft wax; then hold the ends of the gut-loop in the gas-light to blunt them and form little knobs on them, and indenting the gut between your fore teeth, lay it on the waxed end of the line, and beginning at the ends of the loop (figure 4), wrap with fine waxed silk as far as B, and fasten off with the invisible knot, as already described in tying on a hook.

To Splice A Line.-When the angler breaks his line and is not willing to dispense with the part broken off, if it is joined by a knot, it will not pass through the rings of the rod, and splicing becomes a necessity. This is done by tapering the two ends for three quarters of an inch, waxing them well, and laying them together, and wrapping with fine wellwaxed silk. Fastening off with the invisible knot in this instance is different from the manner before described. It is done thus: after wrapping from A to B (figure 5), drop the silk into a loop D, and commencing at C, pass the end four times around the line towards towards B, then taking up the 
slack D, continue to wind (over the end) from B towards C, four turns, and draw the slack through and cut it off

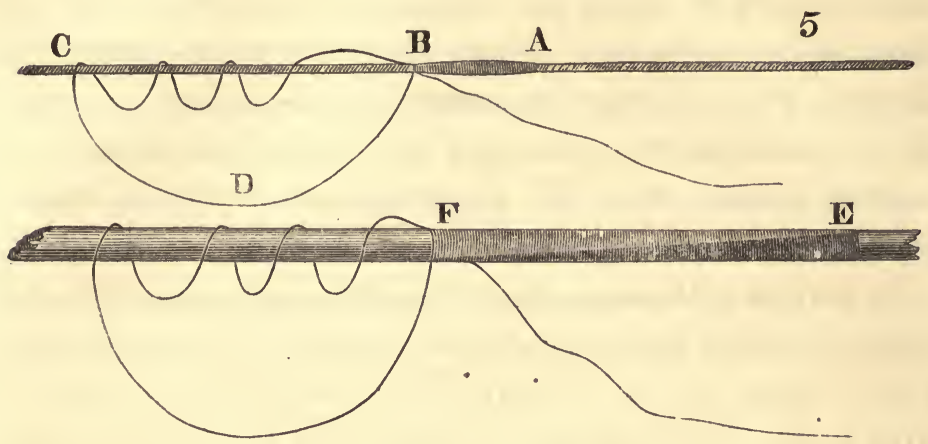

To Splice A RoD.-Trim off the fractured ends obliquely, making a long bevel on each, and after rubbing the surfaces where they are to come in contact with hard shoemaker's wax, wind the splice from $\mathrm{E}$ to $\mathrm{F}$ with fine waxed twine or sadler's silk, and fasten off with the invisible knot, as described in splicing a line.

KNots.-In the next cut, No. 1 is the angler's single knot; it is used in tying a line. No 2 is the angler's double knot, the neatest and most secure in joining gut-lengths. The ends are laid together pointing in opposite directions, and are passed through twice; this knot is indispensable in making leaders for Trout, and casting-lines for Salmon fishing. When drawn together the knot is oblong and the ends may be cut off as close as can be done with a sharp knife, without a possibility of their drawing. No. 3 is a water-knot; it is used mostly in attaching the drop-fly to a leader in Trout-fishing; the ends are tightened, and the knot drawn together after the knotted end of the gut to which the dropper is tied is passed through. The ends of this knot should not be. cut off too close, for fear of their drawing when the gut becomes thoroughly soaked. 
REPAIRS, KNOTS, L OOPS, A N D R C EIPTS. 409
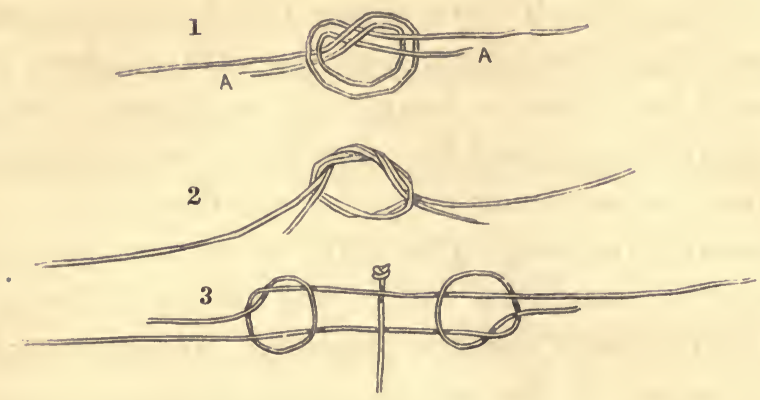

GANGS.-The subjoined cut represents a gang of hooks; it is much used by those who troll the lakes of northern New York, and, as the reader will see, is readily made. In putting - on the bait the single hook at the top of the gang is passed through the lips of the minnow or shiner; one of the pair in the middle, through the body just below the back fin; and one of those at the end of the gang through the minnow just above the tail. The gang should be shorter, or longer, and the hooks larger or smaller, as the case may be, to suit the size of the minnow. I have drawn these hooks too small with the exception of the top hook; they should be twice the size represented.

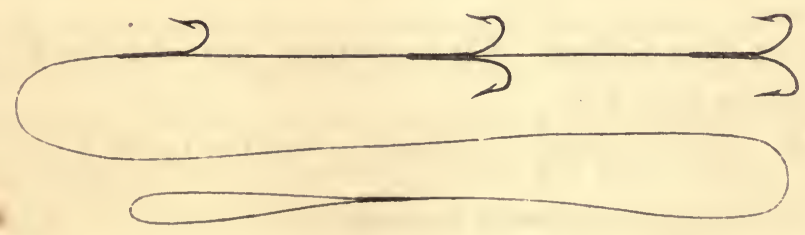

Gut should be soaked in hot water for at least ten minutes to insure a compact, secure knot in tying leaders. If on the stream, the ends may be held in the mouth a few minutes to soften them. Any attempt to tie a knot in dry gut will cause it to break, or fracture so as to endanger its strength. 
Directions For Dyeing Gut.-The following is taken from the "Fly-Fisher's Text-Book," by Chitty. I have found his receipt for dyeing a neutral tint to produce a color so much to my liking, that I have used it for twelve years without trying the compounds for producing other shades.

"General Directions for Dyeing Gut.-In an earthen pipkin boil about one pint and a half of cold water with the dyeing ingredients I shall mention presently. When these have boiled about ten minutes, take the pipkin off the fire, and after a minute or so, immerse the gut, tied, if at all, very loosely, and leave it in the still bubbling liquid, so long only by the watch, as I direct, and it is dyed enough; for observe, that these are all tried means. On taking the gut from the pipkin, cast it into a basin of clean cold water, and rinse it well; wipe it, and let it dry awhile: then take each length separately, and holding it by the end between the fore teeth, rub it with India-rubber, which not only cleans and straightens it, but also tests its strength, avoiding the necessity of doing so again when about to be called into use. After this, clip off the bad ends and tie all up neatly together, and keep it, at full length, in a paper or parchment case, with an inner one of thin paper rubbed with olive-oil, which, in moderation, preserves gut.

"Particular Recipes.-The ingredients are as follows; and first in my esteem is,

"No. 1.-An azure or neutral tint (similar to ink-dye):-

"1 drachm Logwood,

6 grains Copperas,

Immersed $2 \frac{1}{2}$ or 3 minutes.

"No. 2.-An azure tint, more pink than the last:-

"1 drachm Logwood,

1 scruple Alum,

Immersed 3 minutes. 
"Or, five grains alum, added to No. 1, will change it to this color; - but the less we use copperas the better, and, therefore, No. 2 is best for this color.

"No. 3.-A dingy or dirty olive (a very good color):-

"To ingredients of No. 2, add,

3 scruples Quercitron Bark,

Immersed 2 minutes, or perhaps 3 minutes.

"No. 4.-A light brown:-

" 1 drachm Madder,

1 scruple Alum,

Immersed 5, or perhaps 6 minutes.

"No. 6.-A light yellow, or amber:-

“ $1 \frac{1}{2}$ scruple Quercitron Bark,

1 scruple Alum,

6 grains Madder,

4 drops Muriate of Tin,

1 scruple Cream of Tartar,

Immersed $2 \frac{1}{2}$ minutes."

Dyeing Feathers and Dubbing.-It is possible that this work may fall into the hands of some Salmon-fisher to whom the opportunity of importing dyed hackles and dubbing is not often presented, but who can procure the necessary materials. With a view of enabling him to become his own dyer, I have taken the following from the "Book of the Salmon." It is a condensation of directions given in Blacker's "Art of Fly-making and Dyeing."

"The best vessel for dyeing is a Wedgwood-ware pipkin; and one that will hold a quart of fluid will be large enough for all ordinary purposes. Before dyeing pig's hair or wool or mohair, each must be scoured of its grease and dirt by immersion and boiling for half an hour in strong soap-lees. 
Feathers, the chief ones used being hackles, must be also cleansed by washing them with soap in warm water. The principal colors to be obtained are black, brown, blue, red, and yellow, and by combining, in the process of dyeing, those colors, all other hues and shades can be procured. The reader is requested to bear in mind that the art of dyeing is a very delicate one, requiring minute attention and no small experience. The experimental student must exercise considerable patience, and not be at all discouraged by incipient failures. They will dissolve by degrees into successful results.

"Recipe for Blue.-With soft river-water let your pipkin be about three parts full; put it on a slow, clear fire, adding a teaspoonful of 'paste-blue,' which can be purchased at the color-shops. Keep stirring it, and when it is more than lukewarm, add a tablespoonful of cold water, into which you have put twelve drops of sulphuric acid. In this dyeing fluid place a quarter of an ounce of material to be dyed, whether pig's hair, hackles, or mohair, taking care that they have been previously thoroughly cleansed as already directed, and rinsed in hot water, and then wrung out just before you put them into the pipkin. Let the whole boil slowly for fifteen or twenty minutes. Then take out your fur or feathers, or whatever material you are dyeing, and rinse in pure cold water. Dry, if possible, in a sunny atmosphere. For stirring your materials in the pipkin always use a clean piece of wood.

"For Red.-Water as before in your pipkin, and with it two handfuls of Brazil wood, and a quarter of an ounce of pig's hair or feathers, or any other material you want to dye. Boil the whole for half an hour. Take out your material, and cool the dyeing fluid by the addition of a little cold water. When cool, put in sulphuric acid in manner and quantity as before; next, add your material to be dyed, and gently 
simmer the whole for an hour over a slow fire. Then take out fur or feathers, immerse in cold water, and wring and dry as before. If you want a beautiful claret hue, add, in the first boiling, to the Brazil-wood, half the quantity of logwood; and, in the second boiling, a bit of copperas the size of a pea, and the size of a hazel-nut of pearl-ash. Boil an hour, immerse material in cold water, and rinse and dry as before. Take care that the dyeing liquor be cool before you add to it the sulphuric acid.

"For Yellow.-Water as before, in which put a handful of bruised Persian berries; boil for an hour, and then add two tablespoonfuls of turmeric. Put in acid, mohair, \&c., in manner and quantity as before; boil for half an hour, take out and rinse in cold water, and dry. The addition of a tablespoonful of Brazil-wood will change your brilliant yellow to rich orange.

"For Brown.-Water as before, in which boil a handful of walnut-rind, with a very small quantity of red-wood, and of logwood the size of a walnut, for half an hour, together with a quarter of an ounce of the material to be dyed. Take it out, cool the liquor, and add acid as before. Reinsert feathers or fur, \&c., and boil them for another half-hour. Rinse and dry as usual. For cinnamon and fiery brown colors, dye in the above fluid hackles, pig's hair, and so forth, that have been already dyed. yellow. The fiery brown will require more ingredients in the fluid than the cinnamon color.

"For Black.-Water as before, in which boil two handfuls of logwood one hour; then add a little sumach and elderbark, and boil for half an hour longer. Next put in your feathers, \&c., and boil another half-hour. Take them out, cool your liquor, and add acid; dissolve a bit of copperas the size of a nut, and adding a little argil and soda, boil again for half an hour. Take out your feathers, fur, or hair occasion- 
ally, as exposure to air during the process of dyeing tends to promote and fix the black color.

"A mixture of blue and red dyeing liquor boiled together, and afterwards cooled, and acid added to it, will produce a purple color.

"A mixture of blue and yellow dyeing liquor will produce, in accordance with your varying and modifying it, greens of all shades.

"A mixture of blue, red, and yellow liquor produces bright olives, the hues of which may be sobered by the introduction of logwood.

"For Bright Scarlet.-Water as usual, in which put a teaspoonful of crystallized tartar. In this liquid boil the materials you are about to dye; take them out, and put in a tablespoonful of powdered cochineal and a teaspoonful of 'grainspirit,' which can be bought at the drysalter's. When in a simmering state, reintroduce your materials-feathers or fur, \&c.,-and boil the whole gently for half an hour. Wash, rinse, and dry your materials as usual.

"Yellow, and its Varieties for Feathers.-The recipe already given for dyeing yellow, suits pig's-wool, mohair, and furs best. The present recipe is better for feathers, hackles, \&c. Boil two or three handfuls of yellow-wood one hour in a quart of soft water; wash the feathers, be they mottled mallard or any sort of hackle (light-colored ones are the best to be dyed yeHow), in soap and hot water. They must be tied in bunches at the quill end. Boil these bunches a short time in a pint of water, to which you have added a large spoonful of alum and tartar, in a pipkin. Take them out and immerse them in your yellow dyeing liquor, and let it simmer for an hour or two, more or less, according to your desire for a paler or deeper yellow. Finally, take out the feathers, and rinse them in hard spring water. Red hackles, 
boiled in a similar liquor, will become brown or amber. When you want yellow-greens, either of hackles or mohair, add blue paste or indigo steeped in water for twenty-four hours, to your yellow liquor, and by augmenting or diminishing the quantity of blue, you will obtain several shades of yellow green."

W Ax.-The most tenacious is undoubtedly shoemaker's wax, but it is so stiff in cold weather as to make it difficult to wax a delicate thread with it, and in a warm room so much adheres to the silk when tying a fly, that it is objectionable when finishing off at the head, where it should be neat as well as secure. Fly-makers, therefore, have resorted to several methods of rendering shoemaker's wax less adhesive to the fingers and more easily applied to the silk. One is to add a small portion of lard or (Chitty says) pomatum. Many professional fly-dressers have a receipt for making their own wax: the base of all, or that which gives it adhesiveness, of course is rosin. A light-colored rosin is generally used, and lard and beeswax are added in different proportions, and sometimes even gutta-percha. A solvent for the latter constituent is naptha or ether.

Shipley's book (an English work) gives the following receipt for making transparent wax :-

"Put two ounces of the best and lightest-colored rosin and one drachm of beeswax into a pipkin over a slow fire; when well dissolved, simmer them for ten minutes longer, then add two drachms of white pomatum, and allow the whole to simmer for a quarter of an hour longer, constantly stirring it; pour the liquid into a basin of clean, cold water, and it will assume a thick transparent consistency; while yet warm knead it by pulling it very much through the fingers till cold; the last operation giving it toughness and that silvery opacity which it assumes when properly compounded." 
Chitty says he has made this wax after Mr. Shipley's receipt, and finding it too brittle added a half-drachm more of pomatum. He further says, "another receipt for the same, is eight ounces of white rosin and one tablespoonful of linseed-oil. This I have not tried."

Chitty also advises the fly-maker to dissolve a lump of shoemaker's (anglicè cobler's) wax in a sufficient quantity of spirits of wine. I have found alcohol (but not weaker than $95^{\circ}$ ) a solvent, and also ether. This is a liquid wax, and enables one to wax his silk by immersing it in the solution; but I found on trial that the alcohol evaporates after a while, leaving the silk imperfectly. waxed

The best wax I have ever used in making flies was given me by Mr. George, who ties flies for Philip Wilson, Chestnut Street above Fourth, Philadelphia.

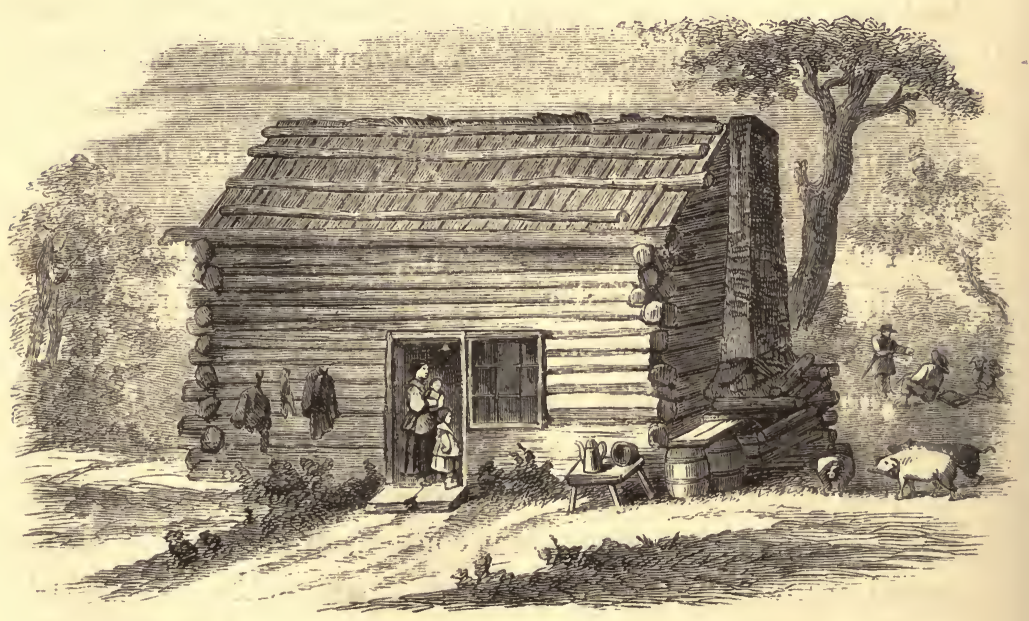




$$
\begin{gathered}
\text { CH A P TER XVI. } \\
\text { F L Y - M A K I N G. }
\end{gathered}
$$


"To frame the little animal, provide

All the gay hues that wait on female pride;

Let Nature guide thee; sometimes golden wire The shining bellies of the fly require;

'The peacock's plumes thy tackle must not fail, Nor the dear purchase of the sable's tail.

Each gaudy bird some tender tribute brings, And lends the growing inseet proper wings: Silks of all colors nust their aid impart, And every fur promote the fisher's art."

GAY. 


\section{CHAPTER X VI.}

\section{FLY-MAKING.}

Implements.-Hand-Vice, Spring-Pliers, \&c.-Book for holding materials. Materials.-Hooks.-Gut.-Tinsel.-Dubbing.-Hackles.-Wings.

To tie a plain Hackle.-To tie a Palmer.--To make a fly with wings.

BEFORE attempting a description of this art, it would be as well to acknowledge that few amateurs attain the neatness and dexterity of those who follow it as a business. To those who have not leisure, or fish but seldom, it does not pay for the trouble and patience bestowed on learning it; such persons had better buy their flies than make them. But to one who has time, and is anxious to become conversant with all that pertains to our gentle craft, there is no in-door occupation so absorbing and time-killing, and one forgets in it little annoyances or heavier cares, and almost finds at home a substitute for the pleasures of the stream. The satisfaction of taking fish is also increased, if it be with the product of one's own skill; and the angler can adopt any little fancy of his own, and produce exactly the thing he desires, and have his flies on the particular size, shape, or make of hook he prefers; he can also use the kind of gut he thinks best for drop-flies or stretchers, and gratify any other whim.

But who can lucidly explain this art? Few writers make it plain, from Cotton down to Hofland, "Ephemera," and Ronalds, with their elaborate illustrations. So it is with some doubt as to enlightening the learner that I attempt it, but 
would rather commend him to some friend who is an adept, or to a professional fly-maker. A few hours spent with a skilful fly-dresser is worth a volume of written directions and illustrations.

IMPLEMENTS.-The amateur fly-tier of the present day has many little implements which assist him greatly: there is the pin-vice, which are fingers to him, holding the hook securely; spring-pliers, or, as some call them, forceps, to assist in hackling; a stout darning-needle to pick out the dubbing; a pair of sharp scissors, \&c., \&c. These can be kept in a wallet or large pocket-book, with the materials for making flies. The

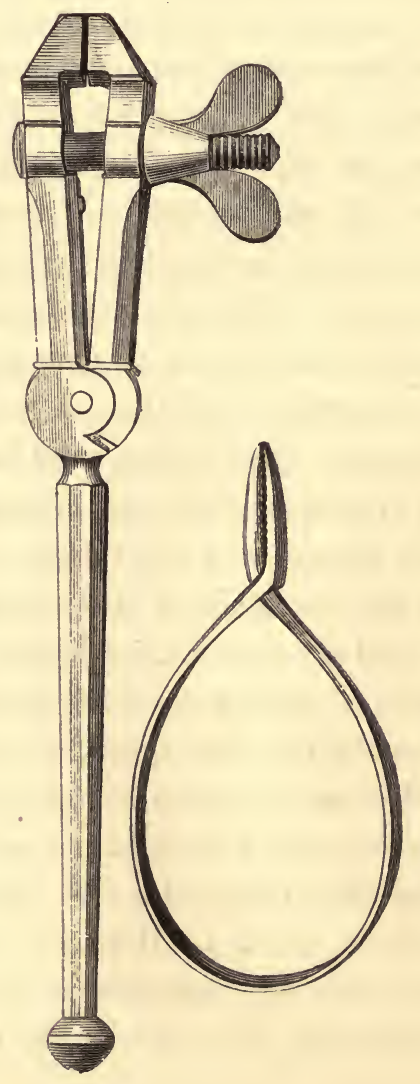


proper shape and size of the vice and spring-pliers are represented by the foregoing cut.

Materials. - In collecting materials for flies, the angler becomes "seised and possessed" of many chattels, which he may husband for years before he finds use for them, and it may be necessary, occasionally, to overhaul his wallet, and discard those that are useless, if he does not wish it to grow to an inconvenient size. There are some materials, in the way of feathers and dubbing, described by English writers, which cannot be had here, unless imported to one's order; but he who has a proper. appreciation of his wants, and keeps his eyes open, can collect all that is necessary, with very little outlay of time or money. He does not see a bird-a wild duck, a cock, an old hen, a turkey, or a peacock, without suitable feathers being presented to his eye. He will see dubbing everywhere: his wife's muff, the cat, or a lapdog, or a gray or red squirrel, or a hare, or a pile of mortar with tufts of cow's hair lying about it, or the place where there has been a hog-killing, with the refuse, down, or furze cast heedlessly by, a buftalo-robe, a bear-skin, a foot-rug, all sug gest dubbing. Old pattern-cards of moreen in the store of his dry-goods friend are begged for. Silk floss of suitable colors are sought after, as well as gold and silver thread and tinsel. All these are garnered up with miserly care, and stuffed into the dubbing-pocket of his book or wallet of fly materials. He need be in no hurry to collect them, for if he has the bump of acquisitiveness, he will in good time stock his wallet to repletion, without sending to Demarara for green monkey's fur, or to India for the feathers of a golden pheasant, or to England for a starling's wing or the fur of a water rat.

A wallet, with suitable pockets and compartments to hold the necessary implements and materials, need not be over eight inches long, five deep, and four or five wide. There 
should be one pocket for dubbing; one for feathers, which are kept most conveniently in envelopes, each kind separate; and another for floss, wrapping-silk, \&c. Hooks should be kept in different parchment parcels, each appropriately numbered, and slipped under a leather band stitched at intervals to the inside of the wrapper of the wallet. Under the same band there should also be loops for each tool. The leather wrapper should be part of the wallet and wrap around it, and should be tied with a leather string. This kind of wallet or book of materials can be opened and spread out on a table, or on the grass, or on a rock; it is easily kept in order, and when folded up is compact and occupies but little space in stowing. A larger one than the size just described is required for materials for Salmon-flies.

It may be asked by the learner, What fowls of the air, or water, or of the barn-yard, furnish these feathers? What is a hackle? What part of the fowl is it plucked from? What feathers of its plumage furnish the wings of the fly? Where do you buy tinsel and floss, and so on, and what kind of hooks are most suitable, and what sizes of them do you use for particular flies? Patience, my dear boy, if you are really anxious to know all about it, or all I can think of just now on so momentous a subject, I will not put you off with the hurried rigmarole I have just given you, but will commence de novo, and tell you in a more orderly way what you will want and how to get it. If we were in London or Dublin or Limerick, we would step into a tackle store, and lay down our money, and, presto, all we wanted, and more too, would appear on the counter. But here we are thrown on our own resources, and must do the best we can ; and the best we can is quite as well as we could do in any of the old cities or towns I have just named, as far as tying Trout-fies is concerned; when we tie our Salmon-fies, we are to some extent dependent 
on them. I say this to disabuse you of the erroneous impression that Mr. John Gay's verses, which I quoted just now, may create in your mind. For although they are very good poetry, it is nonsense about providing "all the gay hues that wait on female pride;" and what he says about "the dear purchase of the sable's tail," or what some other pedantic old fly-fisher says, when he tells you that the tail of a certain fly must be made of "three whisks of a black cat's beard." For you need not go to the furrier's to buy a sable's tail, or go hunting your own or your neighbor's garret for a black cat to get his beard. Only use the most suitable materials you can procure, without spending so much money, or trespassing on your neighbor, and you will catch a great many Trout before they find out that you have not gone according to Mr. Gay's or Cotton's directions, or your humble servant's either. Let us take up the articles in the order in which we use them. The first is the hook, therefore let us talk about

Hooks.-The improved Limerick hook of the O'Shaughnessy pattern, is by all odds the best for winged flies; it is not so apt to draw from a fish's mouth without hooking, as the old-fashioned Limerick. I prefer it to the sneck-bend or Aberdeen hook. For Hackles and Palmers, which have no wings, I like a neat fine-wired Kirby, because the point turns to one side, and it is, therefore, more apt to hook a fish, even than the O'Shaughnessy. The reason I do not use the Kirby for winged flies is, that this turning of the point to one side, has a tendency to throw the fly on its side, and prevent it from swimming true; for the wings of a fly should set upright, that is, they should not incline more to one side than the other. A Hackle or a Palmer having no wings, and the fibres of the hackle-feather, which represent the legs of a caterpillar, or the hairy body of other larvæ, sticking out 
on all sides, regularly unequal, if I may use the term; it matters little whether it floats on its "beam ends," or swims on an "even keel." The reader will note the difference in the shape of the hooks mentioned above, by referring to the plate of hooks on page 61 .

GuT.-Stretcher flies should be tied on full lengths of fine gut. Droppers should be made on short, stout pieces, so that the fly will set well out, and at right-angles from the leader, and not lap over it, or twist around it. For droppers a single length of gut may be divided into at least three parts, for as I have already said, the piece to which a dropper is tied should not be more than five inches long.

WRAPPING-SILK.-If the silk is fine and strong it matters little about the color, for the only place where it is visible after the fly is finished, is at the fastening off of the head. The best silk I have ever seen is kept by the English and Irish tackle-stores, and is made expressly for the purpose. The fine three-cord silk used for sewing machines, No. 000, is the best we can get here.

Tinser.-Silver and gold tinsel, both flat and twisted, are required to rib the body, or tip the end of it. For Trout-flies the flat is chiefly used; in Salmon-flies all four of them will most likely be required. This article is kept sometimes by trimming-stores, or where the trimmings for military clothing are manufactured. The Irish tackle-stores have it made on purpose for tying their own flies, and to sell it to amateur flymakers. When I have not been able to get it in any other way, I have taken the broad woven strips of tinsel, from around pieces of Irish linen, and drawn or ravelled out the particular kind I wanted; it is not as suitable, though, as that sold by the tackle-stores.

DuBBING.-This is the material of which the body of the fly is composed. It may be mohair, seal's wool, pig's wool, 
or floss silk, or the fur of some animal; or ravellings of moreen-an article used to cover the cushions of chairs or pews, or for curtains. The hurls, or as some call them the "harls," of the peacock's tail-feathers, or of ostrich plumes, are also extensively used for the bodies of Trout-flies. Hurls are the long delicate plumelets that grow on each side of the main stem of the feather. Mohair, seal's wool, pig's wool (or pig's down as it is frequently called), and floss-silk, which are chiefly used for Salmon-flies, should be of various colors. Those mostly used are light-red, blood-red, dark-red, and maroon; snuff-brown and dark-brown; pale-yellow or lemoncolor, bright decided yellow, orange, and tawny yellow; light blue and steel or mazarine blue; decided green and peagreen; white, lead-color, and black. Wool should never be used for dubbing, as it absorbs much water and makes the fly soggy. I seldom use mohair, pig's wool, or seal's wool for 'Trout-flies (they are better for Salmon-flies, seal's wool being preferable), and as far as I can, discard fur, as a dubbing, and use chiefly the ravellings of moreens, flosses, and hurls. Of the peacock's hurl, the copper-colored tint is greatly to be preferred; three-fourths of the bodies of the Trout-flies I make for my own use are wrapped with it.

Mohair, pig's wool, and seal's wool, when the fly-maker wants them already dyed, must be imported from England and Ireland. Fur-dubbing, flosses, and hurls, can easily be obtained here. If the reader wishes to try his hand at dyeing dubbing, he will find receipts in the preceding chapter.

HACKLES.-The word "hackle" is used in two senses; when spoken of as a material, it is that which represents the legs of the winged $\mathrm{fly}$, and is wound around the body under the wings, or spirally over the body from the tail. The word is also used to designate the hairy-looking representation of an insect, or caterpillar, or other larva, and with 
fly-fishers, a "Hackle," or a "Palmer," though neither has wings, is known as "a fly."

I mention the "hackle" here as a material; there are two kinds. First, the hackles of the domestic fowl. Those of the cock are the long brilliant feathers that droop gracefully on each side of the tail; they are known amongst ornithologists as the "tail-coverts;" the boys call them "shiners." There are hackles also on the neck of the cock, which are shorter and also stiffer towards the head. The neck-hackles in most cases are of lighter color than the tail-coverts; the latter may be dark enough to make a good Soldier or Red Hackle, while those on the neck of the same cock may be light, and have sufficient yellow tinge in them for Ginger Hackles. The same cock may also furnish short, stiff hackles from between the tail-coverts, just on the lower part of its back, which are of a brownish red tint, and will make an excellent Brown Hackle on a small hook. Hens furnish hackles only from the neck, which are short and soft. A Furnace Hackle is a commixture of fiery red and black; a "Coch a bondu" has its fibres black at the roots and red at the extremities.

When other feathers than those of the domestic fowl are used as hackles, they are taken indiscriminately from any part of the bird's body, where the best feathers for the purpose can be found; such as the wing-coverts, or rump-feathers of the pinnated grouse (prairie fowl); spruce grouse (Canadian); partridge, snipe, woodcock, or wren's tail. Such feathers, though, are not as suitable as those taken from a cock, for the fibres do not set out so stiffly, and when used for droppers and dapping along on the surface of the water, the fibres close against the body and give it an unattractive appearance.

Cock's hackles, in all their variety, white, yellow, ginger, red, brown, furnace, coch a bondu, and black, can be had of 
your friends who keep fowls, or in any barnyard, and with the hackles from the birds above mentioned, are all that are required for Trout-flies.

Hackles for Salmon-flies are nearly all of them dyed, and are generally imported to one's order. If the reader wishes to try his hand at dyeing them for himself, as I have said of dubbing, he can find receipts for the different colors in the preceding chapter.

WINGs.-The most suitable feathers of the birds common to our country, for Trout-flies, are the tail and secondary wing feathers (those next the pinions) of the wild and tame pigeons, the gull, blue heron, prairie-fowl, spruce-grouse, snipe, woodcock, partridge, and domestic hen, and from the wingcoverts of the mallard and wood-duck. These, with a few feathers of the red ibis and flamingo, are all that are required for Trout-flies. The last two are foreign birds, and the feathers are seldom used except for the Sea-Trout of the British provinces, or lake-flies. For the wings of Salmonflies, the best feathers of native birds are the wing-coverts of the teal, mallard, wood-duck, and canvas-back, the tail-feathers of the wild and tame turkey, the domestic hen, and the peafowl. It may be as well to say here that the drake mallard only furnishes that beautifully mottled brown feather that all fly-makers admire so much; there are but five or six on each side of the duck; they are found just at the elbows of the wings; immediately beneath them are found two or three gray feathers, which are serviceable when a light wing is required for high water. The imported feathers used for Salmon-flies are from the crest, ruff, tail, and wing of the golden pheasant, and tail and wing of the argus pheasant. Blue, yellow, and red macaw are used for feelers (antennæ), but from my experience, I am convinced that feelers on a Salmon-fly are about as useless as the long tails made of silk- 
worm gut, which English fly-makers append to Trout-flies, with a vague idea of imitating the tails of the ephemeridæ. The throat, or rather the upper part of the body, of a Salmonfly occasionally has a few turns of a blue-jay's feather (taken from the butt of the wing), or of some high-colored breastfeather of a water-fowl or land-bird. The collars and tags of Salmon-flies are made generally of peacock or ostrich hurl, or the breast-feathers of birds of brilliant plumage.

And now, my incipient fly-maker (I do not write this for the 'old ones') I have told you in a few minutes what it has taken me nearly a quarter of a century to learn; I have picked it up by mites, "here a little, and there a little," and I do.not know half as much as I would like to know and hope to know, for fly-makers and fly-fishers are learning something of the art as long as they can twirl their fingers or cast a whip of flies. Both branches of the science, the rudiments of which are so easy to learn, run into the abstruse-I was going to say even into the occult: the subject, like the tip of a fine fly-rod, is almost infinitesimal in its tenuity. I would have given a great deal to know as much as I have told you, when I was a beginner-a great deal more than you will have to pay for what many persons will deem a very foolish book.Let them alone, "for to them it is not given" to know of the things that pertain to the gentle art, or to appreciate the scenes through which the pursuit of it leads us; for "seeing, they see not" God's love and handiwork in the little wild flowers that grow along our path; and "hearing, they hear not" His voice in the song of the bird and the music of the brook, "neither do they understand." I hope such people will not bother us while I endeavor to show you how to tie a fly with the help of these four simple figures, which I have drawn expressly for the purpose. 
To tie Hackles and Palmers.-To make the first lesson as easy as possible, suppose we tie a plain Ginger Hackle for a drop-fly. It will b; easier to make it on a large hook, say No. 4. Let us select the materials, and lay them before us: viz., wrapping-silk, hook, floss-silk, a ginger hackle, and a short stout piece of gut, as we intend it for a dropper. Now let us begin :-

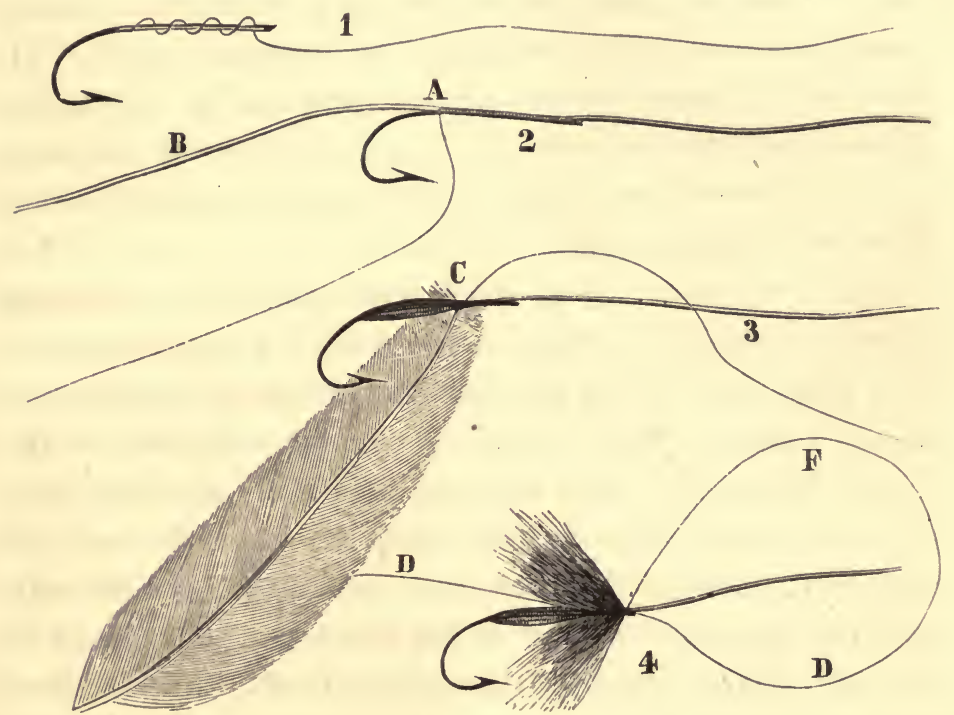

Figure 1 is a hook in its proper position, whether it is held in the jaws of your pin-vice or between the thumb and forefinger of your left hand. You see that I have laid the silk on near the bend of the hook, and taken four or five turns, the last one about an eighth of an inch from the head.

Figure 2 shows that I have laid a short piece of gut (after indenting it four or five times with my fore teeth) on the top of the shank (underneath will do as well), and whipped it on securely as far down as A, where I have fastened in a bit of tawny yellow silk-floss, which should be about six inches long. 
We now come to figure 3. I have taken a few turns of my wrapping-silk up the shank to $\mathrm{C}$, and followed it with the floss, increasing the bulk of the body somewhat towards the upper end. I have also fastened the end of the floss, and tied in the tip end of a ginger hackle with three turns of my wrapping-silk, the under part of the hackle being uppermost, so that, in winding it on, the back of it will lie next to the hook. I ought to have stroked the fibres of the hackle back towards the root of the feather; it is my usual custom. If you use the spring-pliers, grasp the butt end of the hackle between its jaws; its chief use is in holding the hackle in place, by its pendent weight, when you have occasion to let it go, or in fastening off.

Now for figure 4. You see I have wound the hackle on carefully to nearly the head of the hook. I have fastened it with three turns of my silk, and nipped off the surplus end of the hackle. Now I lay the wrapping-silk DD on the shank of the hook, and form the loop DF, and then take three turns with the slack F, wrapping over the end DD towards the head of the hook, and, holding it down securely with the finger and thumb of my left hand, I take hold of the end D which you see sticking out to the left, and draw in the slack FD, and cut it off. If the fibres of the hackle stick out irregularly, pointing in different directions and looking wild, like a little boy's head when he gets up in the morning, I take my large darning-needle and "order them aright."

I have a phial of varnish not larger than the end of my finger sitting on the table; there is a sharp little stick thrust through the cork; I now pull out the cork, and touch the head of the fly with a drop of shellac on the end of the stick, and lay it by to dry.

You will no doubt notice that in drawing the fourth figure 
the width of the page has limited the length of the gut to which the fly is tied. I hope you will not use so short a piece. In tying a fly on a whole length of gut, for the sake of convenience the gut is coiled up into a circumference not larger than the loop FD, and the end passed through two or three times to hold it in coil.

"Let me tell you, Scholar," that the plain-looking Hackle we have just tied, is the root to this tree of knowledge, which the uninitiated think so difficult to climb; but take it easy, and tie a half-dozen or so of such hackles, and just as certain as Trout rise at a fly, you will in time climb the tree and attain to all the higher branches-even to the most elaborate and gaudy Salmon-fly, that adorns the topmost bough.

Now let us beautify our Hackle with a little bit of tinsel, and then I will introduce you to its first cousin the Palmer.

If you intend to tip the tail of your fly with tinsel, let B in figure 2 represent a strip of it. It is to be fastened in at A, and three turns of it taken towards the bend of the hook, and then two or three turns back to $A$, where it is fastened with three turns of the wrapping-silk. The floss, or hurl, or dubbing is then fastened in and the fly proceeded with as before described.

If you wish to rib the body with tinsel or gold thread, you must tie it in at A before you tie in the end of floss or hurl that you intend to make the body of. After the body is formed, the tinsel, or gold, or silver thread is wound on spirally as far as C, and the fly from that point completed as already shown.

To make a Palmer with a floss silk or hurl body, you first tie in the end of the hackle at A (figure 2), then the tinsel, and then the floss or hurl. The material you tie in last must be wound on first. For instance, first wind on the hurl or 
floss to C (figure 3), then the tinsel, and then the hackle in the spaces left between the spiral coils of the tinsel; they are fastened each with two turns of the silk, and the ends cut off in the order in 'which they are mentioned, and then the head of the fly is finished as before directed.

The term "dubbing," is applied more especially to material of short fibre used in making the body of the fly, as fur, or pig's or seal's wool; it is spun sparsely around the waxed wrapping-silk, and wound on with it. In making a body of peacock hurl, three or four of the little plumelets are fastened in at the tail, then twisted with the wrapping-silk and wound on. The hurl does not fray off if wound on thus, as it does when it is wrapped around by itself.

I have now described the manner of making four different kinds of hackles. First, a plain Hackle without tinsel. Second, a Hackle, its end tipped with tinsel. Third, a Hackle, its body ribbed with tinsel or gold thread. Fourth, a Palmer, its body ribbed with tinsel or gold thread, and a hackle wound between the spaces or coils of the tinsel or gold thread, from tail to head. A Palmer may also be made without any tinsel, that is, it may be wound with the hackle alone. When a Palmer of this description is intended to be "buz," that is, very bushy, two hackles, are tied in at the tail and wound together to the head, where they are fastened as before directed.

Before we go any further, let me say a word or two about selecting your hackles-I mean the feather of which you make your Hackle-fly-and warn you against a fault, which professional fly-makers, who are not practical fly-fishers, are apt to fall into. In choosing your feathers, the length of the fibres should be in proportion to the size of the hook, or rather the length of its shank. We frequently see a Hackle or a Palmer wound with a feather, the fibres of which are so 
short as to make it look bare-like a long-legged boy in a bobtail coat. In this case there is more hook than hackle exposed to the eye of the expectant Trout, and of course it is the less attractive. Then, again, we see a small hook wound with a hackle, the fibres of which are too long, coming far below the bend-like a short-legged boy dressed in his "daddy's" long-tail coat. Now if such a boy should be detected in stealing your peaches, and should make his exit from your premises through a hole in the fence, if you were somewhat slow in grabbing him, you would most likely find yourself in the predicament in which Joseph left Potiphar's wife; that is, with only a part of the extremity of the aforesaid long-tail coat in your fist. Judge then of the disappointment of the Trout and yourself too. He expects to grab a good-looking caterpillar, but if he does not open his mouth very wide, or if he $s$ at all indifferent, he goes off with a few hairlike fibres between his teeth. You expect from the beautiful rise, and the tug you feel, that you have a Trout on, but the next moment your line comes bootless home to you. And thus with a small hook and a long-fibred hackle, you will frequently fool the Trout and the Trout will fool you. It does not follow, as many fly-makers suppose, that because a fly is tied on a small hook it is a small fly; on the contrary, a great many of the flies sold in tackle-stores are large flies on small hooks. In other words, the hackle or wings so far exceed the hook in their proportions, as to make the fly unattractive to the fish, and less apt to. hook him, when he tries to seize it. The fibres of the hackle, therefore, while they may reach the bottom of the hook, should never extend much, if at all, below it.

To Make a FLY With Wings.- "Thus far we have run before the wind," and although it may appear that we have made but little headway, still, if you have taken your 
observations' carefully, and kept a proper reckoning, by referring to our little chart, you will find that your voyage of exploration is nearly ended. By the foregoing you have found out what materials the ship is built of, and how to put them together, and you ought by this time certainly to "know the ropes;" the mere tying on of the wings is nothing more than bending the sails. I have made the drawing below to show how easily it is done.

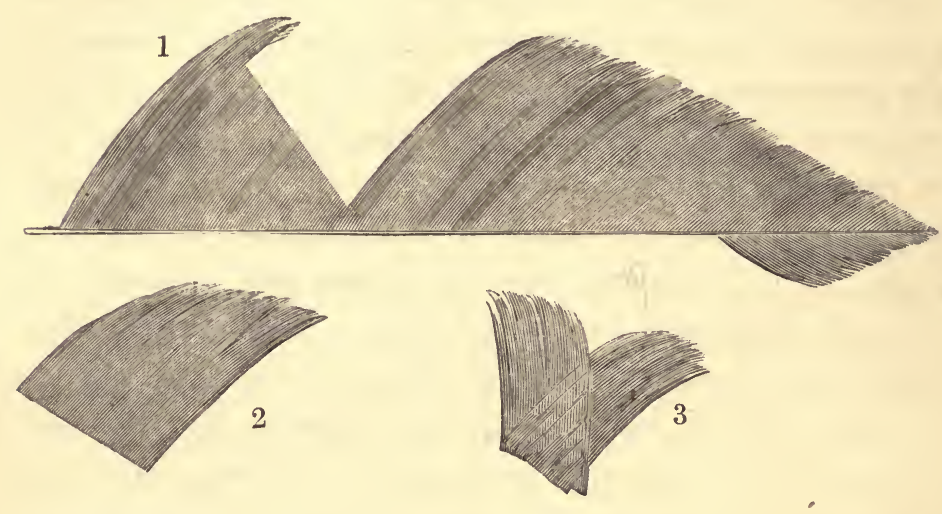

Figure $1^{-}$is a feather with a section large enough for the wings of a fly for a No. 4 hook clipped from it. Figure 2 is the section removed. 3 is the section after once folding it. It is then folded again, compressed between the thumb and forefinger of the right hand, and laid on the back of the hook with the tips of the fibres pointing towards the bend.

The manipulation which precedes the tying on of the wings, is the same as already described in making a Hackle, with these few exceptions:-First, in forming the body, it should be elongated somewhat towards the head. Secondly, the hackle should be shorter, or the fibres stripped from one side of the stem. For the legs of a winged fly, which the fibres of the hackle are intended to represent, are not as 
numerous as the legs or bristling hairs of larvæ. Thirdly, the cock's hackle should not extend over more than half as much of the shank of the hook, as it does in the Hackle-fly I have already shown you how to tie; and, in winding it on, the fibres should be pressed downwards under the belly of the fly; few or none of them being allowed to remain sticking up between the wings. Fourthly, space enough should be left at the head for setting on the wings and fastening off:

By referring to the foregoing illustration, the reader will observe, as I have already explained, that figure 2 is a section clipped from a feather. By doubling the two edges of the section togther, it will represent wings pointing obliquely in different directions. (See figure 3.) Now double it again, and still again, if necessary, and compress the fibres closely between your thumb and forefinger, and lay them on the back of the hook, so that the edge of the section will set upwards, as you will observe in figures $5,6,7$, or 8 of the plate of Trout-flies. Now take three turns with your silk, clip off the surplus at the butt end of the wings, and fasten off with the invisible knot as already shown.

TAILs.--In flies where tinsel is not used, the tail is fastened in immediately after the gut is whipped on. If the body is tipped with tinsel, this material is first wrapped on, and the tail fastened in above it.

Much unnecessary trouble is spared by not attempting to tie on the wings (either of Trout or Salmon flies) separately, as some writers direct. Nor is at all necessary to pass the wrapping-silk diagonally between the fibres to separate them into wings. For in doubling the section of a feather, as already shown, the fibres will point somewhat obliquely in opposite directions, representing the two points of the wings; and even if they do not, it makes no difference, for most of the natural flies that light on the water belong to that order 
whose wings are held in an upright position when at rest, and are folded so closely together as to look like one wing rising from the middle of the back. When a fly of this order is to be represented, two turns of your wrapping-silk should be taken close up under the butt of the wings, to give them an upright set. The most accomplished fly-maker I ever met with (an amateur), has a way of terminating the body abruptly near the head, making a shoulder against which he presses the root of the wings, and secures them firmly.

Flies without tails are of that order known as beetle-flies, as the Phryganidæ and similar families, which fold their wings flat on their backs when at rest. Those with tails belong to the Ephemeridæ.

A winged fly is sometimes made without a hackle, if pig'swool is used for dubbing, the rough coarse fibre of the dub. bing being picked out under the wings, to represent the legs of the fly.

There are several different ways of tying flies; nearly every fly-maker has something peculiar in his method. Some tie on the wings immediately before whipping on the gut, the tips of the wings pointing forward; they are turned back into their proper position, and secured with three turns of the wrapping-silk after the body is completed and the hackle wound on. Other fly-makers begin at the head, after the gut is whipped on, and work towards the tail, where they finish off: The method which I have described, and which I conceive to be the easiest, is the one most generally adopted.

I shall not prolong this chapter, which I have already extended beyond the limit I first intended, by attempting to describe the manner of tying Salmon-flies, but assure the reader that any person who can tie Trout-flies, will find no difficulty in it. It is requisite that Salmon-flies should be tied with a greater regard to strength and durability. Although 
there is more detail and elaboration, they do not require the same delicate manipulation that Trout-flies do.

It is much better to learn to tie a fly without a hand-vice or spring-pliers. If one's fingers are long and pliant, the knack can be acquired with perseverance. Those who use only their fingers are the great masters in the art. If your fingers are clumsy or dumpy, these accessories should be used; but the abominable permanent vice screwed to a table, as depicted in the books of some of my co-laborers in this "field of science," no one should resort to, unless he has ten thumbs on his two hands; and even to such persons the pinvice which I have pictured on a preceding page would be more convenient.

A few pages back I deprecated the use of hackles with long fibres on small hooks; there is also another vanity which is "done under the sun" by tackle-makers. I am ashamed to own that it is purely an Americanism. Irishmen, and even the London tackle-makers with all their cockney foolery, have never perpetrated such a thing. It was originated by some New York angler, without regard to truth or nature, and the tackle-stores there have perpetuated the humbug, and imposed these deformities on greenhorns ever since. I refer to those short-winged, pot-bellied flies; there are several of them; one is known as the "Deer-fly." No such fly daps on the water or hovers over its surface to deposit its eggs, any more than a bumble-bee does. The Deer-fly, if found in nature at all, is the very opposite of flies that Trout feer on, such as the gossimer-winged ephemera, which soars and flits through the air, like a thought in a dream, while the imitation of the other, with its big body and short wings, is more like the picture of a Dutch angel on a pane of painted glass. Do not buy them, do not make them; they are gross humbugs. 
There is one thing more I want to tell you before I close this chapter, which almost unconsciously to me has assumed the style of an epistle (I hope I am not too familiar on so short an'acquaintance); it is this: do not throw away all your first attempts that appear big-headed or wild in their habiliments, for a much rougher-looking fly than you suppose will kill; but if you are ashamed to let them be seen by the "old ones," lay them in the back folds of your fly-book to give away to the boys on your fishing excursions, for you will be very apt to meet some dumpy, pigeon-toed little fellow on the stream or in the road, who will salute you with,

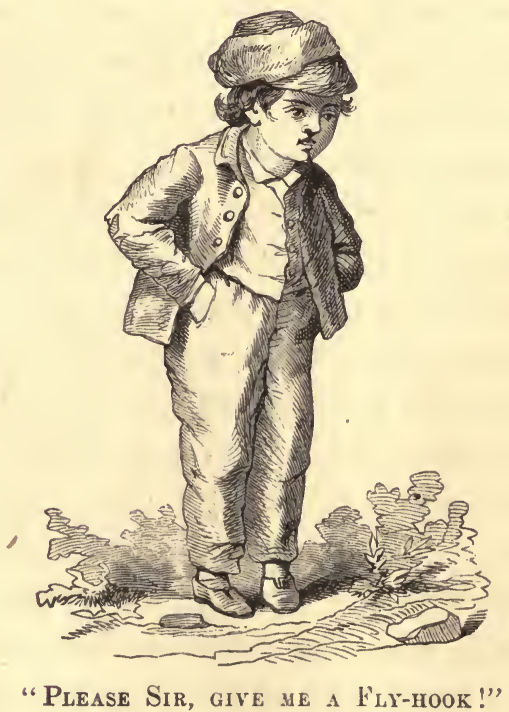


CHA P TER XVII.

$$
\text { R O D - M A K I N G. }
$$


"ALI. things are full of labor, man cannot utter it: the eye is not satisfier with seeing, nor the ear filled with hearing. The thing that Irath been, is that which shall be; and that which is done, is that which shall ve done; and there is no new thing under the sun."

Ecclesiastes. 


\section{CHAPTER XVII.}

ROD-MAKING.

Woods used in making rods.-Wood and Malacca cane for fly-rods.Materials used by amateur rod-makers.-To make a fly-rod of three pieces.-To make a tip.-To stain a rod.-Oiling and varnishing.Wrapping splices and putting on rings.-To make a "rent and glued," or quarter-sectioned tip.-Draw-plate and $\mathrm{V}$ tool illustrated and explained.-Manner of splitting cane and joining the pieces of a quartersectioned tip described by diagram.-Making middle pieces and tips without splices.-Manner of making a fly-rod to be adjusted to light or heavy fishing.-Ferule-making.

ANGLERs are apt to become fastidious as to the spring and taper of their rods, especially those used in fly-fishing, and are frequently considered by persons of less experience, "more nice than wise." If the former have leisure and a mechanical turn, they can make rods for different kinds of angling, and whether for bottom or fly-fishing, can adopt any fancy they may have as to proportions or materials. Thus rod-making, like tying flies, becomes not only an amusement, but may be ranked among the useful as well as the ornamental requisites in the education of a complete angler.

The early attempts of the writer were in reducing the joints of his fly-rods, which he thought over stiff; then in making an occasional new joint, or tip, wrapping on rings, \&c., and so on to making ferules, which at first was done without the help of a lathe. Having learned the art of brazing and rounding them over a mandrel from a neighboring jeweller, 
he made them smooth and to. fit neatly by the simple use of flat files, emery powder, and a burnisher. A love of "tinkering," however, and the kind approval of friends as to some fancied or real excellence in the rods he made for them, induced an investment in a lathe, work-bench, tools, \&c., and many pleasant hours have since been given to making rods, from the withy little switch of a fly-rod, for Trout-fishing, to the "heavy artillery" used in trolling, Bass-fishing, and even in taking the lordly Salmon.

WoODS USED IN ROD-MAKING.- It should be borne in mind that there is much difference in the strength and elasticity of woods of the same kind. A tree of slow growth is much harder and closer grained than one whose growth has been rapid. The white part, which is called the "sap," in contradistinction to the heart, as a general thing is preferable if not too near the bark. There are several kinds of hickory and ash, the white coarse-grained of the latter, possessing a third or a half more strength and spring than the red ash.

American hickory is used almost exclusively by English rod-makers for second and third joints; it has the recommendation of strength, and if well seasoned is elastic, though inferior in either respect to ironwood,* which appears to be scarcely known, or certainly not appreciated by rod-makers in this country or in England. This wood is found in the mountainous districts of North America, from Canada to Virginia and perhaps even further south. It grows generrally in damp places, and is known under other local names, as "hornbeam," "leverwood," and "barwood." It is almost

* There are two different trees known as ironwood; that referred to here is mentioned in botanical books as Carpinus ostrya. It has a smooth cylindrical trunk with a-thin grayish bark, and is of slow growth; a tree of five or six inches when sawed in two, showing forty or fifty concentric circles, indicating that it is just so many years old. 
white, even to the heart, and the laminæ remarkably close and fine; it breaks with a long splintery fracture, the very opposite of lancewood, which though stiff and springy is not so strong, but short and crisp in its grain.

For trolling or bait rods, the butt may be of almost any hard wood. If hollow, good maple or ash will do; sometimes holly is used in England. The second piece should be of good white ash or hickory; the third of hickory or ironwood; and the tip of lancewood or the best-seasoned ironwood, or spliced bamboo, or East India reed, known as "Malacca cane."

Unless ordered in three, English fly-rods, intended for Trout-fishing, are generally of four pieces. The woods mostly used are, ash for the butt, and hickory for the second and third joints. The tip for one-fourth or a third of its length, of hickôry or lancewood, and the remainder, out to the point, of spliced bamboo.

I would recommend for a Trout fly-rod, white ash for the but, ironwood for the middle piece, and Malacca cane, rent and glued, for the tip. The latter material is much superior to the short-jointed bamboo used by professional rod-makers, both in strength and elasticity, having a steel-like spring which the bamboo does not possess, besides being longer between the joints, and consequently requiring fewer splices. The bamboo is seldom more than ten inches, while the cane is frequently sixteen or eighteen inches between the joints, if taken near the butt.

The amateur rod-maker should be provided with a workbench six or eight feet long, and a vice on one side or at one end of it, a drawing-knife, a jack and a fore plane, a large coarse flat file (those used for sharpening mill-saws are best), sand-paper, and several strips of wood about two feet long, with grooves of different sizes in them. One of these pieces of wood is to be screwed firmly in the vice, and the stick is 
to be held in the groove, and turned with the left hand, while you are spokeshaving or filing it with your right.

TO MAKE a FLY-Rod of THREE PIECES-After deciding on the proportions of the rod, and having made or bought ferules of appropriate size, select a well-seasoned piece of ash for the butt, and, with the drawing-knife and plane, work it down to something like the desired size; that is, sufficiently large at one end for the grasp of the hand, and tapering to something larger than the size of the ferule at the other end; the sides of the stick all the while being kept as nearly square as possible. Then plane the corners off, so that a section will present as near the shape of an octagon as you can get it. Now screw the strip of wood with the largest groove fast in your vice, and, laying the stick in it, work it as nearly round as you can with your spokeshave and file, bringing it all the while nearer the intended shape and size. Then polish it off with fine sand-paper, and fit on the first ferule.

Tó make the second or middle joint, as it may be called, use only the plane, laying the stick between two thin strips, tacked on the work-bench while planing it (on account of its length and small size), keeping it square and taking off the corners, to bring it to an octagon. Then screw into your vice a strip of wood with a smaller groove than the one you used for the butt, and round the stick with spokeshave and file, and rub it down with sand-paper as you did the butt, and fit the larger end into the first ferule, and the smaller into the second ferule.

Let me here say that there is some sleight required in filing a long thin piece of wood. The file should be held obliquely, and passed over the stick as it is held and turned in the groove with the left hand; occasionally rubbing the file with a straight fore-and-aft motion over the stick, as if planing it, which will take off any irregularities left from the other mode of filing. 
To MAKE a Tip (Anglice "Top").-Take a piece of good Malacca cane, as long between the joints as you can get it. Split off' as many pieces of the size as you require, and reduce each piece with spokeshave and file, cutting away the soft inner part, each piece being smaller than the preceding one as you approach the small end of the tip. In working down the pieces for the tip, the groove in the strip of wood which you screw into your vice should be very small. Bevel the ends of each piece of cane sufficiently to let them make a good splice, say two inches and a half, two inches, and an inch and a half. Apply the glue hot to the surfaces which come into contact, lay them together, and wrap the splice firmly with strong fine twine or good packthread, and lay them by for twelve hours for the glue to set and dry.

If the splices are well glued, you may remove the wrappings next day, and finish your tip without any fear of its coming apart while you work it down. The final wrapping of the splices, which I will presently describe, it is better to defer until after the tip and stouter joints of the rod are oiled and varnished.

Afterer the tip is finished, join all three pieces of the rod together, and, by bending and handling it, find where it requires reducing to make it spring uniformly and feel exactly right to the hand, unjointing it and filing each piece separately in doing so.

To Stain a RoD.-Before staining, wet the different pieces and let them dry, when the fibres of the wood will rise and present a rough surface; then rub each stick smooth with sand-paper, and repeat the operation until the grain of the wood will remain smooth after wetting. If you intend to varnish it without staining, this process is unnecessary. In staining, avoid powerful acids, particularly in the delicate parts of the rod, and try rather to dye the grain of the wood 
than merely to color the surface. By experimenting with red and black ink, the extract of logwood, and water in different proportions, many shades of maroon and brown can be had. Common writing-ink diluted with water produces a neutral tint, and smoking-tobacco steeped in hot water a light tawny yellow. The rod should not be too deeply stained, if you wish the grain of the wood to show handsomely. Repeated coats of ink produce a black.

Oiling ANd VARNishing.-After trying several varnishes that were warranted to stand weather and using, I have found them all to rub or chip off so much in the course of a summer, as to expose the wood to moisture, which seriously impairs its elasticity. I have had fly-rods which were covered with three or four coats of shellac, and even those varnished with copal, become so limp with moisture on a drizzly day, as to be almost useless. To obviate such faults, I at last adopted the following method as the best to make a rod impervious, and to prevent the varnish from chipping off.

When the rod has become perfectly dry after staining it, warm each piece before a stove or fire or over a spirit-lamp, and pouring some boiled linseed-oil on a rag, rub it well into the grain of the wood; repeat the operation two or three days after, and lay the rod by in some warm dry place for the oil to penetrate the wood and become hard on the surface; then if any excess of oil appears, assuming a glossy appearance and a sticky feeling, warm the stick again, and dissipate it by rubbing with a woollen rag with a very small portion of oil on it, and lay the rod by for a few days more.

When you apply the varnish (let it be shellac), the first coat should be thin, pouring it on a rag and rubbing it on quickly and lightly, so that it may become incorporated somewhat with the coat of oil, and in a few hours apply another thin coat in the same way. The next day give it a thicker 
coat with a flat eamel's-hair brush,' and repeat it every day or two for a week, and lay the rod by until the varnish has become hard enough to be rubbed down with powdered pumice or emery. This is done by spreading about a tablespoonful of the powder on a dripping-wet rag, and rubbing lightly, thereby giving a perfectly smooth surface. The pumice or emery powder should be washed off, and the rod receive another rubbing if not perfectly polished. When thoroughly dry, a final coat of very thin copal should be applied. Shellac can be diluted by adding alcohol, and removed from the fingers with the same solvent. The ferules should be permanently stuck on with hot shellac, after the oiling and varnishing is completed. Shellac is the best cement one can use in joining metal to wood, and is applied by heating the end of a joint over a spirit-lamp, and sticking on bits of the gum, turning the joint the meanwhile over the blaze, to keep the shellac flowing around the wood. Now stick on the ferule, hold it over the flame to heat it slightly, and press the joint in as far as necessary. The shellac will become hard in a few minutes. The custom of fastening on ferules with pins impairs the strength of the wood just where a rod is most likely to break.

Little remains to be done now but wrapping the splices of the tip and putting on the rings. The former is performed thus: Stick a stout awl into the edge of your work-bench or into the top of a table, and holding the tip in the right hand, lay on the end of the silk with the left; then, turning the tip with the right and guiding the silk with the left (the tip in the mean while bearing and revolving against the opposite side of the awl), wrap closely over the end of the silk and the whole length of the splice, and fasten off with the invisible knot. 
The ring-keepers* are wrapped in the same way; but the manner of doing this can be better explained by examining the way in which the rings are put on any rod from a tacklestore. The same may be said of the wire loop through which the line passes at the end of the tip. Before putting on the rings, the rod should be joined together, getting it as nearly straight as possible, and marking the places for the rings. It may then be taken apart, and the rings put on each piece separately. On a tip four feet long, there should be about seven rings, beginning five or six inches from the small end, and in. creasing the distance between them as you near the larger end. Four rings are enough for the middle piece, and one or two for the butt. Small rings made of very light wire should be used for tips, and instead of the ordinary clumsy ring-keepers sold at the tackle-stores, it is better to cut from very thin sheet-brass, strips not more than the thirty-second part of an inch wide, and of convenient length-say six or eight inches long: these are more easily handled, the surplus length of the strip being nipped off after wrapping, and used for the next ring. To protect the wrappings of the splices and ringkeepers, apply several coats of thick shellac varnish with a small camel's-hair brush.

The reel-bands, for reasons stated on a preceding page, should be at the extreme end of the butt, and below the place where it is grasped by the hand when casting.

To make a Rent and Glued, or Quarter-Section Tip.With the object of uniting the greatest degree of strength and spring in the delicate portions of a fly-rod, and more particularly in the tip, an artist friend, who is not only a fine amateur mechanic, but an accomplished fly-fisher, some years

* The little pieces of thin brass or copper that hold the rings against the rod. 
ago explained to me, by a few strokes of his pencil, how the soft inner part of cane or bamboo could be got rid of, and the hard elastic exterior only used, gluing four strips together side by side, and producing what he called a quartersection tip, or what English rod-makers term a "rent and glued" tip. He also made the simple tool represented below, in which are united what may be called a " $V$ tool" and a "draw-plate." It is made of thin steel, and tempered very hard.

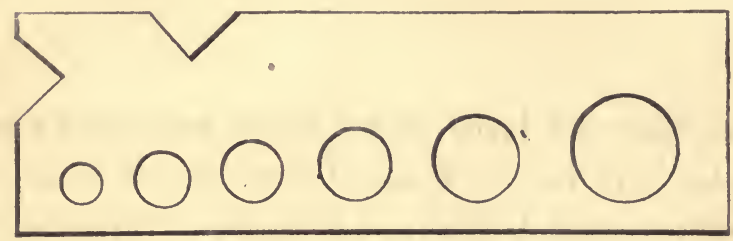

The notch in the end and top of the plate are true right angles, with a cutting or rather a scraping edge; the holes also have scraping edges. When this implement is screwed in a vice, by drawing a piece of split cane through the $\nabla$, with the outer surface of the cane uppermost, the soft inner part is scraped off; and when four such pieces have been reduced to the required size, and glued together, a section presents the appearance of figure $G$ on the next wood-cut, the softer part of each strip coming together in the centre. The corners of $G$ are then rounded off with a file, and to make each glued piece more truly round than an amateur can generally file them, they are still further reduced by drawing them through a hole of appropriate size in the plate, when the end of a piece will present the appearance of figure $\mathrm{H}$ in the next wood-cut.

To be more explicit, and to insure a neater job, I will go over the ground again, and describe minutely my own way of making a four-sectioned tip. Take a piece of Malacca 


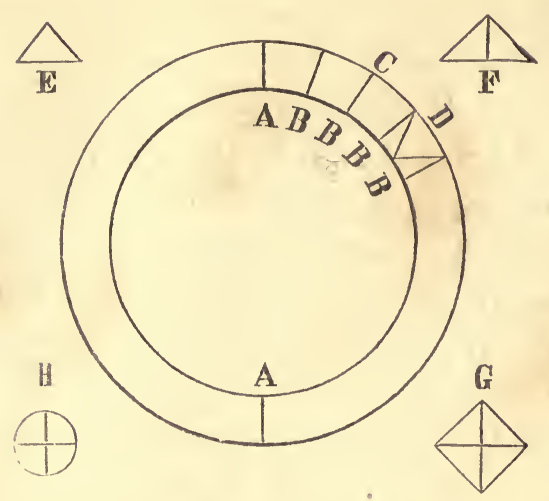

cane, the outer and inner circles above presenting a section of it, split it in half at $A \mathrm{~A}$, and from one of these halves split the four strips $\mathrm{BBBB}$, and draw each strip through the $\mathrm{V}$ tool, scraping them down to the required size, the ends presenting the shape of the right angle under $\mathrm{D}$ or the little figure E. Then join two of these pieces lengthwise with hot glue, wrapping them tightly, and then the other two pieces in the same way, the end of each twin piece being represented by the figure F. Straighten them while pliant with the glue, and lay them by over night for the glue to set firmly. Next day unwrap the twine from around the twin pieces, and laying one of them in a small grove in the strip of wood screwed in your vice, the broad surface being uppermost, with your coarse file make it perfectly level. Then treat the other twin piece in the same way, and, applying the glue to the surface of each twin piece, bind them tightly together, straighten the quadruple piece thus formed (a section of which is represented by G), and lay it aside for the glue to dry. Although I have shown where the seams are in the butt ends or sections in the figures F, G, and $\mathrm{H}$, there are no seams visible when the strips are glued together.

I have already explained how the quadruple pieces are 
reduced and rounded; any number of them can be prepared at the same time. For several reasons, it is better that the last ten or twelve inches of a tip for a Trout fly-rod should be a single piece; that is, the piece itself should be a unit, not rent and glued after the manner just described; for in reducing so delicate a part, if quadrupled, the four pieces are apt to be of unequal thickness. Besides, the point of the tip is more apt to get wet than the lower part, and of course would be more apt to divide or split apart when so small a portion of glue is used. A tip made in this way should be wrapped at intervals of an inch along its whole length; six or eight turns of fine silk at each wrapping are sufficient; each separate wrapping should be fastened off with the invisible knot.

The middle piece of a Trout fly-rod may be made without splices, by splitting a piece of Malacca cane through the joints, the whole length required, avoiding the root of the shoot, or bud, represented in the drawing of a piece of cane below. There is only one bud or shoot at each joint, and as

they occur alternately on opposite sides, they can be easily avoided in splitting. Tips may be made in the same manner the quarters being drawn through the $\mathrm{V}$ tool, and glued and finished as already described. Tips for Salmon-rods made in this way are unequalled.

The only alleged objection to rent and glued tips is, that they require care in keeping them from getting wet. I have fished with thern for more than ten years, and only on one occasion, when I persisted in fishing all day in a rain, have I found them defective in this particular, and then only because the varnish had worn off. This was before I resorted to oiling my rods, and when I did not have the wrappings so 
close together. If joined with the best glue, and well oiled before applying the varnish, such an accident would seldom or never occur. Besides, there is no necessity for an angler getting his rod wet at all. A good tip may be made by gluing two pieces of cane together after cutting away the soft inner part, though they are not as apt to bend equally as a quarter-section tip does.

GLUE.-Irish glue has a reputation with some persons. I have generally used the white American article known as "bone glue;" but from some experiments lately made with "Hilton's glue and cement," which is said to be waterproof, I am convinced of its superiority over anything else for a rodmaker's purposes.

In making fly-rods for some of my friends, I have lately adopted a plan by which the same rod may be used for either light or heavy fishing. This improvement consists in having the butt in two pieces; the upper piece being about three feet long, has a ferule on the lower end, into which the handleif I may so call the lower part of the butt-is fitted. There are two handles, one of a foot or fifteen inches, and the other two feet long. In wading the stream it is intended that a tip of the ordinary length, that is, as long as the middle joint, and the short handle shall be used. In fishing from a boat where the run of Trout is large, the rod is rigged with a stouter tip, but nine inches shorter, and the long handle. Thus taking from the rod at the small end or tip, and adding as much at the butt. If the rod is to be lengthened, the longer tip and long butt are both used.

To MAKe FERULeS.-The materials and implements used in making ferules for fishing-rods are, sheet-brass or German silver, a pair of shears to cut it, mandrels to round the ferules on, a knife file, annealed (or, as it is sometimes called soldering) wire, a small smooth-faced hammer, a light wooden 
mallet, a pair of pliers, a blowpipe, a lump of borax, a strip of thin silver solder, and a lump of charcoal-most of these articles can be had at hardware-stores. The silver solder may be found at the stores where watchmakers' and jewellers' materials are sold. The mandrel is a cylindrical piece of cast steel, and should be the size that you want the inside of the ferule.

To take the width of a piece of brass required for a ferule, wrap a piece of stiff paper around the mandrel so as to lap, and pass a knife along it lengthwise as straight as you can, which cuts the paper the exact size. This is moistened and laid on the sheet-brass for a pattern, and the brass cut to the size of the paper with a pair of shears. The brass is then bent over the mandrel by the proper use of a wooden mallet and the vice, and the edges brought nearly together (not to overlap), and the knife-file passed between to take off any inequality in the edges, and to insure their coming in contact the whole length of the ferule, when bound by the annealed wire. The vice should be used in bringing the edges in contact, and the ferule bound in the middle and at both ends with wire, while it is held in the jaws of the vice; to do this effectually, the ends of the wire after lapping the ferule are twisted with the pliers.

To make the flux for your solder, wet a piece of borax and rub it on a piece of rough slate, grinding off the surface of the borax until the mixed water and borax assumies the appearance and consistency of cream. Apply it to the seam inside of the ferule with a small camel's-hair brush, and then cut a thin strip of silver solder (the thirty-second part of an inch is wide enough), and of the required length, straighten it, smear it with the diluted borax, lay it on the seam inside of the ferule, and place the ferule with the seam downwards in a groove, made just large enough in a piece of charcoal to 
contain it. Now with a good flame of gas, or a spirit-lamp used for such purposes, direct a jet of flame on the ferule with the blowpipe until the solder flows over the seam.

There is some knack in using the blowpipe. Hard puffis which exhaust the breath are not as efficacious in producing the requisite heat as a more gentle but continuous blowing. Persons accustomed to the use of this implement acquire a way of inhaling through the nostrils and blowing with the mouth at the same time, making thereby a very long exhalation; it is done by distending the cheeks and working the jaws somewhat in imitation of the blowing of a blacksmith's bellows.

Those who make ferules in quantities, of course braze them in a charcoal furnace; but as the limited space of an amateur's workshop does not often allow of such an appliance, it is well to learn the use of the blowpipe, which, in fact, is indispensable in delicate soldering. In using gas it is better to remove the ordinary burner and direct the full stream on the ferule, or procure what is termed an Argand or a jeweller's burner. The common gutta-percha tube is convenient in bringing the gas to any convenient place on a work-bench or table. The ferule should have no grease on it to interfere with the soldering. It is well also before binding with it wire to dip the brush in the borax while it is thin, and pass it between the edges.

The ferule should be allowed to cool of itself, as dipping it in water impairs the toughness of the brass. When the wire bindings are taken off, the inner surface should be scaled with a rat-tail file, and any surplus solder along the seam removed. Brass is always annealed by heating it to a red and allowing it to cool gradually, and of course the ferule is soft and not fit for use unless it is hardened. This is done by hammering lightly, as it is rounded and stretched over the 
mandrel. If you want the ferule perfectly straight, round, and true, the mandrel should fit it exactly when it is stretched.

The mandrel should taper a little for a half inch or so at the end, to enable you to enter it in the end of the ferule. In doing so, drive it in tightly as far as it will go, without straining the ferule, and laying it on an anvil or smooth surface or iron, tap it lightly with your hammer, turning the mandrel the mean while with the left hand. Drive the mandrel in as the ferule is stretched, hammering evenly and turning slowly as the ferule passes over the smaller part of the mandrel, and confine the hammering to that part. The ferule as it is driven on assumes the size, the roundness, and the straightness of the mandrel, and is hardened by the hammering.

When the ferule has thus been stretched, hardened, and straightened, the mandrel with the ferule fitting tightly on it is put into the lathe and turned down smooth, and to the required thickness, with an ordinary graver; or it may be finished with a fine flat file and emery paper of different degrees of fineness, if you have no such piece of machinery, though it is a laborious operation. A lathe is almost indispensable in making a male ferule, that is, a ferule intended to fit into another.

When I first began to make ferules, I cleansed and made the inside smooth, by wrapping a strip of sand-paper spirally on a round stick, so as to fit the ferule just tight enough to turn in it, and afterwards gave a smoother finish to it by wrapping a piece of emery paper on the same stick. The same contrivance can be used by putting the stick in a lathe and holding the ferule on it with a rag saturated with water to prevent the brass from heating as the stick revolves.

A male ferule is made in the same manner as just 
described, and of course on a smaller mandrel, or on the same mandrel turned smaller for two inches or so at one end. As there is no strain on a male ferule it is not necessary to harden it.

A professional rod-maker would no doubt be somewhat amused at these directions, and consider this a roundabout way of making a rod; but as I before said, I only wish to throw out a few hints for the benefit of anglers who wish to amuse themselves in-doors, or instruct those who seldom have the opportunity of purchasing rods of tackle-stores.

For fear I may leave the reader in some doubt as to the material I have recommended for quarter-sectioned tips, on a preceding page, I would here say, that by "Malacca cane," I refer to those long East India tishing-rods, which are marked with irregular tracings; charred with a hot iron or some strong acid. They are easily distinguished from our native cane-rods, or the bamboo used by professional rod-makers. 
CHA P T R X VIII.

F I S H - B R E E D I N G. 
" AND God said, Let the waters bring forth abundantly, the moving creature that hath life." 


\section{CHAPTER XVIII.}

\section{FISH-BREEDING.}

Causes of the decrease of Salmon and Trout.-Remarks on fish-ponds and the manner of stocking them.

Artificial Fish-Breeding-with illustrations, showing the manner of expressing the ova and milt, the arrangement of hatching-troughs, and the growth of the fish; from "A Complete Treatise on Artificial FishBreeding," by W. H. Fry, Esq., with some remarks of the author of this work.

The Aquariom-its appropriate size and form, and manner of stocking it with fish and introducing suitable aquatic plants.

REMARKS ON Fish-PONDS, AND THE MANNER OF PRODUCING AND REARING FISH IN A NATURAL WAY.-All "truehearted anglers," (we thank Dr. Bethune for the word), who have witnessed the ruthless and indiscriminate destruction of game-fish, will take an interest in the plans proposed and the means now happily adopted for their increase. Many a fly-fisher who travels a long way to enjoy his favorite sport, is shocked at witnessing the wilful extermination of Salmon and Trout. The former by spearing, netting, and erecting high dams without providing for their free passage up and down-the latter by snaring them on their spawning-beds, catching them in seines and eel-weirs, and drawing off millponds. On Trout-streams there are still other agencies at work. The coal-mine poisoning the brook with sulphur; the saw-mill filling it with slabs and saw-dust; the factory with 
its dyestuff; and the tannery fouling che clear stream, covering the bottom of the pools and the spawn-beds with its leached bark, and killing the fish by hundreds with the noxious discharge of its lime-vat. Any law against such vandalism in the United States is seldom or but feebly enforced.

We are also disgusted occasionally by hearing persons, who pretend to be sportsmen, boast of the number of Trout they have taken by unfair means. I was once present when a person of this kind, who had just returned from an excursion to the head waters of the Croton for woodcock, told how he had snared a hundred Trout, each a foot long, on their spawning-bed. To use his own vernacular, he would have "punched a fellow's head," who would trap a partridge or kill her on her nest. Which of the two is the more dastardly act? When fishing Jessup River in Hamilton County, New York, some years ago, the guide pointed out a place at the mouth of a little brook, where a snob deer-hunter from Troy, the September previous, with a bass-rod and a red hackle, lifted out sixty pounds of Trout, which had collected there to spawn. If time-serving legislators have not the independence to pass laws for a more thorough protection of Trout, or officials do not enforce those that are passed, the fly-fisher at no distant day will have to go hundreds of miles farther than he does now, to find them. But unless I should appear to be travelling out of my way in condemnation of such means and such persons as I have alluded to, I will proceed with my observations on fish-breeding; giving first a few suggestive remarks on fish-ponds, the manner of stocking them, and of producing the young fish in the natural way; and then describe at length the mode which has been adopted, within a few years past, of hatching the eggs and rearing the young fish to a certain age by artificial means.

In many parts of Europe, and in China, where fresh sea- 
fish are not to be had, fish-ponds are common, and fish culture is almost a matter of as much concern as agriculture. Great care is even bestowed on breeding and rearing the coarser kinds, including those that belong to the Carp family. Such fish are considered almost worthless here, where there are so many firm-fleshed, well-flavored species of the Perch family; and our sluggish waters, where Trout would not thrive, could be as easily stocked with these, and with the ugly though excellent Catfish, as with the soft insipid Cyprinoids.

Whatever be the condition of the water one may control, sluggish or rapid, shaded or exposed; whether a brook, or a pond of an acre or two, fed even by a diminutive stream, he may breed fish whose natural habitat is such water, or make them in a great degree capable of living and thriving in their circumscribed home.

From my boyhood I have known ponds stocked with large fish which were not native to such waters. One instance was the transfer of what was called the "James River Chub," the magniticent fresh-water Bass, Grystes salmoides. They were taken from the James River and placed in mill-ponds fed by small brooks a hundred miles north of Richmond, and in a few years by natural propagation and increase became numerous, many of them attaining a weight of five pounds. The White Perch, Labrax pallidus, is prolific in ponds and canals. It is even said the Rockfish will live entirely in fresh water, though I doubt whether it will grow to a large size if debarred from returning to salt water in winter. The Shad, which Mr. Pell produced by artificial propagation, must certainly have degenerated if confined to his ponds, and, I think, would most likely cease to reproduce after several generations; for they are anadromous fish, and their annual visit to the sea is requisite to their perfection.

I have seen Trout breed and grow rapidly in a pond cover- 
ing not more than an eighth of an acre, near Philadelphia. It was in a little dell shaded by oaks, maples, and wild poplars. Several springs bubbled out at the head of the ravine, and a small breastwork of stone and sod, thirty yards below, dammed the water, which flowed over the sluice, in a stream which could have been discharged through a two-inch auger-hole. The Trout, thirty in number, and varying in size from six to ten inches, were brought from Chester County and placed in the pond in the month of February. The following autumn they spawned, and in the month of April they were caught in a fine net, in the little pool beneath the overflow of the dam, and in the rill in the meadow below, two inches long. The next season they were also found in the brook into which the rill flowed, and in a mill-pond below, where they had grown to seven inches. At the time of stocking his pond the owner did not ascertain how many of each sex he put in. It is a matter of conjecture how many of them spawned, or how much of the spawn was consumed by the fish; how much of it came to maturity, or how many of the young fish were devoured after being hatched out. It is highly probable that but few of those which remained in the pond escaped the voracity of the adults; and those that went over the dam through the sluice (which was not more than nine inches wide, and three-fourths of an inch in depth), must have made their escape from instinctive fear of the larger fish. Some of the fish which were very small when placed in the pond, in two or three summers grew to the length of fourteen inches, and were very stout, weighing perhaps a pound and a quarter; they were fed occasionally with chopped raw meat, worms, and grasshoppers. In a few years the place fell into other hands, and the fish were caught out of the pond by poachers, or persons of less appreciation than the proprietor who stocked it. 
I have given these few facts to show that a pond is easily stocked with Trout, and the streams below as a matter of course. With a little care, and providing ponds below (as would have been the case had the original owner just alluded to remained in possession), the number and size might have been increased to the utmost capacity of the water.

If fish are thus easily bred and reared with so little attention, by natural propagation, the ova being unprotected on the spawning-beds, and the young subjected to the ravages of the large fish, how must it be when all causes which would prevent the hatching of impregnated spawn are removed, and the young, by a proper arrangement, kept from being devoured?

In stocking ponds, an observing person will remember to put in such fish as the water is suitable or natural to.

A pond for Trout should have as great a proportion of spring or cool brook water as is possible, though it is not essential in all cases that the supply should be large. If the stream which supplies it enters in a rough little cascade, it is better, as the water is thereby mixed with air. If there be several ponds on the same brook, they should be supplied in the same manner, if the fall in the stream is sufficient. Each should have a shallow shelving margin, as well as a deep side; plenty of shade, trees, and shrubbery, to encourage the presence of flies and insects; also aquatic plants, rock, stones, and pebbles through the pond and on the margin. Shallow water strewed with pebbles is considered as necessary as aerated water in the natural propagation of Trout, though few of these conditions were found in the pond just described, for it was almost of uniform depth, and the back-water covered the springs that supplied it.

In breeding the different species of the Perch family; acrated water, or even that of a low temperature, is not so 
necessary, if there is a reasonable quantity of aquatic vegetation in it. The mere damming of a stream, and increasing the body of water, promotes a larger growth of those fish which are native to the brook. In the instance first mentioned, of stocking ponds with the large fresh-water Bass, a freshet swept the dam away, when the fish escaped and sought the larger water of the rivers below, none, even of the small ones remaining to reproduce when the dam was renewed.

Trout taken from a small brook where they never grow to a length exceeding eight inches, have been known to attain a weight of three or four pounds when transferred to a large pond or lake.

"Ephemera," in his "Book of the Salmon," objects with much reason to the term "artificial propagation;" for after all, the expression of the spawn by manipulation, and protection of the young fry, are only accessories, and nature is only directed, followed, or assisted, as the judgment of the fish-breeder may dictate.

Artificial Fish-Breeding.-With the object of showing how easily fish can be produced by artificial culture, I have obtained from Mr. W. H. Fry, the editor, and Messrs. Appleton \& Co., publishers, of New York, their consent to make extracts and copy some of the explanatory cuts from a work to which I have already alluded, called "A Complete Treatise on Artificial Fish-breeding." In treating this subject, therefore, it will be necessary to repeat, in substance or verbatim, much of the matter of a preceding chapter. Before reading Mr. Fry's book, I had met with several brief articles on the subject, one of which I clipped from a daily paper; it reads as follows :-

"Pisciculture in New York.-At a meeting of the Farmers" 
Club of New York, held recently, the following proceedings took place, as we learn from the Times of that city:

"The secretary, Henry Meigs, Esq., read a letter from John G. Adams, M. D., now in Paris, on the subject of Pisciculture (breeding fish), which was the subject for discussion by the club for the day. Mr. Adams explains at length the mode of breeding fish, now in successful operation in the College of France. The eggs selected for the purpose of breeding are, he says, those of the Trout and Salmon. They are brought in boxes. The boxes may be tight, and, if kept at a moderate temperature, may be transported an immense distance. At the college the eggs are placed in oblong earthen troughs, in single layers, upon trays of willow-work, so that the water may circulate freely around them; for the arrangement of running water, these troughs are arranged in pyramids, and a small stream of water is continually flowing into them. The eggs, after forty days, are hatched, and the young fish are seen running about in one part of the trough, while in another part of it the eggs are in a different stage of incubation. The pouring of the water seems to have no deleterious effect on the process.

"The operation, it is believed, will be highly successful.

"Mr. R. L. Pell, of Pelham, discussed the subject of Pisciculture to a great extent. Among other matters, he informed the club that he had taken the spawn from the fernale Shad and impregnated it with the male Shad, and that the eggs produced Shad in great numbers. He has numerous fishponds, in which there are forty-five varieties of foreign and native fish, thousands of which came at the ringing of a bell to be fed out of his hand. Sturgeons nine feet long may be seen in his ponds.

"Mr. Pell has made arrangements to import the ova of the Tench, Barbel, and Carp from Europe, for his ponds, and like- 
wise the spawn of the famous Turbot and Sole; and is about to apply to the legislature for a law to make it incumbent upon all persons in the state who gain a livelihood by the capture of fish, to plant impregnated spawn upon their fishing-grounds.

"Remarks on the same subject were made by other members of the club, all of whom were sanguine of its success, and confident that it would be of service to the community."

I have since read other articles showing the feasibility of producing and breeding fish artificially, and have heard of experimenters being entirely successful in it. Amongst the latter are some enterprising fish-breeders of Hartford, Connecticut, one of whom has visited France for the purpose of witnessing the modus operandi and obtaining information on the subject. There are also several instances of complete success said to have occurred on Long Island and in Ohio.

Although, in the following pages, I quote chiefly from M. Coste's directions, found in Mr. Fry's book, Messrs. Gehin and Remy, fishermen of the Commune of Bresse, of the department of Vosges, were the discoverers, and the first who turned their attention, in a practical way, to the production of fish by artificial propagation. These two humble Frenchmen afterwards brought the subject to the notice of scientific men, who procured for it the patronage of the French government; and notwithstanding M. Coste claims for Jacobi, a German, the discovery of fecundating the ova by artificial means, as early as 1758, it appears that Gehin and Remy were not aware of any previous experiments having been made. According to M. Coste's account, Jacobi, like these two fish. ermen, founded his theory on a simple fact which he disco. vered by careful observation; it is that the spawn of the female is not impregnated by the seminal fluid of the male until after it is ejected. M. Coste further says that this 
naturalist communicated the result of his experiments to Count de Goldstein, Grand Chancellor of His Palatinate Highness for the Duchies of Burges and Juliers, in an essay in the German language, which Count de Goldstein afterwards translated into Latin for M. de Fourcray. It appears strange that so important a discovery should not have been made public, and followed up at the time by establishing fishbreeding as a trade or science.

It is natural to suppose that Gehin and Remy's discovery would soon become generally known to those who were interested in restocking impoverished and exhausted waters. So we find Messrs. Young, Shaw, and other British naturalists not only in possession of this knowledge, but successfully experimenting on it.

The following extracts and wood-cuts from Mr. Fry's work, I am satisfied will convince any intelligent reader that thousands of fish may be produced and raised with as little or perhaps less difficulty than a tenth of the same number of poultry. I would, however, advise those who wish to engage in the experiment, to procure Mr. Fry's work, in which he has translated from the French, "Facts furnished the Academy of Sciences at Paris, by M. Gehin;" "M. Coste's Practical Instructions in Fish-raising ;" and "M. Milne Edwards' Report on Artificial Fish-culture, and stocking barren or impoverished rivers with fish artificially hatched." His book also embraces "Lessons on the Natural History and Habits of the Salmon," by "Ephemera," the gist of which will be found in the previous part of this book, beginning at page 214 .

The Trout being one of the most interesting and easily procured fish, I will first refer to the method of breeding it. - This fish generally spawns from the latter part of September to the first or middle of November. The preparatory step is to procure hatching-troughs. 


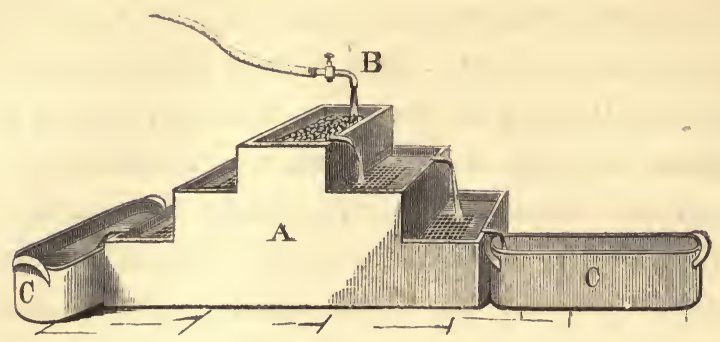

These, as the reader will observe from the cut, are simply a succession of troughs placed one above the other. The water flowing from the stop-cock B, in any desired quantity, into the topmost trough, falls in little cascades into those below, which aerates it sufficiently during the term of hatching. By means of these troughs the fecundated eggs may be watched with care, and examined without the danger of disturbing the process of incubation, as would be the case if the spawn was placed in hatching-boxes, according to $\mathrm{M}$. Gehin's plan, and deposited in the stream, and removed from it occasionally to examine them.

The troughs may be placed in any spare room where it is convenient to lead a small supply-pipe, and place another for the discharge of the water. They should be supplied to the depth of four inches with clean gravel and a little coarse sand. Each trough should be raised somewhat at the end where it receives the overflow from the trough above, so as to cause a slight current. M. Coste recommends that the eggs be spread on closely-woven hurdles of willow, and sunk an inch or two below the surface; his reasons for doing so are given in a subsequent extract. If the bottoms of the troughs are covered with gravel, the water-which may be supplied through a quarter-inch pipe-should flow through them for a few days, so as to remove any impurity amongst the peb. bles. 
Trout may be procured by observing them in the brook when preparing to spawn; they should be taken in nets, and removed as carefully as possible. A less number of males than females are required, as the milt of one male will fecun. date the eggs from three or four females. Care should be taken in selecting fish that are well advanced. The mere pressure in handling will cause the roe or milt to start, if sufficiently mature; if it is not, the fish may be placed in a tank conveniently near, supplied with running water, and examined daily until the proper time arrives.

The vessel for the reception of the spawn may be of earthenware, wood, glass, or tinned iron, and should have a flat bottom as wide as its top. After having washed it clean, it should have one or two pints of clear water poured in. The next process is

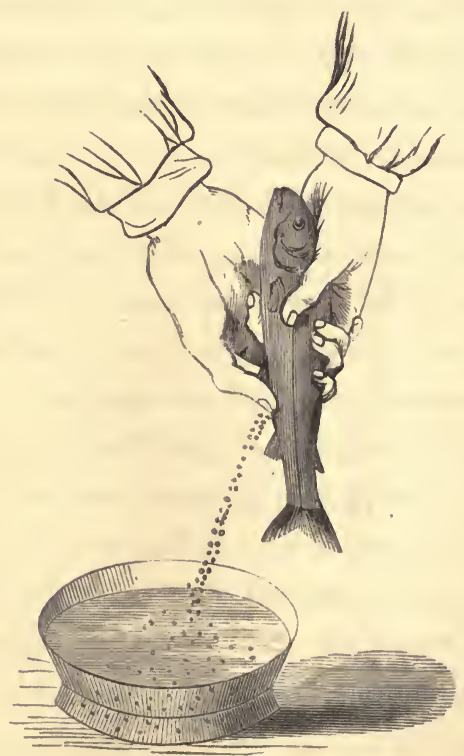

To Express THE SPAWn.-The female fish is taken by the head and throat with the left hand, while the right hand, its 
thumb upon the belly and its fingers on the back and sides, is passed liked a ring lightly backwards and forwards, to bring the eggs near the opening through which they are passed. The male fish is then to be operated on in the same way, and the milt expressed; the manipulation causing the expulsion of only so much of the ova and milt as may be perfectly mature. For, as will be seen by the observations quoted from "The Book of the Salmon," in a previous chapter, all the roe and milt does not ripen at once, but that the time of laying the eggs and fecundating them in a natural way, extends over a period of ten days or more. Hence the necessity of a tank supplied with running water, as a temporary residence for the breeding fish, that the ova and milt may be expressed as it matures.

The appearance of all the eggs, whether fecundated or not, is much changed in the course of a few minutes. They are, at first more opaque than they were when discharged from the fish, and then assume their transparency. M. Coste says it is only after some days that the barren eggs can be distinguished from the fecundated, and that they deteriorate rapidly, become more and more opaque, turn white or else preserve their transparency, but show no interior change. Taking the spawn and milt from the fish is a matter of so much interest, that I quote his remarks at length.

"If the eggs are hard, and already free from the membrane of the ovaries, the slightest pressure suffices to expel them, and under this pressure the abdomen is emptied without injury to the female operated upon; for the following year she will become as fruitful as if she had spawned naturally, as we have often had occasion to observe at the establishment at Huningen.

"If, on the contrary, it appears that a greater degree of pressure is necessary to bring out the eggs, we may be sure 
they are still enclosed in the tissue of the organ which produces them, and that the operation is premature. In this case it should not be persisted in, but the female should be put back into the pond, and allowed to remain there till her full time is accomplished, care being taken that this will soon occur; for if a female fish in this condition is kept captive for any length of time in a circumscribed place, her eggs will spoil.

"If the females are too large to be held and emptied of their eggs by a single operator, another can aid him in hold. ing them over the receptacle, either by passing his fingers in their gills, or by securing them with a cord, and if the convulsive struggles are very violent, it may be necessary for a third person to hold the tail. The operator, then, with his thumbs upon the thorax and his fingers upon the animal's sides, presses from top to bottom the enormous mass of eggs which distend the coats of the belly. The vertical position in which the fish is held usually suffices to press out the eggs nearest the opening, and the pressure of the hands, repeated several times, will successively bring all the rest.

"The easy expulsion of the eggs proves their maturity, for it shows they are detached from the ovaries; but it does not prove absolutely their capability of being fecundated. For there are some cases, the causes of which we have not ascertained, where the female being in a stream and at liberty, and having gone her full time, and her eggs being ready for delivery, yet she does not or cannot free herself from them, and being thus retained past their time they lose their reproductive faculty.

"Experienced persons easily recognise eggs of this sort by two evident characterističs: one is the flowing out with them of a foreign matter, of which there is no trace in their normal state, which gives a muddy hue to the water when the eggs 
begin to fall into it; another is, the white color of these eggs when they come in contact with the water. When neither of these appearances is observed, we may be almost sure the operation will be successful; for the eggs will then be in a good condition. But in all cases we must guard against allowing too great a quantity of eggs to fall into one vessel, for if those on the bottom are covered over by too many others, they will not perhaps come in contact with the milt, which should reach every part of them. It will be well, if the females are found to be very productive, to empty the spawn into a number of vessels. The results will then be more satisfactory.

"As soon as the process of delivering the female of the spawn is complete, if it appears that the operation of expressing it has brought along with it any part of the mucus which is secreted by her intestines, the water should be immediately changed, so as to free it from every impuirity, care being: always taken that the eggs are not allowed to become dry: This done, a male fish should be taken, and his milt expressed in the same manner as the female's eggs. If the milt has arrived at a state of maturity it will flow abundantly, white and thick like cream, and as soon as enough has been taken from him to give the water in the vessel the appearance of whey, it is saturated sufficiently. But in order that the fecundating particles may be spread everywhere and uniformly, the precaution should be taken of agitating the mixture, and of softly turning over the eggs with the hand, or what is better, with the fine long hairs of a brush, so that no part of their surface shall escape contact with the fecundating element.

"After two or three minutes' rest the fecundation is accomplished, and then the eggs, with the water surrounding them, should be emptied into the hatching basins; or if these 
basins are some distance removed from where the operation has been performed, the water must be renewed before they arrive at their destination, provided the distance be not too great, for then other means must be taken.

"While the mixture is agitated to help the absorption of the semen, if the eggs are of that species which are found to be naturally cemented together by a gelatinous matter, as, for example, are those of the Perch, great care must be taken not to pull them apart. This agglutination is a natural condition of their development, of which it would be injurious to deprive them.

"There is still another mode of treating the mixture of fecundating particles with the water, which serves as a vehicle, and of aiding their absorption by the eggs to be fecundated; it is to place in the vessel a cullender well riddled, or better still, a fine basket. Into this, while in the water, the eggs are expressed, and then the milt. The cullender should then be moved about, up and down, and from side to side, care being taken to keep it always in the water. This movement has a double result: it thoroughly mixes the fecundating liquor and bring's it in contact with every part of the eggs, and the experiment will be successful if, after the agitation of the cullender, it is allowed to remain at the bottom of the vessel quietly for two or three minutes.

"A third process is to express into the vessel the milt, and not cause the eggs to fall into the water till it has been thus first charged with fecundating particles. The medium being thus prepared beforehand, the eggs reach it in a condition of peculiar aptitude for absorption, which they possess in the highest degree the first moment of their immersion. This mode then seems to offer the greater chance of success. I do not mean to assert that eggs laid in the water some time before the milt is brought in contact with them, lose the 
power of receiving its influence. For, many times, on the Rhine, I have had occasion to observe that those of the Salmon and Trout that had been expressed into the water nearly two hours before a male could be caught, still preserved their aptitude for fecundation. But still it is an unfavorable condition, in which, if possible, they should not be placed; above all, when the eggs of other species are treated, which have not, like the Salmon and Trout, a protecting and resisting envelope, but which are more sensitive to the influence of the exterior world.

"Another mode of treating artificial fecundation, and one more nearly resembling nature's processes, is to spread the eggs on a sieve fitted in a channel or trough of wood or stone, through which runs a current from a water-pipe, under the spout of which the end of the trough is placed, and then to pour at this point the spermatized water, and leave to the running current the care of carrying the vivifying particles to the eggs; but to operate in this way requires an apparatus not always at hand, and perhaps only to be found in an establishment designed for the business. For general use and ready application I recommend, therefore, the process described at the commencement of this chapter.

"The milt of a single male will suffice to fecundate the eggs of a large number of females, provided he is fed while in the pond or tank, and that care is taken not to take him from the brook and shut him up there until his milt is fully matured. Of this fact the author of the memoir published by the Count de Goldstein was aware, and I have often had occasion to verify it while on board the boat of the fisherman Glasser, at Bâle, where the male Salmon and Trout emptied one day to fecundate the eggs destined for the government establishment at Huningen, are found gorged the next, and so on every day, for the five or six during which their organs 
secrete semen. It is not necessary, therefore, in experimenting on a large scale, to have numerous males, but only that they should be in the condition I have indicated."

M. Coste does not entertain a doubt that breeds may be crossed. Any two species of the Genus Salmo would no doubt reproduce, by pressing the eggs from the one and fecundating them with the milt of the, other. This may even be the case with fish of different families, as the Perch and Pike, or either of these with the Trout; but the farther we depart from the laws of nature in producing mongrels, the more imperfect the progeny must be, and in either of the cases above mentioned, it is likely the produce would be mules incapable of reproduction.

Treatment of the Fecundated Eggs.-The time of incubation varies according to the temperature of the water and room in which the troughs are placed. I would recommend that the latter be sixty-five or seventy degrees above zero. M. Coste in his experiments, found that the eggs were hatched in from thirty to sixty days, which is a much shorter time than if the ova was deposited in a natural way by the fish in the brook.

The eggs should be distributed evenly over the gravel in the hatching-troughs, more thickly at the head where the water enters. The unfecundated eggs should be taken out, and any sediment forming on them removed with a soft brush.

M. Coste give the following interesting account of the appearance and growth of the young in the egg, and its escape from the shell.

"In eggs vivified with the fecundating molecules, one may see after a time, which varies according to the species and to the temperature of the water, on the interior globe a line, 
which covers about a quarter of its circumference. This line, which seems whitish when the eggs are on a dark ground, or opaque when they are held up to the light (in the manner in which our farmers examine hens' eggs), is the origin of the fœetus, and represents the spinal column. As this line increases in size, one end of it grows out to a point to form a tail, and the other extends in the form of a spatula. This last corresponds to the embryo's head, and of this there is soon no doubt, for the eyes now appear, two points of a blackish brown, easily distinguished, and forming nearly two-thirds of the whole mass of the head. As each day develops its form, the young fish may be seen under the shell or membrane, stretching itself, and drawing itself up, and wagging its tail. When hatching-time comes, these movements, the probable object of which is to weaken or tear the shell, become more active. With Salmon and Trout there is another sign of the approach of hatching besides the quick movements of the young. The outer envelope of the egg becomes a little opaque, and as it were furfuraceous. With other species with which I have made observations, this sign does not appear so plainly. At last a little opening is made in the shell, and that part of the embryo next the opening comes through it. Ordinarily the tail or the head first appears, but sometimes it is the umbilical bladder.

"Whatever part may be first disengaged, more than half the body still remains imprisoned, and the efforts of the young fish are unceasing, till after several hours it frees itself from the shell. This membrane, which has protected its development, but has not served to form any part of its organs, being now cast off, either is decomposed where it lies, or is carried off by the current.

"Certain kinds, like the Pike and the Ferrat, begin imme. diately to range about in the waters where they have just 
been hatched; others on the contrary, such as the Salmon and the Trout, weighed down by their enormous umbilical bladder (figure 2), can only move with great difficulty, and remain lying on one side, or even on the bladder itself. Some few attempt to move from one place to another, but soon give up the effort.
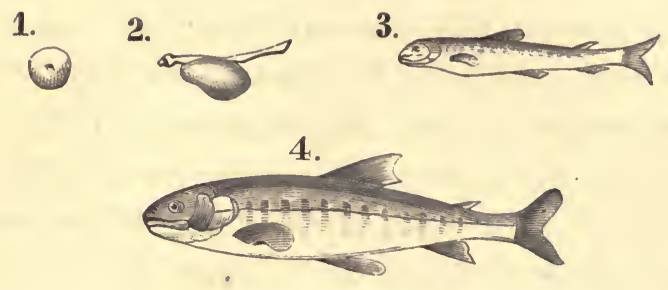

"The time for hatching is not the same with all species. Some, like the Pike, hatch at the end of eight, ten, or fifteen days; others, like the Salmon, take from a month and a half to two months.

"Besides development is more or less hastened, according as the temperature of the water in which they are laid is more or less elevated. Pike's eggs placed in a vase, the water of which without being renewed was exposed to the sun's rays, hatched in nine days; while others of the same spawning, placed in the shade in water constantly renewed took eighteen to twenty days to hatch. It required also twenty days to hatch eggs of the ombre, which, more favorably placed, hatched in twelve to fifteen days. Still greater variations of time appear in the incubation of other species of the Salmon family. In running water of a warm temperature, the eggs of Salmon and Trout will hatch in about thirty days, while the same eggs in a cold stream will take seven or eight weeks. The term of incubation may even extend to a hundred and ten days, as was proved by the experiments made in 
Scotland, by Mr. Shaw, to which I have referred in the introduction.

"During their change the eggs should not be left to themselves; they require, on the contrary, a certain watchfulness and frequent visits, in fact, such care as can be easily bestowed by the aid of the hatching apparatus which I use.

"Whether the artificial streamlets, which I propose, be used, or in preference to them any other mode, one precaution should always be taken; the eggs should never be heaped upon one another. Their accumulation prevents a proper surveillance of. all of them; and besides may retard or even prevent their development. Another and more serious inconvenience often results: if one of the eggs becomes spoiled and covered with byssus, this byssus spreads to the adjoining eggs, and in a few days reaches all that are contiguous and destroys them. The only mode to diminish the extent or arrest the progress of this evil, when the eggs have not been heaped up, is to remove, at once, from the hatching-place all that show the least trace of alteration. If in place of sacrificing, an attempt is made to save them by freeing them, with the aid of a brush, from the vegetable parasites covering them, not only will it be a useless trouble, since the tainted eggs are already struck with death, but the evil will be aggravated by spreading over the healthy eggs the particles of destructive byssus, by the very operation of cleansing."

Fig. 2, in the preceding cut, shows the appearance of a young Salmon on emerging from the egg; 3 its size at two, and 4 when three months old. The umbilical bladder sustains it for about four weeks, during which time it refuses other nourishment; at the end of this time, the nutritive matter of the bladder is consumed or rather absorbed, when the young fish instinctively begins to seek its food. Previous to this, any attempt to feed them is not only unnecessary but hurtful, as 
any anımai matter thrown in only serves to make the water impure, and of course affects the health of the fish.

Fendng-Troughs.-The depth of water in the feedingtroughs need not be more than four inches, and the area proportioned to the number of fish. M. Coste says he was enabled to feed and bring up in a space of twenty-one inches long, six wide, and three deep, as many as two thousand young Salmon at once. This seems improbable; the space is certainly more circumscribed than necessary. A trough of eight feet long and four feet wide would no doubt be sufficient for that number of young Trout during the first three months, at which time they will likely bé from two to two and a half inches in length. They could then be transferred to ponds, the size of which may be about eight yards wide and twenty-four long, which would cover nearly the twentyfourth part of an acre. According to such calculation, it will be seen that a single acre divided into twenty-four ponds, would sustain forty-eight thousand Trout during the first year.

Food For Young Trout.-After trying several kinds of food for young fish, I have found none so readily received or divisible into small particles as fish-roe. On crumbling it, after being fried or boiled, into an aquarium, the smaller fish, especially those of a predatory species, seize a single egg greedily before it falls to the bottom, and the Goldfish hunt for it industriously amongst the gravel, and leave none to affect the purity of the water. I would therefore recommend it as preferable to any other, where it can be had; if not, boiled meat of any kind (as I have also ascertained from experiment), when cold and crumbled in small particles, is the best substitute. It is better to give a less quantity than the young brood can consume, for reasons already stated. 
After the fish are removed to larger ponds, there is no doubt that rye, after being thoroughly soaked or steamed, and then rolled in blood-which should be allowed to dry on the grains before they have time to become hard-would be a desirable article of food to be given with the crumbled fibre of meat.

Any substance of which albumen forms a principal constituent promotes the growth of fish; the white of eggs would, therefore, be appropriate food. Trout kept in springhouses grow to an immense size when fed on nothing else than curds.

The liver or heart of a'sheep or ox, hung over a pond, will produce the larva of the common fly, which will fall into the pond, and furnish a more natural food than meat.

With these hints on feeding, the reader who is not already better informed, cannot fail, by observation and ingenuity, to raise young fish, after placing them in ponds larger than those already suggested.

Ponds covering a half-acre and upwards, will afford a large amount of natural food after the first or second year, if judiciously supplied with aquatic plants, brush, logs, \&c.; nevertheless, feeding as we have suggested will greatly promote the growth of the fish. It is desirable, for many reasons, to have the ponds well shaded. Smaller species of fish, as Shiners, Roach, Minnows, \&c., may be advantageously introduced, but not in ponds where Trout are intended to breed, as they devour a large proportion of their ova. These small worthless species furnish a considerable proportion of food for large Trout in their natural haunts.

In connection with this subject I should not omit to mention that there have been numerous instances of stocking streams in England, Scotland, and Ireland, which had become barren or depopulated by improvident fishing and poaching. 
Some rivers which Salmon were known never to enter have been rendered productive. The manner of effecting this has been to transport the parent fish when about to spawn, and allow them to spawn in the stream; or proceed according to the usual mode of artificial propagation; or to bring the fecundated roe, and place it in the waters intended to be stocked. It has become a matter not of mere experiment, but certain success; as much so as a farmer getting his wheat or potatoes from another part of the country, in view of increasing the product and quality of the crop by a change of seed.

I should not wonder if fishing clubs in England have resorted to this means of restocking their exhausted waters, and now find good angling in streams that previously afforded but a limited amount of sport.

I have before adverted to the fact that impregnated spawn is an article of commerce in China, and that in some parts of Germany, Carp-ponds drawn off for the purpose of cultivating the soil are not restocked when the water is let on again, the fecundated ova remaining in the soil two or three years, replenishing the pond.

M. Coste advises that, for transportation, the impregnated eggs be packed in wet sand, alternate layers of each; and thinks the gravel used in M. Gehin's directions would crush a portion of the eggs if the box should be jostled.

A singular evidence of the number of Trout that will thrive in a small space can be witnessed at Hellertown, a few miles south of Bethlehem, Pennsylvania. Owen Desh, who keeps a hotel there, has a trough in his yard which is twenty. four feet long by two feet wide, with a depth of water not over eighteen inches. In this limited space he generally has from six to eight hundred Trout, from nine to twelve inches long. He has even kept twelve hundred in the same trough, 
and all in a healthy condition, where they grow rapidly and get fat on a small quantity of curds fed to them once a day: these Trout are even preferred to those caught fresh from the Saucon, which flows close by. The trough in question contains seventy-two cubic feet of water, and when it has seven hundred and twenty Trout in it, there are just ten fish to a cubic foot. This useful aquarium was established many years ago by Mr. Desh's father; Trout seldom die in it. The spring which supplies it rises in the garden, a few yards above, and would flow through a hole an inch and a half square. The fish are bred naturally by a farmer in the neighborhood, and brought in large tubs. There have been instanees of their breeding in the trough.

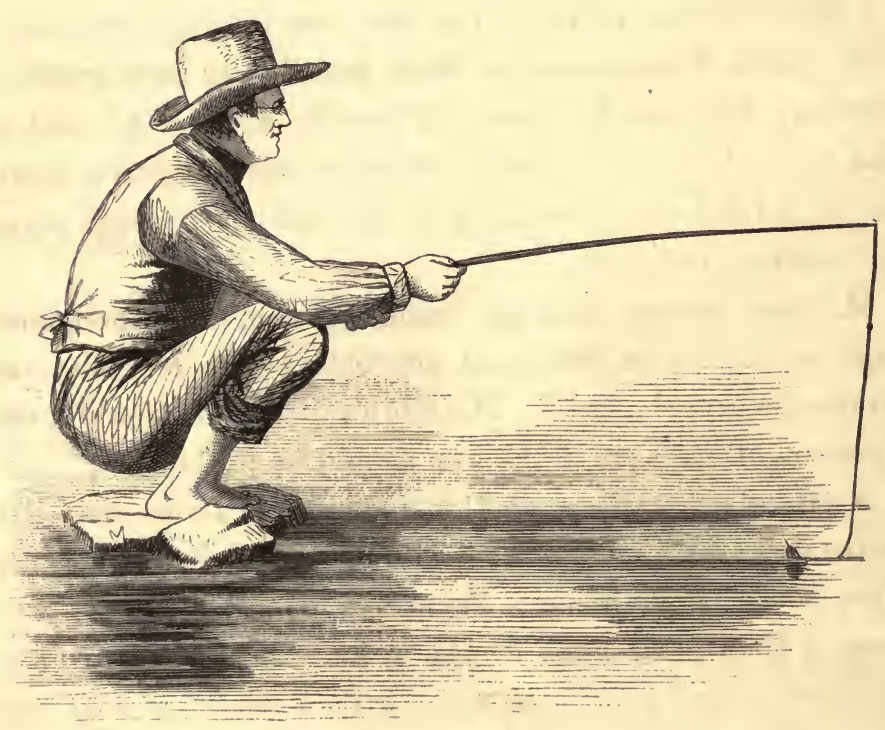




\section{THE AQUARIUM.}

Five or six years since quite a sensation was produced by this novel sort of fish-cage. It is simply a tank with glass sides, and a wooden, stone, or cast-iron bottom. It is supplied to the depth of three or four inches with gravel or sand, and aquatic plants tastefully introduced in groups. The latter are not intended as an ornament only, but to keep the water pure and the fish healthy by the oxygen which they give off, while the carbonic acid exhaled by the fish promotes the growth of the plants.

The most convenient size I have found to be one of thirty inches in length, sixteen wide, and sixteen deep, which will hold nearly thirty gallons of water, and is large enough to sustain sixteen or eighteen fish from three to five inches long. There is no ornament more beautiful than a well-kept Aquarium. It furnishes a fine opportunity for a display of delicate taste in the arrangement of plants, shells, and miniature grottos. It is always a source of amusement and wonderment to children, and furnishes an opportunity on a small scale for studying the habits and dispositions of fish. Barnum's fish-tanks, at his Museum in New York, are well worth the observation and study of anglers and naturalists. Those who would establish one on scientific principles, should procure Mr. Arthur N. Edwards's little book, called "Life beneath the Waters."

Any glass vessel of sufficient capacity will answer for a tank, if the bottom is wide enough to set out plants in it. 
The best shape is one of four sides. In a round vessel the proportions of the fish are distorted, when seen through the convex sides, as any person has observed in looking at Goldfish in a glass globe.

Wood is an objectionable material for the bottom of an Aquarium, on account of its liability to warp. Soapstone can be used, but cast-iron is the most suitable. No fear need be entertained on account of its liability to contract with cold or expand with heat, as the water in the tank will serve to maintain an uniformity of temperature between the glass sides and iron bottom. For the same reason the frame (the four posts at the corners and the rim around the top of the glass), should also be of iron. The plate glass forming the sides and ends should fit neatly into grooves in the bottom and frame, and should be cemented with some composition which does not contain any ingredient that will affect the health of the fish. The tank should be filled with water and let stand for a few days, to see that it is perfectly water tight before putting the fish into it.

If placed at a window with a southern exposure, the growth of the plants is accelerated; though in such situation care should be used to lower the shade of the window, if the sun shines for any great length of time on the tank.

Clean white gravel has been found to be the best bottom, as it can be removed whenever it becomes necessary, and returned after washing. The ornamental rockwork, such as arches, grottos, \&c., can be arranged according to one's own taste.

Plants for the Aquarium.-Suitable aquatic plants can be procured in almost any running water or mill-pond in the vicinity of the city. The ditches into which the water from the Delaware and Schuylkill flow through sluices, and where 
it falls and rises with the tide, are filled with them, and produce a great variety.

I have tried with satisfactory results many of the plants recommended by Mr. Edwards, some of them merely as ornaments, others to supply oxygen to the water, and those that require no root, and float on the water, to give shade to the fish. I have used the little plant known by the common name of "duck-weed" or "duck-meat" for this latter purpose. The only objection to it, though, is that fish that live on vegetable food, as Carp and Roach, eat it. This they will also do with many of the plants beneath the water, and are much given to nibbling at them. I have had two or three Goldfish to destroy a large bunch of the Eudora canadensis in a day or two. This plant is remarkably crisp and mucillaginous, with a pleasant flavor. It is said by persons who profess to know, that it is the "water celery," on which the far-famed canvas-back feeds, in the waters of the Chesapeake Bay. It is well, therefore, to avoid plants that fish nibble at; for the gravel is frequently strewed with it, and the small pieces floating about decay and tend to make the water impure.

In Mr. Edwards's list of plants, he specifies those intended for ornament and those for aerators; of the former the common arrowhead (Sagittaria sagittifolia) and two or three kinds of water-lilies. Of those used for the rockwork where it comes above the surface of the water, the forget-me-not, the sundew, \&c. Those used for aerating, and wholly or partly submerged; Valisneria spiralis, hornwort. witer starwort, Anacharis canadensis, Udora canadensis, marestail, water molit, \&c.

In setting out any of these plants, except the water-lilies, flags, and forget-me-nots, it is not necessary for them to have roots; these they soon throw out, whether floating or planted 
in the gravel. Those that belong to the family of lilies should have the roots encased in lumps of stiff clay, and the gravel strewn over them after setting them out.

After trying water-lizards, tadpoles, snails, young terrapins, \&c., I discarded them, and found that Roach, Goldfish, and other Cyprinoids were as good scavengers as the ugly reptiles, and that they cleaned the bottom very effectually of any food left by the Sunfish, and others of the Perch family, which, as a general rule, seize their food before it falls to the bottom.

To prevent the fish from biting the plants it is necessary to feed them: care should be taken, however, that little of the food remains. A thimble will contain as much chopped meat as will sustain a dozen fish for a week; half of that quantity given twice a week would be better. Flies or live insects thrown on the water are greedily seized by the Sunfish.

One reason for preferring a four-sided vessel with parallel sides is, that by standing in front of it you can see entirely through it, as the fish are moving about. When you look at them at a little distance from one of the corners, and above the level of the aquarium, the refraction creates a pleasing illusion, each fish near the angle appearing like four. 


\section{DIES PISCATORI A.}


"YE who love the haunts of Nature, Love the sunshine of the meadow, Love the shadow of the forest, Love the wind among the branches, And the rain-shower, and the snow-storm, And the rushing of great rivers, Through their palisades and pine trees, And the thunder in the mountains, Whose innumerable echoes Flap like eagles in their eyries;I.isten!"

LONGFELLOW. 


\section{DIES PISCATORIA.}

Many readers, when they come to "APPENDIX," will shut up a book and throw it aside, for the word sounds to them very much like "appendage," and is associated in their minds with caudal appendage, or, according to the nomenclature adopted by that eminent naturalist Mr. Sparrowgrass, in his observations on the dog, "organ of recognition." Such people think, with Mr. Sparrowgrass's butcher, that a dog's tail or any other appendix is a useless or superfluous thing. I differ with them, for it is not so with the appendix to a good book or to a good saddle of mutton. An author, though, or a politician, must not combat popular prejudice, if he would gain the ear of the people; but when an old idea or an old principle becomes hackneyed or unpopular, it may still be presented to advantage under a new name, "by either of the aforesaid, as the case may be." I therefore discard that stale old word "appendix," and use the new bait at the head of this page, to lure the reader on to the end of the book.

In the following pages, I have taken up the old angling authors' dialogue-method of telling what I have to say about fishing-places. The information given is fact, the scenes described are real, and the persons appearing to take part in the dialogue are real and of the "Houseless." The place mentioned as the scene of each nooning is real or supposed, or both, or like the romance "founded on fact." 
As mention of the "Houseless" has most likely been made in the preceding, and certainly will be in the following, pages, it may not be out of place here to explain what is meant by the word, or rather to what it refers.

About twelve years since, a few brethren of the rod and angle, some of whom had met for the first time on the stream, and had become acquainted without any conventional introduction, feeling that they were drawn towards each other by a love of the gentle art, met by agreement at the house of one of the brethren, and formed themselves into an association, under the unassuming name of the "Houseless Anglers." This title was adopted in contradistinction to the old Fish-House clubs-associations rather of a convivial tendency than that of pure angling.

All the members (their number never exceeded ten) were fly-fishers. They were of various pursuits: amongst them were a few artists, professionally so, and two more who were merely amateurs. To one of the latter I am indebted for the vignettes and some of the drawings of fish found in this book.

Stated meetings of the association have fallen into disuse of late years, some of the "Houseless" having removed to neighboring cities, and some to the country; but as many as can do so, meet occasionally in a social and informal way, and whatever their tenets-religious, political, or otherwise-they are one as regards angling, and still the subject that most interests them is fly-fishing, with its blessed associations and scenes.

The prevalent feeling, or if the reader is so disposed to call it, the sentiment amongst the members has been to avoid display or notoriety, or setting forth their piscatorial achievements in public print; believing with Izaak Walton, that fishing, like virtue "is its own reward." Also, as far as they 
could influence others, to curb that disposition, which alas, is so common, to fill the creel at the sacrifice of the rules of fair angling, and to repress any inordinate rivalry or competition on the stream; being convinced that to enjoy the sport to its fullest, the angler should be at peace with himself and all the world. These lessons they endeavor to teach by precept and example, wherever they find those who desire to be instructed in the mysteries of their craft.

When the "Houseless" were organized as a club, our good president was appointed to draft a set of rules for our guidance, and a preamble and address setting forth the object of our association. It has lain undisturbed on a shelf of my tacklecloset, bound in its cover of modest brown paper, and tied with an old fishing-line, this many a long year. I took it down the other day, and read it with a feeling akin to reverence. Why should I not insert it here? I think it will touch a chord of sympathy in every devout angler's heart.

P REA M B L E.

WHEREAS: We, the undersigned, being drawn towards each other by that feeling of regard and sympathy which should animate the hearts of all true anglers, having in view the humble virtues of honest Izaak of blessed memory, which we would emulate; and recalling with heartfelt pleasure the happy hours we have passed by stream and pool, and the peaceful friendship which has ripened there, do heartily concur in the sentiments expressed in the following address by our brother, W. M***** $D^{* * * *}:-$

\section{ADDRESS.}

In the year 1653, now just two complete centuries since, was published by one Izaak Walton, a Treatise, entitled "The Complete Angler; or the Contemplative Man's Recreation." Therein he performed a mission ; and how well 'twas done the united testimony of all true "Brothers of the Angle" bear loving witness.

Therein he sayeth, "I doubt not but if you and I did converse together but a few hours, to leave you possessed with the same high and happy 
thoughts that now possess me of angling, not only of the high antiquity of it, but that it deserves commendation, and that it is an art, and an art worthy the knowledge and practice of a wise man."

That we have conversed with this humble, zealous, loving heart, not for hours, but through long years, and that we are "possessed with those high and happy thoughts" concerning the "gentle art," let our present meeting, our Brotherly Association, and our future study and practice, bear witness.

Two centuries have well tested the beautiful spirit manifested in his work, and it seems to me most happily appropriate that at this time we, a few humble followers in his footsteps, recognising the power of association, do unite to lend each other a helping hand in the attainment of that, which he was assured "was worthy the knowledge and practice of a wise man." That we are wise men, I shall not stop to maintain, but that we do love angling we are assured of, and therein we know we are in unison with very many greatly wise and wisely good men.

So, filled with this love, the desire to ennoble our art in this western world, and a sense of the kind confidence you have reposed in me, I have thought it was right to lay before you "some of the thoughts which have possessed my soul since we few have met together."

A handful of sand, thrown with what force soever into a placid pool, could scarcely do more than, for an instant, ruffle the glassy surface; yet these same particles associated and compacted into a stone, and but dropped in, will produce not only a wave but a succession of wavelets which will reach the utmost confines of the pool; indeed, learned men tell us that, be the ocean ever so large, these little waves will continue until the whole vast surface feels the influence of the associative force of these same particles. Even so with us. Either in the little pool of local mind by which we are surrounded, or in the illimitable ocean of the earth's mind, we, as individuals, fall as the grain of sand unfelt; yet bound together by a common sentiment, we may by association possess new powers and properties, even as the stone possesses other powers and properties than the shifting sand, and by these powers we may produce effects reaching far beyond the circumseribed limits of our home or city. Whether that effect be for good or evil, is for us in a considerable degree to determine. That the effect be for good is my most earnest desire, and that it may be, our aim should be elevated, even as I before said, to the ennobling of the art of angling, thereby commending it to those "who, being born to it," need only "the discourse and practice" to win them to that which, "having. 
once got and practised," "they will find, like virtue, to be its own reward," and the more commending it to all true men by the showing that the angler should, like our worthy father, "the rather prove himself a gentleman by being learned and humble, valiant and inoffensive, temperate, virtuous, and communicative, than by any fond ostentation of riches."

Let it be seen that the true angler is not an insatiate slayer of fishes, but that he taketh thereof in moderation, and remembering the future, for himself and his brother who may follow him, with a wise and humane forecast he returneth to life and freedom those fishes which in the thoughtless greediness of youth may come into his hands. Let it be known of men that the angler's study is as much to people streams with new fishes, as it is to take those found therein ; and that he is the fishes' best protector from the indiscriminate slaughter of net and weir.

Let it be seen that a love of the "gentle art" openeth first the heart, then the fly-book, and soon the stores of experience and knowledge garnered up through long years, wheresoever we meet a "Brother of the Angle;" and that to us "angling is an employment of our idle time, which is not then idly spent; that therein we find " a rest to the mind, a cheerer of the spirits, a diverter of sadness, a calmer of unquiet thoughts, a moderator of the passions, a procurer of contentedness, and that it begets habits of peace and patience in those that possess and practise it." Let us so study, teach, and practise the art that in whatsoever place the angler may be thrown, be there but water and fishes, he may therein find sport in the taking of those fishes, in a true angling spirit, which seemeth to me to be this.

The angler is best pleased in capturing the kind of fish for which the cast was made; the fisherman is pleased according to the value of his capture. The taking of a good trout to a fisherman is always a pleasure ; with the angler the pleasure is lessened, had the fly been dressed and the cast made especially for the capture of a chub, or in the words of an humble colored brother of the angle, "When you go a cattin', go a cattin'."

And for him who may think this is but sentiment, and therefore to be undervalued, let me say, in this world, so given to work and trade, sentiment doth not so abound that we may wisely reject that which may beget even thus little. So, my friends, rather let us thank God for even this, and store it near our hearts. As I began, so let me conclude in the language of Walton:- "When I would beget content and increase confidence in the power and wisdom and providence of Almighty God, I will walk 
the meadows by some gliding stream, and there contemplate the lilies that take no care, and those very many other various little living creatures, that were not only made but fed, man knows not how, by the goodness of the God of nature, and therefore trust in Him.

"And let the.blessing of St. Peter's Master be with mine, upon all that are lovers of virtue, and dare trust in His Providence, and be quiet, and go a-angling."

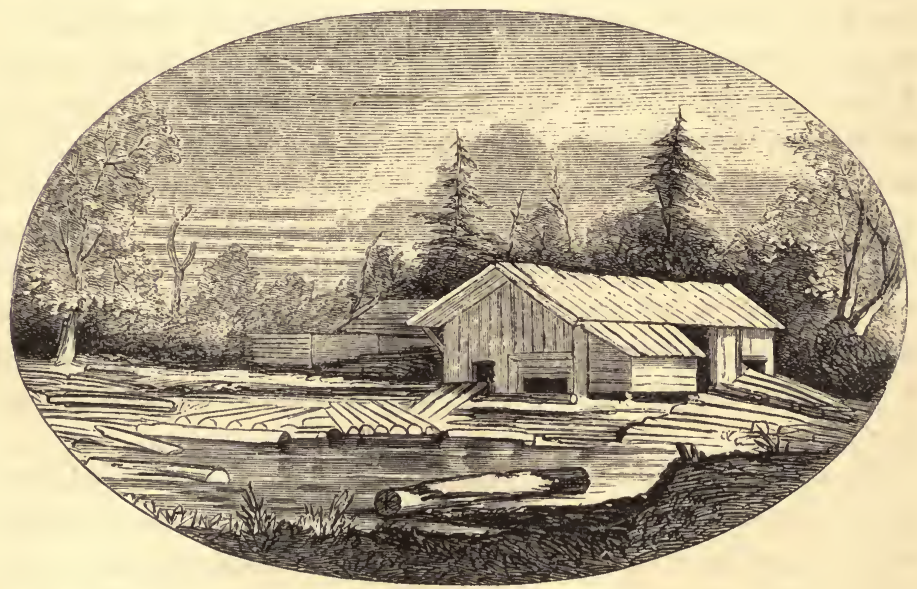




\section{THE NOONDAY ROAST.}


"Soms boys belonging to an old field school,

Dismissed at twelve, a long established rule.

As they discussed their bread and bones of bacon,

Strange tales were told, and jokes were gi'n and taken"

BiRd (not N.P) Will.Is. 


\section{THE NOONDAY ROAST.}

I HAVE often thought that the fly-fisher whose experience does not include the roast or the bake at noonday, has fallen short of some of the pleasures that can be crowded into a day on the stream, and that the angler who has never enjoyed it, has something to live for. The roast has long been an institution amongst the "Houseless:" some of the members of our little club were initiated into its mysteries in days "lang syne," by Chester Darby or Uncle Peter, on the Beaverkill, since which its cuisine has improved, and many pleasant hours have been passed under the dark sugar-maple or birch cooking, eating, smoking, chatting, sleeping; many a long story has been told, and perhaps occasionally a long bow drawn.

A provident fisher who leaves his lodging after breakfast, with the proper necessaries for a roast, need not trudge home in the hot sun to get his dinner, or munch his cold snack, or pass his time irksomely or unprofitably during the hours of midday, when Trout merely nip at one's flies in the rifts, and utterly disregard them in still pools. But to begin :-

When the angler leaves his quarters for a day's fishing, let him take as large a portion of a loaf of bread as will suffice for the party, from which he will remove so much of the crumb or inside, as will leave a cavity large enough to hold as much butter as he deems necessary; after the hole is filled with butter, it is covered with a slice of bread. Then, with salt and pepper, a few matches in one of his pockets, 
above high-water mark, and his "provender" wrapped in a large napkin or handkerchief, and slung over his shoulder, he is ready for a start. If it is the intention of the party to go up the stream, a bottle of claret or ale may be added. After selecting a place of rendezvous, the pack may be hid close by in the bushes, or in an old stump, or a hollow log, and the party can then go up and fish down stream to the "cache," making the distance and time suitable. On arriving at the place for dinner, select a suitable location for building the fire, and place rods and creels to the windward. While some are gathering wood and building the fire, let others collect a few clean flat stones for plates, and put them in a position before the fire to warm properly. If you wish a roast, select the smallest fish, those under nine inches are best; scour them well in sand, wash them clean, and open them, but allow no water to touch the inside, as the blood and natural juices of the fish should be retained as far as possible; cut off the heads, score them (not too deeply), and pepper and salt them well inside and out. Cut one or more branches (sweet birch is best), with as many twigs or shoots on them as is required for the number of fish to be roasted, and stick a fish on each twig, either end foremost, running the twig along the upper side of the backbone, and hold them to the fire. By keeping an eye on the inside of your fish, it is easy to ascertain when they are done. Always take them off with a twist or wrench, to disengage the twig from the flesh, and lay them on a hot stone, buttering them while warm.

In baking or steaming them under the coals and ashes do not cut off the heads, but season them, and then take a piece of strong thin paper and smearing it thinly with butter, roll a fish in it, and then envelope it in five or six plies of coarse straiy, paper; after saturating each fish so encased in the stream, lay them side by side in a bed of hot ashes and coals; cover them up, and give a minute to an inch: that is, if a fish 
is ten inches long, give it ten minutes, and so on. When you uncover them, they can be removed from the ashes by inserting the forked end of a long stick beneath, and drawing them out. When you take them out of the paper, unroll them carefully on a flat hot stone, open and butter them to your liking, and, above all, regard the head as a precious morsel; it contains much that is glutinous and fatty; in the language of Father "Izaak," "they are too good for any but honest anglers."

Of course it will occur to the diner-out that a larger fire is necessary in baking than in roasting, and that it should burn down well, in order to produce the requisite quantity of coals and ashes. Trout of nine to twelve inches are best cooked in this manner. Though there are other ways of cooking them on the stream, as frying on flat stones which have been heated in the fire, or "planking" large Trout, none can compare with this mode; if there is an objection to it, it is that one is never satisfied afterwards with the taste of Trout cooked indoors. Old anglers have confessed, after a roast or bake, that they had missed much by not before adopting this simple way of providing a sumptuous dinner; and that all indoor methods, with their epicurean appliances, were not to be compared with roasting or baking under the ashes. The latter is the surest mode of retaining the natural flavor and sweet juices of the fish.

There is also a good-humored dash of vagabondism accompanying a dinner of this kind; and as you light your pipe from a coal, and kick the smouldering chunks and impromptu cooking utensils aside, there is a quiet trust in a bountiful Providence and your own skill, for as sumptuous a meal and hot plates of the same kind on the morrow.

And now, if you have dined to your satisfaction by these simple directions, take that small piece of India-rubber from your vest pocket, and rub the frayed fibres from the gut of 
your leader and dropper, and light a fresh pipe; and as you wade into the limpid water, you will find your rod to deliver the line straighter, and your flies to fall lighter than they did a few hours ago, and yourself cooler in the contest that awaits you with the speckled beauty that refused your fly before dinner, and is now ready to give you a tussle; and the experience of the "Houseless" has been that the rift or the pool nearest our fire furnishes a few moments of the most active and exciting sport we experience in the day's fishing.

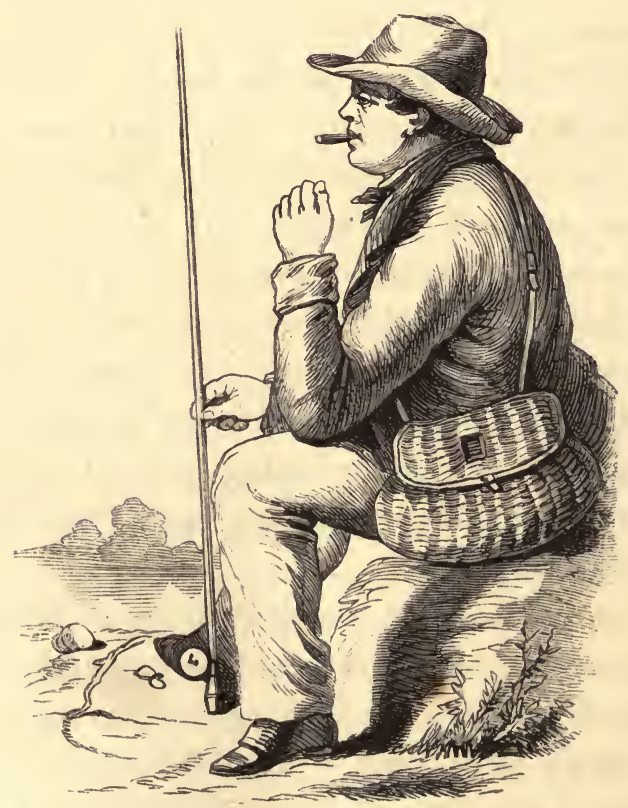


FIRST NOONING.

TROUT-FISHING IN HAMILTON COUNTY, N. Y. 
"BUT he heard the Wawonaisa,

Heard the Whippoorwill complaining,

Perched upon his lonely wigwam;

Heard the rushing Sebowisha,

Heard the rivulet rippling near him,

'Talking to the darksome forest;

Heard the sighing of the branches,

As they lifted and subsided

At the passing of the night-wind;

Heard them, as one hears in slumber

Far off murmurs, gentle whispers."

LONGFLLLOW. 


\section{TROUT-FISHING IN HAMILTON COUNTY, N. Y.}

\section{- FIRST NOONING.}

[Scene, the shady bank of a 'Trout-Stream.-Time, after the Roast.Present: Noruan, Walter, and Nestor.]

W ALter. Well, about fishing at Lake Pleasant and Louie Lake; how do you get there?

Nestor. The usual route is, or was, by way of Albany and Amsterdam, a station some thirty miles beyond, on the New York Central Railroad, where you take a stage or private conveyance to Northville, and there another for Lake Pleasant.

Brundage, a spry old fellow of seventy, used to drive us up from Northville, and as we trotted merrily along the Sagandoga, and crept up the ascent of the table-land, whose forests embosom the beautiful lake, and heard the waters of the outlet dashing through the ravine below, in the dim twilight or pale moonshine, the garrulous old man would entertain us with stories about his son-in-law Partridge, or as he called him "Patridge," who kept the tavern where we had dined on wild-pigeon squabs, or tell us of the "Piseco Club," who went up the week before, and that it took one wagon to carry the anglers, and another to carry their meat and drink. Their fishing, though, must have exceeded their feeding, for we have it on record, that they caught in one week over eight hundred pounds of Lake and Brook Trout. Our little club, the "Houseless," wêre only occasional not annual visitors, and fished the lakes and rivers north of Piseco Lake. 
Holmes formerly kept a house for the entertainment of sportsmen at the upper end of the lake, near the stream of water which connects Lake Pleasant with Round Lake. I always preferred stopping at Satterlee's, a house of less pretension, at the lower end of Lake Pleasant, near the outlet, which was four miles nearer Jessup River and Louie Lake.

The first week in June is considered the most favorable time for visiting Hamilton County; then there is good trolling in the lakes; fly-fishing is at its height a week or so later. There were good boats for trolling the lakes, and expert oarsmen who also acted as guides for the guests of both houses-tough, sinewy fellows who could carry a pack of forty or fifty pounds, and the inseparable and indispensable axe on their backs all day long, and a gun also, if you had a fancy for the steak of a yearling buck.

A few days on Lake Pleasant and Round Lake generally gave us trolling enough; hitching on to a big "laker" and smoking a whole segar, while you waited on him in his runs and sulks, ceased to be sport after performing several feats of the kind, and we would long for more active service amongst the speckled, notwithstanding the certainty of encountering the mosquitoes and black flies in camping out. Our return, though, to a good straw bed at Satterlee's, and a day's trolling on the lake, was what my friend, the little Doctor, called a "let up."

Norman. But about the fly-fishing and camping out?

Nes. Every man ought to enjoy the sentiment of camping out, if only for once or twice in his lifetime. You have your provisions packed and the guide straps it on his back: perhaps the landlord gives a lift with his wagon as far as the road is practicable, if there is one in the direction of your place of destination. When you get to your camping-place the guide makes a shanty of spruce-bark, which, with a fire in 
tront of it, is hot, if the nights are warm; or one of hemlock boughs, which is like a patent ventilator or a refrigerator, if the nights are cold. There is a pleasing novelty associated with this "happy-go-lucky" way of living, if the time does not extend beyond a few days or a week. A couple of us once set up our shanty, or rather our guide did it for us, at a place known as the "Indian Clearing," eight or nine miles from Satterlee's, on the Jessup River. It was a beautiful eminence of four or five hundred acres, covered with ferns. In olden times the tribe of St. Regis Indians made it their chief abode, and their lodges covered the top of the hill. We made our shanty on the wooded slope, within hearing of the rapids, to avoid the cool night winds. My recollection of the scene has been refreshed by reading some beautiful lines in Hiawatha,-shall I repeat them to you?

Nor. I don't like Longfellow's hexameters, they jingle like the song of "The Nigger Gin'ral," that Old Dick Cooper used to sing with his banjo accompaniment,-go on and tell us about the fishing.

NES. You are no poet.-Well, when you fish the ripples, you wade of course; but there is not a great deal of rough water in that part of the country, though there are some rifts on Jessup River and the outlets of some of the lakes. All the month of June you have great sport in the rapids, but after that time there is apt to be but little water on them, and the fish are found mostly in deep, still water, where cool spring brooks enter. In the early part of June I have filled a large creel during the last hour of an afternoon by fishing the rapids, but in that space of time the flies have taken the angler as often as the fish have taken his flies, and with slapping and scratching, you are glad when at sundown you see the guide away down the river under the lee of a good 
smudge, and you hurry along to seek the protection of its friendly though almost blinding smoke.

Nor. You say you cannot fish the still waters without a boat; where do you get one if you are far away from your quarters?

NES. Part of a guide's business is to have some sort of a boat on all the waters where he may be required to pilot the angler during the summer; if on a stream of alternate rapids and still water, any kind of a light boat or scow is concealed in the undergrowth along the bank; if a distant lake is to be fished, or an outlet leading from one to another, a shapely easy rowing boat is hidden where it can be found when required. The boats are used also for deer-hunting in the fall of the year, and are generally hauled to such places on sleds during the previous winter.

Your guide rows you over miles of dark water wooded to its very brink; he will tell you there is no fishing there, though if you are content to troll, you may take a straggler now and then. After a while he will stop at some bend of the river or by a high rock, to you as unlikely a looking place as any you have passed over, and tell. you to get ready and go to work. Then if you get your flies over the fish in almost any way, so you do not make too much of a stir or go too close, you have a fellow of a pound and a half at the first cast, and as he goes sailing around, another of a pound may take a fancy to your other fly. Take it coolly, and perhaps you may have two or three dozen from twelve to sixteen inches long before you move. If you ask your guide why the fish should be there, and not in the water you have passed over, he will likely point out a little spring branch which

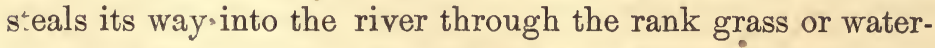
lilies; the fish collect there because the water is cooler, and you may catch the whole school on a favorable day, and in a 
week or ten days the pool will be stocked with as great a number as you have taken.- By the first of August most of the Trout in the rivers of the Adirondack regions collect at such places and remain until spawning time.

WALT. I would suppose from the way in which you speak of the Trout of Hamilton County, that they were much larger than the average of this morning's catch-are they the same species?

Nes. There is no specific difference, although the average size is larger and the tints much darker: so is their flesh, but that is no criterion of excellence or condition in the waters in this part of the country; they do not compare in flavor or delicacy with those we have just eaten. Anglers who are fond of killing great quantities of Trout should go to Hamilton and Franklin Counties, that they may get a complete surfeit of fish-catching, which in all cases is not strictly angling. It is a great country for cockney fishermen, who are fond of telling a good story when they get home, though their success generally depends more on their guides than any skill of their own. I once knew a couple of verdant fishermen whom Old Sturgis had taken to Louie Lake, take forty weight out of a pool not larger than the floor of your parlor. For my part, I would rather fish clear lively water like this, with strong rifts and occasionally a still pool; with its banks sometimes overhung with laurel and alders; and then a stretch of clean gravelly beach, for here the angler has all kinds of practice; the long light cast for the still pool, or dapping his droppers across the rift as he brings them home, or chucking his flies under the bushes with the backhanded cast, and added to this is the greater sport of killing a fish in rapid water.

NoR. Brook Trout are also taken by trolling, are they not? 
Nes. Certainly, I have had great sport on Whittaker Lake, a little sheet of water between Satterlee's and the Indian Clearing. Some of the lakes appear to have a variety peculiar to their own water. Those of Louie Lake are very long and round in the body and exceedingly active. Two of us once got our friend Satterlee to haul a boat from Lake Pleasant and launch it in Echo Lake, a fairy little water a mile or so from his house, to troll for some Brook Trout of fabulous size which we were told inhabited it. We returned at nightfall with one Trout, which Old Sturgis declared was "as broad as a spruce shingle." We did not weigh it, but it took four hungry men to eat it for supper.

WaLt. How wide was the spruce shingle to which the old guide compared the Trout?

Nes. You must not cross-question me. I have said that we did not use the scales, nor an inch-measure; the measure was our appetites, and Sturgis's comparison was what Father Tom Maguire calls "a figure of speech." If you want facts, with dates, and figures of arithmetic, I refer you to the appendix to Dr. Bethune's edition of Walton, where he gives extracts from the journal of the Lake Piseco Club.

Nor. How about deer-shooting? you spoke just now of a steak from a spike buck?

Nes. Spike bucks and young does, are the only good venison you get in June, the old does have fawns at that time, and old bucks are out of season. You must go after the middle of August for deer-hunting. Our guide once sent his dog out and drove a deer into the water within a hundred yards of us, but there was more murder than sport in killing it. After it swam some distance from the shore we put after it; a short race brought the boat alongside, when the guide garroted it with a leather thong tied to the two prongs of a forked stick; he passed his knife across its windpipe, and the "antlered 
monarch" died ignobly. It was a sickening sight, and one I hope never to witness again. When a man on a drive takes his stand, his blood is up with the excitement of the chase, and as the buck bounds by at full tilt, the heel of his gun comes to his shoulder, his sight falls along the line of the barrel, and his finger instinctively finds the trigger: but this cold-blooded murder should be made a capital offence. Great numbers of deer are sometimes destroyed, where they collect during the time of a deep snow, in what are called "yards," when a continued tramping makes a depressed enclosure, from which they are unwilling or unable to escape. Here it is that those who follow hunting as a business, come upon them on their snow-shoes, shoot them down, and send the venison to market. A continued restriction to a yard though, makes them very lean.

WALT. You intimated that there were four of you, on your last visit to Lake Pleasant; did the whole party go together when you camped out?

NES. A pair of us only, when we wanted good fishing, and the whole party, when we were not so eager and wanted a good time; then the little Doctor was an important personage; you ought to have known him twelve or fourteen years agohe is a sedate man now; then he never could be quiet when on an excursion,

"But spent his days in riot most uncouth, And vexed with mirth the drowsy ear of night;

Ah me! in sooth he was a shameless wight, Sore given to revel."

WaLt. Never mind Dr. Caleb, and the bard with the turned-down shirt collar; there is a very different kind of person across the creek looking at us, - who the deuce is he?

Nor. Why that's the man who denied me the right of way 
through his field, along the still water above the saw-mill. I pulled out my segar case and then my flask and offered him a drink, but he obstinately refused, and sticking his hands in his breeches pockets, all he said was: "Thee musn't go through that rye!"

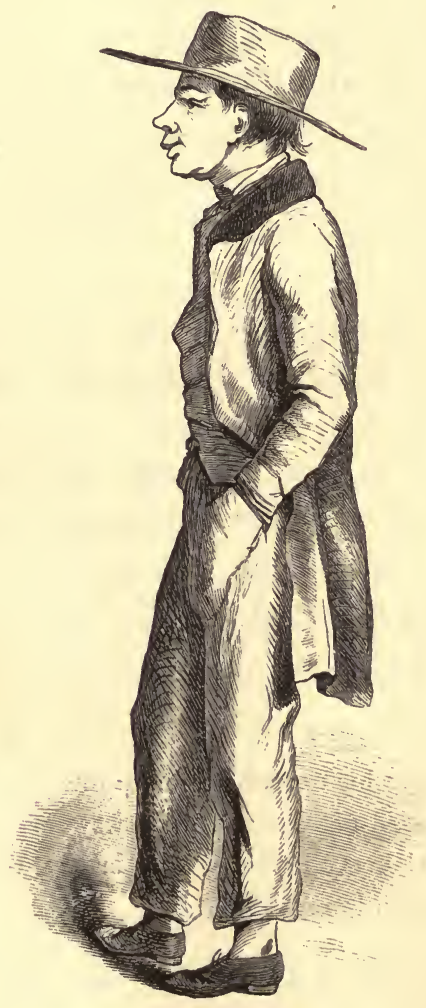


SECOND NOONI ING.

TROUT-FISHING IN NEW HAMPSHIRE. 
"IF oĩ de groun' you chance to lie, You soon find out de blue-tail fly.

Jinuy crack corn, I don't care." 


\section{'IROUT-FISHING IN NEW HAMPSHIRE.}

\section{SECOND NOONING.}

[Present: Joe, Walter, and Nestor.]

JoE. Well, we have been robbed to-day: bread all gone; butter gone ; pepper and salt "non est inventus ;" drinking-cup crushed, but the bottle all safe, and it seems to say, "And I alone am left to tell the tale.' One of us must run down the road to the saw-mill, and get us some bread and butter and some salt and pepper.

[Exit JoE, jingling his small change in his pocket.]

[N. B.-Never make a cache in the leaves or bushes on the ground, or within reach of any four-footed animal that has an acute sense of smell ; but put you provender high up in the bushes or in a hollow log, and stop up the end securely.]

[Our commissary returns, and reports.]

JoE. No bread; potatoes, a quarter peck, small; butter, half a pound ; eggs, a short dozen ; pepper and salt, "quantum suf." Expense, twenty-nine cents.

WALTER. Throw on plenty of wood, and make a good bed of coals and ashes; roll the Trout in wet paper, and lay each fish in as carefully as they do a baby in a crib; make a hole also in the hottest part of the fire for the potatoes; the eggs we will keep for a dessert.

Joe. If you have dined now, Nestor, tell us about fishing in New Hampshire.

Nestor. I know nothing about it from personal experience; all the information I can give is second-hand. I can 
only tell you what Brown told me of the fishing at the White Mountains. But here are some leaves from an old number of the Knickerbocker, with a description of the adventures of three very scientific anglers in Northern New Hampshire. I brought it along, intending to read it in the house or in Uncle Ickey's saw-mill, some day when we were weatherbound; but it will do as well now. So take your dudeen out of your mouth, and read it yourself."

[ $\mathrm{J} \mathrm{OE}$ takes his seat on a stump, and "ab alto toro sic incipit."]

\section{TROUTING IN NORTHERN NEW HAMPSHIRE.}

I HAD often heard of people catching Trout "as fast as they could haul 'em out:" I had often been assured of the plausibility of such a fact, but I had my doubts. I knew I had fished for Trout, and never "hauled 'em out" at all, and so I was a sceptic as to any such proceedings as enthusiastic anglers from the north of the Granite State had repeatedly affirmed to have been within their daily experience. Taking all things into con. sideration, therefore, I determined to try for myself.

There were three of us: our baggage as follows: Item, one bottle of gin, two shirts: Item, one bottle schnapps, two pair stockings: Item, one bottle Schiedam, one pair fishing-pants: Item, one bottle genuine aromatic, by Udolpho Wolfe, name on the wrapper, without which the article is fictitious, one pair extra boots: Item, one bottle extract of juniper-berry ; one bottle brandy, long and wide, prescribed by scientific skill for medicinal purposes. Also, rods, flies, tackle in abundance, and a supply of gin; in addition, each of us had a quart-flask in our pockets, containing gin. We also had some gin inside when we started.

Thus prepared, we started by rail from where the gin was purchased, for Littleton, which we reached in the afternoon.

Littleton is a large and flourishing community, composed chiefly of ophemeral stage drivers, black-legs, and acute landlords, who play poker with unsuspecting travellers over night, to whom they lend money in the morning to pay their tavern-bills. We did not abide in Littleton. We procured a wagon and two horses, or rather, about one and a half, and set forth about three P. M. As soon as we reached the highway, and were clear of the surrounding houses, I obtained my first view of New Hampshire scenery. 
Buck of us lay the lofty summits of the White Mountains-Washington, La Fayette, and Adams, towering above the rest, as those illustrious names among mankind. At the distance of twenty or thirty miles, their welldefined outlines rose against the sky in solemn, gloomy grandeur, and their immense presence seemed to annihilate the space that intervened.

I have been in the habit of thinking that my own native West is the most beautiful country upon God's earth, and, indeed, in richness of foliage and verdure, in brilliancy of color, I know of none that surpasses it. In the spring-time of the year, when everything is bursting forth in vigorous life; when the trees bud in fearless defiance of frost, and flowers bloom in bright profusion; when the corn transcends all limits of respectable growth, and the grain starts its tender shoots before the snow has quite gone, and in later summer, when the golden harvest is ripe for the sickle, and. swayed by the gentle wind, the vast field rolls like the billows of the sea; with the cultivated garden, the farm with its barns of plenty, and its presses bursting with new wine; the plain with its velvet grass, the hillside with its luxuriant vine, Nature presents no lovelier sight than meets the eye and gladdens the heart of the dweller in the Buckeye State.

Still, such scenery conveys no impression of the vast or grand, for the horizon is limited in its view. But among the mountains of the Eastern States, the landscape stretches away before you for miles upon miles, with lakes, streams and rivers, villages and farms, spread out in one great picture.

But however beautiful the sight, the sun began to get hot, and ideas of sentiment rapidly vanished, and soon arriving at one of those cool springs that burst forth from the hill-side at every few rods, we stopped to refresh our parched constitutions.

The second day's ride brought us to Colebrook, where the reign of pork begins. And here let me say a word of this staple commodity of the "rural districts."

After you get up into this country, you see nothing but pork. Not fresh pork (shades of Elia, defend us!) but salt pork, that has been pickled, brined, and put away in a barrel. They chiefly fry it, when it resolves itself into a compound of liquid grease, and a tough substance, resembling underdone sole-leather, nutritive but not attractive. 'They fry pork for: breakfast, they do the same for dinner, and are not original in the point of supper. They fry it with their potatoes; sometimes they fry it in a skillet: I believe they use it in their tea. For two mortal weeks we had nothing but pork, until we got among the Trout, and then we had trout and 
pork, and pork and trout, and trout with or without pork, and pork with or without trout, according to the taste and fancy of the person porking or trouting, either or both respectively.

At Colebrook, as I said, we began on pork. It was the first I had experienced, and I thought it considerably great. Subsequent events, however, succeeded in eradicating that notion from my bosom.

Leaving Colebrook, we started for the Dixville Notch. We inquired the state of the route before starting, and were informed that, "in some places, it wasn't so good as others," which was about the extent of the information to be obtained. The people of New Hampshire are remarkably cautious in their statements, and not at all prone to exaggeration, and when we learned that our route was "in some places a little rough," we thought to have a comparatively easy time of it. But, shades and ministers of grace defend us! people surrounded by the comforts of civilized life can have no idea of what roads are, or rather what a road ean be, if it only has a mind to. In the first place, it is like going up and down the side of a house. In going down a steep pitch, a bottle was jolted out of the rear of the wagon, and fell over the horses' heads. That's a fact! I have the affidavits. In addition, the way is impeded by immense granite boulders, a number of feet one way, and as many the other, which seem to have been shaken out of a bag, with the profusion of a pepper-box. Then, again, there is no road to speak of at all, it having been abandoned, as we afterward learned, some ten years past; the rain also has washed out deep gulleys, where your wheels are on each side, and your horses down below, underneath the wagon. But the crowning feature is the bridges. Bridges here are made to let people through into the water; for that purpose they have large holes in them, loosely covered with brush-wood, and when the unwary traveller steps upon it, he is seen no more; and when they can't get holes big enough, they have immense logs rotted to the proper point, and when you step upon them the log caves, as it were, and you then perceive the exact purpose for which the structure was intended, as above stated. We came to one of these bridges, and two of us, having some idea relative to personal safety, declined crossing in the wagon, and got out to see it go down, and sure enough, when the near horse got in the middle, away went the whole concern, and the animal went through into the bottom of the creek.

It was not, however, so deep but that, by a judicious use of his fore-legs, he could erawl out of the hole through which he had gone down, and he came up on terra firma a wet, and, to some extent, an agitated quadruped. 
This may not perhaps be interesting to the uninitiated, but one who has not witnessed cannot conceive how funny it looks, to be driving a pair of horses, and suddenly see one disappear to the extent of about one-half, his fore-legs pawing in the air, and his hind-legs somewhere else, not inmediately visible, the general effect being that of an attempt to climb a tree, without any particular prospect of success. No accident, however, happened, and no other inconvenience than that of one or more legs going through every bridge we crossed.

The next day we reached the falls of the Androscoggin, but had not yet attained the trouting region. We took a boat and guide, loaded in our traps, and put out for the Megalloway. This river is crooked beyond any power of description; it is a practical exemplification of the ways of the Evil One. One minute the sun is behind you; the next, ahead; then right and left, cross the middle, up and down in every imaginable position. You have to row three miles to get anywhere, if it isn't more than twenty rods off. We reached the lower landing, at the farm where we stopped, and it was about an eighth of a mile by land, and two miles and a half by the river, to the house. Water is not a speedy means of locomotion in Northern New Hampshire.

Our first day's fishing was in the Diamond River, and a good time we had of it. I tried to keep my feet dry till I tumbled in, and then I stayed in. The water here is rapid, and the stream full of rocks, on which you step, and in you go: this is invariable.

In fishing for Trout, two things are to be observed ; first, you must fall down in the water, and secondily, break your rod: $\mathrm{N}$ - had broken his before he started, and soon in he went, up to his neck. To tumble down in a stream like the Diamond, beside being inconvenient, is confusing; the water carries you off your feet, and bumps you against the rocks; its roar deafens you, and you think you're going to drown; your fishingbasket goes one way, and your tackle another, and you regain your feet with a general sense of damp, to hear your friend laughing at you.

In this day's fishing we caught about seventy-five pounds of Trout among four of us. At night we returned, quite well tired, to the farm-house which was our temporary abode. We had fried pork for supper. I believe I stated that they had pork in this country. We then went to bed, or rather to musquitoes.

There were four of us, with two beds, in a room, which, so far from David Copperfield's being able to swing a cat in it, he couldn't have performed that feat with a kitten. 
Having prepaled ourselves for repose, out went the candle, and in cinie the musquitoes. $\mathrm{N}-$ had brought with him a concoction prepared by some medical friend, which was to keep off these invidious inseets. It smelt strongly of spearmint and anclean oil. It worked, however, like a miracle, for the musquitoes would light on our faces, and their feet would stick fast in the stuff-it had an extract of tar in it for that purpose-and by the time a small troop were thus entrapped, then you had music. Anon you would hear $\mathrm{H} \longrightarrow$ give a rousing clap, and with an expletive state: "There! I missed him!" So we rolled and tossed, till finally Nburst out laughing, wanting to know if I was awake.

Sleep being impossible, we lit our pipes, and sat up in bed to take a smoke. Jokes were cracked, stories were told, and we made night, up in that room, comparatively hideous. Next morning we learned that there was a sick baby down stairs, and the supposition in the family was, that our noise hadn't helped its colic any.

That house will not soon fade from our memory. We slept in an attic, where the roof slanted down over the heads of the beds, so that it was not ten inches above the pillow; the roof was innocent of lath, plaster, or any of those little amenities that tend to make existence endurable. Rustic ingenuity, upon the rafters over-head, had pinned, in the character of wall-paper, certain emanations of the press, among which were the Christian Herald, Boston Post, and New Hampshire Patriot.

The strong point of this contrivance was, that all manner of bugs, spiders, and other creeping things, seemed to assemble in convention in the silent watches of the night, and essayed the climbing of these papers, which being rather much inclined, rendered the task of the insects diffieult; but perseverance seemed to be a predominant trait, for all night long we heard these reptiles scratehing, scraping, and rustling up and down the paper, at the acreeable distance of about a foot from our beads. Oceasionally a spider, more adventurous than the rest, would drop down by his web, and alight on our faces, but he generally beat a precipitate retreat. Then, too, there was a death-watch near the head-board, and he kept up his dismal ticking as long as we were conscious. This death-watch is an abominable nuisance. Its regular, monotonous, unceasing beat, heard in fearful proximity about eleven o'clock at night, when everybody else is asleep, is enough to drive a nervous man crazy. I would rather have six-pounders fired off at me all night.

Howcrer, morning at last came, and we consulted as to what course should be taken, whether to turn homeward and fish on our way back, or 
strike further north. We finally concluded to adopt the latter course. We procured a guide, got a wagon, left most of our luggage, took a change of raiment, all the gin, and started. We rode about six miles to a house, which is the last one upon the extremities of civilization. From this place we were to walk over a "carry," stated to be about a mile and a half long, but which was nearer six. So we packed our traps on our backs. Our guide carried all the camp equipage. $\mathrm{N}$ - had a fishing-basket with the gin in it; the carpet-bag with our vestments, an axe, a rifle, a skillet, a bag of salt, a chunk of pork-they have pork in this countrysome wet matehes, and an over-coat: the rest of us followed with such articles as-remained, piled on in a promiscuous manner.

This was my first experience in "earrying," the generic word for this sort of business, and I must be allowed to state that, as a general proposition, I do not admire this species of locomotion either in point of speed or comfort. The day was hot, and such a road! eye hath not seen, ear hath not heard, neither hath it entered into the heart of any man to conceive. It was up hill and down; through bogs and swamps; over fallen trees; encountering impenetrable thickets. A wagon-path had formerly been cut through the woods, as though some one had entertained the idea that such a route might be travelled by beasts of burden, in connection with some kind of vehicle; if such a notion was ever conceived, we can only be amused at the simplicity of the individual. The path was infested with immense rocks that were smooth and slippery with moss, and when you put your foot on them, down you went, and when you were down, the mos quitoes had you; for though when in motion their attacks were suspended. yet, if you stopped, they came at you with renewed vehemence.

Slipping and falling, when you are fresh and light, is not of much consequence; but when you are tired out, and have an hundred pounds on your back, it's a fearful joke. I had trudged on till, through fatigue, I had become just desperate, and would not have made any exertion to save life itself. I stepped on the point of a stone, it was treacherous, and myself, pack and all, reposed softly in the morass. The mud was knee-deep; exhausted nature had spent all her energies; I could not move hand nor foot; the mosquitoes assailed me in legions; through an opening in the trees the sun poured down his relentless rays; I thought my hour had come, and, memory unconsciously reverting to the days of childhood, I was about beginning, "Now I lay me down," - when I heard N- on ahead exclaiming, at the top of his voice, in all the consciousness of immense and impregnable strength- 
"There is a pleasure in the pathless wood."

It would have afforded me satisfaction, there and then, to have knocked his head off.

We accomplished the end, nevertheless, and reached the bank of the Megalloway just above the falls, to avoid which we had passed the "carry." We found here a little flat-bottomed boat, about fourteen feet long, and amply sufficient to carry a pound of butter and a dozen eggs, and when the guide told us that we were all to go in that cockle-shell, I proceeded to narrate to him a legend relating to three individuals of age and experience, who are reported to have dwelt in the State of New York, and who set forth upon a certain journey by water, in a class of sailing-craft not popularly in vogue among mariners, and with regard to whom it is confidently asserted that if their means of conveyance had been of a more permanent character, their traditionary reminiscences would have been prolonged.

Our guide, however, assured us that the week before the same frail bark had brought down four men with a moose they had killed; and somewhat reassured, but still with fear and trembling, we loaded our luggage. The vessel sank in the water to within three inches of her gunwale, and we had to keep the trim so nicely adjusted that if you winked one eye without the other, you were in imminent danger of upsetting.

Once fairly started, thoughts of danger vanished, and our little boat glanced over the water at a refreshing rate.

The river was perfectly still, with no current, and its smooth surface only broken by the leap of the Trout, and the splashing start of the frightened wild-duck. High mountains arose on either side, and the river-banks were lined with scrubby pine and birch, whose interlaced boughs rendered passage impervious except to the denizens of the forest.

Our point of destination was a place called Beaver Brook, some two miles up the stream, where it was supposed that 'Trout would be found. We reached there about five o'clock in the afternoon, and the sport then began in earnest. In my time I have fished, as it may be, considerable. I have fished for various specimens of the finny tribe; I have essayed Cod in Boston Harbor, and Herring and Mackerel on the sea-coast; I have whipped almost every stream for Trout in Massachusetts and Connecticut: I have taken Salmon in the Ohio, Trout in Mackinaw and Minnesota, Perch in the Mississippi, and bobbed for Whale on the coasts of Florida, but I bad not reached the acme of fishing. As before stated, I had heard all 
Eort of " fish stories" from persons who had explored the northern regions: I had listened to their statements with silent acquiescence, but inwardly distrusting; but when the reality came, there was no exaggeration that could at all come up to the simple fact. Innocent stranger! Thou who readest these lines! perhaps you never caught a Trout. If so, thou knowest not for what life was originally intended. Thou art a vain, insignificant mortal! pursuing shadows! Ambition lures thee, Fame dazzles, Wealth leads thec on, panting! Thou art chasing spectres, goblins that satisfy not. If thou hast not caught a trout, this world is to thee, as yet, a blank, existence is a dream! Go and weep. Come with me, and thou shalt see for what man was made. Thou shalt learn for what those faculties were given, that thou art wasting on minor objects. The brook rolls brightly before thee; the forest is deep and wild, and its branches hang over the stream; it leaps on with silvery laughter, like youth that bounds joyfully to the dark ocean of age. Its smooth waters dash against the rocks, and become brawling foam, as broken hopes are turned to raging passions. It darts through narrow places, over opposing obstacles, as untiring energy bursts its way through untried and devious paths. It gathers in quiet pools, and returns in gentle eddies up the stream, as the thwarted purpose, the disappointed wish recoils upon itself, or settles into sluggish apathy.

Now, put up your pole, and take your first Trout, poor innocent. Rig on your fly! not that great big red thing-put on that little gray one with the small hook. Don't you know that a Trout is the daintiest, most delicate fish that swims? You pitch at him a bait as big as your fist, and he'll turn up his nose in disgust; but just cover the point of your hook with the smallest possible piece of worm, or take the smallest fly, and he'll go at it like a Shark. Now, do you see that dark object off yonder, lying by the side of that stone?-that's about a pound and a half: we'll have him. Pitch in your fly, and skip it over the water lively; not that way-that's down the stream; cast your fly up. If you had any sense, which you haven't, you'd know that Trout always lie with their heads up-stream ; and if you cast down-stream, in the first place, they'll see you, and won't bite, and if they do, you'll pull the hook right out of their mouths; but if you throw up-stream they bite faster, and you have a better chance of striking your barb through their gills. There! your fly touches the water; see those fellows jump at it; but those are little fellows, and don't weigh more than a quarter of a pound. Follow $\mathbf{N}-$ 's suggestion, and put up a notice on the bank: "Small Trout are requested not to bite!"

Now heave again. See there :-that was a pretty jump he made; but 
he missed. 'Try him once more and you'll strike. Now he's on ; let your reel run; there he goes up-stream. How nicely he springs out of the water! he's got frightened, and don't know what's the rumpus. Reel him in a little; don't pull too hard, or you'll break your pole; you see, it's bent double already. Just hold him tight enough to guide him, and he'll tire himself out in a few minutes; he can't stand it long, dashing about at this rate. Don't get too much excited, or he'll fool you yet. When you strike a fish you must be cool and collected. You see they are of an excitable temperament, and when they get the barb into their mouths they become agitated; they are also gamy, and make a good fight, and consequently, if you are anywise rash, and attempt to get them in too soon, ten to one you'll break your line. Now you see the rascal has started downstream for the river, and thinks if he gets into deep water he'll be out of the way. Let him slide; let your reel go out its full length. Now he's still; he don't feel you pull, and thinks he's safe. Begin and reel him up. Now he's waked up again worse than ever. Don't he go pretty? Just hold him steady up the stream, and as his mouth is wide open, he'll drown soon; because, if you drown a Trout he thereby becomes dead, and when dead, is in a perfectly passive state. See, his struggles are becoming feebler and feebler; you'll have him soon. Be patient: now he's still; put him up to the side of the boat, and take hold of him just behind the gills. There, isn't he a beauty? Don't those bright spots and silver stripes go to your heart? Don't you wish you were as good-looking as a Trout? Wouldn't you captivate your friends?

The shades of eve begin to fall. I sit in the foot; $\mathrm{N}-$ a little below ; $\mathrm{H}$ - above. It is still as night, except the repeated splash of fish as they rise at the fly, or as they struggle in vain attempts to escape.

I have at various times, in various places, made various statements with regard to our success upon that particular afternoon, none of which have as yet been believed. Friends, of whom I had a right to expect better things, have upon occasions winked knowingly when I have narrated my experience; some have laughed outright; some have remarked unreservedly that that was a "fish story." Others have detected seeming inconsistencies; and irreverently asked for explanations; and again it has been inquired which was the trout, and which was the gin. I therefore will content myself with the following statement, made upon honor, that in a very short time we eaught a very large number of fish:

While we were fishing, our guide was pitehing our tent. Our guide was a great institution; he was a complete backwoodsman. With an axe 
lic could do or make anything in the world. I believe he could make a wateh with that axe. He eould chop down a tree in no time, and in the tree he'd find a coon, or a nest of squirrels, and a whole hive full of wild honey; whereupon he'd have food and raiment for a month. He had great skill and mechanical ingenuity; and though of slight frame, his strength was enormous, and his endurance eternal. He could row a boat all day without stopping. He could climb over rocks and mountains for a week with a pack on his back, that I couldn't lift with a pair of horses. He'd be in the water for twelve hours without inconvenience. Ile was modest, good-natured, always ready to do anything, and was amazingly tickled to.hear us talk and joke. He confined himself principally to gin. In the few days he was with us, he became very fond of us; and when we parted, he rigged a sail out of my shawl, with which we rowed comfortably against a head-wind for seven miles.

He was fond of woods sport. When we had finished fishing and it grew dark, we went ashore to where he had rigged our tent. He had cut a quantity of small hemlock boughs, with which he covered the floor of the tent about six inches deep, over which he spread his camp blankets, and made a'couch softer than downy pillows are. He had also a huge log fire, and we made preparations to cook supper. Imprimis, a skillet is indispensable in the woods. It is convertible to many uses and purposes : you can bail a boat with it splendidly; wash your face with it; boil water and make tea, and wash the dishes; bake bread ; fry potatoes, pork, and Trout, and feed the dogs with it after supper.

So we got out the skillet, cleaned a lot of Trout, eut the slices of pork (we had brought a piece of pork, and a bag containing bread and doughnuts; to be sure, they had been in the bottom of the boat, and all got soaked, but that made no difference), and the pork hissed, and we turned the Trout with a wooden spoon and put salt on them, and then the Trout hissed; once in a while one would drop into the fire, and if the dog wasn't watching, and you were quick, you could get it again. But I had a big fight over one great fellow that tumbled out of the pan: I got him by the head and the dog got him by the tail, and it was nip and tuck, pull Dick pull devil: the dog a little ahead, for the fish broke in two, and he got unor'n half; but he subsequently choked on the back-bone, at which I was rejoiced. We rang the bell for tea. The guide made some torches of birch-bark, and stuck them up around, and we had an illuminated banquet-hall.

We spread our viands on another piece of birch-bark; each fellow took 
a forked stick, and then and there we fed. We then cleared away the table and washed the dishes, by throwing the birch-bark into the fire and leaving the skillet to the dog.

We then held a council of war, and concluded to cross-examine a bottle of gin. Gin has its uses in the woods. But we were without water, and had nothing but those leathern drinking-cups, holding about a gill. Here was a difficulty at once, for to be under the necessity of going down to the stream every time you wanted a drink, was not to be thought of; beside, we might be thirsty in the night. But our guide solved the problem. He took that immortal axe and went off into the woods, and came back in a minute with some large sheets of birch-bark-birch-bark is also a wonderful invention; so he sat down to make a birch-bark bucket. I don't know how it's done; $\mathrm{N} \longrightarrow$ does, and he showed me two or three times; but for the life of me, I couldn't see through it. About these things I'm thick about the head. It is somehow thus: You take a large square sheet of birch-bark and some wooden pins, you turn up one end of the bark and stick in a pin, you then turn up the side and fasten it to the end; you double the ends together and fasten them with these pins; turn it up all around, so the water won't run out, fasten it, and there's your bucket; it is a very simple contrivance, and eminently practical. He got one completed, and found a knot-hole in the bottom, but finally made one that held about three quarts; so we filled it, placed it beside the tent, and began those experiments with the gin, to which brief allusion has been made.

After eating and drinking we lit our pipes. You take pipes and tobacco in this country altogether; segars are perfectly useless. I carried the tobacen loose in one of my pockets, which was a reservoir for the whole party. One has no idea of the luxury of a pipe in the woods until it has been tried; it is vastly superior to any other known method of combusting the weed. You might smoke forty segars and not obtain the same amount of satisfaction that a solitary pipe affords. 'Therefore we sat in the door of the tent, and as the smoke curled gracefully away we had sundry operatic performances; in which $\mathrm{I}$ acted the part of Prima, and $\mathrm{N}-$ - of base, Donna; and the woods rang with the entrancing melody of our voices; while afar off we heard the hoot of the owl, and once in a while the scream of a wild-cat; but we were not at all alarmed.

I should not omit to relate one of my troubles, and that was in the way of boots. A kind friend at Hanover lent me a fine pair of fishing-boots, that came almost up to my ears, and had great big legs to them. I first 
fished with them in the Diamond River. I endeavored to manœuvre so as not to go over boot-top, but pretty soon I tumbled in, and when I got up my boots were full of water, and weighed about two tons apiece; so I waded ashore for the purpose of eliminating the element. I laid down on my back, and raised my heels up in the air, and the ultimate consequenees were, that the whole quantity of fluid found its way out at the back of my neck, just below the left ear. During our whole trip the great occasion of the day was the getting my boots off. Many of you know what wet boots are; I had them in perfection. Our guide was a first-rate boot-jack, otherwise I should be wearing the articles at the present day. I lay down on the floor, $\mathrm{N}$ - would take hold of my shoulders, the guide and $\mathrm{H}-$ hold of my boots, and we would work, and twist, and accomplish the feat, or rather feet, in about an half-hour. Item, when fishing for 'Trout, wear shoes.

Boots off, and otherwise haply, we lay in the tent, smoked, and employed ourselves in the charms of conversation. Our guide had gone off into the woods some distance, and soon we heard a crackling and snapping as though the world was about to conflagrate. We rushed out of the tent, and saw, off in the forest, a large tree all on fire from turret to foundationstone. It flashed, and blazed, and roared, and I thought the whole wilderness was going, so I seized a few articles of value, and was about taking to the water for safety, but was restrained by $\mathrm{N}-$, who said it was some of the guide's work, which it proved to be. Birch trees are covered with a light bark, which every year peels off to about the thickness of a sheet of paper; this dies, and drying, becomes like tinder, and is used as such; and if you touch a match to the root of a tree, the blaze flashes up in a moment over every limb, and makes as fine a specimen of indigenous firework as may be desired. The night was very dark, and there-the tree stood, every limb and branch, all in a blaze, and lighting up the forest like day. The wild birds started from their roosts, flying helter-skelter; deer and other vermin were scampering in promiscuous confusion, and altogether it was pleasant. Soon another tree started, and then another, and soon half a dozen, in all directions; and to us, who were novices, the spectåcle was beautiful. Our guide soon came back-he had been prowling round in his stocking feet-and we all went to bed.

The next morning we all went to fishing, and fished to our hearts' content; in fact we became perfectly satiated and disgusted. They bit so fast, and we caught so many, that we lost all relish for it. We filled our boat almost full. Anything less than a half pound in weight we threw 
back into the water; and after we all got sick of it, we agreed to take down our poles and not put them up again in that part of the country. About eighty pounds of the largest we concluded to take home with us; so our guide made a species of box out of elm-bark, in which we salted down our fish, to pack on our backs.

I have thus given an outline of one day's occurrences, and the others were like unto it. We had just as much Trout-fishing as we wanted. We eat so many that we almost killed ourselves; and finally came to the conclusion that Trout were not what they were cracked up to be, after all.

JoE. Well, what do you think of it?

Nes. Why, I think of the author, that from his frequent allusions to pork, he was from Cincinnati. His description of bridges reminds me of a ride from Hankins's Station to Chester Darby's with Baron G., twelve years ago, when we were caught in a thunderstorm, and did not get to Chester's until midnight; we crossed a few horse-traps of the kind he describes in the dark. The spiders, bugs, and death-watch refresh my recollections of old friend Snell, on the Loyalsock.

JoE. He is right about the pipes and the skillet, but may possibly be wrong as to the guide's ability to produce a chronometer with his axe. As to drawing off wading-boots, I have had some experience in the matter myself, and can testify as to the course the water takes when a man lies on his back and elevates his heels. His instructions, though, in casting and killing a Trout, are inimitable; all who would be scientific anglers ought to read them. Here are more stray leaves from the Knickerbocker-poetry, too: "The Skeleton Monk," six pages; and "The Girl with the Calico Dress."

WALT. Keep them to read in the saw-mill some rainy day. [Exit WALTER, with sketch-hook.]

Jok. But hold on; here is "Hans Breitmann's Barty :" 
it is poetry done up prose fashion. Clark suspects Mace Sloper of having perpetrated it.

Nes. Let us have it, by all means. Vive le lager! Vive le pretzel! Vive le Engel \& Wolf!

JoE. Well, then, be quiet, while I read you the adventure and impressions made on the mind of the gentleman who attended

HANS B REITMANN'S B IRTY.

Hans Breitmann gife a barty-dey had biano blayin-l felled in lofe mit a Meriean frau. IIer name was Madilda Yane. She hat haar as proun as a pretzel bun; de eyes were himmel blue; and ven she lonket into mine, dey shplit mine heart in two.

Hans Breitmann gife a barty: I vent dar you'll pe pound. I valzet mit der Madilda Yane-und vent shpinnen round und round. De pootiest freilein in the house--she vayed pout doo hoondert pound.

Hans Breitmann gife a barty-I dells you, it cost him dear. Dey rollt in more as seven kecks of foost rate Lager Bier-und venefer dey knocks de shpicket in, de Deutschers gifes a cheer. I dinks dat so vine a barty nefer eoom to a het dis year.

Hans Breitmann gife a barty. Dar all vas souse and brouse. Ven de sooper come in, de gompany did make demselves de house. Dey ate das Brot und Gensybroost; die Bratwoorst and Braten fine, and wash das Abendessen down mit four parrels of Neckarwein.

IIans Breitmann gife a barty: ve all got troonk as pigs: I poot mine mout to a parrel of bier und schwallowed it oop mit a schwigs-und denn I kissed Madilda Yane, und she schlap me on de kop, und de goompany fought mit taple lecks dill de coonstaple made oos schtop.

Hans Breitmann gife a barty: vhere is dat barty now? Vhere is de lofely golten cloudt dat float on der moundain's prow? Vhere is de himmelstrahlende stern-de schtar of de spirit's light-all goned afay mit de Lager Bier - afay in der Evigkeit.

.JoE. The editor's comment is, that the "internal evidence" here is very strong.

NES. There is a touch of sublime melancholy in the last verse that reminds me of Jack Reeves, in the character of a 
sentimental old cook reading the "Sorrows of Werter," and skinning eels. I have some impression of the meaning of "Evigkeit," from the connection in which it is used. What is the true translation?

JoE. I admired the effusion so much at the time it appeared, that I read it once to a German friend, who fully appreciated it, and laughing, explained the word you refer to, by saying, "de schtar of de spirit's light," and de lager all went away together into de everlasting, de futurity.-But what is Walter doing!-

Nes. Just what Benjamin West did when he caught the man stealing his father's pears-taking the rogue's picture.

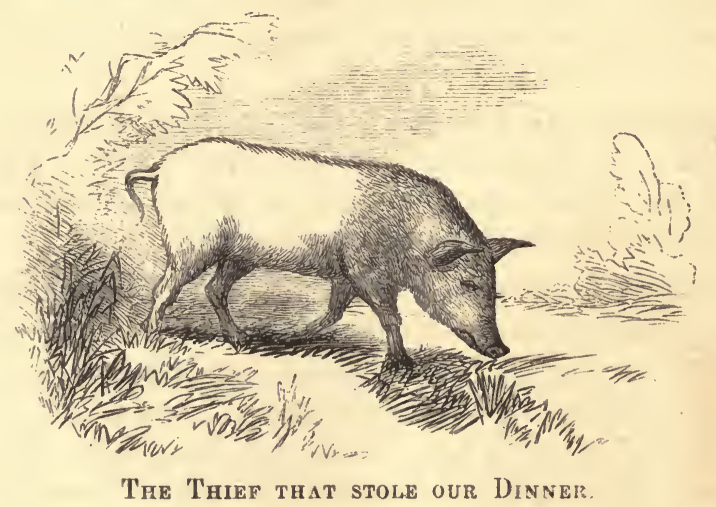


THIRD NOONING.

TROUT-FISHING IN THE REGIONS OF LAKE SUPERIOR.

it 
"CAN it be the sun descending

o'er the level plain of water?

Or the Red Swan floating, flying,

Wounded by the magic arrow,

Staining all the waves with crimson,

With the crimson of its life-blood,

Filling all the air with splendor

With the splendor of its plumage?

"Yes; it is the sun descending,

sinking down into the water;

All the sky is stained with purple,

All the water flushed with crimson!

No; it is the Red Swan floating,

Diving down beneath the water;

To the sky its wings are lifted.

With its blood the waves are reddened!

Over it the Star of Evening

Melts and trembles in the purple,

Hangs suspended in the twilight.

$\mathrm{No}^{\circ}$ it is a bead of wampum,

On the robes of the Great Spirit,

As he passes through the twilight,

Walks in silence throngh the heavens !"

LONGFELLW. 


\section{'TROUT-FISHING IN THE REGIONS OF LAKE SUPERIOR.}

THIRD NOONING.

[After the Roast.-Present: Norman, Morry, and Nestor.]

Norman. You say, Nestor, that you have been to Lake Superior, and that there is fine fishing there.

NesTor. I have never been farther than the little town of St. Mary, which is at the "Sault," the outlet of the lake. I have fished there for Trout, but that was twenty years ago. Several of my friends have visited Lake Superior since the canal around the rapids has been completed, and have had fine sport. Boats leave Buffialo and Detroit every week during the summer for the towns that have sprung up on Lake Superior since the copper region has been opened, and, from what I can learn, the trip would richly repay an .angler, who would bundle his rods and pack up his traps, and depart about the 1st of June for that beautiful country. I had a talk with my friend Roberts after his return three years ago. He had fine sport during the month of June in the rapids at Sault Ste. Marie, and wherever he stayed for a few days on Lake Superior. I have a passteboard profile of a Brook Trout, which he gave me, hanging against my wall, at home, with this note on it:* "Taken by J. E. Cady, of St. Mary, Michigan,

* A repetition of this same memorandum appears on page 204; as this is an account of the Trout-fishing of that part of the country I reinsert it here. 
July 30, 1858. Weight, $6 \frac{1}{4}$ pounds; length, 24 inches; circumference, $13 \frac{1}{2}$; taken in the Batchewaunaung, Canada West. At the same time took six more. Weight of the seven fish, $31 \frac{1}{4}$ pounds." Roberts says that Mr. Cady's word is not to be doubted. The head of the Lake Trout which you may see in the window, at Philip Wilson's gun and tackle store, in Chestnut above Fourth Street, was brought from Lake Superior, by the President of our little club, and though it is twenty-one inches in circumference, it is from a small fish compared with some that have been taken there. I have no doubt, that a person who was properly prepared, could troll successfully for these monster Trout-if he could hit the right time, say in June, and find boatmen who knew where to fish for them.

I. have been told also, that the Canadian steamers, which ply between Toronto and Chicago, stop at several points on Manitouline Islands, where there are fine Trout-streams within easy distance; but there it would be unnecessary to camp out. It is said, that there is also fine Black Bass fishing in the little bays along the same islands.

Nor. But, what do you know personally of the fly-fish. ing on Lake Superior?

Nes. I have already told you that it is now more than twenty years since I was at Sault Ste. Marie, and that I was never beyond there; I have a letter, though, in the breastpocket of my old fishing-jacket, which was written by your humble servant to a brother of the angle, while waiting at Mackinaw for a boat, after his return from the Sault; if you have energy enough left, and can keep awake after the halfdozen Trout you have eaten, you may read it.

Nor. Let me knock the ashes out of my pipe, and moisten my mouth with the little bit of claret you have left in that bottle, and I'll try it. 
“Mackinaw, June 24, 1843.

"Dear Will :-

"In your last letter, which I received just before leaving New Orleans, you begged 'that I would all my pilgrimage dilate,' and tell you if my anticipations of Trout-fishing at Sault Ste. Marie were realized. As I shall have to wait here until the 27 th for the Detroit boat, and have seen all the sights about the island, I take this method of killing time, and will tell you of my adventures 'and portance in my travel's history.'

"Previous to my departure from New Orleans, I made the acquaintance of Mr. Chew, of Mississippi, who gave me a pressing invitation to call on him on my way up, and make one of a party to visit 'Lake Bruin,' opposite Grand Gulf, where he had caught, in an afternoon of the previous summer, thirty 'Trout' (Southern Bass), each of them two feet long Think of that! sixty feet of Bass at a single fishing! As I had in view my trip to Lake Superior, I reluctantly declined Mr. Chew's kind invitation, and pushed on to St. Louis, and then to see our cousins near Boonville.

"The Brents have settled some fifteen miles back of the town, on the edge of a prairie, and are doing well; one of the complaints, though, amongst the settlers from the Old Dominion is, that they have scarcely tasted a smoked herring since leaving their native state. The afternoon of the day of my arrival, Bob proposed fishing in some of the 'sleughs' and ponds supplied by the back water of the Tête Saline, in time of the spring freshets; when the Bass and Perch run up to spawn, and many of them are left in the ponds when the water recedes. Fancy two men, armed with long reed-poles, on leggy horses, loping over the prairie à la Camanche, nothing in sight but the blue sky above, and the rolling green beneath, and no sound but the occasional whirring of a 
prairie-fowl.-What a lonesome, beautifully monotonous scene! After twenty minutes' gallop we saw trees in a hollow at a distance, which are sure indications of water on the prairie. We soon had our lines tied to the ends of our rods, and caught minnows for bait, and then caught Bass and Perch-fishing from horseback when trying the different sleughs, and dismounting whenever the fish bit freely. We came back at sunset, each with a string of fish at his saddle-bow.

"On returning to St. Louis, I took a boat for Peoria, Illinois, and then a smaller one for Peru. We had but few passengers on the smaller boat, and I found the engineer a clever fellow, with a rifle in his room and a bucket of live minnows in the wheelhouse. When we stopped to wood, or tinker up the old engine, as we did once for half a day, I tried a live minnow, and sometimes one 'bridled,' and caught some fine Black Bass, one of them eighteen inches long. At Peru we took the stage, and after thirty hours' ride over the green desolate prairie, interspersed occasionally with little settlements, arrived at Chicago and embarked on the steamer, and found myself at this strange-looking old town on the afternoon of the second day.

"The first odd thing I noticed here was a rough little fourwheeled wagon, which the owner drove on board the steamer; it was drawn by two stout dogs, and loaded with immense Lake Trout and Whitefish. It is all dog (not horse) power here. The inhabitants use them to draw wood from the island on the opposite side of the Strait in winter, and say that a pair of them will draw a sled on the ice loaded with a halfcord of wood without difficulty; dogs are also used in travelling over land when there is a hard crust on the snow.

"The water in the Straits here, as in all of these lakes, is exceedingly clear. You can easily distinguish the heads of the nails and the seams in the hull of a steamboat as it lies 
at the wharf, and see clear under her, as if she was suspended in the air. I saw boys trying to spear Lake Herrings in fifteen feet water, at the end of the pier; the fish were plainly visible at the bottom.

"Mackinaw is a queer old town; it was built by the French soon after they made their first settlements at Quebec and Montreal, and was one of the principal posts of the early furtraders. The houses of the 'habitans,' as the native French are called, are weather-boarded and roofed with cedar bark, the moss and lichens adhering to it, and causing even a new house to look hoary with age. The bay, or harbor, is crescentshaped, with a wide pebbly beach, dotted with the tents of the Chippewa Indians, who receive the government annuities, and buy most of their goods here. When they come with a fair gale, it is a beautiful sight to see the sailing of their light birch canoes; with a fresh breeze astern, they sail like the wind.

"At the fort on the hill I became acquainted with the veritable Captain Martin Scott, so well known as a crack rifleshot, and his connection with the Coon Story. I had supposed him to be a mere myth before; he never shoots now, but rests on the reputation he has won. I have had no fishing with - my rod here; before my visit to the Sault, though, I went out one day near Bois Blanc Island with my landlord's son, to lift his gill-nets, and took some large Lake Trout and Whitefish out of them. I am told that there is fine Trout-fishing in Carp River, about ten miles from here, where they take a piece of pork, or an artificial fly indiscriminately. I have seen a Lake Trout here which weighed forty-five pounds; it was caught with a hand-line in deep water. The man who captured it told me he has taken them twice as large, and that they have been caught in Lake Superior weighing as much as a hundred pounds " 
Nor. (laying down the letter.) Whe-e-euh! that's a whopper.

Nes. Which, the fish or the story?

Nor. Both-the story, in particular. You ought to have asked that man to fall a pound or two.

NeS. I thought it was rather a "fish story," but I believe that there are Lake Trout of that size.

Nor. You are a good believer, Nestor, and I must confess that I have tried your faith a little myself, on one or two oceasions. But when I hear it "piled up" in that way, I say, with fat old Jack, "Lord, how this world is given to lying!" I see, though, your journal is bringing us towards the Sault at last.

[Reads again.]

"On a bright June morning, at sunrise, I started on a steamboat, the first that ever made the passage to the Sault; it was her second trip. The only way of reaching it before this time, was in Mackinaw boats in summer, and on snowshoes and dog-sleds in winter. I arrived in nine hours, and stopped with Mr. Barbier, an old voyageur and guide, whose life has been spent in this wilderness of woods and waters. He keeps a store with a general assortment of Indian goods, which he sells for money, or barters for furs, sun-dried corn, and maple sugar.

"There is no eascade, or what might properly be called a fall, in the outlet of Lake Superior, but the 'Sault,' as the word implies, is a rapid, or a succession of them. There is a descent of about twenty-five feet in three-quarters of a mile. A canal to pass the rapids has been projected, and already commenced by the government, which will open all the rich copper region on the lake, to the navigation of steamboats and sailing-craft of moderate draft of water. A brig and a schooner, built on the lake above, were taken safely down the rapids last summer. It is about fifteen miles to Gros 
Cap, at the lower end of Lake Superior. My limited time, and my anxiety to fish the rapids, did not allow of my visiting it.

"The town of St. Mary, I will venture to say, has more dogs, for its population, than any village this side of the Esquimaux country. Every white man, half breed, and Indian has more of them than a Virginia farmer has cows and horses; it is a wonder where they all get enough to 'pit their paunch in.' Barbier says that dead horse, dead cow, dead dog, or anything they can steal, from a spermāceti candle to a pair of greased moccasins, does not come amiss to them; and, as our old friend, Jack Tancil, of Warrenton, says of his hounds, 'they are everlastingly sarching.' As there is no dog law in St. Mary, the tribe does not diminish.

"I found a portion of the tribe of Chippewas encamped at the lower end of the rapids, just. above the village. "Barbier says they live here entirely on Whitefish, which they take with the spear and dip-net. The latter resembles the common dip-net we have seen used at Fairmount dam on the Schuylkill; the handle, though, is longer, and is bent near the bow of the net-I have seen the Indians take Whitefish with it. They go in their birch canoes to the foot of the rapid, two in a boat; the one in the bow, who generally has an old coat or blanket tied in frout like an apron, to keep off the spray, holds the net; the other in the stern, by the ready use of his paddle or pole, keeps the head of the cockle-shell in its proper direction, while his companion in the bow finds the fish, and by dexterously casting his net over the prey, gives it a turn sideways and secures it. The net appeared always to be pressed downwards, as if the fish was forced towards the bottom, and then turned apparently to prevent its escape; and I suppose this is why the handle has that peculiar bend near the bow. These Whitefish are as large as Shad, and are 
delicious, resembling the Shad somewhat in flavor, but not so bony. I have seen the Indians take twenty or thirty in an hour; sometimes two at a single dip of the net.

"Soon after my arrival at St. Mary, I made the acquaintance of Louie Leponts, a half-beed Indian, in a long swallowtailed blue coat, who I found was addicted to whipping his wife, getting drunk, and going a fishing. I profited by Louie's acquaintance, and engaged him and his brother as my 'voyageurs,' in going up and down the rapids on my fishing excursions. The ascent and descent of the Sault is no child's play; nothing but long practice, a quick eye, great skill in the use of the paddle and pole, and steadiness of nerve can accomplish it.

"On my first day's fishing, Louie held a pole of fifteen feet, with which he did great execution, catching two to my one. $\mathrm{He}$ is as good a specimen of a natural angler as I ever met with; and, considering his rough tackle, casts a large fly (and none other should be used here) with considerable skill. The fly, which he made himself, was on a rough Kirby hook, size 00 , a piece of red flannel tied around the shank, and a tuft of feathers bunglingly fastened at the head. On our second trip I was lucky enough to break the small end of his rod in getting into the canoe, thus monoplizing the sport; and in our excursions afterwards prevailed on him to leave it behind. I also fished the Little Falls, two or three miles down the river, near the Methodist Mission, and had great sport, my largest fish weighing about three pounds, and most of them were from fourteen to sixteen inches in length. My first trip up and down the Sault produced thirty-five fish. On the second day I had more sport, catching them mostly with the fly, but when they would not rise, used an artificial minnow. or the 'Kill-devil,' or a strip of the belly of the fish. After- 
wards, I got the knack of steadying myself in the canoe, when casting, and used the fly altogether.

"There is a long narrow island on the Canadian side of the river, and between it and the shore a narrow channel, which, I am told, can be waded in most places, and that it affords fine fishing. If the water had not been so cold I would have tried it.

"In going up and down the rapids I found that Louie's brother had good reason for taking his net and spear along. In our first ascent he caught three Whitefish in his net, at a single dip; he also speared several, besides a large goggleeyed Pickerel. He did not throw his spear when in the rapid water, but moved the iron cautiously towards the fish, and then with a thrust pinned it to the bottom, when the ashen handle would quiver and shake with the death-struggle of the victim and the force of the current. He frequently tried to point out a fish to me before he speared it, but it was no use; I could not see it through the rushing water.

"In the rapids the canoe was at all times under perfect control. In ascending, advantage was always taken of any eddy formed below a ledge, or a large rock that jutted above, or came near the surface, the light bark was pushed along the still water, and then turned quickly into the sharp current at the side of the rock, when there would be a fierce struggle, the water foaming and boiling almost over the bow as it was forced up the declivity. Sometimes the delicate ribs of the canoe would bend as the thin sides were compressed in passing between rocks where it would have been impossible for an ordinary boat to get through, or where its stiff planks would have been broken. What was most astonishing, though, was the way that Auguste alone would hold the canoe steady with his setting-pole, when we stopped to fish, the bow always dividing the current equally, and neve veering in the least to one side or the other. 
"I spent one Sabbath at the Sault, and attended worship at the old stockade fort in the morning, and in the afternoon visited the Methodist Mission at the Little Falls, two or three miles below, and met the man 'Tanner,' who was captured by the Indians when a boy, and who spent thirty years of his life amongst them. He acts as interpreter for the Mission.

"I returned from the Sault in one of those ancient crafts called a 'Mackinaw boat,' paying five dollars passage, with the privilege of rowing as much as I pleased. Our journey occupied two days; the first night we camped in a swampy place, when we were almost devoured by mosquitoes; the second night we slept on a rocky point, extending far out into the lake, where we had a good breeze, and were not troubled with them. There was a beautiful little island right in front of us, with a few trees on it, and as the sun went down I thought of the picture of the Prison of Chillon, which you gave me, and of Byron's lines, alluding to its inmate, who, when at last allowed to climb to the grated window, describes what he saw :-

"And then there was a little isle, Which in my very face did smile,

The only one in view;

A small green isle, it seem'd no more, Scarce broader than my dungeon floor, But in it there were three tall trees, And o'er it blew the mountain breeze, And by it, there were waters flowing, And on it, there were young flowers growing of gentle breath and hue."

Nor. (folding up the letter.) I'll stop now, Nestor. You would never die happy if you did not cram a few rhymes into your narratives; besides, we have got past the fishing, and I have no further interest in your lengthy "billy-doo." 
Nes. If you profess to love angling for its associations, and cannot appreciate such rhymes as those, I give you up; there are some lines on the back of that old letter that don't rhyme. I copied them from Hiawatha when I first read the book. Lake Superior, you know, was the "Gitchie-Gumee" of the Ojibwas, or, as they are called now, Chippewas, and according to their wild tradition, the Red Swan, after it was wounded by the magic arrow of Ojibwa, went slowly flapping its wings across its broad surface towards the setting sun: you had better not read the extract though, after saying, as you did the other day, that "Hiawatha" had the same jingle as the "Nigger Gin'ral."

Nor. I did not mean to disparage Longfellow, by comparing his "Hiawatha" with the "Nigger Gin'ral," I only implied that they were both of the same metre, and very "particular metre" it is. I'll give you a few lines of the "Nigger Gin'ral," as Old Dick Cooper used to sing it, and you can judge for yourself. I leave out the chorus, and as I have no banjo, the accompaniment also.

"Now, my boys, I'm bound to tell you, 0 listen a while and I will tell you; I'll tell you 'bout de Nigger Gin'ral, I'll tell you 'bout de Gin'ral Gable.

A leetle boy betrayed his gin'ral, A leetle boy, by de name o' Dan'el;

Betrayed him down to Norfo'k landin',

Becase he called him Uncle Gable.

“ 'O how dy do, my Uncle Gable?'

'O no I ain't your Uncle Gable!'

' $O$ yes you is my Uncle Gable.'

'O no I aint your Uncle Gable, For I do know your Uncle Gable, A man belong to Major Prosser.' " 
Now I call that hexameter in the rough, and taking it all through, it is pretty good legendary poetry, to boot.

Nes. Your taste in such matters, my dear boy, betrays your "bringing up;" but it seems to me, that a man who spends much of his time on lake or river, and allows the "particular metre," as you call it, and the repetitions in "Hiawatha" to prejudice him against the book, comes short of a full appreciation of camping out, or cooking his dinner on the stream.

Nor. Now you are a beautiful specimen of a star-struck fisherman, with your hair poking through the crown of that old hat, and that terrible rent in your trousers; how you would captivate your wife, and the ladies in general. But let me give you the concluding lines of the drama, as well as I can recollect them, and then if you can see no similarity between the "Song of Hiawatha," and the "Song of the Nigger Gin'ral," I'll consent to a truce between Longfellow and Dick Cooper. See now, how harmoniously the descriptive blends with the dramatic.

"Thursday week come on his trial,

Ho my boys you most done.

(But I forgot, I did not mean to put in the chorus.)

"Dey sont an called all de county,

To come and see de Nigger Gin'ral;

Some dey called him Archy Mullin,-

Right name was John de Cullin.

I'm here to-day and gone to-morrow,

I didn't come to stay forever.

"Dey drove him down to de gallus,

Drove him down wid fo' gray hosses ;

Diggs's Ben he druv de wagon.

Dar dey hung him and dey swung him, An dat's de end of de Nigger Gin'ral. 


\section{"Hard times in Old Virginny, Ole Virginny almost ruined, Ruined by de Nigger Gin'ral.}

" Polly what you got for supper;

Mutton shank and apple dumplins, Good enuf for hi'erd niggas."

MorRy. Very dramatic indeed-the last three lines particularly so-but tell me, were Gin'ral Gable and Nat Turner the same or different persons?

Nor. Different-Gabriel was the chief of an early and much better-planned insurrection: Nat Turner headed the last outbreak of the negroes in lower Virginia. It is said, that both of them were fellows of great aptitude as leaders, and had they made their escape by an underground railroad and lived to the present time, you and your friends would no doubt have made them captains in the Corps d'Afrique.

Mor. Perhaps if your friend Dick Cooper was alive, since you have such an opinion of his talents, you would use your influence to have hirn appointed leader of a regimental band in the Corps d'Afrique, and introduce the banjo as an instrument of martial music.

Nor. Dick was not a scientific musician, tune and harmony with him were intuitive; to have taught him music from a book would have cramped his genius, and to write his songs on paper would have spoiled them; as any true and natural negro music will be spoiled by trying to adapt it to the taste of those who generally attend the concerts of what are called "negro minstrels." If you had asked him if he played by note, he would likely have replied, as a black fiddler of celebrity once did at a dance in Kentucky, "No Sir, I plays by de night."-But what have we here? It fell from one of the pockets of your fly-book, as I was about to replace 
your letter; it is a sketch of some old fisherman-who is it?

NEs. Why that's "Uncle Lot," a mysterious old fellow, who haunted the Williwemock and Beaverkill, about Chester Darby's, for many years. Nobody knew where he came from, and, I am told, he at last disappeared, and nobody knew where he went to; the people of the neighborhood called him,

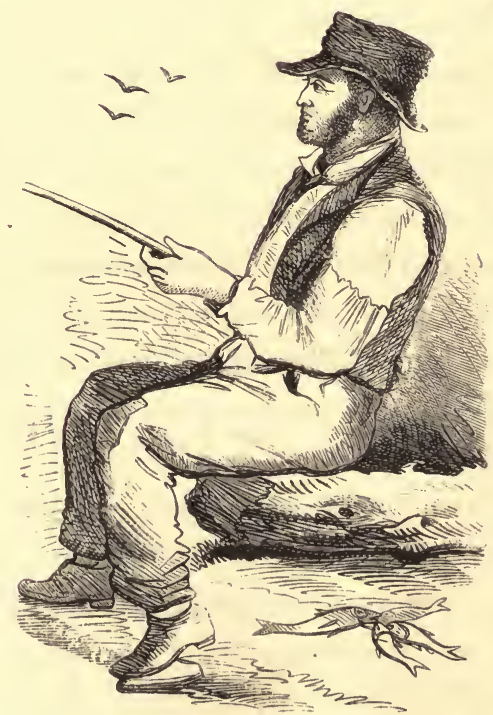

The Fish-Hawk. 
FOURTH NOONING.

\section{TROUT-FISHING IN THE ADIRONDACKS.}


"THE sounding cataract

Haunted him like a passion: the tall rock,

The mountain, and the deep and gloomy wood, Their colors and their forms, were then to hum An appetite; a feeling and a love

That had no need of a remoter charm By thought supplied."

WoRDsWORTH. 


\section{TROUT-FISHING IN THE ADIRONDACKS.}

\section{FOURTH NOONING.}

[Scene, a Saw-Mill.-Time, after the Roast.-Present: Norman, JoE, and Nestor.]

Jok. How it pours!

Nes. A good, steady, honest rain, and there will be no fishing until a day or two after it clears up; it will take that time for the creek to fall sufficiently; then the water will be just right, as Broadhead says, "of a tea color," and we will nick them. Those we cooked in the old fire-place were caught by Uncle Ickey with worm-bait, under the fall of the dam.

Nor. There is no better time for telling us of your excursion to the Adirondacks last summer. But how did you happen to go there in August? You could not have chosen a worse time for fishing.

Nes. I'll tell you. You know that Walter hurt his knee in the early part of last season, when wading the creek at Jim Henry's, and as fishing and sketching are two of the necessaries of life to him, he was obliged, for the remainder of the summer, to adopt the alternative of drawing and fishing from a boat. In no part of the country is this more easily done than on the lakes and still waters amongst the Adirondacks; so he tied his rods in a bundle, and packing his flybook, sketch-book, and a few colors, in his wallet, started for Martin's, on the Lower Saranac, where he hobbled about on his two canes all summer. like "the Devil on two Sticks" 
(though not as lively a cripple as his Satanic Majesty is said to be), and made frequent excursions, by boat, to the different fishing-places in the neighborhood, and went several times to the Raquette River and the lakes beyond. When his camp or his lodgings were more than twenty yards from the place of landing from his boat, Sam Dunning, an old fellow who stands about six feet two in his stockings, with breadth of beam in proportion, carried him "pick-a-back." He made a sketch illustrating this mode of locomotion, but as the picture flatters Sam and disparages the Artist, he would not let me have it, though he gave me several sketches of illustrious personages, which I will show you as I tell my story. I promised him I would let no one but the "Houseless" see them. He wrote me a glowing description of the scenery, fishing, and his manner of life, and as I had long wished to see that country, and hoped to be alone with him, I joined him after he had been there a month or six weeks.

JoE. Does the country resemble that about Lake Pleasant?

Nes. Not in the least. The Saranac Lakes, particularly the lower, appear to have been thrown down amongst the high peaks of the Adirondacks, the upper lake being rather north and west of the mountains; while Piseco, Lake Pleasant, Round Lake, and Louie Lake, are rather south-east of the main range, and occupy the high table-land in the southern part of Hamilton County, where the face of the country, although it is rolling, can hardly be called mountainous, as it is further north.

JoE. What route do you take to get there?

NES. It is a mere pleasure trip, by way of Albany and Whitehall, at the southern or upper end of Lake Champlain. T'here you take the boat which runs to Rouse's Point, stopping at all the landings on its passage down the lake, and passing several places of historical interest. When you arrive at 
Port Kent, you find stages in readiness to carry you to Keeseville, a distance of four or five miles inland, where you stay all night, and in the morning after breakfast take wagons, provided with spring-seats, for Baker's or Martin's, on the Lower Saranac. You get an excellent supper and a good bed in Keeseville, at a little hotel kept by Taggard, an obsequious fussy old fellow, who has a store under the same roof, and occasionally sells an embryo sportsman what he calls his "outfit."

Nor. Is it necessary to lay in stores or provisions for the excursion?

NEs. By no means. Martin, at the lake, can 'supply all the necessaries a reasonable man may require. If one is over particular he had better take the few luxuries he may want from town.

JoE. Did you find many persons visiting the Adirondacks in August?

Nes. Crowds of them; there are more excursionists at that time than at any other. I found Taggard's hotel crammed with cockney sportsmen, going and returning from the lakes; some of them the most pretentious, verdant-looking hunters you ever laid eyes on. I recollect one party from Bostonthree out of the four were pop-eyed men with spectacles. You meet with a man now and then, don't you, who looks, if you were to slap him on the back with a shingle, as if his eyes would fly out? Well, the Nimrod of the party, who talked about "driving deer" and "shining deer," was of that sort. I'll bet he could not tell a buck from an old stump at thirty yards, much less hit one. They all affected the rough, and walked about with bowie-knives stuck in the belts of their hunting-shirts, as if they expected next minute to meet a live Indian-perfect Daniel Boones and Kit Carsons. It almost made me afraid to look at them, though no doubt they were 
1noffensive people at home. What a deuce of a propensity city folks have, when they do anything out of the way, to "dress the character !"

JoE. What in the name of common sense has all this to do with fishing in the Adirondacks? Go on with your story; do you go up the Saranac River?

Nes. My dear Joe, you should never be in a hurry when you go a fishing, or talk about fishing; but pass me that bottle of ale, and I'll "grease the wheels" and go on. You don't go up the Saranac; besides, the Saranac can hardly be called a river; you go up the Au Sable. You must know that Keeseville is on the Au Sable. There is a splendid cataract just before you enter the town, and cascades in the town, for the river comes tearing right through it, and is bridged in two or three places. There are no falls above the town, except where the river is dammed at the iron-works, and they are not as high as the falls of Niagara; but you see beautiful rapids and pools as you drive up the river, where there must have been fine Salmon-casts in other days.

Nor. What, did you say, was the height of the fall just before you enter Keeseville?

Nes. Thirty feet, I suppose; it falls as perpendicularly as water can come down, and as a certain London book-maker says, in his "Tourist's Guide" of Glenn's Falls on the Hudson, "Here the water thunders and spirts," just as if the cataract that Cooper immortalizes in "The Last of the Mohicans" could behave itself like a barrel of new cider, or spruce beer.

NoR. What a poor theorist you are! you said that there were no doubt fine Salmon-casts on the Au Sable, above Keeseville, in olden times, and that the falls below the town are thirty feet high, and perpendicular. How could a Salmon get over a cataract of thirty feet?

NES. I give it up; it is all a matter of fancy, and my 
theory in direct opposition to facts and reason. Salmon did run up the Saranac, though; I have the word of one of the "oldest inhabitants" for that, and no doubt found their way into the lakes above.

JoE. But how did they get into Lake Champlain?

Nes. Through the Sorel River, of course, from the St. Lawrence. The ride up the Au Sable would not be interesting, but for the ever-varying mountain scenery in the distance. The hills and peaks rise up in rugged grandeur before you. A way off to the south, on a fair day, you get a glimpse of Mount Marcy; the Indians called it Ta-haw-wus-the Mountain that touches the Sky. But it has dropped its significant Indian name, and is complimented with that of Mr. Marcy, just as another peak has been robbed of its fine old title, and is now called "Mount Seward."

Nor. A like liberty has been taken with the name of a railroad station, at a bridge between Philadelphia and Bristol; it was called by the beautiful Indian name of the river itself, "Neshamony," until some enterprising individual, it appears, started a town there, and called it after himself: it now bears the euphonic name of Schencksville. When will there be a law passed to make perpetrations of this sort a capital crime? -I suppose you have a pretty rough ride from Keeseville to Martin's.

NeS. By no means; there is a plank-road for two-thirds of the way, and the last third, where it is not planked, is better than the improved part; for you know, that a plankroad, when it is well worn and rotted, is rather bumpety, and, if not kept in repair, degenerates into a "corduroy" road, or, as we used to call it when we were boys, a "codgeroy." It is a whole day's ride to Martin's, which is at the northern end of the lower lake. Baker's is four miles this side, where the Saranac River is crossed by a good bridge; a tavern, 
a store, a post-office, and a blacksmith-shop, are the usual germs of a future village. Here is a little sketch, which is positive evidence that Walter was detained there when passing. Of course he could not be idle, and for want of a better subject procured the blacksmith's boy, as he afterwards told me for the sum of one dime; the lad's face is a receipt for the amount of happiness so large a sum of money can create.

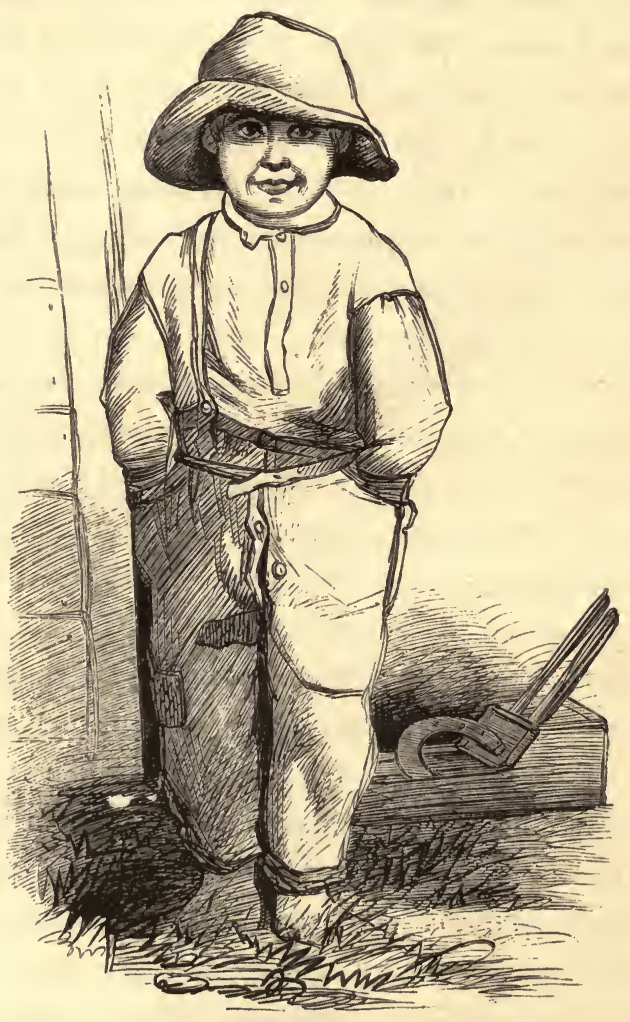

Mr. Baker told me there was fine fly-fishing in the rapids in front of his house in June, though Martin's is more convenient to the angler, and all those who take boats and guides for the lakes and Raquette River, embark at his house. 
Nor. I have always been under the impression that a good log-cabin and "fixins" to suit, was as much as one could hope for on the Saranac.

Nes. Now, bless your innocent heart! Bill Martin has a frame house as big as a watercure establishment; and in it a tenpin-alley, a ball-room, a piano, a ladies' parlor, opening out on a verandah that overlooks the lake, a gentleman's sitting-room, where you lounge and tie flies, a fleet of fairy little boats - some of them that don't weigh a hundred pounds-and a score or two of stalwart retainers, who act as guides, and can take you almost anywhere. Besides, he has deerhounds, rifles, shot-guns, trolling-rods, fly-rods, and all that; for he is a great deer-hunter and a good fly-fisher, and always has venison and Trout on his table.-Why he is a sort of "Lord of the Isles;" for I think there are some fifty turreted pine-clad little islands in the lake, near his house. ['ll show you a sketch of a pair of Bill's retainers-Walter took them as they were discussing the subject of the draft.

JoE. The man with the hip-roofed hat, looks as if he had the worst of the argument-of course there must be a good many excursionists to warrant an establishment of that kind?

NES. There are; and that is an offset to the pleasure of the trip with one who likes, when he leaves town, to leave town people behind; for the Saranac Lakes are so easy of access, that they have even become fashionable. Martin's is a kind of a jumping-off place from the civilized world into the wilds beyond: I have seen men embark at his landing with their wives, children, and other baggage; their cooking utensils, their India-rubber bags stuffed with luxuries, their bass-rods, which the owners essayed in vain to cast a fly with, and their highly finished guns that were innocent of the death of deer, all crammed into boats, when starting for the upper Saranac or some of the lakelets and ponds beyond the Raquette, to 


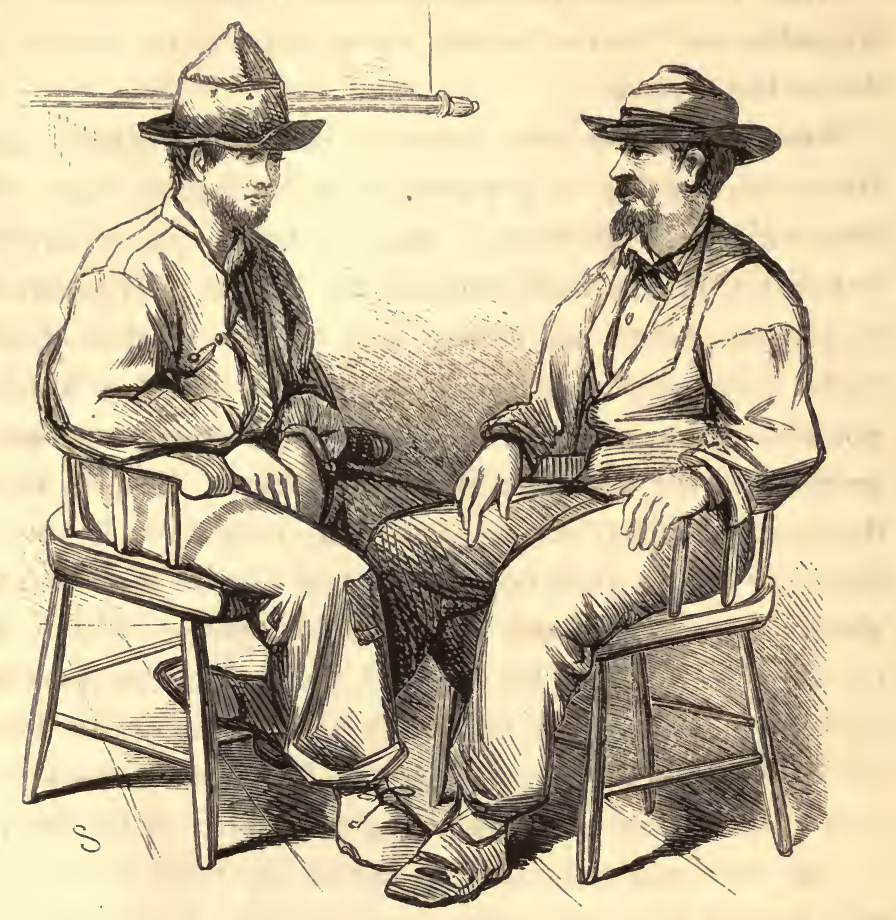

camp out for weeks. Many of these are people who live in luxury at home, who have become weary of Newport, Saratoga, and Nahant, and come out "to rough it." Some "satisfy the sentiment" in a single trip, others repeat the excursion year after year, until the men become passable woodsmen, and the women right good squaws.

Nor. Fishing and philandering, I think, are very opposite amusements. I don't like to mix them; and meeting any number of town folks amongst such places and scenes as I have heard Walter describe, would seem to me like an untimed intrusion.

NEs. I think it rather adds to the charm when one can take his wife and children on such an excursion; that is, if he 
is not so ardent a sportsman that it interferes with his hunting and fishing. Still, I confess, I was somewhat shocked at times to find the Adirondacks so hackneyed; the "carries" from one lake to another, as you go from Martin's to the Raquette are well-worn roads, and at two of them there are wagons to convey canoes and baggage across. The little outlet of Stony Creek Pond which flows into the Raquette, and the Raquette itself, are so much travelled in the month of August as to suggest the idea of "the raging canawl." I recollect on one occasion, after Walter and I had been forestalled at several good fly-casts by some rough bait-fishers bound for the Raquette, that we came to the mouth of Amphusand Brook, and thought we would have a good, quiet, lonely time. Our guides put our boats within easy cast of the best places, the Trout were dimpling the water all around, and we had made a few successful casts, "when faint from further distance borne, was heard the clang" —of something like a canal tin horn, and looking up towards the head of Stony Creek Pond, a boat rounded the point, a flag flying at the bow, and two red-shirted "Bowery-boy" looking fellows in the middle of it, approached us flourishing an empty bottle, and singing Old Dan Tucker.- "Oh solitude, where are thy charms?" exclaimed Walter mournfully, winding up his line, while I sat down as Major Jack Dade of Virginia says, "in the most pi-ignant grief." We gave up fishing and went back to Stephen Martin's, where we had engaged lodgings for the night.

JoE. I have heard that hunting is as great an inducement to go to the Adirondacks as fishing.

NES. It is with most persons; a friend. who encamped for nearly a month on Wolf Pond, beyond the Raquette, last September, had a fresh deer hanging before his tent-door every day. If a person has a guide who is a good hunter, 
and dogs to drive them into lake or river, it requires very little skill on his part to get venison; and a man who is a very poor shot will sometimes start from Martin's and return in a few days with two or three deer, for when they are driven into into the water, there is very little chance of their escape, if the hunter is watching near the place where they go in; or in "shining" them either, for the guide silently paddles you up almost close enough to catch the victim by the tail; and then there is some chance of shooting the guide, or the dog, or yourself in the excitement of the moment, or the guide has to knock the deer on the head with a club, if you don't kill him. When Martin wants venison, he sends any of the guides who may be lounging about the house off on a drive. Here is a rough copy of one of my artist's sketches.

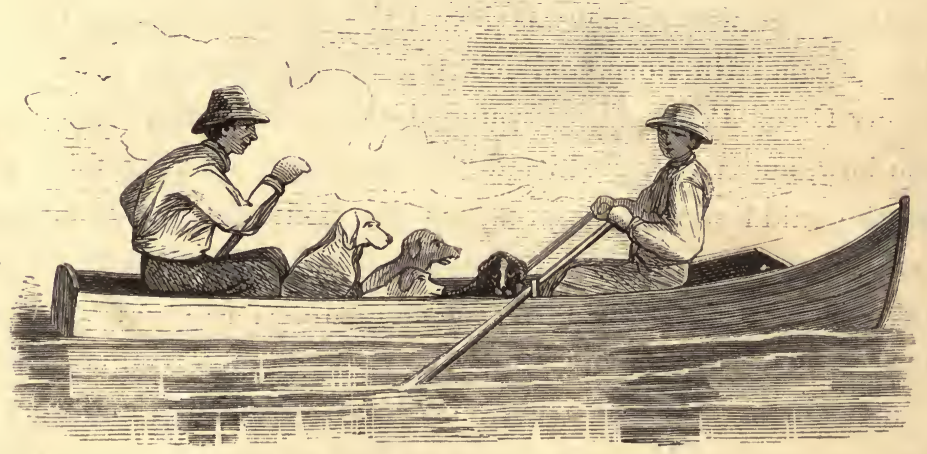

JoE. Of course there are anglers who are not less verdant than the hunters?

Nes. Anglers!-hand me that ale, I'm dry, talking so much-Why it does not require angling to catch Lake Trout, for in trolling the guide rows you over the fish, and when one lays hold you must reel him in and take him off as a matter of course. If you fish the rapids when the Brook 
Trout are there, or stop at the mouths of some of the cool brooks, where they collect as the summer advances, you have only to throw your flies over them, and there is no preventing their hitching on, and then a man who catches a basket full may be an angler, or a mere fisherman.

JoE. Why what difference can there be between an angler and a fisherman?

NEs. Difference! That is exactly the question somebody once asked Dr. Bethune. The Doctor was buying some tackle at Conroy's, when one of his friends dropped in. "What, are you a fisherman ?" said the good man, in surprise. "No, I am an angler," replied the Doctor. "Well, what is the difference?" asked the querist. The Doctor referred him to Mr. Conroy (so goes the story) for an explanation. "Why," said the great tackleman, delicately lifting between his thumb and forefinger the two dollar note that the Doctor had laid on the counter, and dropping it into the till, as if it would contaminate him-" An angler, Sir, uses the finest tackle, and catches his fish scientifically-Trout for instance-with the artificial fly, and he is mostly a quiet, well-behaved gentleman. A fisherman, Sir, uses any kind of 'ooks and lines, and catches them any way, so he gets them it's all one to 'im, and he is generally a noisy fellah, Sir, something like a gunner." The man smiled, and looked at the Doctor inquiringly, to see if he endorsed the distinction drawn by $\mathrm{Mr}$. Conroy. The Doctor, it is said, nodded his head affirmatively, pocketed his tackle, and laughing, walked out of the store. So you see I have the authority of two very distinguished gentlemen for the difference I claim between an angler and a fisherman.

JoE. Speaking of distinguished gentlemen, who is Mr. Jack Dade that talks about "pi-ignant grief?" Is he the man who inquired "who is the Mary McDan'el that the minister alluded to so often in his sermon?" 
Nes. The same, though a very different kind of person from the one you may have in your mind's eye; besides. he is not "Mister," he is Major Jack Dade. He is or was, for I don't know that he is alive now, one of "the first gentlemen of Virginia, sir"; a relic of that ancient order who were the last to leave off blue coat, buff waistcoat, and drab trousers; who were "au fait" in politics and card-playing, bacon, mutton, Madeira, and old whiskey; and could tell you the pedigree of every race-horse between tide-water and Blue Ridge; besides being pretty well satisfied with their own pedigree. Jack was one of them; but with all his early advantages, as his father used to say of him, "he couldn't take larning." Major Dade was a captain at the battle of Bladensburg, "sir." General Winder sent him with his company through an extensive cornfield to reconnoitre the British brig Vulture, then lying in the Potomac, and he would have made a successful reconnoissance if it had not been for the panic which seized his militia. In telling the story. Major Jack says they thought they heard the British troops stealing upon them, when it was only the north-west wind rustling the dry tops of the "kaun," and, as a matter of course, when they ran, he had to follow them, "sir." The major is opposed to all kinds of innovations, especially improved farming and imported cattle. $\mathrm{He}$ condemns short horns and Berkshire hogs, affirming positively that there is no bacon so good as that made from an old-fashioned "fiddle-faced hog."

Nor. I think I saw him once at the town of Warrenton, and that he came with Charley Randolph, another old relic, in a coach and four; though, by the by, the coach, which was a little the worse for wear, had but three horses to it, and there was a calf-skin stretched across the back of the coach (the tail hanging down) to keep out the weather. The old gentleman struck me as being fond of a noise, for I never saw a 
man erack a whip like him, or respond as loudly in church. What story was that Sam Chilton told us of Jack Dade, interrupting Charley at his morning devotions?

Nes. Sam was always telling stories about somebody. I suppose you refer to what occurred once when Jack stayed at Charley's all night. The host next morning, like a good churchman, was reading prayers to the collected household, and Jack, who got up a little too late, entered the dining. room without noticing the devotional attitude of the family, but seeing the bunch of mint, the sugar-bowl, and decanter set out as usual, made a straight line for the sideboard. When Charley, seeing his mistake, raised his eyes from the book and said, "Hold on, Jack, I'll join you presently." The service over, the julep followed as a matter of course.

Nor. Speaking of Sam Chilton, your continual digressions remind me of a reply he made to a speech of Henry A. Wise, at a Virginia State Convention, some years ago. In debating some question, Wise sat down after a fiery speech, in which there was a great deal of declamation, and very little logic. Sam rose, and taking an old quid from his mouth, and dropping it softly on the floor, said he had asked Mr. Wise for argument, and he gave him only words; for facts, and he had given him declamation. The gentleman's speech reminded him of Falstaff's tavern-bill, "Sack, five shillings and sixpence; bread, a half-penny." I have asked you to tell us about fishing in the Adirondacks, but you have told us very little about it, and talked of almost anything else. What was the greatest number and weight of fish you killed in a day?

Nes. You led me into this digression yourself, by your confounded questions. I have already said that I was there at an unfavorable time for fishing. Trolling in the lakes is over by the middle of June, and the Brook Trout have generally left the rapids by that time. I have been told, though, 
that thirty pounds have been taken by a single rod in the rapids on the Raquette in a forenoon in the latter part of May, and as much as fifty pounds in the outlet of the Lower Saranac, where Rodgers and Cold Brook come in.

Jok. What was the size of the largest you killed?

Nes. I did not take any that exceeded a pound and a half. The largest I caught were at the mouths of Rodgers and Cold Brook, where they come into the outlet. Our friend H. K. B. killed fish a few days after at the mouths of some spring brooks that come into the Raquette, below Fish Hawk and Setting-Pole Rapids, that weighed over two pounds. He was not as successful at the mouth of Bog River, which tumbles in at the upper end of Tupper's Lake, where he had such fine sport five or six years ago; but that was in September, when the Trout collect again in the rapids, after having deserted them during the heat of summer. There were several parties encamped at 'Tupper's Lake in the early part of last June, and those who fished with the fly had fine sport at Bog River Falls, while those who trolled, took Lake Trout as large as ten and twelve pounds.

Joe. How do you get into the Raquette River from Martins?

Nes. Hand me that pocket-map, and I'll show you. You see there are three lakes, they are all connected by a stream of moderate size; the eastern is the Lower Saranac, the south. ern, Round Lake, and the western, the Upper Saranac. You observe, also, that there are three ponds still further west; these are the Stony Creek Ponds, and from one of them a small stream of the same name flows, with gentle current, into the Raquette. The first portage or "carry" is at the upper end of the Lower Saranac, about six miles from Martin's; the next at the outlet of the Upper Saranac, three or four miles further on; and the last is between the western side of the 
Upper Saranac and one of the Stony Creek Ponds. The last portage is about three-quarters of a mile, and is called the Indian Carry. The Saint Regis tribe used it a great deal some years back. When you get there, you have come about, fifteen miles, and if you prefer sleeping under a roof, and getting a good supper, you will stop at Stephen Martin's. Bartlett keeps a house for the accommodation of sportsmen at the second carry, where there is good fly-fishing in the rapids of the outlet, and below his house, until the 1st of July. You get into the Raquette, as I have already told, by way of Stony Creek Ponds, and the outlet called Stony Brook. There is fine fly-fishing at the mouth of Amphusand Brook, which comes into the lower pond, within a stone's throw of where the outlet runs from it. Some years back H. K. B. killed a Trout of four pounds in Stony Brook, but when I was there the boats of excursionists bound to or from the Raquette, passing so frequently, had scared all the fish out of it, or made them too shy to rise in the few pools you pass by. When you emerge into the Raquette you are twenty miles from William Martin's.

The Raquette is a quiet, dark river, with a gentle current and but few rapids. It heads in the lakes of Hamilton County, and flows north into the St. Lawrence, above Lake St. Francis. It is about fifteen miles from the entrance of Stony Creek to Tupper's Lake, which connects with the river by a wide, deep outlet. If you are not prepared to camp out, you can find accommodations at Stetson's, on the Raquette, about two miles this side of the lake.

Tupper's Lake is a beautiful sheet of water with pretty islands, but you have not the splendid view of the sharp peaks of the Adirondacks, which you get from almost any part of the Lower Saranac, for you have passed to the west, and beyond that range of mountains. 
This region of country is much frequented by artists, and some fine pictures of real and supposed scenes in the Adirondacks have been painted. On my return home, I had the agreeable company, for the greater part of the way, of our young sculptor friend $\mathrm{Q}$. W. and his wife. They had gone in from Crown Point, and came down Long Lake and the Raquette to Stony Brook, and then by way of the Saranacs to Martin's, loitering on the way, the trip occupying about ten days.

JoE. Are there any other fish of the Salmon family in the Adirondacks besides Lake and Brook Trout?

Nes. There is a species of Coregonus, or Whitefish, in the Saranacs, similar to those known as Lake Herring in the larger lakes. I did not see any of them, but was told that their average size is not over eight inches, which is even smaller than the Laverett and Gwynaid taken in the lakes of Scotland. They do not rise at a fly, however, or take a bait. When we made the short portage on the stream connecting the Lower Saranac with Round Lake, my guide pointed out an eddy below the rapid, where, he said, he has taken five or six barrels of them in a few days, with a "lift-net," when they collect there to spawn, which is in November. They are sent to market frozen, and are highly esteemed for their delicate flavor. I have never heard of these fish being taken in the lakes of Hamilton County, or in those that connect with the Raquette.

Nor. I thought all the fish of the Salmon family would take a bait or rise at a fly.

Nes. By no means; you confound the family Salmonidx with the genus Salmo. The Salmon is the type of the family as well as the genus. All that belong to the genus Salmo are voracious fish; but the genus known as Coregonus, which 
embraces all the Whitefish-large and small-and of which this little fish is a species, are not predatory; they are peaceable dwellers in the deeps of the lakes, except in the month of November, when they come into the rapids to spawn. Great numbers of them are no doubt devoured in the lakes by the large Lake Trout.

JoE. Why did you not take a tent and camp out, instead of sleeping under-roof, after leaving Martins?

NES. As Walter was lame it was more convenient to sleep on beds, and unless these are buggy, as they frequently are in the houses of the settlers, I prefer sleeping in-doors. It is always necessary to camp out, when you wish to enjoy all the advantages of a favorite hunting-station, and then it is well to be provided with a mosquito-net if you go before August; after that time you are not annoyed with black flies, and there are then but few mosquitos.

Jow. So you think camping out is not so much a matter of comfort as of sentiment, as you call it!

NES. It is like angling-with some persons a mere matter of fancy. Washington Irving, in one of his sketches, describes a fishing party, which included himself; these gentlemen thought they were in love with angling, from reading Isaac Walton, forgetting that like "reading and writing," as Dogberry says, it "comes by nature." They provided themselves with Trout-rods, reels, artificial flies, \&c., and started. After poking through the bushes and floundering along a rough little mountain stream all day, and damaging their fine tackle without catching any fish, and having "satisfied the sentiment," they met with a country lad, his trousers rolled up, an alder-pole with its rough horsehair line in one hand, and in the other a handsome string of "Trout.

Jok. "Some men are born great"-there are natural 
anglers and natural hunters; but "what boots it," who have we here, sitting on a stump?

Nes. That is a natural hunter, my young guide, Reuben Reynolds. watching for deer.

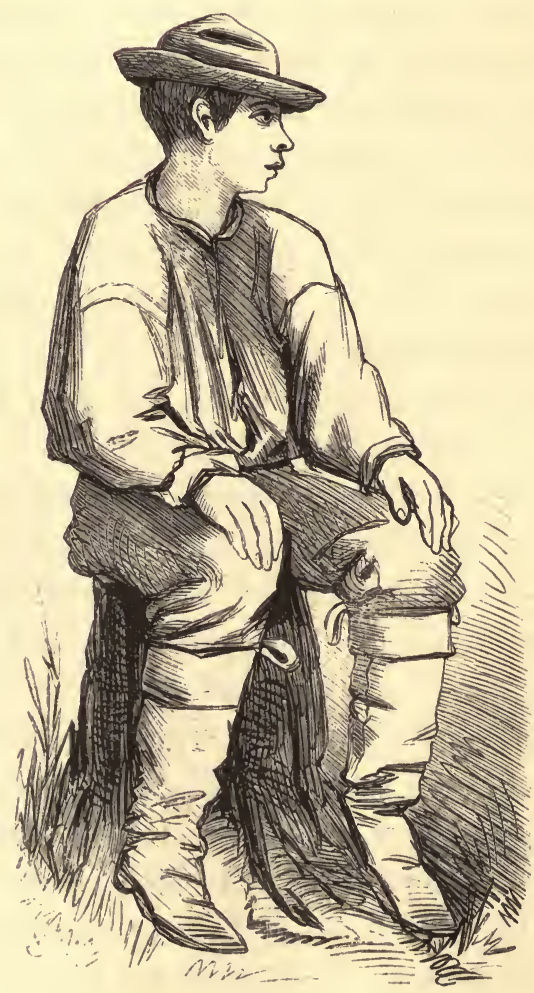


FLY-FISHING ALONE. 
"To him who in the love of nature holds Communion with her visible forms, she speaks A various language; for his gayer hours, She has a voice of gladness, and a smile, And eloquence of beauty, and she glides Into his darker musings, with a mild And healing sympathy, that steals away Their sharpness ere he is aware."

BRYANT. 


\section{FLY-FISHING ALONE.}

W ITH many persons fishing is a mere recreation, a pleasant way of killing time. To the true angler, however, the sensation it produces is a deep unspoken joy, born of a longing for that which is quiet and peaceful, and fostered by an inbred love of communing with nature, as he walks through grassy meads, or listens to the music of the mountain torrent. This is why he loves occasionally-whatever may be his social propensity in-doors - to shun the habitations and usual haunts of men, and wander alone by the stream, casting his flies over its bright waters: or in his lone canoe to skim the unruffled surface of the inland lake, where no sound comes to his ear but the wild, flute-like cry of the loon, and where no human form is seen but his own, mirrored in the glassy water.

No wonder, then, that the fly-fisher loves at times to take a day, all by himself; for his very loneliness begets a comfortable feeling of independence and leisure, and a quiet assurance of resources within himself to meet all difficulties that may arise.

As he takes a near cut to the stream, along some blind road or cattle-path, he hears the wood-robin with its "to-whe," calling to its mate in the thicket, where itself was fledged the summer before. When he stops to rest at the "wind clearing," he recalls the traditionary stories told by the old lumbermen, of the Indians who occupied the country when their grandfathers moved out to the "back settlements," and, as he 
ruminates on the extinction, or silent removal of these children of the forest, he may think of the simple eloquent words of the chief to his companions, the last he uttered: "I will die, and you will go home to your people, and, as you go along, you will see the flowers, and hear the birds sing; but Pushmuttaha will see them and hear them no more; and when you come to your people they will say, 'Where is Pushmuttaha?' and you will say, 'He is dead:' then will your words come upon them, like the falling of the great oak in the stillness of the woods."

As he resumes his walk and crosses the little brook that "goes singing by," he remembers what he has read of the Turks, who built their bowers by the falling water, that they might be lulled by its music, as they smoked and dreamed of Paradise. But when the hoarse roar of the creek, where it surges against the base of the crag it has washed for ages, strikes his ear, or he hears it brawling over the big stones, his step quickens, and his pulse beats louder-he is no true angler if it does not-and he is not content until he gets a glimpse of its bright rushing waters at the foot of the hill.

Come forth, my little rod- " a better never did itself support upon" an angler's arm,-and let us rig up here on this pebbly shore! The rings are in a line, and now with this bit of waxed silk we take a few hitches backward and forward over the little wire loops which point in opposite directions at the ends of the ferules, to keep the joints from coming apart; for it would be no joke to throw the upper part of the rod out of the butt ferule, and have it sailing down some strong rift. The reel is on underneath, and not on top, as those Bassfishers have it, who are always talking of Fire Island, Newport, and Narragansett Bay.

What shall my whip be? The water is full, I'll try a red hackle, its tail tipped with gold tinsel ; for my dropper, I'll 
put on a good sized coachman with lead-colored wings, and as soon as I get a few handsful of grass, to throw in the bottom of my creel, I'll button on my landing-net and cross over, with the help of this stick of drift-wood, for it is pretty strong wading just here. Do you see that rift, and the flat rock at the lower end of it which just comes above the surface of the water, and divides the stream as it rushes into the pool below? There's fishing in rift and pool both; so I'll begin at the top of the rift, if I can get through these alders. Go in, my little rod, point foremost; I would not break that tip at this time to save the hair on my head;-hold! that twig has caught my dropper-easy, now,-all clear-through the bushes at last.

When I was here last July, and fished the pool below, there was no rift above, the water hardly came above my ankles; now it is knee-deep; if there was less it would be better for the pool; but it makes two casts now, where there was only one last summer, and I have no doubt there is a pretty fellow by the margin of the strong water, on this side of the rock, - an easy cast, too,- -just about eight yards from the end of my tip. Not there-a little nearer the rock. What a swirl! He did not show more than his back; but he has my hackle. I had to strike him, too, for he took it under water like a baitthey will do so when the stream is full. Get out of that current, my hearty, and don't be flouncing on top, but keep underneath, and deport yourself like an honest, fair fighter! There you are, now, in slack water; you can't last long, tugging at this rate; so come along, to my landing-net; it's no use shaking your head at me! What a shame to thrust my thumb under that rosy gill! but there is no help for it, for you might give me the slip as I take the hook out of your mouth, and thrust you, tail-foremost, into the hole of my creel. You are my first fish, and you know you are my luck; so I 
would not lose you even if you were a little fellow of seven inches, instead of a good half-pound. I imbibed that superstition, not to throw away my first fish, when I was a boy, and have never got rid of it. Now, tumble about as much as you please; you have the whole basket to yourself.

Another cast-there ought to be more fish there. He rose short,--a little longer line-three feet more will do it-exactly so. Gently, my nine-incher! Take the spring of the rod for a minute or so-here you are! Once more, now. How the "young 'un" jumps! I'll throw it to him until he learns to catch; there, he has it. No use reeling in a chap of your size, but come along, hand-over-hand; I'll release you. Go, now, and don't rise at a fly again until you are over nine inches.

Not a fly on the water! So I have nothing to imitate, even if imitation were necessary. Take care! that loose stone almost threw me. I'll work my way across the current, and get under the lee of that boulder, and try each side of the rift where it runs into the pool below the flat rock. Not a fish in the slack water on this side; they are looking for grub and larvæ in the rift. Now, how would you like my coachman, by way of a change of diet? There's a chance for you -try it. Bosh! he missed it; but he is not pricked. Once more. Oh, ho! is it there you are, my beauty? Don't tear that dropper off. Hold him tight, O'Shaughnessy; you are the greatest hook ever invented. How he runs the line out, and plays off into the swift water! It would be rash to check him now; but I'll give him a few feet, and edge him over to the side of the rift where there is slack water. That's better; now tug away, while I recover some of my line. You are off into the current again, are you? but not so wicked. The click on this reel is too weak, by half-he gives in now, and is coming along, like an amiable, docile fish, as he 
is. Whiz! why, what's the matter, now? Has "the devil kicked him on end?" as my friend with the "tarry breeks" has it. He has taken but two or three yards of line, though. How he hugs the bottom, and keeps the main channel! Well, he can't last much longer. Here he comes now, with a heavy drag, and a distressing strain on my middle joint; and now I see him dimly, as I get him into the eddy; but there's something tugging at the tail-fly. Yes, I have a brace of them, and that accounts for the last dash, and the stubborn groping for the bottom. What a clever way of trolling! to get an obliging Trout to take your dropper, and go sailing around with four feet of gut, and a handsome stretcher at the end of it, setting all the fish in the pool crazy, until some unlucky fellow hooks himself in the side of his mouth. How shall I get the pair into my basket? There is no way but reeling close up, and getting the lower one into my net first, and then with another dip to secure the fish on the dropper; but it must be done gently. So-well done; three-quarters of a pound to be credited to the dropper, and a half-pound to the stretcher-total, one pound and a quarter. That will do for the present. So I'll sit down on that flat rock and light my dudeen, and try the remainder of the water presently. I'll not compromise for less than four half-pound fish before I leave the pool.

These are some of the incidents that the lone fly-fisher experiences on a favorable day, and the dreams and anticipations he has indulged in through the long gloomy winter are in part realized. "Real joy," some one has said, is " a serious thing;" and the solitary angler proves it conclusively to himself. He is not troubled that some ardent young brother of the rod may fish ahead of him, and disturb the water without availing himself of all the chances; or that a more discreet companion may pass by some of the pools and rifts without 
bestowing the attention on them they deserve; but in perfect quietude, and confidence in his ability to meet every contingency that may occur, he patiently and leisurely tries all the places that offer fair. What if he does get hung up in a projecting branch of some old elm, that leans over the water? he does not swear and jerk his line away, and leave his flies dangling there-it is a difficulty that will bring into play his ingenuity, and perhaps his dexterity in climbing, and he sets about recovering his flies with the same patient steadiness of purpose that Cæsar did in building his bridge, or that possessed Bonaparte in crossing the Alps, and feels as much satisfaction as either of those great generals, in accomplishing his ends.

If he takes "an extraordinary risk," as underwriters call it, in casting under boughs that hang within a few feet of the water, on the opposite side of some unwadeable rift or pool, and his stretcher should fasten itself in a tough twig, or his dropper grasp the stem of an obstinate leaf, he does not give it up in despair, or, consoling himself with the idea that he has plenty of flies and leaders in his book, pull away and leave his pet spinner and some favorite hackle to hang there as a memento of his temerity in casting so near the bushes. Far from it; he draws sufficient line off his reel and through the rings to give slack enough to lay his rod down, marking well where his flies have caught, and finds some place above or below where he can cross; then by twisting with a forked stick, or drawing in the limb with a hooked one, he releases his leader, and throws it clear off into the water, that he may regain it when he returns to his rod, and reels in his line; or he cuts it off and lays it carefully in his fly-book, and then recrosses the river. A fig for the clearing-ring and rod-scythe and all such cockney contrivances, he never cumbers his pockets with them. Suppose he does break his rod-he sits 
patiently down and splices it. If the fracture is a compound one, and it would shorten the piece too much to splice it, he resorts to a sailor's device, and fishes the stick, by binding a couple of flat pieces of hard wood on each side.

Captain Marryatt, in one of his books, says, a man's whole lifetime is spent in getting into scrapes and getting out of them. This is very much the case with the fly-fisher, and he should always curb any feeling of haste or undue excitement, remembering at such times, that if he loses his temper he is apt to lose his fish, and sometimes his tackle also.

My neighbor asked me once if Trout-fishing was not a very unhealthy amusement-he thought a man must frequently have damp feet. Well, it is, I answered; but if he gets wet up to his middle at the outset, and has reasonable luck, there is no healthier recreation._-But I have sat here long enough. I'll fill my pipe again and try the head of that swift waterIf this confounded war lasts a year longer "Lynchburg" will go up to three dollars a pound, but it will be cheap then compared with those soaked and drugged segars that are imposed upon us for the "Simon-Pure," under so many captivating names. At all events this is what it professes to be, good homely tobac__ Whe-e-euh! What a dash! and how strong and steady he pulls; some old fellow "with moss on his back," from under that log, no doubt of it. Is it line you want? -take it, eight_ten-fifteen feet-but no more if you please. How he keeps the middle of the rift! Don't tell me about the "grace of the curve," and all that sort of thing; if the bend of this rod isn't the line of beauty I never saw it before, except of course in the outline of a woman's drapery. Speaking of lines, I'll get a little of this in as I lead the fellow down stream, even at the risk of disturbing the swim below. It is the best plan with a large fish; I have Sir Humphrey Davy's authority for it, although I believe with Fisher, of the 
"Angler's Souvenir," that he was more of a philosopher than an angler. Talk of "dressing for dinner," when the fish are rising! Steady and slow, my boy, you are giving in at lasttwo pounds and a half or not an ounce! now I see you "as through a glass, darkly" - a little nearer, my beauty-Bah! what a fool I am! here a fish of a half-pound has hooked himself amidship, and of course offering five times the resistance he would if fairly hooked in the mouth, and no damage to his breathing apparatus while fighting, either; for he keeps his wind all the while. If he had been regularly harnessed, he could not have pulled with more advantage to himself and greater danger to my tackle in this rough water. I thought I had been deceived in this way often enough to know when a fish was hooked foul.

Now I call it strong wading coming down through that dark ravine; I must take a rest and put on a fresh dropper. And so my friend asked me if it was not very lonesome, fishing by myself. Why these little people of the woods are much better company than folks who continually bore you with the weather, and the state of their stomachs or livers, and what they ate for breakfast, or the price of gold, or the stock-market, when you have forgotten whether you have a liver or not, and don't care the toss of a penny what the price of gold is; or whether "Reading" is up or down. Lonesome!-It was only just now the red squirrel came down the limb of that birch, whisking his bushy tail, and chattering almost in my face. The mink, as he snuffed the fish-tainted air from my old creel, came out from his hole amongst the rocks and ran along within a few feet of me. Did he take my old coat to be a part of this rock, covered with lichens and gray mosses? I recollect once in the dim twilight of evening, a doe with her fawns came down to the stream to drink; I had the wind of her, and could see into 
her great motherly eyes as she raised her head. A moment since the noisy king-fisher poised himself on the dead branch of the hemlock, over my left shoulder, as if he would peep into the hole of my fish-basket. The little warbler sang in the alders close by my old felt hat, as if he would burst his swelling throat with his loud glad song. Did either of them know that I am of a race whose first impulse is to throw a stone or shoot a gun at them? And the sparrow-hawk on that leafless spray extending over the water, sitting there as grave and dignified as a bank president when you ask him for a discount; is he aware that I can tap him on the head with the tip of my rod? - These are some of the simple incidents on the stream, which afterwards awaken memories,

"That like voices from afar off

Call to us to pause and listen;

Speak in tones so plain and childlike,

That the ear can scarce distinguish

Whether they are sung or spoken."

But I must start for the open water below-What a glorious haze there is just now, and how demurely the world's great eye peeps through it! Trout are not very shy though, 'before the middle of May, even when the sun is bright. I have sometimes taken my best fish at high noon, at this season of the year.-I am as hungry as a horsefly, though it is only "a wee short hour ayont the twal." So I'll unsling my creel by that big sycamore, and build my fire in the hollow of it. If I burn it down there will be no action for trespass in a wooden country like this.

What boys are those crossing the foot-log? I'll press them into my service for awhile, and make them bring wood for my fire. I know them now; the larger one has cause to remember me "with tears of gratitude," for I bestowed 
on him last summer a score of old flies, a used-up leader, and a limp old rod. He offered me the liberal sum of two shillings for the very implement I have in my hand now; and to buy three flies from me at four cents apiece.-Halloo, Paul! what have you done with the rod I gave you-caught many Trout with it this season? Come over the creek, you and your brother, and get me some dry wood, and gather a handful or two of the furze from that old birch to light it with. I'll give you a pair of flies-real gay ones.

Dining alone may be counted almost the only drawback to one's taking a day to himself, and you are glad of any stray native who is attracted by the smoke of your fire. Your whiskey is beyond a peradventure, better than he has in his cupboard at home: he is invariably out of tobacco-a chew or a pipeful, and a swig at your flask, will make him communicative. If he has not already dined, he will readily accept a roasted Trout and a piece of bread and butter, and while eating will post you as to all the Trout-streams within ten miles.

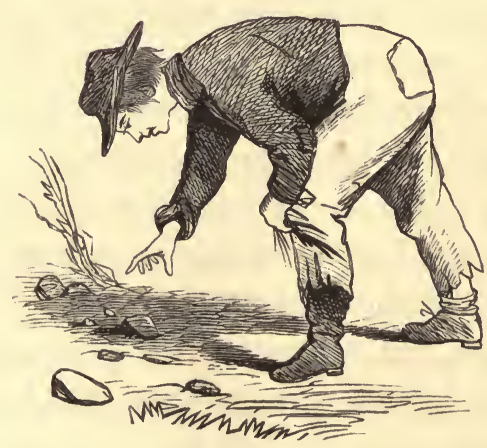

It is, therefore, a matter of policy to cultivate the good feeling of the natives, the boys especially, as stones are of very convenient size along the creek to throw at a surly fisherman. A few of "Conroy's journal-flies," which have 
occupied the back leaves of your fly-book for long years are profitable things to invest in this way, for three boys out of four you meet with, will ask you to sell them "a pair of flyhooks," which of course results in your giving them a brace or so that are a little the worse for wear, or too gay for your own use.

If the fly-fisher, though, would have "society where none . intrudes," or society that won't intrude, let him take a lad of ten or twelve along to carry his dinner, and to relieve him after the roast, by transferring part of the contents of his creel to the empty dinner-basket. The garrulity and queer questions of a country boy of this age are amusing, when you are disposed to talk. Any person who has sojourned at my friend Jim Henry's, and had his good-natured untiring boy Luther for his gilly, will acknowledge the advantage of such a "tail " even if it has not as many joints as a Highland laird's.

If there is an objection to a Trout-roast, it is that a man eats too much, and feels lazy after dinner. But what of that? it is a luxurious indolence, without care for the morrowCare! why, he left that at home when he bought his railroad ticket, and shook off the dust of the city from his hobnailed boots.

What pretty bright Trout there are in this bold rocky creek! it would be called a river in England, and so it is. We Americans have an ugly way of calling every stream not a hundred yards wide, a creek. It is all well enough when the name is applied to some still sedgy water, which loses half of its depth, and three-fourths of its width, at low tide, and is bank-full on the flood. But speckled fellows like these don't live there. De Kay must have received some inspiration at a Trout-roast, when he gave them the specific name of "Fontinalis," and they are truly the Salmon of the fountain; for a stream like this and its little tributaries, 
whose fountains are everywhere amongst these rugged hills, are their proper home. What an, ignorant fellow Poietes was to ask Halieus if the red spots on a Trout were not "marks of disease-a hectic kind of beauty?" Any boy along the creek knows better. And what a pedantic old theorist Sir Humphrey was, to tell him that the absence of these spots was a sign of high condition. Well, it may be in England, for the river Trout there, are a different species from ours. But I'll bet my old rod against a bob-fly that there is twice as much pluck and dash in our little fellows with the "hectic" spots. I don't wonder that Trout like these so inspired Mr. Barnwell, who wrote the "Game Fish of the North," when, with his fancy in high feather, he mounted his Pegasus and went off-"How splendid is the sport to deftly throw the long line and small fly, with the pliant single-handed rod, and with eye and nerve on the strain, to watch the loveliest darling of the wave, the spotted naiad, dart from her mossy bed, leap high into the air, carrying the strange deception in her mouth, and, turning in her flight, plunge back to her crystal home."

Julius Cæsar! what "high-flying" Trout this gentleman must have met with in his time. Now, I never saw a Trout "dart from her mossy bed," because I never found Trout to lie on a bed of that sort; nor "leap high into the air, and turning in her flight plunge back," as a fish-hawk does. In fact, I may safely say I never saw a Trout soar more than eight or ten inches above its "crystal home." I honor "Barnwell" for the Anglomania which has seized him-he has been inoculated with a good scab, and the virus has penetrated his system: but I can't help being reminded by his description, of the eloquence of a member of a country debating society in Kentucky, who commenced- "Happiness, Mr. President, is like a crow situated on some far-distant 
mountain, which the eager sportsman endeavors in vain to no purpose to reproach." And concluded- "The poor man, Mr. President, reclines beneath the shade of some widespreading and umbrageous tree, and calling his wife and the rest of his little children around him, bids their thoughts inspire to scenes beyond the skies. He views Neptune, Plato, Venus, and Jupiter, the Lost Pleides, the Auroly Bolyallis, and other fixed stars, which it was the lot of the immorral Newton first to depreciate and then to deplore."

But a gray-headed man who cannot tie a decent knot in his casting-line without the aid of his spectacles, should forget such nonsense. There is one consolation, however, that this "decay of natur," which brings with it the necessity for glasses in seeing small objects within arm's length, gives in like ratio, the power of seeing one's flies at a distance on the water; there was old Uncle Peter Stewart who could knock a pheasant's head off at fifty yards with his rifle, and see a gnat across the Beaverkill, when he was past sixty.

Here is the sun shining as bright now as if he had not blinked at noon, and such weather, not too hot and not too cold; I must acknowledge, though, my teeth did chatter this morning when I waded across at the ford.

"Sweet day, so cool, so calm, so bright,

The bridal of the earth and sky;

The dew shall weep thy fall to night, For thou must die."

I'll start in here, for it appears there is always luck in the pool or rift under the lee of the smoke where one cooks his Trout. It is strange, too, for it seems natural that the smoke would drive the flies away, and as a consequence the fish get out of the notion of rising. But no matter, here goes. Just as I supposed, and a brace of them at the first cast. Come 
ashore on the sloping gravel, my lively little fellows,-eight and nine inches-the very size for the pan; but who wants to eat fried Trout after cooking them under the ashes or on a forked stick?

There are no good fish here; the water is not much more than knee-deep, and they have no harbor amongst those small pebble-stones. I have thrown in a dozen little fellows within the last ten minutes. I'll go to the tail of that strong rift below the saw-mill. The last time I fished it was when that lean hungry-looking Scotchman came over here from Jim Henry's; he had been sneaking through the bushes and poaching all the little brooks around, where the fish had run up to spawn, with his confounded worm-bait. This stream was low then and the fish shy; I had approached the end of the rift carefully and was trying to raise them at long cast in the deep water, when he-without even saying "by your leave"-waded in within a few yards of where they were rising, and splashed his buck-shot sinker and wad of worms right amongst them. I said nothing, and he did not appear to think that interfering with my sport so rudely was any breach of good manners, or of the rules of fair fishing. A Scotchman, to catch Trout with a worm! Poor fellow! his piscatory education must have been neglected, or he belonged to that school who brag only on numbers. I know a party of that sort who come up here every summer from Easton and bring a sauer-kraut stanner to pack their Trout in, and salt down all they take without eating one, until they get home They catch all they can and keep all they catch, great and small. Bah! a poor little salted Trout-it tastes more like a piece of "yaller soap" than a fish. Such fishermen are but one remove from the bark peelers I found snaring and netting Trout in the still water below here, last August. I can just şee their shanty from here. "Instruments of cruelty are in their 
habitations. O my soul, come not thou into their secret; unto their assembly, mine honor, be not thou united!"

There is the sawyer's dog; if he comes much nearer I'll psychologize him with one of these "dunnicks"! But he turns tail as soon as I stoop to pick one up. Now for it-just at the end of the swift water-ah! my beauty-fifteen inches, by all that is lovely! He threw his whole length out of water -try it again-I can't raise him. This won't do. Am I cold, or am I nervous, that I should shake like a palsied old man because I missed that fish ? Fie on you, Mr. Nestor, you who have run the rapids at the "Rough Waters" on the Nipissiguit, in a birch canoe, with a Salmon at the end of sixty yards of line, and your pipe in your mouth; I thought you had gotten past a weakness of this kind. But it will only make bad worse, and convince that Trout of the cheat to throw over him again; so I must leave him now, and get back to the log on that sunny bank and compose myself with a few whiffs, while I change my flies. It will be just fifteen minutes until I knock the ashes out of my pipe; by that time my vaulting friend will likely forget the counterfeit I tried to impose on him, if I offer him something else.

Now Dick gave me this for a meershaum, and I have no doubt Mr. Doll sold it for one in good faith; but it is a very "pale complected" pipe for one of that family. I have smoked it steadily for a year, and there is only the slightest possible tinge of orange about the root of the stem. It is hardly as dark as this ginger hackle in my hat-band. However, it is light, and carries a big charge for a pipe of its size, and the shortness of the stem brings the smoke so comfortably under the nose-a great desideratum in the open air. The pipe must have been instituted expressly for the fisherman; it is company when he is lonesome, and never talks when he wants to be quiet; it concentrates his ideas and assists his judgment 
when he discusses any important matter with himself, such as the selection of a killing stretcher. No wonder the Indians smoked at their council-fires; and, as for the nerves, I'll put it against Mrs. Winslow's soothing syrup. What a pity it is that infants are not taught to smoke! What shall my stretcher be; that fish refused Hofland's Fancy; now let me try one of my own fancy. Here is something a great deal prettier; a purple body in place of a snuff-brown, and light wings from a lead-colored pigeon instead of a sober woodcock feather. What a pretty fly-half sad, half gay in its attire, like an interesting young widow, when she decides on shedding her weeds, and "begins to take notice." I'll change my dropper also-here it is; body of copper-colored peacock hurl, wings of the feather of an old brown hen, mottled with yellow specks. What a plain homely look it has; it reminds me of "the Girl with the Calico Dress." You are not as showy, my dear miss, as the charming little widow, but certain individuals of my acquaintance are quite conscious of your worth. Let me see which of you will prove most attractive to my speckled friend. So here goes - two to one on the widowlost, by jingo! He looked at her and sailed slowly away. Has he ever heard of the warning that the sage Mr. Weller gave his son "Samivel ?" Perhaps, then, he will take a notion to "the girl with the calico dress." Once more-now do take care! Ah ha! my old boy, you would be indiscreet, after all, and the widow has victimized you. Now she'll lead you a dance! Don't be travelling off with her as if you were on your wedding tour, for I know you would like to get rid of her already; but there is no divorce beneath the water,-you are mine, says she, "until death us do part!"

There you are, now! the three-minutes' fight has completely taken the wind out of you. That's the last flap of your tail; the widow has killed you "as dead as a mackerel." Acting 
the gay Lothario, were you? I know some scaly old fellows who play the same game ashore, stealthily patronizing Mrs. Allen, subsidizing the tailor, bootmaker, dentist, and barber, and slyly endeavoring to take off a discount of twenty-five per cent. from old Father Time's bill. But that won't do, for folks of any discernment know at a glance those spavined, short-winded, shaky old fellows, who trot themselves out, as if they were done-up for the horse-market. Lie there, my Turveydrop, until I move down a little, and try under the bushes, on the opposite side.

With this length of line I can just come close enough to the alders to miss them. Dance lightly, O my brown girl, and follow in her wake, dear widow, as I draw you hitherward. Ah, ha! and so it is : there is one dashing fellow who sees charms in your homely dress. How he vaults!-nine rails, and a top rail! Did you ever know Turner Ashby? Not Beau Turner-I mean Black Turner. Did he ever straddle a bit of horse-flesh with more mettle? None of your Conestogas. There he goes again! How long have you belonged to the circus? But he can't run all day at that gait; he begins to flag, at last, and here he is now, coming in on the "quarter stretch." There you are, at last-died as game as a Dominica chicken. Once more, now. I knew it.-And again.

Three times my brace of beauties have come tripping home across the deep whirling rapid, and three bright Trout lie ou the gravel behind me. I begin at last to long for the sound of some friendly voice, and the sight of a good-humored face. I must keep my appointment with Walter at the foot-bridge; so I am off. Some of the "Houseless" don't like this solitary sport. I know one of them who would as soon be guilty of drinking alone; but he is not a contemplative angler, and has never realized how hungry some folks get through the winter 
for a little fishing. May-be he has never read what Williain Howitt says, in his "Rural Life in England," about fishing alone. It will come home to every quiet fly-fisher. See what an unveiling of the heart it is, when the angler is alone with God and Nature.

"People that have not been innoculated with the true spirit may wonder at the infatuation of anglers-but true anglers leave them very contentedly to their wondering, and follow their diversions with a keen delight. Many old men there are of this class that have in them a world of science-not science of the book, or of regular tuition, but the science of actual experience. Science that lives, and will die with them; except it be dropped out piecemeal, and with the gravity becoming its importance, to some young neophyte who has won their good graces by his devotion to their beloved craft. All the mysteries of times and seasons, of baits, flies of every shape and hue; worms, gentles, beetles, compositions, or sub. stances found by proof to possess singular charms. These are a possession which they hold with pride, and do not hold in vain. After a close day in the shop or factory, what a luxury is a fine summer evening to one of these men, following some rapid stream, or seated on a green bank, deep in grass and flowers, pulling out the spotted Trout, or resolutely but subtilely bringing some huge Pike or fair Grayling from its lurking place beneath the broad stump and spreading boughs of the alder. Or a day, a summer's day, to such a man, by the Dove or the Wye, amid the pleasant Derbyshire hills: by Yorkshire or Northumbrian stream; by Trent or Tweed; or the banks of Yarrow; by Teith or Leven, with the glorious hills and heaths of Scotland around him. Why, such a day to such a man, has in it a life and spirit of enjoy. ment to which the feelings of cities and palaces are dim. The heart of such a man-the power and passion of deep felicity 
that come breathing from mountains and moorlands; from clouds that sail above, and storms blustering and growling in the wind; from all the mighty magnificence, the solitude and antiquity of Nature upon him-Ebenezer Elliott only can unfold. The weight of the poor man's life-the cares of poverty-the striving of huge cities, visit him as he sits by the beautiful stream-beautiful as a dream of eternity, and translucent as the everlasting canopy of heaven above him; - they come, but he casts them off for the time, with the power of one who feels himself strong in the kindred spirit of all things around; strong in the knowledge that he is a man; an immortal-a child and pupil in the world-school of the Almighty. For that day he is more than a king-he has the heart of humanity, and faith and spirit of a saint. It is not the rod and line that floats before him-it is not the flowing water, or the captured prey that he perceives in those moments of admission to the heart of nature, so much as the law of the testimony of love and goodness written on everything around him with the pencil of Divine beauty. He is no longer the wearied and oppressed-the trodden and despised-walking in threadbare garments amid men, who scarcely deign to look upon him as a brother man-but he is reassured and recognised to himself in his own soul, as one of those puzzling, aspiring, and mysterious existences for whom all this splendid world was built, and for whom eternity opens its expecting gates. These are magnificent speculations for a poor, angling carpenter or weaver; but Ebenezer Elliott can tell us that they are his legitimate thoughts, when he can break for an instant the bonds of his toiling age, and escape to the open fields. Let us leave him dipping his line in the waters of refreshing thought."

'Thus writes William Howitt. But there is the foot-bridge, and here are my little friends, the Sand-pipers. How often 
the fly-fisher sees them running along the pebbly margin of the Trout stream (as Wilson truly says), "continually nodding their heads;" sometimes starting with their peculiar short shrill note, from their nests in the wave-washed tufts of long grass, flapping along the creek sideways, as if wounded in leg or wing, to decoy the fancied destroyer from the nest of downy little snipelings. And there, where the waters of the noisy rapid finds rest in the broad shallow below, is one perched on a big gray boulder, as gray as herself. How lonely she seems there, like the last of her race, were it not that her constant mate is on the strand below, busily engaged picking up larva and seedling muscles for its little ones in the nest up the creek.

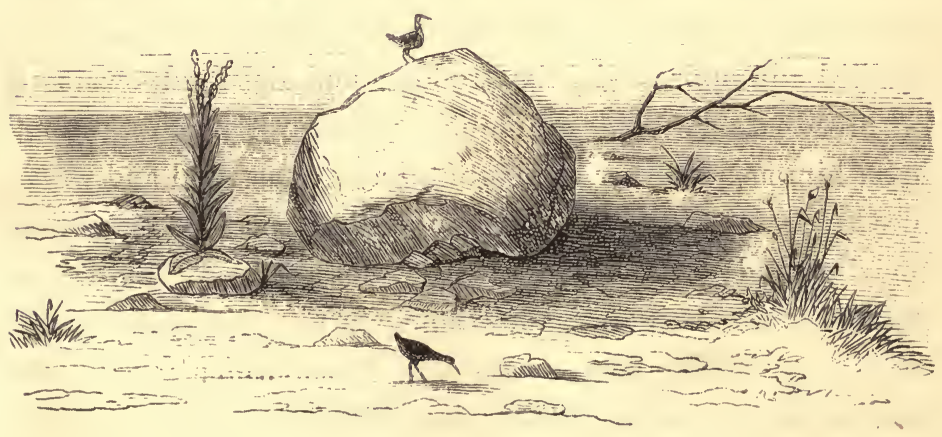


THE ANGLER'S SABBATH. 
"The first men that our Saviour dear Did choose to wait upon Him here

Blest fishers were, and fish the last Food was that $\mathrm{He}$ on earth did taste; I therefore strive to follow those, Whom He to follow Him hath chose."

Waltox. 


\section{THE ANGLER'S SABBATH.}

How peacefully the Sabbath dawns on the weary angler! Whether he is sojourning within sound of the hoarse breakers, or amongst the mountains of a rugged Trout country.

If at some ocean watering-place, after his refreshing bath in the surf, and his breakfast, if there be no place of public worship near, he whiles away the day as he best can. Strolling along the sea-shore, picking up smooth-worn shells and bright pebbles, and scaring the little snipe that follow the retreating rollers to catch the marine insects they leave, or ply their spindle-shanks shoreward, as they are chased up the beach by the incoming surf. Or he walks along the bay-shore, flushing the curlew and willet, and startling the colonies of busy little fiddler crabs on the muddy flats, each one apparently shouldering its big hind-leg, as it scrambles away to its smoothly-burrowed hole.

If in a Trout country, the day is ushered in with the singing of birds, and God's blessed sunshine lighting up the sides of the hills, and pervading his heart. If he rises late, it is because he is stiff from wading the rough stream the day before; perhaps he has a few bruises on his shins, but a good breakfast and a little exercise after it, supple his joints and rejuvenate him. The creels have been washed, and hang against the sunny side of the house, and the rods rest in the outer angle of the chimney, or on wooden pegs along the sides of the porch. The sight of the biggest Trout at break. 
fast acts as a reminder of some of the ludicrous mishaps of yesterday, and good-natured repartee and jest give a zest to the meal. Some remember the commandment-" In it thou shalt not do any work," and get ready to go to meeting with the hostess or the girls; while others take a quiet stroll through the woods, or along the stream, and see sights and hear sounds that come back to them at times, amid the busy hum of the dense city, like "far-off murmurs, gentle whispers."

But the girls are waiting, dressed in their Sunday gear. You would scarcely know Kate for the naked-ankled lass you saw milking as you came in last evening; and there is Hans and his dog "Watch," all ready to start. There is no. chancelled or steepled church here, so we walk a mile or two down the creek to the township school-house, where sturdy farmers, gaunt raftsmen, staid matrons, and "unco lads and clever hizzies" sit waiting in silence the coming of the circuit preacher.

All is peace within; the only thing that betokens discord without, is a disposition of "Watch," and Captain Ellis's dog "Top," to renew an ancient feud, which might involve "Cæsar," who stands by with tail erect, bristling in armed neutrality, but ready to take sides with the party that proves strongest: this of course would wake up the pugnacity of a pompous little fellow with his tail curled over his back so stiffly that his hind feet scarcely touch the ground; even the "bench-legged fice," and the sheep-stealing-looking "yaller dog," with his bushy associate, who has been curtailed of his "fair proportions" so close to his hurdies, that it is difficult to say whether it has been "cut off or druv in;" the lapeared hound would also pitch in, and there would be no preventing a free fight. But Hans calls Watch off, and as he slinks under the bench by his side, the casus belli is removed. 
Let us follow Watch, and enter the log school-house. How the primitive institoot brings back recollections of the time when we walked two or three miles to an old field-school, and carried our dinners in a basket! Its very smell. is familiar; the long slab benches, just such as we used to polish with our corduroy trousers, and carve the initials of our sweethearts' and our own name on; the wooden pegs like those we hung our hats and bonnets on; the teacher's desk, and the long low windows, of the same pattern they were forty years ago; and there is the old ten-plate wood-stove standing in the middle of the floor, with its side-doors off the hinges, so like the one we used to toast our bread or fry our bacon on, at playtime, and, when the master was not looking, spit against during school-hours, to see it dance and sizzle. Let us read the maker's name on the side-plate-" Reuben Trexler-Mary Ann Furnace." What an affectionate way those old ironmasters had, of naming their furnaces after their wives or some favorite daughter! I never read any other than a feminine name on a ten-plate stove. I don't believe there ever was a male furnace, at least there were none when I was a boy; but there was "Rebecca Furnace," or "Mary Ann Furnace," or "Maria Furnace," or "Isabella Furnace," or "Sarah Ann Furnace." It was always some dear woman's name that appeared on the hard black side-plates.

What delays the preacher? he is fifteen minutes behind time! Perhaps his horse is grass-fed, and he remembers on this warm June morning, that "the merciful man is merciful to his beast," and rides slowly; or the fair sisters at old brother Ezra's, where he stayed all night, twelve miles away, have been a little sweet on the young preacher, and he sat longer over his coffee than usual. The company are getting restless; there is a frequent "ahem !" from the women, and the little boys are munching maple-sugar, or indulging 
in a sly game of heads and points with crooked pins, to while away the time. But Captain Ellis, appreciating this state of "public feeling," likè a considerate brother, strikes up-with only a slight nasal twang in his big manly voice-that grand old hymn,

"When all thy mereies, 0 my God,

My rising soul surveys,

Transported with the view I'm lost

In wonder, love, and praise."

Ail join in, and, as the hymn closes, the minister enters. The gospel of peace and salvation is preached, and we say amen to the closing prayer, that it may accomplish that "whereunto it is sent."

The service over, there is kindly greeting of neighbors; perhaps some talk about "craps" and lumber, and then the homeward walk.

After dinner and a nap, we take a walk to the falls, or the pigeon-roost; and on our return, as we come down the creek, we see the diverging circles dimpling the still pools as the Trout quietly rise and take in the little yellow ephemera that fly over us, and settle on the water.

In the evening one of the brethren reads from his pocket edition of Walton, the discourse on thankfulness, delivered by Father "Izaak," to his friend Venator, as he was journeying towards Tottenham High-Cross; which we here insert for the perusal of all anglers, who "Remember to keep the Sabbath day holy."

"Well, Scholar, having now taught you to paint your rod, and we having still a mile to Tottenham High-Cross, I will, as we walk towards it, in the cool shade of this sweet honeysuckle hedge, mention to you some of the thoughts and joys 
that have possessed my soul since we two met together. And these thoughts shall be told you, that you also may join with me in thankfulness to the Giver of every good and perfect gift for our happiness. And, that our present happiness may appear to be the greater, and we the more thankful for it, I will beg you to consider with me, how many do, even at this very time, lie under the torment of the stone, the gout, and toothache; and this we are free from. And every misery that I miss is a new mercy; and therefore let us be thankful. There have been, since we met, others that have met disasters of broken limbs; some have been blasted; others thunder-strucken; and we have been freed from these, and all those many miseries that threaten human nature: let us therefore rejoice and be thankful. Nay, which is a far greater mercy, we are free from the unsupportable burthen of an accusing tormenting conscience, a misery that none can bear; and therefore let us praise Him for his preventing grace; and say, Every misery that I miss is a new mercy. Nay, let me tell you, there be many that have forty times our estates, that would give the greatest part of it to be healthful and cheerful like us; who, with the expense of a little money, have ate and drank, and laughed, and angled, and sung, and slept securely; and rose next day, and cast away care, and sung, and laughed, and angled again; which are blessings rich men cannot purchase with all their money. Let me tell you, Scholar, I have a rich neighbor, that is always so busy that he has no leisure to laugh; the whole business of his life is to get money, and more money, that he may still get more and more money; he is still drudging on, and says, that Solomon says, "The diligent hand maketh rich;' and it is true indeed; but he considers not that it is not in the power of riches to make a man happy; for it was wisely said, by a man of great observation, "That there be 
as many miseries beyond riches, as on this side them :' and yet Grod deliver us from pinching poverty; and grant, that having a competency, we may be content and thankful. Let not us repine, or so much as think the gifts of God unequally dealt, if we see another abound with riches; when, as God knows, the cares, that are the keys that keep those riches, hang often so heavily at the rich man's girdle, that they clog him with weary days and restless nights, even when others sleep quietly. We see but the outside of the rich man's happiness; few consider him to be like the silkworm, that, when she seems to play, is, at the very same time, spinning her own bowels, and consuming herself. And this many rich men do; loading themselves with corroding cares, to keep what they have, probably, unconscionably got. Let us, therefore, be thankful for health and a competence, and above all, for a quiet conscience.

"Let me tell you, Scholar, that Diogenes walked on a day, with a friend, to see a country fair; where he saw ribbons, and looking-glasses, and nut-crackers, and fiddles, and hobbyhorses, and many other gimcracks; and having observed them, and all the other finnimbruns that make a complete country fair; he said to his friend, 'Lord, how many things are there in this world of which Diogenes hath no need!' And truly it is so, or might be so, with very many who vex and toil themselves to get what they have no need of. Can any man charge God, that he hath not given him enough to make his life happy? No, doubtless; for nature is content with a little: and yet you shall hardly meet with a man that complains not of some want; though he, indeed, wants nothing but his will, it may be nothing but his will of his poor neighbor, for not worshipping, or not flattering him: and thus, when we might be happy and quiet, we create trouble to ourselves. I have heard of a man that was angry 
with himself because he was no taller, and of a woman that broke her looking-glass because it would not show her face to be as young and handsome as her next neighbor's was. And I knew another, to whom God had given health and plenty, but a wife that nature had made peevish, and her husband's riches had made purse-proud, and must, because she was rich, and for no other virtue, sit in the highest pew in the church; which being denied her, she engaged her husband into a contention for it, and at last into a lawsuit with a dogged neighbor, who was as rich as he, and had a wife as peevish and purse-proud as the other: and this lawsuit begot higher oppositions, and actionable words, and more vexations and lawsuits; for you must remember that both were rich, and must therefore have their wills. Well, this wilful purse-proud lawsuit lasted during the life of the first husband; after which his wife vexed and chid, and chid and vexed, till she also chid and vexed herself into her grave: and so the wealth of these poor rich people was curst into a punishment, because they wanted meek and thankful hearts; for those only can make us happy. I knew a man that had health and riches, and several houses, all beautiful and ready furnished, and would often trouble himself and family to be removing from one house to another; and being asked by a friend, why be removed so often from one house to another, replied, 'It was to find content in some of-them.' But his friend, knowing his temper, told him, if he would find content in any of his houses, he must leave himself behind him: for content will never dwell but in a meek and quiet soul. And this may appear, if we read and consider what our Saviour says in St. Matthew's Gospel ; for he there says, - Blessed be the merciful, for they shall obtain mercy. Blessed be the pure in heart, for they shall see God. Blessed be the poor in spirit, for theirs is the kingdom of heaven. 
And, Blessed be the meek, for they shall possess the earth.' Not that the meek shall not also obtain mercy, and see God, and be comforted, and at last come to the kingdom of heaven; but in the mean time he, and he only, possesses the earth as he goes toward that kingdom of heaven, by being humble and cheerful, and content with what his good God has allotted him: he has no turbulent, repining, vexatious thoughts that he deserves better; nor is vexed when he sees others possessed of more honor or more riches than his wise God has allotted for his share; but he possesses what he has with a meek and contented quietness, such a quietness as makes his very dreams pleasing both to God and himself.

"My honest Scholar, all this is told to incline you to thankfulness: and to incline you the more, let me tell you, that though the prophet David was guilty of murder and adultery, and many other of the more deadly sins; yet he was said to be a man after God's own heart, because he abounded more with thankfulness than any other that is mentioned in holy Scripture, as may appear in his book of Psalms; where there is such a commixture of his confessing of his sins and unworthiness, and such thankfulness for God's pardon and mercies, as did make him to be accounted, even by God himself, to be a man after his own heart. And let us. in that, labor to be as like him as we can: let not the blessings w e receive daily from God, make us not to value, or not praise him, because they be common; let not us forget to praise him for the innocent mirth and pleasure we have met with since we have met together. What would a blind man give to see the pleasant rivers, and meadows, and flowers, and fountains, that we have met with since we met together? I have been told, that if a man, that was born blind, could obtain to have his sight, for but only one hour during his whole life, and should, at the first opening of his 
eyes, fix his sight upon the sun when it was in his full glory, either at the rising or setting of it, he would be so transported and amazed, and so admire the glory of it, that he would not willingly turn his eyes from that first ravishing object, to behold all the other various beauties this world could present to him. And this, and many other like blessings, we enjoy daily; and for most of them, because they be so common, most men forget to pay their praises : but let not us; because it is a sacrifice so pleasing to him that made that sun and us, and still protects us, and gives us flowers, and showers, and stomachs, and meat, and content, and leisure to go a fishing.

"Well, Scholar, I have almost tired myself, and, I fear, more than almost tired you: but I now see Tottenham HighCross; and our short walk thither shall put a period to my too long discourse; in which my meaning was, and is, to plant that in your mind, with which I labor to possess my own soul; that is, a meek and thankful heart. And, to that end, I have showed you that riches without them do not make any man happy. But let me tell you, that riches with them remove many fears and cares; and therefore my advice is, that you endeavor to be honestly rich, or contentedly poor: but be sure that your riches be justly got, or you spoil all. For it is well said by. Caussin, "he that loses his conscience, has nothing left that is worth keeping.' Therefore be sure you look to that. And, in the next place, look to your health: and if you have it, praise God, and value it next to a good conscience; for health is the second blessing that we mortals are capable of, a blessing that money cannot buy; and therefore value it, and be thankful for it. As for money, which may be said to be the third blessing, neglect it not: but note, that there is no necessity of being rich; for I told you, there be as many miseries beyond riches, as on this side them: and, if you have a competence, enjoy it with a 
meek, cheerful, thankful heart. I will tell you, Scholar, I have heard a grave divine say, that God has two dwellings, one in heaven, and the other in a meek and thankful heart. Which Almighty God grant to me and to my honest Scholar; and so you are welcome to Tottenham High-Cross." * * *

"'Let every thing that hath breath praise the Lord:' and let the blessing of 'St. Peter's Master be with mine.

"And upon all that are lovers of virtue; and dare trust in his Providence, and be quiet, and go a-angling."

May no true angler forget to praise God for his blessings "because they are so common;" for "it is a sacrifice so pleasing to him, who made the sun and us, and still protects us, and gives us flowers, and showers, and stomachs, and meat, and content, and leisure to go a-fishing."

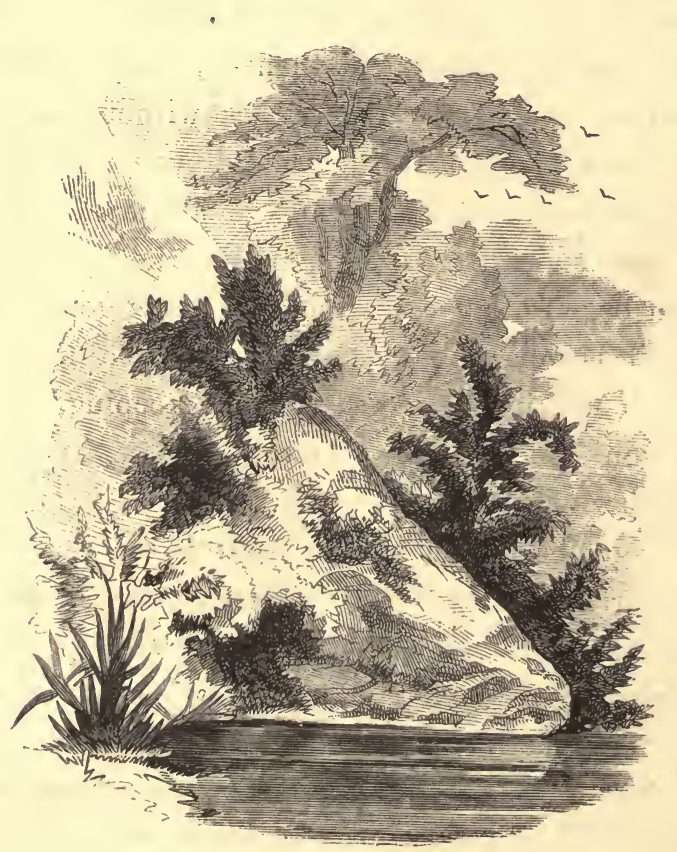




\section{CONCLUSION.}

ONE who has had the patience to read the foregoing pages consecutively through, has no doubt observed, that in several instances I have repeated in a special way, much in word or substance that I had said in a preceding chapter, or in a general way. As an example, I have had occasion to refer to the manner of propagation with fishes in no less than four distinct articles; either of which would have been incomplete, or lacking the interest it was entitled to, had I omitted to do so. Again, there are certain sporting or rather angling terms which I have unavoidably reiterated.-I hope the reader will not regard such repetitions as blunders, for I am deeply conscious that in this my first and likely my last attempt at writing for publication, there are enough real.sins of omission and commission in my compositions to answer for; even after adopting the hints and suggestions of the friend with whom I have read the proof-sheets.

Readers are not generally aware of the obligations we authors are under to honest, careful proof-readers, and how much bad grammar, bad spelling, and imperfect composition would be inflicted on them, were our productions sent forth without being cauterized and plastered by them. I am indebted to the firm who stereotyped these pages, not only for their aid in this respect, but for the tasteful and judicious arrangement of the book. The junior member of the firm (being one of our craft) has taken an especial interest in the respectability of its appearance, In fact his solicitude on this score has even been exhibited at times in an unamiable manner. For instance, in reading some of the earlier proofsheets, he would abruptly ask me, how many times in a single 
chapter I intended to accuse the City Gas-Works of having spoiled the fishing in the Schuylkill? or, how many friends I had on whose statements I could rely? or how many times in my article on Fly-Fishing, I intended to use the term "spring of the rod," on a single page? He has even been so regardless of my feelings, as to ridicule my drawing of the Black Bass, on page 103, saying, that he always felt an inclination to stick a "quid" in its mouth; and laughed outright, when I tried to explain that the expression of that feature was intended to make the fish look gay.-I hope the reader will regard my deficiencies as artist or author with more leniency.

If I have at times laid down rules at variance with the practice of experienced anglers, I would suggest, that there may be more than one process of accomplishing the same thing. With a certain class of fishers it may be, that

The very head and front of my offending

Hath this extent, no more-

that I have in as strong language as I could decorously use, condemned unfair and unsportsmanlike angling, and held up to scorn the mere Pot-fisher and Snob. If such be the case I am content. "It is a very pretty quarrel as it stands," but to every HoNest ANGLER-whether a fly-fisher or a baitfisher, adept, or struggling with adverse circumstances in his efforts to reach the higher branches of the art, I tender my sincerest sympathies.

And now, dear Reader, may you by keeping a conscience void of offence, keep at peace with yourself and

The Author. 


\section{N D E X.}

Abloden grunniens, 122.

Alosa præstibilus, 171.

Anglers' Sabbath, 589.

Angler, What and who is an angler ? 29.

The Fussy Angler, 30.

The Snob Angler, 30.

The Greedy Pushing Angler, 30.

The Spick and Span Angler, 30.

The Rough and Ready Angler, 30.

The Literary Angler, 30.

The Pretentious Angler, 31.

The Shad-roe Fisherman, 31.

The English Admiral an Angler, 33.

Angling, its harmonizing influences, 27.

Recollections of, in boyhood, 28.

Its after influences on manbood, 29.

Its social tendency, 29.

Anguilla communis, 186.

Aquarium, 483.

Artificial Fish-Breeding, 459, 464.

Hatching Troughs, 468, 471.

Expressing the Spawn, 469.

Treatment of Fecundated Eggs, 475.

Food for Young Trout, 479.

Back's Grayling, 259.

Bait, Fishing for Trout, 272.

Barb, or Kingfish, 286.

Barthrolomœus pampanus, 298.

Bass. Black, of the Lakes, 103.

Trolling for, 105.

Fresh Water of the South and West, 99.

Oswego, 110.

Striped, or Rockfish, 110.

Striped of the Ohio, 108.

Short Striped, 109.

White of the Lakes, 97.

Blackfish, 300.

Bluefish, or Snapping Mackerel, 294.

Bream, 118.
Brook Trout, Scientific description, 194.

Habits and manner of breeding, 195.

Growth of, 196.

Difference in the size of, 196.

Effect of light and water on, 199.

Errors in regard to new species, 199.

Food of, 200.

Geographic range of, 202.

Large size of, 204.

Former abundance and cause of decrease, 202.

Buffalo Fish, 155.

Buffalo Perch, 122.

Camping on the River, 368 .

Camp Equipage, 368 .

Cooking Utensils, 371.

Clothing, 321.

Stores for, 371.

Canadian Trout, 238.

Capelin, 267.

Carp Family, 153.

Casting the fly-

For Trout, 327.

For Salmon, 356 .

Catfish and Eels, 177.

Catfish, extract from Iconographic Encyclopædia, 177 .

Catfish of Atlantic and Western States, 180.

Care for the young, 182.

Catostomus babulos, 155.

"6 communis, 154.

Clupeidæ, 165.

Chamberlain, John, 392.

Chub, Errors in regard to size of, 157. An annoyance to Fly-Fishers, 158.

Chub-Fishing on the Brandywine, 159.

Umbrella invented by a Chub-fisherman, 160. 
Cooking Fish. See the conclusion of article on each fish described.

Cooking Salmon on the river, 372 .

To boil, 372 .

To broil, 372.

Cold, 372.

Soused, 373.

To bake Grilse, 373.

Cooking Trout on the stream, 497.

Coregonus albus, 269.

Corvina ocellata, 293.

Croaker, 291.

Cybium maculatum, 296.

Cyprinidæ, 153.

Dies Piscatoria, 489.

Houseless Anglers, 490.

Introductory Remarks, 491.

Noonday Roast, 497 .

First Nooning, 503.

Second " 513.

Third "531.

Fourth " 547.

Fly-Fishing alone, 567.

The Anglers' Sabbath, 589.

Conclusion, 599.

Drumfish, 299.

Eels, observations on, 183.

The Lamprey, 183.

The Electric, 184.

The Common, 186.

Esox lucioides, 131.

estor, 135.

vittatus, 118.

Fall fish, 157.

Fish-Breeding, 460 .

Artificial, 464.

Fish, Definition of, 39 .

General remarks on, 39 .

Origin and order in Creation, 40.

Natural mode of propagation, 41.

Habits as regards maternity, 43 .

Migration of, 45 .

Vitality of, 47.

External organs of, 51 .

Internal organization of, 52 .

Travelling on land, 50 .

Mucous secretion on, its use, 54.

Teeth of, 54 .

Fish-Ponds. Manner of stocking them by ova left in the soil, 48,461 .

Flies for Trout, 312.

" "Salmon, 350.

Flounder, 299.
Fly-Making, 419.

Implements for, 420 .

Materials for, 421,423 .

Making hackles, 429.

Winged flies, 434 .

Frost fish, 309 .

Gangs for trolling, 409.

Gar fish, 128.

Goody, 283.

Great Lake Pickerel, 131.

Great Lake Trout, 250.

Manner of taking them, 251.

Grilse, 229.

Grystes salmoides, 99 .

" nigricans, 103.

Gymnotidæ, 184.

Hans Breitmann's Barty, 527.

Hérring Family, remarks on, 155.

Great abundance in United States, 170.

Hooks, 64.

Houseless Anglers, account of, 490.

Ichthy ology, 56 .

Iron-wood, 442.

Jackfisb, 130.

Jack fishing in Eastern Virginia, 144.

Kingfish, 286.

Knots, 409 .

Labrax albidus, 97.

Labrax lineatus, 81 .

Labrax pallidus, 90 .

Leaders, 69 .

Leiostomus obliquus, 289 .

Lesser Lake Trout, 255.

Trolling for, 256 .

Leucosomus nothus, 157.

Lines, 70, 312, 349.

Long Beach, 278.

Loops, 406.

Lucioperca Americana, 120.

Mallotus villosus, 267.

Mascalonge, 135.

Micropogon undulatus, 291.

Mingan River, 386.

Mirimichi, 388 .

Moisie River, 385

Fishing in, 384.

Mosquitoes, protection against, 369 .

Mullet, 300.

Murænidæ, 183. 
New Brunswiok, rivers of, 386.

Nigger Gen'ral, The, 541.

Nipissiguit River, 390.

Noonday Roast, The, 497.

Nooning, 1st, 503.

$$
\begin{array}{ll}
\text { “ } 2 \mathrm{~d}, 511 . \\
\text { “ } 3 \mathrm{~d}, 529 . \\
4 \mathrm{th}, 545 .
\end{array}
$$

Ohio Salmon, 120.

Osmerus viridesoens, 263.

0 tolithus regalis, 283 .

Pagrus argyrops, 301.

Perca flavescens, 114.

chrysops, 108.

Perch Family, 77.

Perch, White, 90.

¿Yellow barred, 114.

Buffalo, 122.

Fishing, 92.

Chinkapin, 111.

Percidæ, remarks on, 77.

Great numbers of American species, 77.

Paucity of European species, 78.

Distinguishing marks of, 78 .

Migratory habits, 79 .

Petromyzontidæ, 183.

Pickerel, Great Northern, 131.

Trolling for, 133.

Pigfish, 289.

Pike Family, 127.

Remarks on, 127.

Pond, 138.

Great Blue, 147.

Little, of Long Island, 147.

Streaked, of the Ohio, 148.

Fishing, 139.

Trolling for, 139.

Fishing in Eastern Virginia, 143.

Pliny's, 129.

Gesner's, 129.

Pike Perch, 120.

Pogonias cromis, 299.

Pomoxis hexicanthus, 111.

Pomotis vulgaris, 115.

Porgy, 301.

\section{Receipts, 410.}

Dyeing gut, 410.

Feathers and dubbing, 411.

Preparing Salmon lines in oil, 349.

Redfish of the Gulf of Mexicu, 293.

Reels, 71, 312, 348.
Repairs, 407, 408.

Roach and Roach-fishing, 161.

Rockfish, 81 .

Rock-fishing on the Lower Rappahis?. nock, 87.

Rod-Making,

Wood and cane used for, 442.

Tools used in, 443.

To make a fly-rod, 444.

To make a tip, 445.

To stain, oil, and varnish, 445 .

Wrapping, splicing, \&c., 447.

To make a rent and glued tip, 448.

Fly-rod adjusted for light or beavy fishing, 452.

Ferules, 452.

Rods, 72, 308, 345 .

Sac-à-lai, 111.

Saguenay River, 381.

Salmon-Fishing.

Tackle for.

Rods, 345.

Reels, 348.

Reel lines, 349.

How to prepare lines in oil, 349 .

Casting lines, 350.

Flies, 350 .

Materials for Salmon flies, 352.

Flies for rivers of New Brunswick, 353 .

Flies for rivers of Canada, 355 .

Casting the Fly-

Theory and practice, 356.

Compared with Trout-fishing, 357.

The straight cast described, 358.

Casting over the left shoulder, 361 .

Casting in difficult places, 361 .

Casting in an unfavorable wind, 362 .

Striking and playing a Salmon, 364.

Gaffing, 367 .

Salmon, former abundance in the Tnited States, 206. Great numbers in California, Oregon, and the British Possessions, 208.

Decline of Salmon fisheries, 209.

Scientific description, 211.

Natural process of propagation, 212.

Growth of the young, 222.

Grilse, 229.

Mature, 231.

Size of, 232, 233.

Instinct of, 233.

Migration of, 234.

Leaps of, 235. 
Food of, 234, 236.

Dwarf, of the St. Croix, 248.

Cooking, on the river, 372.

Law and custom of the river, 374 .

Rivers of British Provinces, 380. Salmonidæ, Salmon Family, 191.

Remarks on, 191.

Silmo salar, 206.

Canadensis, 238.

Gloveri, 248.

Namaycush, 250.

Adirondakus, 255.

Fontinalis, 194.

Salt Water Fishing-Introductory rcmarks, 277.

Sheepshead, 279.

Weakfish, or Salt-water Trout, 283.

Barb, or Kingfish, 296.

Spot, Pigfish, or Goody, 289.

Croaker, 291.

Redfisb, 293.

Bluefish, 294.

Spanish Mackerel, 296.

Pompano, 298.

Drumfish, 299.

Flounder, 299.

Sea Bass, 300.

Blackfish, 300 .

Mullet, 300.

Tom Cod, or Frostfish, 301.

Porgy, 301.

Sammy Shourds, 278.

Sandre, 121.

Sargus oris, 279 .

Scientific Terms :-

Acanthopterygii, 56 .

Ctenoids, 40.

Cycloids, 40.

Malacopterygii, 56 .

Thoracii, 57.

Abdominal, 57.

Placoids, 40.

Ganoids, 40.

Schoodic Trout, 248.

Fishing for them, 249.

Scouring earth-worms, 273.

Sea-bass, 300.

Shad, delicacy as food, 171.

Migratory babits, 172 .

Taken with a minnow, 173.

Shad-roe as bait, 174.

Sheepshead, 279.

Sinkers, 68.

Smelt-Great numbers of-on Northern Coast, 265.
In Schuylkill and Raritan, 263.

Quantity sent South, from Boston, 265.

Used as a fertilizer, 265.

Cooking, 266.

Snapping Mackerel, 294.

Snoods, 68.

Spanish Mackerel, 296.

Splicing, 407, 408.

Spot, 289.

St. Margaret River, 381 .

Stores for camping out, 371 .

Sucker, 154.

Sunfish, or Sunny, 115.

Swivels, 68.

Tackle in general, 63.

Temnodon saltator, 294.

Tent, 368.

Thymallus signifer, 259.

Tom-Cod, 301.

Trout-fishing in Hamilton County, New York, 503.

In New Hampshire, 513.

In the regions of Lake Superior, 531 .

In the Adirondacks, 547 .

Trout Fly-fishing-Outfit and tackle.

Wading jacket, 305 .

Trousers, 305 .

Boots, 305.

Creel or basket, 306 .

Landing net, 306.

Rods, 308.

Reels, 311.

Lines, 312.

Leaders, 312.

Flies, 312.

The whip, 321.

The Stream-Casting the Fly, 327.

Theory of strict imitation, 334 .

Striking and killing a fish, 335 .

Likely places, and how to fish them, 337.

Umbrina nebulosa, 286.

Wax, 415.

Waxing silk and thread, 405.

Weakfish, 283.

Whitefish, 269.

Value as food, 270.

How taken, 270.

Habits, 271. 



RETURN TO the circulation desk of any University of California Library or to the

NORTHERN REGIONAL LIBRARY FACILITY Bldg. 400, Richmond Field Station University of California Richmond, CA 94804-4698

ALL BOOKS MAY BE RECALLED AFTER 7 DAYS

- 2-month loans may be renewed by calling (510) 642-6753

- 1-year loans may be recharged by bringing books to NRLF

- Renewals and recharges may be made 4 days prior to due date.

DUE AS STAMPED BELOW

\section{JAN 7 १997}

\section{RETURNED}

\section{JU 101997}

nant- C. "ibn 


\section{AN ANGLER'S RHYME.}

T WROTE you, last Easter, a welcome to spring,

When I opened my window, and heard the birds sing, But alas! by the movable feasts of the Church, The poor bluebirds this year are quite left in the lureh?

I have seen one stray robin around the back door, Looking lonesome, like "Oliver asking for more," And a blue bird's reported, but then I must say, That the neighbor, who spoke of it, thought 'twas a jay!

I have heard but one bird song, and that from the kitchen, And its notes were more piercing and clear than bewitching. For they came from a bantam, who nearly got froze In a livels March blizzard, which crippled his toes.

The snow still lies deep on the valleys and hills, And no voices are heard from the "murmuring rills," For the brooks in their fetters of ice are still bound. And all nature is sleeping in silence profound.

Yet the daylight grows longer, the skies are more warm, And brighter the sunshine that follows the storm. While we trust the old promise, through ages proved sure, That seedtime and harvest shall ever endure.

Though the rods in their closet still rest on the shelf, With the fly-books beside them, well stored with their pelf, The day will soon come, when their spring we shall feel, And our ears shall rejoice in the click of the reel.

old winter, good bye! please be off with your train, Let us greet gentle spring with a welcome again. When our feet by the brookside may wander at will, While each leap of the trout to our heart sends a thrill.

When the song of the birds shall enliven the hours, And our eyes shall be blessed by the smile of the flowers, While we wend our way home, as the daylight fades out, With our hearts full of joy and our creels full of trout. New HaMPShire, April 1.

VON W. 
